
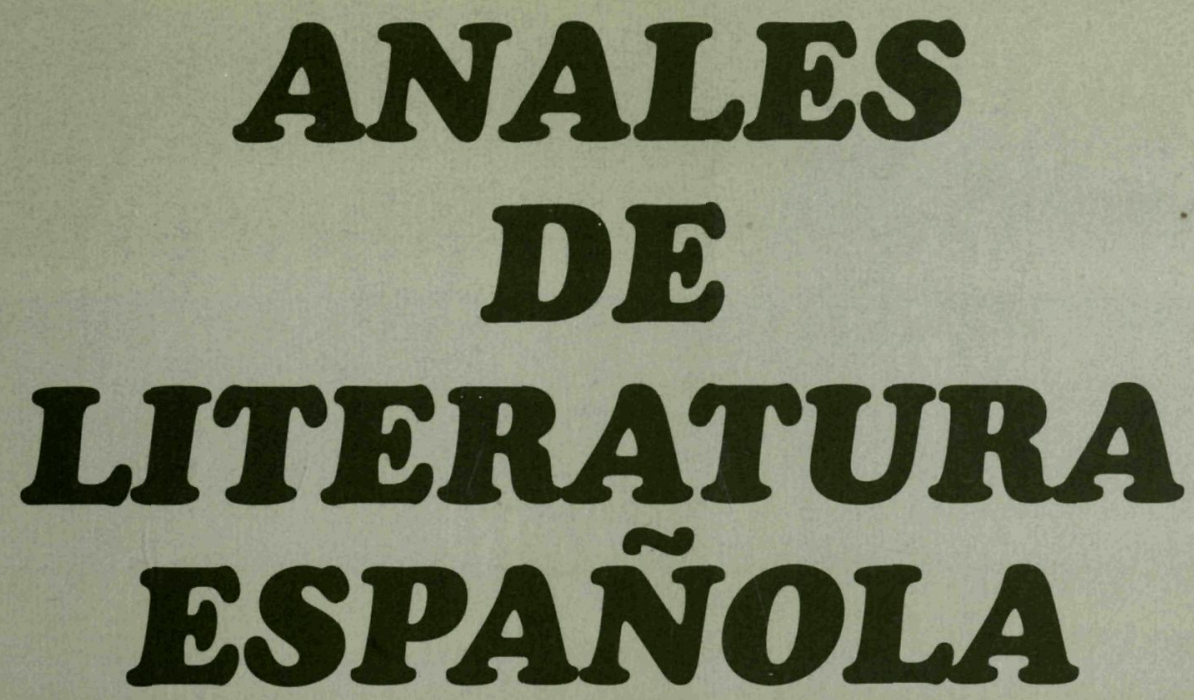

UNIVERSIDAD DE ALICANTE - No 10, 1994

Joaquín ÁLVAREZ BARRIENTOS

El escritor según Tomás de Iriarte: su plan de una Academia de Ciencias y Buenas Letras

\section{Guillermo CARNERO}

Los dogmas neoclásicos en el ámbito teatral

Ángeles EZAMA GIL

La erótica de la muerte en un personaje clariniano: Ángel Cuervo. Estudio de una pasión

\section{Luis MIGUEL FERNÁNDEZ}

De la "póetica de los muertos" al paisaje trascendente. Una aproximación a las relaciones entre Chateaubriand y Bécquer

\section{Nigel GLENDINNING}

Lo gótico, lo funeral y lo macabro en la cultura española y europea del siglo XVIII
Claudio GUILLÉN

Imágenes nacionales y literatura

Solange HIBBS-LISSORGUES

La prensa católica catalana de 1868 a 1900 (III)

Francisco LAFARGA

Territorios de lo exótico en las letras españolas del siglo XVIII

Dolores ROMEROLÓPEZDELASHAZAS Variantes y modulaciones de las Soledades de Antonio Machado

Guillermo SERÉS

El concepto de Fantasía, desde la estética clásica a la dieciochesca

Jesusa VEGA

Irracionalidad popular en el arte figurativo español del siglo XVIII 




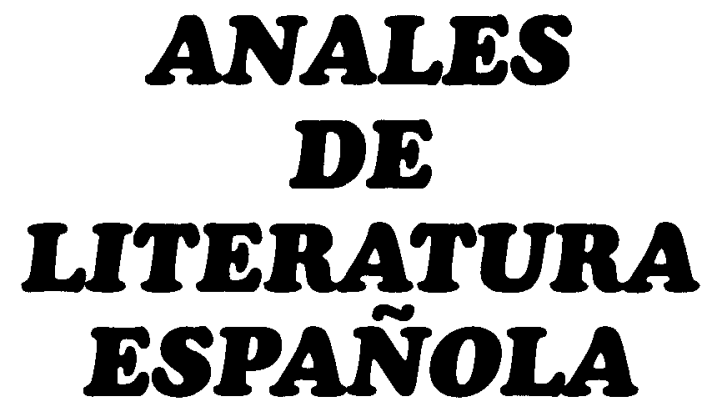


Anales de la Universidad de Alicante

Literatura Española

Director: Guillermo CARNERO ARBAT

Secretario: Enrique RUBIO CREMADES

Consejo de Redacción: Departamento de

Literatura Española de la Universidad

de Alicante 


\section{ANALES DE LITERATURA ESPAÑOLA}




\section{ÍNDICE}

Pág.

Joaquín ÁLVAREZ BARRIENTOS

El escritor según Tomás de Iriarte: su plan de una Academia de Ciencias y

Buenas Letras

\section{Guillermo CARNERO}

Los dogmas neoclásicos en el ámbito teatral

Ángeles EZAMA GIL

La erótica de la muerte en un personaje clariniano: Ángel Cuervo. Estudio de una pasión

Luis MIGUEL FERNÁNDEZ

De la "poética de los muertos" al paisaje trascendente. Una aproximación a las relaciones entre Chateaubriand y Bécquer.

Nigel GLENDINNING

Lo gótico, lo funeral y lo macabro en la cultura española y europea del siglo XVIII.

Claudio GUILLÉN

Imágenes nacionales y literatura

Solange HIBBS-LISSORGUES

La prensa católica catalana de 1868 a 1900 (III)

Francisco LAFARGA

Territorios de lo exótico en las letras españolas del siglo XVIII

Dolores ROMERO LÓPEZ DE LAS HAZAS

Variantes y modulaciones de las Soledades de Antonio Machado

Guillermo SERÉS

El concepto de Fantasía, desde la estética clásica a la dieciochesca 


\title{
EL ESCRITOR SEGÚN TOMÁS DE IRIARTE: SU PLAN DE UNA ACADEMIA DE CIENCIAS Y BUENAS LETRAS
}

\author{
Joaquín ÁLVAREZ BARRIENTOS \\ CSIC Madrid
}

Cuando Tomás de Iriarte redacta entre 1779 y 1780 el Plan de una Academia de Ciencias y Buenas Letras, existía en el ambiente cultural español la esperanza, ya un poco deprimida, de que las cosas podían cambiar, para mejorar. Tras el empuje que se dio a las Letras durante el reinado de Fernando VI, se pensó que con Carlos III llegarían las mejoras necesarias en todos los ámbitos de la política, además de una mejor situación para los miembros de la República Literaria española. A esta actitud ante el nuevo rey no era ajena su fama como activo agente cultural durante su período napolitano. Manuel Lanz de Casafonda, por ejemplo, lo presenta en sus Diálogos de Chindulza (1761) como el benefactor de las Letras y las Ciencias en aquel reino, y señala que lo mismo se espera de él en España: "Ha hecho [...] en Nápoles [...] florecer las Ciencias y las Bellas Artes; a su celo, protección y liberalidad se debe el estado que hoy tienen en este reino y en el de las dos Cicilias (sic) [no se olvide que el diálogo se supone entre dos italianos y en Italia]. Él ha sido el verdadero restaurador de las Letras, y espero que también lo ha de ser en España" (1972, pág. 38). Para la década de los ochenta esas esperanzas, si no están muertas, están decaídas, y peor será la situación a medida que el gobierno de Floridablanca avance en el tiempo, ya que su relación con los elementos progresistas se hará difícil y sospechosa, cerrándose al diálogo ante los hechos de la Revolución Francesa.

Antes que Iriarte, Luzán y Jorge Juan - y otros después - redactaron diversos proyectos que una Academia de Ciencias y Letras, a veces sólo de Ciencias, pero siempre en la idea de que el Estado debía ayudar a los literatos',

1. Pedro Roca (1899, pp. 845-940) publica los proyectos de Luzán y Jorge Juan; Julio Guillén Tato (1940, pp. 440-460) hace lo propio con el de Jorge Juan. El Plan de Luzán fue editado 
agrupándolos en un centro que facilitara su trabajo y dotándoles de un sueldo que les permitiera vivir de su actividad literaria —en el más amplio sentido de la palabra-, sin necesidad de desviar su atención y sus capacidades a la busca del sustento, de lo que queda palmaria constancia en el Plan de Iriarte.

Sólo a finales de siglo parece abandonarse la idea de establecer un gran centro cultural (como una ciudad literaria dentro de la propia ciudad) que agrupara a los estudiosos de las más diversas materias, desde la astronomía a la física, pasando por la historia, la botánica, la medicina, etc. Esta idea, fruto de una mentalidad centralizadora, cedió paso a otra, más acorde con los tiempo, que imponía la especialización de los estudios, y así se formaron centros más pequeños dedicados a materias específicas. Es una labor de la que se alaba el Príncipe de la Paz en sus Memorias. En ese gran centro que aunaría a las mentes más claras del país se llevaría a cabo la investigación necesaria, tanto para culturizar a la población, como para poner a la nación al nivel científico europeo.

Aunque de formar una Academia de Ciencias se hablara durante el reinado de Felipe $\mathrm{V}$, quien dio forma y reflexionó sobre la planta y distribución que debía tener ese gran centro de trabajo intelectual fue el padre Martín Sarmiento en sus Reflexiones literarias para una Biblioteca Real y para otras bibliotecas públicas, hechas [...] en el mes de Diciembre del año de 1743, dirigidas a Juan Iriarte, que trabajaba en la Biblioteca Real, y que no vieron la luz pública, aunque parece que se conocían manuscritas, hasta 1789, cuando las publicó Valladares de Sotomayor en su Semanario erudito ${ }^{2}$. Lo que para Sarmiento había de ser una Biblioteca Real, para los sucesivos "tracistas" de proyectos académicos debía ser una Academia que integrara artes y ciencias ${ }^{3}$. Este establecimiento cuya ideal distribución espacial incluye en el proyecto- debía tener imprenta propia ${ }^{4}$, librería de venta directa al público, observatorio astronómico, además de asumir las academias de la Historia, de Medicina, de la Lengua y todas las demás. "De modo que todo el palacio literario, o este grande edificio de la Real Biblioteca, se pueda llamar con propiedad Real Palacio de Palas o de Minerva; o, para excusar mitologías, el Palacio de la Sabiduría" (pág. 117).

de nuevo por Didier Ozanam (1962, pp. 188-208) y, más completo, por Guillermo Carnero (1990, pp. 139-184). En 1796 el padre Villalpando presentó otro proyecto, estudiado por mí en "El padre Francisco de Villalpando y el proyecto de fundación de una Academia de Ciencias y Letras de Madrid", Homenaje al prof. Caso González (en prensa). Véase también Alberto Gil Novales (1980, pp. 3-23).

2. Aguilar Piñal (1988, pp. 25-33) alude a algunas de las propuestas de Sarmiento.

3. En 1744, Campomanes se refiere a ello al llamar la atención sobre la necesidad de una Academia Universal de todas las Ciencias, en su discurso de ingreso en la Academia de la Historia.

4. Tener la imprenta en la misma Biblioteca le parecía beneficioso al benedictino porque era una fuente de ingresos. Sin embargo, cuando en 1796 el padre Villalpando lo proponga también en su proyecto, se considerará contraproducente, cuando no ilegal, pues chocaba con los privilegios de la Imprenta Real, por lo demás, inexistente cuando Sarmiento escribe sus Reflexiones. 
Fue el propio fray Martín quien propuso a Juan de Iriarte la creación, en esa Biblioteca-Academia-Palacio, de una "Junta Real de Literatos y Jueces de la Literatura, de cuyas disposiciones dependiese el gobierno de toda la República Literaria de los dominos de España" (pp. 214-215), de modo semejante a como, años después, hará Tomas de Iriarte al plantear la formación de una mesa censoria ${ }^{5}$. Es posible, desde luego, que la idea flotara en el ambiente, como la de establecer una Academia de Traductores, pero tampoco es improbable que Juan de Iriarte se apropiara de ella, ya que Sarmiento no publicó ese escritorio. En cualquier caso, el proyecto del benedictino parece a menudo ser el núcleo del que después salieron los posteriores planes de academias.

Lo que para Sarmiento era una reflexión personal, en tiempos de los hermanos Iriarte es ya un proyecto político que arrastra su inviabilidad, habiendo figurado en los programas de Ensenada y Floridablanca ${ }^{6}$. En el del primero, de forma muy vaga ${ }^{7}$; en el del segundo, de manera explícita en su Instrucción reservada que, sin embargo, es de 1787 , es decir, siete años posterior a la redacción del Plan de Iriarte ${ }^{8}$. Bernardo de Iriarte fue quien sugirió al Conde la conveniencia y necesidad de erigir dicho establecimiento, y podemos saber con relativa precisión cuándo se lo propuso. Floridablanca fue nombrado Ministro de Estado en Noviembre de 1776 - si bien no se presentó ante el rey hasta el 19 de Febrero de 1777, como deja constancia en su Memorial a Carlos III (1856, pág. 307)-, a los pocos días mantiene una conversación con Bernardo de Iriarte, que trabajaba en la Secretaría de Estado, de la que tenemos conocimiento por el escrito titulado Primera conversación que tuve con el conde de Floridablanca cuando vino al Ministerio de Estado desde Roma. Algunos datos y reflexiones posteriores". La charla tuvo lugar "unos quince días después de haber tomado posesión $[\ldots]$ a cosa de las 9 de la noche en su despacho $[\ldots]$ en el Pardo".

El Ministro le pregunta su opinión sobre cuál debe ser la política y la dirección del Ministerio. Iriarte le contesta que es el momento de mejorar el país, comenzando por la educación de los jóvenes. El relato de Iriarte acentúa su resentimiento a medida que narra los hechos, que continúan de esta manera:

5. Sarmiento (pp. 216-221) establece también las clases de académicos, sus sueldos, los tipos de juntas y su periodicidad, los premios que se debían proponer por las academias, etc. Prácticamente todo lo que encontraremos después en los proyectos de academias. Ninguna de las existentes en 1743 tenía premios públicos. También Luzán, que conocía a Juan de Iriarte y a Sarmiento, propone en su Plan "una especie de Consejo Literario" que censuraría los libros que se quisieran imprimir.

6. Emilio Cotarelo y Mori (1897) dedica las pp. 230-233 al proyecto del escritorio canario.

7. En sus Puntos de gobierno se refiere a la necesidad de crear academias que fomenten el estudio, cfr. Roca, (1899, pág. 855). $224 b)$.

8. El punto 69 de la Instrucción es el dedicado a la Academia (Floridablanca, 1856, pág.

9. Se conserva en el AHN, Estado, 2817. 
Algunos años llevaba ya de Ministro (tres o cuatro) el Sr. Conde, cuando a duras penas le persuadí promoviese el establecimiento de una Academia de Ciencias, estimulándole con significarle que nunca había habido ministro de provecho que no las hubiese promovido; que la nación ignorante no hacía otra cosa que ignorancias y sería siempre vencida en la guerra e infeliz y miserable en la paz, etc.

Adoptó la idea. Quiso que mi hermano D. Tomás de Iriarte, a quien lisonjeó muchos años con vanas esperanzas, y cuyo ingenio, penetración y superior lógica le asustaban, formase el plan de la Academia, como en efecto lo hizo ${ }^{10}$. Leísele al conde, y le aprobó. Cuando salí yo de la Primera Secretaría de Estado en el año de 1780 para la plaza del Consejo de Indias, quise entregarle el expediente, pero me dijo le retuviese en mi poder y se le enviase en la próxima jornada de San Ildefondo. Hícelo así, acompañándole con una carta confidencial, de que conservo minuta!!.

El proyecto durmió junto con los estatutos de semejantes academias europeas que sirvieron para la redacción del Plan ${ }^{12}$.

Más tarde, el 8 de Julio de 1787, en el punto 69 de la citada Instrucción reservada para el gobierno de la Junta de Estado, se establecía que era deseo del rey erigir una Academia de Ciencias, "con el fin de promover entre mis vasallos el estudio, aplicación y perfección de estos conocimientos [...], y encargo muy particularmente a la Junta coopere a estas ideas y las recuerde con frecuencia y oportunidad" (pág. 224b). Por esas fechas, Floridablanca había decidido construir un gran edificio que albergaría a los científicos que formarían la proyectada Academia. Este edificio, el actual Museo del Prado (Rumeu de Armas, 1980), atrajo en seguida las críticas, pues se veía como una obra inútil y gravosa. Bernardo de Iriarte lo cuenta así en su Primera conversación:

Algún tiempo después resolvió se edificase una casa en el Prado para la futura Academia. Pensó en el edificio; pero no en los sabios presentes ni futuros, porque los temía y no los amaba, especialmente a los primeros, pues siempre le hicieron sombra y le estorbaron durante su ministerio, y los humilló y abatió, exaltando a los necios e ignorantes.

La casa prosigue; ;ojalá veamos desde luego protegidos dignamente a los que hayan de habitarla!

Estas objeciones de Iriarte, posteriores a los hechos, eran las que se hacían al proyecto contemporáneamente. Los enemigos del Conde que escribieron la Sátira tercera. Confesión del conde de Floridablanca, señalaban en el punto $32^{13}$ :

10. Sin embargo de estas palabras, Tomás de Iriarte publicó gracias a Floridablanca en 1780 el poema La música, y también, por indicación del ministro, compuso sus Lecciones para niños que, por problemas durante la impresión, no llegaron a ver la luz hasta 1794, muerto ya Iriarte.

11. Probablemente es la carta fechada el 8 de Agosto de 1780 que se publica en este trabajo.

12. Hoy en el AHN, Estado, 3022.

13. Titulado Obras públicas, arañando el dinero y alabándome de mis manos. Edificio para la Academia sin ciencias, (1856, pág. 287b). 
La más magnífica, y a proporción menos costosa, de estas obras, es la que se levanta en el Prado; pero también la más inútil [... ¿Cómo se ha de hallar dignos académicos de las ciencias, cuando jamás he proporcionado un pedazo de pan a un hombre hábil, y tengo esclavizados hasta los entendimientos, sin haber dado entrada ni querido rozarme con personas de luces, por no descubrir la hilaza? (p. 287b).

Las críticas a Floridablanca inciden en su falta de ayuda a los intelectuales, en su mala gestión política y económica, y se alargan todavía durante el año 1789. En el Memorial renunciando al Ministerio, elevado a Carlos III el 10 de Octubre de 1788 y en el que presenta a Carlos IV el 6 de Noviembre de 1789 (que es el mismo con algún añadido), se defiende de las acusaciones de que es objeto, aunque más por extenso lo hace en las Observaciones sobre el papel intitulado Confesión del conde de Floridablanca, de 8 de Septiembre de $1789^{14}$. Todas estas censuras, y el hecho de que finalmente el edificio se dedicara a museo y la academia no tuviera efecto, no impidieron que Alberto Lista, en su Elogio histórico del Serenísimo Sr. D. José Moñino, conde de Floridablanca, le dedicara unas expresivas palabras en el sentido contrario al de las críticas ${ }^{15}$.

En todas esas réplicas y contrarréplicas defensivas no se dice de qué manera se financiaba la construcción de "edificio tan suntuoso y magnífico". Tenemos que acudir para saberlo al Testamento político del conde de Floridablanca, como denomina Rumeu de Armas (1962) a los informes y memoriales que Moñino envió a Aranda durante el año 1792, tras ser expulsado del Ministerio el 28 de Febrero. En él comenta que se estaba levantando con los bienes y temporalidades de los ex-jesuitas ${ }^{16}$.

Ya se ve que la expectación era grande, no sólo como demuestran las críticas antes citadas, sino como se comprueba también por el hecho de que la prensa le dedicara cierto espacio en 1788 , precisamente algunos meses antes de morir Carlos III:

La filosofía no es término ni carrera en España; es medio para las tres que dan de comer por los estudios: la medicina, la jurisprudencia y la teología [...] La tercera es sobre todas y tiene más alumnos; pero ni en todas tres se podrán contar otros tantos filósofos.

14. Estos textos pueden leerse en Floridablanca (1856).

15. "Las academias, los cuerpos científicos, los establecimientos literarios, que antes presentaban un aspecto cadavérico, recibieron, bajo su protección, movimiento y vida. El Museo de Madrid, obra suya, destinada para la reunión de una grande academia de ciencias, probará a la posteridad la ilustración de Floridablanca y su celo por los progresos de las luces", (Floridablanca, 1856, pág. 519 a).

16. Siguiendo la idea desarrollada por Sarmiento, "se unían el Jardín Botánico y el Observatorio Astronómico, que se meditaba, con el Gabinete de Historia Natural, la Academia de Ciencias y el Laboratorio Químico, quedando disposición todavía para la Academia de las tres Artes, cuya casa actual podía reducirse a cuartos alquilables que produjesen una renta capaz de pagar el censo con que está gravada y dejar sobrantes para la misma Academia" (Rumeu 1962, pág. 161). 
La munificencia de nuestro gran Rey lo arreglará todo, y no tardará mucho. ¡Oh, tiempo, si al paso que alargaras la vida de nuestro augusto Soberano y su sabio Ministerio, apresuraras el establecimiento de la Academia de Ciencias, a que ya se han echado los cimientos! (art. introductorio del Memorial literario, XIII, Enero 1788 , pp. 11-12) ${ }^{17}$.

Bernardo de Iriarte siguió recordando sus conversaciones con el Ministro y nos cuenta que, "reinando ya Carlos IV, me repitió el conde de Floridablanca un día en su casa después de comer la misma pregunta... qué decía yo". Iriarte escribe esta contestación: "Que ha perdido Vm (le dije) un tiempo precioso. ¡Cuántas cosas pudo $\mathrm{Vm}$ hacer que no hizo durante el reinado de Carlos III! No sé si podrá hacerlo en el actual". Y entre otras cosas que añade, la siguiente referida al asunto de la Academia: "Pensó en establecer una Academia de Ciencias $y$, en vez de juntar los sabios, aunque hubiese sido en un desván, dispuso se edificase una casa en el Prado para ellos".

Entre tanto, fue pasando el tiempo y el proyecto, a pesar del interés que tantos habían mostrado por él, se olvidó hasta que en 1796 Bernardo de Iriarte lo presenta de nuevo a Godoy (véase la carta que se publica de Septiembre de 1796), tras haber fracasado el padre Villalpando en su intento de ofrecer un proyecto de Academia de Ciencias adecuado a las condiciones del momento. En el informe a Godoy del proyecto de Villalpando se hace alusión precisamente al fracaso del Plan de Academia en los tiempos de Floridablanca: "La inercia del anterior ministerio, que tantas cosas proyectaba y tan pocas ponía en ejecución, llevó hasta su fin arrastrando aquel pensamiento sin haberlo puesto siquiera en estado de concluirlo. En Abril del 91 decía el conde de Floridablanca que en aquella jornada había pensado arreglar la Academia, pero no por eso llegó el día de semejante arreglo. VE le ha dado un impulso nuevo, y es de creer que sea eficaz a producir de una vez tan deseado efecto" ${ }^{18}$. Como ya sabemos, esto no ocurrió, pero la figura del padre Villalpando se vuelve ahora más importante por el hecho de que él mismo desautorizó, al parecer, el Plan compuesto por Tomás de Iriarte. Es lo que se desprende de las siguientes palabras de su hermano, que, quizá pensando que si en tiempos de Floridablanca el padre Villalpando había desestimado el proyecto de su hermano, y Godoy rechazaba ahora el del propio padre capuchino, tal vez era el momento de volver a presentar el que había instigado en 1780. Dice así Iriarte, al final de su Primera conversación:

Después de la caída del Conde supe por un individuo de la Secretaría de Estado que aquel Ministro, no obstante haberme manifestado aprobaba el plan propuesto por mi hermano Tomás, le había pasado reservadamente a

17. Interesa este testimonio, además, porque expresa con claridad que los estudios "literarios" no estaban bien considerados, que no había filósofos y que donde se ganaba dinero era con la medicina (de lo que hay constancia en algún plan de Academia), con el derecho y con la teología, pues los teólogos tomaban la "carrera eclesiástica".

18. Vid. mi artículo "El padre Francisco de Villalpando...", cit. en nota 2. 
informe del Reverendísimo Capuchino Padre Villalpando y que éste, reprobando dicho plan, propuso uno sumamente desatinado y muy conforme a sus principios barbones.

Y quizá le falla la memoria al mayor de los Iriarte, pues el proyecto lo presentó el capuchino a Godoy, Príncipe de la Paz, no a Floridablanca.

Hasta aquí lo que podemos llamar participación de los Iriarte en la historia externa del proyecto de una Academia de Ciencias y Letras. Su episodio es justamente anterior al del padre Villalpando, y, al mismo tiempo, posterior, puesto que, como ya se ha dicho, Bernardo de Iriarte intentó colocar de nuevo el Plan de su hermano, visto el fracaso del capuchino. Pasemos ahora a comentar las ideas que propone Tomás de Iriarte en su escrito. El mayor de los hermanos, hombre político que desempeña un importante puesto en la Administración, ofrece al Ministro los servicios literarios de su hermano y éste redacta unas consideraciones y unas reflexiones, además de unos apuntamientos y un Plan, en los que plantea problemas relativos a la consideración social del autor en el siglo XVIII y propone posibles soluciones — parciales- a algunos de esos problemas, principalmente al de conseguir que el escritor pueda vivir de su propio trabajo y, puesto que no sea así porque no hay suficiente número de lectores, que pueda vivir de su actividad literaria pagado por el Estado, al menos mientras se prepara y educa una generación de jóvenes, a los que se habrá despertado el gusto por la lectura y la compra de libros, que será capaz en el futuro, como sucedía en Francia al presente, de mejorar la situación - económica y social- de los literatos. Es en este sentido en el que el escrito de Iriarte tiene importancia, ya que lo que propone en cuanto a estatutos es muy poco y vago, además de encontrarse en los demás proyectos de Academia.

Tomás de Iriarte defiende que la de escritor es una actividad seria y difícil -requiere dedicación exclusiva-, útil y necesaria al Estado, tan respetable como cualquier otra y que, por ello mismo, ha de ser considerada como profesión o carrera digna. Por un lado, Iriarte intenta mostrar la necesidad de dicha Academia señalando su existencia y utilidad en los países europeos a los que España quiere parecerse; por otro, las razones que presenta son de carácter interno: es necesario que el pueblo se dé cuenta de que el gobierno valora y atiende a los intelectuales, es necesario que aquellos que hacen por mejorar la situación cultural y científica de la nación no malvivan olvidados y despreciados, sino que obtengan las retribuciones adecuadas a su trabajo. Todo ello redundará en beneficio de la nación.

Por otra parte, si muestra interés en valorar la institución académica convirtiéndola en una profesión de la cual se pueda vivir, también lo hace del modo inverso, es decir, negando importancia a aquellas que llama "academias de conversación", entre las que cita la Histórico-Geográfica de Caballeros de Valladolid, que se venía reuniendo desde 1746. 
Iriarte tenía fuerte conciencia de la profesionalidad de la actividad literaria, así como de la existencia de un grupo, cuando no de una clase, que podía ampararse bajo la denominación de República Literaria, a cuyos miembros llamaba literatos. Deja constancia de ello en casi toda su obra poética, pues gran parte de sus composiciones están dedicadas, o aluden, a asuntos literarios, y también en Los literatos en Cuaresma, de 1773, que es o pretende ser una reflexión sobre el mundo de la Literatura y sobre los problemas a que se enfrenta el escritor. Los tertulianos disertan sobre la oposición al adelantamiento de las Letras; sobre "las obligaciones y dificultades del oficio de poeta" reparemos en la palabra "oficio" referida a la actividad poética- y sobre las parcialidades de los críticos, entre otros temas. Desgraciadamente, de los tres citados, sólo dio lugar la Cuaresma a tratar del primero de los indicados, quedándose los demás en mera propuesta ${ }^{19}$. Ahora bien, como hará en sus "Consideraciones", también en Los literatos reflexiona sobre la necesidad de un cuerpo de censores, un "tribunal de críticos" (pág. 26) que sea culto e imparcial. Ese tribunal, al parecer de Iriarte, debía realizarse desde los periódicos, como se hacía en Europa, pero no deja de ser claro el objetivo del escritor canario, pues esa mesa censoria debía velar por instaurar un gusto concreto de literatura, y no otro. Donde sí muestra más libertad es al considerar que el literato debe tener facilidades para publicar:

Requiérese igualmente que todos contribuyan a facilitarle la publicación de sus obras por medio de la prensa; pues así como nunca puede quejarse el Gobierno Político de que en el mercado abunden los víveres, unos mejores que otros, con tal que ninguno de ellos sea del todo pernicioso a la salud corporal; así también ha de procurar el Gobierno Literario que a sus mercados, que son las bibliotecas, traiga cada autor a vender sus libros, como no sean enteramente nocivos a la salud del entendimiento (1805, pág. 26).

Se perciben ecos de los apuntes que el padre Sarmiento presentó a Juan de Iriarte, en los que no se cansa de reiterar la obligación que tiene el Estado de facilitar al hombre de letras su tarea, tanto a la hora del estudio, como en el momento de llevar a la imprenta su obra, siempre y cuando no sea ésta dañina ni inútil.

Iriarte insiste en su propuesta en que sólo mediante la retribución adecuada y la buena consideración del literato puede dignificarse su profesión. Comprende, como su hermano y como todos los que se refieren a este asunto, que "las estrecheces del Erario" son uno de los impedimentos más graves para conseguir una decorosa remuneración del erudito que trabaje en la Academia, que se entiende como lugar para la investigación y no como centro honorífico. Y, si "es menester que por ahora el Gobierno lo haga todo" en este sentido, es porque

19. Los tertulianos escuchan disertaciones sobre los frenos al adelantamiento de las letras, sobre lá educación de los niños y sobre teatro. Esta última, como es sabido, a cargo de Miguel de Cervantes Saavedra (Iriarte, 1805, pp. 3-96). 
nadie puede vivir de lo que le producen sus obras, "porque el público no paga los libros" ni los nobles "da[n] de comer a literato alguno", como sucedía en el pasado. La cosa no ha cambiado, o lo ha hecho poco, respecto a los tiempos en que escribía Sarmiento, que deja constancia de "ser escasísimo el número de compradores" de libros (1789, pág. 127).

Todo se reduce en la práctica a que no existe lo que el padre benedictino llamó "comercio literario", y a que los autores no tienen facilidades para imprimir sus obras ni para cobrar lo que les correspondería por "derechos de autor". Sarmiento insiste una y otra vez en que el beneficiado principal con la venta de libros debe ser el autor — no el impresor ${ }^{20}$ _ y en que el primero es el que debe tener los privilegios de impresión, cosa que sucedía sobre el papel de las leyes pero no en la realidad. Algo semejante, aunque sin entrar en tanto detalle, presenta Tomas de Iriarte en sus reflexiones, quien remacha una y otra vez que la "profesión literaria" es ocupación digna, a pesar del desprestigio que sufren los literatos, "que no sólo llegan [...] a ninguna alta fortuna, pero ni aun hallan qué comer si no abandonan la literatura para ocuparse en empleos de oficinas". En cualquier caso, ninguno de los dos llega a exponer las cosas tan detalladamente como lo hizo Diderot en su Letrre historique et politique [...] sur le comerce de la librairie, de 1763.

Esta visión de los hechos se contrapone a la de otros escritores que, por esas mismas fechas, se ganaban la vida más o menos con los periódicos y los folletos, dando pie a que a las Letras se las Ilamara "letras de cambio". Y, si los escritores "cultos" veían con desprecio la proliferación de papelistas que, con escasa preparación cultural pero con ojo perspicaz, eran capaces de sobrevivir con los periódicos, aunque sin hacer "literatura", también era mal vista esa floración por los gobernantes, que contemplaban de qué manera los periódicos se volvían medios peligrosos de expresión ideológica: El censor, El observador, El correo de los ciegos, etc.

El proyecto de Iriarte forma parte de los intentos que a lo largo del XVIII se hicieron para incorporar a España al tren europeo. Como en otros casos, el miedo de los gobernantes, la falta de dinero (o su mala distribución), lo hicieron inviable. Tomás de Iriarte aprovechó la oportunidad que le brindaba su hermano, más que para proporcionar unos estatutos acabados, para presentar a Floridablanca unas consideraciones sobre la profesión literaria y sobre los medios para mejorar su estado. El conde los desestimó, y prefirió ayudar a algunos escritores por vía de limosna u otorgándoles pensiones sobre las rentas de Correos y otras dependencias ministeriales, "siguiendo las pisadas de antiguos ministros de Estado" (Rumeu, 1962, pág. 166). Godoy, aunque también ayudó

20. Dedica unas sabrosas páginas a hablar de las envidias que sienten del éxito de ventas de un autor (1789, pp. 189-190). Lanz de Casafonda se expresa en semejantes términos, respecto a los libreros, que sólo miran su propia ganancia (1972, pág. 59). 
a los literatos cercanos a Moratín, Estala y Melo, fue más drástico, pues dio fin a la historia de la Academia de Ciencias el 6 de Septiembre de 1796 con estas palabras, que son contestación a la carta de Bernardo de Iriarte del 4 de Septiembre:

Póngase todo con el expediente, pero ciertamente que en mi tiempo no se verá concluido el establecimiento. Los abusos en él y los excesos de cada particular son consiguientes cuando se amplía la facultad de lucir el talento, la energía, elegancia, etc. Y esta Academia quitó el cetro a Luis XVI.

Todo parece dar la razón a Lanz de Casafonda, cuando, con amargura, pensaba que "tiene un cierto hado la literatura de España, que se pudiera hacer una historia de las desgracias de muchos proyectos utilísimos que se han propuesto para el restablecimiento de las Letras, que se han malogrado, y de otros que se han puesto en ejecución [...] y por falta de buena dirección no han producido el efecto que se deseaba" (1972, pág. 74).

\section{PLAN DE UNA ACADEMIA DE CIENCIAS Y BELLAS ARTES, formado} por D. Tomás de Iriarte ${ }^{21}$

[De B. de Iriarte al conde de Floridablanca]

\section{Excmo Sr.}

Mi jefe y señor. Me he abstenido de escribir directamente a VE dándole cuenta de mi persona por no molestarle. VE no puede haber dudado de mi gratitud y respeto, ni del amor que le profeso; y, si hoy escribo, lo hago sólo para remitirle, como me advirtió, el Plan trabajado por mi hermano Tomás, de acuerdo conmigo, y según las órdenes de VE para una Academia de Ciencias y Buenas Letras, y juntamente con él las Consideraciones separadas y Reflexiones sueltas que él mismo extendió y creo convendrá se tengan presentes para que no se proceda sin el pleno conocimiento que se requiere en la materia.

Acompañan las Constituciones que pude recoger de otras Academias, y que se reconocieron atentamente para la formación del Plan de la proyectada en Madrid, según conviene a nuestra actual situación.

Si mi hermano y yo podemos contribuir en algún modo al logro de las importantes ideas que VE se propone, las cuales deben suministrar a la nación la luz que necesita para empezar a salir de las densas tinieblas que la rodean constituyéndola en punto de Letras, Ciencias y Artes casi la última de todas las

21. "NOTA. Hay dos cartas del Sr. D. Bernardo de Iriarte, una fecha en Agosto de 1780, al Sr. conde de Floridablanca, y otra en Septiembre de 1796, al Sr. Príncipe de la Paz". Esta indicación figura al frente del expediente, en el que, como se ve, se llama a la Academia de "Bellas" Letras, y no de Buenas, como se indica en los demás lugares. El expediente se conserva bajo ese título en el AHN, Estado, 3022 (17). 
de Europa, ya sabe VE cuán prontos nos hallará siempre a ello en lo que alcancemos, tanto más que estamos persuadidos de que es indispensable evitar cuidadosamente intervengan personas, o preocupadas, o poco instruidas, o guiadas del pernicioso espíritu de partido que, ya por un camino, ya por otro, domina en los ánimos, y frustrará los mejores pensamientos.

Bien comprendo que las estrecheces del Erario y la gravedad de negocios del día no permitirán a VE pensar en el establecimiento de la premeditada Academia, pero cumplo lo que VE me mandó remitiéndole todo el expediente en los primeros días de agosto.

A mí me va muy bien con mi Consejo. Deseo que VE goce de salud y logre felicidades que contribuyan a ella, las cuales, acelerando la paz ${ }^{22}$, dejen a VE tiempo y le faciliten los arbitrios de promover sólidamente el bien interior del reino, y ratifico a VE el perpetuo reonocimiento y la inviolable buena ley con que está siempre a disposición de VE

Bernardo Iriarte (rúbrica)

Madrid, a 8 de Agosto de 1780

Excmo. Sr. Conde de Floridablanca

[De B. de Iriarte al Príncipe de la Paz]

Excmo. Sr. y mi amado protector, tuve que venirme a Madrid sin poder tomar en el Sitio las últimas órdenes de VE porque la posta no podía esperar más. VE sabe que estoy siempre a ellas, y podrá comunicarme las que sean más de su agrado.

Como fui yo quien persuadí al conde de Floridablanca la necesidad de establecer una Academia de Ciencias y Bellas (sic) Letras; como mi hermano Tomás trabajó el Plan de ella con vista y examen de los estatutos de las varias academias de esta clase establecidas en Europa, los cuales hice traer de fuera del reino para el fin; como aquél me escribió sobre el particular varias cartas que yo leía al conde, en contestación a otras mías, y además extendió dos papeles de Reflexiones sobre la tal Academia y sus circunstancias; como el tener estos presentes podría acaso conducir a dar idea de los motivos y fundamentos que tuvo para proponer su Plan en los términos que lo hizo, y no en otros, considerando por una parte el estado de las cosas en España y, por otra, que las academias extranjeras de la misma clase se establecieron también en sus principios con respecto a la situación relativa, alterándose y perfeccionándose después según los progresos que se advertían y lo que dictaba la experiencia; y, en suma, como varias veces me había ocurrido durante el

22. España tomó parte en la guerra de independencia de los Estados Unidos en 1779, que acabó en 1783, al firmarse la paz con Inglaterra. 
Ministerio de VE podría convenir se tuviesen presentes los dos Apuntamientos, dispuse se sacasen copias de ellos con la mira de hacer algún uso conveniente, ya que la materia era de tal entidad, y cosa tan esencial fuese este establecimiento el que se requiere y no otro, o por su demasiada extensión a ramos y facultades inconducentes, o por limitarse a menos de lo necesario y urgente.

Me había propuesto entregar a VE ambos Apuntamientos por si juzgaba del caso mandar se agregasen al expediente para que se tuviese a la vista al tiempo de determinar la consistencia de la Academia, pero no habiéndoseme proporcionado oportunidad de ello, me ha parecido no omitir dirigirlas a VE por si en la actualidad condujeren al intento, bajo el concepto de que la nación pocos progresos creo haya hecho desde entonces, excepto alguna mayor persuasión que ha adquirido de la importancia del estudio de las Ciencias Naturales, algunas luces que se han ido difundiendo, y unos cuantos libros elementales que se han traducido y aun compuesto ${ }^{23}$.

Disimule VE le distraiga de sus más serias ocupaciones por la gran trascendencia de la proyectada Academia, persuadido yo firmemente de que no debe contemplarse menos esencial determinar los objetos de sus tareas que la acertada elección de los individuos que hayan de componerla, siendo, como son, raros los sujetos instruidos en las respectivas facultades, laboriosos, de sólidos y no equivocados principios, y libres de las preocupaciones, parcialidades y fines particulares, que tanto abundan, puesto que académicos de otra especie más daño que provecho harían.

Reitero a VE mi rendimiento, mi gratitud a sus honras y favores y la constante afectuosa estimación con que es y será siempre de VE, y queda a su órdenes

Excmo Sr. Bernardo Iriarte Madrid, a 4 de Septiembre de 1796 Excmo. Sr. Príncipe de la Paz

\title{
CONSIDERACIONES QUE SE HAN TENIDO PRESENTES PARA LA EXTENSIÓN DEL PLAN DE LA ACADEMIA DE CIENCIAS Y BUENAS LETRAS
}

\author{
por Don Tomás de Iriarte ${ }^{24}$
}

Incluyo el bosquejo que he hecho de la Academia proyectada, en que acaso habrá algo bueno, y acaso bastante que mudar, porque éste es un primer pensamiento y estas cosas no salen bien sino pensando y escribiendo mucho, y alterando después todo lo que la experiencia vaya demostrando que no conviene.

23. Gil Novales (1980, pág. 22) cree que se refiere a las obras de Pestalozzi.

24. "NOTA. D. Bernardo de Iriarte, que fue quien propuso al Sr. Floridablanca la fundación de la Academia, cuyo Plan formó D. Tomás de Iriarte, leyó estas Consideraciones, como otros varios 
Expondré aquí algunas reflexiones en que me he fundado, valgan por lo que valieren.

Sé que en otros tiempos se habló en Madrid de establecer una Academia de Traductores $^{25}$, y oí apuntar este pensamiento a mi tío D. Juan de Iriarte. El fin de este cuerpo era utilísimo y lo será siempre, porque todas las naciones, sin dejar de tener sus escritores originales, se han aprovechado de lo que han adelantado los de las naciones extranjeras; y según una máxima cierta, el que no imita, jamás será imitado. Aunque en España ha habido sabios en varias facultades, es preciso confesar que en las que se llaman Ciencias Naturales y Ciencias Exactas hemos sido descuidados, al paso que en las naciones extrañas han florecido los Pascales, Buffones, Linneos, Leibnitzes, Newtones, Galileis, etc., etc. En lo que mira a las Buenas Letras, hemos tenido ingenios, pero sin gusto delicado ni crítica; y también ha sido tal nuestro descuido que, entre doscientos poetas que contamos, ninguno ha hecho todavía un verdadero poema épico que dé honor a la nación. Para que se formen hombres de doctrina y gusto es menester adoptar lo bueno de los extranjeros, porque es difícil que, de repente, adelantemos lo que ellos, sin imitarlos; y para esto sería preciso traducir bien los mejores libros elementales. Ésta es nuestra mayor necesidad. No nos falta ingenio sino libros que le guíen, le enriquezcan, le rectifiquen, y le abran sendas que él por sí solo no puede descubrir sin ayuda del estudio. Esto está casi hecho entre los extranjeros: sólo resta trasladarlo a nuestro suelo, alterando, quitando y añadiendo con libertad lo que convenga; de suerte que unos traductores juiciosos y no serviles, lejos de corromper nuestra lengua y hacernos en todo medio extranjeros, evitarían la decadencia de nuestra literatura ${ }^{26}$.

Por otra parte, se ha hablado muchas veces de establecer aquí una Mesa censoria para la censura de libros ${ }^{27}$.

Apuntamientos y cartas de éste último, a aquel ministro, para contribuir al objeto e impedir se tomase algún sesgo opuesto a lo mejor, etc." Esta y otras notas posteriores, que se encuentran en el original, parecen de letra del propio Bernardo de Iriarte. Según Cotarelo (1897, pág. 231), estas "Consideraciones" son del 15 de octubre de 1779.

25. En 1785 el duque de Híjar, en colaboración con otros intelectuales, propuso establecer una academia de traductores, que no pareció conveniente.

26. Juan Sempere y Guarinos (1789, pp. 229-230) se refiere a las traducciones en términos valorativos semejantes. En el artículo introductorio al año 1788 , del citado Memorial literario, se alude a esta carencia: "estamos invadidos de traductores; pocas traducciones de las que salen importan algo; no debemos buscar fuera sino lo que nos hace falta, pues sobran libros místicos, novelas y bagatelas" (pp. 7-8). Juan Manuel Munárriz, que es quien hace estas observaciones, propone traducir extractos de las "Memorias de las Reales Academias de Ciencias de los reinos extranjeros" (pág. 9), y ofrece un plan que va desde las obras de matemáticas, artes y oficios, hasta "lo perteneciente a Historia y Buenas Letras" (pág. 10).

27. Sobre esta idea y su relación con lo que expuso el padre Sarmiento en sus Reflexiones de 1743, véanse las páginas precedentes. 
También se ha hablado de Academia de Ciencias, porque es una vergüenza que la tengan todas las capitales de los grandes Imperios, y aun muchas ciudades particulares, y sólo Madrid esté sin ella, siendo cabeza de tantos reinos.

Últimamente muchos han deseado el establecimiento de una Academia de Buenas Letras en Madrid, ya que ni la de Sevilla ni la de Barcelona han hecho progresos dignos de memoria ${ }^{28}$.

Pues ahora bien, fórmese un Cuerpo que sea a un mismo tiempo Academia de Ciencias, de Buenas Letras, de Traductores y Mesa censoria: todo lo cual es muy compatible. Una Academia con título de Ciencias y Buenas Letras lo abrazaría todo. Con la división de clases que se propone no se confundirían estos dos ramos; el de Traducción se agregaría naturalísimamente porque las tareas del Cuerpo en los primeros años serían principalmente buenas traducciones de libros magistrales y ûtiles. Lo de Mesa censoria se refundiría insensiblemente en la Academia, porque el Consejo de Castilla enviaría a ella la censura de casi todos los libros que se publicasen, y tampoco hallaría fuera de ella censores más caracterizados e inteligentes que los académicos; y véase aquí cómo, sin sonar otro título que el de Academia de Ciencias y Buenas Letras teníamos un Cuerpo comprehensivo de todo lo que nos hace falta. El título de Academia de Traductores que, como se ha dicho, se proyectó hace algunos años, sublevaría a ciertas gentes que, persuadidas de que los españoles lo sabemos todo, se escandalizarían de que se autorizase un Cuerpo destinado exclusivamente a infestarnos, como ellos dicen, con doctrina extranjera. El título de Mesa censoria tal vez retraería o intimidaría a algunos escritores, dando lugar a que se creyese que, en lugar de dar mayor libertad a la imprenta, se tiraba a coartar la que tiene. Pero, sin que aparezca ninguno de estos títulos, la Academia de Ciencias y Buenas Letras restablecería el buen orden en la Literatura y facilitaría la abundancia de buenos libros publicándolos ella misma ${ }^{29}$.

Esta es la idea general de semejante establecimiento. Veamos ahora por qué se unen en un mismo Cuerpo las Ciencias y las Buenas Letras. No podemos prescindir del buen gusto y de las humanidades, porque sin él y sin ellas las Ciencias se tratan de modo que todos huyen de estudiarlas, además de que la substancia sin el estilo a poco libros ha hecho generalmente famosos. Entre nosotros no sólo falta el profundo conocimiento de muchas ciencias sino también

28. Han estudiado estas dos Academias, Francisco Aguilar Piñal (1966) y M $\mathrm{M}^{\ddagger}$ Teresa Carracedo Carracedo (1974), la Sevillana; Luis Faraudo de Saint -Germain y Martín de Riquer (1953), la de Barcelona.

29. Tanto Iriarte como Sarmiento y el padre Villalpando exponen la conveniencia y los beneficios de tener imprenta propia. Luzán no es tan explícito, pero también parece participar de esa idea. 
el arte de escribir en estilo digno de ellas y de exornarlas con erudición, gusto, ingenio, elegancia, etc. Supongamos, por ejemplo, que uno de los individuos de la Academia en la clase de Ciencias traduce la Historia Natural de Buffon ${ }^{30}$. Desde luego, podría ser habilísimo en aquella ciencia, y faltarle el gusto y la elegancia. Pues, ayúdele en su trabajo un académico de la clase de Buenas Letras; y corresponderá su obra a la exactitud, amenidad y estilo correcto del original francés. Al contrario, supongamos que un académico de Buenas Letras escribe una oración, una disertación, un poema, y toca algún punto alusivo, v.g. a la astronomía o a la botánica. Podría muy bien incurrir en un error, pero el académico de Ciencias se le corregiría. De este modo se aseguraría el acierto.

En París hay una Academia de Inscripciones y Bellas Letras, y por esto allí no se comprenden estos ramos en la de Ciencias. Pero en Berlín hay una Sociedad Real, dividida en cuatro clases, y la cuarta de ellas es la de Buenas Letras. En Rouen hày una Academia que se intitula de Ciencias y Buenas Letras, y un Cuerpo que abrace ambos institutos es el que, en mi dictamen, nos conviene en el día.

En cuanto a asignar pensiones a los académicos facultativos, parece indispensable que se les estimule con premios. En París, aunque no todas las plazas de las academias son pensionadas, hay bastantes académicos que gozan pensiones, y el rey de Francia da a la Academia de las Ciencias 264.000 reales anuales, sin contar las pensiones particulares que tiene asignadas a varios académicos $^{31}$. Allá basta esto, pero aquí es menester que por ahora el Gobierno lo haga todo, porque ningun Señor da de comer a literato alguno, y el público no paga los libros. Tenemos bastantes academias que se reducen a tertulias de pura conversación. Si sus individuos, en vez de ser unos meros aficionados que si trabajan algo es a ratos y sólo por un poquillo de honor, fuesen profesores que viviesen de las Letras, no tendrían excusa para no aplicarse. En el Plan general que va adjunto se apuntan algunas reflexiones sobre este punto que es muy esencial.

Se proponen veinticuatro plazas de Ciencias y doce de Buenas Letras, sin contar los dos presidentes y los dos secretarios. Las facultades, ciencias o profesiones que se señalan a cada plaza son las que parece deben entrar en el instituto del nuevo cuerpo. Omítese la Historia, porque hay en Madrid una Academia separada que no tiene otro objeto que éste, y omítese también la Política, porque esta ciencia se incluye en la Jurisprudencia, y hay razones para que no se forme de ella una facultad separada. En lo demás se ha procurado no olvidar ciencia alguna de las que pueden contribuir al lustre y utilidad de una nación culta.

30. Otra mano ha escrito en nota: "Posteriormente tomó a su cargo esta empresa D. José Clavijo Fajardo, desempeñándola con acierto". Se editó en Madrid, Joaquín Ibarra, 1786-1805, 21 vols.

31. La renta que señalaba Luzán en 1751 era de 230.500 reales al año (punto 27 ). 
Es muy de creer que no se hallen sujetos idóneos para ocupar las dos plazas que se destinan a cada facultad; pero, además de que debemos contentarnos con gente medianamente instruida, ya que no tenemos sabios de primer orden, puede también proveerse sólo una de las plazas y reservarse la otra hasta que se aparezca persona capaz de desempeñarla. Conviene que haya a lo menos dos profesores de cada ciencia, así para que supla uno en la ausencia o en la enfermedad de otro, como para evitar la parcialidad y acaso el despotismo que se introduciría naturalmente si uno solo fuese juez en su ramo ${ }^{32}$.

La clase que se propone de académicos adjuntos, parece de suma utilidad. En el primer establecimiento de la Academia de Ciencias de París, se nombraron académicos alumnos, o élèves (como ellos llaman). Después, en 1716, se quitaron los alumnos y se pusieron los adjuntos, que han probado muy bien.

Conviene que haya algunos Honorarios porque varios sujetos hábiles que no necesiten de la pensión de la Academia podrán trabajar en ella sólo por honor.

Igualmente conviene que haya correspondientes que suministren a la Academia, desde fuera de Madrid, las noticias que se les pidan; y últimamente es importante que haya la Junta de Gobierno, compuesta de individuos de la misma Academia, y de modo que ningún académico pueda quejarse de que no tiene parte en el gobierno del cuerpo, pues cuando se trate de algún punto tocante a su profesión, tendrá voto en la Junta cualquier académico de los facultativos pensionados de número.

32. La misma mano que escribió la nota anterior, redactó ésta: "En las repetidas conversaciones que D. Bernardo Iriarte (que fue quien sugirió al Sr. Conde de Floridablanca la idea de establecer esta Academia de Ciencias) tuvo con aquel caballero, insistió siempre en la necesidad de echar mano de algunos extranjeros hábiles para completar las plazas, especialmente por lo respectivo a las Ciencias Naturales, tan atrasadas entre nosotros. Esta insistencia era furiosa para vencer la repugnancia del Sr. Conde a todo lo extranjero y su antiguo odio personal a todo francés, sin distinción de individuos y talentos. Hubo, sin embargo, uno (Condom) a quien se entregó indebidamente y con general desaprobación". El financiero Juan Bautista Condom es objeto de crítica en el punto 15 de la Sátira tercera, cit., titulado "Canales. Fabricación de vales reales, pretextando su destino siempre perjudicial, y el hecho es que su valor me aprovecha con la dirección de mi amigo Condom, a quien no dejan pobre". Allí se dice: "el amigo, cuyo nombre callo por ser obsceno en francés, y no desconocido en las demás lenguas" (Floridablanca, 1856 , pág. 282b). Condom negoció la aportación económica del holandés Kroyenhoff a la obra del Canal Imperial. Los vales se emitieron al $4 \%$ de interés, cuando el capital reunido para realizar la obra se agotó. La única garantía de ellos fue el propio Canal y el compromiso de la Secretaría de Hacienda de pagar los réditos. Según Rumeu de Armas (1962, pág. 55), "su gestión económica fue siempre muy confusa, rayando en lo delictivo". En general, sobre el problema de los vales reales, Vid. Richard Herr (1978) y Eugene N. White (1987). 


\section{ESPECIES Y REFLEXIONES SUELTAS DE D. TOMÁS DE IRIARTE QUE SU HERMANO D. BERNARDO LEYÓ AL SR. FLORIDABLANCA SOBRE EL ESTABLECIMIENTO DE UNA ACADEMIA DE CIENCIAS Y BUENAS LETRAS.}

Apunto aquí algunas reflexiones que, aunque por ir escritas cálamo currente y según me van ocurriendo, podrán servir para dichas en conversación.

En la Academia de Madrid se excusa la clase de Artes, porque si éstas se entienden Artes liberales, ya las tenemos incluidas en la clase de las Ciencias, y si se entienden Artes mecánicas, no deben mezclarse en un mismo cuerpo con las otras, además de que en la Sociedad Matritense hay una clase que llaman de Oficios, que dicen se ocupa en este ramo, y no conviene injerirnos en los asuntos de aquella Sociedad, ni podemos abarcarlo todo. Si me pusiese a averiguar en qué otras ciudades hay academias que reunen las Ciencias y las Bellas [sic] Letras, hallaría todavía algunas más, porque sé que las hay, y las he visto citadas en papeles públicos que ahora no tengo presentes.

Aunque nadie ignora el abatimiento en que está aquí la Profesión Literaria ${ }^{33}$, debo decir lo que sobre esto observo para sacar después algunas consecuencias sobre la necesidad del establecimiento de la Academia y sobre el único medio que hay de hacerla útil.

Aquí no se conoce ni estima el trabajo del que hace un libro, y se conoce aún menos la importancia de que haya hombres que escriban. No creo que lo difinió mal el que dijo ${ }^{34}$, hablando de este país:
En donde el numen, gusto y fantasía,
la erudición y el literato juicio, solamente parecen
un divertido y frívolo ejercicio
de traviesos ingenios
que al impulso obedecen
de sus inclinaciones y sus genios;
y no móvil activo,
perenne manantial, causa primera
del buen gobierno, general cultivo,
dicha y honor de una nación entera.

Aquí creen que un autor "produce un libro como un árbol hojas" $35 ;$ y como (exceptuando alguno que, aunque autor, medre por otras causas) ven que los

33. Véase, por ejemplo, su Epístola III, de Septiembre de 1777: "A la verdad que a un mero literato/ las letras solas no darán un plato,/ no digo de faisanes y compotas, / pero ni aun de sardinas y bellotas" (vv. 18-21). Toda la pieza está dedicada a ese asunto (Tomás de Iriarte 1976, pág. 151).

34. "D. Tomás de Iriarte", aclara la misma mano que escribió las notas precedentes.

35. "Verso del mismo D. Tomás de Iriarte". No he podido localizar este verso. Los anteriores pertenecen al poema El egoísmo, fantasía poética, aunque los primeros son una variante de los que figuran en la edición de sus poesías, que son estos: "Donde la exactitud, la fantasía,/ sabia 
que escriben, no sólo no llegan por eso a ninguna alta fortuna, pero ni aun hallan qué comer si no abandonan la literatura para ocuparse en empleos de oficinas, etc., infieren mazorralmente que la tal literatura no es verdadera profesión, ni carrera, ni ocupación digan de que un hombre se mate por ella, si no una mera diversión, como tocar un instrumento, hacer juegos de manos, jugar bien a los naipes, etc. ${ }^{36}$. Ven al mismo tiempo que los empleos de descanso y utilidad se dan rara vez a hombres que hayan estudiado, y así ningún padre se esmera en que su hijo aprenda ni aun un poco de mal latín. De suerte que, a excepción de la Biblioteca Real, no hay carrera en que las humanidades den con qué mantenerse ${ }^{37}$. De aquí nace que todos molestan con empeños a los ministros para lograr acomodos de aquellos que sólo piden saber escribir y $\operatorname{contar}^{38}$.

Para desterrar esta preocupación es indispensable que la plebe (llamo plebe a todo el conjunto de los ignorantes) vea que el Ministerio piensa seriamente en los estudiosos, que les da medios de vivir; que hace caso de un libro bueno, al paso que desestima los malos y de mala crítica; que busca los literatos donde quiera que estén; que los honra con distinciones de obra y de palabra, y que da en esta parte un buen ejemplo a los Señores y a toda la nación. Para esto es menester dinero, y suponer que, así como el Erario se echa la carga

demostración, profundo juicio/ mero efecto parecen/ de un divertido y fútil ejercicio...", etc. Tomás de Iriarte, Colección de obras en verso y prosa de..., Tomo II, Madrid, Benito Cano, 1787, pág. 137. Este poema lleva una nota que tiene cierto interés: "Los versos que aquí se reúnen bajo el título de Fantasía poética se han entresacado de un poema filosófico-moral que el autor empezó a componer en el año de 1776, y que después no pudo continuar. No deben, pues, considerarse sino como primer ensayo, o tentativa de una obra que meditaba escribir con mayor formalidad y extensión" (pág. 129). De esta forma, los versos que se citan en el Plan pertenecerían a una versión anterior de "El egoísmo", ya que el escrito de Iriarte debió de redactarse entre 1779 y 1780. Agradezco al profesor Ángel L. Prieto de Paula que localizara para mí este pasaje poético.

36. Era opinión muy extendida que la de las letras no era una carrera ni una profesión. Sintetizando mucho de lo escrito durante el siglo en este sentido, y satirizándolo, Mariano Madramany y Calatayud escribió un papel titulado Nuevo ramo de industria cultivado por los adocenados escritores del día de pane quaerendo. Su autor Don Veracio Chacota, Madrid, José Herrera, 1787, en el que pasa revista a diferentes tópicos, como la proliferación de papelistas, la oposición paterna a que los hijos se dediquen a las Letras y otros nuevos asuntos de industria relacionados con ellas.

37. "El [bibliotecario] mayor [gana] más de mil pesos y [tiene] casa, los otros quinientos, y algunos de ellos también tienen casa, y no hay ninguno que no tenga su beneficio que le valga casi otro tanto; y el gramático, que es seglar [Juan de Iriarte], tiene tales adealas y agregados, que compone cerca de cuatro mil reales y se decía por muy cierto... que en la nueva planta [en 1761] se ponía al bibliotecario mayor treinta y seis mil reales de sueldo, a los demás mil pesos a cada uno...", (Lanz de Casafonda, 1972, pág. 73).

38. El padre Martín Sarmiento, en las Reflexiones ya citadas, alude a este mismo problema, observando que en las catedrales había sólo "cuatro prebendas de letras", cuyo valor no era mayor que el percibido por las "demás que no son de letras". Consideraba que las catedrales debían dedicar a las letras al menos la mitad de ellas. "Del mismo modo se podrá discurrir de otras píngües rentas eclesiásticas, que suele percibir un solo individuo. Aun se pudiera extender esta misma consideración, aplicando a hombres de letras muchas de las rentas seculares públicas, que se suelen dar al primero que se presenta a pedirlas" (1789, pp. 157-158). 
de un tribunal nuevo, o de una fábrica, o de otro establecimiento semejante de los que cada día están plantificando a costa suya, se echa también la carga de premiar a los que trabajan en todo lo que pertenece al entendimiento humano. Se asegura que Luis XIV gastaba anualmente en los años florecientes de su Imperio más de cinco millones de libras destinados a pensiones concedidas a cuerpos literarios, y a particulares que seguían las Letras; de suerte que llegó el caso de que el Parlamento le representase que era excesivo aquel gasto, a lo que replicó el Soberano que "aquello era poner su dinero a ganancia, y que le daría mil por uno, refundiéndose todo en la riqueza que ganaría su nación, además del crédito que adquiriría". En España, donde hay más obstáculos que vencer que los que había en Francia, ¿qué dinero no se necesitaría para hacer otro tanto? Pero contentémonos con que se destine alguna suma a tan loable y necesario fin, $y$ con que los padres sepan que dando buenos estudios a sus hijos les dejan, si no un patrimonio píngüe, a lo menos un medio decente y seguro de no morirse de hambre. Mientras no haya esto, no espero cosa de provecho.

Es muy fácil establecer academias de conversación (como las he llamado en mi Plan). En cualquiera ciudad en que hay quince o veinte caballeretes desocupados que sepan un poco de latín y otro poco de francés se puede armar una academia de esta especie, v.g. como la Histórico-Geográfica de Caballeros de Valladolid ${ }^{39}$. Uno que gusta de que le llamen académico de número, de mérito, de honor, etc.; otro que desea lucir con cuatro párrafos de un discurso, bien o mal hilado, y por lo regular robado de algún libro francés; otro que gusta de verse impreso de letra de molde, como yo gustaba cuando sabía menos que ahora lo que es escribir; y otro, en fin, que cree que en diciendo "yo me soy académico de allá, o de acullá" adquiere el derecho de aprobar o reprobar decisivamente lo que se le antoja, y sojuzgar en las disputas a cualquiera que sin ser académico sabe más que él; todos estos, digo, se unen facilísimamente, porque así se distraen en algo, logran que se hable poco o mucho de ellos y, aunque en su vida tomen la pluma, mueren con la satisfacción de que han sido tan académicos como D'Alembert. Yo no sé si estas causas, unidas al deseo de ser hombres públicos, han influido en la abundancia de Sociedades Económicas, cuya erección se ha hecho moda en nuestros días ${ }^{40}$. Un solo cuerpo que, en lugar de exigir dinero, le diese, y que en vez de meterse a reimpresor de libros (como la Academia Española), compusiese y publicase los que nos hacen falta, corrigiéndolos mejor que ella su Gramática, sería verdadera Academia útil, de quien la nación podría esperar progresos importantes. Yo sería de parecer de que si llegase el caso de establecer la Academia proyectada, se prohibiese todo

39. Sobre esta Academia, Celso Almuiña Fernández (1974, pp. 33-36).

40. Iriarte alude a un proceso que estaba comenzando en esas fechas y que, a partir de entonces, caracterizará al hombre de letras o, más en general, al hombre de cultura: su nueva condición de hombre público, anteriormente apenas conocida por algunos dramaturgos. 
lo que sea habladuría, cumplimientos, elogios, etc. En el día de la abertura [sic] se debería leer un discurso corto, y después ponerse a trabajar sin hablar más palabra; de modo que, a los ocho días, hubiese cuarenta plumas enarboladas y, antes de un año, empezasen a salir libros y más libros, traducidos u originales, continuando en trabajar de este modo, sin contestar a necios, ni a malsines hasta que la abundancia y bondad de las obras de la Academia impusiese silencio a unos y a otros. Entonces empezarían a oírse elogios, no impresos por ella misma, como se nota en otras academias, sino formados por la voz pública de hombres ya desengañados a fuerza de ver buenos efectos del bueno establecimiento.

Otras mil reflexiones me ocurren...; pero todas se reducirán a nada si no nos ponemos de acuerdo en lo principal, que es el fondo. Me hago cargo de que es mucho lo que se necesitaría para costear los gastos del nuevo Cuerpo, los cuales consistirían en cinco objetos: $1^{\circ}$ Pensiones; $2^{\underline{0}}$ Fondo para impresión de obras; $3^{\circ}$ Fondo para alquiler de casa y gastos indispensables, así de dependientes como de escritorio, carbón, esteras, etc.; $4^{2}$ Fondo para librería, algunas máquinas e instrumentos y otros menesteres para el ejercicio de las Ciencias; y $5^{\underline{a}}$ Fondo para proponer premios anuales a los que escribiesen sobre asuntos dados por la Academia. Conozco que todo esto no se podrá costear de golpe, y que sería mucho pedir, pero, aunque no se considere más que el punto de las pensiones, dadas a treinta y ocho individuos (porque los dos presidentes serían sin sueldo y sólo por honor a causa de elegirse sujetos de conveniencias) se hallará que levantará mucho la suma que para esto se necesita. También es de advertir que a muchos de los literatos empleados en la Academia no se podría dar pensión bastante para que se mantuviesen con decencia; pero para eso están los empleos que llaman bobos, y los beneficios simples, o para simples, que se deberían dar con preferencia a los académicos más hábiles. Más digo: que siempre que el Ministerio pudiese acomodar a algún literato en algún destino que, dándole que comer, le dejase sobrado tiempo para ocuparse en las tareas del Cuerpo, se dispondría que no cobrase la pensión y continuase en ser académico, de modo que a él le saliese la misma cuenta que si percibiese la recompensa por la Academia; a ésta se la seguía el beneficio de poder invertir aquella pensión en impresión de libro o en otros gastos útiles y necesarios, y al Ministerio sería fácil, sin gravar el Erario, premiar con semejantes empleos a hombres de provecho, en vez de darlos, como pudiera, a gente negada que sólo sirve de carga al Estado. Para esto convendría que todos los ministros pensasen debidamente ${ }^{41}$.

41. Recuérdense las palabras antes citadas de Sarmiento, en el mismo sentido. Es posible encontrar en el AHN peticiones de "oficios literarios", que suelen ser secretarías, puestos de embajadas y otros similares. 


\section{APUNTAMIENTOS SOBRE EL PROYECTO DE ESTABLECIMIENTO DE UNA ACADEMIA DE CIENCIAS Y BUENAS LETRAS EN MADRID $^{42}$.}

1. La reunión de las Ciencias y las Buenas Letras en un Cuerpo que abrace unas y otras, semejante a las que hay en Berlín, Rouen, Toulouse, Besançon, Lyon, Bordeaux y otras ciudades, parece el único medio de fomentar en España las facultades que se fundan ya en el juicio, exactitud y solidez, ya en el ingenio, erudición y buen gusto, de suerte que se atienda a un mismo tiempo a lo útil, y a lo agradable.

2. Este pensamiento puesto en práctica no dejará excusa a la desaplicación, congregará los pocos hombres doctos que tenemos, facilitará la extensión de sus luces a los jóvenes que emprendan la profesión literaria, y les proporcionará una carrera decorosa que seguir con provecho suyo y de la nación, y adquiriendo gloria para sí, y para ella.

3. No debemos pretender que desde luego se forme un Cuerpo de sabios capaces de competir con los de las academias de Londres, París, Berlín, etc. Basta que, recogiendo de todas partes los hombres medianamente instruidos que nos quedan, se establezca un plantel que siempre se renueve y crezca, para evitar la decadencia a que caminan las Ciencias y Buenas Letras por falta de premio, y para que logren los venideros el fruto que en nuestros días no logramos por incuria de los que mandaban en los siglos anteriores.

4. Por consiguiente, debemos proponernos el fin de formar hombres, el cual no puede conseguirse de otro modo que premiando a los que hay para que otros se animen, y no se pierda enteramente la casta (digámoslo así) de los sabios.

5. Es indubitable que sólo dos móviles son capaces de impeler a los hombres a cosas grandes: el interés y la gloria. La gloria sola puede ser bastante estímulo para los que ya tienen conveniencias; mas, para los que carecen de lo necesario, lo primero es el interés; y, como cualquier ramo de literatura requiere que el hombre se aplique exclusivamente a él, sin distraerse a otros cuidados, resulta que todo literato que se vea precisado a buscar que comer con otra cosa que con las Letras, jamás llegará a aquel grado de inteligencia magistral que sólo se adquiere con el estudio incesante. Todos los que ganan su vida en destinos ajenos de la Literatura, y quieren dedicarse a ella, son y deben ser literatos a medias, y sus obras suelen salir

42. Este plan lleva el número 1 y el siguiente comentario en papel aparte: "comprehende demasiadas cosas, pero hay especies útiles". 
diminutas $^{43}$, o poco exactas, como hechas a ratos perdidos, o por mero entretenimiento. Así vemos, por ejemplo, que la Gramática castellana publicada por la Academia de la Lengua es defectuosísima, porque la ordenó un hombre que empleaba las horas más útiles del día en la obligación de una oficina, y la revisaron en una lectura rápida e interrumpida otros hombres empleados en otras oficinas y destinos semejantes, y que no podían haber aprobado aquella obra, si la hubieran examinado y corregido con entera quietud y meditación en el retiro de su gabinete ${ }^{44}$. Con todo, es menester agradecer a estos académicos que hayan hecho aquel libro tal cual es, porque ninguno de ellos vive del oficio de literato ${ }^{45}$, y cumple con manifestar su celo, ya que no puede hacer un estudio profundo en los cortos ratos que roba a sus obligaciones. Al contrario, se nota que los grandes literatos lo han sido porque su único oficio era serlo, y ni Newton tuvo más ocupación que la Física y la Astronomía, ni Linneo más que la Botánica, ni Boileau más que la Poesía, ni Rameau más que la Música.

6. Sentados estos supuestos, la Academia de Ciencias y Buenas Letras de Madrid, no deberá ser un cuerpo (como muchos que hay en el reino) compuesto de individuos que contentándose con el vano título honorífico de académicos, le desempeñen o no cuando puedan o como quieran o como sepan, sino de verdaderos profesores, cuya primera obligación sea trabajar en la instrucción de su nación con la actividad correspondiente a la recompensa que se les asigne como a tales profesores, y no como a meros aficionados. Es preciso que el gobierno les dé de comer, durante algunos años; pues cuando ya se haya extendido la ilustración y el gusto a las Letras, cuando haya gran número de lectores, que ahora no tenemos, y cuando por consiguiente logren despacho los buenos libros que hoy pocos impresores se atreven a costear, porque se lee muy poco, y se estudia menos, el público mismo mantendrá a los literatos comprando sus obras, y los que por estar ya bien acomodados no necesiten el estímulo del interés pecuniario, podrán trabajar meramente por la gloria, supuesto que hallarán lectores

43. Diminuto: "Defectuoso y falto de lo que debía tener para su cabal perfección. Ordinariamente se aplica a los tratados, discursos y autores", Diccionario de Autoridades, s.v.

44. Cotarelo (1897, pág. 232, nota 1) piensa que se refiere a Luzán; sin embargo, éste había muerto en 1754, mientras que la primera edición de la Gramática apareció en 1771. Y, aunque Luzán tuvo un importante papel en la elaboración del tratado de la Academia, no puede imputársele su composición, ni todos sus errores, principalmente si tenemos presente que los académicos siguieron trabajando en dicha obra durante casi veinte años más después de la desaparición de Luzán. Él mismo se refería a la necesidad de "perficionar lo que hay trabajado de la Gramática", en su Plan de una Academia..., vid. Carnero (1990, pág. 170). Para la labor de Luzán en los trabajos académicos, vid. Álvarez Barrientos, "La aportación de Ignacio de Luzán a la Ortografía y la Gramática de la Academia" (en prensa).

45. Iriarte es de los pocos que habla del oficio de escritor, y lo entiende como profesión. Obsérvese, de paso, el amplio sentido del término literato, en consonancia con la significación que se daba a la palabra literatura. 
que se la den ${ }^{46}$. Las pensiones y honores que en tiempos de Luis XIV y de sus ministros Louvois y Colbert se concedieron a los literatos, animaron entonces a los escritores y obligaron a los padres a dar buena enseñanza a sus hijos. Después se ha disminuido mucho aquellos premios, pero como a la sazón está difundido el gusto y el amor a la lectura, la misma nación, más que el Ministerio, es quien alienta y recompensa a los sabios, ya que la Literatura es allí realmente una carrera útil como lo son en España las oficinas, y el comercio de libros ha atraido inmensos tesoros y crédito a aquella Monarquía.

7. La Academia de Ciencias y Buenas Letras, cuyo establecimiento formado según estas ideas proporcionará con el tiempo a los estudiosos honor y provecho, debería fundarse conforme al Plan siguiente, en que sólo se indica la disposición general de ella, sin descender a los estatutos particulares que habrán de arreglarse para su gobierno.

La Academia se dividirá en dos clases: una de Ciencias, que será la más numerosa, y otra de Buenas Letras, que no lo será tanto. Cada clase tendrá su Presidente y su Secretario; y celebrará sus juntas particulares ordinarias en sala separada, no debiéndose celebrar Junta General de las dos clases unidas sino de tiempo en tiempo, como v.g. una vez cada mes.

II

En la clase de Ciencias habrá los 26 individuos siguientes:

un Presidente,

un Secretario,

24 académicos, profesores de varias facultades, en esta conformidad:

2 de Matemáticas en general,

2 de Cosmografía, Astronomía y Geografía,

2 de Mecánica,

2 de Física,

2 de Química e Historia Natural,

2 de Botánica y Farmacia,

2 de Fisiología, Anatomía y Medicina,

2 de Filosofía racional y moral,

2 de Teología e Historia eclesiástica,

2 de Jurisprudencia y Cánones,

2 de Fortificación y Táctica militar,

2 de Música

46. Floridablanca debió de leer, en efecto, estas páginas de Tomás de Iriarte porque hace la misma observación en algunos de los comentarios que escribió, al margen, en las peticiones que le dirigieron algunos escritores suplicándole alguna ayuda o la posibilidad de dedicarle sus obras. 
La clase de Buenas Letras tendrá los siguientes individuos:

un Presidente,

un Secretario,

12 académicos, con esta distribución:

3 de Crítica e Historia literaria, principalmente de España,

3 de Gramática general y particular, de Retórica y de buen estilo,

2 de Lenguas sabias,

2 de Poesía,

2 de Antigüedades e Inscripciones.

\section{2}

Suman los individuos de ambas clases 40, cuyo número se podrá acaso reducir, ya sea no destinando a alguna de las dichas facultades más que una sola plaza en lugar de dos o tres, o ya reuniendo en un mismo sujeto dos facultades que sean análogas, o en que pueda haber personas igualmente versadas.

El Protector de la Academia deberá ser siempre el Primer Secretario de Estado.

Habrá algunos académicos honorarios que nunca podrán ser en número superior al de los pensionados, para evitar que se convierta este Cuerpo en sociedad numerosa de gentes que sólo quieran el título honorífico de académicos, sin trabajar como verdaderos profesores; y así v.g. en la clase de Ciencias podrá limitarse el número de los honorarios a quince o veinte, y en la de Buenas Letras, a ocho o diez.

Para impedir lo menos que sea dable las tareas de los académicos de número, que deben entregarse a sus respectivas facultades sin distracción ninguna, se compondrá una Junta de Gobierno que cuide de los asuntos económicos del cuerpo, reparta las comisiones, represente a S.M. y al protector de la Academia en nombre de toda ella, etc. Pudiera componerse esta Junta de los sujetos siguientes:

El Presidente de Ciencias,

El de Buenas Letras,

El Secretario de Ciencias,

El de Buenas Letras,

2 individuos honorarios, uno de Ciencias, y otro de Buenas Letras, Otros dos pensionados, uno de Ciencias, y otro de Buenas Letras. 
Cuando en esta Junta se examine algún punto relativo a determinada facultad, se llamará a ella a uno de los académicos profesores de la tal facultad, de suerte que todos puedan tener entrada y voto en la Junta, siempre que se trate de asuntos que toquen a su respectivas profesiones, y cuando en la misma Junta se haya de ver alguna obra hecha por cualquier académico, se le citará para que asista y pueda dar razón de su obra, oir los reparos, aclarar las dudas que tenga la Junta, etc.

\section{VI}

Además de los pensionados y honorarios, habrá una clase de académicos adjuntos o asociados, los cuales, trabajando para el Cuerpo sin pensión alguna, harán mérito para obtenerla algun día, según su habilidad y adelantamiento, en las vacantes que ocurran; bien que no ha de ser condición precisa que todo el que entre a ser académico pensionista haya de haber sido antes adjunto o asociado. Estos adjuntos deberán ser, cuando más, otros tantos como los pensionados; y se procurará admitir en esta clase personas jóvenes que descubran buenas disposiciones y tengan ya suficientes principios, y adjudicarlos a las varias facultades, ya de Ciencias, ya de Buenas Letras, como por ejemplo, uno o dos a las Matemáticas, otros tantos a la Física, otros tantos a la Poesía, etc. De este modo se irán criando literatos que con la esperanza bastante fundada de suceder en la pensión y en la plaza a los académicos facultativos de número y con los ejemplares que advertirían de ser preferidos los hábiles y estudiosos, y postergados o nunca atentidos los inhábiles e indolentes, se aplicarían útilmente, formándose al lado de hombres expertos. Este parece el mejor medio de renovar siempre los literatos.

\section{VII}

Habría últimamente otra clase de académicos correspondientes, como los hay en casi todas las academias, de suerte que la de Ciencias y Buenas Letras vendrá a tener cuatro clases de individuos:

I. Pensionados.

II. Honorarios.

III. Adjuntos o Asociados.

IV. Correspondientes.

VIII

Los pensionados se deberán elegir proponiendo la Academia para cada plaza dos o tres sujetos en consulta hecha a S.M. por mano de su Protector Primer Secretario de Estado.

Los honorarios y los adjuntos se nombrarán precediendo votación de la Academia y beneplácito del Protector sin consultar al rey; y los correspondientes se elegirán por la Academia sola. 
Cuando se hayan meditado, corregido y aprobado estos puntos generales, se podrá tratar de extender los estatutos del Cuerpo, y determinar cuáles han de ser sus tareas, suponiendo desde luego que la principal ocupación de la nueva Academia ha de ser por ahora traducir bien los mejores libros elementales de las Ciencias, y Artes liberales, sin cuyo principio nada podrá adelantarse en la Instrucción Pública, ni lograrse el fin de formar hombres hábiles, que es el principal objeto de la Academia.

\section{BIBLIOGRAFÍA}

AGUILAR PIÑAL, Francisco. 1966. La Real Academia Sevillana de Buenas Letras en el siglo XVIII, Madrid, CSIC.

- 1988. "El mundo del libro en el siglo XVIII", en Varia bibliographica. Homenaje a José Simón Díaz, Kassel, Edition Reichenberger, pp. 25-33.

ALMUIÑA FERNÁNDEZ, Celso. 1974. Teatro y cultura en el Valladolid de la Ilustración. Los medios de difusión en la segunda mitad del siglo XVIII, Valladolid, Ayuntamiento.

ÁLVAREZ BARRIENTOS, Joaquín (en prensa). "La aportación de Ignacio de Luzán a la Ortografía y la Gramática de la Academia", en Ignacio de Luzán. Obras raras y desconocidas, II, coord. Guillermo Carnero, Zaragoza, Inst. Fernando el Católico.

- (en prensa). "El padre Francisco de Villalpando y el proyecto de fundación de un Academia de Ciencias y Letras de Madrid", en Homenaje al prof. Caso González.

CARNERO, Guillermo. 1990. "Plan de una Academia de Ciencias y Artes", en Ignacio de Luzán. Obras raras y desconocidas, I, Zaragoza, Inst. Fernando el Católico, pp. 139-184.

CARRACEDO CARRACEDO, Mª Teresa. 1974. Disertaciones leídas en la Real Academia Sevillana de Buenas Letras (1751-1874), Sevilla, Real Academia.

COTARELO Y MORI, Emilio. 1897. Iriarte y su época, Madrid, Rivadeneyra.

DIDEROT, Denis. [1763] 1975. Lettre historique et politique adressée à un magistrat sur le commerce de la librairie, son état ancien et actuel, ses règlements, ses privilèges, les permissions tacites, les colporteurs, le passage des ponts et autres objets relatifs à la police littéraire, en Oeuvres complètes, VIII, eds. $\mathrm{H}$. Dieckmann, J. Fabre, J. Proust et J. Varloot, Paris, Husmann, pp. 479-567.

FARAUDO DE SAINT-GERMAIN, Luis. 1953. "La historia literaria en la Real Academia de Buenas Letras", Boletín de la Real Academia de Buenas Letras, XXV, pp. 391-420.

FLORIDABLANCA, conde de. 1856. Obras originales del... y escritos referentes a su persona, coleccionados por D. Ángel Ferrer del Río, BAE, 59. 
GIL NOVALES, Alberto. 1980. "El concepto de Academia de Ciencias en el siglo XVIII español", BOCESXVIII, 7-8, pp. 3-23.

GUILLÉN TATO, Julio. 1940. "Juan y Ulloa y los precedentes del siglo XVIII de la Real Academia de Ciencias", Revista de la Real Academia de Ciencias Exactas, Físicas y Naturales, 34, pp. 440-460.

HERR, Richard. 1978. "El experimento de los vales reales (1708 a 1808)", Moneda y Crédito, pp. 115-124.

IRIARTE, Tomás de. [1773] 1805. Los literatos en Cuaresma, en Colección de obras en verso y prosa VII, Madrid, Imp. Real, pp. 3-96.

- 1976. Poesías, ed. Alberto Navarro González, Madrid, Espasa-Calpe (Clásicos Castellanos).

LANZ DE CASAFONDA, Manuel [1761] 1972. Diálogos de Chindulza, ed. Francisco Aguilar Piñal, Oviedo, Cat. Feijoo.

OZANAM, Didier. 1962. “L'ideal académique d'un poète éclairé: Luzán et son projet d'Academie Royale des Sciences, Arts et Belles Lettres, 1750-1751", BHi, 64bis, pp. 188-208.

RIQUER, Martín de. 1953. "Breve historia de la Real Academia de Buenas Letras de Barcelona", Boletín, cit., XXV, pp. 275-304.

ROCA, Pedro. 1899. “Orígenes de la Real Academia de Ciencias Exactas, Físicas y Naturales (Historia científica del primer gobierno de Fernando VI)", en Homenaje a Menéndez Pelayo, II, Madrid, V. Suárez, pp. 845-940.

RUMEU DE ARMAS. Antonio. 1962. El testamento político del conde de Floridablanca, Madrid, CSIC.

- 1980. Origen y fundación del Museo del Prado, Madrid, Inst. de España.

SARMIENTO, Martín. [1743] 1789. "Reflexiones literarias para una Biblioteca Real, y para otras bibliotecas públicas, hechas por el Reverendo Padre Maestro Fray..., benedictino, en el mes de Diciembre del año de 1743", Semanario erudito, XXI, pp. 99-273.

SEMPERE Y GUARINOS, Juan. 1789. Ensayo de una biblioteca de los mejores escritores del reinado de Carlos III, VI, Madrid, Imp. Real.

WHITE, Eugene N. 1987. “ ¿Fueron inflacionarias las finanzas estatales en el siglo XVIII? Una nueva interpretación de los vales reales", Revista de Historia Económica, 3, pp. 509-526. 



\title{
LOS DOGMAS NEOCLÁSICOS EN EL ÁMBITO TEATRAL*
}

\author{
Guillermo CARNERO \\ Universidad de Alicante
}

\section{EI Neoclasicismo, una estética blindada}

El problema básico al que nos hemos de enfrentar en el momento de penetrar en el universo literario del Neoclasicismo no es el de exponer y desentrañar las leyes que constituyen el sistema que lleva ese nombre, sino algo previo e imprescindible: definir y, naturalmente, admitir la perspectiva desde la que fue formulado. Las leyes neoclásicas no tiene en sí mismas dificultad, pero sí la tiene el asentimiento a esa perspectiva. Si el espectador equivoca el ángulo visual, el espectáculo resulta deforme y grotesco. Lo mismo sucede cuando miramos de frente y desde lejos una fachada barroca que fue diseñada para ser mirada desde cerca y desde abajo en una calle estrecha; o ante el cuadro de Holbein llamado Los Embajadores, donde la absurda forma entre los dos personajes resulta ser, desde abajo y desde la izquierda (posición en que se encontraba, en el lugar para el que fue pintado, la puerta por la que el espectador tenía forzosamente que pasar, y desde la cual dirigía una última mirada a ese cuadro que lo había ido inquietando progresivamente a medida que avanzaba hacia ella por una sala alargada), un cráneo humano, símbolo de la vanidad del poder.

En lo que respecta al Neoclasicismo, la Historia nos ha ido desdibujando sistemáticamente la perspectiva. Los románticos del XIX la convirtieron en caricatura: véase el artículo que Espronceda publicó en El Artista de 1835 con el título de El pastor Clasiquino, contra el último representante del Neoclasicismo

* Este estudio se escribió para el volumen de Siglo XVIII de una Historia de la Literatura Española donde aparece reducido, sin intervención en ello de su autor, a la cuarta parte de su extensión. Lo damos íntegro porque dicha reducción no refleja los conocimientos que lo sustentan ni los matices del pensamiento que pretende exponer. 
en la España de su tiempo, Don José Mamerto Gómez Hermosilla. Los escritores e historiadores de la Literatura del XIX nos legaron el tópico de la falta de originalidad y de calidad del siglo XVIIr, repetido como dogma de fe hasta no hace mucho; para Menéndez Pelayo y Emilio Cotarelo, neoclásico es sinónimo de antinacional, extranjerizante y literariamente deficiente, frente al genio "español" de Ramón de la Cruz; y desde el siglo XIX, la conversión de la literatura en mercancía competitiva ha tendido a exaltar, como valor supremo, la originalidad independiente de todo precepto creativo, es decir, la actitud diametralmente opuesta a la neoclásica.

Para asumir la perspectiva neoclásica es preciso partir de tres dogmas básicos, previos a las reglas en las que se articula la teoría literaria del Neoclasicismo.

1. Un radicalismo y una intolerancia que, en una primera aproximación, pueden resultar sorpendentes o repugnantes, pero que se legitiman por estar basados en la tradición de la Antigüedad grecolatina, en la razón y en las exigencias de la psicología del destinatario de la literatura; tres ejes de coordenadas supuestamente fijos y con respecto a los cuales el discurso neoclásico se define como de trayectoria única e invariable, y válida para cualquier tiempo y cualquier lugar. Ningún factor de relativismo (diferentes culturas, literaturas, peculiaridades de los caracteres nacionales) puede afectarla, y debe imponerse sobre los usos aberrantes que la ignorancia, la inercia tradicional o la sumisión a una demanda de entretenimiento mal entendida hayan podido establecer. Los neoclásicos (y hay que decirlo sin temor) legislaron en cuestiones literarias para el Universo y para la Eternidad; creyeron que, partiendo de una correcta definición de la función social de la literatura, de un planteamiento realista de los requisitos del asentimiento de su destinatario y de una correcta aplicación de la razón para lograr lo primero con subordinación a lo segundo, las conclusiones sólo podían ser unas; y creyeron también que su época estaba llamada a establecerlas de una vez por todas, porque por primera vez en la Historia presenciaba la humanidad la aurora de una nueva era en la que lo justo y lo razonable brillarían con el resplandor de un sol universal, dejando de ser el candil de una minoría incomprendida y aislada.

Así habla Juan José López de Sedano, en el prefacio a su tragedia Jahel (1763), de las "sólidas e inalterables reglas del arte" (pág. VII) desde las cuales es necesario reformar el teatro, que en su imperfección es "vergüenza y oprobio de un siglo tan ilustrado como el presente" (pág. XLVII). Y escribe Luzán que los preceptos de la Poética "en todas partes son, o a lo menos deben ser, unos mismos" (1977, pág. 148; cito siempre por esta edición); que "son tales y tan conformes y ajustados a la razón natural, a la prudencia, al buen gusto y al paladar de los mejores críticos que sería especie de desvarío querer inventar nuevos sistemas" (pág. 152); y que 
se distinguen con tan evidente diferencia que será bien ciego o muy apasionado el que no conozca y confiese la solidez, la racionalidad, la congruencia y simetría con que arreglaron los antiguos sus principios, y la irregularidad y extravagancia de los que han seguido ciegamente al vulgo en nuestros teatros. Libre será a cualquier poeta componer sus comedias según el sistema que más se acomodare a su discurso, a su capricho o al paladar del vulgo; pero en todos tiempos habrá entendimientos instruidos y superiores al vulgo, que harán justicia a lo que se funda en razón y no lo confundirán con lo que merece desprecio (pág. 427).

Por su parte, Nicolás Moratín considera que las reglas son consecuencia natural de la razón, y tan irrebatibles como la Ley de la Gravedad:

Para que las obras arregladas no agraden es menester que la omnipotencia de Dios trastorne y pervierta todo el orden de la Naturaleza, porque el arte está fundado en ella y una obra con arte es lo mismo que decir una obra buena (Desengaño I, pág. 8).

2. Los neoclásicos creyeron que su época estaba llamada a realizar, entre otras, una reforma de los usos y comportamientos sociales, y a configurar un nuevo tipo de ciudadano más solidario, más cívico y más feliz. Esa reforma debía hacerse, por supuesto, poniendo en pie los instrumentos legales y coactivos adecuados, pero también intentando modificar la mentalidad colectiva por medio de la educación y la persuasión. Se puede persuadir por medio de un discurso teórico, pero este procedimiento tendrá siempre el inconveniente de exigir un destinatario con superior capacidad intelectual y con voluntad de ser instruido, o sea un destinatario minoritario.

Para llegar a la mayoría, a la que es indiferente la instrucción, es mejor utilizar el tradicional procedimiento indirecto de enseñar deleitando: utilizar el arte - la literatura de modo que la enseñanza se adquiera involuntariamente, por ósmosis. En una sociedad como la del XVIII existen dos medios tradicionales de comunicación de masas: el púlpito y el teatro (y empieza a imponerse un tercero: la prensa periódica). El mensaje neoclásico va a utilizar el teatro como cauce de recepción mayoritaria, porque el teatro es el género literario más accesible; se recibe pasivamente, sin necesidad de abrir un libro; se recibe por la vista y el oído, de modo que alcanza incluso a los analfabetos; y lo recibe un mayor número de personas y con mayor frecuencia, porque el teatro es una de las distracciones básicas del pueblo y un acto social habitual para las demás clases sociales.

Para que el teatro cumpla su misión educadora se requieren dos cosas: 1) que, aun siendo el entretenimiento o la diversión del espectador una finalidad legítima y necesaria, nunca se pierda de vista que está subordinada a la mejor transmisión del mensaje, y por lo tanto nunca debe ese entretenimeinto salirse de cauce impidiendo la transmisión del mensaje, o transmitiendo uno inmoral o ambiguo; 2) que la obra dramática debe estar confeccionada de modo que el espectador, sin proponérselo, interiorice y haga suyo psíquicamente el mensaje; es decir, que se logre la identificación del espectador con el discurso dramático 
$o$, en otras palabras, que se impida su distanciamiento. De estas exigencias, la primera explica la hostilidad de los neoclásicos hacia el teatro del Siglo de Oro, y la segunda la razón de ser de las famosas "reglas" neoclásicas, especialmente las llamadas "tres Unidades".

La función didáctica del teatro es uno de los tópicos más repetidos en las poéticas y manifiestos del Neoclasicismo. En la Poética de René Rapin:

La poesía debe agradar para así ser útil, y el placer que produce es un medio a través del cual instruir. Así toda poesía perfecta debe necesariamente ser una lección pública de buenas costumbres para educar al pueblo. La poesía heroica propone el ejemplo de las grandes virtudes y los grandes vicios, para incitar a los hombres a amar las primeras y detestar los segundos [...] La tragedia [...] enseña a los hombres que el vicio nunca queda sin castigo [...] y que los favores de la fortuna y las grandezas del mundo no son siempre bienes verdaderos [...] La comedia, que es representación de la vida diaria, corrige los vicios corrientes (1970, pág. 23 - traducción mía).

En los Elementos de Literatura de Jean-François Marmontel:

Aunque el propósito inmediato del espectáculo teatral sea divertir, agradar o emocionar, no es éste su fin último, sino el de dejar al espectador más instruido, más sabio y más formado [...] El placer que obtiene el espectador al emocionarse o regocijarse es la miel con que se unta el borde del vaso en el que se administra una medicina. Los pueblos infantiles no pretenden más que lamer la miel. Los pueblos racionales quieren algo más que distracciones estériles y frívolas [...] quieren espectáculos que les dejen sensaciones útiles, que exalten su espíritu y su alma $[. .$.$] en una palabra, que$ los instruyan (1867, I, pág. 90 - traducción mía).

En la Jahel de Sedano:

[La reforma del teatro es asunto] en que se interesa nada menos que las buenas costumbres y una gran parte del decoro literario de la nación (pág. XLVI).

\section{En el Pensamiento 9ํ de El Pensador de José Clavijo y Fajardo:}

Un corazón acostumbrado a los impulsos de la cátharsis trágica, nacidos de la frecuente magia con que el teatro lo conmueve, se hace más dulce, más benéfico, más piadoso. Allí desenvuelve todas las virtudes morales cuya semilla tenía en el corazón [...] La buena comedia es tan capaz de reformar un pueblo y de mantenerlo reformado, como la que presenta malos ejemplos es capaz de pervertirlo o mantenerlo corrompido (I, pp. 10-11 y 15).

En la Memoria para el arreglo de la policía de los espectáculos y diversiones públicas de Jovellanos:

Un teatro donde pueden verse continuos y heroicos ejemplos de reverencia al Ser supremo y a la religión de nuestro padres, de amor a la Patria, al Soberano y a la constitución: de respeto a las jerarquías, a las leyes y a los depositarios de la autoridad; de fidelidad conyugal, de amor paterno, de ternura y obediencia filial [...] En una palabra, hombres heroicos y esforzados, amantes del bien público, celosos de su libertad y sus derechos, y protectores 
de la inocencia y acérrimos perseguidores de la iniquidad [...] Un teatro tal, después de entretener honesta y agradablemente a los espectadores, iría también formando su corazón y cultivando su espíritu; es decir, que iría mejorando la educación de la nobleza y rica juventud que de ordinario le frecuenta (1963, pág. 496).

En el texto antes citado de Clavijo se decía que, dada la importancia del teatro en materia de moral colectiva, la dirección del mismo "debía ser uno de los principales objetos del gobierno". A este respecto es un documento paradigmático la carta dirigida por Leandro Moratín a Manuel Godoy el 20 de Diciembre de 1792:

El estado en que hoy día se halla el teatro español es tal que no hay hombre medianamente instruido que no convenga en la urgente necesidad de su reforma. Los abusos que se han introducido en él nacen en la poca atención que ha mereceido al gobierno un objeto tan importante [...] Nadie ignora el poderoso influjo que tiene el teatro en las ideas y costumbres del pueblo: éste no tiene otra escuela ni ejemplos más inmediatos que seguir que los que ve allí, autorizados en cierto modo por la tolerancia de los que gobiernan. Un mal teatro es capaz de perder las costumbres públicas, y cuando éstas llegan a corromperse es muy difícil mantener el imperio legítimo de las leyes, obligándolas a luchar continuamente con una multitud pervertida e ignorante [...] Arreglado y dirigido como corresponde producirá felices efectos no sólo a la ilustración y cultura nacional, sino también a la corrección de las costumbres y, por consecuencia, a la estabilidad del orden civil, que mantiene los estados en la dependencia justa de la suprema autoridad (1973, pp. 141-144).

En resumen, que el teatro es escuela de moralidad, no sólo en el ámbito privado sino también en el cívico, y por lo tanto es asunto directamente relacionado con la estabilidad social y el orden público. La autoridad debe, pues, diseñar una política teatral, creando instituciones conducentes a la reforma del teatro, concediendo recompensas a los dramaturgos correctos, estimulando la puesta en escena y la publicación de las obras acertadas y prohibiendo la difusión de las que no lo son.

Ignacio de Luzán participa de estos ideales, con la salvedad de que en su tiempo (murió en 1754) aún no era un dogma establecido el de la intervención activa del poder en materia teatral, como lo sería en la segunda mitad del siglo con la prohibición de los autos sacramentales y las comedias de magia y el ambicioso Plan de 1799.

\section{Dice Luzán en la Poética:}

Sólo del feliz maridaje de la utilidad con el deleite nacen, como hijos legítimos, los maravillosos efectos que en las costumbres y en los ánimos produce la perfecta poesía [...] Todas las artes, como es razón, están subordinadas a la política, cuyo objeto es el bien público, y lo que más coopera en la política es la moral [...] El poeta puede, y debe siempre que tenga ocasión oportuna, instruir a sus lectores, ya en la moral con máximas y sentencias graves que siembra en sus versos, ya en la política con los 
discursos de un ministro en una tragedia [...] ya en la economía con los avisos de un padre de familia en una comedia (pp. 185, 173 y 197).

En la dedicatoria de la comedia, traducida de Nivelle de La Chausée, La Razón contra la moda ((1751):

Las buenas [comedias] deben aprovechar deleitando, y si sus autores se contentan con el solo deleite desde luego deben tenerse por malas en una república bien ordenada, y por pésimas si mezclando al deleite algún género de veneno volviesen en estrago de las costumbres lo que se inventó y se destinó para su corrección. Por manera que es abusar de la razón humana y delirar manifiestamente el decir que la comedia, como mera diversión, es enteramente libre, que no está sujeta a leyes ni a reglas [...] La utilidad [...] y la buena moral de una comedia es su más estimable circunstancia, y en tanto debe el buen poeta procurar que sea igualmente deleitable lo útil, en cuanto con la mezcla del honesto deleite se consigue más eficazmente el aprovechamiento (pp. [6] - [8]).

En su Plan de una Academia de Ciencias y Artes en que se habian de refundir la Española y la de la Historia, Luzán, anticipando el ideal de dirigismo cultural que hemos visto en palabras de Moratín, propuso que su soñada Academia General dispusiera de fondos para premiar el teatro correctamente escrito, y de autoridad para censurar el original de toda publicación antes de ser impresa. Jovellanos, en la Memoria citada, pedía que ninguna obra pudiera representarse sin aprobación de la Real Academia Española; Samaniego afirmaba en el discurso 92 de El Censor que "la elección de los dramas que se ofrecen al público debiera ser uno de los primeros cuidados de nuestra policía" (1972, pág. 169).

En cuanto a Nicolás Moratín, opinaba en el Desengaño I que "la perfección del teatro es negocio que no sólo importa al honor de la nación, sino que se hace precisa en conciencia para la indemnidad de las costumbres [...] Después del púlpito, que es la cátedra del Espíritu Santo, no hay escuela para enseñarnos más a propósito que el teatro" (pp. 2, 12).

En la Sátira $I$ afirmaba que la denuncia del vicio es actividad propia del escritor, en colaboración con la autoridad civil:

Ejecuta los fueros de tu empleo, /pinta de la maldad que la sujeta [la virtud] / lo infame, lo ridículo y lo feo, / que éstas son del dignísimo poeta / justas ocupaciones, y su verso / reduce la república perfeta; / [...]/ ni temas contra el vicio ser osado, / porque yo en nombre suyo te aseguro / la noble protección del magistrado.

3. En cuanto al mecanismo creativo, los neoclásicos admitieron la necesidad de las motivaciones irracionales e innatas a las que se da el nombre de inspiración; pero creyéndolas necesarias las supusieron insuficientes para producir una obra correcta sin el auxilio de una técnica, racional y adquirida por la reflexión y el estudio, y que comprendía el arte y la ciencia. Arte era el conjunto de normas aplicables a la concepción y estructura de la obra literaria, 
y ciencia el de los saberes auxiliares relativos a su contenido (como la Historia, la Geografía, la psicología y las costumbres de los distintos pueblos y épocas, todo ello esencial para delinear las conductas y reacciones de los personajes puestos en escena, y no cometer impropiedades en el tratamiento de asuntos situados en tiempos y espacios lejanos, o sea en las obras de tema histórico).

Está muy claro en el Arte poética de Nicolás Boileau:

Es inútil que un escritor temerario intente alcanzar la excelencia si no se encuentra bajo la secreta influencia del cielo y si su destino no lo ha hecho poeta al nacer [...] Amad siempre la razón; que vuestros escritos le deban siempre su valor y su brillantez (1967, I, vv. 1-4, 37-38 - traducción mía).

En la Poética de Rapin:

El genio, que no depende del arte ni del estudio, que es un don del cielo, debe apoyarse en el juicio [...] Lo mismo que éste es frío y lánguido sin aquél, el genio sin juicio es ciego y extravagante [...] Sólo es posible agradar cumpliendo las reglas [...] Horacio muestra en su Poética la necesidad de seguirlas y los extravíos ridículos en que puede caerse cuando sólo se confía en el genio, porque si éste no está sujeto a reglas no es más que un puro capricho, del que no puede resultar nada razonable (1970, pp. 13-14, 24, 26).

Y en la de Luzán:

[Lope y Calderón], engañados de ese común error, pretendieron que su ingenio solo bastaba para acertar en todo, sin reparar que quien camina a ciegas, sin luz ni guía, por erradas sendas, sólo puede esperar caídas y precipicios [...] Pues no hay duda [...] de que quien escribe sin principios ni reglas se expone a todos los yerros imaginables, porque, si bien la poesía depende en gran parte del genio y numen, sin embargo si éste no es arreglado no podrá jamás producir cosa buena [...] El solo ingenio y naturaleza sola no bastan, sin el estudio y arte, para formar un perfecto poeta (pp. 125-126, 537).

Para poner en pie su ideal de teatro didáctico y razonable, el Neoclasicismo exigió el cumplimiento de unos principios de los que nos ocuparemos ahora, intentando justificarlos desde una mentalidad que, aun siendo desde luego discutible, es mucho más que la rutinaria y pedantesca imposición de unas cuantas fórmulas mecánicas, como ha querido hacernos creer una secular tradición que desde principios del XIX se ha obstinado en ignorar la entraña y hasta la letra del pensamiento neoclásico.

\section{Ilusión o engaño teatral}

Es el dogma básico y esencial, desposeyendo a la palabra "engaño" de las connotaciones peyorativas actuales. La ilusión corresponde a la identificación del espectador y se opone a su distanciamiento. Asumiendo la identificación de modo radical y absoluto, y contando con la psicología primaria del espectador, se trata de aprovechar y potenciar la tendencia instintiva de éste a interiorizar y 
hacer propios los conflictos, las situaciones y las personalidades del drama, de tal modo que pierda de vista su mundo real para introducirse en el imaginario que le ofrece el teatro, sin que esa ilusión sea rota en ningún momento por nada que lo haga percatarse de la índole ficcional de la representación. En el hecho teatral nos encontramos con tres ámbitos: dos físicos, el del espectador y el de la representación (actores y escenario), y uno imaginario, el del relato. E1 Neoclasicismo pretende que el espectador se sitúe psíquicamente en el espacio imaginario sin encontrar obstáculo alguno ni en sí mismo ni en el espacio de la representación. $\mathrm{O}$ sea: $1^{\circ}$, que se despoje de su propia identidad y asuma la de los personajes del relato atravesando la de los actores; $2^{\circ}$, que abandone el espacio del coliseo para situarse en el del relato atravesando el espacio escénico; $3^{2}$ que se traslade de su tiempo vital al tiempo del relato atravesando el tiempo escénico. Para ello será necesario que ese deplazamiento inconsciente, en tres dimensiones, no tropiece, ni en lo que concierne al relato ni en lo que concierne a la representación, con ningún impedimento que dispare el resorte de la conciencia y, por lo tanto, devuelva al espectador a la percepción de la propia identidad, del espacio y del tiempo reales que tenía en el momento del alzarse el telón. La Ilusión teatral es la clave de la teoría neoclásica, y en última instancia todos los pecados contra ésta se definen como quebrantamientos de aquélla.

Luzán lo expresa perfectamente en la epístola dedicatoria de La Razón contra la moda:

El auditorio que ve representar una comedia no puede lograr cumplido deleite ni conmoverse en los lances fingidos, ni aprovechar de la representación de aquellos casos, si no es mediante la ilusión teatral, que es una especie de encanto o enajenación que suspende por aquel rato los sentidos y las reflexiones y hace que lo fingido produzca efectos de verdadero. De aquí nace que los oyentes lloran, se entristecen, se enternecen, se apasionan, se ríen, como si lo que representa pasase realmente entre personas verdaderas y no entre cómicos que las imitan. Pero para que esto suceda así es preciso que el poeta y los representantes contribuyan cada uno por su parte a no deshacer la ilusión, antes bien a conservarla y fomentarla en toda la representación [...] Es preciso que tengan verosimilitud los lances, constancia las costumbres, naturalidad la solución, propiedad el estilo y proporción la sentencia, porque a cualquiera de estas cosas que falte notablemente huye la ilusión, se manifiesta el poeta y el auditorio reconoce a la luz de la mala imitación el engaño y la ficción del teatro (1751, pp. [17] - [18], [25]).

Nicolás Moratín recalca en varias ocasiones la necesidad de mantener la Ilusión o engaño teatral:

Aquella comedia o tragedia tan bien escrita y representada que no deje resquicio al auditorio por donde pueda conocer que aquello es falso, sino que lo imagine sucediendo, aquella es buena; y toda la perfección consiste en engañar a aquella gente que lo está oyendo... (Desengaño I, pp. 3-4). 
El teatro se hizo para representarnos las cosas con tanta viveza y exactitud que, arrebatadas nuestras potencias, no las juzguemos fingidas sino verdaderas. y de aquí procede el mágico y dulce encanto que resulta de la ilusión teatral, de cuya delicia no han gustado todavía los ignorantes (Desengaño II, pág. 21).

El drama no refiere cosa como pasada sino que la pone en acción sobre el teatro como presente, para hacer creer al auditorio que es verdad lo que está oyendo; y para esto es indispensable que no represente cosas imposibles de suceder, pues de lo contrario se percibe el engaño y se echó a perder la pieza (Desengaño III, pág. 50).

En el texto de Luzán que hemos citado en primer lugar tenemos una expresión preciosa, en su trasparente ingenuidad, para aproximarnos a lo que los neoclásicos entendieron por ilusión; una obra incorrectamente confeccionada tiene el defecto capital de que durante su representación y ante su público "se manifiesta el poeta", es decir: se hace evidente que aquello es una obra literaria producida por un autor y a la cual se asiste, en lugar de ser una experiencia vivida e instintivamente asumida. Por eso decía antes que la llusión neoclásica es lo contrario del distanciamiento. De sobra sabemos que el segundo es la garantía del espectador ante la recepción acrítica del mensaje de la obra; no es raro que el Neoclasicismo exigiera la primera como requisito de los fines de dicho mensaje, sin que debamos olvidar el propósito de captación ideológica y hasta de "abuso de confianza psíquica" (como decía André Breton en otro orden de cosas) que ello supone.

\section{Imitación de la naturaleza}

El reflejo de la realidad por medio del discurso artístico o literario puede afrontarse tomando como objeto seres o hechos individuales aislados en su singularidad, o bien dotando de alcance generalizador la representación de lo concreto. Los neoclásicos llamaron a lo primero imitación de lo particular o icástica, y de lo universal o fantástica a lo segundo. Luzán reconoce la filiación platónica de esta distinción cuando afirma que las cosas "que hemos dicho poder ser objeto de la poesía se deben considerar de dos modos, esto es, o como son en sí y en cada individuo o particular, o como son en aquella idea universal que nos formamos de las cosas, la cual idea viene a ser como un original o ejemplar de quienes son como copias los individuos o particulares" (1977, pág. 169). Imitación icástica, sigue Luzán, es la del pintor que realiza el retrato realista de una persona determinada; imitación fantástica, la que corresponde a la leyenda del pintor Zeuxis, "que para pintar a la famosa Helena no se contentó con copiar la belleza particular de alguna mujer, sino que juntando todas las más hermosas tomó de cada una aquella parte que le pareció más perfecta, y así formó, más que el retrato de Helena, el dechado de la misma hermosura" (pág. 170). La imitación de lo particular, que convierte al artista en un mero espejo pasivo, parece actividad subalterna frente a su intervención más amplia y propiamente creadora en la de lo universal, incluso por razones 
etimológicas, pues poeta (término que en el XVIII equivale al actual de escritor creativo) significa hacedor, "lo que da a entender que el poeta sólo es poeta cuando cría con su ingenio y fantasía nuevas fábulas" (Ibíd).

Por otra parte, aunque todo lo existente es objeto potencial del arte, es obvio que la mayor nobleza de éste residirá en cargarse de trascendencia ética ocupándose del ser del hombre, de sus acciones y conductas: "La poética imitación tiene por objeto principal las cosas del mundo humano, esto es, la moral, las acciones, los afectos y pensamientos del hombre", concluye Luzán (pág. 240); y Santos Díez González define la poesía (o sea la Literatura) como "imitación de las acciones humanas, en verso y con ficción" (1793, pág. 2). Así pues, siendo lo humano espiritual y moral el objeto predilecto de la literatura, y la de lo universal la mejor imitación, el poeta deberá convertirse en un Zeuxis de la espiritualidad humana y de su casuística moral. Es éste uno de los tópicos más reiterados por los dramaturgos del Neoclasicismo; Moratín iniciará el prólogo de La Comedia nueva declarando que "procuró el autor, así en la formación de la fábula [argumento] como en la elección de los caracteres, imitar la naturaleza en lo universal" (1970, pág. 67), porque la misión de la comedia no es darnos el retrato satírico de individuos determinados, y así "resulta la pintura con toda la expresión característica que es conveniente, y al mismo tiempo carece de aquella semejanza individual (odiosa sin duda) que es propia sólo de quien retrata y no de quien inventa" (Ibíd). Y si la misión del comediógrafo, artífice de lo universal, es superior a la del satírico (retratista de lo particular), la del poeta lo es a la del historiador, pues éste está sujeto a la crónica fiel de la multitud de los hechos sucedidos. Por ello, cuando el poeta tome por asunto uno de esos hechos, no estará obligado a sujetarse escrupulosamente a su verdad, porque la verdad de lo concreto es siempre manifestación de la contingencia de lo particular.

Podemos pues entender, en el ámbito de la preceptiva teatral, la imitación de la naturaleza como imitación de la naturaleza humana en lo universal.

No significa reproducción fotográfica de cualquier integrante de la realidad, sino interpretación generalizadora y paradigmática de acuerdo con los principios y comportamientos de la naturaleza en su integridad; se trata de trazar individuos que funcionen como símbolos o paradigmas, y que así reflejen toda la extensión de las posibilidades del universo al que representan. En resumen: $1^{\circ}$, lo más frecuente o "universal", con exclusión de lo que se desvía de esa norma; $2^{\circ}$, lo arquetípico, es decir, lo que presenta dichos rasgos en grado sumo; $3^{\circ}$, lo identificable y admisible como generalidad por los destinatarios de la obra de arte. Lo cual supone un doble problema: primero de generalización y selección, que tendrá, puesto que nos movemos en un terreno de conductas humanas vistas desde la moralidad y el didactismo, una solución forzosamente ideológica que conduce al dogma del Decoro; segundo, de recepción y asentimiento, que conduce al de la Versosimilitud. 
Dice Charles Batteux en Las Bellas Artes reducidas a un único principio:

Hay que deducir que, si las Artes son imitaciones de la naturaleza, debe ser la suya una imitación sabia y que no la copie servilmente sino que, escogiendo los objetos y sus características, los presente con toda la perfección que en ellos cabe; una imitación en que se vea la naturaleza no como es en sí misma sino como puede ser y como la podemos imaginar (1969, pág. 45 - traducción mía).

\section{Y Luzán en su Poética:}

Cuando el poeta $[\ldots$... imita la naturaleza en lo universal, formando una imagen de los hombres no como regularmente son en sí sino como deben ser según la idea más perfecta, es cierto que los más de los hombres (que de ordinario no tocan en los extremos del vicio o de la virtud) no verán representado allí su retrato [...] pero sí verán un dechado y un ejemplar perfecto en cuyo cotejo puedan examinar sus mismos vicios y virtudes, y apurar cuánto distan éstas de la perfección y cuánto se acercan aquéllos al extremo [...] El poeta, pues, queriendo representar a nuestros ojos la virtud en su mayor belleza, para darla mayor fuerza y eficacia de prendar nuestros corazones, y el vicio en toda su fealdad, para hacérnosle más aborrecible, no se contenta con imitar la virtud y el valor de un individuo [...] sino que, dando de mano a estos particulares, que le parecen siempre imperfectos, consulta a la idea más perfecta que ha concebido en su mente de aquel carácter o genio que quiere pintar, y adornando de todas las virutdes y perfecciones, que para su intento tiene ideadas, una de las personas de su poema o de su tragedia, ofrece en ella un perfecto dechado [...] El poeta, pues, debe perfeccionar la naturaleza, esto es, hacerla y representarla eminente en todas sus acciones, costumbres, afectos y demás calidades buenas o malas. Si quiere pintarnos un valeroso y excelente capitán, recurre a las ideas universales y según éstas le coloca en el más alto grado de valor; asimismo, si quiere ponernos delante el retrato de un vicioso, le copia con $\tan$ vivos y subidos colores que raras veces la naturaleza suele producir cosa semejante (pp. 172-174, 240).

\section{Verosimilitud y Decoro}

La Verosimilitud es, para los neoclásicos, resultado de la Imitación de la naturaleza en el sentido antes indicado; es requisito del asentimiento del receptor y por lo tanto del efecto didáctico del arte. Aplicada al argumento, requiere encadenamiento estructurado de los hechos y fundamento en las acciones de los personajes; aplicada al modo de ser de éstos, equivale al Decoro; aplicada a la representación, exige las Unidades.

La Verosimilitud nos pone frente a los mismos problemas de manipulación de la realidad que la Imitación de la naturaleza. Los neoclásicos contaban al respecto con unas formulaciones un tanto sibilinas de la Poética de Aristóteles:

- Se debe preferir lo imposible verosímil a lo posible inverosímil.

- No corresponde al poeta decir lo que ha sucedido, sino lo que podría suceder, es decir lo posible según la verosimilitud o la necesidad. 
- El historiador dice lo que ha sucedido, el poeta lo que podría suceder.

- Es verosímil que también sucedan cosas al margen de lo verosímil (1974, pp. 157-158, 223, 233).

Estamos en realidad ante la distinción de tres conceptos: lo verdadero, lo posible y lo verosímil. Lo verdadero es el conjunto de hechos producidos en la realidad del mundo natural y de la Historia. Lo posible, lo predictible a la vista de lo verdadero, dando por supuesta la continuidad de las leyes naturales. La unión de lo verdadero y lo posible configura la verdad de los doctos. Lo verosímil, en cambio, corresponde a la opinión de la masa indocta destinataria del teatro (tanto la opinión que ya tiene como la que en ella se pretende crear), y a lo esperable desde la universalidad de la imitación; y puede no coincidir con la verdad. Cuando esto ocurra el poeta debe adoptar lo definido como verosímil, aun imposible y falso, y rechazar lo verdadero y posible cuando sea inverosimil. Cuando trate un asunto histórico deberá modificarlo para adaptar la verdad a la verosimilitud; ésta es la diferencia entre Poesía e Historia, a la que antes hemos aludido.

Dice en la Poética Luzán:

Acerca de la verosimilitud tenemos en Aristóteles un precepto comúnmente aprobado de todos, es a saber que los poetas deben anteponer lo verosímil y creíble a la misma verdad. Lo cual se debe entender [...] de la verdad perteneciente a las ciencias especulativas y a la Historia. La razón de este precepto así entendido es evidente: porque como el fin del poeta es enseñar y aprovechar deleitando, no siendo tan acomodada para este fin la verdad histórica o científica como lo es lo verosímil y creíble, es junto que el poeta eche mano de éste [...] Asimismo la verdad de las ciencias no es siempre conforme a las opiniones del vulgo; y como lo que no es conforme a la opinión no es creíble ni persuade, ni puede ser útil, por eso es preciso que el poeta se aparte muchas veces de las verdades científicas por seguir las opiniones vulgares (pág. 233).

Ya a fines del XVI observaba burlonamente el Pinciano que sería improcedente en literatura seguir una verdad incompatible con el asentimiento del público: "Haced un poema [...] de eso [el mayor tamaño del Sol en relación a la Tierra]; veréis como se ríen las gentes, llevadas de la incredulidad y falta de verosimilitud para con ellas" (1973, II, pág. 69). Unos 40 años después, en su comentario de la Poética de Aristóteles (Nueva idea de la tragedia antigua), reeditado en 1778, José Antonio González de Salas anotaba que "las [cosas] posibles repugnan a la credulidad muchas veces, y esto no puede suceder a las verosímiles" (1778, pág. 43). Aubignac, en su Pratique du théâtre de 1657 matiza que lo verdadero y lo posible no han de quedar proscritos de la escena, aunque serán admitidos en ella únicamente en lo que tengan de verosímil, y después de haber sido examinados y en su caso modificados por el poeta (1971, pág. 67). La verdad, observa Rapin, suele ser inverosímil por su sujeción a lo particular y anecdótico, de suerte que lo verosímil y lo universal coinciden y se exigen mutuamente (1970, pág. 41). 
Existe, por otra parte, una verosimilitud extraordinaria e insólita, que el poeta deberá conseguir y justificar, y a cambio de la sorpresa y novedad que con ello introduzca logrará el interés de su público. Esa verosimilitud extraordinaria es fuente de admiración, junto al carácter arquetípico o extremo de la universalidad cuando la imitación la consigue.

Decoro es el resultado de la aplicación de verosimilitud y universalidad a los personajes. Significa que sean arquetípicos y psíquicamente coherentes, y que su conducta y lenguaje correspondan a su status, edad, sexo, etnia y época. En virtud de la verosimilitud extraordinaria podrán tolerarse desviaciones de lo que normalmente exige el Decoro (por ejemplo, que en circunstancias extremas, de grave necesidad y peligro, una mujer adopte comportamientos viriles como caudillo militar). El concepto no tiene una base exclusivamente moral, pero sí la tiene, y además ideológica, la definición de sus implicaciones en función de status y sexo. Por otra parte, afecta a cuestiones tan prácticas como los movimientos y actitudes de los actores, el vestuario y la escenografía.

Boileau aconseja a los dramaturgos, en aras del Decoro, lo siguiente:

Que la naturaleza sea vuestro único estudio, autores que aspiráis a la fama en la comedia. Aquel que conoce bien al hombre, y con penetración sabe cómo es un manirroto, un avaro, un hombre honrado, un vanidoso, un valiente, puede adecuadamente ponerlos en escena y hacerlos vivir, actuar y hablar ante nosotros [...] No hagáis hablar a un anciano como un joven, y a un joven como un anciano (III, vv. 359-366, 389-390 - traducción mía).

Y Luzán:

La opinión que tenemos de Aquiles, de Alejandro, de Escipión, etc., es que fueron muy valientes y esforzados capitanes; conque si el poeta nos los representa pusilánimes y cobardes diremos con razón que su representación es inverosímil [...] Asimismo los pastores, según nuestra opinión, son incultos, ignorantes y rudos, por lo que si un mal poeta introduce un pastor $o$ un hombre del campo a hablar de filosofía y de política, y a decir sentencias tan graves como las diría un Sócrates o un Séneca, a cualquiera parece inverosímil esa imitación [...] y lo mismo será si la frase, los términos y el artificio con que un pastor explica sus sentimientos fueren tales que más parezcan estilo de un culto cortesano [...] Debe pues el poeta saber lo que conviene a cada edad, a cada sexo, a cada nación, a cada empleo y dignidad (1977, pp. 229-230, 497).

Si un joven habla y obra como un viejo, sin especial motivo, o un viejo como un joven; si un lacayo gasta tan discretos conceptos como un caballero; si una doncella discurre como un gran filósofo; si un hombre regular dice sonetos y décimas de repente, con muchas agudezas, ¿a dónde irá a parar la ilusión, quién no conocerá la instante que el que habla así es un cómico que ha decorado [memorizado] unos versos que el poeta trabajó en su estudio con mucha aplicación y con mucho espacio...? (1751, pp. [25] - [26]). 
El problema de la inadecuación del vestuario de los actores preocupó grandemente a los neoclásicos: quebrantaba el Decoro y era fuente de inversimilitud. Samaniego, en el discurso 92 de $E l$ Censor, se lamenta de que "un tetrarca de Jerusalén vista de militar o de golilla, la viuda de Héctor lleve ahuecador o guardainfante, y el conquistador de la India se presente con sombrero de tres picos y tacones colorados" (pág. 176).

La razón de la impropiedad de los trajes usados en escena, en relación a la época o la etnia de los personajes, estaba en la tradición que imponía a los actores el correr con los gastos de su vestuario. Cada actor procuraba disponer del mínimo guardarropa, y tenía que usarlo a tuertas o a derechas. Los neoclásicos exigían que los teatros dispusieran de un amplio y variado guardarropa, o bien que los empresarios corrieran con el correspondiente gasto, librando de él en todo caso a los actores.

\section{Las Unidades}

Las tres Unidades (de Lugar, Tiempo y Acción) son el más vistoso de los ingredientes de la teoría literaria neoclásica. Boileau las resume en el verso 45 del canto III de su Arte poética: "un lugar, un día, una sola acción completa". Las Unidades se consideraban necesarias para el mantenimiento de la Ilusión del espectador, por las razones que veremos acto seguido.

La Unidad de Lugar exige que toda la acción dramática transcurra en un mismo espacio físico imaginario, designado por el autor dramático. Pecan contra ella las obras cuyo argumento consta de acontecimientos que se desarrollan en espacios distantes unos de otros. Su razón de ser está en que, de no cumplirse, el espectador observaría que los personajes viajan en el espacio mientras él mismo y los actores permanecen fijos, y se quebraría la Ilusión.

Aristóteles no mencionó la Unidad de Lugar; los neoclásicos supusieron que la consideró implícita, por ser obvia y por venir exigida necesariamente por la Unidad de Tiempo.

Planteaba la dificultad de obligar al autor a situar verosímilmente todos los sucesos dramáticos en un mismo lugar, aunque esa dificultad resultaba disminuida por la corta duración, en el tiempo imaginario, de la acción, de acuerdo con la Unidad de Tiempo. Además de su sentido estricto tenía uno amplio, que autorizaba el uso de distintos espacios dentro de un mismo edificio, e incluso el de varios lugares próximos, como una ciudad y sus alrededores. Los hechos necesarios para la economía de la acción dramática y que no pudieran verosímilmente adaptarse a la Unidad de Lugar no debían ser escenificados rompiéndola, sino ser narrados por un personaje.

Dice Luzán en su Poética: 
Es absurdo, inverosímil y contra la buena imitación que mientras el auditorio no se mueve de un mismo lugar, los representantes se alejen de él y vayan a representar a otros parajes distintos, y no obstante sean vistos y oídos por el auditorio. Conșiste pues esta Unidad en que el lugar donde se finge que están y hablan los actores sea siempre uno, estable y fijo desde el principio del drama hasta el fin; y cuando poco o mucho no fuere uno y estable el lugar, será faltar poco o mucho a la Unidad. Supongamos que en una comedia el teatro, al principio, se finge ser una calle de Zaragoza; digo que el teatro ha de ser la misma calle por toda la comedia. Supongamos ahora que lo que al principio fue, por ejemplo, el Coso, se finge después ser el mercado o la calle del Pilar; éste será un yerro contra la Unidad de Lugar, aunque muy ligero y perdonable. Pero si se finge después que lo que era calle del Coso es el Arenal de Sevilla o un palacio en la isla de Chipre o el monte Atlante en África, no habrá quien pueda sufrir tal absurdo (pág. 464).

Nicolás Moratín insiste en dejar bien claro, en todas y cada una de sus obras dramáticas, que ha respetado escrupulosamente la Unidad de Lugar. En el prólogo a La Petimetra:

La acción se representa en Madrid; y aunque algunos autores [...] permiten que una comedia se represente en una ciudad y en sus contornos, yo no he querido usar de tanta licencia. Nuestro Luzán dice que en distintos parajes de una ciudad se puede hacer la comedia, porque le parece inverosímil que en uno sucedan todos los lances; pero sin que, a mi parecer, se note inverosimilitud ni violencia he logrado colocarla no en el ancho circuito de Madrid ni en una casa, sino en una pieza particular donde tiene el tocador doña Jerónima, y de allí no se sale un paso ni aun al cuarto de más afuera, y esto es lo que con propiedad debe llamarse Unidad de Lugar (1762, pp. 21-22).

En la primera escena de la comedia don Damián informa a don Félix, sin más propósito que advertir al auditorio del respecto verosímil de la Unidad, que doña Jerónima y doña María "viven en un mismo cuarto" (pág. 27).

En el prólogo a Lucrecia leemos que "la de Lugar se guarda tan fielmente que todo se supone sin violencia sucedido en cuatro palmos de tierra" (1763, pág. 8); en el de Hormesinda, que "la de Lugar se reduce a un salón". El mantenimiento de la Unidad de Lugar obliga a Moratín a una pintoresca justificación en el prólogo a Guzmán el Bueno:

La Unidad de Lugar no está quebrantada aunque se representa el suceso en el muro y acampamento, porque el auditorio se supone estar en el adarve de Tarifa, desde donde oye y ve cuanto pasa en ambas partes bien contiguas, mayormente considerando el antiguo modo de sitiar las plazas, tan diferente del moderno pues se hablaban unos y otros (1777, pp. 7-8).

La Unidad de Tiempo requiere, en sentido estricto, que el tiempo imaginario de la acción y el tiempo real de la representación coincidan, de modo que el primero se limite a poco más de tres horas. En sentido amplio se admitían hasta 24 , de acuerdo con la interpretación menos estricta del "giro del sol" mencionado por Aristóteles, e incluso 48. Podía colisionar con Verosimilitud y Decoro al obligar a los personajes a evolucionar psíquicamente en tan corto espacio de 
tiempo, aunque para justificarlo se disponía de la peripecia (cambio de la acción por un hecho que la modifica radicalmente) y la agnición o anagnórisis (la revelación de la identidad, previamente oculta, de un personaje clave). La mejor agnición es que la produce peripecia; y el mejor argumento (la fábula impleja) es el que contiene peripecia, agnición o preferentemente ambas. Los hechos anteriores al tiempo acotado y necesarios para la fábula no podían ser escenificados sino que debían ser narrados, como ocurría a propósito de la Unidad de Lugar.

No es menos necesaria a la fábula la Unidad de Tiempo que la de Acción. Unidad de Tiempo, según yo entiendo, quiere decir que el espacio de tiempo que se supone y se dice haber durado la acción sea uno mismo e igual con el espacio de tiempo que dura la representación de la fábula en el teatro (Luzán, 1977, pág. 459).

Supongamos asimismo que un poeta hace que de una jornada a otra pase más tiempo del que permite la regla de la Unidad de Tiempo, de modo que la persona que en la primera jornada salió niño o joven se vea después en la segunda o tercera ya hombre hecho o viejo decrépito [...] se desvanece la ilusión del autidorio, reconocen los espectadores que aquellos lances son representados y no verdaderos [...] De aquí procede que una ficción tan manifiestamente descubierta y una imitación tan desemejante de lo natural y tan mal ejecutada no produce efecto alguno de los que debiera producir (1751,pp. [20] - [21]).

Nicolás Moratín se preciaba de una observancia de la Unidad de Tiempo tan estricta como de la de Lugar. Es inverosímil, dice en el prólogo a La Petimetra, "que en tres horas se vean cosas que se supone que pasan en muchos años" (pág. 7). Y más allá, en el mismo texto:

La de Tiempo está guardada tan fielmente que no se tarda en la acción más de lo que pueda tardar en representarse, de suerte que su duración no pasará de tres horas. Y aunque pudiera alargarla por todo el giro o período del Sol que da Aristóteles, he querido sujetarme a lo que es más natural. Y aunque está ya recibido, si se mira con rigor no dejará de ser violento que lo que pasa en ocho o diez horas pueda reducirse a tres; pero yo no intento quitar esta libertad (pág. 22).

Idénticas manifestaciones en los prólogos a Lucrecia (pág. 8), Hormesinda (pág. 4) y Guzmán el Bueno (pág. 8).

Leandro Moratín fue asimismo cuidadoso con la Unidad de Tiempo. La Comedia nueva desarrolla su argumento en dos horas; El Viejo y la niña en unas tres horas; El Barón en cuatro; La mojigata en siete y El sí de las niñas en diez. En El Barón se dan indicios al espectador de cuál es el tiempo de la acción dramática: en acto I escena 5, casi al comienzo, de la conversación entre dos personajes se deduce que nos encontramos después de la siesta, y algo después de las tres; y en una de las últimas escenas del segundo y último acto se nos dice que van a dar las nueve de la noche.

Nicolás utiliza un procedimiento similar en el acto I de La Petimetra, y más ampliamente Jovellano en El Delincuente honrado, que transcurre en unas treinta 
horas. El día primero, desde el amanecer a la hora de comer, incluye los dos primeros actos; la tarde y noche, los dos siguientes, y el quinto ocurre en la mañana del día siguiente, hasta las once. En I,2 Torcuato mira su reloj y dice que son las siete y cuarto, En II, 3 Laura recuerda que aún no se ha realizado la comida del mediodía, y en II,13 un criado la anuncia. En V,1 un reloj da las once de la mañana del día siguiente.

La Unidad de Acción exige que ésta sea única, unitaria (es decir, conste de una serie de hechos necesarios y coherentes) completa (con planteamiento, desarrollo y desenlace) y de un solo protagonista.

Pecan contra ella las obras que contengan varias acciones de un protagonista, una de varios protagonistas y varias de varios; y en estos casos y también en el de una acción de uno, las acciones con hechos secundarios desvinculados de la acción principal (los que daban lugar a un argumento "episódico"). Cuando la obra escenifique un hecho histórico hay que respetarla igualmente, aun contra la verdad, en aras de la verosimilitud, habida cuenta de la no identidad entre Poesía e Historia. Los hechos necesarios para la economía del argumento pero que rompan la Unidad de Acción no podrán ser escenificados sino narrados, como en lo tocante a las otras Unidades.

\section{La definición de Luzán en la Poética es como sigue:}

Consiste en ser una la fábula, o sea el argumento, compuesto de varias partes dirigidas todas a un mismo fin y a una misma conclusión. De manera que todas las dichas partes o las varias acciones que componen el todo de la fábula han de ser, según Aristóteles, tan esenciales, tan coherentes y eslabonadas unas de otras que, quitada cualquiera de ellas, quede imperfecta y mutilada la fábula [...] Las partes esenciales se hacen inseparables por la fuerte trabazón con que están entre sí ensambladas y unidas, y mirando todas a un mismo fin y blanco forman la unidad de la acción que debe tener la fábula. Aquí se podría dudar si bastaría para la unidad de la fábula el referir muchas acciones, pero de uno. Lo cual, aunque no deja de tener cierta unidad, no es la perfecta unidad que requiere el poema épico o dramático, que principalmente consiste en la unidad de acción, no en la unidad de persona [...] Mucho más remoto de la perfecta unidad y mucho más opuesto será el referir muchas acciones diversas e incoherentes de muchos [...] En suma, la Unidad de la fábula consiste en ser una la acción, cuyas partes conspiren todas a un mismo fin y se junten en un punto, que es el blanco de todas. Y si la acción fuere una y de uno, entonces será más perfecta la unidad (pp. 457-459).

Y en La Razón contra la moda:

Consiguientemente a las dos Unidades de Tiempo y de Lugar es la Unidad de Acción, porque si repugna a la razón y a la imitación que en tres horas de tiempo se supongan pasar muchos años o muchos días, y que en las mismas tres horas se anden muchísimas leguas y se vea desde un mismo puesto lo que pasa en Constantinopla, en Londres y en Sevilla, también ha de repugnar que se reduzcan a un mismo lugar y a un mismo tiempo dos 
acciones que requieren distinto tiempo y distinto lugar [...] Aun cuando las dos acciones fuesen de un mismo héroe y de un mismo galán, no cabe que hayan sucedido en un mismo lugar y en un mismo tiempo, fuera de que siendo necesario para la ilusión y para los efectos que se piden a la comedia o tragedia que la atención del auditorio esté recogida, intensa y fija en una acción seguida (pp. 23-24).

\section{Reglas menores}

Llamo reglas menores a preceptos que se deducen de los anteriormente expuestos, o que no fueron propugnados por el Neoclasicismo como leyes incuestionables; $y$, en fin, a cuestiones de menor cuantía que no tienen la enjundia de las que hemos visto hasta ahora.

a) No representar la violencia o la muerte en escena sino narrarla, ya que de otro modo se quiebra la ilusión o identificación del espectador, que es bruscamente devuelto a la realidad ("se manifiesta el poeta") al advertir que ni él ni los actores han sido realmente heridos o muertos. González de Salas observaba que la tradición preceptiva se oponía a "poner a los ojos de los oyentes aquella manifiesta ejecución" y consideraba preferible "comunicar sólo su noticia por relaciones", aunque no todos los tragediógrafos de la Antigüedad cumplieron tal precepto (1778, pp. 56-57). En cuanto a "hacer las muertes en público", Luzán (1977, pp. 492-493) matiza la prohibición según el grado de inhumanidad y barbarie; Díez González es partidario de "huir de presentar a vista de los espectadores en el teatro escenas atroces y sanguinarias" (1793, pág. 105).

b) Evitar los apartes. La razón de su inconveniencia la explica inmejorablemente Montiano, en el primero de sus Discursos (1750, pág. 62): "Otro [defecto] comunísimo en nuestros teatros, y que se opone a la verdadera imitación de la acción, es el hablar a parte los actores, estando otros delante, porque es inverosímil que no oigan lo que dicen, cuando lo escucha todo el auditorio". Luzán es tolerante al respecto (en el prólogo a La Razón contra la moda) lo mismo que Aubignac (pp. 234-238). Discutió igualmente el Neoclasicismo la verosimilitud del soliloquio, mucho mayor que la del aparte.

c) Dar al lenguaje claridad frente a los alambicamientos barrocos y no usar estrofas artificiosas, por ser lo uno y lo otro, tanto en tragedia como en comedia, inverosímil e indecoroso.

d) En cuanto al número de actos, aunque la tradición preceptiva imponía el de cinco (véase Aubignac, pp. 195-197), el peso de la costumbre española hizo a nuestros neoclásicos admitir tres e incluso dos (Luzán, 1977, pág. 518; Díez González, 1793, pp. 79-80).

Finalmente, se consideraba conveniente que la escena nunca estuviera vacía, salvo en fin de acto, y que el número de personajes hablantes no fuera 
superior a tres. Fue también objeto de debate la licitud de un héroe trágico movido por la pasión amorosa.

Y no se crea que el calificativo de menores que he aplicado a estas cuestiones significa que sean despreciables en el ámbito del pensamiento neoclásico; cuando Ignacio Bernascone quiere elogiar a Nicolás Moratín en el prólogo a Hormesinda, no olvida que "ésta es una tragedia sin amor, sin episodios extraños, sin soliloquios, sin apartes, sin dejar solo el teatro desde el principio hasta el fin" (N. Moratín, 1770, pág. [3]).

El teatro musical suponía dificultades específicas desde el punto de vista de la verosimilitud de la unión de música y parlamento, escollo que plantea con toda claridad Antonio Eximeno:

Siempre parecerá inverosímil a todo el que lo examine con imparcialidad. Por más que se esfuerce el arte en producir esta pretendida ilusión, nunca podrá conseguirla, y siempre será un absurdo intolerable el ver a los héroes del melodrama moderno referir cantando, disputar cantando, matar y morir cantando. Siendo el alma de todo drama la imitación, ia quién imitan los personajes del melodrama? (1796 pp. 218-219)

Luzán opinaba además que el encanto de la música puede llegar a marginar los fines educativos del teatro, "introduciendo, en vez de este deleite que podemos llamar racional, porque fundado en razón y en discurso, otro deleite de sentido" (1977, pág. 515)

La falta de verosimilitud también le parecía a Moratín un grave defecto del teatro musical (véase Andioc 1965 pág. 317), Luzán (op . cit. pág. 516) había reprobado incluso la ópera. Díez González la acepta, y llega incluso a censurar a quienes niegan licitud a todo teatro musical en nombre de la verosimilitud (pág. 173 n.), actitud adoptada antes por Tomás de Iriarte en La Música y por Andrés (1787 pp. 351-354), e incluso la reglamenta con detalle (1793 pp. 145188). La zarzuela y sus análogos, en cambio, no merecieron el beneplácito de D. Santos:

Esto de estar hablando un actor y en el momento inmediato, cuando menos se espera, cantar, y luego volver a su primera declamación, me parece cosa irregular y fuera de lo que dicta la razón y el buen gusto (op. cit. pág. 141).

Más tolerante y propicio a la disculpa fue $\mathrm{D}$. Tomás, en nombre del gusto nacional y "la española natural prontitud" (1989, pág. 266), y también Eximeno:

... dramas en música que llaman zarzuelas, en las cuales se declaman las escenas y solamente se canta la parte que exige música, esto es los pasajes en que brilla alguna pasión. De este modo no se fastidia a los espectadores con la insufrible monotonía del recitado italiano. (op. cit. pp. 195196) 


\section{Distinción entre tragedia y comedia}

Para el Neoclasicismo, tragedia y comedia son dos formas dramáticas perfectamente delimitadas que no admiten entre sí híbridos, aun cuando una distinción radical entre ambas carece de aval en la Poética de Aristóteles y en el teatro griego. Cuando determinadas formas intermedias aparezcan (tragedia burguesa, comedia sentimental) se producirá la gran renovación del teatro dieciochesco, de la que no cabe ocuparse aquí.

La tragedia, según la Poética de Luzán (pág. 433) es:

Una representación dramática de una gran mudanza de fortuna acaecida a reyes, príncipes y personajes de gran calidad y dignidad, cuyas caídas, muertes, desgracias y peligros exciten terror y compasión en los ánimos del auditorio y los curen y purguen de estas y otras pasiones, sirviendo de ejemplo y escarmiento a todos, pero especialmente a los reyes y a las personas de mayor autoridad y poder.

Las características de esa tragedia son la siguientes:

$1^{\text {a }}$. Debe ser de asunto y protagonista históricos; se supone que lo realmente sucedido y divulgado afecta más al espectador y es más didáctico; además, siendo el héroe un príncipe, la Historia conservará por fuerza acciones de muchos de ellos aptas para ser dramatizadas. No debe olvidarse que el poeta está autorizado a modificar la verdad particular de los hechos y de los personajes históricos, como vimos más arriba.

2 . Los asuntos no deben corresponder al contexto espacio-temporal del espectador. Si corresponden a su mismo tiempo, deben situarse en espacio remoto; si a su mismo espacio, en un tiempo remoto; o bien en espacio y tiempo remotos ambos. La razón es que de otro modo el espectador podría estar informado de toda clase de detalles sobre acontecimientos y conducta de personajes, y sorprenderse ante las adaptaciones que de ellos debe realizar el poeta en aras de la Verosimilitud, el Decoro y la no sumisión de la Poesía a la Historia.

3․ El héroe trágico debe ser de rango elevado, puesto que sólo un poder y unas circunstancias como los suyos permiten acometer las acciones que son materia trágica, o sufrirlas; también porque se supone que los príncipes están rodeados de veneración e interés, y que sus destinos mueven a todos porque afectan a las naciones o comunidades por ellos regidas. Ese rango obliga a hacerlos actuar movidos por las pasiones que les son propias (ambición, orgullo, afán de poder), de acuerdo con las exigencias de Verosimilitud y Decoro. La pasión amorosa, cuando se desenvuelve en la esfera estrictamente privada en su alcance y consecuencias, o cuando da lugar a una mera intriga galante, no es un resorte propiamente trágico. Escribe Luzán:

Divide Aristóteles los hombres en mejores y peores; los primeros son propios de la tragedia, los segundos de la comedia. Y claro está que Aristóteles por mejores entiende los mejores en fortuna, en poder, en riquezas y en 
fama, y por peores entiende la gente vulgar y los hombres particulares. Y la razón por que aquéllos y no éstos son propios para la tragedia es porque como la tragedia es una imitación de un hecho grande y famoso y tiene por fin el excitar en los ánimos del auditorio los afectos de terror y de compasión, los personajes ilustres y grandes son más a propósito para mover tales afectos; sus caídas son más ruidosas, sirven de mayor escarmiento y causan mayor terror y más lástima. Al contrario, los hombres particulares y plebeyos no son propios para la tragedia, porque regularmente entre tales personas no suceden casos tan extraños ni de tan grandes consecuencias, y dado que sucedan y por ellos caigan de la felicidad en la miseria, la caída es tan baja y tan poco considerable que no podría causar mucho terror ni mucha lástima" (Ibíd, pág. 471).

El Pinciano habla de "personas ilustres", "varones gravísimos" y "personas graves" (1973, I, pp. 240 y 246; II, pág. 330), y sintetiza perfectamente las razones de su idoneidad:

... personas graves, las cuales naturalmente mueven más a compasión cuanto de más alto estado vienen a mayor miseria; y las personas que son conocidas de todos por las Historias antiguas y poemas serán más a propósito, lo uno porque como conocidas hacen más compasión, y lo otro porque como públicas hacen más fe y verosimilitud en la acción (Ibíd. II, pp. 330-331).

Para Aubignac, la tragedia representa "la vida de los príncipes, llena de inquietudes, de temores, de trastornos, de rebeliones, de guerras, de muertes, de pasiones violentas y de grandes aventuras" (1971, pág. 128 - traducción mía). Rapin cifra la utilidad moral de la tragedia en el ejemplo de la caída de "los grandes y las personas más considerables" (1970, pág. 97). Según Luzán, "de ordinario las fábulas trágicas se sacan de algún hecho verdadero e histórico" y de "las desgracias de reyes, etc." (1977, pp. 440, 532). Montiano reconoce que "Ios hechos ideales y fingidos, por más que sean verosímiles, no mueven tanto como los reales y verdaderos" (1750, pág. 118) y se cree obligado a disculparse porque los protagonistas de su Virginia no son príncipes y por lo tanto "dista la inferioridad de su estado de la elevación que se requiere" (Ibíd. pág. 86).

La elevación social de la tragedia en lo tocante a protagonistas y acciones llega incluso a sugerir que los mismos príncipes son su destinatario predilecto, ya que sólo ellos podrán propiamente aplicar el mensaje moral trágico a situaciones, móviles y conductas similares a los vistos en escena, los cuales sólo podrán ser asumidos por personas de menor rango tras una minoración analógica. El Pinciano escribe que la finalidad de la tragedia es "suadir a los príncipes" (I, pág. 246); Luzán que en ella "los príncipes pueden aprender a moderar su ambición, su ira y otras pasiones con los ejemplos que se representan de príncipes caídos", mientras "el pueblo y los hombres particulares logran su aprovechamiento en la comedia" (1977, pág. 194); Díez González, que la tragedia "sirve de ejemplo y escarmiento a los grandes personajes" (1793, pág. 86). 
Por otra parte, Luzán recomienda al autor de tragedias que "no saque los argumentos de historias muy modernas [...] por lo cual debe siempre echar mano de historias y acciones antiguas y apartadas de nuestra edad", aunque "también puede el poeta servirse de casos modernos y recientes, como sean de países muy distantes, porque para el vulgo lo mismo es la distancia de mil leguas que la antiguiedad de mil años" (1977, pág. 455). Leandro Moratín, en sus anotaciones a La Comedia nueva, da por sentado que "son muy poderosas las razones que hay para elegir los héroes de la tragedia en épocas y regiones distantes de nosotros" (1970, pág. 198).

$4^{a}$. El héroe trágico debe ser moralmente intermedio. La tragedia exige habitualmente un final desgraciado, y produce su efecto didáctico gracias a la kátharsis o purificación de las pasiones. Ésta exige a su vez que el espectador sienta terror y compasión o piedad ante el héroe, al mismo tiempo que acepta moralmente la licitud de su castigo. Tales sentimientos no los puede suscitar un héroe totalmente virtuosos e intachable, ni uno totalmente vicioso y repobable, sino uno básicamente virtuoso pero lastrado por un vicio, una falta o un error. Tras plantearse las combinaciones posibles entre las categorías morales (hombres buenos y virtuosos, malos y viciosos, indiferentes -estos últimos los que hemos llamado intermedios) y las "mudanzas de fortuna" (paso de la felicidad a la desgracia y viceversa), Luzán concluye:

[El caso] en el cual los indiferentes bajan de la felicidad a la miseria es la constitución que Aristóteles aprueba sobre todas para la tragedia, con la circunstancia de que tales personas no fragüen su desgracia por algún delito enorme sino por ignorancia, yerro o falta pequeña que no pueda llamarse delito (1977, pág. 472).

La justificación psicológica de esta preferencia puede verse, por ejemplo, en Cascales:

Las acciones de los buenos no pueden causar terror y compasión, aunque más sean conducidas a mísero y desastrado fin, porque no siendo por culpa o pecado suyo el infortunio o muerte que les suceda, será su fin de mal ejemplo y será mal recibido de los oyentes, viendo que los buenos son castigados. Ni más ni menos las acciones de los malos no producen el efecto que buscamos de conmiseración y terror, porque siendo malos cualquier mal suceso que les venga será tenido por justo y bueno, cuyo castigo no solamente no moverá a lástima y horror pero le alabarán y tendrán por bueno. Según esto, las personas que son en parte buenas y en parte malas son aptas para mover a misericordia y miedo, y es porque le parece al oyente que aunque el que padece merece pena, pero no tanta ni tan grave. Y esta justicia mezclada con el rigor y gravedad de la pena induce aquel horror y compasión que es necesario en la tragedia (1975, pp. 186-187).

En resumen: la tragedia debe inspirarse en hechos reales ofrecidos por la Historia; es el paso de la felicidad a la desgracia de personajes históricos, no correspondientes al tiempo ni al espacio del espectador, socialmente elevados y moralmente intermedios; su efecto didáctico se produce por medio de la 
kátharsis. En el epígrafe siguiente señalaremos los problemas que implican los conceptos de kátharsis y de culpa o error.

La comedia, por su parte, ha de ser de asunto inventado y contemporáneo, y reflejar las tribulaciones de personajes positivos pero no excelsos, que triunfan frente a otros negativos o viciosos, pero no moralmente monstruosos ni desaforados. Son todos ficticios, socialmente bajos (lo que llamaríamos pueblo y clase media) y correspondientes al espacio y tiempo del espectador; el efecto didáctico se produce por la ridiculización de los vicios de los personajes negativos, y el hecho de que sean susceptibles de ridículo y risa indica bien a las clara su corto alcance y poca gravedad. Oigamos de nuevo a Luzán:

Lo que más importa en las comedias es que la virtud se represente amable y premiada, y el vicio feo, ridículo y castigado, porque de ahí resulta el aprovechamiento del público (1751, pp. [11] - [12]).

La comedia [...] es una representación dramática de un hecho particular y de un enredo de poca importancia para el público, el cual hecho o enredo se finja haber sucedido entre personas particulares o plebeyas con fin alegre y regocijado, y que todo sea dirigido a utilidad y entretenimiento del auditorio inspirando insensiblemente amor a la virtud y aversión al vicio, por medio de lo amable y feliz de aquélla y de lo ridículo e infeliz de éste (1977, pág. 528).

Es esencialmente la misma definición de Leandro Moratín en el "Discurso preliminar" a sus comedias.

Mientras "la tragedia se funda en Historia, la comedia es toda fábula", y fábula "alegre y regocijada entre personas comunes", observaba el Pinciano (III, pág. 20; I, pág. 241). La razón del carácter ficticio de la fábula cómica viene, en última instancia, de un prejuicio clasista según el cual sólo príncipes y aristócratas son sujetos dignos de la memoria histórica:

Las acciones de los particulares y del pueblo no se extienden de ordinario más allá del barrio donde suceden, ni la memoria de ellas se conserva en las Historias; antes bien, como el público se interesa muy poco en semejantes sucesos, se entrega luego a perpetuo olvido. Por esto la fábula cómica, aunque sea verdadera su acción, siempre será como fingida (Luzán, 1977, pág. 456).

Moratín asigna a la comedia la pintura de "acciones domésticas, caracteres comunes, privados intereses, ridiculeces, errores, defectos incómodos [...] las costumbres populares que hoy existen, no las que pasaron ya; las nacionales, no las extranjeras" (op. cit. pp. 198-199). Por eso no caben en la mentalidad neoclásica comedias de "reyes, príncipes, archiduques, pontífices y emperadores, y asaltos y conquistas", es decir las comedias heroicas del Siglo de Oro y sus descendientes del XVIII (Ibíd, pp. 201-202). Los vicios materia de la comedia "son o deben ser tales que no se deban castigar con las penas graves de las leyes" sino con el desprecio y la risa (Díez González, 1793, pág. 143), a diferencia de los graves desafueros y delitos trágicos. 
Finalmente, Luzán sostiene (1977, pp. 371, 510-511) que la solemnidad y elevación de la tragedia exigen el uso del verso, endecasílabo y heptasílabo, con estructura simple y no artificiosa de rimas, o bien suelto. La comedia puede escribirse en prosa o bien en romance, de acuerdo con su naturalidad y sencillez. No podrá, según Luzán, haber tragedia en prosa. Idéntica es la opinión de Leandro Moratín (1944,pp. 320-321), que compuso dos de sus comedias (La Comedia nueva y El sí de las niñas) en prosa, y las otras tres en romance.

La visión aristocéntrica del mundo y el desdén hacia las clases popular y burguesa que revela la oposición neoclásica entre tragedia y comedia traiciona los prejuicios estamentales de la sociedad del Antiguo Régimen y supone que bajo su inspiración se realizó una lectura reductora de la Poética de Aristóteles. La lógica de la historia y la presión social de los particulares y plebeyos daría pronto lugar a la comedia sentimental, la tragedia burguesa y la toma de la Bastilla.

\section{EI Neoclasicismo, Aristóteles y el teatro griego}

Nuestro planteamiento de la codificación dieciochesca del Neoclasicismo (que fue menos sutil que el de los dos siglos precedentes) resultará enriquecido con algunos matices.

En cuanto a los personajes y el asunto de tragedia y comedia, Aristóteles (1974, pp. 131-132, 138, 141-145, 170-171, 181-182) asigna a la primera las acciones esforzadas (heroicas, de envergadura, superadoras de grandes obstáculos y necesitadas de gran esfuerzo) de hombres esforzados y mejores, y a la segunda las conductas viciosas (pero no en toda la extensión del vicio, sino en lo que no causa gran dolor ni ruina y es en último extremo risible aunque reprobable) de hombres de baja calidad y peores. La ambigüedad de la distinción entre mejores y peores es considerable; entenderla en cuanto "al vicio o la virtud" (frase probablemente interpolada en la Poética), aun en una lectura no cristiana de ambos términos, parece dudoso a la vista de Edipos y Medeas. Más aceptable es referirla al rango social, como entendió el Neoclasicismo habida cuenta de la naturaleza principesca de los linajes míticos de la tragedia griega: y no es imposible suponer que mejores aluda al carácter arquetípico o universalidad de la imitación, más exigible en la tragedia que en la comedia.

La naturaleza y requisitos de la kátharsis son el principal atolladero conceptual de la interpretación de la Poética de Aristóteles (véase 1974, pp. 143-145, 169-170). Charles Perrault llega a escribir en el cuarto diálogo de su Parallèle des anciens et des modernes (1971, pág. 266) que la purgación de las pasiones es "un galimatías que ha sido explicado tan diversamente que podemos deducir que nadie lo ha entendido" (traducción mía).

La delimitación de compasión y temor empieza por resultar confusa. Según la Retórica del mismo Aristóteles (1974, p. 341-349), se siente compasión 
hacia el esforzado en tribulación grave no merecida, y hacia el semejante que sufre un mal que puede alcanzarnos también; pero por otra parte sabemos que el personaje trágico merece en parte, y en parte no merece, su desdicha, y que la de los absolutamente virtuosos o malvados no cabe en el planteamiento trágico. Temor, a su vez, se siente hacia lo que puede sucedernos a nosotros y ante lo que, al afectar o amenazar a otros, nos mueve a compasión. La compasión parece dirigirse al inocente y el temor al semejante, pero con la paradójica circunstancia de que el completamente inocente quede excluido de la primera, y de que los horribles destinos de los personajes trágicos puedan llevarnos a creernos sus semejantes.

Pero, por otra parte, no hay en buena lógica razón ninguna para que las tribulaciones del absolutamente inocente, sea cual sea su rango social, no puedan ser objeto trágico. Admitirlo abre una de las vías hacia la Tragedia Burguesa y la Comedia Sentimental:

Quedan aún otros prejuicios que combatir, entre ellos la supuesta norma teatral que exige que en cada obra quede el vicio castigado y triunfante la virtud [...] Erraría el poeta que pretendiera hacernos creer que la inocencia es siempre reconocida y premiada. No sólo digo que excluiría la piedad y el terror, que apenas despertaría el sentimiento de la compasión [...], sino que añado que presentaría el teatro del mundo bien distinto de lo que en realidad es [...] Pero, se me objetará [...], cuando los hombres vean el triunfo del crimen, ¿no irán a alistarse en las filas donde parece reinar la impunidad? [...] Si el poeta siente verdaderamente amor a la justicia, ese amor se hará patente a pesar del desenlace injusto; mostrará a la inocencia [...] satisfecha en último término de saberse respetada y amada por todos los que la conocen, cifrando su recompensa en su admiración... (Mercier, 1970, pp. 246-251)

¿Acaso no podéis imaginar el efecto que os haría una situación real, vestiduras de hoy [...] y peligros que amenazan a vuestros padres y amigos, y a vos mismo? Un revés económico, el miedo a la vergüenza, las consecuencias de la miseria, una pasión que lleva al hombre a la ruina, a la desesperación y a la muerte violenta, no son sucesos infrecuentes; $\measuredangle y$ no admitís que os afectarían tanto como la muerte fabulosa de un tirano o el sacrificio de un niño en el altar de los dioses de Atenas o de Roma? (Diderot, 1967, pág. 92 — traducción mía en ambos casos).

Según la Política (Ibíd, pp. 349-351), los cantos entusiásticos ponen fuera de sí al poseído y producen purgación, o sea alivio y placer resultado de la relajación de la tensión psíquica al actualizarse y exteriorizarse las pasiones habitualmente reprimidas.

Una lectura literal de la Poética lleva a entender que las pasiones purgadas son exclusivamente la compasión y el temor mismos. Ésta parece ser la interpretación del Pinciano:

¿Cómo con temor y misericordia se quita la misericordia y el temor? ¿Por ventura es ésta acción de clavo, que con uno se saca el otro, o de sacamolero, que con un dolor quita otro? 
Eso mismo, dijo Hugo, porque con el ver un Príamo y una Hécuba y un Héctor y un Ulises tan fatigados de la fortuna, viene el hombre en temor no le acontezcan semejantes cosas y desastres; y aunque por la compasión de mirarlas con sus ojos en otros se compadece y teme estando presente la tal acción, mas después pierde el miedo y temor con la experiencia de haber mirado tan horrendos actos, y hace reflexión en el ánimo, de manera que alabando y magnificando al que fue osado y sufrido, y vituperando al que fue cobarde y pusilánime, queda hecho mucho más fuerte que antes; y de aquí luego sucede el librarse de la conmiseración, porque la persona que es fuerte para en su casa también lo será en la ajena, y de la ajena miseria no sentirá compasión tanta (1973, II, pp. 314-315).

Para González de Salas, "habituándose el ánimo a aquellas pasiones de miedo y de lástima, frecuentadas en la representación trágica, vendrán forzosamente a ser menos ofensivas [...] pues es cosa natural que de las acciones acostumbradas, aunque penosas sean, no se contraiga pasión" (1778, pp. 25-26).

Puede por lo tanto entenderse que compasión y temor, por la experiencia teatral, se moderan y templan a sí mismas a consecuencia del ejercicio y del hábito. Más sutil fue la interpretación de Lessing, para quien ambas pasiones alcanzan, cada una por su cuenta, su justa medida por incremento o disminución, y se equilibran entre sí como vasos comunicantes donde el exceso o defecto de cada una es compensado por la otral.

Pero junto a esta interpretación, restrictiva por respetuosa de la lectura del texto aristotélico, era inevitable que la orientación del didactismo teatral desde la moral cristiana impusiera que "en las tragedias no solamente se corrijan la compasión y el miedo, sino otras muchas pasiones" (Luzán, 1977, pág. 433), es decir que se entendiera la kátharsis como corrección de los vicios morales encarnados en los personajes trágicos, "para que los reyes y los poderosos corrijan con este medio sus vicios y pasiones violentas, porque movidos a misericordia y lástima por la representación de casos atroces y lastimosos, es fuerza que templen en parte la crueldad, la ira, la ambición, y se inclinen a las virtudes opuestas a tales vicios, y que el temor y horror concebidos en el teatro los haga más cuerdos y menos desvanecidos en la próspera fortuna y más sufridos y constantes en la adversa" (Ibíd, pág. 490).

1. Un espectador excesivamente compasivo verá su compasión reducida por la que experimenta en el teatro, por el hábito de ejercitarla. La compasión excesiva será igualmente reducida por el temor teatral, al desplazarse la preocupación por el mal ajeno, propia de la primera, hacia la preocupación por el mal propio, propia del segundo.

Una compasión insuficiente será aumentada por el estímulo de la compasión teatral; y también por el temor teatral, desde la analogía que percibe el espectador entre su propio yo y el del personaje trágico.

Un temor excesivo será reducido por el temor teatral, por la insensibilización relativa que produce el ejercicio del segundo; y por la compasión teatral, al ceder parte del temor egoísta en beneficio de la simpatía compasiva.

Un temor insuficiente será aumentado por el estímulo del temor teatral, y también por la compasión teatral, desde la analogía antes mencionada. Véase Kommerell, 1990, pp. 111-112. 
A las ambigüedades internas de la Poética de Aristóteles en algunos de sus puntos hay que añadir las que resultan de la comparación de sus preceptos con la práctica del teatro que fue su supuesta inspiración, y de la lectura cristiana de éste.

Sabemos que el personaje trágico pasa al infortunio no por radical maldad o vicio, sino por un grave error. Ese concepto se vuelve problemático cuando lo trasladamos desde el mundo griego a las ideas de responsabilidad moral propias de la civilización cristiana. En éstas caben la soberbia, la ambición, la desmesura y la impiedad de Jerjes de las que habla la Sombra de Darío en Los Persas de Esquilo (desde ahora E); la arrogancia de Agamenón, que usurpa honores reservados a los dioses tras la conquista de Troya en el Agamenón (E); el dilema de Antígona entre la obediencia a Creonte y la piedad hacia Polinice muerto en la Antígona de Sófocles (desde ahora S); el orgullo impío de Edipo ante Tiresias en el Edipo rey (S); la ambición e infidelidad de Jasón en la Medea de Eurípides (desde ahora Ee); pero desde ellas son difícilmente admisibles el engaño y la envidia de los dioses en Los Persas, la maldición que pesa sobre los linajes de Layo y Atreo, la venganza de Medea, el oráculo del que pende el destino de Hércules en Las Traquinias (S), o la responsabilidad de Palas en el Áyax (S), de Venus en el Hipólito (Ee) o de Baco en Bacantes (Ee).

En cuanto a las Unidades, es dudoso que Hipólito y Andrómaca $(\mathrm{Ee})$ cumplan la de Tiempo (en el primer caso, por la duración verosímil del trayecto de Hipólito hasta la costa donde sufre el accidente, los viajes del mensajero y el traslado del cuerpo del herido; en el segundo, por el viaje de la esclava que ha ido a buscar a Peleo para salvar a Andrómaca de Menelao, por el del mismo Peleo, por el del mensajero que relata la muerte de Neoptólemo en Delfos y por el que de la comitiva que transporta el cadáver). Andrómaca y Suplicantes (Ee) son ejemplos de fábula episódica, contraria a la Unidad de Acción.

La no escenificación de la violencia se cumple en términos generales en el teatro griego: las muertes son relatadas por un mensajero u otro personaje en Los siete contra Tebas (E), Las Traquinias (S), Antígona (S) o Hipólito (Ee), por ejemplo, o bien se recurre a poner ante el espectador el momento en que un personaje es conducido a la muerte, a hacerle oír sus gritos entre bastidores cuando es herido o a mostrar su cadáver, como ocurre en Agamenón (E), Coéforas (E), Electra (S), Medea (Ee) o Electra (Ee). Pero, por otra parte, aun dejando a un lado el teatro de Séneca, Áyax se suicida en escena en Áyax (S), y en Bacantes (Ee), tras la narración de la muerte y descuartizamiento de Penteo por su propia madre y las mujeres tebanas, enloquecidas por Baco, la madre manipula en escena la cabeza de su hijo e invita a todos a un festín ritual en el que se comería su cadáver.

Sobre los personajes y el asunto de la tragedia es necesaria una puntualización. Ya sabemos que se consideró que debían ser históricos, y por 
qué motivos. Sin embargo, Aristóteles (1974, págs. 159-160) dejó escrito que hay tragedias, y no por ello inferiores, de personajes y asunto ficticios, como La Flor de Agatón (uno de los contertulios del Banquete platónico), y que al fin y al cabo lo histórico no es conocido de todos ni por completo (lo que significa tanto que podemos modificar la Historia de acuerdo con las exigencias de la Poesía, como que una tragedia de materia inventada podría cumplir perfectamente sus funciones - y acaso ser entendida dicha materia como histórica, del mismo modo que Luzán señalaba que la de una comedia, aun siendo histórica, se entendría siempre como inventada).

Luzán, tras preguntarse si "el argumento de la tragedia debe tomarse de la historia o puede fingirse de planta", llega a la conclusión de que "se pueden hacer tragedias de argumento fingido, en lo cual no pongo la menor duda, persuadido de la razón no menos que de la autoridad de Aristóteles", porque lo que de verdad importa no es la ficción o verdad de fábula y personajes sino "la buena constitución de la fábula y otras circunstancias" (1977, pág. 453). La posibilidad teórica quedaba desde luego abierta, aunque para el Neoclasicismo resultaba dudosa su aplicación porque "hoy no tenemos tragedia alguna griega o latina que no contenga fábula de argumento conocido y verdadero; y con singularidad, para apoyo de su doctrina, pudo apenas nombrar Aristóteles una tragedia fingida de Agatón" (González de Salas, 1778, pág. 48), para mayor inri perdida. De modo que si la autoridad de Aristóteles y el sentido común obligaban a admitir la tragedia fingida como posibilidad, de todos modos resultaba desaconsejable por la falta de modelos y porque la tragedia histórica era siempre preferible, al ser el conocimiento previo de su asunto garantía del asentimiento del público, hasta tal punto que ese conocimiento era piedra de toque para valorar unos argumentos históricos en comparación con otros:

Así como los argumentos verdaderos son mejores que los fingidos, asimismo entre los verdaderos hay unos mejores que otros, pues si por ser notorio un argumento verdadero es mejor que el fingido, por ser más notorio un argumento verdadero que otro también verdadero, será asimismo mejor, más creíble y más útil (Luzán, 1977, pág. 454).

También debemos tener en cuenta, por paradójico que pueda parecer, que la preceptiva aristotélica dejaba abierta la posibilidad de una tragedia de final feliz, aunque con notable ambigüedad: Aristóteles establece que la constitución trágica puede ser el paso de la dicha al infortunio o viceversa (1974, pp. 155, 191) - teniendo en cuenta la condena de la fábula doble en la tragedia pero no en la comedia (Ibíd, pp. 172-173)-, para afirmar luego que la buena tragedia es la de fin desgraciado (Ibíd, pág. 171). Es sabido que obras como el Filoctetes de Sófocles o Ion, Ifigenia entre los tauros, Helena y Alcestes de Eurípides tienen buen fin, aunque es dudoso que el nombre de tragedias les convenga.

Aubignac afirma que no está justificado privar del nombre de tragedia a obras de desenlace feliz en las que la acción y los personajes sean de naturaleza 
trágica (acción esforzada de hombres ilustres), porque "la índole de los hechos y la condición de las personas" es lo que define la tragedia, y no el desenlace (1971, pp. 133-135). Luzán admite "aquellas en que muere el principal personado, como aquellas en que solamente peligra o tan sólo es abatido de la felicidad a la miseria, y también las de éxito feliz" (1977, pág. 433, subrayado mío); y en concordancia con Aubignac afirma que "aun en éstas las principales personas se ven en gravísimos peligros de perder la vida o el estado o la felicidad" (Ibíd, pág. 529), con lo cual lo esforzado y gravemente peligroso de la acción prima sobre el desenlace. Así el Pinciano reconocía que, si no cabe comedia de fin desgraciado, sí en cambio tragedia de "alegres fines": "Si la tragedia alguna vez, que son pocas, viene a rematar en tales remates, tiene primero mil miserias, llantos y tristezas de los actores y representantes, y mil temores y compasiones de los oyentes" (1973, III, pág. 25). De modo que pudiendo la compasión y el temor ser excitados por la acción sea cual sea el desenlace, cabe tragedia feliz, aunque será de más débiles efectos.

Podemos observar por lo tanto que la vulgata del Neoclasicismo resultaba menos rica en matices y más rígida que la Poética de Aristóteles y que el pensamiento de sus buenos conocedores. En estos matices estaba el germen de la renovación teatral del XVIII, sin más que interpretar libremente la tradición aristotélica. Siendo posible una tragedia de asunto y personajes ficticios (lo que nos aproxima al asunto y personajes de la comedia, particulares y plebeyos) estaba trazado el camino hacia la tragedia burguesa o doméstica: y ese mismo tipo de tragedia, con un final feliz, nos conduce directamente a la comedia sentimental. La rigidez neoclásica no procedía de Aristóteles, sino de la ideología estamental que, secuestrando el teatro de asunto esforzado para ejercicio de personajes ilustres y dando por supuesto que fuera de la aristocracia no podían existir personas graves, intentó confinar a los personajes de clase media y popular, degradando sus problemas y conflictos, en el ámbito de lo cómico risible.

\section{OBRAS CITADAS}

ANDIOC, René. 1965. "Une zarzuela retrouvée: El Barón de Moratín", Mélanges de la Casa de Velázquez 1 (1965), pp. 289-321.

ANDRÉS, Juan. 1787. Origen, progresos y estado actual de toda la literatura, IV, Madrid, Sancha.

ARISTÓTELES. 1974. Poética (con extractos de Retórica y Política), ed. Valentín García Yebra, Madrid, Gredos.

D'AUBIGNAC, François H. 1971. La pratique du thêâtre, Ginebra, Slatkine.

BATTEUX, Charles. 1969. Les Beaux Arts réduits à un même principe, Ginebra, Slatkine. 
BOILEAU-DESPRÉAUX, Nicolas. 1967. Art poétique, en Épîtres. Art Poétique. Lutrin, ed. Charles Boudhors, París, Belles Lettres.

CASCALES, Francisco. 1975. Tablas poéticas, ed. Benito Brancaforte, Madrid, Espasa-Calpe.

CLAVIJO Y FAJARDO, José. 1762-1767. El Pensador, Madrid, Ibarra, 6 vols.

DIDEROT, Denis. 1967. Entretiens sur Le Fils Naturel. Paradoxe sur le comédien, ed. Raymond Laubreaux, París, Garnier-Flammarion.

DÍEZ GONZÁLEZ, Santos. 1973. Instituciones poéticas, Madrid, Benito Cano.

EXIMENO, Antonio. 1796. Del origen y reglas de la música, III, Madrid, Impta. Real.

GONZÁLEZ DE SALAS, José Antonio. 1778. Nueva idea de la tragedia antiguao ilustración última al libro singular de Poética de Aristóteles Stagirita, I, Madrid, Sancha.

IRIARTE, Tomás de. 1989. La Música, en Colección de obras en verso y prosa, I, microficha ed. 1787, Oviedo, Pentalfa.

JOVELLANOS, Gaspar M. de 1963. Memoria para el arreglo de la policía de los espectáculos y diversiones públicas, en Obras, I (BAE XLVI), Madrid, Atlas.

KOMMERELL, Max. 1990. Lessing y Aristóteles. Investigación acerca de la teoría de la tragedia, Madrid, Visor.

LÓPEZ PINCIANO, Alonso.1973. Filosofía antigua poética, ed. Alfredo Carballo Picazo, Madrid, CSIC, 3 vols.

LÓPEZ DE SEDANO, Juan José. 1763. Jahel, Madrid, Ibarra.

LUZÁN, Ignacio de. 1751. Traducción de Pierre Nivelle de La Chaussée, La Razón contra la moda, Madrid, Orga.

- 1977. Poética, ed. Russell P. Sebold, Barcelona, Labor.

- 1990. Plan de una Academia de Ciencias y Artes, en Obras raras y desconocidas, ed. Guillermo Carnero, vol. I, Zaragoza, Instit. Fernando el Católico.

MARMONTEL, Jean-François. 1867. Éléments de Litteráture, París, Didot, 3 vols.

[MERCIER, Louis-Sébastien]. 1970. Du Théâtre, ou Nouvel essai sur l'art dramatique, Ginebra, Slatkine.

MONTIANO, Agustín de. 1750. Discurso sobre las tragedias españolas, con la tragedia Virginia, Madrid, Orga.

MORATÍN, Leandro F. de 1970. La Comedia Nueva, ed. John Dowling, Madrid, Castalia. Anotaciones de Moratín en pp. 163-216.

- 1973. Carta a Godoy de 20-XII-1972, en Epistolario, ed. René Andioc, 
Madrid, Castalia.

MORATíN, Nicolás F. de. 1762. La Petimetra, Madrid, Muñoz.

- 1762-1763. Desengaño (I), II y III al teatro español, Madrid, s.i., 3 vols.

- 1763. Lucrecia, Madrid, Martínez Abad.

- 1764. Sátiras, en El Poeta, Madrid, Escribano, no 3 pp. 42-48; n 6 pp. 8796; no 9, pp. 133-144; y en L. y N.F. de Moratín, 1944, pp. 31-34.

- 1770. Hormesinda, Madrid, Sancha.

- 1777. Guzmán el Bueno, Madrid, Sancha.

MORATÍN, Leandro y Nicolás F. de 1944. Obras (BAE II), Madrid, Atlas.

PERRAULT, Charles. 1971. Parallèle des anciens et des modernes, Ginebra, Slatkine.

RAPIN, René. 1970. Réflexions sur la poétique de ce temps, ed. E.T. Dubois, Ginebra, Droz \& París, Minard.

[SAMANIEGO, Félix Mª]. 1972. Discurso 92, en El Censor, ed. Elsa García Pandavenes, Barcelona, Labor, pp. 167-179. 


\title{
LA ERÓTICA DE LA MUERTE EN UN PERSONAJE CLARINIANO: ÁNGEL CUERVO. ESTUDIO DE UNA PASIÓN
}

\author{
Ángeles EZAMA GIL \\ Universidad de Zaragoza
}

\begin{abstract}
Fue entonces, en efecto, cuando empezó a escribir su Confesión, [...] que era el relato de su lucha íntima con la pasión que fue su vida [...] Esta confesión se hacía dirigida a su hija, pero tan penetrado estaba él del profundo valor trágico de su vida de pasión y de la pasión de su vida, que acariciaba la esperanza de que un día su hija o sus nietos la dieran al mundo, para que éste se sobrecogiera de admiración y de espanto (M. de Unamuno, Abel Sánchez. Una historia de pasión, pág. 147).
\end{abstract}

La novelita clariniana Cuervo se publica por vez primera en el diario madrileño La Justicia los días 1, 2 y 3 de Enero de 1888 (Botrel y Blanquat, pág. 56); con posterioridad aparece en las páginas del "Suplemento de ciencias, literatura y artes" de La Correspondencia de España los días 9, 16, 30 de Noviembre y 21 de Diciembre de 1890 . Por fin, en 1892 se publica en volumen junto con Doña Berta y Superchería en la editorial de Fernando Fe.

La primera edición en volumen incluye las novelitas por este orden: Doña Berta, Cuervo, Superchería, orden que se respeta en la edición publicada en 1929 por la Editorial Renacimiento, así como en la de 1943 con prólogo de Ramón Pérez de Ayala. La edición de Taurus de 1970 altera este orden (Superchería, Cuervo, Doña Berta), contraviniendo así las indicaciones del propio escritor al respecto, el cual, en carta a su editor, le manifiesta su intención de publicar un volumen de tres "nouvelles" con Doña Berta al frente, y destacada en el título sobre las otras dos: "Deseo que en la portada se lea Doña Berta con letras mayores y después con otras bastante más pequeñas Cuervo-Superchería" (Botrel y Blanquat, pág. 6).

Cuervo es el relato más breve del volumen de 1892 y también el que menor atención crítica ha recibido. Además, las valoraciones de que ha sido objeto 
han tendido, más que a subrayar sus valores intrínsecos, su cualidad de "producción extraña" en el conjunto de la narrativa clariniana. Así, Ricardo Gullón la considera una novela fracasada, porque Clarín "para crear aladamente necesitaba sentir por los personajes una corriente de simpatía que en el caso de Cuervo no llegó a experimentar".

Por su parte, Sobejano (pp. 94-96) la considera una novela heterodoxa, "producto extraño o único" entre las otras dos que integran el volumen de 1892; Laura de los Ríos (pág. 89) dice de ella que es "una obra extraña, difícil de clasificar"; y José M. González Herrán (1987, pág. 86) la conceptúa de "rara avis en el corpus narrativo de Clarín".

Estas más que cuestionables apreciaciones sobre el relato son el resultado de un desenfoque en su valoración: el juicio sobre Cuervo se hace en términos relativos, mediante su cotejo con Doña Berta y Superchería, relatos cuya técnica compositiva es muy distinta, como ya lo hizo notar Ramón Pérez de Ayala (pág. 23): “Aquí tienes, lector, un libro de Clarín. Contiene tres novelas cortas. Mejor dicho, dos novelas cortas (Doña Berta y Superchería) y otra obrilla, de cortas dimensiones, Cuervo, que pertenece a la línea sucesoria de los Caracteres de Teofrasto".

Asimismo, se habla en términos relativos cuando se considera Cuervo como relato inacabado, proyecto o esbozo de personajes para una novela de mayor envergadura. Además, las apreciaciones a este respecto son meras hipótesis, puesto que no disponemos de otros datos sobre este relato que los que nos proporciona el mismo texto; por ello, aventurar suposiciones sobre su condición de relato inacabado resulta, cuando menos, arriesgado.

Hay aún otro aspecto compositivo que hace de Cuervo un relato "atípico" frente a los otros dos del volumen; mientras que en Doña Berta y Superchería el narrador cuenta una experiencia singular que afecta de modo peculiar al personaje en un momento determinado de su vida, en Cuervo el narrador relata una vez un ritual que se repite con frecuencia en la vida del personaje, adoptando ese carácter genérico de "imitación de lo universal", que Leonardo Romero (pág. 256) señala como uno de los ingredientes esenciales del tipo costumbrista. Y, en efecto, este relato clariniano es un ejemplo perfecto para ilustrar las dificultades de deslindar dos géneros tan próximos como el cuento y el artículo de costumbres ${ }^{1}$, como muy acertadamente intuyó Mariano Baquero Goyanes (1949b, pp. 95-102). Textos igualmente problemáticos en su conceptuación genérica los encontramos entre los escritores contemporáneos, v. gr. en cuentos de Joaquín Dicenta como Los blanqueros y El maquinista o de Juan Ochoa como Un genio y Rodríguez Chanchullo.

1. La influencia del costumbrismo en la aparición y desarrollo de la novela realista es uno de los aspectos más discutidos en la crítica sobre el tema, en particular desde el trabajo de José Fernández Montesinos. La vinculación entre las colecciones de tipos y escenas y la obra narrativa de escritores como Alarcón, Valera, Galdós o Blasco Ibáñez resulta incuestionable para Enrique Rubio (1983 y 1988). 
La valoración ajustada de Cuervo implica un cambio en los supuestos desde los que habitualmente ha sido estudiado el relato. Para ello habremos de comenzar por intentar dar una explicación a la más que evidente disfunción estructural entre anécdota narrativa y caracterización del personaje.

\section{La anécdota narrativa.}

La anécdota narrativa ilustra el ambiente de resistencia que acompaña, en la España del momento, los intentos de reforma en el terreno de la "higiene pública"2. Los numerosos tratados elaborados por higienistas como respuesta a este problema social someten invariablemente a consideración el tema del agua, tanto en sus aspectos beneficiosos como en los perjudiciales para la salud; el estancamiento (Pedro Felipe Monlau, 1847, pp. 174-182) y la contaminación de las aguas (José G. Richardson, pp. 83-89) son los causantes de estos últimos.

El relato clariniano asume este estado de opinión en torno al tema de la higiene. El pueblo que sirve de marco a los personajes se llama, y no por casualidad, Laguna, está rodeado de prados pantanosos, es insalubre, y sus habitantes responden al "toponímico" de lagunenses o paludenses"; entre ellos la mortalidad es muy elevada (Pedro Felipe Monlau, 1847, pág. 176). El médico higienista $\mathrm{D}$. Torcuato Resma, encargado de velar por la higiene pública, encuentra la causa de tan elevada mortalidad en la contaminación de las aguas:

De todo le echa la culpa al río, y dice que por el río puede venir la peste, y que se filtran por las capas de la tierra no sé qué diablos de animalejos que nos envenenan; y cita ejemplos de cosas que pasaron allá en tierras de franchutes; tal como el haber echado entre el estiércol de un corral no sé qué sustancias que solitas, pian, pianito, vinieron por debajo de tierra para

2. La tan debatida cuestión de la higiene pública no alcanza su fundamento científico hasta el siglo XIX (AA.VV.; Mercedes Granjel, pp. 17-74): entre 1848 y 1914 la higiene se constituye como ciencia y quedan definitivamente resueltas las doctrinas del contagio con las investigaciones sobre microbiología. El método que sirve de base a esta ciencia en una primera fase es el de la estadística demográfico-sanitaria, de cuya utilización dan fe, entre otros, los trabajos de A. Quetelet (conocido por su concepto de "l'homme moyen").

La influencia inglesa, pionera en las investigaciones sobre el tema, se hizo sentir en varios países, entre ellos España, donde destaca la labor de Pedro Felipe Monlau, sin duda el más brillante de los higienistas españoles (1846, 1847).

3. Cf. P.F. Monlau, 1847, ed. 1871, pág. 175:

Tanto y más que las corrientes deben llamar la atención las aguas estancadas, generalmente impuras y funestas para la salud de los hombres y la salubridad del territorio. [...] Excede a todo cálculo el número de víctimas que en todo el Globo, y especialmente en nuestra misma España, han sacrificado, y están sacrificando anualmente, las aguas encharcadas [...] Importa sobremanera, pues, dar curso veloz a las aguas impuras o estancadas, desaguar y secar los pantanos y lagunas perjudiciales [...] Al efecto se estudiará el respectivo modo de formación de cada Laguna, pantano o charca, la naturaleza de sus aguas, de su población vegetal y animal, de su fondo, de sus efluvios y de los efectos de éstos, etc. 
envenenar el río y después hacer que reventaran los vecinos de no sé qué ciudad ribereña.. (pág. 125) ${ }^{4}$.

Intenta paliar sus efectos recomendando higiene, recurriendo a las estadísticas demográficas, las tablas de mortalidad y la doctrina del término medio de Quetelet, y realizando observaciones "en el cementerio y en el hospital, y en la malatería y en las viviendas pobres, y hasta en la ropa de los vecinos honrados" (pág. 112).

Las alusiones a la falta de limpieza del pueblo en el cuidado del entorno urbano y del cuerpo (pág. 129), y de Cuervo en el vestido ${ }^{5}$, se orientan en esta misma dirección.

El problema de la higiene, no obstante, no parece afectar solamente al aspecto "material" de la vida de los lagunenses; es evidente que en Cuervo la higiene "moral" manifiesta en el peculiar estado anímico de los habitantes de Laguna (cuya alegría resulta provervial), así como en la "limpieza" que define la concepción de la muerte en Cuervo, no constituyen sino una respuesta ( ¿antídoto tal vez?), eficaz paliativo moral con el que hacer frente a las funestas consecuencias derivadas de la falta de salubridad.

\section{El retrato del personaje.}

Pero el desconcierto que esta novelita produce en el lector no proviene de la anécdota en sí, meramente circunstancial, sino de la reducción de ésta, elemento obligado en el relato breve tradicional (v. gr. Doña Berta y Superchería), al mínimo, y en la intensificación extrema de la parte dedicada al retrato del personaje, retrato "moral" que no es, ni mucho menos, único en la narrativa

4. En adelante citaré la novelita por la edición de 1892, indicando únicamente el título y la páginas.

\section{Cf. José G. Richardson, pp. 83-89:}

Cuando la lluvia cae sobre la tierra, una parte llena los estanques y va a engrosar los ríos; pero la parte mayor filtra a través del suelo, y después de muchas horas, o de muchos días, pasando por pequeños agujeros, se concentra en nuestros pozos. En el curso de su viaje hacia el centro de la tierra, disuelve, según dejamos dicho, numerosas substancias minerales [...] con respecto a las materias animales que encuentra con demasiada frecuencia en su camino, [...] pueden cambiar un agua potable en un veneno oculto y lento, o en un agente de destrucción inmediata.

5. "Don Ángel vestía de negro y enseñaba apenas un centímetro de cuello de camisa, y este poco no muy blanco" (Cuervo, pp. 128 - 129). Nuestro personaje, además usa "sombrero de copa de forma anticuada, algo grasiento" (Cuervo, pág. 119); en 1870 el Dr. Dulcamera afirma en su artículo que el sombrero de copa es antihigiénico.

6. Por estos años se publican algunos ensayos sobre la "higiene de las pasiones", como los de D. Foy y J.B.F. Descuret. Además, en los tratados de "higiene privada" se suele dedicar un capítulo a la higiene de las pasiones; v.gr. P.F. Monlau trata en sus Elementos de higiene privada de las sensaciones internas y de las pasiones, y señala que "el placer y el dolor son indispensables para la existencia y deben servirnos igualmente de reglas de higiene (1846, pág. 334). 
clariniana (vid. v. gr. relatos como El hombre de los estrenos -Pipá-, Un candidato —Palique - o Don Urbano - Cuentos morales; Mariano Baquero Goyanes, 1946, pág. 142 y 1949a, pp. 162 - 164), y que se explica perfectamente a la luz del prólogo que Clarín escribe para su colección de Cuentos morales (pp. 5-6):

Aun reduciendo el significado de moral a la virtud que una cosa puede tener para moralizar a los que cabe que sean seres morales (los individuos racionales), diré que mis cuentos no son morales en tal concepto. Los llamo así porque en ellos predomina la atención del autor a los fenómenos de la conducta libre, a la psicología de las acciones intencionadas. No es lo principal, en la mayor parte de estas invenciones mías, la descripción del mundo exterior ni la narración interesante de vicisitudes históricas, sociales, sino el hombre interior, su pensamiento, su sentir, su voluntad.

A partir de la apreciación de R. Pérez de Ayala en el prólogo a la edición de 1943 de Doña Berta. Cuervo, Superchería, todos los críticos han venido reiterando la adscripción de Cuervo a la línea de literatura moral que se inicia con los Caracteres de Teofrasto (s. IV a.c.), y después de numerosas imitaciones, culmina en el siglo XVII con Les caractères de La Bruyère (1688).

En los estudios sobre la moral confluyen, desde mediados del siglo XVIII, reflexiones filosóficas (David Hume, Charles Letourneau, Mme de Staël), pseudo-ciencias como la fisiognómica (Jean-Gaspard Lavater; Ramón Carnicer, pp. 267-272), investigaciones empíricas que cifran su objetivo en el análisis de la interrelación entre el comportamiento y carácter del ser humano y su fisiología", y manifestaciones literarias como la moda de las "fisiologías" (José Fernández Montesinos, pp. 95-106), estrechamente ligada a la aparición y desarrollo del costumbrismo.

Precisamente un tipo costumbrista, el del "agente fúnebre", de la colección Los españoles de ogaño (Tomás Luceño y Becerra), podría muy bien hallarse en la base de la configuración de Cuervo. Este tipo, perteneciente por lo general a la clase pobre del pueblo, suele vestir "chaqueta larga, chaleco, pantalón y corbata negros, sin omitir nunca el sombrero de copa con grasa ", y "carece de todo sentido de humanidad", considerándose feliz únicamente cuando se muere mucha gente; entra en las casas donde alguien se muere con aspecto risueño y complaciente, haciendo mucho ruido, y se ocupa de todas las circustancias que rodean a la muerte, No obstante, el personaje clariniano supera el aspecto puramente comercial del tipo citado al convertir la vivencia de la muerte en una pasión.

7. La frenología del Dr. Gall, ampliamente conocida en España por medio de traducciones, tratados de divulgación, manuales, revistas, y sobre todo gracias a la obra de Mariano Cubí y Soler, autor de varios trabajos sobre el tema y al que se considera el introductor de esta ciencia en España (Ramón Carnicer), y, posteriormente, las teorías del Dr. Lombroso (Luis Maristany, 1973, 1983); estas últimas ejercen un influjo indudable entre los escritores españoles (Lily Litvak, José Luis y Mariano Peset, Benito Mariano Andrade; Luis Maristany, 1983, pp. 373-381). 
Situado en la línea de todas estas consideraciones sobre la moral, Cuervo no constituye sino el análisis minucioso de un carácter, la anatomía de una pasión. Clarín parece complacerse en encarnar en sus personajes clericales (o seudo-clericales, como es el caso de Cuervo) pasiones avasalladoras; la profundamente sensual de Fermín de Pas, primero hacia Vetusta (su pasión y su presa) y luego hacia Ana Ozores, la del cura de Vericueto (protagonista del cuento de este título) hacia el juego o el amor platónico de Juan de Dios ("El Señor") por Rosario. Ángel Cuervo encarna la pasión por la vida frente a la muerte ajena, el profundo deleite sensual, individual y egoísta del ser humano que afirma su placer de vivir mientras otros se disgregan en la nada.

Cuervo parece un personaje salido de uno de los sermones del Magistral. Este, sin duda uno de los más espléndidos estudios de carácter perfilados en la narrativa clariniana, es además un aficionado a los estudios morales (Clarín, 1884, ed. 1984, pp. 450-453): lee con deleite los Caracteres de la Bruyère ${ }^{8}, E l$ Criterio de Balmes, y novelas contemporáneas que toma como punto de partida para el análisis de costumbres y temperamentos; sobre estos datos, cotejados con los de su experiencia personal, elabora sus sermones, cuyo tema preferido son los vicios y virtudes y sus consecuencias. De suerte que De Pas pinta el tipo del avaro, el del borracho, el del embustero, el del jugador, el del soberbio, el del envidioso y el del joven lujurioso, sin duda "su estudio más acabado", que cuenta con un perfecto exponente en el párroco de Contracayes presentado en el capítulo XII (Clarín, 1884, ed. 1984, pp. 460-464) de la novela.

Un cuasi-clérigo semejante en su apariencia y en su pasión al cura de Contracayes, transformada esta última en lujuria vital que aleja toda idea de destrucción en las proximidades de la muerte, es Cuervo, retrato de un carácter moral no aislado ni en la obra clariniana, como hemos visto, ni en el relato corto contemporáneo (v. gr. en los cuentos de J. O. Picón).

La ocupación habitual de Cuervo es la muerte, que comienza siendo una "necesidad e industria lícita, y en parte afición ingénita" y se convierte luego en "pasión viva, vocación irresistible" (cap. III) que el personaje llega a elevar a categoría de arte (cap. VII), por medio del cual ejerce su dominio sobre los lagunenses. Su concepción de la muerte es esencialmente "limpia" (Cuervo, pág. 128 ), vital (resumida en el "ergo vivamus" del capítulo $X$ ) y, por lo mismo, profundamente sensual, teñida de una voluptuosidad extrema que invita al goce de los sentidos (cap. VIII):

Entonces sí que gozaba de veras don Ángel, sin malicia alguna y sin algazara, que sería monstruosa profanación; gozaba sin darse cuenta de ello, saboreando el placer recóndito, que era el alma, la más profunda médula de

8. La obra del moralista francés hubo de ser bien conocida por los escritores decimonónicos, ya que de ella se publicaron, a lo largo del pasado siglo, al menos cinco ediciones (Robert Garapon, pág. XLV). 
toda esta pasión invencible de nuestro hombre; un placer de que no podía acusarse, porque lo sentía sin reconocer su naturaleza; y consistía en saborear la vida, la salud, el aguardiente, el tabaco, la buena conversación (pág. 134)

El vitalismo de que se nutre el personaje clariniano, afirmación de salud pletórica frente a la muerte ajena, no es sino un sentimiento egoísta, profundamente enraizado en el ser humano, y que surge en la narrativa clariniana como respuesta contra lo excesivamente racional y científico; Mariano Baquero Goyanes ya señalaba en 1949 que Clarín propone en algunos de sus cuentos (v. gr. Doctor Sutilis, La mosca sabia, El gallo de Sócrates) "un vitalismo que, en ocasiones, llega a lo pánico y primario" (1949a, pp. 10-11; 1952, pp. 199 y ss.).

Esta vivencia "apasionada" de la muerte se explica perfectamente a la luz del tratado de Mme de Staël; en el capítulo 5 de la lección 1 trata su autora sobre pasiones como el juego, la avaricia y la ebriedad (pp. 179-189), que caracteriza como "sensations égoïstes", cuya única ventaja cifra en "l'agitation que suspend le sentiment et la pensée; elles donnent une sorte de personnalité matérielle, qui part de soi pour revenir à soi, et fait tripompher ce qu'il y a d'animal dans l'homme sur le reste de sa nature" (pág. 180). Para Mme de Staël la pasión que mejor resume la necesidad de emoción es el juego, y la que satisface del modo más acertado el egoísmo, la avaricia. La pasión por la muerte que embarga a nuestro personaje parece resumirlas ambas.

La carga de sensualidad de que este vitalismo dota al relato nos permite hablar de una auténtica "erótica de la muerte"; revulsivos como la comida, la bebida, el sexo, la naturaleza o la salud se esgrimen como defensa frente a la aniquilación vital ${ }^{10}$, todos ellos acompañados por un derroche de sensaciones auditivas del que forman parte desde el murmullo de las conversaciones y del coro fúnebre, pasando por el orquestado concierto de los pucheros en la cocina, hasta el sonido concertado de la naturaleza.

En el momento supremo del goce sobre la muerte Cuervo encuentra un correlato de su pasión en Antón el Bobo, personaje de mucho menor relieve que aquél pero que constituye un reflejo suyo $^{11}$, como el propio Cuervo reconoce

9. Tal "erótica de la muerte" únicamente es parangonable, en la narrativa clariniana, con la "erótica del poder" experimentada por Fermín de Pas en el capítulo I de La Regenta, mientras escudriña su presa, Vetusta, desde lo alto de la torre de la catedral, o con la voluptuosidad que invade al Magistral en el capítulo XXI al contacto con el recuerdo y la presencia de Ana. Voluptuosidad esta última cuyo símbolo explícito es la rosa: el capullo que De Pas deshoja y muerde con fruición en el parque tras leer la carta de Ana; los capullos de mujer, rosas propiedad del Magistral que son Jas niñas de la Catequesis, y la rosa de Alejandría que Ana deposita en manos de De Pas mientras pasean por el parque.

10. La enumeración sustantiva, suma de elementos aliados de la vida frente a la muerte, es un recurso expresivo de primer orden al servicio de esta sensualidad: "tenía el instinto seguro de los acontecimientos más a propósito para recordar la vida, la actividad, la salud, la fuerza, el movimiento, todo lo contrario de la muerte (Cuervo, pág. 141).

11. El gusto por la "duplicación" de personajes es una constante del volumen de novelas cortas de 1892; en Doña Berta Sabel es un reflejo de Berta, en Superchería Alcázar lo es de Nicolás 
(Cuervo, pág. 150). Antón juega un papel muy preciso en ese entramado casi teatral que rodea al aparato de la muerte: el de simple de sainete (Antón es acogido en los banquetes fúnebres "como un sainete muy oportuno", pág. 154, que admira "los elementos pintorescos y dramáticos de los entierros", pág. 150). Por su parte, Cuervo transforma el escenario de la muerte, a fin de que desaparezcan todos los vestigios de ésta, como el mejor tramoyista; y a los pocos momentos nadie reconocía la habitación en que había resonado un estertor horas antes (pág. 143); protagoniza una "escena, o serie de escenas, a solas con el que quedaba, con la viuda, con el hijo..." (pág. 143) ${ }^{12}$, y dispone todo lo necesario para el banquete fúnebre; el aspecto teatral de su arte encuentra su máxima expresión en el cortejo que acompaña al muerto al cementerio:

Delante la cruz y los ciriales; detrás la caja, y luego, en dos filas, el coro de la muerte, el coro trágico, que calla a ratos, mientras habla el misterio de ultratumba allí dentro, en la caja, sin que lo oigan los del coro; como en el palacio de Agamenón, mientras Orestes asesina a Egisto no se oye nada... Y vuelve el coro a cantar, a cantar los terrores de la muerte; terrores de que no habla la letra, a que nadie atiende, pero de que hablan las voces cavernosas, el canto llano, el aparato fúnebre. (pág. 157).

El sentimiento vital ante la muerte asumido por Cuervo y Antón resume sin duda una inquietud personal del propio Alas, entregado, a partir de 1890, a la búsqueda de una religiosidad auténtica (Yvan Lissorgues, pp. 303-365), apartada de los ritos vacíos de la religión cristiana (Ibíd. pp. 116-130), una religiosidad ejemplar en la que exista una coherencia entre las ideas y los hechos. Tal vez Cuervo constituya un primer paso en esta dirección, pues si bien es cierto que a través del personaje denuncia el narrador la ignorancia de los rezos memorizados y la superficialidad de una religión reducida al puro rito externo, apela a la vez a un sentimiento religioso primitivo, pero auténtico, de marcado carácter pagano.

El rito mortuorio asumido por Cuervo reproduce, a buen seguro, la peculiar mitología asturiana de la muerte; a este respecto resulta ilustrativo repasar el ensayo del folclorista Constantino Cabal La mitología asturiana. Los dioses de la Muerte, en el que encontramos documentadas las circunstancias más notables que rodean la celebración de la muerte en Asturias, algunas de las cuales

Serrano y Tomassuccio de Caterina Porena. Estos personajes, que constituyen un desdoblamiento desdibujado del protagonista, son como un espejo en el que el personaje principal se refleja y gracias al cual destaca en el relato por su mayor relieve frente al otro.

12. En estas escenas Cuervo consigue ahuyentar el fantasma de la muerte en los parientes del difunto: Cuervo se daba arte para irritar en la viuda el sentido íntimo de la salud, del bienestar que busca expansión [...] En adelante Cuervo, a pesar de su aspecto poco pulcro, casi fúnebre, representaba la vida, el placer futuro, la efectividad de la dicha saboreada poco a poco, con deleite [...] Don Ángel venía a ser la Celestina de estas relaciones ilícitas entre la viuda y la infidelidad futura, el amor repuesto, la voluptuosidad aplazada (Cuervo, pp. 144-145; cf. R. de Mesonero Romanos, pág. 122). 
pueden identificarse en Cuervo: la "noche del aguardiente" (Cabal, pp. 73-74; cf. Cuervo, pp. 133-138), el acompañamiento del cadáver por las lloronas (Cabal, pág. 75; cf. Cuervo, pág. 154), el convite tras el entierro (Cabal, pp. 7779; cf. Cuervo, cap. XI), la creencia en una vida bajo tierra (Cabal, pp. 24-31; cf. Cuervo, pp. 132-133), la metempsícosis (Cabal, pp. 31-33; Cuervo, p. 146) incluso.

En la vivencia de la muerte que Cuervo realiza se distinguen dos partes: el rito social y el rito personal (Cuervo, pág. 47); esta distinción condiciona la estructuración del relato, porque el narrador, que apela al orden de los hechos narrados al final del capítulo VI (Cuervo, pág. 129), altera voluntariamente el orden de exposición de los sucesos cuando se refiere al rito mortuorio, comentando primero el rito social (cap. VII: relación con los moribundos; cap. VIII: "La noche del aguardiente"; cap. XI: la vuelta del entierro; cap. X: el consuelo a los parientes) y posponiendo el personal hasta el último capítulo (cap. XI: asistencia al entierro $\left.{ }^{13}\right)$.

De este modo, el capítulo XI se convierte en el momento culminante de la narración, en esa escena en que Cuervo y Antón, escuchando la gozosa letra del "Benedictus", se deleitan "extáticamente" en la contemplación de una naturaleza que anega la muerte en vida, tal vez respondiendo al tono de la antífona que acompaña habitualmente, en el ritual romano, al canto citado: "Ego sum resurrectio et vita". Este final "trascendente", en apariencia inconcluso, es el cierre perfecto del relato porque representa la culminación de la pasión del personaje ${ }^{i 4}$ :

Y en tanto, los pájaros en los setos de la calleja y en los árboles de la huerta, trinan, gorjean, silban y pían; las nubes corren silenciosas, solemnes, por el azul del cielo; la brisa cuchichea y retoza con las mismísimas ropas talares del acompañamiento de la muerte; y Antón y Cuervo, en el colmo de un deliquio, oyen como extáticos, como en ensueños, el run run del Benedictus, los sonidos dulces y misteriosos de la naturaleza, que, como ellos, ve pasar la muerte, sin comprenderla, sin profanarla, sin insultarla, sin temerla, como albergándola en su seno, y haciéndola desaparecer cual una hoja seca en un torrente, entre las olas de vida que derrama el sol, que esparce el viento y de que se empapa la tierra. (pág. 158)

13. El banquete fúnebre que se describe en este capítulo remite al de otro cuento clariniano, Manín de Pepa José, incluido en la colección póstuma Doctor Sutilis.

14. Tal vez pueda detectarse en este final un influjo del también "trascendente" cierre del relato flaubertiano de 1877 Un coeur simple:

Une vapeur d'azur monta dans la chambre de Félicité. Elle avança les narines, en la humant avec une sensualité mystique, puis ferma les paupières. Ses lèvres souriaient. Les mouvements de son coeur se ralentirent un à un, plus vagues chaque fois, plus doux, comme une fontaine s'épuise, comme un écho disparaît; et, quand elle exhala son dernier souffle, elle crut voir, dans les cieux entrouverts, un perroquet gigantesque, planant au-dessus de sa tête (Flaubert, pág. 83). 


\section{BIBLIOGRAFÍA}

AA.VV. 1974 Historia universal de la medicina, coordinada por Pedro Laín Entralgo, Barcelona, Salvat Editores, vols. V (Ilustración y romanticismo) pp. 143-151 y 344-345, y VI (Positivismo) pp. 175-192, 363-370.

ANDRADE, Benito Mariano. 1896. La antropología criminal y la novela naturalista, Madrid, Est. Tip. Sucs. de Rivadeneyra.

BAQUERO GOYANES, Mariano. 1946. "Clarín, novelista olvidado", Revista de la Universidad de Oviedo, pp. 137-145.

- 1949a. "Clarín, creador del cuento español", Cuadernos de Literatura, V, pp. 145-169.

- 1949b. El cuento español en el siglo XIX, Madrid, C.S.I.C.

- 1952. "Exaltación de lo vital en La Regenta", Archivum, II, pp. 189-219.

BOTREL, Jean-François y Josette BLANQUAT. 1981. Clarín y sus editores, 65 cartas inéditas de Leopoldo Alas a Fernando Fe y Manuel Fernández Lasanta, 1884-1893, Rennes, Université de Haute Bretagne.

CABAL, Constantino. 1925. La mitología asturiana, Los dioses de la muerte. Madrid, Imp. Juan Pueyo.

CARNICER, Ramón 1969. Entre la ciencia y la magia, Mariano Cubí. En torno al siglo XIX español, Barcelona, Editorial Seix-Barral.

CLARÍN. 1892. Doña Berta, Cuervo, Superchería, Madrid, Fernando Fe.

- (1875) 1972 “El rito”, El Solfeo, nº. 175, 23-II-1875, en J.F. Botrel, Preludios de Clarín, Oviedo, Instituto de Estudios Asturianos, pp. 50-51.

— (1896) 1982. "Prólogo", Cuentos morales, Madrid Bruguera, pp. 5-7.

- (1884) 1984. La Regenta, ed. de Gonzalo Sobejano, Madrid, Castalia, I.

DESCURET, J.B.F. 1889. La medicina de las pasiones o las pasiones consideradas con respecto a las enfermedades, a las leyes y a la religión, traduc. por Pedro Felipe Monlau, $3^{\text {a }}$ edición revisada, corregida y aumentada con adiciones del traductor, Barcelona, Impta. y Liba. Religiosa y Científica.

DICENTA, Joaquín. 1897. Los blanqueros, El País, 15 de Diciembre de 1897.

- 1898. El maquinista, El País, 1 de Enero de 1898.

DR. DULCAMERA. 1870. "La higiene y la moda. Los sombreros", La América, n. 8, 28-IIV-1870, pp. 3-4.

FERNÁNDEZ MONTESINOS, José. (1959) 1983. Costumbrismo y novela. Ensayo sobre el redescubrimiento de la realidad española, 5a edición, Madrid, Castalia.

FLAUBERT, Gustave. (1877) 1965. "Un coeur simple" (1877) en Trois contes, París, Flammarion. 
FOY, D. 1845. Manual de higiene o estudio de los medios oportunos para conservar la salud y perfeccionar lo físico y lo moral del hombre, Madrid, I. Boix.

GARAPON, Robert. 1962. "Introduction" a La Bruyère, LES CARACTERES de Théophraste traduits du grec avec LES CARACTERES ou les Moeurs de ce siécle, Paris, Editions Garnier Frères.

GONZÁLEZ HERRÁN, José Manuel. 1987, "Construcción y sentido de Cuervo", Los Cuadernos del Norte, n. 4 (monográfico): Hitos y mitos en la Regenta, pp. 86-92.

- 1990. "The structure and meaning of Cuervo" en AA. VV., "Malevolent insemination" and other essays on Clarin, edited by Noël Valis, Michigan Romance Studies, 1990.

GRANJEL, Mercedes. 1983. Pedro Felipe Monlau y la higiene española del siglo $X I X$, Salamanca, Universidad.

GULLON, Ricardo. 1952. "Las novelas-cortas de Clarín", Insula, nº 76, Abril 1952, p. 3.

HUME, David. (1741) 1990. Essays Moral and Political, en Disertación sobre las pasiones y otros ensayos morales, ed. bilingüe, introducción, traducción y notas de José Luis Tasset Carmona, Barcelona, Anthropos.

- (1757) 1990. Four Dissertations, en Ibid.

LAVATER, Jean Gaspard. 1781. Essai sur la physiognomonie. Destiné a faire connaître l'homme et à le faire aimer, La Haye.

LETOURNEAU, Charles. 1887. L'évolution de la morale, París, Delahaye Lacrosnier.

LISSORGUES, Yvan. 1983. "La sociología criminal y su influencia en los escritores españoles del fin de siglo", Révue de Littérature Comparée, tomo XLVIII, n. 1 pp. 12-32.

LUCEÑO Y BECERRA, Tomás. 1872. "El agente fúnebre", Los españoles de ogaño. Colección de tipos de costumbres dibujados a pluma, Madrid, Librería de V. Suárez, vol. I, pp. 158-163.

MARISTANY, Luis. 1973. El gabinete del doctor Lombroso (delincuencia y fin de siglo en España), Barcelona, Anagrama.

- 1983. "Lombroso y España: nuevas consideraciones", Anales de Literatura Española, Universidad de Alicante, $\mathrm{n}^{\circ}$ 2, pp. 361-381.

MESONERO ROMANOS, Ramón de. 1851. "El duelo se despide en la Iglesia", Escenas matritenses, Madrid, Imp. y Lib. de Gaspar y Roig.

MONLAU, Pedro Felipe. 1846. Elementos de higiene privada, Barcelona, Imp. de Pablo Riera.

-(1847) 1871. Elementos de higiene pública o arte de conservar la salud de los pueblos, 3ํㅡㄹ edición, Madrid, Imp. M. Rivadeneyra, vol. I. 
OCHOA, Juan. 1893. "Un genio", La Justicia, 14 de Enero de 1893.

- 1898. Rodríguez Chanchullo (D. Próspero), Madrid Cómico, 18 de Febrero de 1898.

PÉREZ DE ALAYA, Ramón. 1943. "Clarín y Don Leopoldo Alas", en Clarín, Doña Berta, Cuervo, Superchería, Buenos Aires, Emecé Editores.

PESET, José Luis y Mariano. 1975. “Introducción, AA.VV., Lombroso y la escuela positivista italiana, Madrid, C.S.I.C, pp. 9-209.

RICHARDSON, José G. s.a. Arte de llegar a viejo. Medios de conseguirlo, Barcelona, Centro Editorial de La Vida Literaria.

RÍOS, Laura de los. 1965. Los cuentos de Clarín. Proyección de una vida, Madrid, Revista de Occidente.

ROMERO TOBAR, Leonardo. 1983. "Mesonero Romanos: entre costumbrismo y novela", Anales del Instituto de Estudios Madrileños, Madrid, C.S.I.C., tomo XX pp. 243-259.

RUBIO CREMADES, Enrique. 1983. "Costumbrismo y novela en la segunda mitad del siglo XIX”, Anales de Literatura Española, Universidad de Alicante, $\mathrm{n}^{\mathrm{0}} 2$, pp. $457-472$.

- 1988. "Colaboraciones costumbristas de los novelistas de la segunda mitad del siglo XIX", en AA.VV., Realismo y naturalismo en España en la segunda mitad del siglo XIX, Barcelona, Anthropos, pp. 146-157.

SOBEJANO, Gonzalo. 1985. "Leopoldo Alas, maestro de la novela corta y del cuento", Clarín en su obra ejemplar, Madrid, Castalia, pp. 77-114.

Mme de STAEL. (1796) 1818. De l'influence des passions sur le bonheur des individus et des nations, París, Maradan.

UNAMUNO, Miguel de. (1917) 1972. Abel Sánchez. Una historia de pasión, edición de José Luis Abellán, Madrid, Castalia. 


\title{
DE LA "POÉTICA DE LOS MUERTOS" AL PAISAJE TRASCENDENTE. UNA APROXIMACIÓN A LAS RELACIONES ENTRE CHATEAUBRIAND Y BÉCQUER
}

\author{
Luis MIGUEL FERNÁNDEZ \\ Universidad de Santiago de Compostela
}

\section{Introducción}

Uno de los aspectos más invocados por los estudiosos de Bécquer a la hora de analizar su obra es el de sus deudas con gran parte del Romanticismo europeo, sobre todo el alemán y el francés. Sin embargo, en pocas ocasiones se ha ido más allá de un mero cotejo de imágenes, expresiones, ambientes o, lo que es peor, de toda una serie de lugares comunes que más que aclarar han acabado por confundir el supuesto influjo. De ahí que, como réplica a tal saturación, se haya desembocado en la reivindicación del carácter señero e independiente de su literatura, no limitada por ningún tipo de dependencia respecto a la de otras latitudes (Berenguer Carisomo, pág. 138).

En el caso de su relación con Chateaubriand, por el contrario, ésta ha tenido dos buenos valedores. Así, Robert Pageard, muy cautamente y porque se ciñe de un modo estricto al único testimonio que avala la lectura por parte de Bécquer de algunas obras de Chateaubriand, el del contemporáneo y amigo del escritor Julio Nombela, señala cómo aunque el sevillano no menciona nunca al poeta francés éste tuvo mucho que ver con su orientación literaria, y concluye que "il ne paraît guère douteux que le Génie du Christianisme et ses annexes ait contribué à former le goût romantique de Bécquer", siendo visible dicha contribución en Historia de los Templos de España y en muchas de sus poesías (VVAA, pp. 477-524). Para Rubén Benítez, en cambio, la deuda de Bécquer es mayor y se ve, sobre todo, en la prosa: recibe de Genio del Cristianismo la concepción de la historia como manifestación de la Providencia divina, la atracción por lo maravilloso cristiano, y muchas de sus técnicas de descripción de tumbas, templos, santuarios y otros objetos de culto, todo ello perceptible en Historia de los Templos de España así como en varias de sus leyendas y prosas 
(1971, passim); y de la novela Atala la visión cristiana de una naturaleza trascendente que se da en su leyenda El caudillo de las manos rojas (VVAA, pp. 380-382, 392); e incluso le debe parte de los rasgos de algunos personajes, como la judía Sara de La rosa de Pasión, muy semejante a las heroínas de Chateaubriand, las cuales van al sacrificio impulsadas por una creencia nueva (1974, pág. 32) ${ }^{1}$.

Mi intención en el trabajo presente dista de la de ambos investigadores en la medida en que no pretende tanto mostrar los débitos de un autor con respecto al que lo ha precedido, cuanto comprender la obra de arte, y en este caso la literaria, como una totalidad en la que, si algo de ella puede proceder de otro lugar, su funcionamiento ya no será el mismo al estar incluido en una estructura diferente (Wellek, pág. 213), interesándome, a la vez que por las relaciones interiores de las obras de ambos autores, capaces de superar las meras relaciones de hechos que tienden a explicar los fenómenos de un modo genético, por los problemas de su función dentro de un contexto cultural e histórico más amplio.

Ello significa partir de la radical ambigüedad de los textos, productos no de la causalidad que va unidireccionalmente de la fuente a su resultado, sino de la sociabilidad de una escritura literaria "cuya individualidad se cifra hasta cierto punto en el cruce particular de escrituras previas" (Guillén, pág. 313), y también poder avanzar hacia la comprensión de aquellas estructuras significativas, similares o no, que afloran en el diálogo múltiple de unos textos con otros y en los correspondientes procesos de emisión y recepción en una época dada. Tan sólo así parece posible alcanzar una poética comparatista que, apuntando hacia la teoría más que a las relaciones de hechos, busque en la universalidad de la invariante gran parte de su fundamentación metodológica y epistemológica (Marino, passim).

Aquí me fijaré en un aspecto que me parece fundamental para conocer mejor la relación de analogía entre los dos poetas: el del tratamiento de aquellas figuras que, citando a un importante teórico del cine, llamaré de la ausencia ${ }^{2}$, con el propósito de definir la doble relación que Chateaubriand y Bécquer mantienen entre sí y con respecto a algunas de las constantes del Romanticismo europeo; lo que nos permitirá aproximarnos al funcionamiento de unas mismas estructruras significativas y a la lectura que Bécquer hace del

1. No se ha señalado nunca que yo sepa, a propósito de la relación entre los dos autores, la opinión favorable que Chateaubriand mantiene en su Ensayo sobre la literatura inglesa sobre las mujeres judías en contraste con los hombres: "Les juives, lui dis-je, ont échappé à la malédiction dont leurs pères, leurs maris et leurs fils ont été frappés. On ne trouve aucune juive mêlée dans la foule des prêtres et du peuple qui insulta le Fils de l'Homme, le flagella, le couronna d'épines, lui fit subir les ignominies et les doleurs de la croix. Les femmes de la Judée crurent au Sauveur, l'aimèrent, le suivirent, l'assistèrent de leur bien, le soulagèrent dans ses aflictions... Le Christ, à son tour, étendit sa miséricordie et sa grâce sur les juives" (1847, V. pág. 150).

2. Es Marc Vernet quien habla de "figuras de la ausencia" en el cine (1988). 
francés. En este sentido, entiendo por figuras de la ausencia aquellas figuras del discurso, procedimientos descriptivos o motivos que tienen como objeto hacer presente ante el lector a un ausente, sea éste una persona o una idea.

\section{La ausencia conquistada: la "poética de los muertos"}

Uno de los rasgos que mejor definen el Romanticismo es la transformación de las utopías geográficas e históricas dieciochescas en una categoría existencial, de forma que el Otro Lugar y el Otro Tiempo se convierten ahora en el mito de la Alteridad, con una dimensión más interior y sicológica que externa -entiéndase que el esquema dualístico base del mito de la Alteridad responde a un pensamiento que no es más que una reformulación de conceptos religiosos tradicionales fundamentados en la relación del Creador con su criatura (Abrams, II-III)--; lo que supone el intento de liberación del "yo" romántico de lo contingente y material, en una perpetua huida hacia el Otro, meta última de su deseo de alcanzar un nuevo lenguaje (Testa, pp. 131-146). Un lenguaje que pone en duda la prioridad ontológica del objeto sensible frente al poder de la imaginación y se constituye como algo esencialmente ambiguo, fruto de la doble naturaleza terrenal y mental de los objetos, tal como afirma Paul de Man después de estudiar varios textos de Rousseau, Wordsworth y Hölderlin: "Each of these texts describes the passage from a certain type of nature, earthly and material, to another nature wich could be called mental and celestial"; con lo que la palabra poética "has become and offspring of the sky" (13-14) y se convierte en el principal instrumento de esa reconciliación del arte y la naturaleza, del lenguaje y la realidad, que es la ambición romántica fundamental (Wellek, pág. 167).

Por eso, la busca de una invariante de la Alteridad en el Romanticismo, que permita ayudar a definirlo supranacionalmente, ha de tener muy en cuenta ese carácter liminal o transicional entre realidades de orden diferente que señalan el paso del "yo" al Otro a través de las diversas realizaciones que lo ejemplifican y de los lenguajes que lo van construyendo, siendo así que, del mismo modo que puede hablarse de un territorio en el que el deseo del "yo" se neutraliza y desaparece en la indiferencia de la vejez de un Hölderlin, o en la tranquilidad de la muerte y la unión mística con el infinito de un Fóscolo (Testa, pp. 133-140), y de un lenguaje poético basado en el oxymoron, como el que se da en los autores citados por De Man (1-17), también es posible considerar ciertas creaciones de Chateaubriand y Bécquer como una especial plasmación de la inquietud romántica por alcanzar esa otredad por medio de un lenguaje propio.

Destaca, en primer lugar, en ambos autores la consideración del Otro no tanto como algo sin una existencia propia y definida en el orden inmaterial, independiente del sujeto poético, cuanto como un ausente que sólo se reactiva en el reconocimiento que de su voz autónoma hace ese sujeto. De ahí que la 
muerte, más que un espacio al que finalmente llega el "yo" como producto de su difracción, sea el lugar de encuentro de dos realidades independientes, el sujeto poético y un ausente que, bajo la forma de Autoridad, Ideología o Creación estética, es capaz de hablar a través de los muertos; constituyéndose la prosopopeya en la figura privilegiada para dar cuenta de dicha ausencia y de tal encuentro.

Genio del Cristianismo, publicada en 1802, es, además de la obra que cimentará la fama literaria de su autor, una de las primeras en dejar constancia de una nueva conciencia literaria, ya que ante la desaparición de la universalidad que suponía el mundo clásico en ella adviene el nuevo paradigma capaz de sustituirlo y que tan fecundo será en el futuro, el de un cristianismo dotado de un prestigio supranacional y estético equivalente al antiguo (Madaule, pág. 238). Por ello, si lo característico de la época clásica había sido la negación de las particularidades nacionales en bien de una Poética general, lo mismo ocurrirá, paradójicamente, con la obra de Chateaubriand cuando intenta sustituir una poética pagana por una poética cristiana igualmente universalizadora. Esto explica los dos objetivos de la obra: ser un arma ideológica contra los sofistas del momento, los hombres de letras herederos de los postulados racionalistas del siglo anterior, incrédulos y ateos, y la defensa de una poética cristiana más válida estéticamente que la antigua poética clásica. Así lo expresa al comienzo de la obra el propio autor:

On devoit donc chercer à prouver au contraire que, de toutes les religions qui ont jamais existé, la religion chrétienne est la plus poétique, la plus humaine, la plus favorable à la liberté, aux arts et aux lettres; que le monde moderne lui doit tout... On devoit montrer qu'il n'y a rien de plus divin que sa morale, rien de plus aimable, de plus pompeux que ses dogmes, sa doctrine et son culte: on devoit dire qu'elle favorise le génie, épure le goût, développe les passions vertueuses, donne de la vigueur à la pensée, offre des formes nobles à l'écrivain, et des moules parfaits à l'artiste (1847, III, pág. 4).

Por ello la divide en cuatro partes que responden a los objetivos señalados: la primera trata de los dogmas y la doctrina, la segunda y tercera de la poética - entendida como el estudio de la relación con la literatura y el arte--, y la cuarta del culto y las ceremonias. Es precisamente en esta última parte en donde aparece su preocupación por las tumbas y por lo que, citando sus mismas palabras, podríamos denominar la "poética de los muertos", especie de objetofantasma o de cronotopo que aúna en sí los sentidos ideológico y estético del texto, ya que a la vez que da cuenta de la nada del hombre y de la inmortalidad del alma ${ }^{3}$ lo hace, asimismo, de la inmortalidad de un arte que no ha cesado de reproducir la belleza de la voz de la ideología cristiana:

3. "L'idée du néant et celle de l'éternité dont les vagues et le granit semblent l'image, dominent l'une et l'autre sa vie et son oeuvre. Mais pour une âme religieuse la mort aussi est à la fois néant et éternité" (Clarac, pág. 14). 
Enfin, il y a une autre preuve morale de l'inmortalité de l'âme, sur laquelle il faut insister: c'est la vénération des hommes pour les tombeaux. Là, par un charme invincible, la vie est attachée à la mort; là, la nature humaine se montre supérieure au reste de la création, et déclare ses hautes destinées... nous respectons les cendres de nos ancêtres parce qu'une voix nous dit que tout n'est pas éteint en eux. Et c'est cette voix qui consacre le culte funèbre chez tous le peuples de la terre: tous sont également persuadés que le sommeil n'est pas durable, même au tombeau, et que la mort n'est qu'une transfiguration glorieuse (1847, III, pág. 66).

Les derniers devoirs qu'on rend aux hommes seroient bien tristes s'ils étoient dépouillés des signes de la religion. La religion a pris naissance aux tombeaux, et les tombeaux ne peuvent se passer d'elle: il est beau que le cri de l'espérance s'éléve du fond du cercueil, et que le prêtre du Dieu vivant escorte au monument la cendre de l'homme; et c'est en quelque sorte l'immortalité qui marche à la tête de la mort (1847, III, pág. 202).

Observamos en estas palabras una voz que nos habla de la nada y la inmortalidad al mismo tiempo, y que establece el culto fúnebre en todos los pueblos de la tierra, un culto que es, antes que nada, algo bello ("Il est beau que le cri de l'espérance s'éléve du fond du cercueil"). Y esa misma voz, que procede de alguien ausente e inidentificable con una persona de carne y hueso, es la que se transparenta por medio de la prosopopeya que aparece en las invocaciones a los muertos y en la palabra de sus epitafios.

En efecto, tanto en la preceptiva clásica como en la romántica la prosopopeya consiste, entre otras cosas, en permitirle actuar, hablar o responder a los muertos y a los ausentes. Así, para el neoclásico Batteux se basa "en prestar a las cosas insensibles acción, pensamientos, sentimientos, y pasiones; en dirigirles la palabra como si entendiesen, y en dársela como si tuviesen facultad de hablar; en hacer presentes a la personas ausentes; o hacer revivir a los que han muerto, ya dirigiéndoles la palabra, o ya haciéndoles hablar" (1808, VI, pp. 269-270); mientras que para el romántico Fontanier que, a diferencia del anterior, excluye al apóstrofe como uno de los modos de la prosopopeya, "consiste à mettre en quelque sorte en scène les absents, les morts, les êtres surnaturels, ou même les êtres inanimés; à les faire agir, parler, répondre, ainsi qu'on l'entend; ou tout au moins à les prendre pour confidents, pour témoins, pour garants, pour acusateurs, pour vengeurs, pour jugues, etc, etc; et cela, ou par feinte, ou sérieusement, suivant qu'on est ou qu'on n'est pas le maître de son imagination" (404).

En la raíz de este término, el griego prosopon, se traduce, sin embargo, una ambigüedad advertida por De Man, ya que significa al mismo tiempo la máscara y el rostro, lo que está visible y lo que permanece oculto (76); y dicha ambiguiedad es la que resalta, precisamente, en esta forma de necrológica que 
son los epitafios de Chateaubriand, en donde a la vez que se le otorga a cada muerto una voz diferente que remite a un rostro individualizado y no intercambiable con los demás, también se lo imposibilita para tener un rostro propio, siendo la máscara de un ausente que aunque se manifiesta de modos distintos permanece siempre igual, con una voz única. Es decir, que a los muertos se les da una voz que los convierte en rostro de sí mismos y máscara de un ausente; único modo en el que la ideología puede manifestarse en todo su poder. Veamos algunos ejemplos.

Al hablar de los cementerios campestres, el enunciador se fija en algunos epitafios:

On y lisoit pour toute épitaphe: Guillaume ou Paul, né en telle année, mort en telle autre. Sur quelques-uns il n'y avoit pas même de nom. Le laboureur chrétien repose oublié dans la mort, comme ces végétaux utiles au milieu desquels il a vécu...

Cependant, en errant un jour dans un cimetière de campagne, nous apercûmes une épitaphe latine sur une pierre qui annonçoit le tombeau d'un enfant. Surpris de cette magnificence, nous nous en approchâmes, pour connoître l'érudition du curé du village; nous lûmes ces mots de l'Évangile:

"Sinite parvulos venire ad me" - "Laissez les petits enfants venir à moi" (1847, III, pág. 205).

Campesinos con un nombre que, sin embargo, resulta nada ante la muerte, o niños cuya voz les es prestada por un cura, contrastan con los poderosos que reposan en las iglesias, a los que el enunciador describe en sus animadas posturas, invita al lector a que los contemple y, finalmente, les dirige la palabra:

$\mathrm{Au}$ fond de cette chapelle retirée, voici quatre écuyers de marbre, bardés de fer, armés de toutes pièces, les mains jointes, et à genoux aux quatre coins de l'entablement d'un tombeau. Est-ce toi, Bayard, qui rendois la rançon aux vierges, pour les marier à leurs amants? Est-ce toi, Beaumanoir, qui buvois ton sang dans le combat des Trente? Est-ce quelque autre chevalier qui sommeille ici? (1847, III, pág. 206).

También ellos acaban en la nada:

Sans doute ils étoient merveilleux ces temps, mais ils sont passés. La religion avoit averti les chevaliers de cette vanité des choses humaines, lorsqu'à la suite d'une longue énumération de titres pompeux: Haut et puissant seigneur, messire Anne de Montmorency, connétable de France, etc. etc. etc., elle avoit ajouté: Priez pour lui, pauvre pécheur. C'est tout le néant (1847, III, pág. 206)

Aunque al final quede la inmortalidad: "Que votre sommeil soit profond sous ces voûtes, hommes de paix, qui aviez partagé votre héritage mortel à vos frères, et qui, comme le héros de la Grèce, partant pour la conquête d'un autre univers, ne vous étiez réservé que l'espérance (1847, III, pág. 206). 
El ausente se ha concretado ante el lector: es la religión, la Autoridad ${ }^{4}$, quien da la voz y quien superpone su rostro ideológico al de los muertos, mostrando por medio de la prosopopeya las claves de un discurso consistente en enseñarle al lector cómo por debajo de lo aparente (el rostro de los muertos) hay algo oculto: la nada y la inmortalidad, y que ambos son el auténtico rostro que hacen de lo anterior su máscara. Su epopeya, la de los muertos, es como la del mundo clásico, sólo que ahora es la épica de una nueva edad, la cristiana.

Este discurso de la Autoridad como palabra impuesta, que Chateaubriand reproduce en sus Memorias de ultratumba por medio de la relación padre-hijo (Abraham, pp. 177-185), no se encuentra en Bécquer. Su Historia de los Templos de España es un eco de Genio del Cristianismo en muchos aspectos, lo cual no tiene nada de sorprendente si se considera el éxito de Chateaubriand en nuestro país (Peers, pp. 351-382), el autor más leído de entre los tradicionalistas (Benítez, 1971, pp. 17-18); pero es dudoso que puedan establecerse los paralelismos de un modo automático entre uno y otro sin tener en cuenta el sentido que en cada caso adquieren estructuras superficialmente semejantes, como en algunos casos se ha hecho, por ejemplo - y lo tomo como único caso de entre muchos que se podrían citar- al comparar las descripciones que ambos hacen de las catedrales góticas (Pageard, 1971).

Como Chateaubriand, también Bécquer se instala en una doble tradición ideológica y estética cuando se interesa por el arte religioso; aunque, además de su incorporación al campo de escritores que lo precedieron en ese interés por la descripción de los monumentos de España (Arboleda, pp. 11-67), inscribiendo su obra en una serie genérica distinta a la del francés, hay en él un sentido político muy concreto motivado por las especiales circunstancias españolas de la época: la preocupación por conservar las bellezas nacionales (Benítez, 1971, pp. 60-64).

Ese ausente objeto de su deseo se concreta, como en el poeta francés, a través de las tumbas y del proyecto de Bécquer de dotarlas de vida, tal como afirma al comienzo de su Historia: pasado.

La tradición religiosa es el eje de diamante sobre el que gira nuestro

Estudiar el templo, manifestación visible de la-primera, para hacer en un solo libro la síntesis del segundo: he aquí nuestro propósito.

Para conseguirlo, evocaremos, de las olvidadas tumbas en que duermen al pie del santuario, a esos titanes del arte que lo erigieron (809).

4. La importancia de la Autoridad se observa, asimismo, en el recurso a las citas de autoridades religiosas, a Io didáctico y a la afirmación, pruebas de una presencia que bloquea o contradice la apelación al misterio que Chateaubriand hace desde el capítulo tercero del Genio (Barbéris, pág. 130). 
Ahora bien, hay en su propuesta dos hechos que llaman la atención. En primer lugar, se trata de acceder a un pasado nacional, no a un orden universal sustituto del mundo clásico; y en segundo, el poeta evocará a "esos titanes del arte que lo erigieron". Ello explica aquellas palabras de Nombela tantas veces citadas ("lo que Gustavo pretendía era hacer un grandioso poema en el que la fe cristiana, sencilla y humilde, ofreciese el inconmensurable y espléndido cuadro de las bellezas del Catolicismo", Díaz, pág. 52), así como el triple punto de vista adoptado, procedente tal vez de Víctor Hugo (Pincus Sigele, pág. 443), el del historiador, el del artista y el del poeta. Porque ambos remiten a un universo estético más que ideológico ${ }^{5}$ : no se trata tanto de buscar un pasado ideológico con una voz única en la que el poeta se integra, un paisaje que lo preexiste y con el que no cabe más que la identificación, cuanto de integrarse en una tradición de creadores, capaces de dar vida a esos monumentos o voz a los muertos pero siempre desde la distancia que supone el acto de la creación. A Bécquer la tradición le sirve para revelar su propia voz, la del poeta, más que la de la Autoridad o la Institución; de ahí su distanciamiento del historiador que habla sobre el contexto histórico en el que el monumento surgió, sea la del P. Mariana o la de otro cualquiera. Es más un "esfuerzo sentimental", una "memoria afectiva" (Ramírez Araújo, pag. 253) que una memoria ideológica.

Así, cuando describe la iglesia de San Juan de los Reyes, su preocupación es la de mostrar la continuidad de un ciclo creativo, ya que el encuentro en el mismo lugar con otros que le precedieron en la construcción del templo deriva del acto de la creación: primero, el arquitecto y los obreros que lo levantaron, después los ecos del mismo expandiéndose con la creación de un mundo nuevo y la destrucción del antiguo gracias a los Reyes Católicos, y su culminación en la figura de Cisneros; más tarde, la destrucción por los franceses y la reconstrucción por el poeta, quien de ese modo se incorpora a un proyecto comunitario que lo precede y del que no es más que un eslabón.

Desde esta perspectiva, la prosopopeya no consiste en darle a los muertos una voz que no poseen, sino tan sólo en hacerlos actuar siempre consciente de la distancia que mantiene con ellos, porque el poeta, tal como Bécquer dice en su descripción del castillo de Olite, es como Cristo frente a Lázaro: "lo que ha muerto lo saca del sepulcro y le manda que ande" (1035). Es lo que hace con el que años más tarde será el cardenal Cisneros:

... Yo siento vibrar el aire con las aclamaciones de la muchedumbre, el canto de los religiosos y el clamor de las trompas; yo miro descender de sus nichos como para celebrar otra vez su triunfo esa muda generación de reyes, obispos, guerreros, pajes y heraldos cuyas sordas y huecas pisadas parece que retumban en mi oído, cuyos rostros inmóviles veo animarse con el rayo de luz y de vida que les presta mi imaginación.

5. Rica Brown afirma, sin embargo, que tanto en Chateaubriand como en Bécquer "la fe cristiana se basa menos en la verdad del cristianismo que en la belleza de sus manifestaciones en el arte y la arquitectura" (219). 
... Al fulgor de la naciente luna, y sentado al pie de los sauces de nuestro claustro silencioso, me parece aún divisar a Cisneros... El breviario está abierto sobre las rodillas del joven novicio; su mirada se halla fija en el libro santo, pero no lee... ¿Qué pensamientos hervirán en su mente? Tal vez resuenan en su oído los últimos rumores del mundo que acaba de abandonar; acaso ocupa su alma el recuerdo de una mujer querida...

Un estremecimiento nervioso saca de su éxtasis al solitario soñador, que revuelve en torno suyo la pupila, quizá buscando la sombra fugaz que ha creído ver deslizarse ante sus ojos; pero en aquel instante un canto triste y solemne llega a su oído y ve cruzar entre la penumbra de los pilares, silenciosos y como una procesión de fantasmas, dos hileras de monjes cuya frente esconde la capucha, y en cuyas manos las hachas encendidas despiden una lúgubre claridad. Son los religiosos que conducen a su postrer morada a uno de sus hermanos. La sombría idea de la muerte ahuyenta el último desvarío de su irresoluta voluntad, un postrer recuerdo se desvanece con la lágrima que rueda por su mejilla, y la voz de la religión triunfa, al fin, en su alma $(878-879)$.

Aparentemente, el párrafo final es muy parecido al de Chateaubriand citado anteriormente: el joven Cisneros oye la voz de la religión que le habla de la nada que es la muerte y lo insta a alejarse del mundo y sus vanidades. No obstante, aquí la prosopopeya consiste en la animación de un mundo provocada por el poeta, quien crea un personaje del que lo que importa no es lo que le hace tomar una decisión, sino la decisión misma de permanecer en el servicio de la Iglesia, ya que ello es lo que justifica la grandeza posterior de España y de San Juan de los Reyes; es decir, su pertenencia a una tradición y un pasado con su propia individualidad y afirmando su propio rostro, frente a cualquier posible aniquilación en una voz igualadora.

Aunque quizá uno de los ejemplos más claros en cuanto a la diferente perspectiva ante el Otro y la muerte, sea ésta concebida como fruto de un paisaje moral preexistente, de una situación en la que el poeta se integra, o sea el resultado de una creación literaria del poeta en la que éste afirma su propia individualidad al margen de los demás, es la lectura que Bécquer hace de Chateaubriand y de sus cementerios campestres. Si bien se han señalado las analogías de una de las Cartas desde mi celda, la tercera, con el capítulo séptimo del libro cuarto de Genio del Cristianismo, del que ya se citó aquí un fragmento (Benítez, 1971, pág. 60, nota 33; Pageard, VVAA, pp. 486-487), pienso que son tantas las diferencias y, desde luego, más importantes en cuanto al sentido del texto, no sólo respecto a ese fragmento de Genio, sino a un desarrollo mayor y anterior del mismo tema, el que Chateaubriand hizo en un poema de 1796 titulado Les tombeaux champêtres.

En dicho poema el autor francés permanece todavía muy ligado a la tradición utópica dieciochesca del paisaje natural, en el que se da una perfecta armonía del hombre con la naturaleza; un paisaje moral caracterizado por sus virtudes, que en alguna medida conservará en el Genio, aunque aquí ya entra 
en colisión con el paisaje interior propio del Romaticismo. Una de sus estrofas, por ejemplo, dice:

\author{
Là, dorment dans l'oubli des poëtes sans gloire, \\ des orateurs sans voix, des héros sans victoire: \\ Que dis-je! des Titus faits pour être adorés. \\ Mais si le sort voila tant des vertus sublimes \\ sous ces arbres en deuil, combien aussi des crimes \\ le silence et la mort n'ont-ils point dévorés \\ loin d'un monde trompeur, ces bergers sans envie, \\ emportant avec eux leurs tranquiles vertus, \\ sur le fleuve du temps passagers inconnus, \\ traversèrent sans bruit les déserts de la vie. \\ Une pierre, aux passants demandant un soupir, \\ du naufrage des ans a sauvé leur mémoire; \\ une muse ignorante y grava leur histoire, \\ et le texte sacré qui nous aide à mourir. (1847, V, pág. 505)
}

El "yo" poético después de alabar ese mundo campesino, feliz en su insignificancia, desea también en tal lugar una tumba sin honores, distinta a las de los poderosos de las iglesias, y deja escritos ya su historia y su epitafio - en claro paralelismo con esos náufragos sin ruido de los que una tumba cuenta su historia y "le texte sacré qui nous aide à mourir"-, en el cual el paisaje moral que lo ha precedido y en el que se encuentra su tumba se proyecta en la tranquilidad posterior a la muerte, que apela, así, a la conciencia del viajero que lo lee: "Laisse-le reposer sur la rive inconnue, / de l'autre côté du tombeau".

Si ahora nos fijamos en Bécquer no encontraremos nada de esto. También él alaba en la Carta tercera los cementerios campestres en oposición a los de las grandes ciudades y desea una humilde tumba en uno de ellos, pero falta esa dimensión moral y colectiva que aparece en Chateaubriand. El cementerio no aparece ligado a ninguna vida virtuosa de los campesinos y sí, en cambio, a su propia trayectoria de creación personal, al tratarse de la creación en su fantasía de una tumba adecuada a su situación actual, como a lo largo de su vida había soñado otros tipos de tumbas: primero, en sus años juveniles, cuando ansiaba la gloria literaria "en las márgenes del Guadalquivir que conduce al convento de San Jerónimo" (563); más tarde, deseoso de una gloria diferente a la literaria, la del héroe, "en el fondo de uno de esos claustros santos donde vive el eterno silencio y al que los siglos prestan su majestad y su color misterioso e indefinible" (567); por último, y acorde con su "vivir oscuro y dichoso en cuanto es posible, sin deseos, sin inquietudes, sin ambiciones" (570), desea una humilde tumba en el campo. El poeta, en última instancia, recrea una fantasía más, semejante a las anteriores, de forma que la "declaración de fe profunda en la trascendencia del espíritu sobre la materia" que hace al final (Villanueva, pág. 24) sin dejar de ser cierta, no deja también de ser tan imposible, en cuanto literaria, como las anteriores imaginaciones de su mente. Probablemente se podría hablar de un propósito deliberado del artista de crear una distancia entre él y las circunstancias 
o, menos benévolamente, de un "egoísmo feroz" que en modo alguno lo acerca a Chateaubriand (Brown, pág. 258).

Estamos, pues, en este ejemplo ante un tipo de funcionamiento intertextual ${ }^{6}$ que podríamos llamar con Claudio Guillén una inclusión significativa; se trata de incluir en el tejido mismo de los textos, en su interioridad, estructuras significativas en cuanto a la verticalidad semántica de los mismos, y no sólo citas o alusiones exteriores que no lo afectan sustancialmente (319-323). De hecho, aunque el sentido final de los textos de Chateaubriand y Bécquer parece ser el mismo (lo auténticamente importante es lo que atañe al espíritu, no a las vanidades materiales, y eso pertenece a la inmortalidad del alma), en Bécquer hay un proceso de ficcionalización y distancia de la propuesta que la llena de una ambigüedad que no tenía en el de Chateaubriand, al tiempo que señala ante el lector los límites de éste: si el autor francés no se había distanciado de aquel paisaje moral en la historia que crea acerca de sí mismo y de su tumba, Bécquer hace de su historia algo no subordinado nada más que a las leyes de la misma. Lo cual, en definitiva, responde a las diferentes épocas y el distinto momento literario vivido por los dos artistas.

\section{La ausencia inalcanzable: el paisaje trascendente}

No siempre, sin embargo, resulta fácil aquietar el propio deseo y convertirse en el Otro por medio de la muerte. En ocasiones, la vocación por el Ausente es un foco de tensiones entre lo material y lo espiritual que impide alcanzar la armonía entre ambos y obliga al poeta $o$ a sus personajes a permanecer en un estado de insatisfacción por no acceder a la ansiada unidad.

El deseo de reconciliación de la materia y el espíritu, por otra parte, es lo más característico del Romanticismo alemán, sobre todo desde que Schelling defendió una filosofía de la naturaleza antirracionalista, en que la intuición intelectual era lo único que permitía captar lo absoluto dentro de la naturaleza y el espíritu, la identidad de lo real y lo ideal, convirtiendo a la naturaleza en el espíritu visible, y al espíritu en la naturaleza invisible; lo cual le llevó a un rechazo tanto del arte que imitaba lo natural copiando sólo lo feo, como de aquel otro que no partía de la naturaleza sino de los modelos clásicos preestablecidos, arte, en suma, que desde la naturaleza debía elevarse hasta los más altos grados del alma (1972, passim). La íntima unión de naturaleza y

6. Las alusiones intertextuales a Chateaubriand por parte de Bécquer son, no obstante, muchas más; desde ese gusto por contrastar las tumbas de los poderosos con las de los niños, visible en las rimas LXXIII, LXXIV y LXXVI, tal como ha sido señalado por Sebold (1992, pp. 9293), hasta las imágenes de los árboles que rezan por el alma del poeta, semejantes al "murmure plaintif du feuillage et des airs" de la penúltima estrofa del poema Tumbas campestres, o los juncos rodeados de lirios amarillos, que probablemente remitan a las "papillons d'or" que cubren los juncos en otro poema del francés, Quatrième tableau. Le soir dans une vallée. 
espíritu, que sólo puede reconocerse por la intuición del artista, hace que la imaginación sea para todos los poetas románticos un poder creador mediante el que el espíritu penetra en la realidad de las cosas y ve la naturaleza como el símbolo de algo oculto, no perceptible (en muchos casos, Dios o la Eternidad), pero que, sin embargo, manifiesta el alma del mundo (Wellek, pág. 138).

Tanto Chateaubriand como Bécquer presentan idéntico espíritu antirracionalista e igual creencia en una realidad oculta que la naturaleza transmite y que la intuición permite descubrir (Varela, pág. 308). Así, Chateaubriand, anticipándose a la reivindicación de Schelling de un arte que no partiese de los modelos clásicos ya establecidos, defiende en 1795 en su Lettre sur l'art du dessin dans les paysages, una pintura atenta a captar los músculos y las formas de una naturaleza desnuda, capaz de hacerle ver al artista el espíritu de los diferentes paisajes:

Il faut donc que les élèves s'occupent d'abord de l'étude même de la nature: c'est au milieu des campagnes qu'ils doivent prendre leurs premières leçons. Qu'un jeune homme soit frappé de l'effect d'une cascade qui tombe de la cime d'un roc, et dont l'eau bouillonne en s'enfuyant: le mouvement, le bruit, les jets de lumière, les masses d'ombres, les plantes échevelées, la neige de l'écume qui se forme au bas de la chute, les frais gazons qui bordent le cours de l'eau, tout se gravera dans la mémoire de l'élève... Le paysage a sa partie morale et intellectuelle, comme le portrait; il faut qu'il parle aussi, et qu'à travers l'exécution matérielle on éprouve ou les rêveries ou les sentiments que font naître les différents sites (1847, V pág. 553).

Más tarde, el papel preponderante del alma del artista sobre la naturaleza se observa de un modo claro cuando se opone al espíritu racionalista ejemplificado por Rousseau (Dédéyan, pp. 30-32), frente al cual afirma que no es el paisaje quien modula el alma sino, por el contrario, el alma la que se transmite al paisaje (1847, IV, pp. 322-323); o cuando en las Memorias de ultratumba, al mismo tiempo que defiende el papel de la luz como creadora del paisaje, atribuye al artista la función más relevante en el nacimiento de aquél:

Le paysage n'est crée que par le soleil; c'est la lumière qui fait le paysage...

Si les montagnes de nos climats peuvent justifier les éloges de leurs admirateurs, ce n'est que quand elles sont enveloppées dans la nuit dont elles épaississent le chaos: leurs angles, leurs ressauts, leurs saillies, leurs grandes lignes, leurs immenses ombres portées, augmentent d'effet à la clarté de la lune. Les astres les découpent et les gravent dans le ciel en pyramides, en cônes, en obélisques, en architecture d'albâtre, tantôt jetant sur elles un voile de gaze et les harmonisant par des nuances indéterminées, légèrement lavées de bleu; tantôt les sculptant une à une et les separant par des traits d'une grande correction. Chaque vallée, chaque réduit avec ses lacs, ses rochers, ses fôrets, devient un temple de silence et solitude...

Je reconnais tout cela; mais entendons-nous bien: ce ne sont pas les montagnes qui existent telles qu'on les croit voir alors; ce sont les montagnes comme les passions, le talent et la muse en ont tracé les lignes, colorié les 
ciels, les neiges, les pitons, les déclivités, les cascades irisées, l'atmosphère flou, les ombres tendres et légères: le paysage est sur la palette de Claude le Lorrain, non sur le Campo-Vaccino (1983, II, pp. 592-593).

¿Pero qué es lo que el poeta ve oculto en el paisaje? ¿Por qué habla de un “templo de silencio y de soledad"? Según Jean-Pierre Richard todas las figuras que Chateaubriand emplea en la descripción de paisajes (el agua, la tumba, los murmullos, la niebla, la luz de la luna, el eco...) remiten a lo mismo: a un desaparecer, a una puesta en escena de la ausencia que significa al mismo tiempo lo limitado y lo ilimitado ("sin los límites no podría manifestarse lo ilimitado", dirá contemporáneamente Schelling [50]), una nada infinita pero un Dios igualmente infinito. $O$, lo que es igual, la tensión continua entre el ser y el no-ser desde una perspectiva religiosa y cristiana. Por eso, si antes la autoridad religiosa aparecía como la figura del Ausente, ahora es Dios quien lo hace. Y para permanecerle fiel es necesario renunciar a lo inmediato, trátese del contacto amoroso con la mujer amada o de la atracción sensorial por la naturaleza; con lo que la unión con ese Ausente se transforma en una prohibición generadora de conflictos entre la materia y el espíritu; interdicción que neutraliza el deseo de Chactas y Atala (Atala), Eudoro y Velléda (Los mártires), Aben Hamet y Blanca (El último Abencerraje), y de Amèlie y René (René) ${ }^{7}$, y los conduce al alejamiento y la soledad (Richard, pp. 39-45).

De ahí que el bosque, además de la catedral gótica, sea figura privilegiada de esta soledad, al presentar al mismo tiempo una intimidad cerrada sobre sí misma y dirigida hacia lo lejano; imagen paradójica por tratarse "d'une intimité ouverte, ou d'une infinité délimitée" (Richard, pág. 99). Esta dialéctica de lo cerrado y lo abierto hacia la lejanía es visible ya en sus primeros poemas, como en uno de los Tableaux de la nature titulado precisamente La fôret, del que reproduzco un fragmento:

Fôret silencieuse, aimable solitude, que j'aime à parcourir votre ombrage ignoré! Dans vos sombres detours en rêvant égaré, j'éprouve un sentiment libre d'inquiétude. Prestige de mon coeur! je crois voir s'exhaler des arbres, des gazons, une douce tristesse: cette onde que j'entends murmure avec mollesse, et dans le fond des bois semble encor m'appeler.

Oh! que ne puis-je, heureux, passer ma vie entière ici, loin des humains! - Au bruit de ces ruisseaux, sur un tapis de fleurs, sur l'herbe printanière, qu'ignoré je sommeille à l'ombre des ormeaux! Tout parle, tout me plaît sous ces voûtes tranquilles... (1847, V, pág. 501).

7. Esa tensión entre los dos polos genera la ambigüedad de René, según Barbéris: "D'une part, René appuie la thèse du Génie (danger des passions, de la complaisance a soi-même, et fécondité littéraire et psychologique du christianisme); d'autre part, il le mine ou le faire lire autrement (prégnance des passions, problème de la jeunesse)" (125) 
Aquí, la soledad querida por el sujeto poético es interpelada por una naturaleza que tiende a ir más allá del bosque, hacia lo lejano (una onda que lo llama "dans le fond des bois" o una vegetación que al cerrarse por encima de él convierte el bosque en una especie de iglesia con "voûtres tranquilles"), algo todavía indeterminado pero armónico, con un alma capaz de sentir dicha armonía, como en Atala: "Aucun bruit ne se faisoit entendre, hors je ne sais quelle harmonie lointaine qui régnoit dans la profondeur des bois: on eût dit que l'âme de la solitude soupiroit dans toute l'étendue du désert" (1847, IV, pág. 639); y que en ocasiones se le revela como armonía divina en los bosques americanos de Los Natchez:

Une musique qu'on entend partout, et qui n'est nulle part, ne cesse jamais dans ces lieux: tantôt ce sont des murmures comme ceux d'une harpe éolienne que la foible haleine du zéphyr effleure pendant une nuit de printemps; tantôt l'oreille d'un mortel croiroit oüir les plaintes d'une harmonique divine, ces vibrations qui n'ont rien de terrestre, et qui nagent dans la moyenne région de l'air. Des voix, des modulations brillantes sortent tout à coup du fond des fôrets célestes; puis, disperses par le souffle des esprits, ces accents semblent avoir expiré. Mais bientôt une mélodie confuse se relève dans le lointain, et l'on distingue ou les sons veloutés d'un cor sonné par un ange, ou l'hymne d'un séraphin qui chante les grandeurs de Dieu au bord du fleuve de vie (1847, IV, pág. 465).

También en el Bécquer de algunas de las Leyendas y de otras prosas es observable la tensión entre materia y espíritu, sin que les sea posible a sus personajes el poder trascender el primero para llegar al ideal que su alma se ha forjado, sobre todo cuando se trata de una mujer creada por el propio personaje. El Ausente ahora no es Dios, ni hay interdicción religiosa alguna, sino más bien una espiritualidad más vaga, dotada igualmente del carácter de eternidad; pero, del mismo modo que en Chateaubriand es posible descubrir en su sistema descriptivo esa dialéctica entre lo cerrado sobre sí mismo y lo abierto a lo infinito, a través de una distribución interna que señala oposiciones temáticas y lógicas y apunta hacia lo ideológico, en la prosa de Bécquer es advertible en ocasiones una estructura semántica que a la vez que describe de arriba abajo alternando lo limitado y lo ilimitado, establece un procedimiento clausural interpretativo de lo anterior que señala el intento de conectar al espíritu del "yo" con el del mundo que lo rodea, mostrando esa actitud romántica que hace trabajar ideológicamente al texto. De este modo adquieren todo su sentido las palabras de Rubén Benítez cuando dice que la originalidad de su prosa deriva en parte de Chateaubriand (1974, pág. 11); originalidad de unas Leyendas que radica probablemente en ese parecer escritas "entre la niebla del sueño, en el duermevela del amor y de la ensoñación por la imprecisión de su caras y contornos" (Alonso, pág. 166), y que consigue un buen resultado en aquel fragmento de Los ojos verdes en el que el joven Fernando da cuenta a su montero Iñigo del lugar en donde habita la mujer de sus sueños: 
Tú no conoces aquel sitio. Mira: la fuente brota escondida en el seno de una peña, y cae, resbalándose gota a gota, por entre las verdes y flotantes hojas de las plantas que crecen al borde de su cuna. Aquellas gotas, que al desprenderse brillan como puntos de oro y suenan como las notas de un instrumento, se reúnen entre los céspedes y, susurrando, susurrando, con un ruido semejante al de las abejas que zumban en torno de las flores, se alejan por entre las arenas y forman un cauce, y luchan con los obstáculos que se oponen a su camino, y se repliegan sobre sí mismas, y saltan, y huyen, y corren, unas veces con risas, otras con suspiros, hasta caer en un lago. En el lago caen con un rumor indescriptible. Lamentos, palabras, nombres, cantares, yo que sé lo que he oído en aquel rumor cuando me he sentado solo y febril sobre el peñasco a cuyos pies saltan las aguas de la fuente misteriosa, para estancarse en una balsa profunda, cuya inmóvil superficie apenas riza el viento de la tarde.

Todo allí es grande. La soledad, con sus mil rumores desconocidos, vive en aquellos lugares y embriaga el espíritu con su inefable melancolía. En las plateadas hojas de los álamos, en los huecos de las peñas, en las ondas del agua, parece que nos hablan los invisibles espíritus de la Naturaleza, que reconocen un hermano en el inmortal espíritu del hombre (155-156).

Al margen de las coincidencias superficiales con el primero de los textos citados de Chateaubriand (el agua que cae desde lo alto de una peña, su bullir y su huida, la animación y los ruidos...), interesa destacar como, al igual que en otros textos del poeta francés, alternan la tendencia a la huida del agua con la del estancamiento en el lago, la de los fragmentario y pequeño ("resbalándose gota a gota", "brillan como puntos de oro") con lo que esa pequeñez revela, la grandeza de lo que le rodea ("Todo allí es grande", "con sus mil rumores desconocidos"); es decir, la dinámica entre lo limitado (el lago inmóvil, lo pequeño y fragmentario) y lo ilimitado (el agua que corre hasta desaparecer y convertirse en palabras o rumores de seres vivos, la grandeza del lugar), entre el espíritu inmortal del hombre y el espíritu igualmente inmortal de la naturaleza. Y todo ello potenciado por la retórica propia de las narraciones fantásticas, caracterizada por un lenguaje en el que lo sobrenatural nace de tomar literalmente el sentido figurado del texto (Todorov, pp. 94-100, Risco, pp. 173-174): aquí el bullicio y los susurros de las aguas acaban transformándose en palabras auténticas con las que los espíritus hablan al personaje.

La distribución de los términos atendiendo a las coordenadas arriba/abajo y limitado/ilimitado, con esa clausura realizada por la identidad entre el alma del personaje y la de la naturaleza, lo hacen equivalente a muchos de los textos de Chateaubriand y del Romanticismo; una semejanza que, en el caso del primero, es mayor cuando al final del relato se comprueba la imposible unión de Fernando con la diosa del agua poseedora de los ojos verdes, la cual, imaginaria o no (Risco, pp. 170-174, Sebold, 1989, pp. 138-139), revela a un Ausente inasible al que el espíritu del hombre no puede alcanzar, frustrándose de ese modo su deseo de armonía. 
Esta "natura naturans" que es capaz de encarnar en su movimiento los propios movimientos espirituales del personaje (Díaz, pág. 422), conformando así un "paisaje solidario" (García Viñó, pp. 344-346), está presente, asimismo, en textos de intención no ficcional, como la Historia de los Templos de España, en donde se lee los siguiente en el capítulo dedicado a la iglesia de Santa Leocadia en Toledo:

Cuando, después de haber recorrido una gran parte de la ciudad imperial, detuvimos nuestros pasos sobre la altura que corona el hospital de Tavera, desde la que se domina el lugar en que está situada la basílica, el día comenzaba a caer. El cielo se veía cubierto por lagos jirones de nubes pardas y cobrizas, entre los que se deslizaban algunos rayos de sol, que, encendiendo sus orlas y bañando en luz la cima de los montes, doraban las altas agujas y los derruidos muros de la población que acabábamos de abandonar. La vega, que extendiéndose a nuestros pies se dilataba hasta las ondulantes colinas que se elevan en su fondo como las gradas de un colosal anfiteatro, semejábase con sus oscuros manchones de césped y las anchas líneas amarillentas y rojas de su terreno arcilloso a una alfombra sin límites, en la que podíamos admirar la armónica gradación de los colores que se confundían y debilitaban marcando así sus diferentes términos y desigualdades. A nuestra izquierda, y escondiéndose por intervalos entre el follaje de su orillas, el río se alejaba besando los sauces que sombrean su ribera y estrellándose contra los molinos que detienen su curso hasta bañar las blancas paredes de la fábrica de armas, que aparece en su margen, en medio de un bosque de verdura.

Cuanto se ofrecía a nuestros ojos formaba un conjunto pintoresco; pero diríase al contemplarlo que sobre aquel paisaje había extendido el otoño ese velo de niebla azulado y melancólico en que se envuelve la Naturaleza al sentir el soplo helado de sus tardes sin sol; ese silencio profundo, esa vaguedad sin nombre, imposible de expresar con palabras, que, apoderándose de nuestro espíritu, lo sumerge en un océano de meditación y tristeza imponderable.

Claudio Lorena, en algunos de sus maravillosos paisajes, ha logrado sorprender su secreto a la Naturaleza y ha reproducido este último adiós del día con todo el misterio, con toda la indefinible vaguedad que lo embellece (884-885).

De nuevo contemplamos la proximidad a Chateaubriand tanto en imágenes muy concretas como en el sentido global del texto. El "velo de niebla azulado", semejante a aquella "gasa azul" con que la luna vela los objetos en La corza blanca, es un pariente muy cercano del "voile de gaze" de la luna que armoniza con su color azul a las montañas en el fragmento citado anteriormente de Memorias de ultratumba, del "vapeur bleuâtre" que envuelve los campos silenciosos al atardecer en uno de sus poemas, Le soir dans une vallée, y de "la clarté suave qui veloute la surface des objets" de su lejana carta sobre la pintura de los paisajes (1847, V, pág. 554). La atmósfera vaga de los paisajes de Claudio Lorena, por su parte, parece proceder en primera instancia de la lectura del mismo texto de las Memorias, ya que en él se le atribuye al pintor esa atmósfera flou, si bien lo que más interesa de la referencia a Lorena es que la inserta en un 
contexto en el que no se está hablando de un paisaje enteramente objetivo sino lleno de la subjetividad de quien lo contempla, espectador que provoca una trascendencia del paisaje más allá de un inventario realista al ver en él formas inestables y cambiantes; de donde el desconcierto de algunos que, como Edmund L. King, no acaban de entender esa cita ni ven una igualdad sustancial entre su prosa y su poesía $(26,115)$.

En efecto, también en la distribución interna del fragmento es perceptible la dialéctica entre lo cerrado del paisaje ("colosal anfiteatro", molinos que detienen el curso del río) y lo ilimitado ("alfombra sin límites", el río que se aleja, el "océano de meditación y de tristeza"), así como la clausura que lleva a la unión del paisaje con el espíritu del espectador: la vaguedad que sumerge a éste en otra vaguedad igualmente inasible, la del océano de meditación y tristeza; concreción, en definitiva, de un Ausente que, más allá de cualquier pintoresquismo apunta hacia la eternidad.

Precisamente para marcar el tránsito entre una realidad y otra, confundiendo los contornos al hacerlos imprecisos pero también agrandándolos sin fin, y desengañando a quienes pretenden acceder a la unión con el Ausente al mantenerlos en su mundo material, es por lo que reiteradamente aparece en ambos autores el motivo de la claridad de la luna con la doble capacidad de transformar y engañar al mismo tiempo, marca visible de esa ausencia.

En Chateaubriand es lo que activa a su fantasma amoroso cuando, después de construir para sí mismo una mujer ideal, producto de la suma de todas las mujeres vistas por él, un rayo de luna la hace revivir en su presencia; sueño del que finalmente despierta y lo lleva a caer en la desesperación (1983, I, pp. 9394). Por eso, muchos años más tarde se dirigirá a la luna en términos poco halagadores:

O lune! vous avez raison; mais si je parlais bien de vos charmes, vous savez les services qui vous me rendiez; vous éclairiez mes pas alors que je me promenais avec mon fantôme d'amour... Que de fois vous avez regardé mes yeux passionnément attachés sur les vôtres! Astre ingrat et moqueur... (1983, II, pág. 661) ${ }^{8}$.

Ese carácter de astro que provoca transformaciones pero se burla de quienes creen en ellas es el que tiene en varias leyendas de Bécquer, sobre todo en La corza blanca y El rayo de luna; relato este último que, igual que en Chateaubriand, trata de un joven que crea a su propio fantasma amoroso, fruto de la reunión de los rasgos de diferentes mujeres; un fantasma que acaba

8. La luna emparentada con los sueños del poeta es un tema recurrente en Chateaubriand. Ya en Genio del Cristianismo decía lo siguiente: "On retrouve dans la clarté de la lune le Génie des rêveries du coeur; on entend ses soupirs dans le frémissement des bris et dans les plaintes de Philomèle" (1847, III, pág. 121). 
concretándose ante su vista por la actividad de la luna, quien lo engaña y le provoca una frustración que le hace descreer de todo lo que no sea la propia imaginación:

— ¡No! ¡No! —exclamó el joven, incorporándose colérico en su sitial一 . No quiero nada...; es decir, sí quiero: quiero que me dejéis solo... Cantigas..., mujeres..., glorias..., felicidad, mentira todo, fantasmas vanos que formamos en nuestra imaginación y vestimos a nuestro antojo, y los amamos y corremos tras ellos, ¿para qué?, ¿para qué? Para encontrar un rayo de luna (193).

Bien podrían ser éstas las palabras que marcan la diferencia entre Bécquer y Chateaubriand. Si el francés escribe en una época de transición entre un mundo antiguo que se desmorona y otro nuevo que emerge, buscando su paraíso perdido en una épica sustentada por la religión cristiana, el sevillano lo hace cuando varias generaciones de poetas románticos han transformado la nostalgia en energía creadora independiente, capaz de establecer un puente entre la idea y la naturaleza; por ello, aunque hace una lectura de Chateaubriand atenta a su tradicionalismo religioso, le interesa tanto o más su particular manera de mostrar la tensión entre la materia y el espíritu; esto es, su respuesta ante el mito romántico de la Alteridad, una respuesta que oscila entre la posibilidad de alcanzar la unión con el Ausente por medio de la muerte y el imposible acceso a la misma.

\section{OBRAS CITADAS}

ABRAHAM, Bertrand. 1972. "Chateaubriand et les spectres". Communications, 19, pp. 177-185.

ABRAMS, Meyer H. 1992. El Romanticismo: tradición y revolución. Madrid, Visor. ALONSO, Martín. 1972. Segundo estilo de Bécquer. Madrid, Guadarrama.

ARBOLEDA, José R. 1979. Historia de los Templos de España. Barcelona, Puvill.

BARBÉRIS, Pierre. 1976. Chateaubriand. Une réaction au monde moderne. Paris, Larousse.

BATTEUX, Charles. 1802. Principios filosóficos de la literatura. VI. Madrid, Sancha. BÉCQUER, Gustavo A. $1966^{12}$. Obras completas. Madrid, Aguilar.

BENÍTEZ, Rubén. 1971. Bécquer tradicionalista. Madrid, Gredos.

— "La elaboración de El caudillo de las manos rojas" (VVAA, pp. 371-392).

— 1974. "Introducción" a G.A. Bécquer. Leyendas, apólogos y otros relatos. Barcelona, Labor.

BERENGUER CARISOMO, Arturo. 1974. La prosa de Bécquer. Universidad de Sevilla. 
BROWN, Rica. 1963. Bécquer. Barcelona, Aedos.

CLARAC, Pierre. 1975. À la recherche de Chateaubriand. Paris, A.G. Nizet.

CHATEAUBRIAND, François-René de. 1847. Oeuvres complètes. 5 vols. Paris, Firmin Didot.

- 1983. Mémoires d' Outre-Tombe. 2 vols. Paris, Gallimard.

DÉDEYAN, Charles. 1973. Chateaubriand et Rousseau. París, SEDES.

DE MAN, Paul. 1984. The Rhetoric of Romanticism. New York, Columbia University Press.

DíAZ, José P. $1971^{13}$. Gustavo Adolfo Bécquer. Vida y poesía. Madrid, Gredos.

FONTANIER, Pierre. 1968. Les figures du discours. Paris, Flammarion.

GARCÍA VIÑÓ, Manuel. "Los escenarios de las leyendas becquerianas", VVAA, pp. 335-346.

GUILLÉN, Claudio. 1985. Entre lo uno y lo diverso. Barcelona, Crítica.

KING, Edmund L. 1953. Gustavo Adolfo Bécquer: From Painter to Poet. México, Porrúa.

MADAULE, Jean. 1972. "Chateaubriand". En Manuel D'Histoire Littéraire de la France. IV. De 1789 a 1848. (1). P. Abraham et R. Desné (dir). Paris, Editions Sociales, pp. 228-254.

MARINO, Adrian. 1988. Comparatisme et théorie de la littérature. Paris, PUF.

PAGEARD, Robert. 1971. "Notes becqueriennes". Bulletin Hispanique, LXXIII, 3 4, pp. 345-347.

—_Gustavo Adolfo Bécquer et le Romantisme français" VVAA, pp. 477-524.

PEERS, Edgar A. 1924. "La influencia de Chateaubriand en España". Revista de Filología Española, XI, pp. 351-382.

PINCUS SIGELE, Rize1. 1972. "The Historia de los Templos and the Vision of Architecture in the Works of Gustavo Adolfo Bécquer". En Homenaje a Casalduero. R. P. Sigele y G. Sobejano (eds.). Madrid, Gredos, pp. 433-451.

RAMÍREZ ARAÚJO, Alejandro. 1985. "Bécquer y la reconstrucción del pasado". En Gustavo Adolfo Bécquer. Russell P. Sebold (ed.). Madrid, Taurus, pp. 249257.

RICHARD, Jean-Pierre. 1967. Paysage de Chateaubriand. Paris, Seuil.

RISCO, Antonio. 1987. Literatura fantástica de lengua española. Madrid, Taurus.

SCHELLING, Friedrich W.J. $1972^{14}$. La relación de las artes figurativas con la naturaleza. Buenos Aires, Aguilar.

SEBOLD, Russell P. 1989. Bécquer en sus narraciones fantásticas. Madrid, Taurus. 
- 1992. De ilustrados y románticos. Madrid, El Museo Universal.

TESTA, Carlo. 1992. "La obra tierra, el otro yo: el mito de la Alteridad en el Romanticismo". En Mythopoesis: Literatura, totalidad, ideología, J.R. Resina (ed.). Barcelona, Anthropos, pp. 131-146.

TODOROV, Tzvetan. 1972. Introducción a la literatura fantástica. Buenos Aires, Tiempo contemporáneo.

VARELA, José Luis. "Mundo onírico y transfiguración en la prosa de Bécquer" VVAA, pp. 305-334.

VERNET, Marc. 1988. Figures de l'absence. Paris, Editions de l'Etoile.

VILLANUEVA, Darío. 1985. "Introducción" a Gustavo Adolfo Bécquer, Desde mi celda. Madrid, Castalia.

VVAA. 1972. Estudios sobre Gustavo Adolfo Bécquer. Madrid, CSIC.

WELLEK, René. 1968. Conceptos de crítica literaria. Universidad Central de Venezuela. 


\title{
LO GÓTICO, LO FUNERAL Y LO MACABRO EN LA CULTURA ESPAÑOLA Y EUROPEA DEL SIGLO XVIII
}

\author{
Nigel GLENDINNING \\ Queen Mary and Westfield College, \\ Universidad de Londres
}

Las novelas góticas, las tragedias de mazmorra y la poesía sepulcral, en las que se reconcentra el gusto dieciochesco de lo funeral y lo macabro, se consideran con frecuencia fenómenos románticos o prerrománticos, que parecen corresponder a un cambio de sensibilidad en el siglo XVIII (Abrams, 1953). Este cambio se explica de distintas maneras: ya como manifestación puramente literaria o filosófica (engendrada en, y transmitida por, los libros; Praz, 1930), ya como consecuencia del desarrollo de la burguesía en las sociedades europeas (Hauser, 1951), ya como fruto de la introducción de nuevos cementerios y sepulcros más individualizados (Ariès, 1971 y 1974), ya como producto de cierto descenso en las creencias religiosas con su correspondiente ascenso de tendencias libertarias (Gay, 1967); o ya como resultado de las modificaciones de perspectivas y fronteras de las ciencias, que trajeron consigo una revolución psicológica en el Occidente (Foucault, 1966, segunda parte, capítulo 10). Con tales novelas, tragedias y poesías entran de lleno en la literatura del Siglo de las Luces las sombras y los presagios - despreciados por los ilustrados dieciochescos, ridiculizados por los devotos de la Razón en todas las épocas. Irrumpen con ellas también, sin duda, las corrientes socio-psicológicas constantes en la cultura, que se manifiestan asimismo en la literatura carnavalesca, reflejando las preocupaciones y los conflictos de siempre en la sociedad humana lo mismo que los impulsos instintivos. Estas corrientes podrían ser muy bien las que privilegiaban la cara oscura de la imaginación, los monstruos producidos por el sueño de la razón y las obsesiones mórbidas en la novela y la tragedia mencionadas. Son ellas muchas veces las que dan lugar preferente a los temas subversivos, sean sexuales, anti-jerárquicos, anticlericales o simplemente irracionales. La visión histórica a menudo simplifica la interpretación de los fenómenos culturales. 
Pero, en realidad, ni siquiera los estilos aceptados ni los discursos dominantes son unívocos.

La posibilidad de diversas perspectivas sobre un mismo estilo surge muy claramente en el siglo XVIII en el caso del Gótico. El desprecio de este estilo arquitectónico por los árbitros del Gusto, a principios del siglo por ejemplo, corresponde a una visión histórica desfavorable a los godos, que se consideraban progenitores de la barbarie. El gótico era primitivo para estos círculos, y sus edificios llenos de quimeras, harpías, ornamentos grotescos e irracionales, imágenes burdamente esculpidas y amontonadas sin sentido de unidad ni armonía. En la segunda mitad del siglo, en cambio, en una época en que se daba más importancia a la respuesta del espectador y al estímulo de los sentidos por la arquitectura, algunos autores vuelven a elogiar el gótico por la riqueza sensorial de sus edificios ${ }^{1}$. Tales autores se maravillan de la singular delicadeza de los monumentos góticos, alaban su ligereza o ingravidez, y hasta encuentran una elevación majestuosa en sus construcciones, que faltaba en las de la Antigüedad clásica. Gracias al cambio de enfoque, el gótico o neogótico pasaba de los jardines, en donde quedaba arrinconado, al interior de las casas. Al estilo de las grutas y los pabellones rústicos se hace el de las chimeneas, librerías y sillas de los salones. Para algunos, a pesar de todo, el gótico seguía siendo primitivo o más bien lúdico ${ }^{2}$; pero otros ya lo tomaban en serio, identificándolo con lo Sublime, tratándolo de estilo de carácter religioso, que los arquitectos podrían ofrecer a los más adictos a las tradiciones cristianas, y los estetas relacionar con el espíritu nacional de sus países ${ }^{3}$. El neogótico dieciochesco, por lo tanto, supone un abanico de actitudes y colores, lo mismo que el Neoclasicismo (Rosenblum, 1967). El signo de estilo se modifica según las diversas inclinaciones de los autores.

Valga como ejemplo de lo que este estilo podía representar el caso de Horace Walpole (1717-1797), cuarto hijo del primer ministro británico Sir Robert Walpole, que desarrolló y refinó su afición al gótico en sus viajes por Francia e Italia entre 1739 y 1741 . Empezó a remodelar la casa de su habitación en la Cuesta de las Fresas (Strawberry Hill, al oeste de Londres) en el estilo

1. Una revisión de perspectivas sobre el Gótico se encuentra en Francia en Laugier (1753, con nueva edición en 1755). Un contraste de dictámenes favorables y desfavorables aparece en Blondel (1771, I, págs. 458-459), y la continuación de su curso por Patte (1777, VI, págs. 206-207).

2. Se construían edificios góticos o neogóticos más que nada en los jardines de las casas de campo inglesas en la primera mitad del siglo XVIII (McCarthy, 1987, págs. 4-59). Primaba en estos ejemplos el valor decorativo y hasta lúdico. Aun se daban casos parecidos a principios del siglo XIX. Krafft y Ransonnette publicaron un diseño para un molino con arcos góticos (s.a., lamina 47), y elaboraron también un gabinete de lectura neogótico en 1801 (lámina 240).

3. La relación entre lo Gótico y lo Sublime se establece en el contexto de los castillos góticos en Alison (1825, I, pág. 322). Belanger trató de estimular el interés de Chateaubriand por el estilo de los monumentos góticos en 1811, subrayando el sentido religioso del mismo (Stern, 1930, pág. 290). August-Wilhelm Schlegel desarrolló su concepto fundamental del gótico como expresión de los espíritus nacionales alemán y español por la misma época (1809-1811). 
gótico de los años cincuenta, añadiéndole luego nuevas alas y accesorias ${ }^{4}$. $\mathrm{Y}$ en 1764 publicó anónimamente la primera novela de las llamadas góticas, El castillo de Otranto. Walpole disfrutaba con la recreación de las épocas pasadas, tenía gusto de coleccionista, y se llevó a su casa de campo detalles de las antiguas catedrales y los regios palacios (Gray, 1903, pág. 10-11). No era todo respeto en Walpole, sin embargo, para con las cosas viejas. Se divertía con ellas al cambiarlas de contexto, casi parodiándolas. En la novela hay una labor de anticuario parecida; motivos de risa también; y un espíritu de rebeldía edípica, sobre todo en el desparpajo del joven Teodoro y sus conflictos con el tiránico príncipe de Otranto, Manfredo, padre y esposo cruel y egoísta entrado en años.

La imaginación asimismo desempeña un papel importante en la arquitectura y la novela walpolianas. La refuerzan los recuerdos de otros edificios en su casa, ya que la facultad imaginativa servía para "rememoriar las imágenes" en el siglo XVIII (Diderot, 1959, pág. 218). El estímulo de la fantasía vuelve a primar y es más original en El castillo de Otranto. El mismo autor subraya su importancia en uno de sus prólogos, lamentando que se hubiesen tapado "las grandes fuentes imaginativas" en la novela moderna, para poder reflejar mejer la vida de todos los días y los móviles de la conducta humana (Walpole, 1907, pág. LVI). Pero el uso que Walpole hace de la imaginación en El castillo de Otranto es muy distinto del de los proyectos arquitectónicos mencionados. En su casa, la fantasía se relaciona con objetivos exaltados — con lo noble y lo espiritual-mientras que en la novela se asocia con la ambición, la codicia y el abuso del poder de un tirano. La novela ofrece una imagen negativa, al parecer, de los valores celebrados en su casa, aun cuando los aparecidos sean heroicos y virtuosos. En la casa, tan sólo la presencia de retratos de personajes de la corte de Enrique VIII, o de una chimenea de dormitorio inspirada en el altar mayor de la catedral de Ruán (Gray, 1903, III, págs. 10-11), producen un desfase contextual con posibilidades cómicas o burlescas, que hace sospechar cierta ambigüedad o ironía. No cabe duda, desde luego, que la existencia de humor y juego en estas obras aumenta su potencial subversivo y disidente.

En El castillo de Otranto se exige una visión irónica por parte del lector, puesto que se trata de una novela llena de contrastes e incoherencias. En cierto sentido la trama es consoladora, ya que el tirano Manfredo, nieto de un usurpador y celoso él mismo de su poder, malogra la sucesión al trono que ambiciona para su familia, y el principado vuelve a los descendientes del último soberano legítimo. Los malos caen en la novela, por otra parte, y algunos de los buenos suben. El joven Teodoro, por ejemplo, de origen incierto

4. Walpole alquiló la casa en 1747 , y se compró la finca al año siguiente, adquiriendo más terreno en lo sucesivo. Afirmó que tenía la intención de construir "un pequeño castillo gótico" en 1750, y empezó a edificarlo en 1753-1754. De aquellos años son el refectorio y la biblioteca. Se hizo nuevo dormitorio en 1759 y una galería para cuadros, claustro y torre en 1760-1761. Construyó una capilla en 1772-1773 (McCarthy, 1987). 
y al parecer modesto, cuya vida peligra constantemente en la obra, se revela al final tronco de la línea de príncipes legítimos y se casa con una hermosa princesa. Todo esto es, desde luego, consolador y un poco parecido a las tradiciones de los cuentos folklóricos, con sus historias de jóvenes que necesitan luchar mucho para hacerse lugar en el mundo, ayudados a veces por genios protectores.

Es cierto que la providencia protege, en cierto modo, en El castillo de Otranto también. Pero la ineficacia de los buenos es lastimosa. Los más de ellos son mujeres, que no saben hacerse valer contra el poder del tirano, ni quieren poner en tela de juicio su autoridad. Para que sobrevivan algunos buenos es imprescindible la intervención de fuerzas sobrenaturales, en una serie de portentos, sueños y visiones. Sin embargo, éstos tampoco convencen mucho al lector. Los portentos - yelmos encantados, sables gigantescos, casos de agnición o anagnórisis- o son cómicos en sí, o parecen ridículos por su manera de darse a conocer, con frecuencia a través de los balbuceos interminables de la miedosa servidumbre. El terror, por lo tanto, que debería de realzar el papel del Cielo, resulta risible a menudo en vez de sublime ${ }^{5}$. Lo inverosímil de estos sucesos y el consiguiente "suspense" estimulan la imaginación, pero de un modo tan exagerado que provocan más bien la risa que la admiración. Como consecuencia, se socava la autoridad providencial desde el punto de vista del lector.

En las novelas góticas posteriores en Inglaterra, los recursos cómicos (cuando los hay) no afectan tanto a la Providencia. Se disminuye la cantidad de elementos sobrenaturales, y algunos de los autores - Mrs. Radcliffe, por ejemplo- procuran dar siempre una explicación racional de los sucesos que parece sobrenaturales en el primer momento. Varía mucho, por otra parte, la fuerza subversiva y anti-autoritaria en estas novelas. Matthew Lewis, autor de El monje (1795) y de un drama titulado El espectro del castillo (1798) con elementos "góticos", y Mrs. Radcliffe, son bastante audaces. Hay en sus novelas abusos del poder en las diversas jerarquías, en el clero y la nobleza, sobre todo, y crítica implícita o explícita de ellos. Clara Reeve, en cambio, es más conservadora. Hay más figuras-padre buenos en El viejo barón inglés, y ningún humor disidente. Otro elemento positivo, que no se encuentra en El castillo de Otranto, es la naturaleza, cuya belleza y sublimidad, aun cuando realcen los efectos terroríficos de los castillos aislados, manifiestan la fuerza y la bondad divinas en contraste con la maldad humana. Los aspectos sublimes del paisaje montañoso entran en juego poderosamente en las novelas de Mrs. Radcliffe, y

5. Los contemporáneos de Walpole y alguna de sus imitadoras - Clara Reeve- hacen constar el carácter risible de algunos de los episodios "terroríficos" de la novela. Clara Reeve se refiere a esto en el prefacio de la segunda edición de su novela The Old English Baron. A Gothic Story (1967, págs. 4-5). El poeta Thomas Gray no dejó de aprovechar las posibilidades cómicas del estilo gótico en la arquitectura, y hay rasgos paródicos en su descripción de un palacio gótico en el poema A Long Story. 
contribuyen también al impacto del Frankenstein (1818) de Mary Shelley. Esta última novela parece cercana a sus antecedentes góticos con respecto al ambiente oscuro, el terror y la fuerza del mal, aunque distante de ellos en cuanto al uso de la imaginación. Ésta se inspira en los avances científicos y las invenciones de su tiempo en Frankenstein: nuevas fuentes del mal en manos ambiciosas y obsesivas, en un mundo apto a juzgar por las apariencias.

El impacto de estas novelas inglesas en otros países es bastante inmediato. En Francia se las puede relacionar también con algunos elementos del llamado "género sombrío", y sobre todo con el teatro de Baculard d'Arnaud en los años setenta y ochenta, y las obras de Loaisel de Tréogate por la misma época (Estève, 1923). En estos escritos y dramas hay castillos de la era feudal, selvas aisladas y capillas arruinadas; pasillos y bóvedas subterráneas; todo el aparato de mazmorras y calabozos antiguos que se encuentran también en la novela gótica. Hay también en este tipo de obra historias de enamorados recluidos en conventos o monasterios.

Los móviles que se aprecian en estos autores son parecidos a los de los novelistas góticos. Baculard d'Arnaud, por ejemplo, en el prólogo de sus Epreuves du sentiment, realza el mérito del estudio de épocas pasadas, después de hablar de la importancia del sentimiento, insuficientemente desarrollado a su ver por la enseñanza moderna, obsesionada por la primacía de la razón (1779, I, págs. III y sigs.). Muchos modernos tan sólo raciocinan acerca de la antigüedad; no la sienten. En Dolbreuse, Loaisel de Tréogate afirma que el hombre del siglo vuelve hacia la verdad bajo la influencia del sentimiento, no de la razón ${ }^{6}$. Todo lo que puede reforzar la intensidad del afecto se aprecia, y Baculard d'Arnaud se refiere, en el prólogo del Conde de Comminge, a la utilidad de la sombra cuando se trata de estimular los sentimientos del público. Alude a la práctica de pintores como Rembrandt, Rubens y Poussin, que llenaban sus cuadros de tonos oscuros para realzar los efectos sublimes. Entre los poetas hay una tonalidad semejante (con resultados parecidos) en el Infierno del Dante, en el Paraíso perdido de Milton y en las Noches de Young (D'Arnaud, 1768, págs. VII y sigs.).

La historia del conde de Comminge inspiró a dos autores a fines del siglo XVIII, y tiene una relación evidente con el género de novelas y dramas que nos interesa $^{7}$. Es una historia de amores desgraciados, consecuencia de la enemistad

6. Así lo declara el título de esta novela: Dolbreuse ou l'homme du siècle, ramené à la vérité par le sentiment \& par la Raison (1785).

7. El drama de Baculard d'Arnaud fue inspirado por una novela de Mme de Tencin (Le Comte de Comminge, 1735). Hay una epístola poética sobre la misma historia en la Collection d'Héroïdes et pièces fugitives de Dorat, Colardeaux, Pezay, Blin de Saint-More \& autres (1769, I, págs. 25 y sigs.). En esta última edición se incluye también un extracto de las Memorias del conde de Comminges, sin duda, las de la ya mencionada Mme de Tencin. Se publicó una versión española del poema de Dorat, traducida por D.M.A. de C. (1803). 
de dos familias y el rigor de los padres. Los jóvenes - Comminge y su amiga Adelaida - han sido criados juntos y se quieren. Pero los padres de Adelaida la casan con otro, y el conde, por su parte, debe contraer matrimonio con una hija de la Casa de Foix. Se le encierra en una torre cuando quiere renunciar a este destino, pero visita nuevamente a su antigua amiga al salir de la prisión. Desgraciadamente, el marido de esta última encuentra a los amigos juntos y hiere al conde con su espada. Comminge hiere al otro y después se mete monje, condolido de sus acciones. Muerto el marido a consecuencia de la herida, Adelaida entra disfrazada en el mismo monasterio que su amigo. Allí se descubren los amantes justo antes de morir, y caen en el mismo hoyo.

Los amores frustrados se celebran en esta obra, y las sombras, las bóvedas y demás aspectos lúgubres subrayan la negrura y tristeza de la vida. La incomprensión de los padres en el drama recuerda las novelas góticas, en las que los conflictos familiares y los abusos de la patria potestad son frecuentes. En este caso, como en otros, los jóvenes son víctimas de las ambiciones y rencillas familiares, aunque también de la adversa fortuna. Por esto no se trata de una tragedia de tipo aristotélico, en la cual el error o la culpabilidad del protagonista produce la crisis.

El conde de Comminge no llegó a estrenarse hasta el año de 1790, después de la Revolución Francesa, quizás precisamente por la visión negativa de la autoridad paterna que implica. La crítica de un padre por entonces podría tener un sentido alegórico, relacionado con el poder de las altas jerarquías y la monarquía misma. En una versión poética anterior a la misma leyenda - la de Dorat en una de sus Héroïdes - se zanja la crítica al respecto (1769, I, págs. 25 y sigs.). El conde empieza a hablar mal de su padre al final, pero en seguida se corrige, pidiendo perdón. No disminuyen, por esto, los efectos melancólicos y pesimistas en el poema de Dorat. Incluso la presencia de láminas en las ediciones de Dorat, como en las de Baculard d'Arnaud también, subraya la tenebrosidad de la historia. Las escenas representadas son nocturnas u oscuras: un sótano con una cruz y calaveras; una monja (Adelaida) a punto de expirar; el conde al lado del hoyo que prepara para su propio entierro. Otras obras de la época postrevolucionaria, en cambio, buscan desenlaces más esperanzadores. En éstas los amantes se salvan; cásanse y viven felices.

En la novela y el teatro se proyectan o dramatizan los sentimientos y preocupaciones de la sociedad y del autor en el terreno de lo funeral, lo lúgubre o lo macabro. En la poesía también existen formas indirectas dialogadas, por ejemplo, como las églogas, o de ficticio narrador como las cartas al estilo de las Heroidas ovidianas, en las que se pueden tratar los mismos temas o expresar emociones parecidas. Hay otras formas, en cambio, donde la voz del poeta parece sonar más personalmente, aun cuando se trate de temas fílosóficos o se escriban poemas más bien meditando sobre la muerte que expresando sentimientos o experiencias íntimos. 
Un caso muy especial de la poesía sepulcral en el siglo XVIII es el de poeta inglés Edward Young, pastor protestante y autor de un poema en nueve partes o "noches", titulado El lamento, o pensamientos nocturnos (The Complaint, or Night Thoughts). En este conjunto poético, el escritor parte de experiencias propias, pero procura despersonalizarlas para llegar a conclusiones generales acerca del lugar del dolor en la vida humana, con ejemplos del impacto de la muerte de una persona querida sobre los afligidos. También introduce personajes ficticios en diversas secciones de la obra, con experiencias "propias", con el mismo fin de universalizar las observaciones y sensaciones recogidas. Hubo versión francesa en prosa de este largo poema, saneada desde el punto de vista de la doctrina, que llevó la obra a países católicos (Le Tourneur, 1769). Una traducción española, incompleta, salió en la colección de Obras de Eduardo Young... traducidas por Don Juan de Escoiquiz, publicada en Madrid entre 1789 y 1797. El ambiente nocturno, la riqueza de las imágenes y la forma epigramática en que se expresaban los pensamientos filosóficos gustaron. Pero lo que aseguró el éxito de las Noches de Young no fue tanto el doloroso sentir de los personajes, ni las ideas, como el valor que los lectores dieciochescos daban al elemento autobiográfico, fácil de deducir de la Vida de Young, que se incluía en muchas ediciones del poema. Los lectores siempre tienen en cuenta las experiencias del autor, cuando se trata de los temas del amor y de la muerte en la literatura. Pero se acrecienta la respuesta del lectorado a lo personal en el siglo XVIII, al parecer. Otro aspecto seductor del poema de Young sería la conclusión de la última Noche, donde las estrellas reflejan la grandeza de Dios y la bondad del universo creado por Él. Con esto se tranquiliza la inquietud de los afligidos, después de los momentos de tormento y desesperación experimentados por ellos a raíz de sus desgracias. Este fin feliz, algo distinto del de los desenlaces de novela normales, sirvió también para borrar la impresión de reacciones pesimistas ante la vida, evocadas de vez en cuando en la obra.

El auge de las emociones en relación con lo funeral, lo lúgubre y lo gótico no se puede rastrear tan fácilmente en el arte. Es cierto que las Carceri de Piranesi corresponden al mismo gusto que la novela gótica en algunos aspectos ${ }^{8}$, y la representación de la muerte de un padre de familia o de un general en campaña es bastante frecuente en la pintura de la época. Surgen los aparecidos asimismo en los grabados de la serie shakesperiana publicada en Londres por Boydell ${ }^{9}$. Pero

8. La única conexión, en realidad, es el tema de la cárcel. Los encarcelados de Piranesi no se encuentran solos, ni están encerrados en calabozos subterráneos, como era el caso en muchas novelas. Sin embargo, la angustia de los recluidos se percibe en los grabados lo mismo que en las novelas góticas.

9. Aparecen las sombras de cuatro reyes en la primera escena del Acto VI de Macbeth, representadas en un cuadro de Sir Joshua Reynolds (grabado por Thew), y vuelan.brujas por el aire en una pintura de Fuseli, acompañadas por una extraña cara que expresa el horror, en una ilustración para la tercera escena del Acto primero de la misma tragedia (grabada por Caldwell) (Santanietlo, 1968, XXXVII y XXXIX). 
en el arte resulta más difícil separar los sentimientos personales de la retórica. Las figuras mal vestidas, perdidas por las extensas galerías o escaleras de las vastas cárceles de Piranesi, ¿reflejan las emociones del mismo grabador, o son personajes teatrales, por así decirlo, que representan la miseria o el terror de los encarcelados ante la perspectiva de los rigores de la justicia? Los padres que se mueren rodeados por sus familias en los cuadros del siglo XVIII suelen ser ficticios, ejemplares o moralizadores. Los generales pintados en el trance de morir, entre edecanes, oficiales y soldados, en cambio, son reales las más de las veces y no ideales. Pero aquellas muertes, ¿sirven para desencadenar el llanto y el dolor del espectador y son catárticos para el artista, o son tan sólo ejemplo del valor militar, del sacrificio hecho para la patria, y de la ecuanimidad del héroe frente a su fallecimiento ${ }^{10}$

Volviendo al tema del estilo gótico en la arquitectura, y pasando ya a España, es evidente que tampoco se apreciaba mucho a principios del siglo XVIII. Se dan fórmulas para la construcción de los arcos apuntados en libros como el de Tomás Vicente Tosca (Tratados de arquitectura civil, montea y cantería y relojes), pero está bastante claro que el estilo gótico no se aprobaba. Dice Tosca que los arcos apuntados y elípticos son "propios del orden gótico", pero "a más de no ser hermosos, son algo débiles" (1794, pág. 105). El orden gótico es difícil de ejecutar bien, y aun cuando se logre "después de bien ejecutado y trabajado, no es hermoso" (1794, pág. 60). En la segunda mitad del siglo, en cambio, hubo españoles menos reacios con respecto al gótico. Ponz, por ejemplo, en las descripciones de edificios importantes en su Viaje, demuestra cierta simpatía por los monumentos góticos. Pasa lo mismo con otro viajero y académico de San Fernando, el marqués de Ureña, cuyo Viaje por Europa, hecho en 1787 y 1788, acaba de publicarse por primera vez (1992). La delicadeza o finura es lo que Ureña más destaca en este estilo. Una de las capillas de la abadía de Westminster le parece "en lo gótico de lo más delicadamente ejecutado que he visto hasta ahora" (1992, pág. 314). En Amiens, el cuerpo de la iglesia mayor es "delicado en su género" (pág. 269), y la catedral de Amberes, "así por su altura y bella forma en lo gótico, como por su diafanidad y delicadeza" le parece probablemente sin igual en Europa (pág. 532). Mas, en su Viaje, Ureña sólo parece disfrutar de estos edificios parcialmente y nunca del todo. Es como si no hubiese más posibilidad de unidad que la clásica.

10. Se representó la muerte del general Wolfe en un cuadro famoso de West (1770), y la de un héroe anónimo en una pintura de James Barry (1776). Se grabó el cuadro de West, como también el de la muerte del Mayor Pierson, por Copley, para una de las series de Boydell (Friedman, 1976, págs. 39 y 49). En Francia, David pintó La muerte de Séneca (1773), la escena en que se devuelven a Bruto los cadáveres de sus hijos (1789) y el asesinato de Marat (1793). Es de notar el carácter no heroico del cuerpo de Marat, que hace contraste con otras representaciones de la muerte de personajes históricos. 
$\mathrm{Y}$, sin embargo, en otro escrito suyo - las Reflexiones sobre la arquitectura, ornato y música del templo, publicadas en Madrid en 1785- el mejor estilo gótico le parece digno de imitarse. "Podrían los Artistas Filósofos tomar sabias lecciones de la arquitectura gótica del mejor tiempo", afirma Ureña (pp. 150 y 215-216). Se tendrían que reprobar "muchas ideas mezquinas y no pocas deformidades", pero en medio del detallismo característico del estilo hallarían "rasgos de simplicidad, de verdad, de propiedad, de unidad, de carácter, de armonía y de euritmia" (pp. 150 y 216). Estas ideas favorables al gótico no son únicas, pero sí algo raras. Lo normal en España seguía siendo el deseo de corregir y modificar los monumentos góticos: poniéndole nueva fachada neoclásica a la catedral de Pamplona (Ventura Rodríguez, 1783); e introduciendo capillas neoclásicas en la de Valencia. Tan bien hizo Andrés Gilabert su labor en este último caso, que ha sido difícil sacar las capillas y dejar el conjunto en su estado primitivo, no hace muchos años.

Con respecto al neogótico en la arquitectura española de fines del siglo XVIII y principios del XIX, escasean los ejemplos conocidos. Se creó un "gabinete gótico" en el Palacio de la Moncloa en Madrid, a la hora de renovar la antigua Huerta de Eliche en los años ochenta, tarea emprendida por la duquesa de Arcos, asesorada por su hermano Don Pedro de Silva, entre 1781 y 1784, y continuada después por la famosa Cayetana, duquesa de Alba, a partir de entonces (Ezquerra del Bayo, 1929; Glendinning, 1992, pág. 47). En aquel caso se trataba de un oratorio pequeño, nada más. Dominaban la decoración de la casa los adornos clásicos, las ninfas ligeramente vestidas del estilo pompeyano, y los trompe-l'oeil paisajísticos. Hubo por la misma época conato de hacer una sala neogótica en la Casita del Pardo, junta con otras igualmente exóticas, estilo turco, egipcio y chino en el mismo edificio y la Casita de El Escorial (Sancho, 1989a, pp. 17-31; 1989b, pp. 31-36). Pero no se aprobó el proyecto gótico - obra de Dugourc, inspirada en parte en los arcos de la catedral de Ruán, aunque híbrida entre gótico y clásico a decir la verdad- y no sabemos de otros intentos hasta 1830, cuando surge de nuevo el neogótico en una de las construcciones edificadas para celebrar el nacimiento de la futura Isabel II.

Existen, en cambio, elementos góticos en la literatura española por aquella época. Las portadas de los libros ofrecen bastantes ejemplos de letra más o menos gótica en España en las primeras tres décadas del siglo XIX ${ }^{11}$. Hay rasgos de la novela gótica en algún episodio de La Leandra de Antonio Valladares de

11. Hay letra gótica (derivada casi seguramente de libros alemanes) en la portada de las Reflexiones sobre la naturaleza, o consideraciones de las obras de Dios en el orden natural de Sturm, traducidas al francés y de éste al español (Madrid, Benito García, 1803); y en dos ediciones de la Constitución de Cádiz (1820 y 1822). La portada de la edición de las Noches lúgubres de Cadalso, hecha en Valencia por Cabrerizo (1817), tiene también algún rasgo gótico. Existirán, sin duda, muchos ejemplos más. 
Sotomayor (1797-1807), y lo mismo ocurre con El Valdemaro de Vicente Martínez Colomer (1792) (Alvarez Barrientos, 1991, pág. 278; Carnero, 1985, págs. 3940). Hay fantasmas agresivos y terroríficos hasta en el sueño del Filósofo en la Carta X de El evangelio en triunfo de Pablo de Olavide (1797). Las traducciones de novelas góticas extranjeras, sin embargo, tardan en llegar a España. Sólo en los años veinte del siglo XIX se publican versiones españolas de dos novelas de Ana Radcliffe: El confesionario de los penitentes negros (o sea, El italiano), editado en Madrid en 1821; y La abadía de la selva, que se dio a la estampa primero en español en París en 1825, para salir después en Madrid en 1830. No sorprende que la crítica de la Inquisición y la perversa psicología de un monje en El confesionario hayan tenido que esperar una época liberal para publicarse.

En el teatro español del mismo período aparecen también obras inspiradas en la literatura del terror y de la sombra, y en algún sentido góticas por lo tanto. Una carta escrita a Don Dionisio Solís por Leandro Fernández de Moratín describe el fenómeno en Septiembre en 1815, veinte años después de la aparición de Los experimentos de sensibilidad de Baculard d'Arnaud, en versión española. Escribe Moratín desde Barcelona, y dice lo siguiente: "En este emporio cataláunico asoman la cabeza, bastante a menudo, tres o cuatro poetas ropavejeros, muy amigos de sepulcros, paletillas, cráneos rotos y tierra húmeda, con cadenita, jarra de agua, media morena (frase que significa "hogaza", según Cueto), y pobre mujer embovedada, que llora y gime, hasta que en el quinto acto bajan con hachas y estrépito, y el crudo marido la abraza tiernamente, y la consuela, diciéndola que todo aquello no ha sido más que una equivocación. El auditorio queda contento, los empresarios ni más ni menos, los autores dicho se está, y como, por fortuna, las tales piezas no atraviesan ni el Llobregat ni el Bessós, a nadie hacen daño. Mañana echan una, nuevecita, de cinco ahorcados..." (Cueto, 1869, pág. ccxxv, nota 2). El comentario de Moratín refleja bien a las claras la oposición de los ilustrados españoles a la falta de verosimilitud, de racionalismo y de utilidad en los dramas referidos. Pero la frecuencia de las representaciones de este tipo de obra, que consta de la carta de Moratín, no deja de probar su popularidad, y señala el gusto que había por lo irracional y lo inverosímil en el gran público.

No sé a qué piezas se refiere el comediógrafo español en esta carta. Pero hay por lo menos una tragedia anterior, de autor célebre, que sigue la línea gótica a todas sombras: El duque de Viseo de Quintana. Este drama está basado, como se sabe, en El espectro del castillo de Matthew Lewis ya mencionado; y fue acogido con una reseña harto severa, de tipo moratiniano, al estrenarse en 1801 (Dérozier, 1968, I, págs. 76 y sigs.). Para el crítico desdeñoso y remilgado, se trataba de "uno de los monstruosos dramas, forjados sólo para horrorizar a los espectadores", con "un tejido de atrocidades, un cuento inverosímil, cargado de incidentes inconexos y de situaciones forzadas". Quintana era consciente de 
los problemas que la obra de Lewis podía tener, al trasladarse de las tablas londinenses a los teatros menos libres de Madrid (Quintana, 1852, pág. 41), y había modificado bastante el original, evitando las exageraciones más extremadas, simplificando la trama, y sustituyendo a la aparecida por sueños y pesadillas. Desaparece en su versión, por completo, la sombra vestida de ropa blanca y rociada de sangre. Pero Quintana creía que los efectos tremendistas de la tradición gótica eran compatibles con la difusión de ideas serias. Por esto, sin duda, introdujo en su adaptación el tema del trato de los esclavos negros, interesante lo mismo para los ilustrados como para el gran público. No omitió el rasgo popular de la crítica de los magnates perversos o injustos, aunque pasó por alto algún ejemplo de "suspense" democrático, por el que la señorita principal parece huérfana y de orígenes modestos al comienzo, cuando el joven aristócrata (disfrazado) se enamora de ella.

Quintana, que no se permitió espectros en el teatro, los admite desde luego en sus poemas. Si bien don Juan de Padilla no es más que la encarnación de una figura histórica, evocada para fines políticos, los personajes que dialogan en $E l$ Panteón del Escorial salen, en efecto, de sus sepulcros, ofreciendo "mil terribles imágenes" a la fantasía del poeta (Quintana, 1813, pág. 233). En la época de la Guerra de la Independencia, Quintana y otros poetas, como Arriaza y Beña, invocaban a los espíritus de los héroes españoles medievales para animar a sus contemporáneos en la lucha contra los invasores franceses ${ }^{12}$. Los autores de poemas de este tipo se aprovechan de la mezcla de terror y admiración - temor reverencial- que suscitan las sombras para estimular la sensibilidad y las emociones de sus lectores. Goya sigue la misma pauta en su Coloso (Glendinning, 1963, págs. 363-366), y vuelven los aparecidos en su arte en las dos figuras que vuelan en el cuadro llamado Asmodeo, entre las Pinturas Negras, y, en forma más misteriosa, en uno de los Disparates. Huelga decir que Goya corrió toda la gama de los sentimientos provocados por la muerte --desde la desesperación y el horror hasta la piedad, el elogio del sacrificio y la satisfacción que se experimenta ante la caída de un enemigo- en Los desastres de la guerra. En esta última obra añade a las representaciones de los muertos en la lucha y los fallecidos por hambre, las tremendas escenas de fusilados y cadáveres mutilados.

Al hacer un dibujo o diseño para la tumba de la la duquesa de Alba, Goya sigue un estilo totalmente diferente: convencional y clásico - una especie de Deposición o Pietà, con un grupo de figuras que forman pirámide (GassierWilson, no. 759; Ezquerra del Bayo, 1959, pp. 256 y 257). La imagen es controlada y consoladora, como tenía que ser, sin duda, tratándose de un diseño

12. En el poema de Quintana A España después de la revolución de Marzo, escrito en Abril de 1808, aparecen las sombras de Fernando III, Gonzalo de Córdoba y Mio Cid; Arriaza en su Profecía del Pirineo, escrita también en 1808 , introduce un coloso o titán medio desnudo, que representa a España, figura alegórica más que espectro. Se introduce la sombra del rey Jaime I en un poema del mismo tipo y época, por Cristóbal de Beña, lanzando el reto de España contra Francia. 
para el sepulcro de la duquesa en una cripta. Algo parecido se encuentra muchas veces en las elegías de la época, que procuran estetizar la muerte del ser querido, sacándole el aguijón a la muerte misma. La desesperación, la violencia, incluso la ira, que la muerte de un amigo hace estallar a veces, se callan en la elegía clásica, exponiéndose tan sólo el dolor agudo, el elogio del fallecido, el estoicismo frente a la muerte, que formalizan el sentido de pérdida. Pero hay excepciones, y una de ellas en la época que nos interesa es precisamente un poema de Quintana, En la muerte de un amigo. Esta elegía empieza de una manera convencional con ideas de soledad y presagios de muerte sentidos hace tiempo. Mas Quintana cambia de dirección casi en seguida, dando una imagen del muerto sobradamente real, e incapaz de escuchar al poeta. El amigo no está en los campos elíseos, ni en el cielo, sino "en ese seno misterioso, donde / lejos del mundo el infelice vaga" (Quintana, 1813, pág. 189).

Se consuela el poeta momentáneamente, pensando que otros oirán sus expresiones de dolor y el elogio de su amigo, pero pronto manifiesta de nuevo su pesimismo, ante la falta de gente virtuosa capaz de comprenderle, y el exceso de perversos en el mundo. Con tal perspectiva prefiere morir, y da por terminado el poema.

Esta elegía de Quintana acaba rechazando casi todas las posturas convencionales de este tipo de poema, y hace un contraste muy fuerte con las escritas por Jovellanos, Meléndez Valdés y Arriaza, que procuran llegar a conclusiones positivas, consolados por las cualidades del fenecido, por la inevitabilidad de la muerte, por la simpatía de los amigos o de la naturaleza misma ${ }^{13}$. Incluso Cienfuegos, que coincide con Quintana en algunos rasgos de su poema $A$ un amigo en la muerte de un hermano, termina pensando en el futuro y en la consolación de la amistad. Se podría decir quizás que, en el poema de Quintana, tan sólo la forma misma, el vocabulario, el ritmo y la rima o asonancia (presentes de vez en cuanto) imponen orden o control —algo positivosobre los sentimientos desgarradores del autor. No quería Quintana perder el control del todo, desde luego, y no le gustaba tampoco que otros autores lo perdieran. Hizo una crítica muy violenta, por ejemplo, de las Noches lúgubres de Cadalso, y despreciaba los excesos de terror en los dramas de Baculard d'Arnaud y sus imitadores (Glendinning, 1993, pág. 15; Quintana, 1852, pág. 82). No le gustaba, sin duda, la confusa mezcla de razón e irracionalidad, de

13. Basamos estas conclusiones en el análisis de las elegías siguientes: Jovellanos, Oda sáfica al capitân don José de Álava - En la muerte de Doña Engracia Olavide; Meléndez Valdés, Oda en la muerte de Filis, Oda a la mañana: en mi desamparo y orfandad, Oda a la muerte de Nise, Elegía. En la muerte de Filis, seguida del Epitafio del sepulcro de Filis y un Soneto renunciando a la poesía después de la muerte de Filis, Oda al Dr. D. Antonio Tavira ... en la muerte de su hermana, Elegía. La Virtud. En la temprana y dolorosa muerte de un hombre de bien; Arriaza, La Compasión. Canto fúnebre a la muerte del excelentísimo señor duque de Alba; Cienfuegos, A un amigo en la muerte de un hermano y La Escuela del Sepulcro. A la señora marquesa de Fuentehijar con motivo de la muerte de su amiga la señora marquesa de las Mercedes; Quintana, En la muerte de un amigo. 
desesperación y fe en sus propias virtudes, de ideas subversivas sobre la vida y la sociedad en la obra de Cadalso. Y, sin embargo, siente la necesidad de expresarse con pasión y hasta con violencia ante la muerte de un amigo. Es precisamente por esto que tales autores conservan su personalidad en sus obras, y no se esconden completamente debajo de los convencionalismos de su tiempo.

En todos estos escritos hay mucho de lúgubre, pero casi nada macabro. Porque lo macabro está en la mente del espectador o del lector en el siglo XVIII español, más que en la del autor. Quizás valga el epíteto para la obsesión con los gusanos y la podredumbre de Tediato, en las Noches lúgubres de Cadalso, harto más evidente en la Cuarta Noche (no auténtica) que se incluyó en la edición de las Noches publicada en Madrid en 1822. Quizás valga también para los cadáveres que vuelan en el Asmodeo de Goya, si es que son, en efecto, cadáveres. Lo cierto es que la palabra "macabro" falta en los diccionarios españoles del siglo XVIII, aunque esto no quiere decir que la idea de lo macabro estuviera ausente en aquella época, ni en otras anteriores tampoco. El concepto se podría aplicar, desde luego, a las imágenes en torno a la muerte recogidas por la religiosidad popular entonces. ¿No se podría aplicar asimismo a los cuadros de las Postrimerías, pintados por Valdés Leal en el siglo XVII, para la Caridad de Sevilla? Lo macabro entra y sale, en compañía de la muerte, en casi todas las épocas. Lo funeral, en cambio, tiene que respetar las diferentes costumbres y modas de distintos momentos históricos. En el siglo XVIII pasa por los castillos de las novelas góticas, las mazmorras de las tragedias y los sepulcros poéticos, como por su casa. En el arte posa lo macabro en las escenas de brujerías de los Caprichos y, en Inglaterra, en los dibujos de Fuseli.

\section{BIBLIOGRAFÍA}

ABRAMS, Meyer Howard. 1953. The Mirror and the Lamp. Romantic Theory and the Critical Tradition, Oxford, OUP.

ALISON, Archibald. [1790] 1825. Essays on the Nature and Principles of Taste, Edimburgo, Herederos de D. Willison.

ÁlVAREZ BARRIENTOS, Joaquín. 1991. La novela del siglo XVIII (Historia de la literatura española, ed.R. de la Fuente, tomo 28), Madrid, Ediciones Júcar.

ARIÈS, Philippe. 1971. Histoire des populations françaises, París, Editions du Seuil.

- 1974. Western attitudes towards Death, Baltimore, Johns Hopkins.

BACULARD D'ARNAUD, François T. [1764] 1768. Le comte de Comminge, ou Les Amans malheureux, París, Le Jay.

BLONDEL, Jacques François. 1771-1777. Cours d'architecture, ou Traité de la décoration, distribution \& construction des bâtimens; contenant les leçons données en 1750 \& les années suivantes, París, Desaint-Viuda de Desaint. 
BOYDEL, John y BOYDELL, Josiah. Véanse FRIEDMAN, Winifred y SANTIELLO, A.

CADALSO, José. 1993. Noches lúgubres, ed. Nigel GLENDINNING, Madrid, Espàsa-Calpe.

CARNERO, Guillermo, ed. 1985. Véase COLOMER, Vicente Martínez.

COLOMER, Vicente Martínez. [1792] 1985. El Valdemaro, ed. Guillermo CARNERO, Alicante, Instituto de Estudios "Juan Gil-Albert".

CUETO, Leopoldo Augusto de, ed. 1869. "Bosquejo histórico-crítico de la poesía castellana en el siglo XVIII", en Poetas líricos del siglo XVIII, Madrid, Rivadeneyra (BAE, 61).

DÉROZIER, Albert. 1968. Manuel Josef Quintana et la naissance du libéralisme en Espagne, París, Les Belles Lettres.

DIDEROT, Denis. 1959. Oeuvres esthétiques, ed. Paul VERNIERE, París, Garnier.

ESCOIQUIZ, Juan de, trad. 1789-1797. Obras selectas de Eduardo Young, expurgada de todo error, y traducidas del inglés al castellano, Madrid, Imprenta Real.

ESTÈVE, Edmond. 1923. Etudes de littérature préromantique, París, Honoré Champion.

EZQUERRA DEL BAYO, Joaquín. 1929. El Palacete de la Moncloa. Su pasado y su presente, Madrid, Sociedad Española de Amigos del Arte.

- 1959. La duquesa de Alba y Goya, Madrid, Aguilar.

FOUCAULT, Michel. 1966. Les Mots et les choses, París, Gallimard.

FRIEDMAN, Winifred. 1976. Boydell's Shakespeare Gallery, New York-London, Garland.

GASSIER, Pierre y WILSON, Juliet. 1971. Goya. His Life and Work, with a Catalogue Raisonné of the paintings, drawings and engravings, Londres, Thames and Hudson.

GAY, Peter. 1967. The Enlightenment: an interpretation. The rise of modern paganism, Londres, Weidenfeld Nicolson.

GLENDINNING, Nigel. 1963. "Goya and Arriaza's Profecía del Pirineo", Journal of the Warburg and Courtauld Institutes, XXVI, pp. 363-366.

- 1992. Goya. La década de Los Caprichos. Retratos 1792-1804, Madrid, Real Academia de Bellas Artes de San Fernando.

— ed. 1993. Véase CADALSO, José.

GRAY, Thomas. 1903. The Works of Thomas Gray in Prose, ed. Edmund GOSSE, Londres, Macmillan.

GUÉRIN DE TENCIN, Claudine Alexandre. 1749. Mémoires du Comte de Comminge, París, Bibliothèque de Campagne.

KRAFFT, Johann Carl y RANSONNETTE, Nicolas. s.a. Plans, coupes, élévations des plus belles maisons et des hotels construits à Paris et dans les environs, Paris, Pougens. 
HAUSER, Arnold. 1951. Social History of Art, Londres, Routledge and Kegan Paul.

LOAISEL DE TRÉOGATE. 1785. Dolbreuse ou l'Homme du siècle, ramené à la vérité par le sentiment \& par la raison, París, Bélin.

McCARTHY, Michael. 1987. The Origins of the Gothic Revival, New Haven-Londres, Yale UP.

PEMÁN y MEDINA, María, ed. 1992. Véase Marqués de UREÑA.

PRAZ, Mario [1930] 1948. La carne, la morte e il diavolo nella letteratura romantica, Florencia, Sansoni.

QUINTANA, Manuel José. 1813. Poesías, Madrid, Imprenta Nacional.

- 1852. Obras completas, Madrid, Rivadeneyra (BAE, 19).

RANSONNETTE, Nicolas. Véase Johann Carl KRAFFT.

REEVE, Clara. 1967. The Old English Baron. A Gothic Story, ed. James TRAINER, Londres, Oxford UP.

ROSENBLUM, Robert. 1967. Transformations in Late Eighteenth Century Art, Princeton UP.

SANCHO, José Luis. 1989a. "Proyectos de Dugourc para decoraciones arquitectónicas en las Casitas de El Pardo y El Escorial (1)", Reales Sitios, XXVI, 101, pp. 17 31.

- 1989b. "Proyectos de Dugourc para decoraciones arquitectónicas en las Casitas del El Pardo y El Escorial (2)", Reales Sitios, XXVI, 102, pp. 31-36.

SPURGEON, Caroline Frances Eleanor, ed. 1907. Véase Horace WALPOLE.

STERN, Jean. 1930. A l'Ombre de Sophie Arnould. François-Joseph Belanger, architecte, París, Plon.

STURM, Christoph Christian. 1803. Reflexiones sobre la naturaleza, o consideraciones de las obras de Dios en el orden natural: escritas en alemán para todos los días del año... traducidas al Francés, y de éste al español, Madrid, Benito García y Compañía.

TOSCA, Tomás Vicente. [1712] 1794. Tratados de arquitectura civil, montea y cantería, y relojes, Valencia, Hermanos de Orga.

TRAINER, James, ed. 1967. Véase Clara REEVE.

UREÑA, Marqués de. 1992. El viaje europeo del marqués de Ureña (1787-1788), ed. María Pemán Medina, Cádiz, Unicaja.

- 1785. Reflexiones sobre la arquitectura, ornato y música de los templos, Madrid, Joaquín Ibarra.

VERNIÈRE, Paul, ed. 1959. Véase Denis DIDEROT.

WALPOLE, Horace. [1764] 1907. The Castle of Otranto, ed. Caroline F.E. Spurgeon, Londres, Chatto and Windus.

YOUNG, Edward. Véase Juan ESCOIQUIZ y Pierre LE TOURNEUR. 



\title{
IMÁGENES NACIONALES Y LITERATURA*
}

\author{
Claudio GUILLÉN \\ Universidad Pompeu Fabra
}

El escritor, que suele parecerse al común de los mortales, se ve obligado alguna vez a referirse, en el momento en que se interesa por unos acontecimientos, unos comportamientos o unos personajes situados en algún entorno extranjero, a las imágenes que se conservan en su alrededor acerca de ese país. Estas noticias de lo desconocido y remoto están ahí, envolventes, siquiera para ser rechazadas. Puede ocurrir entonces que su sensibilidad dependa de la ajena, en primera instancia, y por lo tanto sus palabras. Ahora bien, entre las imágenes previas de una nación y el acto de escribir se sitúa con frecuencia lo visto, viajado y vivido por el escritor mismo. Pero si así es, ¿quiere esto decir que nuestro escritor desconocía las imágenes que se habían divulgado, o el abreviado recuerdo que de ellas se guardaba en su alrededor? ¿Que no guiaron nunca sus pasos? ¿Que no se esforzó por superarlas? Además, ¿cuántos escenarios extraños habrá podido conocer directa y personalmente? Si por escritura queremos decir aquello de que él tiene alguna noticia y procede de lo opinado, publicado y diseminado por sus predecesores, ¿no es anterior entonces la palabra escrita a lo visto y evaluado por unos y por otros? La experiencia ¿no depende así, radicalmente, de la escritura, como ésta también de las imágenes nacionales existentes? Si una nación, una región o una ciudad ya han sido tematizadas, literarizadas, acaso durante siglos, ¿es concebible que el escritor las contemple y descubra como por primera vez? ¿No será que la literatura nos impide ver el mundo?

* Por amable petición de Francisco Lafarga, contribuí con la primera versión de estas páginas al coloquio dirigido por él sobre "La imagen de Francia en las letras españolas", celebrado del 15 al 18 de Noviembre de 1988 en la Universidad de Barcelona. 
De inmediato estas preguntas y bastantes más se introducen en una reflexión general sobre la imagen de una nación en las letras de otra nación, asunto y objeto de estudio que en este momento vuelven a ocupar a los historiadores de la literatura. Son cuestiones, a mi entender, que tienen muchos inconvenientes para los estudiosos de Literatura Comparada, que por ello han tendido desde hace bastantes años a concederles escasa atención (Guillén, 1985a, pág. 67; Pageaux, 1971, pág. 19) Adolecen de exagerada amplitud, de desdibujada vaguedad, por un lado. Nos alejan, por otro, de una concepción exigente o al menos coherente de la literatura, que aquí pasa a confundirse fácilmente con cualquier forma de escritura o con la cultura en general. Pero hay confusiones que pueden ser fecundas y tan reales como la vida misma. La indiferencia no consigue en absoluto que cierto problemas, por ser en efecto reales, desaparezcan. Una de las características más elogiables de los estudios de Literatura Comparada, considerados históricamente, ha sido la continuidad de sus preocupaciones.

\section{Tristes tópicos}

Procuremos imaginarnos para empezar un espacio triangular cuyos tres ángulos son: escritura, imagen y experiencia. Para ello tenemos que tener presente el ámbito bastante particular al que corresponden los problemas que acabo de bosquejar. Aludo, pues, a la acepción que suele asumir cualquiera de estos tres términos, evidentemente móviles y polisémicos, en el terreno de la inteligencia de lo desconocido y extranjero, por parte lo mismo de individualidades que de sociedades. Por escritura, ya lo dije, se entiende multitud de cosas, textos o escritos que ni siquiera lo son, géneros que de entrada no son literarios o cuyos límites rebosan la literariedad, de lo fantástico a lo utilitario - de un Byron, digamos, a un Baedeker. Por experiencia se entiende la de espacios extranjeros, remotos, en la vida misma, sea individual o colectivamente: sucesos, percepciones, símbolos, conceptos con su poso, sus secuelas, su larga estela en la memoria social.

Imagen es rótulo poco satisfactorio, pero aceptado convencionalmente, sobre todo desde los estudios de Jean-Marie Carré (como Les Ecrivains français et le mirage allemand, 1800-1940, París, 1947), y que abarca significaciones distintas y hasta dispares. Es imagen, en primer lugar, abriendo el compás al máximo, "l'idée qu'on se fait de l'Espagnol, de l'Anglais", etc..., como decía sencillamente Gustave Lanson (Lanson, 1986, pág. 45) ¿Idea? Bueno, digamos que opinión general e impersonal — "qu'on se fait"--, doxa, de vasta difusión, acerca de una nacionalidad, como Suecia, o de una región, como Sicilia, o de una ciudad de mítico prestigio, como Venecia, Granada, Berlín o Nueva York. También se alude, en segundo lugar, a la concepción nacional que se desprende de un autor importante, como Maquiavelo, emblema de Italia en cierta época, o Dostoyevsky de Rusia, merced a ciertos intérpretes, traductores y prologuistas. Noción por lo tanto procedente de determinada recepción. 
Asimismo es imagen para algunos el ambiente nacional o pequeño mundo que construye el conjunto de una obra de imaginación, como Carmen de Mérimée, o un libro de viajes, un Voyage en Espagne tan leído como el de Mme. d'Aulnoy o el de Théophile Gautier. Y, en cuarto lugar, lo que aparece como parte de una obra de ficción, mediante las opiniones manifestadas en ella — Polonia en Cousine Bette de Balzac, o Italia en La Chartreuse de Parme de Stendhal o unos personajes emblemáticos de sus respectivos orígenes - toda la gama de Zauberberg de Thomas Mann. Y no son éstas las únicas virtualidades. De ahí que quepan no ya diferencias sino, dentro de un mismo espacio, tensiones importantes.

En un campo ocupado por tantos estereotipos y no sólo amores sino aborrecimientos, ¿es lícito distinguir entre el juicio y el prejuicio? Puede quizás pensarse que los juicios heredados, recibidos, son prejuicios. ¿Conviene entonces separar el criterio individual de la opinión de muchos? Por más que se entreveren estas clases, en la práctica se tiene que percibir matices diferenciales. Hay pareceres arraigados en ciertas épocas que proceden de una intención descriptiva y analítica, por mucho que luego pasen de mano en mano o de pluma en pluma. Los mejores viajeros románticos, por ejemplo, procuran ir apreciando lo que ven y al propio tiempo confirman lo que dijeron otros, configurando así una visión común, tratándose por ejemplo de España, según veremos. Ya en 1819 George Ticknor había alabado especialmente al pueblo español. Otro tanto pensarán Disraeli y George Borrow; o Richard Ford, que escribe que "the lower classes are by far the best and finest of Spaniards". Y Prosper Mérimée reitera, con algo de condescendencia, que "la canaille est ici intelligente, spirituelle, remplie d'imagination... En Espagne j'ai toujours eu des muletiers et des toreros pour amis" (Alberich, 1984, págs. 37-38). Son juicios que se repiten por cuanto se basan en las mismas condiciones sociopolíticas, como la Guerra de la Independencia, la lucha del pueblo español contra Napoleón, y el reducido prestigio de las clases dirigentes, poco cultas, según estos observadores, y responsables de la supuesta inferioridad de la nación. A fines de siglo, análogamente, el populismo novelesco se deshará en elogios del campesino ruso.

Caen más bien del lado de los prejuicios, por otro lado, unas actitudes tercas, fijas, de marcado carácter negativo y partidista. La negación se une al desconocimiento - matrimonio bien avenido, éste, si los hay, y de los que más duran. Ejemplo clásico entre nosotros -imagen de una imagen tal vez-es el recelo angloamericano ante el so-called carácter español, fundado en intereses antiguos y esquemas pertinaces. Es cuestión demasiado compleja para ser tratada de pasada (Kamen y Perez, 1980). Pero sí está claro el aprovechamiento de este prejuicio por parte de ciertos escritores. Lo que sí sabemos es que la literatura, sobre todo la más vulgar, se alimenta de tonalidades tenebrosas, ajustadas a la leyenda negra, y de tipos criminales. José María Alberich 
recuerda, en un ensayo provechoso, toda una serie de sectarias figuraciones británicas, desde The Spanish Friar (1680) de Dryden, y otras tragicomedias de fines del siglo XVII, hasta la novela de horror del XIX y sus historias anticlericales y espeluznantes "de monjas ensangrentadas, de espectros ululantes, de frailes diabólicos que seducen y luego atormentan a sus penitentes, de pobres chicas recluidas por la fuerza en prisiones conventuales, de novicias que dan a luz el fruto de sus amores sacrílegos y lo entierran luego en los sótanos o los desvanes del convento", etc. etc. (Alberich, 1984, pág. 35).

Los títulos de algunos de estos novelones llamados góticos aclaran que se sitúan en España, como The Abbott of Montserrat, or the Pool of Blood, o Don Sancho, or the Monk of Henares, o también Almagro and Claude, or Monastic Murder, y otras lindezas de este jaez. También es cierto, pero no consolador, que no son los españoles el único blanco de enemigas cuyos orígenes se remontan, siglos atrás, a las guerras de religión. Los ejemplos no son escasos. Sobresale por supuesto el menosprecio del Islam, cuyas vicisitudes durante el siglo XIX, en manos de quienes paradójicamente profesaban el orientalismo en Francia y Gran Bretaña, desde los tiempos de Silvestre de Sacy, fiel servidor de Napoleón, y de Edward William Lane, recuenta Edward W. Said en su importante Orientalism (Nueva York, 1979).

Lo más sencillo es el tópico, el tópico a secas, que no por trivial y mediocre deja de persistir y de influir. Tratándose de rasgos nacionales, la banalidad parece ser ineludible, según anotaba George Orwell:

National characteristics are not easy to pin down, and when pinned down they often turn out to be trivialities or seem to have no connection whit one another. Spaniards are cruel to animals, Italians can do nothing without making a deafening noise, the Chinese are addicted to gambling.

(Berger, 1951, pág. 385).

Los lugares comunes que descuellan y tienen más posibilidades de larga vida son los bons mots que demuestran ingenio, o gracia, o, como los refranes, paralelismo en la forma. El siglo XVII inglés conoció el tópico siguiente, que Francis Bacon formula en uno de sus Essays, Of seeming wise (1625): "It has been an opinion that the French are wiser than they seem, and the Spaniards seem wiser than they are". Notamos que Bacon da la opinión por ya existente; y que reduce a una sencilla inversión el juego retórico de combinaciones que elaboraba Peter Heylin en su Microcosmos (1621), traducido así por Patricia Shaw: "pues, mientras se dice que los españoles parecen sabios, siendo tontos, que los franceses parecen tontos y son sabios, que los italianos parecen sabios y lo son, no se afirma que los portugueses sean sabios ni lo parezcan" (Shaw Fairman, 1981, pág. 141). Se pasa de tal suerte al chiste sobre nacionalidades, de todos conocido. Si los españoles salen malparados de la ocurrencia de Heylin, júzguese por otra parte cómo quedan las españolas en las palabras de un viajero inglés por España en 1623, que recoge en una carta un dicho local: 
"en el baile la francesa, en la cocina la holandesa, en la ventana la italiana, en la mesa la inglesa y en la cama la española" (Shaw Fairman, 1981, pág. 127).

La vocación y destino final de estos conceptos es la pura tontería, corriente y moliente, exenta de gracia o forma, pero no por ello de pretensiones. Es la especie que Flaubert cultiva, humorística y morbosamente, en su Dictionnaire des idées reçues. Véanse unas muestras: "ANGLAIS - Tous riches" "ALLEMANDS —Peuple de rêveurs (vieux)" "BASQUES — Le peuple qui court le mieux" O también: "ITALIE — Doit se voir immédiatement après le mariage -Donne bien des déceptions, n'est pas si belle qu'on dit". Y no olvidemos: "SEVILLE — Célèbre par son barbier. Voir Séville et mourir (v. Naples)".

Haría mucha falta, dicho sea de paso, una buena historia de la tontería en la trayectoría de la literatura. En tiempos modernos se destacarían algunos personajes de Voltaire, de Balzac, de Flaubert, de Clarín, y sobre todo de Proust en Sodome et Gomorrhe, donde brilla con luz propia aquel Dr. Cottard que produce perlas como la siguiente, a propósito de Sócrates:

Q'est-ce qu'il y a dans cette philosophie? Peu de chose en somme. Quand on pense que Charcot et d'autres ont fait des travaux mille fois plus remarquables et qui s'appuient, au moins, sur quelque chose, sur la suppression du réflexe pupillaire comme syndrome de la paralysie générale, et qu'ils sont presque oubliés! En somme Socrate, ce n'est pas extraordinaire. Ce sont des gens qui n'avaient rien à faire, qui passaient toute leur journée à se promener, à discutailler. C'est comme Jésus-Christ: Aimez-vous les uns les autres, c'est très joli.

(Proust, 1988, III, pág. 439).

Lejos de semejantes enormidades, y de los que se divertían con ellas, como el propio Flaubert, se hallan quienes se enfrentaban seriamente con el problema del carácter nacional, de su devenir histórico, de su dudosa autonomía y solidez frente a los condicionamientos económicos, sociales y también políticos que lo modelan de año en año, o de su utilización por parte de cuantos esperan hallar en la literatura o en las artes un principio de cohesión para una nacionalidad precaria o emergente. Es en nuestro siglo, dentro del campo de la psicología social el estudio de las mentalités (como las primitivas, con LévyBruhl, la anglosajona, etc., o las estructuras sociales y mentales investigadas por Gaston Bouthoul); y en el de la antropología cultural ciertas obras, consagradas a pueblos no primitivos, o al menos no tanto, tan valiosas como the Chrysanthemum and the Sword (1946) de Ruth Benedict, sobre el Japón, o The Tahitians (1975) de Robert I. Levy, o Pueblo of the Sierra (1950) de Julian PittRivers. Adviértase el dualismo - esa primera puerta que permite escaparse del corral de la simplificación - propuesto por el título de Ruth Benedict, como también la contradicción y riqueza, plural o polifónica, que implica en su aproximación a culturas comparadas el método de Gregory Bateson, que muestra en distintas naciones unas condiciones bipolares: dominación/sumisión, 
auxilio/dependencia, etc. (Berger, 1951, pág. 382). Pero hemos topado con la Universidad, que nos aleja del ámbito de la tontería, aunque no siempre, y del asunto del presente ensayo. Salvo raras excepciones, estos saberes no han logrado incorporarse a las zonas sociales y culturales, como el mundo de las letras, en que actúan y hasta prosperan las imágenes nacionales. Es evidente que los lectores, editores y autores ocupan muchas veces espacios no sólo dispares sino encontrados, dentro de un mismo entorno cultural.

Un mero observador puede descubrir, sin ir tan lejos, que las relaciones literarias entre dos naciones no reproducen en muchos casos, ni reflejan fielmente, las tensiones o los conflictos que existen entre éstas en lo que toca a la economía y la política, y que afectan la opinión pública en general. Lo primordial es reconocer de entrada que una cultura encierra diversos estratos interactivos, interrelacionados, no reducibles realmente a un principio de identidad singular; que conviene tener presentes estas tensiones, $\mathrm{y}$, es más, ir poniendo muy en tela de juicio el concepto mismo, en este terreno, de principio de identidad.

La imagen política de Estados Unidos en Bogotá habrá sido durante largos años negativa; pero ello no impidió que el modelo de Hemingway -el de los relatos de Nick Adams en In our Time- - afectase positivamente la composición de El coronel no tiene quien le escriba de García Márquez. En nuestros días los ejemplos de estas incongruencias son legión. El comienzo de la llamada Guerra Fría a fines de los años 40 y la ola de intolerancia denominada McCarthyism perjudicaron notoriamente la imagen de Estados Unidos en Italia, pero no el aprecio que sentían Vittorini y Pavese por Faulkner y el mismo Hemingway.

Explica Fernand Braudel que cuando Venecia era el estado más poderoso de Italia y del Mediterráneo, el foco de cultura principal era Florencia, es decir, que no había confusión entre el "centro material" y el "centro cultural" (Guillén, 1985 b, pág. 503). La confusión entre los dos centros o estratos es efectivamente lo que desorienta y abarata tantos juicios y prejuicios de imagen nacional. Hace poco el escritor caucásico Fazil Izkander (de Abjazia, enclavada en Georgia) comentaba el tópico de la enigmática alma rusa, preguntándose si no resultaba de la perplejidad del extranjero al tener noticia simultáneamente de unos grandes escritores, de vasta y libre humanidad, como Turguéniev y Chéjov, y de un existir social grosero y cruel a lo largo del siglo XIX. Es como si habláramos de la enigmática alma hebrea, decía, tras fundir a Einstein con un tendero judíoº.

Todo sucede como si una sociedad o una comunidad no fuese una entidad monolítica, centralizada o indivisible, desde un punto de vista cultural; o si se quiere, como si el acto de escribir se situase en un estrato de la sociedad, en

2 Entrevista en La Vanguardia, Barcelona, 1 de Noviembre de 1988, pp. 44-45. 
primer lugar, distinto del socioeconómico y del político; y se distanciase, en segundo lugar, de todo espacio colectivo por el peso decisivo de la individualidad. Cierto que no siempre se manifiesta esta individualidad, según veremos en quienes admiten más gustosos las imágenes convencionales, o aceptan a pies juntillas un concepto tan sumamente discutible como el de carácter nacional. Pero lo que sí recordaremos en las presentes páginas es que este concepto, generalizado y confuso durante los siglos XVI y XVII, pero respaldado por el incremento de los sentimientos nacionalistas en Europa, útil luego para los philosophes y enciclopedistas del XVIII, deseosos de orientación e información acerca de los estados y sistemas políticos extranjeros, pasa desde principios del XIX a significar algo como un principo de identidad psíquica y colectiva: el "alma" o "genio" de una nacionalidad. Este principio de identidad se interioriza y psicologiza, si se me permite la palabra, durante el Romanticismo.

Todavía en 1866 Hippolyte Taine escribe que "la racine des grands événements est toujours un caractère de peuple, et l'histoire se ramène à la psychologie" (Taine, 1887, pág. 347). Cierto que pocas ideas han envejecido más que ésa. El principio psíquico de identidad colectiva no ha resistido a los avances en nuestro siglo de las disciplinas económicas, sociológicas e históricas, resueltamente analíticas y exteriorizadas. Otros modelos nos interesan, no sólo en la medida en que admitan tensiones, confrontaciones y oposiciones como componentes de una sociedad y, aun más, como condiciones eficaces y necesarias para su funcionamiento -el interaction model de ciertos sociólogos (Guillén, 1989, págs. 245-247)-, sino porque cuestionan con vigor, en el terreno cultural, lo repito, el concepto mismo de identidad.

Pero volvamos a épocas anteriores y al lugar que ocupan imágenes y tópicos generalizados. A ningún nivel es el asunto simplificable. Los unos funden y confunden, según advertía Izkander, generando o repitiendo imágenes vulgares; y los otros distinguen. Un breve ejemplo: recordemos algunas discrepancias que caracterizan un mismo momento histórico, el siglo XVIII, desde el ángulo de las relaciones entre Francia y España. Daniel Henri Pageaux, gran conocedor de nuestro tema, explica que el "sector cultivado" de la sociedad francesa de la primera mitad del siglo se muestra muy severo en sus opiniones acerca de España, despreciativo y hasta injusto. El eje cultural de Europa conduce de Roma a Londres, de la tierra de las artes y las humanidades a la sede del espíritu crítico y la razón política (Pageaux, 1971, pág. 27). Los philosophes y enciclopedistas denuncian la marginalidad y el retraso de la península vecina. El gusto neoclásico desvaloriza la literatura española. Pues bien, el primer volumen de la Bibliothèque universelle des romans, de Julio de 1776, publica una extensa reseña de las letras españolas, sorprendentemente elogiosa y bien informada. Se trata sobre todo de novelas. El autor conoce a Diego de San Pedro y sus sucesores; las novelas de caballerías y pastoriles; buen número de novelas picarescas; relatos "históricos", es decir, moriscos; Ios 
cuentos de Cervantes, Pérez Montalbán y María de Zayas; el Persiles; y hasta obras de Santa Teresa y Sor María de Agreda, de forma narrativa. España no ha inventado, dice, todos los géneros novelescos, pero los ha perfeccionado todos (I, pág. 8). Nos hallamos ante una sensibilidad precursora del hispanismo de principios del siglo XIX, casi prerromántica, tanto en estas apreciaciones como en su caracterización de la nación española, que la lectura de novelas, dice el articulista, hace posible ("ce genre, tout frivole qu'il est, caractérise peut-être mieux l'esprit de chaque Nation qu'aucun autre"). Así pues, España es "une Nation naturellement fière, máis très courageuse; galante et voluptueuse, mais disposée à la jalouise; qui habite un climat brûlant, dont l'ardeur donne plus d'activité à ses qualités estimables et plus de force à ses passions" (I, págs. 6-7). Esta apreciación, tan distinta de otras, pertenece ella también, aunque minoritaria, a una evolución histórica.

Mientras tanto, unos lugares comunes se reiteran a lo largo de los años. Daré otro ejemplo breve, la imagen en Francia del orgullo, la fierté, la vanidad de los españoles. "Les Espagnols", afirma Mme. d'Aulnoy, "ont toujours passé pour être fiers et glorieux" (Foulché-Delbosc, 1926, pág. 204). Leemos en Les Délices de l'Espagne et du Portugal (1707), que firma un tal Alvarez de Colmenar: "les Espagnols ont beaucoup d'honneur et de fierté, et l'on peut dire même que c'est là leur marotte, mais il n'en ont point quand il s'agit de se venger, de quelque manière qu'on les ait offensés" (Alvarez de Colmenar, 1707, II, pág. 838). (Quiere decir marotte, que era el cetro del bufón, manía o idea fija). Asimismo encontramos en los Voyages de France, d'Espagne, du Portugal et d'Italie (1770) de Etienne de Silhouette: "[l'Espagnol] affecte de l'honneur et de la fierté, c'est-là sa marotte; mais il n'en a point quand il s'agit de se venger" (Silhouette, 1770, III, pág. 143). Formulación precisa, ésta, que caerá un día, por fin, en el olvido.

Pero no el sambenito de la soberbia, que reaparece en un ensayo de Taine del año 1866, pongo por caso, en que dice de los españoles: "la superbe est son fonds" (Taine, 1887, pág. 335). Pues las imágenes del extranjero, como las convenciones sociales y artísticas, suelen tener algo en común, su reiteración a lo largo de muchos años. Colectivas, pertinaces, longevas, se mantienen firmes, como tales idées reçues; o bien van evolucionando y cambiando, para ser sustituidas por otras; e incluso para volver a adquirir, tras un tiempo de hibernación, nueva vida.

Conviven en un solo momento, como veremos ahora, opiniones encontradas acerca del mismo país, con sus distintos ritmos y desenvolvimientos. Las diferencias se deberán a factores como la disparidad de orígenes, social o culturalmente, los condicionamientos políticos, y las superposiciones de trayectorias históricas. Veámoslas, con algo más de detenimiento. 


\section{Relaciones recelosas}

Es de sobra evidente, tratándose de relaciones internacionales, que hay una clase de experiencia colectiva que repercute tanto en la imagen como en la escritura: la circunstancia política, sea ésta el fogonazo del suceso deslumbrante, sea la persistencia de la larga duración (Pageaux, 1971, pág. 17).

Tras las guerras y disputas entre Francia y España durante buena parte del siglo XVI, la Paz de Vervins en 1598 trae consigo una relativa tranquilidad, que favorecerá el conocimiento durante el siglo siguiente de la lengua y las letras españolas. Pero en la lucha por el poder de Europa no se vuelve la hoja tan fácilmente. Durante dos siglos más la rivalidad básica entre los dos países afectará a Italia, los países germánicos, toda Europa. Vista desde el vecino del Norte, España es una potencia temible y un pueblo temido. No olvidemos que, pese a pronunciados procesos de decadencia económica y cultural, España aspirará decididamente hasta fines del siglo XVIII, políticamente, a mantener su presencia en Italia, a ampliar su dominio de América Latina, a recobrar Menorca y Gibraltar. Aun es España, escribe un viajero francés en 1730, "une nation conquérante" (Silhouette, 1770, III, pág. 10). Desde tal ángulo es funcional y se vuelve indispensable desde el siglo XVI el conocimiento más inteligente del rival hereditario, el aprendizaje de su lengua, la lectura no sólo de sus grandes escritores sino de otros menos conocidos. Contra ese fondo temporal lento, que transcurre década tras década, se dibujan los acontecimientos y cambios rápidos.

Así los matrimonios reales, signos del juego de alianzas. Hito esencial son las bodas en 1615 de Ana de Austria, hija mayor de Felipe III, con Luis XIII, Rey de Francia, y de Isabel de Borbón con el príncipe don Felipe. Las consecuencias serán palpables. Pero se advierte que el cambio de clima político no deja de acarrear conflictos y debates, como si las imágenes previas no cedieran el paso tan fácilmente a las nuevas. Salieron a la palestra numerosos panfletos, generalmente anónimos: Discours sur les mariages de France et d'Espagne (París, 1614), Remontrance à la Reine sur les Alliances d'Espagne (París, 1614), Réfutation du Discours contre les Mariages de France et d'Espagne (1614), etc. (Pfandl, 1913). ¿Cómo conciliar posturas tan nítidamente opuestas? Poco después aparece en París el importante tratado de Carlos García, La oposición y conjunción de los dos grandes luminares de la tierra... con la Antipatía de franceses y españoles (1617). Esta obra de Carlos García, que era un escritor de raza, ha sido bien estudiada. Sólo apuntaré que es una curiosa mescolanza de pensamiento abstracto, casi escolástico, y de sátira realista, casi picaresca. España y Francia se reparten las virtudes y los defectos del mundo. Las diferencias entre estos dos principios contrarios, que el demonio convirtió en antipatía, han de conducir por voluntad de Dios al entendimiento y la mutua complementación. La experiencia poco cuenta, en su significación global, para Carlos García. Lo que pueda tener de descriptivo o de histórico el retrato de 
cada país se supedita al voluntarioso esquema general. El cambio político ha influido inmediatamente en la escritura, ideológica sin ambages, y de una complejidad que muestra que las imágenes son varias y no cambian tan velozmente.

Durante el siglo XVII perduran las más negativas del español, reducido a unos pocos adjetivos: soberbio, apasionado, imaginativo, celoso, pendenciero, inculto, indolente. Uno de los estereotipos más difundidos, y es evidente que menos serios, campea en un subgénero llamado las Rodomontades espagnoles (siendo así que Rodamonte es personaje de Boiardo y Ariosto), como las de Baillory, de 1589, y sobre todo las de N. Baudoin, aparecidas en 1607, que se reeditan por lo menos diecisiete veces hasta 1686 . Una edición lleva el título Rodomontadas castellanas, recopiladas de los muy espantosos y terribles $e$ invencibles capitanes matamoros Crocodrillo y Rajabroqueles (París, 1611, "en casa de Dom J. de Ibarra"). Es un librillo bilingüe, de carácter más bien jocoso y comercial (Cioranescu, 1937). El capitán ibérico no es objeto de odio, sino de ridículo. Pero nótese que el adjetivo matamore - valentón, fanfarrón- se incorpora a la lengua francesa. Es el nombre de un personaje de L'illusion comique (1636) de Corneille. Y el español jactancioso, versión barroca del viejo miles gloriosus de la comedia latina, hace su aparición en otras latitudes donde España imponía su voluntad imperial, como desde luego Italia. La Angelica, comedia del napolitano Fabrizio de Fornaris (París, Abel l'Angelier, 1585), ya traía a un personaje llamado "capitano Coccodrillo", que era el único que hablaba en español.

Pero el menor disgusto en las relaciones políticas hispanofrancesas hará que resurjan formulaciones abiertamente hispanófobas. Mencionaré solamente la anónima Cabale espagnole, entièrement découverte à l'Avancement de la France et contentement des bons françois (París, 1625), donde se lee que los españoles, "insolents, au dessus des plus audacieux..., se disent effrontément les seuls Catholiques du monde"; y "nous n'avons rien vu de la part des Espagnols que matoiserie et supercherie" (pp. 4, 14). Y unas frases de Henry de Sponde, de 1636:

Voilà quelle est la foi et la sainteté de ce Royaume ingrat, qui peut-être sans la piété et la puissance des François croupirait encore dans les ordures de l'Arianisme, ou gémirait lâchement sour le joug honteux des infidèles Sarrasins... Mais d'autant que leur folie est reconnue de tous, je n'en dirai pas davantage.

(Sponde, 1636, s.p.)

Frases que hoy nos entretienen, pero que en su día rezumaban y resumían lo que Carlos García llamó poco antes antipatía. Recuérdese que cuando la enemistad de Luis XIV va bordeando la guerra abierta, el abate de Saint-Réal, fácil productor de relatos pseudohistóricos, tan de moda a la sazón, publica su Dom Carlos, en 1672, patraña cuya secuela pasará por Otway y Sébastien 
Mercier y llegará hasta Schiller y Verdi. El mismo Saint-Réal fantasea en 1674 La Conjuration des Espagnols contre la République de Venise, que tampoco cayó en saco roto (Dulong, 1921). Robert Escarpit, a propósito de los problemas de la traducción, ha hablado de trahison créatrice. Creo oportuno sugerir, con motivo de imágenes nacionales, que hubo también calumnias creadoras.

¿Se opondrán a éstas los relatos de viaje, las cartas, las relaciones y otros informes proporcionados por los que tuvieron la ocasión de residir en España? Ello no podrá suceder sino muy progresiva y lentamente. Luego volveré sobre el brillante Voyage en Espagne (1691) de la baronesa d'Aulnoy, el más leído en su época. Son escasas las páginas de esta índole que no den voz ante todo al desconcierto que produce la rareza. No se supera, antes bien se confirma, la imagen generalizada del extranjero. El viaje no es pretexto de saber o de entendimiento, sino de escritura. En realidad lo que predomina es el desconocimiento de la península ibérica -inaccesible, distante, extrañamente dispar. Y ante esa oquedad, es difícil que no persistan las simplificaciones y simplezas de siempre.

Sólo durante el siglo XVIII surgirá un tipo nuevo de viajero, ansioso ante todo de conocimiento, de la inteligencia de la diversidad, como el autor de los Voyages de France, d'Espagne, de Portugal et d'Italie, publicados el año 1770 en Amsterdam -el viaje se había efectuado en 1729 y 1730 - y comentados no hace mucho por Daniel-Henri Pageaux. Su autor, Etienne de Silhouette (17091767), como explica muy bien Pageaux (1971, págs. 73-81), es uno de esos hijos de familias acomodadas que viajan por Europa para completar su educación y prepararse para tareas de responsabilidad política. Es algo nuevo, una forma diferente de viajar, el grand Tour inaugurado por los ingleses, y unido en esta ocasión al firme propósito de estudiar las principales instituciones de los países vecinos. Para ello Silhouette -años más tarde será secretario del duque de Orléans y contrôleur général de Finanzas- ha leído, pero según él con poco provecho, a Mme. d'Aulnoy, demasiado fabuladora, al malhumorado dominico Padre Labat, que en 1705 observó con displicencia Cádiz y Sevilla (Labat, 1927), y las Délices de l'Espagne et du Portugal (1707), atribuidas a Álvarez de Colmenar. No se trata de coleccionar sensaciones o états d'âme. El viajero se familiariza con las estructuras administrativas, la agricultura, el comercio, las fuerzas navales, la Iglesia, la Inquisición. Elogia la organización del Estado español, y la perspicacia -_"pénétration"- de sus gobenantes: "jamais hommes n'en eurent davantage, et ne furent plus capables de concevoir en un instant tout le fond d'une affaire..." (Silhouette, 1770, III, pág. 90). La tenacidad de estos gobernantes es notoria y hace que sean durísimos en las relaciones internacionales - "il n'y pas de Nation moins traitable, et avec qui il soit plus difficile de négocier" (pág. 119); y para colmo su ambición no tiene límites: "les Espagnols désirent ardemment, et désirent beacoup de choses" (pág. 127).

Pero Shilouette procura también describir las costumbres de los españoles, que le sorprenden sobremanera, por ejemplo su ardor sexual: 
Les Espagnols sont d'un tempérament extraordinariament chaud, en sorte qu'ils s'épuisent tellement avec leur maîtresses, que la plupart se rendent incapables de remplir les devoirs du mariage... Ce qui fait que bien souvent les femmes, recluses comme des Religieuses, tandis que leurs maris courent leurs aventures amoureuses, se voyant méprisées, cherchent à se dédommager aux dépens de la foi conjugale (pág. 73).

$\mathrm{Y}$, tras unas páginas descriptivas y concretas, no puede el viajero sino tratar de definir el "carácter" nacional, concepto muy de la época, si tenemos en cuenta el Essai sur la poésie épique (1723) de Voltaire, con el comienzo titulado "Des différents goûts des peuples" (Guillén, 1985, pág. 41). Pero la combinación de imágenes tradicionales, que no le abandonan, y de informaciones tan abundantes como contradictorias le sumen en la perplejidad. Véase hasta qué punto le sacan de apuro y sobreviven los tópicos procedentes de tiempos anteriores:

L'Espagnol est un composé bizarre qui paroît inconcevable: lorsqu'il est touché du point d'honneur, il est ferme, inébranlable, généreux, magnifique, hardi, téméraire, supérieur aux menaces et aux promesses. flatteuses: son âme est capable de toute sorte de bien et de mal: son tempérament est propre à toutes les fonctions de l'âme. L'imagination domine en lui, et il se soucie beacoup moins d'être un honnête homme que de le paroître; il affecte de l'honneur et de la fierté, c'est-là sa marotte; mais iln'en a point quand il s'agit de se venger; il fuit le travail; mais la vanité dont il est toujours malade, le rend actif, quoique dans son activité même on reconnoisse un fond d'indolence. Les Troupes Espagnoles résistent mieux que celles d'aucune autre Nation: la grandeur, la diversité et le nombre des actions qu'ils ont faites, ou contre les Mores, ou contre les Indiens, étonnent l'imagination, et affoiblissent la vérité de l'Histoire... A la vanité des Espagnols, à leur paresse, à leur amour de la vengeance, ont peut joindre un très-violent penchant pour le sexe, une jalousie extrême, qui n'a ni bornes, ni modération, et peu de bonne foi dans les réconciliations. Ils ont beaucoup de mépris por les autres Nations; ils s'imaginent que pour être quelque chose de grand il faut être né Espagnol; de sorte que lorsqu'ils traitent avec quelque Etranger, cela va jusqu'à l'arrogance: esclaves de leurs usages, ils sont les premiers à en faire l'éloge, et toujours prêts à condamner ceux des autres Nations.

(Silhouette, 1770, III, págs. 142-144)

Ahora bien, reitero que la amplia difusión de semejantes clichés caracterológicos no impide que se produzcan otras lecturas, otras interpretaciones, en los medios letrados, y hasta entre los impresores y traductores deseosos de satisfacer los intereses del gran público.

Volvamos otra vez al siglo XVII, cuando Baudouin, Carlos García, Sponde o Saint-Réal ponen ante todo de manifiesto los altibajos de unas relaciones sociopolíticas. La rivalidad y la hostilidad abren cauces de conocimiento y hasta de intensa familiaridad. En Francia, como es sabido - hace unos cien años lo contaba A. Morel Fatio en sus Etudes surl'Espagne ("Première série", París, 1888)- se publican numerosos diccionarios, refraneros, libros bilingües de conveniencia pedagógica, y desde luego numerosas traducciones de escritores 
españoles, sobre todo entre 1615 y 1635 . Aludo a intermediarios conocidos como César Oudin, Ambrosio de Salazar, Juan de Luna, Bense du Puis, Desroziers, Vital d'Audiguier, y otros intérpretes y desterrados, sin olvidar, aun en 1660, el manual de Port-Royal, la Nouvelle méthode espagnole de Claude Lancelot. Nada de esto nos sorprende (¿en qué países hay hoy más especialistas en ruso?); pero hay un hecho menos conocido: la difusión de la lengua fue terreno abonado donde fructificaron algunas obras escritas en lengua castellana por franceses aficionados a ella. Voiture, el fácil poeta cortesano, compuso cartas y poemas en un español correcto. No he podido ver la Vida y muerte de los cortesanos, compuesta por el señor de Moulere, caballero gascón, publicada en París el año 1615, aprovechando la coyuntura de los desposorios reales. Sí tuve la oportunidad de leer el relato del asimismo gascón François Loubayssin de Lamarque, Engaños deste siglo y historia sucedida en nuestros tiempos, aparecida en París ese mismo año. Es una extensa "novela ejemplar", vivaz y variopinta, basada en las aventuras generalmente amorosas de un caballero andaluz que, camino de la Corte, se hospeda con su mujer en sucesivas ventas, donde pululan las maritornes, las bellas fregonas y las doncellas disfrazadas.

Claro está que el panorama cambia si atendemos a los mejores autores franceses de la época. Baste aquí con señalar lo más obvio, que es el cambio de signo, de negativo a positivo, que observamos cuando pasamos de la imagen, tan colectiva, a la literatura, tan plural y hasta heterogénea. Es una tentación erigir esta diferencia en ley teórica, pero sería un error, habida cuenta de que no sucede lo mismo en la Italia de los siglos XVI y XVII, abrumada por el peso militar y político de los españoles (Croce, 1948, pág. 110). En Francia no se produce un rechazo cultural tan completo; y saltan a la vista las incitaciones e intertextualidades en las obras de autores fundamentales como Corneille, Molière, Scarron, Madame de Lafayette, es decir en el teatro y la novela principalmente, pero sin olvidar formas menores como el apotegma o la máxima; y las huellas, pasando a otros menos destacados, pero que sí indican el peso de una cultura, de moralistas, escritores religiosos, historiadores y tratadistas políticos como fray Luis de Granada, Santa Teresa, Alonso Rodríguez, Mariana, Saavedra Fajardo y Gracián. Solo agregaré dos observaciones, más discutibles.

Es digna de interés la importancia de la lectura en Francia de los autores de cuentos o relatos cortos, como Cervantes, Lope, Tirso, Pérez Montalbán, Salas Barbadillo, Castillo Solórzano y María de Zayas, que fueron muy leídos y admirados; y sin los cuales pienso que sería distinta buena parte de la narrativa francesa de fines del siglo XVII y sobre todo del XVIII. De toda esa multitud de relatos españoles proviene no sólo un mundo novelesco, todo un espacio imaginario que fascinó a muchos, con sus lances, sus conflictos, sus tipos, sus escenas y mitos característicos, sino también un ritmo, una velocidad narrativa y una concentración de forma y de estilo muy peculiares, y muy opuestos a la andadura de la prolija novela francesa — pastoril, histórica, heroico-galante- del Siglo XVII. 
Me importa acentuar, en segundo lugar, el hispanismo implícito en lo que llamaríamos la literatura periférica y marginal del siglo XVII, desde los libertins como Théophile de Viau, o Charles Sorel y Tristan l'Hermite, hasta los autores satíricos, burlescos y eróticos como Saint-Amant y el hoy olvidado pero ingenioso poeta Claude Le Petit, ejecutado en París el año 1665. Es sorprendente: los heterodoxos, frente al creciente neoclasicismo de los escritores establecidos, hallaban sustento en la agudeza y la sátira españolas, en la picaresca y el perspectivismo cervantino. Tengo presentes desde luego las propuestas teóricas de los Formalistas rusos; y me pregunto si estos francotiradores, estos autores y géneros secundarios no contribuyeron al declive de géneros céntricos y al ascenso, corriendo los años, de quienes pasarían a ocupar, como los novelistas, posiciones predominantes en las instituciones de la literatura. Como quiera que fuera, el desconocimiento y la interpretación convencional del extranjero intervienen muchísimo menos en estas obras que en los escritos, como el extenso tratado de Carlos García o el Dom Carlos de Saint-Réal, en que la temática misma enlaza con la imagen nacional y las circunstancias que la orientan. Todo sucede, en efecto, como si diferentes zonas socioculturales obedeciesen a procesos temporales y ritmos asimismo diferentes.

\section{Déjà lu}

Esa superposición de ritmos es perceptible también cuando se observan las repercusiones en dirección contraria, es decir, las de la imagen nacional en los procesos políticos y sociales. "El ministro que hoy toma una decisión ha sido influido" — comenta J.M. Alberich— "muy probablemente, velis nolis, por imágenes colectivas absorbidas en la escuela, en los libros, en los periódicos (Alberich, 1984, pág. 25). Un ejemplo elegido por Alberich es la expedición inglesa contra Buenos Aires de 1806 y 1807, dirigida por almirantes que esperaban que los argentinos fueran tan antiespañoles como ellos mismos y los recibiesen con los brazos abiertos. Los resultados fueron desastrosos para las tropas de Beresford y Whitelocke. No coincidían los recelos ingleses, acaso por ser más mentales, o más simples, con los argentinos. $Y$ he aquí que esta disposición de ánimos tropieza en el verano de 1808 con una sorpresa dramática: el español despreciado se conveirte en aliado en la lucha contra la Francia napoleónica. La repercusión, más que en la imagen, en la escritura, es inmediata, según indica Alberich a propósito del teatro londinense. Al gran dramaturgo Sheridan, autor de aquel terrorífico Pizarro (1799), sucede en Noviembre de 1808 el autor de una pieza titulada The Siege of St. Quentin, or Spanish Heroism.

Ahora bien, los teatros de Gran Bretaña seguirán ofreciendo al público obras procedentes de coyunturas anteriores, pues ya vimos que en este terreno las actitudes tienen larga vida. Como las posiciones no son simples, sino plurales, o duales, o ambiguas, siempre se puede desempolvar y rescatar, en momentos en que las relaciones son oficialmente positivas, obras poéticas que 
en su día sí lo fueron, como tales, como literatura, aunque no reflejasen la postura mayoritaria. Así, por ejemplo, se puede volver a representar aquel Spanish Friar (1680) de John Dryden, que mencioné antes, y que no era realmente hispanófobo.

La tragicomedia tan enérgica y amena de Dryden, en realidad, sitúa cómodamente su acción, compuesta de combates y amoríos, en una fabulosa Zaragoza medieval. Mezclando como Shakespeare el verso con la prosa, Dryden entrelaza dos intrigas, una amorosa y noble, otra erótica y cómica. A la segunda pertenece Father Dominick, que es un Falstaff más bien pasivo, obeso y bebedor, con ribetes de hipócrita y de trotaconventos, y con tan poca malicia que resulta ser el fácil instrumento de las apetencias de los demás. Sólo él puede justificar la crítica protestante al uso, ante la corrupción de la Iglesia católica y la Inquisición; pero lo mismo de españoles son los personajes heroicos que animan la intriga primera; y la condición indispensable es que el fraile no sea inglés, quiero decir, que España sea aquí lo que Italia en tantas obras de Shakespeare, Webster y sus contemporáneos: un escenario remoto que consigue distanciar la acción y hacer más aceptable la sensualidad, el engaño o el delito por parte de un público inocente.

Téngase en cuenta además la popularidad a la sazón del ambiente teatral español, que John Loftis demuestra en The Spanish Plays of Neoclassical England (1973, págs. 29 ss.). Se trata de la época en que los historiadores ingleses encuadran el denominado Restoration drama, de 1660 a fines de siglo. El título de Loftis destaca ya el predominio del gusto neoclásico francés, al que el propio Dryden se somete en buena parte de su obra. Ahora bien, cuando los teatros de Londres, cerrados desde 1642, bajo Cromwell, vuelven a abrirse con la Restauración monárquica de 1660, la calidad de bastantes modelos dramáticos franceses es discutible. Las comedias mejores de Molière no se han estrenado todavía y la primera pieza de Racine, La Thébaïde, será de 1664. El teatro español, junto al inglés, era no sólo el más atractivo, sino el más próximo a la tradición interrumpida en Londres unos años antes. A partir de 1660 Dryden, como los demás escritores, entrega sus obras a los teatros; y la primera de ambiente español, The Rival Ladies (1664), se esfuerza por competir con el éxito estrepitoso conseguido por Sir Samuel Tuke con la adaptación que éste, a petición del Rey, Charles III, que sabía y leía el español, había realizado de Los empeños de seis horas, atribuida a Calderón ${ }^{3}$, titulada en inglés The Adventures of Five Hours (1663) (Nicoll, 1961, pág. 192; y Hume, 1905, págs. 191-195). La ficción

3 Los empeños de seis horas se atribuyen a Calderón en las Comedias nuevas escogidas de los mejores ingenios de España, Octava parte, Madrid, 1657, que tal vez leyeran el Rey y Tuke. Pero Calderón negó la paternidad, que correspondía a Antonio Coello; y la comedia se publicó con el título Lo que pasa una noche. Comedia famosa de Don Antonio Coello, "a mediados del siglo XVII", según José Simón Díaz, Bibliografía de la Literatura Hispánica, Madrid, 1970, VIII, n 4709 . 
teatral que la crítica inglesa llama the Spanish plot, "la intriga española" (Loftis, 1973, cap. 3), compuesta de complicaciones, equívocos, disfraces, encuentros nocturnos y duelos de honor -en suma, la comedia de enredo calderonianasera compatible con los rasgos negativos procedentes de la leyenda negra. The Spanish Friar contiene esa imagen como una anticuerpo, reducido, según vimos, al personaje de Father Dominick.

En el teatro popular inglés de principios del siglo XIX se superponen, pues, las imágenes nuevas, las románticas, y las anteriores, las figuras propias de la comedia de enredo del Siglo de Oro. "Es decir", comenta Alberich, "el inglés de mil ochocientos veía en las tablas un español totalmente convencional, no sólo producto de una tradición teatral, sino con cerca de dos siglos de retraso también" (Alberich, 1984, pág. 30). Nos hallamos ante un décalage, un desfase, doble, ya que dispara el presente hacia el pasado y también lo aleja de todo cuanto no conocen ni perciben los estereotipos. De ambos modos son radicalmente dispares la experiencia y la escritura, según Jean-Marie Carré puso de relieve con motivo del mirage allemand y los escritores franceses; o dicho sea con Robert Escarpit: "c'est le décalage historique qui existe entre la réalité d'un pays et l'image qu'en donnent les écrivains d'un autre pays même quand ils en ont une expérience directe" (Escarpit, 1964, pág. 242).

¿Experiencias directas? Me niego a creer que no existan; pero son muchas las ocasiones en que éstas ocupan un lugar mảs que subalterno. Recordemos ahora el arquetípico viaje por España, el más leído durante siglo y medio, la Relation du Voyage d'Espagne (1691) de Mme. d'Aulnoy.

Este libro, que consta de quince epístolas extensas, fechadas en diferentes ciudades españolas, se reeditó once veces, hasta 1874 , y dieciséis veces en traducción inglesa, hasta 1899; y se publicó en alemán y holandés. Durante el siglo XIX lo admira todavía Sainte-Beuve; o Barbey d'Aurevilly, que lo considera "un chef d'oeuvre d'observation aigüe" (Foulché-Delbosc, 1926, pág. 5), por su valor literario, pero también como fuente de información. Aprendía mucho leyéndolo el francés, según Taine, que sólo se había imaginado la realidad española a través de Lope de Vega, Calderón, Murillo y Zurbarán; pero con Mme. d'Aulnoy "le lecteur va juger du caractère espagnol, non d'après les oeuvres d'imagination qui le mettent en scène, mais d'après un témoin qui l'a vu" (Taine, 1887, pág. 335). Pues bien, Foulché-Delbosc dedicó un tomo entero de la Revue Hispanique al contraste de lo escrito por este testigo, la baronesa d'Aulnoy, con los lugares que describe, los datos que facilita, los personajes supuestamente reales que retrata, y la cronología más plausible de los acontecimientos que observa o en que participa.

Tras haber observado Foulché-Delbosc que el compañero de viaje de la baronesa que cuenta y explica cosas de Galicia se basa en Le Voyageur d'Europe de A. Jouvin (1678), que para la muerte del príncipe Baltasar Carlos se copia el 
Voyage d'Espagne de A. de Brunel (1655), que la presentación de Burgos lo debe todo a Jouvin, a Brunel y al Journal du voyage d'Espagne de F. Bertaut (1669), que la de Segovia se remonta a Le Fidèle conducteur pour le voyage d'Espagne de Coulon (1654), que la descripción de una corrida de todos se extrae de los Mémoires curieux envoyés de Madrid del secretario de Embajada Carel de Sainte-Garde (1670), que otros pasajes provienen de las cartas y relaciones breves publicadas en La Gazette, que además no puede ser sino anterior a 1640 la lista de Universidades españolas que se ofrece, puesto que incluye a Coimbra, Evora y Lisboa, que en el fondo es cuestión de presentar a los españoles como un pueblo de costumbres "sauvages y galantes" - resume Foulché-Delbosc-y pasiones "violentes y farouches", para lo cual la escritora inventa no pocos lances ficticios, como la historia de una muchacha estrangulada por su hermano, el cual luego es muerto por el amante de su hermana; tras tantas y tan laboriosas elucidaciones, el gran hispanista llega, en resumidas cuentas, a una conclusión ineluctable (Foulché-Delbosc, 1926, pp. 90, 100): Mme. d'Aulnoy no puso los pies en España.

Se trata de una ficción epistolar, presentada como si fuera real —recuérdese el éxito enorme de las Lettres de la religieuse portugaise, de 1669. Asimismo el bonito volumen titulado Délices de l'Espagne et du Portugal $\left(1707,2^{\mathrm{a}} \mathrm{ed}\right.$. 1715), citado por Silhouette, según vimos, es una compilación — cas̀i una guía del viajero- atribuida a un autor imaginario, Juan Álvarez de Colmenar, que saquea la Relation de Mme. d'Aulnoy.

Otros escritores, desde principios del siglo XIX, serán más deseosos de ver ellos mismos lo que describen. Comenta, sin embargo, J.M. Alberich que el viajero de esa época iba a España "con la tarea obligada de reconocer en el país que visitaba la imagen absorbida en las lecturas de estas obras; iba a buscar al doctor Sangrado, a los bandoleros que encerraron a Gil Blas en la cueva, a los venteros y barberos de Don Quijote, etc., y los encontraba" (Alberich, 1984, pág. 30). Raros no eran, efectivamente, esos encuentros con personajes de ficción, aunque andando los años ya no fuera con los de Le Sage y Cervantes, sino con tipos de otra laya: toreros, gitanos, santos, guerrilleros, bandidos generosos, mendigos muy dignos, y andaluzas au sein bronzé. Pero tampoco puede negarse que el modo de viajar y su motivación se van transformando muy sensiblemente. Si el viajero literarizado lee y se prepara, antes de cerrar las maletas, no es para hacer acopio de saberes en primera instancia, sino para estar luego en condiciones de percibir y sentir plenamente. Ahora sí es cuestión de expériences directes por parte del viajero, y mediante ellas de una superación de sus propios límites y hasta de las realidades más próximas, rumbo a lo desconocido y soñado. La previa fecundación literaria, procedente a veces de ficciones, lanza al viajero hacia mundos no ya distintos sino imaginados y fabulosos.

En este contexto cobra sentido la tensión entre escritura y experiencia, a veces creativa, a veces postiza. No se subestime el influjo de los conocimientos 
históricos. A George Borrow, cuando navega por el Guadalquivir, río abajo, le atrae muy poco el paisaje de campos rasos y escasos árboles; pero escribe que sin embargo "es imposible viajar por este río sin recordar que por él navegaron romanos, vándalos y árabes, y que ha presenciado sucesos de universal resonancia, cantados en poesías inmortales" (Zuleta, 1984, pág. 60). El peso de lo ya leído es sin duda evidente en relatos como Mes vacances en Espagne de Edgar Quinet (1843); o la primera descripción importante de España que compone un ruso, B. P. Bodkin (1845). Quinet parece haber reconocido sinceramente en Castilla la Vieja los personajes del Romancero y las huestes del Cid, que él había admirado en su biblioteca de París. La deuda de Bodkin con el reciente Voyage d'Espagne de Théophile Gautier (1840), que algunos críticos rusos le echan en cara $^{4}$, no es sorpendente ni excepcional.

La excepción es Gautier, que se distingue de sus contemporáneos no sólo por su singular talento sino por su voluntad de liberación del peso del déjà lu, para bien o para mal, pues ¿no será un lástima - dice al principio-que se esfume la España del Romancero, de las baladas de Víctor Hugo, de los relatos de Mérimée y los cuentos de Alfred de Musset? En efecto, la realidad percibida por el viajero es otra. Gautier, vivaz, alegre, intranscendente, concreto, sabedor de que en seis semanas no se puede conocer el carácter de un país ni los usos de una sociedad, confirma constantemente la falsedad de los tópicos y la importancia de los cambios históricos. Los mejores guías son el azar y la independencia de criterio. Las fondas no son tan detestables como dicen. Hay muchas españolas rubias y pelirrojas. La desamortización, al suprimir a tantas monjas, ha perjudicado la imagen romántica y aventurera del país, etc. Lo que se describe desde Francia no existe en España. Tanto es así que los propios españoles protestan contra lo que se venía repitiendo acerca de ellos: "ils renient de toute leur force de l'Espagne du Romancero et des Orientales, et une de leurs principales prétentions, c'est de n'être ni poétiques, ni pittoresques, prétentions, hélas!, trop bien justifiées" (Gautier, 1958, pág. 64).

Ejemplo insigne, por otro lado, de la fusión de la escritura con la experiencia, hasta llegar a la alucinación o la mixtificación de sí mismo, es alguna página de Chateaubriand. Para él, comenta R. Lebègue, "la frontière s'effaçait entre ce qu'il avait lu et ce qu'il avait vu" (Lebègue, 1964, pág. 285). Es bien sabido que en sus Voyages en Amérique et en Italie (1827), la descripción de Florida se apoya en las Rêveries de Rousseau y en la información proporcionada por autores como Bartram y Charlevoix. Pero lo insólito del caso es que lo leído o releído incluye la obra del propio autor. La presentación en los Voyages tiene bastante en común con la novelita Atala, muy anterior, de 1801, lo cual dice

4 Hay traducción francesa de Bodkin, Lettres sur l'Espagne, París, Institut d'Estudes Hispaniques, 1969 , versión y prólogo de A. Zviguilsky; con quien colabora B.F. Yegorov para la edición rusa de 1976, Leningrado, Editorial Nauta. 
mucho acerca de la capacidad del extraordinario prosista para atribuir cualidades de autenticidad a los productos de su propia imaginación. El vaivén entre lo vivido y lo escrito, entre la fantasía y la percepción, es múltiple. Bartram y Charlevoix enriquecieron probablemente el viaje real de Chateaubriand por América en 1791, que luego publica Atala y por fin vuelve a ésta y simultáneamente a sus recuerdos para redactar años después los Voyages de 1827.

Claro, ¿a qué imágenes previas no se exponía quien iba más allá de Europa? Tratándose del Nuevo Mundo, la crítica ha acentuado la frecuente intervención de preconcepciones, preopiniones y prejuicios en las actitudes europeas ante América del Norte, y ello desde el siglo XVIII hasta nuestros días. Un especialista, Gilbert Chinard, subrayó "le décalage entre l'imaginaire et le réel que nous constatons quand il s'agit d'Amérique" (Chinard, 1959, pág. 352). Son muchos los ejemplos que Chinard cita, y que no puedo mencionar aquí. Baste con recordar que Sartre no dice otra cosa en un conocido ensayo de Situations, III sobre Estados Unidos, de 1946: "Nulle part peut-être on ne trouvera un tel décalage entre les hommes et les mythes, entre la vie et la représentation collective de la vie" (Sartre, 1949, pág. 130). Cierto que Sartre se refería a los norteamericanos mismos, que generan su propia idealización y mitificación, anteriores a las que pudiera imaginar un viajero europeo. Estados Unidos, escribe un comentarista inglés, Marcus Cunliff, "seguirá siendo un lugar semimítico para los europeos, pero principalmente en la medida en que los americanos lo ven asî" (Cunliff, 1961, pág. 29).

Pero volvamos a los términos más limitados de este ensayo. Me toca tener en cuenta la previa aportación, a la experiencia misma del viaje, de una escritora modesta, apenas literaria en la mayoría de los casos, pero no poco eficaz: las guías del viajero. El Baedeker, el Nagel, el Guide bleu, o el Michelin orientan y acompañan nuestros pasos en ocasiones de manera decisiva. ¿Cuáles fueron los orígenes?

Las peregrinaciones fueron en su tiempo viajes organizados, para los cuales era útil una información compartida. Es hoy famoso el Codex Calixtinus que se conserva en la catedral de Santiago de Compostela. Redactado a principios del siglo XII por encargo probablemente del obispo Gelmírez y del papa Calixto II, con influencias cluniacenses, esta clase de texto ponía al servicio de las peregrinaciones a Compostela unos consejos prácticos sobre el trazado de la ruta y las dificultades que acechaban al peregrino. Basándose en el manuscrito de Santiago y en el de Ripoll, Jeanne Vieillard publicó la Guide du pélerin de SaintJacques de Compostelle, en que se aprecian estimaciones detalladas de pueblos, de nacionalidades, y también de iglesias y obras valiosas como los portales de la catedral de Santiago (Vieillard, 1938). Recordaba Marcel Bataillon la utilidad de algunos siglos más tarde, con la difusión de la imprenta, de aquellas guías cuyo destino era Roma o Jerusalén, como los Mirabiliae Romae, uno de los primeros incunables, y el Viaggio de Venetia al sancto Sepulchro, del franciscano Bianchi, 
ambos reeditados muchas veces durante el siglo XVI.

Indica Bataillon un rasgo propio de esas publicaciones, que es su naturaleza y finalidad normativas: "dire tout ce qu'il faut avoir vu" (Bataillon, 1964, pág. 54). Observación muy acertada, que puede también dirigirse a guías románticas y postrománticas. Describir es seleccionar, seleccionar es preferir, preferir es favorecer, es encarecer, es guiar en el sentido pleno de la palabra, que conduce del texto al acto. ¿Quién no se ha apoyado en estos lazarillos, estos libros tan doctos, tan seguros de sí mismos? Cuenta Jean Bruneau que en 1845, durante su primer viaje a Italia, Flaubert confió siempre en el Guide du voyageur en Italie de J. Barzilay (1823, etc.); y acaso también en algunos más, como el Guide Richard, parte de una serie que tuvo distintas versiones, desde 1826; o los Voyages de Valery, desde 1831; o del mismo autor (seudónimo de A.C. Pasquin), el práctico L'Italie comfortable, Manuel du touriste, 1841 (Bruneau, 1964, págs. 168-169).

Fueron éxitos de librería estas colecciones consagradas por un mismo editor a una variedad de países europeos, como los Murray, los Baedeker y los Joanne. En algunos casos era borrosa - ya desde el siglo XVIII- la distinción entre la guía utilitaria y el cultivo de un género literario. Apuntemos la relevancia de un impresor como John Murray, que admite las dos cosas, pues publica en 1845 el excelente Handbook for Travellers in Spain and Readers at Home del hispanista Richard Ford y también, poco antes, los hoy clásicos libros de George Borrow, The Zincali y The Bible in Spain (1841, 1843). Es más, Richard Ford es quien envía y recomienda The Zincali al editor; y quien le aconseja a Borrow que deje de cultivar un "estilo bello" ("fine writing"), opinión que al parecer Borrow aprovechó en The Bible in Spain (Zulueta, 1984, pág. 57). Barruntaba John Murray lo que hoy tantos empresarios y comerciantes: que todos los seres humanos somos turistas en potencia, ansiosos de conocer aquellos países - si cabemos- en que no queda nada por descubrir.

\section{Abencerrajes y gitanos}

La escritura, en tales casos, modela el viaje, el cual suscita una experiencia digna de convertirse en escritura. Nos hallamos ante un proceso de verbalización que se detiene cierto tiempo en el mundo. No son escasas las ocasiones en que esta cadena se simplifica aún más, reduciéndose a un traslado exclusivamente literario, el que conduce de la palabra ajena a la propia.

No por ello ha de ser el resultado mediocre o alevoso. Mostró Marcel Bataillon que el Viaje de Turquia, escrito hacia 1557, y atribuido por él al doctor Laguna, utiliza sin miramiento alguno y con evidente provecho artístico e ideológico unos libros reales y directamente informados y documentados, como los Costumi et i modi particolari della vita de "Turchi (Roma, 1545) de Luigi Basano, y el Trattato de Costumi et vita de' Turchi (Florencia, 1548) de 
Giovan Antonio Menavino. No es el Viaje de Turquía una mitificación sino por cuanto una escritura literaria apela a malicias e ilusionismos para comunicar su peculiar forma de vida y de verdad, ahí científica y cristiana. Su contemporáneo el Lazarillo de Tormes, asimismo anónimo, empezó por funcionar, nos aclara Francisco Rico, como una superchería o un apócrifo, dando gato por liebre, es decir, ficción por autobiografía (Rico, 1988, págs. 153 ss.). Pero no tarda mucho el lector del Viaje de Turquía en descubrir el uso ficticio de costumbres turcas, en vista de que el protagonista se llama Pedro de Urdemalas y sus interlocutores, Juan de Votadiós y Mátalascallando: popularísimo el primero, judío errante el segundo, proverbial el tercero (Bataillon, 1950, II, 281). Es notable la confianza con que el autor de este coloquio de corte humanístico se apropia de unas palabras de Menavino para afirmar en la epístola dedicatoria a Felipe II que "escribo no como erudito escritor, sino como fiel intérprete y que todo cuanto escribo vi" (no come erudito scrittore, ma como fedel interprete e vero raccontatore delle cose vedute" [Bataillon, 1950, II, 274]). En lo esencial, los orígenes librescos del Viaje no disminuyen para el lector la funcionalidad y significación en él de la imagen y representación de una nación extranjera, puestas al servicio del espíritu irónico y cristiano, a la manera de Erasmo, que con tanto vigor calificó Bataillon.

De semejante modo, aunque con distinto sentido, podría calibrarse la maravillosa Peregrinação de Fernão Mendes Pinto ( $1^{\mathrm{a}}$ ed., Lisboa, 1614). No así aquellas obras en que, por más que se encuentren en ellas huellas de viajes y experiencias vividas directamente, la función del entorno extranjero no pasa de ser secundario. Tengo presente, volviendo al vizconde de Chateaubriand, su Aventures du dernier Abencérage (1826; escrito entre 1807 y 1810).

Tan decisiva fue la prosa de Chateaubriand para el siglo XIX que toda ella ha sido objeto de minucioso escrutinio. Se han publicado muchas páginas acerca de una pequeña curiosidad biográfica: averiguar si el escritor pudo ver Granada, escenario de dicho relato, cuando pasó por Andalucía en Abril de 1807. La pregunta es bastante indiscreta, ya que el vizconde había concertado una cita con su íntima amiga Natalie de Noailles (Christophorov, 1984). Los dos venían de lejos; (él, de Jerusalén). ¿Acaso estuvieron juntos en Granada, pero no la vieron? De todas formas la trama sentimental del Abencérage podía inspirarse en cualquiera de las aventuras amorosas de Chateaubriand, que fueron copiosas; y las descripciones de Granada, en los libros de viajes de la época, como el de Henry Swinburne, o sin ir más lejos, el Voyage pittoresque et historique (1806-1820) de Alexandre de Laborde, que era el hermano de Natalie.

No puede sorprender que el Abencérage, como tantos escritos románticos, aluda de paso al carácter español (Blanca de Vivar, la protagonista, es descendiente del Cid), como también al francés (Lautrec, el caballero amigo), y al árabe (Aben-Hamet, el héroe). Principalmente Chateaubriand recurre al modelo del 
relato morisco para presentar sus temas y tipos predilectos: la hosca soledad del exiliado, la fidelidad al linaje, el amor absoluto, la nostalgia de grandezas pretéritas. El ambiente, espléndidamente reaccionario, es de una novela de caballerías situada en un pasado fabuloso y melancólico, o sea, el marco de las Guerras civiles de Granada $(1595,1619)$ de Pérez de Hita y sus imitadores franceses, que fueron numerosos, desde Mlle. de Scudéry y las Galanteries grenadines (1762) de Mme. de Villedieu hasta el Gonzalve de Cordoue ou Grenade reconquise (1791) de Florian. No digo que el género fuera dieciochesco. Chateaubriand tenía que volver mucho más atrás, hasta la Edad Media. Para ello de algo le sirvió la imagen romántica de España en las letras francesas de la época, con el Poema del Cid y el Romancero, más allá o más acá de tramoyas y bambalinas. ¿Para qué ver Granada con detenimiento, si unos pocos detalles objetivos podían encontrarse en Swinburne o Laborde y lo que más importaba era la recuperación del pasado? Así, el entorno granadino y moro nunca fue más disparatado, creo, que en esta novela.

Pero no fue éste el último de los Abencérages. Hay un personaje de Balzac que no tiene desperdicio, don Felipe Hénarez (o Henarez, o Henares, o Hernández, según los manuscritos), antiguo duque de Soria y Grande de España, proscrito en 1823 tras su adhesión al gobierno constitucional el año 20. Feo como un sapo, católico, sentimental, y reducido al modesto existir de un profesor de lengua en París, es sin embargo un hombre fascinante y misterioso, que enamora a Louise de Chaulieu, una de las dos protagonistas de las Mémoires de deux jeunes mariées (1842). Y es que los orígenes del ex-duque son insólitos, según explica a su hermano Fernando, a quien había cedido el título:

Si le massacre de nos ancêtres dans la cour des Lions nous a faits malgré nous Espagnols et chrétiens, il nous a legué la prudence des Arabes; et peut-être ai-je dû mon salut au sang d'Abencérage qui coule encore dans mes veines... tu dois être le seul être vivant qui sache les secrets du dernier Maure christianisé, dans les veines duquel mourra le sang de la grande famille née au désert, et qui va finir dans la solitude.

(Balzac, 1976, I, págs. 223, 227).

Algo le queda, puesto que conserva tierras en Cerdeña, de origen, según él, árabe también: "la dernière maison hispano-maure de Grenade a retrouvé les déserts d'Afrique, et jusqu'au cheval sarrasin, dans un domaine qui lui vient des Sarrasins" (I, pág. 223). Pero el exilio es grave para quien, a falta de un gran amor, se había consagrado con toda el alma a su país:

A défaut de maîtresse, j'ai adoré l'Espagne. L'Espagne aussi m'a echappé! Maintenant que je ne suis plus rien, je puis contemper le moi détruit, me demander pourquoi la vie y est venue et quand elle s'en ira? pourquoi la race chevaleresque par excellence a jeté dans son dernier rejeton ses premières vertus, son amour africain, sa chaude poésie... Je retrouve en mon âme les déserts paternels, éclairés par un soleil qui les brûle sans y rien laisser croître (I, pág. 226). 
El futuro de don Felipe de Hénarez, que hallará el amor de Louise de Chaulieu, si no el fin del exilio, no será tan sombrío. Pero por el momento se dan en él dos cosas que interesan mucho a Balzac: el declive de un linaje noble, y un fracaso grandioso.

En esta ocasión cabe pensar que la introducción en una obra novelesca de la imagen nacional es un factor funcional y positivo. Lo excepcional del personaje de Hénarez, su pasión, su capacidad de sacrificio, de lealtad, de desprendimiento, se deben a ese complejo de rasgos imaginados que el concepto de España hacía posible y aceptable. ¿Era compatible tanta grandeza, tanto misterio, con la familiaridad? El lector francés de la época, que desconocía el país vecino, pero no a Chateaubriand, a Víctor Hugo, y a otros proveedores de la imagen, podía dar crédito a la aparición de un moderno Abencerraje en el que se encarnaba la cualidad específica de la idea romántica de España: su carácter parcialmente árabe. O es más: su orientalismo. Junto a ello, hay toda una gama de detalles convencionales que revelan el funcionamiento de la imagen, hermana de la ignorancia. Nótese la distracción de Balzac cuando atribuye al personaje español, en primera persona, en la carta que acabo de citar, lo que debiera decir el narrador: "porquoi la race chevaleresque par excellence...", etc. Y: "un véritable Espagnol n'a nul besoin de répéter ses promesses". Y claro está, Hénarez tenía que ser orgulloso: "il est d'une taciturnité castillane, fier comme s'il était Gonzalve de Cordoue”. (Balzac, 1976, I, págs. 223, 233).

Balzac no se pasó la vida escribiendo a marchas forzadas en una buhardilla. Mundano, amigo de duquesas y personalidades eminentes, infatigablemente curioso, viajó mucho por Francia y Europa: conocía muy bien Suiza, donde se reunió con Mme. Hanska, y muy bien Italia, visitada varias veces, unida a su admiración, tan generosa e inteligente, por Stendhal; y observó Heidelberg, Stuttgart, Munich, Viena, Leipzig, Dresde, Riga, San Petersburgo... Pero no vio ninguna ciudad española. Yo no conozco ejemplo mejor de lo que no hace tantos años afirmaba aún Jean Cassou: que España era un sistema cerrado, "un système clos", recluido detrás de los Pirineos (Camp, 1954, pág. vii).

Sí hubo autores, por supuesto, que viajaron al país de la imagen, conociendo el estímulo del contraste y hasta de la decepción. A veces la imagen, en efecto, se tambalea y desmorona, cuando el conocimiento la pone a prueba. Ya apuntamos el talante renovador de Théophile Gautier. Recordemos también el de Flaubert, respecto no a España sino a los tópicos relativos a Italia y al llamado Oriente que prevalecían cuando él era joven. Resume Jean Bruneau que los románticos salían para Italia con ánimo de encontrar "la patrie de la beauté et de l'amour" (Bruneau, 1984, pág. 179). Pero Flaubert viaja como conocedor y amante de las artes. La belleza la persigue ante todo en los museos y monumentos de las ciudades; y no tanto la del Renacimiento como la de la antigua Roma. ¿No había dicho una vez que le hubiera gustado hacer el amor en aquella Roma? Es irresistible en él el ansia de ser otro; de desear lo diferente y trasladarse a lo imaginario. "Je voudrais 
être muletier en Andalousie" —escribe en 1842—, "lazzarone de Naples, ou seulement conducteur de la diligence qui va de Nîmes à Marseille" (Bruneau, 1984, pág. 165). Tan fuerte es este anhelo de otredad como su capacidad de desprecio para todo cuanto de hecho ha visto. Y la dicha no resulta ser la sustitución de un entorno nacional por otro — por lo que dice el año 1851 a su madre:

Pas de costume national à Naples, peu de lazzarone insouciant et se chauffant au soleil en chantant les vers du Tasse. Ils ont des culottes comme les bourgeois. Beaucoup de voitures, beacoup de bruit, l'air d'une capitale, un petit Paris méridional, voilà Naples. (Bruneau, 1984, pág. 175)

Lección esta que será especialmente significativa al tratarse del Oriente, tan soñado, que el escritor visita a lo largo de un periplo inusitadamente largo y empeñoso, pues duró dos años -1849-1851 - y le llevó de Egipto y Palestina a Asia Menor y por fin Grecia, y por segunda vez a Roma. Flaubert procura liberarse de ensueños exóticos y eróticos, descubriendo al propio tiempo nuevos matices de lo humano. Jean-Marie Carré, perito en espejismos, define muy bien el sentido de este descubrimiento: "au moment oú il s'apprête à remonter le Nil, il est sur le chemin de Madame Bovary" (Carré, 1932, II, pág. 100). El viaje por los países árabes ha enriquecido a Flaubert en la medida en que ha puesto a prueba no ya el orientalismo al uso sino el ilusionismo quijotesco de las fáciles imaginerías sentimentales. Es la temible percepción del abismo entre la imagen previa y el sabor de lo real. De vuelta en su casa de Croisset —destaca Haskell Block (1984, pág. 72) —, exactamente dos meses después de rematar sus apuntes y descripciones del viaje al Oriente, Flaubert comienza a escribir Madame Bovary.

Advertimos que la imagen de Andalucía era secundaria en el Abencérage de Chateaubriand. Cuestionemos ahora, para terminar, una obra de imaginación en que la descripción de una nación extranjera es primordial: valga como ejemplo Carmen (1845) de Prosper Mérimée.

La fatídica novelita se presenta al lector como un relato de viaje, o más exactamente, como el viaje de estudios que realiza un arqueólogo francés interesado en la batalla que ganó Julio César en las cercanías de la actual Montilla. El marco narrativo, según observa Ilse Hempel, es triple: en el segundo capítulo el narrador investiga en una biblioteca de Córdoba; y sólo en el tercer capítulo visita la cárcel de la ciudad, donde don José, condenado a muerte, le cuenta sus tragicos amores (Hempel, 1984, pág. 87). La historia de Carmen es un cuento intercalado. Y por si fuera poco, Mérimée agrega finalmente un cuarto capítulo al comentario de carácter erudito, que así llega a ser un marco completo, esta vez con motivo del habla de los gitanos. Como hay marco, sorprende menos el que un historiador, latinista y especialista en las guerras de la antigua Roma se interese hasta tal punto en el caló, basándose en los escritos de George Borrow. Todo lo jusitifica la insaciable curiosidad del narrador; y sobre todo, el propósito de rodear los amoríos de Carmen con 
envolturas protectoras.

De tal suerte se consiguen dos cosas: experimentar y poner a prueba la veracidad de cierta imagen de España, mediante la capacidad de observación del sabio viajero; y prestar apariencia de realidad a la desaforada historieta interpolada. Puede incluso considerarse funcional la distancia que media entre la seriedad y el afán de saber del arqueólogo francés, o su postura científica, y el salvajismo de la conducta de los protagonistas ibéricos.

Mérimée hubiera podido situar su imaginada exploración etnológica en alguna provincia remota de su propio país. ¿Por qué en Andalucía? Es significativo que dos de las nouvelles de Mérimée, Mateo Falcone y Colomba, tengan por escenario a Córcega, supuesta cuna (véase la Vendetta [1830] de Balzac) de odios ancestrales y venganzas terribles. Yo diría que nos hallamos ante la nacionalización de la verosimilitud. No es nuevo el que un escritor atribuya a personajes extranjeros sus figuraciones de la criminalidad humana. Ya lo vimos con motivo del Spanish Friar de Dryden. Hace más de un siglos Euphorion, el bello libro de Vernon Lee, reflexionaba acerca del entorno italiano en que los grandes dramaturgos ingleses de fines del siglo XVI y principios del XVII asentaban su obras más sangrientas (como también en España, recuérdense la Spanish Tragedy [1587] de Kyd y el Changeling [1622] de Middleton). Pues bien, la vigencia especial a principios y mediados del XIX del concepto de carácter nacional convierte el cambio de lugar en un poderoso instrumento no sólo de dramatización, sino de significación. La naturaleza humana se subdivide en un mosaico de virtualidades diferentes, cuyas raíces son nacionales.

Verdad es que Mérimée tiene la delicadeza de hacer que el protagonista masculino, don José, sea vasco-navarro; y que la heroína, Carmen, sea gitana. Las dos nacionalidades poseen idiomas muy suyos. Pero por más que llame la atención el caló, los gitanos son aquí seres primitivos, amorales, sin civilizar. Reúne Carmen todas las osadías, todos los encantos y atractivos de la barbarie en bruto. Lo que sucede, como todo el mundo sabe, es que don José, encanallado, degradado, descivilizado, acaba mezclando los celos del vasco con la brutalidad del gitano. Pese a su relativa marginalidad, ¿no son producto los dos personajes de lo que Mérimée denomina "cette terre classique des voleurs" (Seconde Lettre sur l'Espagne)? Qué duda cabe que el desenlace del cuento de Mérimée, a diferencia por ejemplo del libreto de Meilhac y Halévy, es, para mayor contento de ciertos lectores, singularmente cruel — violento, diríamos hoy. En la ópera el amante inminente de Carmen, Escamilla, a quien ésta acaba de ofrecerse, actúa en una cercana plaza de toros, lo cual intensifica los celos de don José. Pero en la nouvelle la figura del rival, el picador llamado Lucas, permanece muy desdibujada; y es en otro espacio, en la soledad del campo, donde Carmen y don José se enfrentan. Carmen reconoce sinceramente que no ama a nadie. Desamparada pero firme, ella no insulta, ni ataca, ni se defiende. Don José, sin más contemplaciones, la apuñala y mata como una alimaña de los montes. 
La acción es rápida, breve, como el estilo stendhaliano que Mérimée imita con admirable acierto. Y lo que sería inverosímilmente sanguinario más allá de los Pirineos no parece ser, más acá de éstos, sino una clase de comportamiento o de sociabilidad cuyas figuras más representativas, lo mismo en el cuento que en las Lettres sur l'Espagne de Mérimée, son el torero, el majo y el bandolero: como Francisco Montes, ejecutado en Valencia ( $2^{a}$ Lettre) y José María el Tempranillo, puntales de una imagen nacional que la ficción corrobora y que permite expulsar más allá de las propias fronteras toda aleación humana de civilización y de barbarie.

Concluir sería vano. Las consideraciones que anteceden no provocan sino más interrogaciones.

Los estudios de imagen piden una fundamentación histórica que estas páginas no han podido construir. Me refiero no tanto a la periodización del itinerario de cierta escritura y cierta literatura como al examen de las relaciones existentes entre éstas y el concepto de nacionalidad. La conducta social, política o económica de los españoles se prestaba sin duda a un inteligente análisis, como el que llevaban a cabo los embajadores venecianos en sus Relazioni al Senado de la Serenísima, de fascinanate lectura aún hoy. Pero ello no conllevaba en absoluto la idea de una cultura nacional - nacionalidad no significaba cultura específica - sino la apreciación, en el mejor de los casos, de cuanto realizaba un país desde un punto de vista supranacional. Los españoles, informaba el año 1506 uno de esos embajadores, Vicenzo Quirini, "hanno naturalmente ingegno, ma non l'adoperano nè in dottrina nè in studio alcuno" (Alberi, 1839-1840, I, pág. 22). A mediado del siglo XVII Jean Chapelain, que era un gran lector, conocía muy bien a los poetas, narradores y pensadores del país vecino; pero les reprochaba en resumidas cuentas un escaso o insuficiente cultivo de un mismo saber, de unas artes literarias e intelectuales que constituían un acervo común y universal (Chapelain, 1883, págs. 334, 815). Lo que la literatura permitía y prometía era vislumbrar a través de toda lengua lo que Goethe aún llamaría lo general humano, das allgemein Menschliche. La acepción psíquica y perenne del carácter, alma o genio nacional sólo triunfaría con el Romanticismo, haciendo posible, mas no siempre deseable, la coincidencia de la imagen con la literatura.

Asimismo sufre cambio y evoluciones la concepción del nexo entre escritura y experiencia vivida. No es lo mismo, en lo que toca a nuestro tema, una visión clásica de la literatura como reelaboración de ejemplos, modelos o mitos tradicionales de humanidad, que una noción de la palabra escrita como fiel reproducción del mundo vario y visible. Esta visión mimética, "realista", que culmina también durante el siglo pasado, fortalece la credibilidad y posible influjo de toda imagen procedente de la poesía, la novela o el libro de viajes; 
aunque en algún caso sucediera lo contrario, porque la escritura arrancaba no de procesos cognoscitivos sino del prejuicio unido a la ignorancia. Creo que ello es importante para entender lo que proponía una obra como Carmen y sobre todo la forma que tuvo de leerla el gran público.

No hay espejismos - los mirages de J.M. Carré- sin espejos, pues, a lo Stendhal, colocados al borde del camino de la vida; ni imagen especular de origen literario sin concepción mimética de la vinculación de las palabras con las cosas. En la medida en que no convence ni actúa tal mimetismo, la imagen nacional que emerge de escritos y tópicos previos es una visión forzosamente arbitraria y entontecedora de aquellas complejas realidades y naciones que desconocemos; y una invitación permanente al esfuerzo por aprehender y construir, a lo largo del camino de la Historia, una Europa no uniforme ni trivializada, sino compuesta en lo posible de inteligencias reunidas, quiero decir, de mutuas relaciones cognoscitivas.

\section{BIBLIOGRAFÍA}

ALBERI, Eugenio (ed.) 1839-1840. Relazioni degli Ambasciatori Veneti al Senato, Firenze, Società Editrice Fiorentina.

ALBERICH, José María. 1984. "Actitudes inglesas ante la Andalucía romántica", en La imagen de Andalucía... (véase González Troyano, A.), pp. 21-44.

ÁLVAREZ DE COLMENAR, Juan. 1707. Les Délices de l'Espagne et du Portugal, Leiden, Pieter van der Aa.

BALZAC, Honoré de. Mémoires de deux jeunes mariées, en La Comédie humaine, ed. de P.G. Castex, París, Gallimard, "La Pléiade".

BATAILlON, Marcel. 1950. Erasmo y España, México, Fondo de Cultura Económica.

- 1964. "Remarques sur la littérature des voyages", en Connaissance de l'étranger (véase Varios), pp. 51-63.

BERGER, Morroe. 1951. "Understanding National Character -and War", Commentary, XI, pp. 375-386.

BLOCK, Haskell. 1964. "Flaubert's Travels in Relation to his Art", en Connaissance de l'étranger (véase Varios), pp. 64-72.

BRUNEAU, Jean. 1964. "Les deux voyages de Gustave Flaubert in Italie", en Connaissance de l'étranger (véase Varios), pp. 164-180.

CAMP, Jean. 1954. "Preface" a Spain, Ginebra, "Nagel Guides".

CARRÉ, Jean-Marie. 1932. Voyageurs et écrivains français en Egypte, El Cairo, Publications de l'Institut Français d'Archéologie Orientale. 
CHAPELAIN, Jean. 1883. Lettres, ed. P. Tamizey de Larroque, París, Imprimerie Nationale.

CHINARD, Gilbert. 1959. "La littérature comparée et l'histoire des idées dans l'étude des relations franco-américaines", en Proceedings of the IInd Congress of the I.C.L.A., ed. W.P. Friederich, Chapel Hill, N.C., University of North Carolina Press, II, pp. 350-358.

CHRISTOPHOROV, P. "Le Voyage de Chateaubriand en Espagne (à propos d'une discussion littéraire)", en Connaissance de l'étranger (véase Varios), pp. 199 223.

CIORANESCU, Alejandro. 1937. "Les Rodomontades Espagnoles de N. Baudoin", Bulletin Hispanique, XXXIX, pp. 339-355.

CROCE, Alda. 1948. "Relazione della letteratura italiana con la letteratura spagnola", en Letterature comparate, ed. a. Viscardi et al., Milán, C. Marzorati.

CUNLIFFE, Marcus. 1961. "Europe and America: Transatlantic Images", Encounter, XVII, Diciembre, pp. 26-29.

ESCARPIT, Robert. 1964. "La visión de l'étranger comme procédé d'humour", en Connaissance de l'Etranger (véase Varios), pp. 240-246.

DULONG, Gustave. 1921. L'Abbé de Saint-Réal, París, E. Champion.

FOULCHÉ-DELBOSC, Raymond. 1926. "Madame d'Aulnoy et l'Espagne", Revue Hispanique, LXVII, pp. 1-151.

GAUTIER, Théophile. 1958. Voyage en Espagne, París, Hachette.

GONZÁLEZ TROYANO, Alberto, et al. 1984. La imagen de Andalucía en los viajeros románticos, Málaga, Diputación Provincial.

GUILLÉN, Claudio. 1985 a. Entre lo uno y lo diverso. Introducción a la Literatura Comparada, Barcelona, Crítica.

- 1985 b. "Distant Relations: Frech, Anglo-American, Hispanic", World Literature Today, Otoño, pp. 503-507.

- 1989. Teorias de la Historia literaria, Madrid, Espasa Calpe.

HEMPEL-LIPSCHUTZ, Ilse. 1984. "Andalucía, de lo vivido a lo escrito, por tres románticos franceses: François-René de Chateaubriand, Prosper Mérimée y Théophile Gautier", en Imagen de Andalucía... (véase González Troyano, A.), pp. 69-100.

HUME, Martin. 1905. Spanish Influence on English Literature, Londres, Eveleigh Nash.

KAMEN, Henry, y PÉREZ, Joseph. 1980. La imagen internacional de la España de Felipe II, Valladolid, Universidad de Valladolid.

LABAT, Jean-Baptiste. 1927. Voyage du P. Labat en Espagne, 1705-1706, París, Pierre Roger. 
LANSON, Gustave. 1896. "Etudes sur les rapports de la littérature française et de la littérature espagnole au XVIIe siècle (1600-1660)", Revue d'Histoire Littéraire de la France, III, pp. 45-70.

LEBÈGUE, R. 1964. "Structure et but du Voyage en Amérique de Chateaubriand", en Connaissance de l'étranger (véase Varios), pp. 284-291.

LOFTIS, John. 1973. The Spanish Plays of Neoclassical England, New Haven y Londres, Yale University Press.

NICOLL, Allardyce. 1961. A History of English Drama, 4 ed., Cambridge, University Press.

PAGEAUX, Daniel-Henri. 1971. Images du Portugal dans les lettres françaises (1700-1755), París, Fundação Calouste Gulbenkian.

PFANDL, Ludwig. 1913. "Carlos García und sein Anteil and der Geschichte der kulturellen und literarischen Beziehungen Frankreichs zu Spanien", Münchener Museum für Philologie des Mittelaters und derRenaissance, II, pp. 33-52.

PROUST, Marcel. 1988. Sodome et Gomorrhe, en $A$ la recherche du temps perdu, ed. J.Y. Tadié, París, Gallimard, "La Pléiade".

RICO, Francisco. 1988. Problemas del Lazarillo. Madrid, Cátedra.

SARTRE, Jean-Paul. 1949. Situations, III, París, Gallimard.

SHAW FAIRMAN, Patricia. 1981. España vista por los ingleses del siglo XVII, Alcobendas (Madrid), Sociedad General Española de Librería.

SPONDE, Henry de. 1636. "Avertissement au Lecteur", en L'Abrégé des Annales Ecclésiastiques de l'Eminentissime Cardinal Baronius, París.

TAINE, Hippolyte. 1887. "Madame d'Aulnoy" (1866), en Essais de Critique et d'Histoire, París, Hachette.

VARIOS, 1964. Connaissance de l'étranger. Mélanges offerts à la mémoire de Jean Marie Carré, París, Marcel Didier.

VIEILLARD, Jeanne. 1938. Le Guide du pélerin de Saint Jacques de Compostelle, Macon, Protat.

ZULUETA, Carmen de. 1984. "El enigma de George Borrow", en La imagen de Andalucía... (véase González Troyano, A.), pp. 47-66. 
. 


\section{LA PRENSA CATÓlica CATALANA DE 1868 A 1900 (III)*}

Solange HIBBS-LISSORGUES Universidad de Toulouse-Le Mirail

De 1881 a 1884 fracasaron los diferentes intentos, por parte del episcopado español así como de laicos, desde la prensa y las asociaciones religiosas, para poner un término a las disensiones internas de los católicos. El clima de cisma que León XIII intenta apaciguar con su encíclica Cum Multa de 1882 culmina, en 1884 , con la publicación de lo que iba a convertirse en la biblia del integrismo: El liberalismo es pecado de Félix Sardá y Salvany.

En 1884, la virulencia de las campañas anti "mestizas" organizadas desde la prensa carlista y nocedalista agrava las tensiones existentes y afecta la cohesión del episcopado. Esta prensa se convierte en un "segundo poder religioso" y se arroga el papel de organizador de las masas católicas. Los contra-centenarios, las romerías y actos de adhesión a Pío IX y a León XIII así como las suscripciones populares a favor de los obispos más íntegros contribuyeron a transformar los diarios y revistas integristas en instrumentos de movilización ideológica. Publicaciones como El Siglo Futuro (1875-1936) de Cándido Nocedal y la Revista Popular, que hacían alarde de su purismo político-religioso, pretendieron ser los más fieles intérpretes de las tradiciones católicas del pueblo español. Aprovechando las libertades de expresión y de imprenta concedidas por la Constitución, emprendieron campañas de oposición al gobierno canovista y a la monarquía liberal.

La constitución de la Unión Católica de Pidal en 1881 reforzó el comportamiento intolerante de la Comunidad Tradicionalista que sospechaba de los fines políticos del proyecto.

A partir de aquel momento, la prensa se convirtió en el campo de batalla privilegiado de carlista e integristas.

* Continuación de lo publicado en nuestro número 9 (1993). 


\section{Católicos moderados y católicos intransigentes ante la unión católica de Pidal}

Desde 1876 hasta 1880 , Pidal cuyo ideal era crear un partido político semejante al Zentrum alemán de Windhorst, había intentado, por medio de la prensa, atraer a los católicos que seguían a Cándido Nocedal' ${ }^{1}$.

A partir de 1878, varios factores propiciaron el proyecto de Pidal. La designación de Cándido Nocedal como director de la prensa carlista, en 1871, había sido muy mal acogida por los carlistas que temían la orientación intransigente y exclusivista de un hombre político que tenía mucho peso en el partido. Las divergencias estratégicas y doctrinales de prohombres del carlismo como Canga Argüelles y Navarro Villoslada, que dimitieron de la dirección de sus respectivos periódicos en 1872, habían contribuido a debilitar el partido carlista y anunciaban la grave crisis de 1888 (Gómez Aparicio, 1970, pág. 283).

En 1880, Pidal, que se oponía a la postura de total abstención política preconizada por Nocedal, quiso aprovecharse de las tensiones internas de la Comunión Tradicionalista y dirigió, desde las Cortes, un llamamiento a "las honradas masas carlistas" para que participasen a la vida política de la Restauración ${ }^{2}$. Por otra parte, la llegada de León XIII en 1878 como pontífice era un elemento favorable para promover un proyecto de unión de los católicos. Más conciliador y abierto a la sociedad contemporánea que Pío IX, el nuevo Papa preconizaba la colaboración del catolicismo con monarquías y gobiernos liberales. No veía con malos ojos la colaboración con "el mal menor" canovista ${ }^{3}$. Esta orientación conciliadora de León XIII contaba con el apoyo del Secretario de Estado del Papa, el Cardenal Rampolla, que fue Nuncio apostólico en España hasta 1887.

La situación de los católicos franceses iba a brindar una excelente oportunidad a Pidal para llevar a cabo su proyecto. En Marzo de 1880, Monseñor Freppel, obispo de Angers, dirigió un mensaje a los legitimistas franceses exhortándoles

1. En 1880, en uno de los momentos álgidos de la contienda verbal que lo opone a Nocedal y a El Siglo Futuro, Pidal reivindica para la Iglesia ciertas libertades y afirma que todos los católicos deben emprender "la reconquista de la Sociedad que se nos va, y tenemos que hacerlo con los mismos medios de que se ha servido la Revolución para corromperla: [...] por las asociaciones, por todos los medios en fin, legítimos y adecuados al objeto" (Gómez Aparicio, 1970, pág. 314).

2. Este conocido discurso de Pidal ¿Qué esperáis?, que empezaba por una llamada a las honradas masas carlistas, fue comentado de manera muy crítica por la prensa carlista e integrista que lo consideró como una incitación por parte de Pidal para que los carlistas traicionasen la causa de Don Carlos.

3. León XIII incitó a los católicos a no permanecer al margen de la sociedad contemporánea y a utilizar las instituciones liberales a favor de la causa católica. Preconizó la unión de los católicos independientemente de cualquier opción política. Estas orientaciones, que tuvieron un profundo alcance social y político, fueron enunciadas en tres importantes encíclicas: la Cum Multa en 1882, la Inmortale Dei en 1885 y la Libertas en 1888. 
a unirse en contra de las leyes antirreligiosas adoptadas por el gobierno de Gambetta. Con el título "Reunir a los dispersos", El Fénix, cuya finalidad a partir de 1879 era dar una consistencia definitiva al proyecto de la Unión Católica, publicó en Junio de 1880 un artículo en el que felicitaba a Freppel. El autor del artículo era Ceferino Suárez Bravo, antiguo colaborador de El Siglo Futuro. En su artículo, Suárez Bravo acusaba a los intransigentes de obstruir la causa de los católicos con su abstención política (Campomar Fornieles, 1984, pp. 6465). La reacción de El Siglo Futuro y los ajustes de cuentas que se produjeron entre el antiguo colaborador del periódico integrista y Cándido Nocedal reflejaban claramente las divisiones que reinaban en las filas del partido carlista. Aprovechando esta situación, Pidal, después de su llamada de unión desde las Cortes (Junio 1880), envió un mensaje de felicitación a Freppel que fue firmado por personalidades de diferentes tendencias políticas ${ }^{4}$. En este mensaje se invitaba a todos los católicos, cualesquiera que fuesen sus compromisos políticos, a formar una unión contra el gobierno de Sagasta. Más tarde la misma carta, acompañada de una circular, fue enviada a todos los miembros del episcopado español.

En su circular, los promotores de la Unión Católica se declaraban conscientes de las polémicas que suscitaba el proyecto y de las reticencias que podían experimentar algunos miembros del episcopado ${ }^{5}$. Al declarar que no había incompatibilidades entre las opciones políticas de los católicos deseosos de entrar en la Unión y la defensa de la Iglesia, los firmantes de la circular presentaban a la Unión Católica como una amalgama muy flexible.

Al contestar a la circular de Pidal, algunos miembros del episcopado no ocultaron sus reticencias y hasta su declarada hostilidad. El primero en poner reparos al proyecto fue el arzobispo de Granada, Mr. Bienvenido Monzón. Temía que tal proyecto no hiciera más que ahondar las divisiones que ya existían en el campo de los católicos. Con tono profético, describía las repercusiones de un proyecto, demasiado elástico a su juicio, que podría llegar a ser "una nueva manzana de discordia que, arrojada al campo católico, llevaría la perturbación y división a todas partes, y hasta lograría introducirla en el clero y el Episcopado" (La Cruz, 1881c, I pág. 215).

4. Entre los firmantes de este mensaje cabe destacar personalidades carlistas y católicas a favor de la monarquía alfonsina: Ortí y Lara, Valentín Gómez, Leandro Herrero, redactor de El Fénix, el marqués de Viluma, Manuel Pérez Villamil, director de La Ilustración Católica, Menéndez Pelayo, etc.

5. "Nosotros mismos, por nuestra imperefección y flaqueza, acaso demos lugar a que no se nos entienda bien, ni se nos haga completa justicia; quizás demos o hayamos dado ocasión a que la ceguedad, la pasión o la malicia tergiversen nuestros propósitos y den torcida interpretación a nuestros actos" ("Circular de los representantes de la Unión Católica en Madrid a los Señores Obispos", La Cruz, 1881 a, pág. 187). 
También condenaba el "laicismo" de Pidal, que consistía en querer organizar una asociación de católicos sin que hubiese sido previamente aceptada y aprobada por el episcopado. Esta advertencia a los promotores de la Unión era un claro rechazo de la libertad que tomaban los seglares católicos para organizar la política católica fuera de la Iglesia. Evidentemente esta crítica también iba dirigida a los integristas y carlistas que desde la prensa habían organizado una campaña de oposición contra algunos obispos como el de Barcelona, Urquinaona, acusado de colaboración con los "mestizos" de Pidal y con el liberalismo.

Otros serios reparos con respecto al proyecto de Pidal procedían del obispo carlista de Daulia, Josep Serra. Este prelado afirmaba que la única intención de la Unión era política y anticarlista y que estaba contagiada por el liberalismo. A sus ojos, esta "unión heterogénea" sólo quería disolver el carlismo: "Nombres de personas ilustres, de personas muy queridas, muy respetables $[\ldots]$ unidos y confundidos con nombres de sujetos que no han renunciado y no renunciarán probablemente jamás al nombre de liberales" ( $\mathrm{La}$ Cruz, 1881d, I pág. 317).

En cuanto a Salvador Casañas, obispo de Urgel, que no ocultaba su simpatía a favor de los carlistas, fue otro detractor de la Unión Católica. Salvador Casañas, que desde 1875 se había enzarzado en varias contiendas mediante la prensa con los católicos moderados "inficionados por el virus del liberalismo", denunciaba también las intenciones políticas de Pidal para acabar con el partido carlista. Las contestaciones de ambos prelados a la circular de Pidal fueron inmediatamente recogidas por la Revista Popular, así como por otras publicaciones integristas que las consideraban como un argumento más para endurecer su postura intransigente: "Este superior testimonio nos confirma más y más en la absoluta intransigencia que ha sido siempre la de nuestra revista" (R. Popular, 1881, pág. 119).

Pese a las condenas violentas de algunos prelados como los Obispos de Urgel, de Daulia y de Osma, la Unión Católica se beneficiada de la aceptación, a veces cautelosa, de la mayoría del episcopado. La postura prudente y moderada de los obispos de Barcelona, José María Urquinaona y del Arzobispo de Granada, Bienvenido Monzón, incitó el resto de la jerarquía católica a intervenir para que se sentasen las bases y el fin de la asociación, que debía ser ante todo religiosa ${ }^{6}$.

El Cardenal Moreno, arzobispo de Toledo, tomó la iniciativa y el 14 de Febrero de 1881, durante la constitución oficial de la Unión Católica, las nuevas bases de la asociación fueron formuladas con el consentimiento de la

6. El arzobispo de Toledo expresó de manera significativa cuál iba a ser el contenido de la Unión Católica: "Esta Asociación no tiene origen político, esta Asociación no tiene fines políticos; nada más distante de ella que fines políticos. Está presidida por los Señores Obispos y nosotros lo que deseamos es hacer la felicidad de nuestra patria al propio tiempo que trabajamos en defensa de los intereses de la Iglesia" ( $L a$ Cruz, 188le, pág. 425). 
jerarquía católica. Como ya señalaron otros investigadores del tema, al recibir la bendición de los prelados españoles, la Unión Católica se redujo a una asociación exclusivamente religiosa al servicio del episcopado (M. Campomar Fornieles, 1984, pág. 68).

En 1881, la Unión Católica distaba de ser un partido católico comparable a los que existían en Alemania o Bélgica y no tenía porvenir como organización política. Como resumió Sánchez de Toca, uno de los más decididos defensores del proyecto de Pidal, al hacer un balance de la trayectoria política de la Unión:

La Unión no tiene pues ninguna condición de partido político; su propia naturaleza se lo impide. Por parte tiene a su frente la jerarquía episcopal [...] y por otra parte, a diferencia de todo partido político, carece la Unión Católica de soluciones concretas en lo referente a formas e ideales de gobierno (Sánchez de Toca, 1885, pág. 300).

En ningún momento, incluso cuando tuvo su propio periódico, La Unión (1881-1887), la Unión Católica pudo ejercer influencia alguna en las masas católicas. El periódico pidalino no arrastraba a las masas católicas y se limitó a ser una publicación destinada a la intelectualidad española, a un público de "élite" (Campomar Fornieles, 1984, pág. 62).

\section{a. La Unión Católica en Cataluña. Primeras reacciones de la prensa católica catalana: el Diario de Barcelona y La Veu de Montserrat (1878-1889)}

Aunque había sido neutralizada políticamente por el episcopado, la Unión Católica fue acogida con desconfianza y hostilidad por integristas y carlistas. Las advertencias del episcopado a la prensa intransigente no evitaron que la publicística católica se convirtiese en el campo de batalla privilegiado de los íntegros?

Desde el anuncio del proyecto de constitución de la Unión Católica, el Diario de Barcelona siguió muy atentamente las diferentes fases de su evolución. Para este diario, que mantenía una postura abiertamente anti-carlista y rechazaba el integrismo, la Unión Católica aparecía como una hábil maniobra por parte de Pidal para debilitar la comunión tradicionalista ${ }^{8}$. El Diario de Barcelona se

7. Amigo de personalidades políticas como Manuel Durán y Bas, futuro ministro de justicia en el gobierno Silvela, y muy cercano al grupo de los católicos catalanes como el eclesiástico Jaume Collel y el Obispo Morgades, Urquinaona se opuso constantemente al radicalismo religioso de los católicos intransigentes. Consciente de que la Unión Católica iba a profundizar las divisiones de los católicos y preocupado por la agitación que se manifestaba en el episcopado, Urquinaona acogió la Unión con circunspección: "El pensamiento que ustedes han concebido de que todos los católicos se unan para defender los grandes intereses de la Religión [...] no puede ser más recomendable [...]. Más diré a ustedes: no es posible el verdadero catolicismo sin que entre todos los que lo profesan haya unión perfecta..." (La Cruz, I, 1881b, pág. 209).

8. "[...] Y con una oportunidad verdaderamente hábil, los pidales y otros enemigos del Sr. Nocedal y de cuanto reza con El Siglo Futuro sondearon el terreno, fueron minándolo poco a poco y cuando contaban con el asentimiento de casi todo el Estado Mayor de D. Carlos han lanzado a la publicidad la carta dirigida a Monseñor Freppel" (Diario de Barcelona, 1881a, pág. 443). 
apresuró a publicar la circular de los promotores de la Unión así como la contestación de Mr. Freppel a los católicos españoles. Varios artículos de Mañé y Flaquer resultan muy esclarecedores en cuanto a la postura del sector católico moderado y conservador catalán ante el proyecto de Pidal ${ }^{9}$.

Profundamente impregnado por el ejemplo del partido católico belga y el del Centro alemán, que supieron adaptarse a las instituciones políticas para la defensa de los intereses religiosos, Mañé y Flaquer consideraba esperanzador el propósito de la Unión Católica: "Hemos creído siempre que era necesario separar la religión, no de la política, sino de los partidos [...]. Hoy vemos aprobado y bendecido nuestro pensamiento por los prelados españoles y no hemos de ocultar la gran satisfacción que nos causa este importante y trascendental acontecimiento" (Diario de Barcelona, 1881b, pág. 960).

A ojos de Mañé y Flaquer, el radicalismo religioso de los carlistas e integristas era responsable de las profundas divisiones del campo católico y de la situación de cisma que amenazaba a la Iglesia. La Unión Católica, para el director del Diario de Barcelona, puede constituir un medio para poner término a la "desastrosa dictadura" de carlistas e integristas (Diario de Barcelona, $1881 \mathrm{c}$, pág. 4544).

En muchos punto coincidían las reacciones y reflexiones de Juan Mañé y Flaquer y de Urquinaona: el mayor obstáculo para una unión de todos los católicos era la usurpación del magisterio católico por parte de algunos "pontífices laicos y mitra y tiaras laicas". El director del Diario de Barcelona subrayaba el peligro que representaba este "segundo poder religioso" de cierta prensa intransigente, que no acataba las recomendaciones del episcopado. Mañé expresaba abiertamente su repulsa hacia el exclusivismo religioso de los intransigentes que, incapaces de olvidar "las banderías políticas", tomaron pretexto en la Unión Católica para asentar su monopolio del catolicismo y reivindicar la movilización de los católicos.

De hecho, tanto el análisis del entonces obispo de Barcelona como el de Mañé y Flaquer con respecto a la Unión Católica y a sus repercusiones en el campo católico se verificó. El fuerte arraigo del integrismo en Cataluña, al que se adhería la mayoría del clero, imposibilitaba la constitución de la Unión Católica en las diferentes diócesis catalanas. En un informe remitido por Urquinaona al Nuncio, el día 4 de Marzo de 1883, se anunciaba la decisión de descartar en algunas diócesis la organización de la Unión Católica ${ }^{10}$.

9. Estos artículos fueron publicados en 1881 en el Diario de Barcelona bajo el título "La Unión de los católicos" el 25 de Enero, pág. 960 , el 30 de Enero, pág. 1271. También resultan esclarecedores otros artículos que salieron en el Diario de Barcelona hasta finales de Abril de 1881.

10. "Debo advertir que yo, viendo la actitud tan pronunciada de los nocedalistas contra la Unión Católica, por evitar cuestiones y disgustos, me abstuve de crearla en mi diócesis, y nada he hecho en favor de ella" (Bonet y Martí, 1990, pág. 42). 
Esta postura, que excluía cualquier tipo de radicalismo religioso, era compartida también por otros católicos moderados catalanes como Torras i Bages, Jaume Collell y Eduardo Llanas. Tanto Jaume Collell como Eduardo Llanas desempeñaron un papel importante en cuanto a la difusión de un cristianismo al margen de las banderías políticas y conforme con las orientaciones más realistas y conciliadoras de León XIII Se destaca la importancia de la revista dirigida por el eclesiástico Llanas, El Criterio Católico (1884) cuyo fin era oponerse a las campañas integristas ${ }^{11}$. En cuanto a Jaume Collell, fue el fundador de la revista semanal La Veu de Montserrat que salió a la luz en 1878. Contaba con la colaboración de católicos prestigiosos como el poeta Verdaguer, el escritor Milá i Fontanals Víctor Balaguer entre otros. Esta revista, de carácter regionalista, ejerció una profunda influencia en el movimiento regionalista catalán. Muchos artículos de Collell se dedicaban a reivindicar el renacimiento de un cristianismo específico de Cataluña. A partir de 1886, publicó la importantísima obra de Torras i Bages, La Tradició Catalana. Menos combativa que El Criterio Católico cuando se trataba de intervenir en las contiendas con carlistas e integristas, La Veu de Montserrat anunció desde el principio de su publicación su intención de permanecer al margen de las polémicas políticoreligiosas ${ }^{12}$.

Jaume Collell, que pretendía, como periodista, seguir ajeno a cualquier tipo de compromiso político, abandonó en determinadas ocasiones su distanciamiento prudente. Se produjo el caso en el momento de la constitución de la Unión Católica, que desencadenó violentas posturas de rechazo y hostilidad por parte de los integristas catalanes. En 1881, la agitación y la mordacidad de la prensa intransigente eran tan fuertes que Jaume Collell se sintió obligado a comentar el proyecto de Pidal y sus repercusiones en Cataluña: "Creemos del caso decir cuatro palabras; porque si antes podía ser prudente el silencio que desde el primer momento nos impusimos, de ahora en adelante podría dar lugar a recelos o sospechas temerarias" (La Veu de Montserrat, 1881b, pág. 1) ${ }^{13}$.

Los comentarios de Collell con respecto a la Unión Católica reflejaban las orientaciones de la revista: en ningún momento debían mezclarse la actividad pastoral y el compromiso político y sólo el respeto de la autoridad episcopal podía asegurar la unión de los católicos. Como otras personalidades católicas relevantes de su época, por ejemplo Morgades, Torras i Bages, Collell era el

11. En el momento de su aparición, en Noviembre de 1884, en "Nuestro Programa", Llanas advierte que la revista no tiene la vocación "de un diario político redactado a vuela pluma y obedeciendo a las pasiones del momento sino [...] de una publicación católica en toda la extensión de la palabra".

12. "Pero ya lo hemos dicho y no nos cansaremos de repetirlo, nuestra pluma no se ha puesto al lado de nadie; sólo sirve una gran idea para la cual tenemos que trabajar si queremos conservar el espíritu catalán, el verdadero espíritu de aquella raza vigorosa, nutrida como todos los pueblos latinos en la amorosa falda de la Iglesia" (La Veu de Montserrat, 1881a, pág. 1). 
representante de un humanismo cristiano preocupado por las exigencias de una nueva época y completamente conforme con las enseñanzas religiosas y sociales de León XIII. Collell no hacía referencia a las intenciones políticas de la Unión de Pidal y afirmaba que una asociación de esta índole sólo podía funcionar bajo la autoridad del episcopado. El director de La Veu de Montserrat, de igual modo que lo hacían otros católicos moderados como Eduardo Llanas en 1884, denunciaba las prerrogativas que se otorgaban los católicos laicos en materia de interpretación de la doctrina católica. Estos laicos, afirmaba Collell, se aprovechaban de la prensa y de algunas asociaciones católicas para erigirse en jueces, al margen de la jerarquía católica ${ }^{14}$. Las hondas divisiones de los católicos, las exacerbadas polémicas provocadas por los que identificaban religión y política hacían ilusoria una asociación como la Unión Católica. En 1882, al analizar más detenidamente las causas del fracaso de la Unión, Collell constataba con cierto desencanto que, contrariamente a algunos países como Alemania, donde el Centro alemán de Windhorst supo lograr sus propósitos, en España los católicos no habían sido capaces de promover una asociación semejante por "falta de unión y de firme organización" (La Veu de Montserrat, 1882a, pág. 17).

La Veu de Montserrat, en la que se expresaron los católicos catalanes, constituyó en los años críticos de los enfrentamientos entre intransigentes y mestizos el reflejo de las nuevas orientaciones conciliadoras que se estaban fraguando en la Iglesia española bajo el impulso de León XIII.

Esta visión de la religión y de la misión de la Iglesia ante la sociedad de su época quedó plasmada en la importante obra de Torras i Bages, El Clero en la vida social moderna (1888). Activo colaborador de La Veu de Montserrat, el que llegó a ser obispo de Vich en 1889 se vio directamente implicado en las contiendas periodísticas al ser nombrado censor de la prensa en 1889 por el obispo de Barcelona ${ }^{15}$. Torras i Bages volvía a plantear el problema que tan acuciante se había vuelto durante este período y que trataba con frecuencia Jaume Collell en las páginas de su revista: ¿cuál debía ser el cometido del clero ante la sociedad moderna?

Aunque no debía manifestarse a favor de partido político alguno debe preciarse de leal y ser fidelísimo al poder civil y amigo de ayudarle cuanto pueda [...]. Nunca como ahora ha sido conveniente hacer un llamamiento a la independencia política del clero (Torras i Bages, 1948, pág. 1731).

13. La postura de Jaume Collel ante los ataques de la prensa intransigente y más especialmente de El Correo Catalán fue analizada por Bonet i Baltá y Casimir Martí, en L'integrisme en Catalunya, 1990, pp. 43-45.

14. "No se alarmen con el ruido de las desavenencias que en el campo de la prensa católica han surgido, no tengan en cuenta las disputas y polémicas de los periodistas seglares que no tienen más autoridad que la que puede darles su mérito personal" (La Veu de Montserrat, 1881b, pág. 42).

15. En una carta dirigida el 10 de Febrero de 1883 a Torras y Bages, Urquinaona ponía de relieve el carácter dramático de las polémicas entre católicos y el papel de la prensa intransigente en la crisis religiosa (Torras i Bages, 1934, pág. 271). 
El clero en la vida social moderna constituye un valioso testimonio para profundizar en las causas de los conflictos políticos religiosos que afectaban a la Iglesia española con especial gravedad en los años 1880-1882. También es el reflejo de la postura conciliadora de algunos católicos.

Estos católicos moderados, que no consideraban la Unión Católica como la única respuesta válida para la defensa del catolicismo, se expresaron en Cataluña por medio de publicaciones que surgieron a partir de 1875 , como una respuesta y un freno al militantismo exacerbado de la prensa intransigente.

\section{b. Exacerbadas polémicas en la prensa intransigente con motivo de la Unión Católica}

La Unión Católica brindó una oportunidad más a los carlistas e integristas para afirmar desde la prensa, con tono abiertamente acusatorio, su condena de los mestizos. Las numerosas publicaciones integristas catalanas que surgieron entre 1880 y 1884 se ocuparon de manera casi obsesiva de la Unión de Pidal, considerada como una maniobra por parte de los mestizos para estorbar la comunión tradicionalista ${ }^{16}$. La mayoría de esas nuevas publicaciones integristas eran semanarios satíricos, con grabados ferozmente antiliberales y claramente denigrantes con respecto a los llamados mestizos, también apodados pasteleros (La Vespa, 1882, pág. 1). La violencia verbal y la mordacidad de las críticas también se manifestaban en diarios carlistas como El Correo Catalán que, desde el principio, había declarado una guerra sin cuartel a los "transaccionistas"17 (Bonet y Martí, 1990, pp. 39-40).

A ojos de carlistas e integristas, la Unión Católica aparecía como un intento por parte de Pidal para debilitar el partido carlista en el que evidentemente existían disensiones a raíz del nombramiento de Cándido Nocedal como representante político en Madrid. La prensa carlista reflejaba estos temores. Pese a las palabras tranquilizadoras de Llauder, que afirmaba en 1882 que sólo "hay una pequeña fracción muy insignificante por el número que está separada de la masa general" (Llauder, 1882, pág. 3), las restantes publicaciones intransigentes no cesaban de denunciar las consecuencias de la maniobra pidalina ${ }^{18}$.

Todas las publicaciones intransigentes adoptaron el mismo procedimiento, que consistía en publicar sólo las pastorales y circulares de los prelados que

16. La revista integrista La Vespa (1882), en un artículo titulado "Punzadas" del 30 de Noviembre 1882, declaraba que "la Unión es una pantalla para encubrir ambiciones de los que quieren destruir el único obstáculo que se opone al compieto triunfo de la Revolución en nuestra desgraciada tierra, el tradicionalismo".

17. Entre las revistas intransigentes satíricas cabe destacar La Vespa (1882), Lo Fuet (1882), Lo Burinot (1879-1882), L'Avi Vell (1882).

18. La Vespa habla de una "liga de católicos liberales para destruir la gran comunión tradicionalista" (1882a, pág. 1). 
habían manifestado abiertamente sus reparos, e incluso su hostilidad, con respecto a la Unión Católica. Algunas revistas como La Vespa organizaron homenajes y suscripciones populares en honor de prelados intransigentes como los obispos de Osma y de Daulia. En 1881, la Revista Popular, cuya conducta era un modelo para las demás publicaciones integristas, publicó las cartas de los obispos de Granada y de Urgel con el siguiente comentario: "Este superior testimonio nos confirma más y más en la absoluta intransigencia que ha sido siempre la de nuestra revista" (1881, pág. 119).

Pero la prensa intransigente no se satisfacía sólo con publicar las cartas de los prelados adscritos a su causa. Las publicaciones integristas y carlistas declararon que pensaban utilizar "todas las armas que matan espiritualmente". Así es como se acudía a la calumnia, a la caricatura y a la crítica verbal más despiadada. Un procedimiento corriente esgrimido entonces por las revistas satíricas era la utilización de grabados caricaturescos que solían ilustrar los artículos de fondo de la primera página de la publicación. El desarrollo de esta prensa católica satírica fue importante después de 1875 y perduró hasta 1888 . Muchas de estas publicaciones joco-serias surgieron con la finalidad de oponerse a las revistas marcadamente anticlericales que, como La Campana de Gracia o El Loro, habían alcanzado tiradas muy sustanciales (Bozal, 1979, pág. 183) ${ }^{19}$.

El contenido ideológico se acentuó notablemente después de la Restauración. Muchos de los que colaboraban en dichas revistas eran miembros del clero como Ignasi Puig o Pedro Reig ${ }^{20}$.

La finalidad militante y la detracción constante eran las características más notables de una prensa que reflejaba las intensas contiendas politíco-religiosas de finales de siglo. De escasa duración ya que algunas sólo llegaron a publicarse durante un año, las revistas satíricas carlistas e integristas llegaron a tales extremos durante sus campañas de crítica y condena de los mestizos y de algunos miembros del episcopado, que tanto el Nuncio de León XIII como los obispos de Barcelona y de Tarragona tuvieron que intervenir y suspender su publicación ${ }^{21}$.

19. El periódico católico ilustrado La Campana de la Catedral, que empieza a publicarse en Enero de 1872 , reconoce en su primera publicación que quiere luchar con "la prensa inmoral y antirreligiosa". Su título evoca intencionadamente La Campana de Gracia. Lo Burinot, "periódico ilustrado y satírico", que surge en Enero de 1880 , multiplica los ataques a la prensa anticlerical joco-seria como El Diluvio o la Esquella de la Torratxa.

20. También se puede mencionar al eclesiástico Francisco Mateos Gago, colaborador de la Revista Popular y de la publicación integrista Dogma y Razón (1897), que publicó varios artículos en contra de la Unión Católica y de los prelados "cómplices del liberalismo" en la revista La Vespa (1882): “'Insistirán muchos de nuestros Prelados en manifestar sus simpatías por la Unión y sus pocos disimulados desdenes a los tradicionalistas en sus Boletines, en sus Pastorales y hasta en el púlpito?", La Vespa, 30 de Noviembre de 1882.

21. En Marzo de 1882, el obispo Urquinaona, en una circular dirigida a los católicos de su diócesis, se lamenta de la situación de cisma provocada por la prensa intransigente que alimenta y exacerba los conflictos religiosos: "[...] la presunción crece y se manifiesta más erguida, prescindiendo 
A.L.E.U.A. $/ 10$

También diarios carlistas como El Correo Catalán participaban en estos ajustes de cuentas con respecto al episcopado. Al felicitar el Obispo intransigente de Osma que supo "desenmascarar" a los transaccionistas, Llauder añade que prelados como él simbolizan los valores esenciales del carlismo, y entre otros, la intransigencia.

Este lenguaje ofensivo y estos procedimientos de detracción con respecto a la jerarquía católica se manejaban constantemente en la prensa integrista de 1881 y por lo menos hasta 1888 . La prensa aparecía como el instrumento privilegiado de las contiendas entre católicos y constituía el soporte esencial de difusión de las tesis integristas ${ }^{22}$. Con publicaciones tan importantes como $E l$ Correo Catalán, la Revista Popular y con la proliferación de revistas y semanarios de orientación integrista en Barcelona pero también en provincias, el integrismo disponía en Cataluña de unos medios "logísticos" eficientes (Bonet, 1990, pág. 47). Por otra parte, si se tiene en cuenta que muchas asociaciones católicas como la Juventud Católica o la Asociación de Católicos, implantadas en algunas diócesis, eran afines al integrismo, se comprende mejor el alcance de las advertencias de algunos miembros del episcopado, que afirmaban en la mayoría del clero y gran parte de los fieles seguían las consignas integristas ${ }^{23}$.

\section{Las grandes campañas de movilización religiosa de 1881 y 1882 - Recuperación por parte de la prensa intransigente de las romerías y peregrinaciones}

A partir de 1881, con la celebración de distintos centenarios y con la organización de romerías y peregrinaciones, el sector católico intransigente

ya completamente de nuestro sagrado ministerio para interpretar documentos pontíficos, decidiéndose en tono magistral sobre asuntos de nuestra exclusiva competencia", Boletín Oficial Eclesiástico del Obispado de Barcelona, 9 de Marzo de 1882, pág. 156.

Se suspendió, en Marzo de 1882, la revista satírica Lo Fuet. En una carta dirigida a Torras i Bages en 1883, el obispo de Barcelona alude a la situación caótica de la prensa católica en Cataluña y emplea la palabra "secta" para designar a los laicos católicos y algunos miembros del clero que comparten el radicalismo religioso de C. Nocedal: "[...] realmente secta es lo que se nos ha introducido en la Iglesia de España y con tales bríos que no basta la fuerza moral para acabar con ella" (Torras i Bages, 1934, pág. 272).

22. En 1882 La Vespa afirmaba que el mundo era un campo de batalla en el que la prensa era una de las mejores armas: "Es de buen sentido que en toda guerra, uno de los enemigos se aprovecha de las invenciones y tretas del otro" (La Vespa, 1882b, pág. 2).

23. En una pastoral del mes de Marzo 1882, el obispo de Barcelona, Uquinaona, denunciaba la grave crisis que afectaba la Iglesia española y que podía llevar a un cisma. Condenaba la propensión de la prensa integrista y carlista a utilizar la calumnia y el insulto contra miembros del episcopado. El arzobispo de Tarragona, Benito Vilamitjana, en un documento que se titulaba Reglas de conducta que, en los actuales momentos de perturbación religiosa, dan a sus diocesanos los Prelados de la Provincia Eclesiástica Tarraconense... del mes de Marzo 1882, advertía a los fieles que uno de los males que corroía la Iglesia era "el laicismo [...] que tiende a secularizar la Iglesia y a convertir al Reino de Cristo en institución humana" ( La Veu, 1882d, pp. 108-109). 
emprendió verdaderas campañas de movilización contra los mestizos. Estas campañas de propaganda tenían una dimensión política. Se trataba para los integristas y carlistas de demostrar que su poder de convocatoria de las masas católicas estaba intacto y que los católicos que habían aceptado la política transaccionista de Pidal no representaban "La España de Recaredo y otros campeones de la fe católica"24. Una vez más, esta movilización se encauzó por medio de la prensa y de las asociaciones católicas en las que predominaba la orientación integrista ${ }^{25}$. Esto fue especialmente el caso en Cataluña donde, como ya se ha señalado, el integrismo había arraigado con particular vitalidad (Bonet y Martí, 1990, pp. 9-48).

En Julio de 1881, con motivo del traslado del cuerpo de Pío IX al Quirinal, los integristas quisieron demostrar una vez más que las masas católicas respondían a las consignas del sector intransigente y promovieron una peregrinación de desagravio a Roma. La organización de la romería había sido propuesta por Cándido y Ramón Nocedal, que explicitaron su proyecto más adelante en una carta a León XIII. Los términos de dicho documento revelaban de manera bastante explícita la voluntad de los promotores de la romería de dar una orientación integrista a esta nueva manifestación: "Una gran romería, pura y absolutamente católica, como la que de España fue a Roma el año 1876 y el día de Santa Teresa, se postró a los pies de Pío IX" (Revista Popular, 1882a, pág. 21).

Por otra parte, las juntas de organización de la peregrinación estaban constituidas, en su mayoría, por conocidas personalidades integristas y carlistas ${ }^{26}$. La prensa intransigente, con tono triunfalista, destacaba el carácter católico puro de las juntas organizadas " $[\ldots]$ sin ningún contubernio, ni mezcolanza con apestados de epidemia liberal" (R. Popular, 1882b, pág. 54).

También puntualizaba esta prensa que las juntas se habían constituido oficiosamente sin la aprobación previa de los prelados de las diócesis (El Correo Catalán, 1882, pág. 3). Sólo después de la constitución de las juntas, Cándido y Ramón Nocedal enviaron una carta a los prelados para que presidiesen la peregrinación. Los católicos moderados y algunos obispos que se habían visto excluidos de las juntas protestaron abiertamente. La prensa intransigente se

24. En un conocido artículo sobre la celebración del centenario de Calderón en Agosto de 1882, Sardá y Salvany proclamaba que esta celebración de los centenarios debía ser "castizamente española, o lo que es lo mismo, católica, apostólica, romana, sin mezcla de heterodoxos elementos" (Revista Popular, 1882d, pág. 65).

25. En los años 1881-1882, tanto la Juventud Católica como la asociación de San Miguel Arcángel, en Barcelona, promovieron la organización, conjuntamente con la prensa intransigente, de distintas peregrinaciones. Luis Cuenca y de Pessino, católico integrista, presidente de la Juventud Católica y colaborador de El Correo Catalán y de la Revista Popular, no oculta la orientación abiertamente integrista de la Juventud al declarar en 1882: "Esta Juventud Católica os llama de nuevo en la seguridad de ser oídos como siempre que ha levantado pendón por la causa íntegramente católica" (Revista Popular, 1882f, pág. 247). 
aprovechó una vez más de las tensiones provocadas por un acontecimiento de tipo religioso para recuperar la situación con fines políticos. La Revista Popular volvió a afirmar la postura intransigente de los promotores del proyecto: "Que no ha llegado todavía, y esperamos en la misericordia de Dios no llegará jamás, la hora de las concesiones y transacciones, sino que sigue aún [...] la de las a todo trance enérgicas resistencias" (R. Popular, 1882c, pág. 99).

En Enero de 1882, las tensiones entre católicos moderados e intransigentes habían llegado a tal extremo que el Obispo de Tarragona, Benito Vilamitjana, publicó un documento en el que mencionaba la situación de cisma que amenazaba a la Iglesia. Este documento era una advertencia a los integristas y más especialmente a Ramón y Cándido Nocedal, a quienes envió también una carta en la que afirmaba que de ningún modo podían los prelados "aceptar el papel de comparsas que parece ser el que se nos destina"27.

Hasta las publicaciones más moderadas, que querían mantenerse alejadas de la contienda como La Veu de Montserrat, intervinieron para enjuiciar los conflictos promovidos por la prensa integrista y carlista. Jaume Collell, al comparar la Iglesia española a un ejército derrotado, explica a sus lectores que los abusos de la prensa católica imposibilitan cualquier esfuerzo de conciliación de los católicos ( $L a$ Veu, 1882b, pp. 33-34). A partir de 1882 se multiplicaron las advertencias y hasta las amenazas por parte del episcopado con respecto a la prensa intransigente. Algunos obispos como Ceferino González, obispo de Córdoba, constatan que algunas publicaciones intransigentes son tan nefastas para la causa católica como la prensa liberal: "Si todos los periodistas y lectores de periódicos católicos hubieran tenido esto presente no lamentaríamos hoy esa profunda división de las fuerzas cristianas que contrista a los buenos y regocija a los malos" (La Veu, 1882c, pág. 2).

\section{EI "laicismo" en la prensa integrista}

En los años 1881-1882 uno de los problemas más acuciantes a ojos de la Iglesia española, y más particularmente de una mayoría del episcopado, era el "laicismo" de algunos miembros del clero y de muchos católicos seglares que desde la prensa daban y quitaban patentes de catolicismo e interpretaban los documentos pontificios. Varias razones explican la violencia con la que la

26. La junta de Madrid estaba presidida por el obispo integrista de Daulia y por Cándido Nocedal. En ella figuraban Mateos Gago, Antonio Valbuena, Navarro Villoslada y Leandro Herrero. En cuanto a la junta de Barcelona presidida por Luis María de Llauder, se encontraban Sardá y Salvany y Luis Cuenca y de Pessino, entre otros.

27. Esta carta de Benito Vilamitjana era una contestación a Ramón y Cándido Nocedal, que habían pedido a los prelados de varias diócesis que presidieran las juntas de la peregrinación organizadas sin el acuerdo previo de la jerarquía católica (Juan Corominas, 1891, pág. 637). 
corriente integrista, que predomina entonces en el partido carlista, se opone al episcopado catalán y a los católicos moderados. En Cataluña, el fuerte arraigo del sector integrista, que abarcaba a una mayoría del clero, representó un freno constante para los tímidos intentos de adaptación social y política de la Iglesia española a la sociedad de su tiempo ${ }^{28}$. Mientras que con Pío IX los católicos intransigentes se habían beneficiado, en su condena del liberalismo, del apoyo de un poder espiritual, con León XIII la situación es distinta. León XIII aparece, para los integristas y carlistas, como el Papa de la hipótesis ya que considera la libertades modernas como un mal menor. El Pontífice, en varias ocasiones, afirma su rechazo de los católicos que identifican la defensa del catolicismo con un partido político. Con el nuevo Papa la condena del liberalismo sigue tan firme como con Pío IX; pero León XIII incita a todos los católicos a unirse y acudir a las instituciones parlamentarias para estar presentes en la vida política. Las referencias constantes del sector integrista en 1881 y 1882 a Pío IX reflejan su nostalgia de una época en la que se sentían apoyados en su radicalismo religioso. Al no poder oponerse abiertamente a la política religiosa más conciliadora de León XIII, estos católicos "íntegros" se encerraron con inusitada violencia en una postura de obstrucción contra las recomendaciones y orientaciones del episcopado.

Por otra parte, la vitalidad de la prensa intransigente y la abierta colaboración de asociaciones católicas, como la Juventud Católica o San Miguel Arcángel, representaban un eficiente instrumento de movilización de los católicos en pro del integrismo ${ }^{29}$.

Los católicos intransigentes no dejan de referirse constantemente al Syllabus y a Pío IX y proponen una interpretación de los documentos y de las encíclicas de León XIII que favorecía su postura intransigente. En el momento en que se difunde la Cum Multa de León XIII, los carlistas y mestizos utilizaron la encíclica pontificia para reforzar su radicalismo religioso, y la prensa intransigente pasó por alto las orientaciones conciliadoras contenidas en este documento ${ }^{30}$.

28. Varios testimonios de prelados catalanes recalcan el peso del integrismo en Cataluña y la aspereza de los enfrentamientos entre católicos de varias diócesis. Pueden citarse la Pastoral dirigida al clero y fieles de la provincia eclesiástica de Tarragona del 21 de Junio de 1883, B.O.E. del Obispado de Barcelona y que fue firmada por el arzobispo de Vich, los obispos de Lérida, Gerona, Urgel y Tortosa, así como la carta del eclesiástico Eduardo Llanas (Llanas, 1887, pág. 115).

29. Es significativo a este respecto el artículo publicado en la revista integrista La Vespa en 1883, que recalcaba la orientación intransigente de la mayoría de las asociaciones católicas catalanas: "Las asociaciones católicas de vida activa, que tan numerosas son en España y tan buenos frutos producen ¿quién las inspira y anima sino el partido tradicionalista?" (La Vespa, 1883, pág. 2).

30. La prensa integrista y carlista provocó una polémica tan acerba con respecto a la interpretación de la Cum Multa que la Nunciatura Apostólica tuvo que publicar una circular, dirigida a los prelados españoles, para aclarar la postura del Pontífice con respecto a las divisiones de los católicos españoles: "Algunos reverendísimos Prelados de estos Reinos se han dirigido a esta 


\section{La Cum Multa (1882) - recomendaciones de León XIII a los periodistas católicos antes los excesos de la prensa}

La encíclica Cum Multa del 8 de Diciembre de 1882 es un documento de particular importancia por varias razones. Por una parte contiene numerosas referencias a la situación de la Iglesia española y aclara algunas de las causas de los conflictos que dividen a los católicos. Sin lugar a dudas la situación de cisma que afectaba a la Iglesia española preocupa hondamente al Pontífice, que disponía de muchas informaciones acerca de España ${ }^{31}$.

Pero esta encíclica también es importante ya que explicita la postura de León XIII con respecto a la acción religiosa de los católicos y su participación en las instituciones políticas. En la Cum Multa, León XIII condena tanto a los que "suelen no distinguir la política de la Religión" como los que "mezclan e identifican la Religión con algún partido político hasta el punto de tener poco menos que por separados del Catolicismo a los que pertenecen a otro partido" (R. Popular, 1882f, pág. 430). Indudablemente el Papa rechaza a los liberales que quieren la separación del Estado y de la Iglesia, pero también cualquier forma de radicalismo religioso. Al preconizar la concordia de todos los católicos y su intervención en la vida política, León XIII se sitúa en el terreno de la hipótesis y acepta los hechos consumados. La Iglesia y el Estado son dos potestades aparte, cada una con su misión en la sociedad.

En posteriores encíclicas como la Inmortale Dei en 1885 y Libertas en 1888, León XIII volverá a subrayar el concepto de libertad de los católicos reflejado en la Cum Multa. La libertad bien entendida es la tolerancia con respecto a las opiniones políticas de todos en la medida en que no interfieran con la jurisdicción de la Iglesia. Lo que constituye un peligro son los excesos y la libertad utilizada contra la Iglesia. En este aspecto, las referencias a la situación de los católicos son evidentes. La causa del cisma es la negación de la autoridad de la Iglesia y de sus representantes, los prelados, por aquellos católicos que actúan al margen

\footnotetext{
Nunciatura Apostólica exponiendo la postura de sus respectivas diócesis y pidiendo instrucciones en vista de las deplorables divisiones que separan a los católicos españoles y de las ásperas polémicas, las cuales, no obstante los avisos dados por su Santidad en la Sapientísima Encíclica [...] continúan todavía en algunos puntos de España escandalizando a los fieles" (B.O.E., Obispado de Barcelona, 1883, pág. 201.)

31. Para aclarar las relaciones privilegiadas que existían entre la Iglesia española y Roma, cabe tener en cuenta la abundante corespondencia entre el arzobispo de Vich, Morgades y Mr. Palloti, representante de la Curia romana en España. En dos cartas confidenciales dirigidas al Secretario de Estado de León XIII, Morgades analiza los diferentes momentos de la crisis políticoreligiosa española. En su contestación a Morgades, Mr. Palloti le consulta acerca de una posible intervención en España del Papa, mediante una encíclica u otro documento. Sin lugar a dudas el extenso informe enviado por Morgades a Mr. Palloti en Septiembre de 1882 fue una valiosa aportación para León XIII acerca de la situación de los católicos españoles y en el momento de preparación de la Cum Multa.
} 
del episcopado y usurpan su magisterio: "El fundamento de esta discordia es en la sociedad cristiana el mismo que en toda república bien establecida, a saber la obediencia a la potestad legítima, que ora mandando, ora prohibiendo, ora rigiendo, hace unánimes y concordes los ánimos diferentes de los hombres" (lbíd).

Consciente de las graves tensiones que perturban la Iglesia española, León XIII hace una advertencia a los católicos "rebeldes" que no acatan la autoridad del episcopado y al clero que pretenden interpretar los documentos episcopales y pontificios: "[...] No corresponde a su deber el que los sacerdotes se entreguen completamente a las pasiones de partidos, de manera que pueda parecer que más cuidado ponen en las cosas humanas que en las divinas" (Ibíd). Al subrayar el origen de los conflictos, el Pontífice precisa cuál debe ser el papel de la prensa y de las asociaciones católicas. En cuanto a las publicaciones católicas, "deben estar sometidas a los Obispos y hacer grandísima estima de su autoridad y protección” (Ibid, pág. 431).

En anteriores ocasiones el Pontífice había destacado la importancia de la prensa católica para la defensa de los intereses de la Iglesia. Con la Cum Multa, León XIII reconoce la imposibilidad de la prensa católica para organizarse y competir eficazmente con la prensa liberal. Deplora la excesiva politización de muchas publicaciones cuya dimensión militante y polémica agudiza los conflictos y esteriliza cualquier esfuerzo para fomentar una prensa católica estructurada y duradera.

Las directrices moderadas de León XIII contenidas en la Cum Multa no apaciguaron los conflictos que dividían a los católicos. Defraudados por la postura conciliadora del Papa, los integristas se resistieron a corregir los excesos de su actuación política y a moderar la violencia de la prensa intransigente. Con pretexto de la difusión de la Cum Multa, los integristas emprendieron desde la prensa una nueva campaña contra los mestizos. Sin desautorizar abiertamente a León XIII, reclamaron el derecho a defender un catolicismo "puro" que fuese la aplicación del Syllabus.

\section{a. Reacciones de la prensa integrista con respecto a la Cum Multa}

En 1882, el Nuncio Apostólico en España reconocía que la Cum Multa no había logrado resolver la profunda discordia religiosa y que "no obstante los avisos dados por su Santidad, [los conflictos] continúan todavía en algunos puntos de España escandalizando a los fieles".

Los carlistas e integristas no quisieron conceder una importancia desmesurada a la encíclica pontificia y algunas publicaciones como la Revista Popular la publicaron casi sin comentarios. Cuando el episcopado español envió un mensaje de adhesión a León XIII, la Revista Popular publicó una serie de artículos 
en los que exhortaba a los católicos "puros" a seguir "el combate de la vida" con términos que reflejaban el más absoluto radicalismo religioso ${ }^{32}$.

El mismo lenguaje se encuentra en otras publicaciones que, como La Vespa, afirman que la encíclica es una clara condena de los mestizos y que "sólo una bandera es la buena", en este caso, la de los católicos intransigentes. La ofensiva desencadenada por la Revista Popular y La Vespa es alimentada por otras publicaciones intransigentes que como Lo Bon Catolich, acusan al Diario de Barcelona de desnaturalizar la Cum Multa al presentarla como un intento de conciliación por parte de León XIII (Lo Bon Catolich, 1883, pág. 2).

Para la prensa integrista, la encíclica desautoriza a los mestizos y sus publicaciones, "que creían que la Encíclica era una mordaza puesta en los labios de los escritores católicos [...], que creían que éstos podrían continuar haciendo la guerra al partido tradicionalista, sin que éstos se atrevieran a decir esta boca es mía" (Lo Bon Cristiá, 1883, pág. 1).

El sector intransigente parece haber ignorado deliberadamente la censura contenida en la encíclica con respecto al radicalismo religioso. Los acontecimientos posteriores confirmaron la conducta partidista de estos católicos, que preferían referirse a Pío IX más que a León XIII y que siguieron interpretando las pastorales y los documentos episcopales de acuerdo con su credo político-religioso.

De hecho la Cum Multa, que pretendía fomentar la pacífica convivencia de los católicos españoles, fracasó ${ }^{33}$. El incidente del Cardenal Pitra en 1885, que puso de relieve la clara preferencia de los integristas españoles y ultramontanos franceses por Pío IX, el tono triunfalista de la prensa intransigente con ocasión de la publicación de El liberalismo es pecado de Sardá y Salvany en 1884, reflejaron la voluntad de estos católicos de ignorar el cambio de actitud que había empezado a manifestarse en la Iglesia española desde 1878.

\section{b. La publicación de El liberalismo es pecado (1884) agudiza los conflictos de la prensa católica}

La publicación en 1884 de la polémica obra del eclesiástico integrista Sardá y Salvany dio un nuevo impulso al sector intransigente. Publicado por

32. "No hay el recurso aquí de declararse neutral. La ley divina mándale empuñar las armas en su defensa; no hacerlo es y con esto solo declararse del bando contrario. No cabe por lo mismo pensarlo, [...] ni andarse ideando trasacciones" (R. Popular, 15 Marzo 1883, pág. 163).

33. En una Pastoral dirigida al clero y fieles de la provincia eclesiástica de Tarragona, del 21 de Junio de 1883, el arzobispo de Vich, los obispos de Lérida, Gerona, Urgel y Tortosa reconocen el fracaso de las orientaciones conciliadoras de Léon XIII en España y más particularmente en Cataluña: "Ni las venerandas enseñanzas de la Santa Sede, ni las medidas dictadas por los Prelados para conjurar los males de la Religión y de la moral, y restablecer entre los católicos españoles la obediencia jerárquica y la mutua caridad tan quebrantada entre nosotros [...] han dado el resultado apetecido $[\ldots] "$. 
entregas desde 1883 en El Semanario de Tortosa y El Correo Catalán, este opúsculo tenía según palabras de Sardá una finalidad batalladora ${ }^{34}$.

Sin detenernos en un análisis pormenorizado de la polémica suscitada por la publicación de El liberalismo es pecado, nos interesa subrayar la concepción del periodismo desarrollada por Sardá y Salvany en su opúsculo. En 1884, las disputas entre mestizos e intransigentes habían alcanzado su punto álgido. La integración definitiva de la Unión Católica en el sistema político de la Restauración, las medidas tomadas por ciertos miembros del episcopado español contra de los integristas y la intervención del Nuncio de León XIII para corregir algunas interpretaciones confusas y partidistas de la Cum Multa por parte del sector intransigente habían enardecido los ánimos de carlistas e integristas.

La virulencia de la prensa integrista encontró un terreno abonado en los enfrentamientos apasionados desencadenados por el folleto de Sardá. De hecho El liberalismo es pecado ilustraba perfectamente la concepción militante y el papel de movilización de la prensa intransigente.

En su opúsculo, Sardá enunciaba reglas y recomendaciones para desenmascarar a los católicos-liberales y describía los numerosos casos de complicidad liberal (Sardá, 1884, pág. 60). Las alusiones críticas a los miembros del clero que colaboraban en publicaciones liberales constituyeron para Sardá la oportunidad de hacer un ajuste de cuentas con eclesiásticos moderados como Eduardo Llanas, Jaume Collell e Ildefonso Gatell que desde sus respectivas publicaciones denunciaban las campañas integristas.

En la "cruzada" anti-liberal preconizada por el eclesiástico integrista, la prensa se convierte en un instrumento de combate privilegiado. En su apología de la intolerancia, Sardá afirma que al no poder matar al enemigo materialmente, convienen destruirlo "espiritualmente": "Así en guerra justa, como se hieren y matan hombres por el servicio de la patria, se pueden herir y matar hombres por el servicio de Dios" (Ibíd, pág. 80).

No se trata para los periodistas católicos de respetar un estilo académico, ni de proporcionar informaciones de manera neutral. Al utilizar esta nueva "cátedra" que le proporcionaba la prensa, el periodista debe suscitar las pasiones y movilizar a sus lectores: "Sólo se emocionan con la literatura calurosa y encendida y apasionada. No es malo el apasionamiento producido por la santa pasión de la verdad" (Ibíd, pág. 83).

Pese a su total rechazo de mezclar las publicaciones religiosas con asuntos políticos, Sardá reconoce que la prensa debe fomentar en el público una

34. Para un estudio exhaustivo de la publicación de El liberalismo es pecado, y de su alcance en el contexto religioso y político de finales del siglo XIX, ver la excelente aportación de Joan Bonet y Baltá y Casimir Martí en L'integrisme en Catalunya. 
adhesión afectiva y también ideológica. Recalca esta dimensión ideológica de la prensa intransigente a lo largo de varios capítulos dedicados al periodismo católico y compara a los periodistas con "soldados" que se deben luchar en "una guerra sin cuartel" 35 .

Las armas de todo verdadero "soldado" de la prensa son el sarcasmo, la calumnia. Para justificar "las intemperancias del moderno periodismo", Sardá recurre a ejemplos de grandes predicadores "íntegramente católicos" que, para desautorizar al enemigo, no vacilaban en invectivarle y cubrirle de insultos (Ibíd, pp. 84-85).

Es significativo notar la importancia concedida por el autor del opúsculo al lenguaje, ya que "las palabras vienen a ser la fisonomía exterior de las ideas" (pág. 51). No en balde sabían los integristas la importancia de los términos que utilizaban para designar a los católicos moderados. La horrorosa confusión de criterios provocada en la prensa católica por las apelaciones de mestizo, neo, pastelero, transaccionista, pidalista, había hecho aún más difícil la convivencia de los católicos de finales de siglo.

La intolerancia y la violencia reivindicadas por Sardá eran las principales características de la prensa intransigente desde 1875. La publicación de El liberalismo es pecado en 1884 no hizo más que reforzar el radicalismo religioso de muchas publicaciones católicas como El Correo Catalán y las revistas satíricas ya mencionadas. En 1885, con la publicación de un artículo polémico en El Siglo Futuro, referente a las atribuciones religiosas y políticas del Nuncio Apostólico, se organizó una nueva campaña integristas que ilustraba uno de los principios defendidos por Sardá y Salvany, que afirmaba que al combatir el error, la prensa católica tenía el derecho de "encarnizarse en la personalidad del que lo sustenta"36.

\section{La encíclica Inmortale Dei: otra iniciativa por parte del pontífice para acabar con los enfrentamientos entre católicos}

La encíclica Inmortale Dei del 1 de Noviembre de 1885 aparece en un contexto de fuertes tensiones religiosas. La contienda entre integristas y católicos moderados se había agudizado a raíz de la publicación del folleto El liberalismo

35. Estos capítulos son "De la sana intransigencia católica en oposición a la falsa caridad liberal" (XXI); "De la caridad en lo que se llama las formas de polémica [...]" (XXII); "Si es conveniente al combatir el error, combatir y desautorizar la personalidad del que lo sustenta y propala" (XIII).

36. En 1885 un grave acontecimiento protagonizado por la prensa integrista obligó a los representantes del Vaticano en España a intervenir para atajar las polémicas entre católicos. Se trataba de un artículo publicado en El Siglo Futuro del 9 de Marzo de 1885 en el que Francisco María de las Rivas ponían en entredicho la autoridad del Nuncio. 
es pecado (Bonet Martí, pp. 331-389). La denuncia por parte de algunos miembros del episcopado catalán como Morgades, obispo de Vich, de la infiltración de las orientaciones integristas en los seminarios y asociaciones católicas y del papel de cierta prensa católica en las campañas y manifestaciones intransigentes, ponían en evidencia el impacto que tenía el integrismo sobre el clero y los fieles de muchas diócesis. La Inmortale Dei, en la que León XIII planteaba el problema de la actitud de los católicos ante las constituciones y libertades modernas, había sido anunciada por la prensa católica española como un documento contra el liberalismo bajo todas sus formas (Ibíd, pág. 392).

Una vez más un documento pontifico iba a convertirse en fuente de distintas interpretaciones. La Encíclica de 1885, que precisaba los derechos y los fines de la sociedad civil, las relaciones de la Iglesia con la civilización moderna y la libertad "sana y legítima" de los católicos y su derecho de participación en la vida política, fue acogida con regocijo por parte de los católicos moderados, que la consideraban como una confirmación de la hipótesis. Llanas dedicó numerosos artículos a la encíclica que fueron publicados en $E l$ Criterio Católico de Noviembre de 1885 hasta Mayo de 1886. En su glosa de la Inmortale Dei, Llanas subrayaba la importancia concedida por el Pontífice a los principios de caridad y tolerancia y "la honesta diversidad de opiniones" que podía existir entre los católicos.

En cuanto a las advertencias de León XIII a la prensa católica que "se alimenta de polémicas intestinas y cuestiones partidistas", reflejaban para el eclesiástico Eduardo Llanas una condena del sector más intransigente.

Esta lectura de la encíclica también fue la del episcopado español, que envió un mensaje de adhesión a León XIII. Numerosos prelados que habían sido hostigados personalmente por los integristas vieron con la difusión de la encíclica una ocasión para manifestar públicamente su apoyo a la postura tolerante y moderada de León XIII. En el mensaje enviado al Pontífice, el episcopado hacía referencia sin rodeos a las polémicas y contiendas de ciertas diócesis en las que el clero y los fieles confundían la doctrina católica y los asuntos políticos. Denunciaban la arrogancia de la prensa católica intransigente que quería atribuirse el monopolio del magisterio católico:

Ningún periódico, revista, folleto o publicación de cualquier género, sea cual fuere la autoridad que prestarles pueda el nombre de sus respectivos autores, tiene la misión de calificar, y menos de definir, si tal o cual teoría y opinión cabe o no dentro de la doctrina católica (Boletín Oficial Eclesiástico, 1885, pág. 28).

Este mensaje a León XIII fue denunciado por la prensa carlista e integrista como una "manifestación política" por parte del episcopado. Algunas publicaciones como Lo Crit de la Patria y El Correo Catalán afirmaron que la presencia de miembros del episcopado en los funerales de Alfonso XII constituía 
A.L.E.U.A. $/ 10$

una prueba de adhesión a la Regencia. En general la prensa intransigente hizo una interpretación de la encíclica favorable a la postura integrista ${ }^{37}$.

La Inmortale Dei no tuvo el efecto conciliador que esperaba el episcopado. En 1887, Morgades, obispo de Vich, en una circular publicada el 15 de Abril de 1887, reconocía la situación de graves desórdenes que persistía en Cataluña y que podía achacarse en gran parte a la prensa intransigente:

[Cataluña se ha convertido] en un foco permanente de rebelión y discordia, constantemente atizado por una prensa periódica que, confundiendo la insolencia con la intransigencia, fomenta un espíritu de indisciplina tal entre los católicos [...] que si no llega a tiempo el remedio, ha de producir frutos amargos para la Iglesia, como ya está actualmente causando gravísimos perjuicios a la causa de la verdadera restauración social del Reinado de Jesucristo (La Dinastía, 1887).

Sin embargo, ya desde 1885 aparecen las primera brechas en las filas del sector católico intransigente. Anunciadores de la ruptura entre integristas y carlistas en 1888 , los enfrentamientos que se producen en 1885 iban a modificar notablemente el paisaje político-religioso español.

\section{1888-1890: progresiva marginación del integrismo y agotamiento de la prensa católica carlista e integrista}

\section{a. La ruptura entre carlistas e integristas}

La ruptura entre carlistas e integristas en 1888 es la culminación de un largo proceso de exacerbación de las tensiones entre dos orientaciones distintas, presentes en el partido carlista desde 1871 . No es nuestro propósito detallar en estas páginas las divergencias doctrinales y los conflictos personales que motivaron la ruptura. Este período de la historia política-religiosa española merecería por sí solo un estudio exhaustivo ${ }^{38}$.

De 1871 hasta 1885 predominó en el partido carlista la postura de absoluta intransigencia de Cándido Nocedal con la que se había identificado la mayoría de las publicaciones carlistas. Esta radicalización constante del partido y su rechazo de cualquier tipo de participación en la vida política nacional después de 1876 desembocaron, en 1885, en una grave crisis. En esta fecha, la muerte

37. Son significativas a este respecto los artículos Te Deum Laudamus (19 de Noviembre de 1885), pp. 325-328, y Tesis, antítesis y hypótesis (3 de Diciembre de 1885), pp. 358-360 en la Revista Popular.

38. Cabe señalar que esta cuestión ha sido extensamente tratada por Gómez Aparicio en su Historia del periodismo español, capítulo VIII, pp. 311-333. 
de Cándido Nocedal planteó un problema de sucesión que no pudo resolverse inmediatamente. Un sector más moderado del partido carlista abogaba entonces por un cambio de orientación de la política del partido. A la muerte de C. Nocedal, Don Carlos tomó personalmente la dirección del partido. Otro síntoma revelador del cambio que se estaba produciendo fue la reintegración del periódico $\mathrm{La} \mathrm{Fe} \mathrm{(1876)} \mathrm{a} \mathrm{las} \mathrm{filas} \mathrm{de} \mathrm{la} \mathrm{prensa} \mathrm{carlista.} \mathrm{Diario} \mathrm{de} \mathrm{Cataluña,}$ periódico integrista que se empezó a publicar el 27 de Julio de 1888 , y cuyo director era José Pallés y Beltrán, denunciaba la presencia de $L a F e$ como una maniobra del sector carlista moderado ${ }^{39}$.

A partir de aquel momento, El Siglo Futuro y su director Ramón Nocedal, tomando pretexto de los indicios que reflejaban una voluntad de renovación del partido, desencadenaron una verdadera ofensiva contra el sector carlista moderado e, indirectamente, contra Don Carlos. En opinión de El Siglo, Don Carlos, presionado por el sector "acomodaticio", sacrificaba los principios antiliberales e intransigentes que habían regido el partido desde la Restauración. La consecuencia de las campañas de El Siglo Futuro y otras publicaciones integristas como la Revista Popular y Dogma y Razón (1887) fue la carta de Don Carlos enviada desde Gratz el 4 de Junio de 1888 a Ramón Nocedal, en la que se excluía oficiosamente a los integristas del partido.

A principios de Julio de 1888 , el periódico integrista de Pamplona $E l$ Tradicionalista (1886) organizó nuevas hostilidades contra Don Carlos y su partido. En un artículo insultante para los carlistas, El Tradicionalista reivindicaba el término de "tradicionalista" para los católicos que no habían traicionado la doctrina integrista y comparaba el partido carlista con la Unión de Pidal ${ }^{40}$.

Después de la exclusión de El Tradicionalista del partido y de la publicación del Manifiesto a mis leales de Don Carlos, las publicaciones integristas difundieron un documento, Manifestación de la prensa tradicionalista, en Agosto de 1888, muy esclarecedor en cuanto a las divergencias doctrinales entre el carlismo y el integrismo. Este manifiesto de la prensa integrista firmado por 24 publicaciones intransigentes era la primera etapa hacia la constitución del partido integrista.

\section{b. Agotamiento de la prensa integrista}

Desde su ruptura con el partido carlista en 1888 , el sector integrista había entrado en una fase de progresiva marginación. Los datos más esclarecedores a este respecto son los que se refieren a la evolución de la prensa desde 1888 . La mayoría de las publicaciones católicas que se habían adherido a la postura de

39. "Muerto empero D. Cándido Nocedal, cobraron los mestizos nuevos bríos; y aquellos mismos que habían sido integrados por D. Carlos como un puñado de díscolos al desprecio de los leales, lograron penetrar otra vez en las regiones oficiales" (Diario de Cataluña, 1888, pág. 1).

40. Este artículo fue publicado después por Dogma y Razón (1888, pp. 305-306). 
Ramón Nocedal y habían entrado en el partido integrista acabaron por desaparecer progresivamente. La existencia efímera de algunos diarios y revistas que surgieron en Cataluña en los años 1887 y 1888 es significativa con respecto al cometido militante y de "púlpito ideológico" desempeñado por dicha prensa. Pueden citarse el caso de periódicos como El Integrista de Gerona que surgió en 1888 y no pasó de algunos meses. También ocurre lo mismo con El Eco de Queralt (1888) y El Seminario de Bisbal (1888) que tuvieron un breve destello de vida en los momento cruciales de la contienda entre carlistas e integristas ${ }^{41}$. Otras publicaciones como el Diario de Cataluña (1888-1891) desaparecen para resurgir bajo otro título. En cuanto a los diarios y revistas integristas que aparecieron después de 1888, no prolongaron mucho tiempo su publicación. $L a$ Tradición Catalana, que sale a la luz en 1893 dejó de publicarse aquel mismo año. Parece ser que sólo la Revista Popular perduró hasta después de 1900 aunque, a partir de 1888 , su tirada experimentó un fuerte bajón ${ }^{42}$.

Esta evolución de la prensa integrista en general refleja la pérdida de vitalidad del integrismo de 1888 a 1900 . Varios testimonios parecen confirmar este hecho. En una correspondencia confidencial, en 1894, entre el obispo de Vich, Morgades y Mr. Cretoni, Nuncio Apostólico, se advierte que, aunque perduran muchas tensiones entre los católicos, "la ruptura entre los carlistas e integristas disminuyó la intensidad de la lucha [...]. Al no haber ocurrido la división que he significado ya entre carlistas e integristas, estaríamos imponderablemente peor de lo que estamos [...]. El calor ha disminuido gracias a Dios, pero no hay duda que bajo las cenizas hay ascuas"

La constatación final de Morgades al referirse en su carta a la "horrible lucha" que había dividido a los católicos puntualiza que, después de 1888 , la situación había experimentado un cambio importante: "Mi obispado era sin duda uno de los más perturbados; por haber obrado a tiempo en la conformidad expresada, doy gracias a Dios de poder decir con toda verdad que es ahora uno de los más tranquilos [...]. Sin duda que todos no estarán convictos, pero guardan silencio y esto basta para que no haya perturbación".

Otro testimonio es el de Eduardo Llanas. En uno de los últimos números de El Criterio Católico, Llanas admite que el equilibrio de las fuerzas católicas ha cambiado y que por lo tanto ya puede interrumpirse la publicación de la revista: "Nuestro periódico hubo de convertirse en arma de combate y mientras ha sido menester combatir, no hemos faltado a nuestro puesto de honor [...]. Hoy la situación ha cambiado" (El Criterio Católico, 1888, pág. 553).

41. El Semanario de Figueras, El Semanario de Tortosa se publican sólo unos meses.

42. En un editorial titulado Muy importante, el 24 de Diciembre de 1889, Sardá y Salvany reconoce que, desde 1888 , la tirada anual de la revista s6́lo es 7.000 ejemplares.

43. Morgades, Cartas del 7 al 16 de Noviembre de 1894, Seminario de Historia Contemporánea de la Iglesia en Cataluña, dirigido por Joan Bonet i Baltá. 
Por lo que respecta a la prensa carlista, pese a la expulsión en 1888 de muchas publicaciones que se declararon abiertamente integristas, parece que gozaba de cierta vitalidad:

"La prensa [carlista] es importante [...] porque además de los periódicos de la Corte cuenta con varios en poblaciones subalternas, y entre lo propio y copiado, sobra para mantener la rebelión" ${ }^{44}$.

Según datos publicados en el Boletín de Buenas Lecturas de 1904, El Correo Catalán es una de las publicaciones que más suscripciones tiene en las distintas diócesis catalanas, seguida por la revista carlista La Hormiga de Oro, también dirigida por Luis María del Llauder (Boletín de Buenas Lecturas, 1904, pp. 2628).

En 1904, la primera Asamblea Nacional de la Buena Prensa que tuvo lugar en Sevilla recalcó en una de sus numerosas conclusiones la necesidad para la prensa católica de abandonar su protagonismo en las cuestiones políticoreligiosas y su obligación de "hablar siempre con respeto de las personas e instituciones eclesiásticas y religiosas".

A lo largo de la segunda mitad del siglo XIX, la prensa católica fue el reflejo de distintos grupos ideológicos. Utilizada como un instrumento de poder religioso y político por carlistas e integristas, esta prensa tenía una dimensión ante todo militante y combativa. Se benefició de la movilización y colaboración del clero, que en Cataluña se adhería en su gran mayoría al integrismo. Presente y activo en los seminarios y en las asociaciones de católicos, este clero ejerció un notable protagonismo para la difusión del integrismo. Es de notar la colaboración, en dicha prensa, de los políticos católicos que con sus luchas intestinas la transformaron en tribuna política. La prensa católica no sólo refleja las divisiones de los católicos, sino que también las recogía e incluso las agravaba.

\section{BIBLIOGRAFÍA}

Boletín de Buenas Lecturas. 1904. "Nota de las hojas, folletos, libros repartidos y nuevas suscripciones logradas para los periódicos católicos por las juntas de la Buena Prensa y parroquias de nuestra diócesis", Noviembre, pp. 26-28.

Boletín Oficial Eclesiástico del Obispado de Barcelona. 1883. "Instrucciones de la Nunciatura Apostólica a los Prelados de España, pp. 201-208.

44. Correspondencia del 16 de Noviembre de 1894 entre Morgades y Mgr. Cretoni, Archivo del Seminario de Historia Contemporánea de la Iglesia de Cataluña, consultada gracias a la amabilidad de su director, Joan Bonet i Baltá. 
- 1885. "Documentos que los Prelados reunidos en Madrid con motivo de las honras fúnebres que allí se han celebrado por el alma del malogrado Rey D. Alfonso XII dirigen a los fieles de su diócesis", 20 de Diciembre, pp. 28-30.

Bon Catolich, Lo. 1883. "Errores en que ha caído el Diario de Barcelona desde el 10 de Agosto de 1883", 14 de Junio, pág. 2.

Bon Cristià, Lo. 1883. "La mesticería ante la encíclica", 5 de Julio, pág 1.

BONET I BALTÁ, Joan, MARTÍ, Casimir. 1990. L'integrisme en Catalunya. Les grans polèmiques: 1881-1888, Barcelona, Editorial Vicens Vives.

BOZAL, Valeriano. 1979. La Ilustración gráfica del siglo XX en España, Madrid, Alberto Corazón Editor.

CAMPOMAR FORNIELES, Marta. 1984. La cuestión religiosa en la Restauración. Historia de los heterodoxos españoles, Santander, Sociedad Menéndez Pelayo.

Correo Catalán, El. 1882. "Crónica", 9 de Marzo, pág. 2.

COROMINAS, Juan. 1891. Pastorales del Excelentísimo e Ilustrísimo Benito Vilamitjana, Tarragona, Establecimiento Tipográficos de F. Arise.

Criterio Católico, El. 1882. “A nuestros amigos", 3 de Noviembre, pp. 553-554.

Cruz, La. 1881a. "Circular de los representantes de la Unión Católica en Madrid a los Señores Obispos”, pág. 187.

- 1881b. "Contestación del Señor Obispo de Barcelona a los Señores representantes de la Unión Católica", pág. 209.

— 1881c. "Respuesta del Señor Arzobispo de Granada", pág. 215.

- 1881d. "Contestación del Obispo de Daulia a los representantes de la Unión Católica", pág. 317.

- 1881e. "Sesión general extraordinaria de la Unión Católica, celebrada el 28 de Mayo de $1881 "$, pág. 425.

Diario de Barcelona, 1881a. "Correspondencias particulares", 11 de Enero, pág. 443.

— 1881b. "La Unión de los Católicos", 22 de Enero, pág. 960.

- 1881c. "El sentimiento religioso y la pasión de partido", 17 de Abril, pág. 4544.

Diario de Cataluña. 1888, 13 de Agosto, pág. 1.

Dinastía, La. 1887. "Un documento notable", 15 de Abril.

Dogma y Razón. 1888. "Cuenten con nosotros", 10 de Julio, pp. 305-306.

GÓMEZ APARICIO, Pedro. 1971. Historia del periodismo español, Madrid, Editora

Nacional, vol. I. 
LLANAS, Eduardo. 1887. Exposición a León XIII acerca de la actual crisis religiosa por varios católicos españoles, Barcelona, Tipografía de la Casa Provincial de Madrid.

LLAUDER, Luis María de. 1882. "Justicia y Paz", El Correo Catalán, 19 de Marzo, pág. 3.

Revista Popular. 1881. "Crónica general", 17 de Febrero, pág. 119.

- 1882a. "Muy importante", 12 de Enero, pág. 21.

- 1882b. "La próxima peregrinación", 26 de Enero, pág. 54.

- 1882c. " "A Roma, a Roma!”, 16 de Febrero, pág. 99.

- 1882d. "Nuestros centenarios", III, 3 de Agosto, pág. 65.

- 1882e. "Nuestros centenarios", IV, 10 de Agosto, pp. 81-82.

- 1882f. "Obispado de Barcelona", 12 de Octubre, pág. 247.

- 1883. "El combate de la vida", 15 de Marzo, VI, pág. 163.

SÁNCHEZ DE TOCA, Joaquín. 1885. Ensayo sobre política y religión, Madrid, Imprenta de F. Maroto e Hijos.

TORRAS I BAGES, Joseph. 1934. Obres Completes, Barcelona, Biblioteca Balmes.

- 1948. "El clero en la vida social moderna", Obres Completes, Barcelona, Biblioteca Perenne, pp. 1687-1737.

Vespa, La. 1882a. "El cisma", 26 de Abril, pág. 1

- 1882b. "Al pan, pan, y al vino, vino", 14 de Junio, pág. 2

- 1882c. "Manyas y flaquesas", 29 de Diciembre, pp. 1-2

- 1883. “Los católicos, ¿dónde están?” 23 de Marzo, pág. 2.

Veu de Montserrat, La. 1881a. "Tornemhi", 8 de Enero, pág. 1.

- 1881b. "Bandera blanca", 12 de Febrero, pág. 42.

- 1882a. "¿Por qué nos aprendemos?”, 21 de Febrero, pág. 17

- 1882b. "Calma y coraje", 14 de Febrero, pp. 33-34.

- 1882c. "Pastoral del Obispo de Córdoba", 25 de Febrero, pág. 50.

- 1882d. "Reglas de conducta cristiana...", 8 de Abril, pp. 108-109. 


\title{
TERRITORIOS DE LO EXÓTICO EN LAS LETRAS ESPAÑOLAS DEL SIGLO XVIII
}

\author{
Francisco LAFARGA \\ Universidad Pompeu Fabra
}

Antes de entrar en materia resultará útil referirse a las definiciones contenidas en distintos diccionarios.

El de la Real Academia española dice en exótico: "1. Extranjero, peregrino, especialmente si procede de un país lejano. /2. Extraño, chocante, extravagante". En el Diccionario ideológico de Julio Casares puede leerse en la misma voz: "Extranjero, peregrino, de origen extraño y aún no aclimatado o admitido en el país de importación". La voz exotismo no ha sido admitida por la Academia hasta fecha reciente, e incorporada en la última edición (1992) del diccionario con estas definiciones: "1. Cualidad de exótico. / 2. Tendencia a asimilar formas y estilos artísticos de un país o cultura distintos de los propios". Anteriormente los sustantivos admitidos eran exotiquez y exoticidad. María Moliner recoge en exótico: "Se aplica a lo que procede de un país extranjero. También a lo que resulta extraño y tiene aspecto de extranjero".

Estas definiciones introducen matices no exentos de consecuencias: estamos en el terreno de los nacionalismos, de las literaturas nacionales, en el de los escritores no aclimatados o mal admitidos, en el de los marginales. Con todo, tomada al pie de la letra, alguna definición podría no ser de aplicación a lo literario, cuando de escritura o literatura exótica se trata, ya que en ella lo extraño o extranjero no puede decirse que no esté aclimatado, pues no sólo está aceptado dentro de la obra, sino que forma parte consustancial de la misma. Ahora bien, tal afirmación es válida dentro de la propia obra, ya sea literaria o

1. Algunos diccionarios franceses (Robert, Larousse), ampliando el campo, establecen el límite en el ámbito de la cultura occidental. 
artística, aunque el valor "extraño" continúa presente y activo para lo que está fuera de ella, para el lector o el observador.

Lo exótico puede concebirse también como un secreto de toda literatura, como fuente de misterio, con capacidad de producir el interés del lector y mantener la tensión de la lectura. Por eso, la representación del extranjero o de lo extranjero en la literatura, en ocasiones la instituye y constituye como tal (véase Fernández Cardo 1989).

La concepción del exotismo ha tenido distintas direcciones y presenta diversos matices.

En algunos autores consiste fundamentalmente en el deseo de describir un país distinto del propio, ya sea basándose en elementos reales, vividos por el propio escritor o debidamente documentados, o ya utilizando nociones convencionales, nutridas de estereotipos e ideas preconcebidas.

En otros casos lo que mueve al escritor es el deseo de aventura, el ansia de huida o la búsqueda de la felicidad.

También puede estar animado por un intento de conocimiento, de descubrimiento de nuevos paisajes, de modos de vivir distintos, en suma, por un nuevo humanismo.

Visto desde un prisma estrictamente literario, el exotismo es un procedimiento que se ha utilizado como ornato por el agradable colorido que aporta o por la variedad que produce; su presencia en este sentido ha sido más notable a partir del Romanticismo.

Se ha utilizado asimismo para la demostración de una tesis o como tapadera para la crítica social y filosófica. Tal uso, como es sabido, tuvo sus mejores expresiones durante el siglo XVIII.

Finalmente, se da también un exotismo exacto, realista. Es el de los viajeros cuando son escritores de talento: Chateaubriand, Flaubert, Loti. Hay en estos autores una búsqueda de sensaciones más intensas, de emociones más fuertes que las que podían experimentar en sus círculos habituales. Con todo, como escritores que son llevan a cabo una selección de lo que ven, una elaboración "literaria" de sus experiencias, con lo cual se distinguen de los autores de relatos de viajes que son simples viajeros.

Tal vez sea difícil, si no imposible, hablar de literatura exótica como expresión caracterizada, definida de una actitud del escritor ante un objeto determinado. Es más cómodo, y más acorde también con la realidad, referirse a presencias de lo exótico en la literatura o a los "territorios" de lo exótico. Además, interviene aquí la cuestión de los límites que se quieran dar a la "literatura" o a lo "literario". Conviene saber si, aparte de los grandes géneros tradicionales, debemos o podemos considerar literatura los libros de viajes o la 
prensa, por ejemplo. A nadie se le oculta que el exotismo tiene en el relato de viaje su lugar natural, aunque el autor (no necesariamente escritor) no se proponga incidir en una vena exótica.

Hay otros límites a tener en cuenta: la propia frontera de lo exótico, es decir, saber dónde empieza lo "extranjero", lo "peregrino" y dónde termina lo nacional o lo habitual. Creo que lo exótico es, por naturaleza, subjetivo y cambiante; y parece que no hay que adoptar una interpretación tajante y restrictiva, que consideraría exótico todo lo extranjero. Porque, además, esa interpretación lleva de la mano otra no poco ardua: ¿qué es lo nacional? La respuesta a tal interrogante debería barajar aspectos geográficos, lingüísticos, raciales, políticos. Aun a riesgo de limitar el campo, o tal vez para delimitarlo, sería partidario de considerar exótico aquello que no pertenece al ámbito cultural amplio del país en que se analiza el fenómeno: en este caso, lo que se halla fuera del ámbito europeo. Pero, se me dirá: ¿qué era Europa en el siglo XVIII? ¿De qué Europa se trata?

Por otro lado, el concepto o, mejor dicho, el grado de exotismo puede variar de una época a otra. Es cierto que las facilidades actuales para viajar, unidas a una mayor difusión de todo lo extranjero, hacen que cada vez resulte más difícil sorprender a un público medianamente culto. Ya a mediados del siglo XIX, el escritor francés Xavier Marmier se lamentaba de la pérdida de prestigio de los viajeros:

Adiós a los vagos prestigios con que uno se cubría al regreso de lejanas regiones. Ya no quedan regiones lejanas. Se va usted a pasar varios meses al campo. Regresa a París al mismo tiempo que la gente de mundo... Durante el poco tiempo que Vd. los ha dejado, éste ha cruzado el Sahara, aquél ha ido a ver las ruinas de Tebas o los palacios de Granada o las orillas del Neva. El que sólo ha ido a Alemania permanece humildemente a un lado y no se atreve a decir ni una palabra de una excursión tan cortita. ¿Adónde habrá que ir, Dios mío, para poder decir que se viene de lejos? ¿No se va en veinte días a Suez a Bombay, en tres semanas de Londres a Nueva York, y con los barcos transatlánticos no se irá también en pocas semanas de Burdeos a México? De México al cabo de Hornos no hay más que un paso. Con una hélice y varias toneladas de carbón se soluciona el asunto... Sin duda alguna nuestro globo se ha quedado demasiado pequeño... pronto ya no habrá viajes extraordinarios ${ }^{2}$.

2. “Adieu les vagues prestiges dont on était paré au retour de régions lointaines. Il n'y a plus de régions lointaines. Vous vous en allez passer quelques mois à la campagne. Vous rentrez à Paris au temps où les gens du monde y reviennent... pendant la peu de temps que vous les avez quittés, celui-ci a traversé le Sahara, cet autre a été voir les ruines de Thèbes ou les palais de Grenade, ou les rives de la Néva. Celui qui n'a été qu'en Allemagne se tient humblement à l'écart et n'ose dire un mot d'une si petite excursion. De quel côté se tourner, grand Dieu! pour pouvoir dire qu'on vient de loin? Ne va-t-on pas en vingt jours de Suez à Bombay, en trois semaines de Londres à New York, et avec les bateaux transatlantiques n'ira-t-on pas de même en quelques semaines de Bordeaux au Mexique? Du Mexique au cap Horn il n'y a qu'un pas. Une hélice et quelques tonnes de charbon en feront l'affaire... Décidément notre globe est trop petit... bientôt il n'y aura plus de voyages extraordinaires": X. Marmier, Du Rhin au Nil, París, 1846, vol. II, págs. 2-3; cit. por Jourda, pág. 22 nota 1. 
Cabría, finalmente, plantear otro tema: el de la presencia de lo exótico en las distintas épocas o períodos literarios. ¿Existen épocas privilegiadas, en las que el grado o la carga de exotismo, si podemos hablar en términos cuantitativos, es mayor que en otras? La respuesta es, pues así lo demuestra la historia, afirmativa. El siglo XIX y, en particular, el Romanticismo, por distintas razones (gusto por el color local, ansia de huida), aparecen más impregnados de exotismo que cualquier otra época. Pero eso no significa que en épocas anteriores lo exótico estuviera totalmente ausente de la literatura. No parece llevar mucha razón Gérard de Nerval cuando escribe en su Voyage en Orient, de 1851:

Ha habido tiempos en los cuales no han existido impresiones de viaje [...]. Es posible, pues, viajar sin mirar, o bien mirar sin ver. Fue preciso que Bernardin de Saint-Pierre viera los extraños paisajes de América y de las Indias para crear, de algún modo, el color local [...]. Pues bien, el propio Bernardin de Saint-Pierre sólo encuentra admiración para los árboles y las flores; vio Italia, Flandes y Alemania sin notar más que ciudades bien o mal trazadas ${ }^{3}$.

Ignoraba Nerval los relatos medievales, de los que bastará recordar El millón de Marco Polo, así como los numerosos textos redactados en el siglo XVI, época de descubrimientos, de apertura de horizontes, de choque de razas y culturas. En este contexto, España, tanto por su itinerario histórico como por su situación geográfica, se hallaba en una posición bastante peculiar respecto del resto de los países de su entorno cultural.

Sin tender a considerar aquello de que "África empieza en los Pirineos" (pues de todos es sabido que empieza al otro lado del estrecho de Gibraltar), lo cierto es que la península se halla en una situación privilegiada para los contactos entre Europa y los países musulmanes del norte de África. Por otra parte, no está de más recordar los siete siglos de permanencia de árabes o norteafricanos en España, que dejaron innumerables huellas en la lengua, la toponimia, la literatura y el arte, y no sólo en la corona de Castilla.

Por ello, al tratar de exotismo, y sobre todo de exotismo oriental, parece como si en el caso de España los límites fueran todavía más imprecisos. No quiero decir que en la España del siglo XVIII se tuviera perfectamente asumido o asimilado lo oriental o parte de ello, grosso modo de Arabia para acá: D. Pelayo, las Navas de Tolosa e incluso la toma de Granada quedaban ya bastante lejos. Sin embargo, los musulmanes, los moros, formaban parte de la historia de España, de las luchas por la expansión hacia el sur de los nacientes reinos

3. "Il y a eu des temps où l'impression de voyage n'existait pas. [...] Il est donc possible qu'on voyage sans regarder, ou bien qu'on regarde sans voir. Il a fallu que Bernardin de SaintPierre vit les étranges paysages de l'Amérique et des Indes pour créer en quelque sorte la couleur locale. [...] Eh bien, Bernardin de Saint-Pierre lui-même ne trouve d'admiration que pour les arbres et pour les fleurs; il a vu l'Italie et la Flandre et 1'Allemagne sans y remarquer autre chose que des villes bien ou mal bâties": G. de Nerval, Voyage en Orient, París, Calmann Lévy, 1883, t. II, págs. 438-440, cit. por Jourda 1938, pág. 17. 
cristianos, y también de la simbiosis cultural que se fue gestando durante aquellos siglos.

Cabría, con todo, establecer una diferenciación entre el musulmán que forma parte de la historia de España o, si se quiere, de Al-Andalus y el otro, el del norte de África, de Egipto o de Arabia. Todos pueden ser considerados desde el mismo prisma, pero el grado de exotismo, de extrañeza es distinto.

Otro tanto podría decirse de lo americano, lo hispanoamericano. Quedaba ya lejos 1492, con el choque de dos culturas, de dos mundos, el acceso a lo desconocido, a lo imprevisto. Se habían multiplicado durante los siglos XVI y XVII los testimonios de descubridores, conquistadores, colonizadores $\mathrm{o}$ evangelizadores. Viajeros y cronistas primero, literatos más tarde, habían integrado lo americano al acervo común.

Parece que en el siglo XVIII los españoles viajaron menos que otros europeos, y pocos fueron los viajeros que dejaron constancia escrita de sus experiencias. Eso hace que la literatura de viajes sea relativamente limitada: cierto es que hay textos por estudiar, incluso por descubrir. De los conocidos, la mayoría tuvieron como meta algún país europeo, Francia sobre todo, aunque también Inglaterra e Italia. Los que se dirigieron al continente americano tuvieron normalmente por objetivo alguna misión científica, aunque los relatos de los mismos contienen también indicaciones correspondientes a las gentes y a las culturas.

De la expedición que Jorge Juan y Antonio de Ulloa, en compañía del francés Godin, realizaron entre 1735 y 1744 al Perú para medir un arco de meridiano terrestre y conocer con exactitud la forma de la Tierra ha quedado una Relación histórica del viaje a la América meridional (Madrid, A. Marín, 1748). Años más tarde, en 1767, el mismo Jorge Juan realizó como embajador un viaje a Marruecos, aunque el diario del mismo no se publicó hasta principios del siglo XIX (Madrid, s.i., 1816). Casi diez años (1777-1787) estuvieron investigando en el Perú los botánicos José Pavón e Hipólito Ruiz: el resultado de sus esfuerzos fue, entre otras obras, una monumental Flora peruviana et chilensis (Madrid, G. de Sancha, 1798-1802, 3 vols.). Con todo, la más famosa de las expediciones españolas fue el viaje alrededor del mundo realizado entre 1789 y 1794 por Alejandro Malaspina y José Bustamante, con visitas a todas las colonias españolas de Ultramar. No pasaron por Tahití, isla que durante cuatro años (1772-1776) fue llamada por los españoles Isla de Amat, en homenaje al virrey del Perú que ordenó distintas expediciones, logrando incluso que los jefes nativos reconocieran por soberano a Carlos III. Los diarios de a bordo y las descripciones de los lugares visitados se publicaron a finales del siglo XIX con el título Viaje político-científico alrededor del mundo (Madrid, Vda. e hijos de Abienzo, 1885) ${ }^{4}$.

4. Sobre estas expediciones puede consultarse AA.VV. 1989 (obra rica en información e iconografía), así como la bibliografía crítica recogida por Aguilar Piñal 1988, págs. 282-286. 
Los Viajes de Ali Bey por África y Asia merecen un momento de atención. Se trata de un caso bastante particular, pues implica una transformación del individuo, un cambio de personalidad. Domingo Badía, empleado del monopolio de Tabacos, arabista autodidacta, profundo conocedor del mundo musulmán, emprendió en 1803 un largo viaje (financiado al parecer por el príncipe de la Paz) que, durante cinco años, iba a llevarle de Madrid a La Meca, pasando por Marruecos, Trípoli, Chipre; Egipto, Palestina, Siria y Turquía. Para tal periplo, después de haberse hecho circuncidar, asumió la personalidad del príncipe Alí Bey el Abasí, hijo de Otmán. Como dice en la introducción:

Después de haber empleado tantos años por los estados cristianos estudiando en sus escuelas las ciencias de la Naturaleza y las artes útiles al hombre en el estado de sociedad, sea cual fuese el culto o religión de su corazón, tomé en fin la resolución de viajar por los países musulmanes, y cumpliendo al mismo tiempo con el sagrado deber de la peregrinación a La Meca, observar las costumbres, usos y naturaleza de las tierras que se hallasen al paso, a fin de no hacer inútiles las fatigas de tan larga travesía, y sí provechosas a mis conciudadanos en el país que escoja finalmente por patria (Véase Badía 1986, I, págs. 15-16).

Habiendo regresado a España tras su viaje, sirvió a José Bonaparte, por lo que hubo de abandonar el país con los franceses. Y su libro se publicó primero en París y en francés (1814), y aun en inglés e italiano antes de ver la luz en español $(1826)^{5}$. La riqueza de su relato es impresionante, pues a las detalladas descripciones se unen mapas y dibujos de su propia mano sobre monumentos visitados o curiosidades vividas. Para Juan Goytisolo, en el prólogo a una edición reciente de los Viajes:

La variedad y soltura de la narración, el acopio de datos etnológicos, científicos y geográficos, el rigor y exactitud con que describe las ceremonias sagradas, lo estupendo de algunos episodios y aventuras le otorgan un puesto privilegiado y a veces único en esta pléyade de aventureros, exploradores, misioneros y agentes coloniales que [...] adopta ese peculiar sistema de l'éducation par le voyage que tanta aceptación tuvo entre los escritores románticos, mezclando los móviles políticos y profesionales con una querencia personal a los modos de vida árabes y una íntima fascinación por el Islam (Véase Badía 1986, I, pág. XI).

Otro aspecto no desdeñable hay en el texto: una postura de rechazo de la sociedad mercantilista o industrial y la busca de una autenticidad primitiva.

El interés por los relatos de viajes hizo sin duda que se publicaran antiguos periplos, como el primer viaje alrededor del mundo de Magallanes y Elcano, dado a luz en 1769 por el médico y botánico Casimiro Gómez Ortega. El jurista Llaguno y Amírola publicó también la Historia del gran Tamorlán (Madrid, A. de Sancha, 1782), con el relato de la embajada enviada por Enrique III de Castilla.

5. Véase para las ediciones, así como para los estudios sobre esta obra, Aguilar Piñal 1981, I, págs. 483-484. 
Otros relatos de viajes o descripciones de lugares recónditos procedían de otras lenguas. Así, el Imperio de Osmán, comúnmente llamado Otomano (1785), traducido del alemán Busching, a través del francés; o el Viaje al interior de la China y Tartaria hecho por el embajador del rey de Inglaterra a finales de siglo ${ }^{6}$. Es original, descripción de la embajada que Carlos III envió al sultán con numerosos regalos, el Viaje a Constantinopla en el año 1784 de José Moreno (Madrid, Imprenta Real, 1790), que cuenta, según anuncio aparecido en la Gaceta, "los usos más notables del país, las costumbres de sus gentes, el sistema de su gobierno, su constitución política y militar", e incluye una veintena de grabados. También original es la Idea del imperio otomano (Madrid, Sancha, 1793) que el capitán de fragata José Solano, hijo del marqués del Socorro, redactó en su viaje a Constantinopla de 1787.

Los periódicos de la época ofrecían noticias y comentarios sobre viajes o descripciones de países lejanos. Una de las primeras menciones que he encontrado aparece en el Diario curioso, histórico, comercial, público y económico de Barcelona de 3 de Abril de 1762: se trata de la descripción de la "mezquita mayor del Gran Turco". El Correo de Madrid (1786-1791)7 insertó también varias descripciones de lugares y artículos históricos: sobre Tamerlán o Tamorlán, emperador mogol, dentro de una serie en la que figuraban Filipo de Macedonia, Mecenas, Tomás Moro o el Tasso, por ejemplo; sobre el heroísmo de Murad, gran visir del sultán Ahmet I. Sin embargo, predominan en este periódico los cuentos y apólogos orientales (El envidioso, El juez prudente, Hamet y Raschid, Medio de resucitar los muertos, La reina de Goa, El testamento); en este sentido, cabe decir que el Diario de Madrid fue uno de los primeros en dar ejemplo con la publicación, entre Junio y Julio de 1759, de la traducción o, mejor dicho, de la adaptación de Zadig, el célebre cuento volteriano (véase Guinard, 1958).

En otros casos (y volviendo al Correo), el decorado oriental sirve de excusa a la sátira, como la burlesca Idea de un escrito en forma de diccionario propuesto por un abate del Japón, o la Carta de un viajante chino a un amigo suyo de Pekín, sobre la injusticia. Algunos textos tienen asimismo una dimensión crítica, como la Noticia de los harenes y serrallos y el Paralelo de la suerte feliz o desgraciada entre las mujeres asiáticas y africanas y las europeas.

Resueltamente cosmopolita, el Espíritu de los mejores diarios literarios que se publican en la Europa (1787-1791) no podía dejar de insertar artículos o comentarios referidos al Oriente, pues éste ocupaba un lugar privilegiado en los periódicos extranjeros (véase Varela 1966). Los textos suelen ser más técnicos que los que aparecían en el Correo. Así, pudieron leerse en sus páginas un resumen de la religión y de la moral de los indios (Bhaguat Geeta o Diálogo de Kroesha y de Arjou), una Descripción de una fiesta religiosa en la costa de

6. Se publicó en Madrid, en 1798, traducido por María Josefa Luzuriaga.

7. Véase el vaciado del periódico en Iglesias y Mañá 1968. 
Malabar, una Noticia de la isla de Ceilán, reseñas de varios relatos de viajes ingleses y franceses, así como del libro de J.B. Toderini sobre la literatura de los turcos. Pareció también interesante relatar la embajada del príncipe de Cochinchina a la corte de Luis XVI. No siempre la mirada se dirigía al Este: prueba de ello son unas Reflexiones sobre los hotentotes. Son escasas las obras que pueden considerarse de creación: alguna fábula y varias anécdotas, como la que recoge la orden del emperador chino Kim Long, que mandaba premiar a todos los ancianos respetables.

Anecdótica, aunque vivida por muchos madrileños, fue la llegada a la corte de una embajada del sultán, que traía originales regalos para Carlos III:

Vienen para S.M. doce dromedarios, que es una especie de camello salvo que tiene dos gibas, cargados cada uno con arcas de cedro [...] en que vienen muchas piezas de estrofa, paños, especies y aromas de Asia. Un hermosísimo elefante asiático de 38 años, tan diestro y bien disciplinado, que al son del laúd hace en dos pies diferentes mudanzas de baile tudesco. Para cuidar de este elefante vienen dos lacayos o mozos de caballerizas. Estos mozos vienen con sus mujeres e hijos, que son todos bellísimas criaturas. Conducen asimismo en dos grandes jaulas dos grandes caimanes nilóticos, fieras jamás vistas en Europa, las cuales, aunque son por naturaleza muy feroces, estos están domesticados y se dejan manosear y meter el brazo en la boca [...]. Asimismo envía el sultán doce caballos de la Morea con todos sus jaeces bordados primorosamente en oro y plata, y con cada uno viene de regalo un jenízaro, que es una especie de soldado valientísimo $[\ldots]$ vestido riquísimamente a la turca, con sus cimitarras, fusiles, pistolas y demás armas con guarniciones de oro labradas en Persia. Vienen también de regalo para S.M. seis doncellas georgianas hermosísimas, muy blancas y fornidas, vestidas a la persa [...]. Para custodia y resguardo de estas hermosas doncellas vienen doce eunucos esclavos, que también vienen de regalo. Poseen el arte de la música y cantan maravillosamente con voz atiplada ${ }^{8}$.

Parece que lo que más llamó la atención popular fue el elefante, pues poco tiempo después Ramón de la Cruz hizo representar un divertido sainete, El elefante fingido, en el que, precedidos por la fama del animal, unos gitanos simulan uno de trapo para conseguir unas monedas en los pueblos que visitan ${ }^{9}$. En los periódicos de los últimos meses de dicho año se anunció la venta de folletos y grabados que representaban elefantes ${ }^{10}$, y el fabulista Iriarte escribió en Enero de 1774 una epístola a su amigo Cadalso en la que se hacía eco de la visita:

8. Texto citado por Bravo Morata 1972, págs. 79-81, sin indicar la fuente.

9. Permaneció inédito hasta su publicación en Cruz 1915, II, págs. 323b-329b.

10. Así: Descripción del elefante, con su alimento, costumbres, enemigos e instinto; y explicación del uso que se hace de los elefantes, modo de cazarlos y utilidades de sus colmillos en la Medicina y en las Artes: con la estampa y noticias circunstanciadas del que se ha remitido de Manila para el Rey nuestro señor (anuncio de la Gaceta de Madrid de 7 de Septiembre de 1779, n. 36, pág. 320), - la Estampa de marca mayor que representa el elefante, copiado del natural, y su esqueleto; el rinoceronte o abada, y la historia natural de uno y otro, con noticia del elefante y rinoceronte que hubo en esta corte en tiempo del rey D. Felipe II (anuncio de la Gaceta de 7 de Diciembre del mismo año, n. 49, pág. 428). Nótese la utilización comercial de acontecimientos anteriores. 


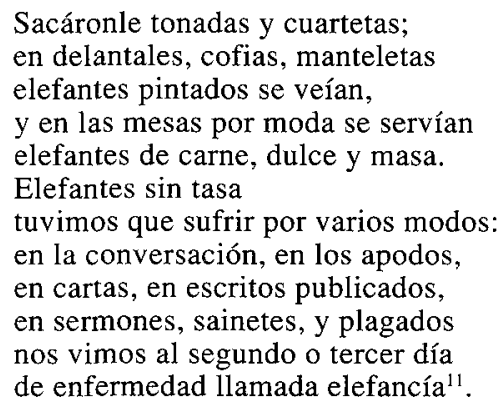

La literatura de creación adoptará, también en España, ambientes o personajes exóticos para la expresión de una sensualidad o de una crítica social.

Parte de la literatura narrativa procedía del extranjero, usualmente a través de textos franceses. En el catálogo establecido por Fernández Montesinos podemos hallar títulos representativos, algunos de ellos de aparición tardía en castellano: Las mil y una noches de Galland (París, 1838), las Cartas persas de Montesquieu por Marchena (Nîmes, 1818), Gonzalo de Córdoba o La conquista de Granada de Florian por Juan López de Peñalver (Madrid, 1794), Viajes de Antenor por Grecia y Asia de Lantier (Madrid, 1802, 3 vols.), Pablo y Virginia de Bernardin de Saint-Pierre por José Miguel de Alea (Madrid, 1798) y El inglés en la India o La cabaña indiana del mismo autor (Salamanca, 1803), los Viajes del capitán Lemuel Gulliver a diversos países remotos de J. Swift por Ramón M. Espartel (Madrid, 1793, 3 vols.) $)^{12}$, a los que habría que añadir las Cartas de una peruana de Mme de Graffigny, traducidas por Marta Romero Masegosa (Valladolid, 1792).

El carácter crítico o/y erótico de algunas obras no pasó inadvertido a la Inquisición, que prohibió, entre otros, los siguientes relatos: Lettres persanes, Lettres chinoises, Lettres juives, Lettres d'une Péruvienne, Le sopha, Angola, Robinson Crusoe, Les mille et une heures (véase Defourneaux 1973).

El Consejo de Castilla tampoco concedió la necesaria licencia de impresión a Ramón Bonifaz para editar su Viaje de Roberto Montgolfier al país de las antípodas de la Nueva Zelanda. Vieron la luz, sin embargo, algunos otros textos más o menos utópicos, como los Viajes de Enrique Wanton a las tierras incógnitas australes y al país de las monas (Alcalá-Madrid, 1769-1778): de los cuatro volúmenes de que constaba, los dos primeros eran traducidos de Zaccaria Seriman, mientras que los dos restantes eran originales del traductor, Gutierre Joaquín Vaca de Guzmán. Siguiendo el ya conocido expediente del naufragio y

11. Cit. por Cotarelo 1897, págs. 133-134; compuso también Iriarte un soneto y dos décimas al mismo asunto, publicados en AA.VV. 1952, 2, págs. 51 y 60.

12. Todas estas traducciones aparecen mencionadas en Fernández Montesinos 1966. 
del arribo a una isla, se suceden en la obra lances y aventuras, acompañadas de la crítica de la sociedad (véase Escobar y Percival 1984).

Más plenamente utópico resulta el breve relato sobre las costumbres de un pueblo imaginario, los Ayparcontes, inserto en tres "discursos" (el 61, el 63 y el 75) de El Censor de 1783: utopía religiosa que tiene por finalidad realizar una profunda crítica del clero, describiendo la sociedad de un país desconocido situado, una vez más, en tierras australes, de una isla a la que, una vez más, llega un viajero tras naufragar.

Vieron la luz también en las páginas de los periódicos dos textos novelescos en forma de cartas, pertenecientes a dos de los mejores autores del siglo: Cadalso y Meléndez Valdés.

Las Cartas marruecas estaban ya listas en 1774 y el manuscrito presentado al Consejo de Castilla para su aprobación: a pesar de obtenerla, su autor no las publicó en su día y, de hecho, murió sin ver cumplida la empresa. Aparecieron entre Febrero y Julio de 1789 en las páginas del Correo de Madrid, y cuatro años más tarde fueron publicadas formando volumen.

Respondían a un esquema de cierto prestigio en Europa: se ha hablado ya tanto de sus relaciones formales y temáticas con las Cartas persas de Montesquieu que es superfluo evocarlas aquí ${ }^{13}$. Con todo, hay un punto que me interesaría poner de relieve: la conciencia que tenía Cadalso de que el procedimiento que pensaba utilizar no era original y su deseo de dar visos de verosimilitud a su texto. "Sería increíble el título de cartas persianas, turcas o chinescas, escritas desde este lado de los Pirineos", dice en la introducción, y tenía razón, pues las relaciones entre España y aquellos países eran prácticamente nulas.

Muy distinto era el caso de Marruecos, vecino de España, con quien se intentaba mantener buenas relaciones. Había causado sensación, en 1766, la visita a España de Sidi Hamet al Ghazzali, embajador del emperador marroquí: folletos, grabados, noticias en la prensa nos informan del fasto de su séquito y de los honores con que fue recibido en las distintas ciudades que visitó. El protagonista de las Cartas marruecas es precisamente Gazel, miembro del séquito de un embajador marroquí que solicita quedarse en España para conocer mejor el país ${ }^{14}$.

Menos célebres que las marruecas son las Cartas turcas (o Cartas de Ibrahim) de Meléndez Valdés, que tienen su origen precisamente en un deseo de continuar y completar las de su amigo Cadalso, ya fallecido. Así se desprende de la solicitud de impresión remitida al Consejo de Castilla: aunque éste no puso reparos a la publicación, las cartas no se imprimieron nunca en forma de libro

13. Véanse, entre otros, Bremer 1971, Cotton 1931, Huges 1969, y Laborde 1952.

14. Véase el prólogo de Cadalso 1966. 
y su original desapareció. Sólo vieron la luz las dos primeras, en sendos periódicos: la carta de Ibrahim en Madrid a su esposa Fátima en Estambul en el Diario de Madrid de 10 de Diciembre de 1787, y la respuesta de Fátima en el Correo de Madrid de 19 del mismo mes. Lo que en ellas se dirime es la cuestión de la distinta situación de la mujer en España y Turquía, la educación que debe recibir, la libertad de que puede o debe gozar. Esta idea había aparecido ya en las Cartas persas (que tienen un personaje "contado" de nombre Ibrahim), aunque no expresada de modo tan directo como aquí, en que Fátima sale en defensa de la autonomía de la mujer frente al hombre de modo general... aunque declarando su fidelidad y sumisión a Ibrahim. Algo, sin embargo, parece estar fraguándose en el lejano harén, bajo la aparente calma de unas esposas resignadas. Desgraciadamente, no podemos saber por ahora la continuación (véase Deacon 1981, que incluye el texto de las cartas).

El disfraz chino le sirvió a Juan Pablo Forner para lanzar una violenta sátira contra su enemigo Tomás de Iriarte, titulada Los gramáticos. Historia chinesca. La obra se redactó en el verano de 1782 y el autor pidió licencia para publicarla, pero le fue denegada por considerarla un libelo infamatorio, al parecer por presiones del propio Iriarte y de su hermano Bernardo, ambos muy influyentes en la Corte. Sea como fuere, el tex to quedó inédito hasta 1970, año en que aparecieron dos ediciones ${ }^{15}$. John H.R. Polt, en el prólogo de la suya, resume así la obra:

El joven Chao-Kong, habiendo estudiado con los bonzos del Japón, vuelve a Pekín y es nombrado preceptor del hijo de un prócer. A pesar de su calidad de mero gramático, hace carrera; y después de bien establecido en la corte imperial trae a ella a dos sobrinos suyos. Uno de estos, Chu-su, recibe de su tío valiosas lecciones en el arte de parecer sabio sin serlo y de ser poeta sin ciencia y sin esfuerzos. El filósofo Kin-taiso trata de desengañar a Chusu, pero éste se deja llevar por su vanidad. En este momento un recién llegado a la corte publica un folleto en el cual llama asno a Chu-su. Éste quiere responderle, pero Kin-taiso le persuade a hacer un viaje a Europa. En Madrid llega a sus manos la relación de una controversia ocurrida entre dos literatos españoles, marcadamente parecida a cuanto le ocurriera en Pekín. Encuentra además una crítica devastadora de las obras de Tomás de Iriarte, a quien se había propuesto imitar. Con esto se da cuenta de su propia ignorancia, ligereza y vanidad, y se propone una radical enmienda (Forner 1970, ed. Polt. págs. 14-15).

La alegoría es bantante clara: Chao-kong es Juan de Iriarte, tío de Tomás, o sea Chu-su; el Japón es Francia y los bonzos son los jesuitas; Pekín es Madrid. El joven que increpa a Iriarte es Forner, cuyas ideas expresa también el filósofo Kin-taiso. La carga de crítica social que se oculta tras los disfraces chinos es mínima, y la parte del león se la lleva la sátira personal, a menudo

15. La de José Jurado, Madrid, Espasa-Calpe ("Clásicos Castellanos") y la de John H.R. Polt. Madrid, Castalia. 
violenta y que termina por cansar al lector precisamente por personalizada. Queda, con todo, la utilización de nombres y ambientes chinos, de algunos términos filosóficos o religiosos, tomados seguramente por Forner de la Enciclopedia, del Ensayo sobre las costumbres de Voltaire o del compendio del padre Du Halde. Se ha llamado la atención, y con razón, sobre el hecho de que Tomás de Iriarte hubiera traducido hacia 1770 la tragedia de Voltaire $E l$ huérfano de la China, y de que el filósofo francés, blanco de los ataques de Forner, hubiese elogiado la ciencia de los chinos:

La autoridad es tomada de un célebre cómputo de M. de Voltaire; y es que allá cuando no sabían escribir, escribieron los chinos unas terribles crónica que hacían subir la existencia de su nación mucho más arriba de la existencia del universo; y lo que es más, halló dicho Señor Filo-histori-critipoeti-físico-matemático que en aquel puntual y crudo tiempo eran ya los chinos estupendos astrónomos y acérrimos impresores ${ }^{16}$.

En los últimos años del siglo y primeros del XIX se publicaron distintos relatos en los que lo exótico tiene notable presencia. En la Colección de cuentos morales (Salamanca, Tójar, 1796), traducida por Francisco de Tójar, prolífico traductor, adaptador y editor, se halla Zimeo, original de Saint-Lambert, historia de la revuelta del protagonista, esclavo negro, contra los terratenientes blancos de Jamaica. La negritud, asociada a la sensibilidad, se halla también en una de las Nuevas novelas de Florian, traducidas por Gaspar de Zavala y Zamora en 1799: Sélico, "novela africana" que intenta mostrar que la virtud y la justicia se hallan incluso entre los pueblos considerados más bárbaros. En 1804 (Madrid, Vda. de López), seis años después de la muerte de su autor, vieron la luz los dos volúmenes de Mis pasatiempos, conjunto de relatos de Cándido María Trigueros, subtitulado "Almacén de fruslerías agradables". En él pueden hallarse distintos relatos o cuentos de ambiente árabe: La hija del visir de Garnat (la acción transcurre en Granada), El juez astuto, El paraíso de Shedad, El santón Hasan, El egipcio generoso. La moraleja que puede extraerse de todos ello es muy clara: la felicidad se consigue con la virtud (véase Álvarez Barrientos 1991 y Aguilar Piñal 1987, págs. 255-263).

Mayor envergadura tiene Oderay, novela traducida del francés (atribuida a Palissot de Beauvois) por Zavala y Zamora y publicada el mismo año de 1804 (Madrid, Fuentenebro y Cía.). Su largo subtítulo es todo un programa: Usos, trajes, ritos, costumbres y leyes de los habitantes de la América septentrional. Es la historia de un europeo ya adulto, adoptado por una tribu de indios, en la que se convierte en un guerrero más, cambiando incluso de nombre. Todo se lo debe a la india Oderay, que acaba enamorándose de él y siendo rechazada por el muchacho, que conserva el recuerdo de una amada que dejó en Europa. La

16. Forner 1970, ed. de Polt, pág. 93. En Candide de Voltaire, el preceptor Pangloss enseña la "métaphysico-théologo-cosmolonigologie". 
novela termina con el suicidio de Oderay. El relato, que contiene muchas noticias sobre las costumbres y creencias de los indios, aúna el exotismo americano con la idea del buen salvaje y cierta dosis de sentimentalismo ${ }^{17}$.

En cambio, la acción de El emprendedor o aventuras de un español en el Asia de Jerónimo Martín (Madrid, Vega y Cía., 1805) transcurre en Basora. El autor demuestra gran conocimiento de la cultura árabe, a la que presenta sin prejuicios civilizadores, otorgando a sus creencias y costumbres un valor y un grado de respetabilidad semejantes a las de España u otros países europeos. En la misma línea de reivindicación de la cultura árabe, en este caso a través de la cultura gitana, se halla La gitana o memorias egipcias, novela del periodista Pedro María Olivé publicada en 1817 formando parte de la Biblioteca universal de novelas, historias y cuentos, que él mismo dirigía (Madrid, L. Núñez). Es, al mismo tiempo, una afirmación del papel de la mujer en la sociedad... árabe, y occidental por transposición.

La presencia de lo exótico en el teatro venía avalada por una larga tradición en Francia y otros países cuando empiezan a darse en España tragedias y comedias nuevas, modernas y, en general, ajustadas a las reglas. La Zaira de Voltaire conoce su primera versión castellana en 1765, a la que seguirán otras hasta la más célebre de García de la Huerta en $1784^{18}$. Ramón de la Cruz tradujo en 1769 el Bayaceto de Pradon y poco más tarde ideó un sainete paródico (en realidad adaptación de una obrita francesa) que tituló Zara, seguramente en recuerdo de la tragedia de Voltaire, pero que no es parodia de ésta (véase Lafarga 1977). Por su parte, el duque de Aliaga compuso en 1797, para que fuera representada en el teatro particular del palacio de su padre, el duque de Híjar, una adaptación de la tragedia francesa Mahomet II o el fanatismo de la gloria (Madrid, B. Cano, 1797): en ella el sultán de Turquía, enamorado de Irene, esclava griega cristiana, debe enfrentarse a distintas presiones de sus consejeros y de los notables; como en la Raquel de García de la Huerta, la intrusa deberá perecer.

La primera tragedia oriental española fue, sin duda, El Viting de Cándido María Trigueros. Fue escrita en 1768 y se conserva en un manuscrito fechado en 1776, no llegando a ser publicada ni representada en teatros públicos (impresa, anónima, en Barcelona, P. Nadal, 1799). Según afirma su autor en una carta dedicatoria, "el hecho o acción de esta tragedia es sacado de una historieta italiana manuscrita, que se dice traducida del lenguaje chino y trata de la destrucción de la familia o dinastía Ming por los tártaros, hoy dominantes

17. Véase Carnero 1988, págs. 23-29. Hay ed. moderna de Oderay por G. Carnero (Barcelona, Sirmio/Universidad de Alicante, 1992).

18. Sobre estas versiones puede verse Lafarga 1982, págs. 164-174, ampliado en la versión francesa, Lafarga 1989, págs. 113-122. 
en China". El nudo de la pieza es el dilema (que acabará en muerte) entre el deber y el amor en que se debate el protagonista, entre la fidelidad debida a su padre el emperador y a su patria, y el amor que siente por la princesa tártara Taicún. En las acotaciones se realzan los elementos exóticos que podían dar vistosidad a la ación: "La escena representa un magnífico salón adornado a la chinesca. Por un lado se verá el cuarto del emperador; por otro, el de Viting. Tiene otras puertas para el resto del palacio. En el frente la entrada a la torre o prisión de los reos de Estado. A un lado un tribunal, a otro el trono imperial". Aun cuando en la censura se insiste en que en la tragedia se da un pésimo ejemplo al pueblo, pues "en ella se trama una rebelión contra el rey, se asalta su palacio y se asesina al heredero", los censores no pasaron por alto el lado oriental de la obra, y así dicen: "La afectación de usar voces chinas en donde debieran servirse de las equivalentes castellanas y las alusiones frecuentes a los ritos y sucesos de aquel país hacen oscuro el sentido, especialmente para los que carecen de aquella noticia" (véase Aguilar Piñal 1987, págs. 184-186).

Pertenece también al ámbito oriental la tragedia Solaya o los circasianos de José Cadalso. Escrita probablemente hacia 1770, fue rechazada por los censores y no llegó a representarse ni a ser publicada. Su texto ha permanecido desconocido hasta su hallazgo y publicación reciente ${ }^{19}$. La acción de la pieza transcurre en Circasia, en el Cáucaso, en la época de Tamerlán: es la historia del amor imposible entre Solaya, noble circasiana, y Selim, embajador e hijo del kan de Tartaria, tirano de Circasia. La lucha entre el amor, el honor y el patriotismo se saldará con la muerte del joven tártaro. A diferencia del Viting, en esta tragedia apenas hay indicaciones escenográficas y el color local aparece reducido a su mínima expresión.

La acción de otras tragedias originales españolas transcurre en el norte de África ${ }^{20}$. Así, la Zafira (1787, impresa en Barcelona, Vda. Piferrer, s.a.) de Luis Repiso, escenifica la intervención española en Argel a principios del siglo XVI contra el tirano Aruch Barbarroja, mezclando en el asunto una historia de amor no correspondido entre el tirano y Zafira, madre del rey de Tremecén. Se exalta en la pieza el valor de los españoles, que aparecen como libertadores del pueblo y destructores de la tiranía. Del mismo año, Brahem ben Alí (Alcalá, P. López, 1787) de Manuel Amigó, que usó el seudónimo de José Milanés, presenta la historia de un sultán de Marruecos del siglo XIII, que debe enfrentarse a la sublevación de un jefe bereber. A los últimos años del siglo pertenece la tragedia de José Villaverde Zorayda, reina de Túnez (Alcalá, I. López, 1793).

19. Por F. Aguilar Piñal, Madrid, Castalia, 1982.

20. Existe precisa y abundante información sobre estas obras en Mendoza 1979; el mismo autor ha tratado aspectos parciales en Mendoza 1981 y en Mendoza 1988. Véanse también las páginas dedicadas al género por Palacios 1988. 
En Turquía está ambientada la comedia El gran visir otomano (1789, inédita), atribuida recientemente a José Concha (véase Santoro 1988), con intriga complicada, golpes de efecto, puesta en escena espectacular (batallas, desfiles). La escenografía está también muy cuidada en Alí-Bek (Madrid, B. García, 1801) de Rosa María Gálvez: "La escena es en las alturas de Saldeik, en el interior de la tienda de Mahomad, magníficamente adornada al uso oriental. Habrá hacia el foro una mesa al gusto asiático y varios almohadones para sentarse". La pieza tiene por asunto la conjura urdida por el rebelde Mahomad contra el rey de Egipto, en la que intervienen también el amor y la religión, pues la esposa de Alí-Bek es cristiana. Más al este se sitúa la acción de Gombela y Suni-Ada (Madrid, B. García, 1800) de Juan Francisco del Plano: desposeída del trono de Ceilán, Gombela lucha, con la ayuda de su enamorado Suni-Ada, para vengar la muerte de sus tres hermanos y expulsar al tirano usurpador.

Grupo aparte, por lo dicho al principio, lo forman las tragedias que escenifican episodios de la Reconquista. En algunos casos se han dado curiosas coincidencias. Así, El Pelayo (1769, impreso en Madrid, s.i., 1792) de Jovellanos (conocida también por Munuza), la Hormesinda (Madrid, P. Aznar, 1770) de Nicolás Fernández de Moratín y el Pelayo (Madrid, García y Cía., 1805) de Quintana se basan en los supuestos amores de Hormesinda, hermana de D. Pelayo, con Munuza, gobernador árabe de Gijón. También coinciden en el tema Don Sancho García (Madrid, Ibarra, 1771) de Cadalso y La condesa de Castilla (1798, impresa en Valencia, I. Mompié, 1815) de Âlvarez Cienfuegos: los amores de Almanzor con la condesa Ava, madre de Sancho, y las implicaciones políticas de los mismos. Pueden señalarse asimismo Guzmán el Bueno (Madrid, A. de Sancha, 1777), tragedia de Nicolás Fernández de Moratín, y el soliloquio homónimo con intervalos musicales de Tomás de Iriarte (1789, impreso en Cádiz, Ximénez Carreño, 1790). Algo al margen quedaría la Zoraida (1798, impresa en Valencia, I. Mompié, 1815) de Cienfuegos, sobre los amores de una dama de la corte de Boabdil con Abenamet, abencerraje preso, que terminarán con la muerte de ambos ordenada por el rey.

Y lo dicho para estas obras es de aplicación a las piezas, normalmente tragedias, relativas a la conquista y colonización de la América española: el Motezuma (Madrid, J. Ibarra, 1784) de Bernardo María de Calzada, si no elogiosa por lo menos en absoluto crítica respecto de la intervención española; o el Atuhualpa (Madrid, A. de Sancha, 1784) de Cristóbal María Cortés, que refleja las luchas por el poder entre los incas Huascar y Atahualpa, con la aparición de Pizarro que ofrece la protección del rey de España. Otras tragedias fueron traducciones: el mejor ejemplo es el de Alzira de Voltaire, traducida entre otros por el mencionado Calzada.

Durante el siglo XVIII las tragedias de asunto oriental o americano partían de un hecho histórico, aunque matizado o alterado por el autor. Dice María Rosa Gálvez en el prólogo a su Ali-Bek: 
La presente tragedia es enteramente original. Su acción está sacada de la historia de Egipto y de la rebelión, sorpresa y muerte de Alí-Bek, acaecida en aquel país a mediados del siglo último. Lo estéril del asunto y el poco interés que podía causar su representación si nada se hubiese añadido a los hechos históricos han movido a la autora a inventar algunos.

Al mantenimiento del interés de los espectadores ayudó, además de la complicación de la intriga, la fastuosidad y el propio exotismo de los decorados. Así, en una de las versiones de Alzira, titulada La Elmira, la pomposa escenificación se opone totalmente a la sencillez de la tragedia volteriana, la acción de la cual transcurre por entero en la sala de un palacio. Ahora, en el primer acto el escenario debe representar una "campiña dilatada y frondosa con varios cocos, palmas y otros frutales silvestres esparcidos en lo más retirado del foro", mientras que en el cuarto, cuando va a celebrarse una boda, debe aparecer "un atrio espacioso de un templo con su fachada al frente y puerta usual en ella. Soldados españoles sobre las armas hacia alrededor, al tiempo que salen tropas de doncellas españolas e indias damas de Elmira, Álvaro Guzmán, Mozoco, Tello y Elmira con guirnaldas de mirto y jazmín en la cabeza. La guardia del gobernador cierra la comitiva"21.

No menos espectaculares debían resultar los bailes, en cuya organización destacó el coreógrafo italiano afincado en Madrid Domingo Rossi: a él se deben títulos como La victoria de Tamerlán sobre Bayaceto, La Alzira, o El primer día del año en China o sea el matrimonio que en este día contrae el emperador, a que comúnmente llaman la fiesta de la linterna.

Los primeros años del siglo XIX presenciaron la aparición de distintos dramas y tragedias que, por la fuerza de las pasiones que pintaban parecían señalar una nueva época: del duque de Rivas, por ejemplo, Aliatar (Sevilla, Cano, 1816) y Malek-Adhel (1818, impresa en Madrid, Sancha, 1820), historias de amores imposibles entre musulmanes y cristianas, adaptación el segundo de la novela de Mme Cottin Mathilde; de Martínez de la Rosa Morayma (1818, impresa en París, 1829), episodio de las guerras civiles de Granada.

También fue una época de triunfo del melodrama, género que unía a una intriga complicada y patética una escenografía aparatosa. La mayoría de los melodramas que se representaron en España son traducciones del francés, a veces a partir de un original alemán (de Kotzebue): Tipoo-Saib o La toma de Seringapatán, El poder de la inocencia o Los moros de Granada, Los inquilinos de Sir John o La familia de la India, Aradín Barbarroja, El mágico y el cestero o El diablo verde (interesante por la aparición de la magia).

21. Véanse Elmira o la Americana. Valencia, Domingo y Mompié, 1820. 
Algunas - pocas - presencias de lo exótico en poesía se hallan en tipos muy distintos de composiciones poéticas ${ }^{22}$. En la poesía épica hallamos una Muerte de Barbarroja, poema en octavas de Ignacio Merás (Madrid, B. Cano, 1797). La poesía erótica parecía de entrada idónea para dar cabida a la sensualidad o, mejor, a la lascivia oriental. Pocas son, sin embargo, las composiciones del Jardín de Venus de Samaniego con protagonistas no europeos: los negros africanos de El país de afloja y aprieta, el turco de El piñón y los árabes de La peregrinación (véase Samaniego, 1976).

Más abundante es la poesía amatoria, muy sensual a veces, como la que se encuentra en el libro Poesías asiáticas del Conde de Noroña, publicado en París en 1833 (Didot), aunque escrito mucho antes, pues el autor había muerto en 1815 . Se trata de un conjunto de 128 poemas traducidos del inglés, de muy distinto cariz, acompañados de abundantes notas: la mayoría son árabes, salvo 26 poemas persas y 2 turcos. Parece que las recopilaciones de donde los tomó el conde fueron Poeseos asiaticae commentarii (1774) de William Jones, Specimens of Arabian Poetry (1796) de Joseph Dacre Carlyle y The Flowers of Persian Literature (1801) de Samuel Rousseau (véase Fitzmaurice-Kelly, 1908). Como presintiendo el lugar que iba a ocupar la poesía árabe en la renovación del gusto occidental escribe el autor estas palabras en su advertencia:

Me prometo que los amantes de la verdadera poesía distinguirán estas composiciones llenas de fuego e imágenes pintorescas, de las insulsas filosóficas prosas rimadas que nos han venido de algún tiempo acá de allende de los Pirineos, vendiéndonoslas como buena mercancía. Los genios españoles, que tanto han brillado por su fecunda y hermosa imaginación, deben abandonar esas gálicas frialdades y no desdeñarse de leer los poetas del Oriente, en quienes todo es calor y entusiasmo, y entre los cuales suenan con honor algunos hispanos, cuyas obras yacen sepultadas en el Escorial (Véase AA.VV. 1952, pág. 471).

Quisiera, para terminar, traer a colación una palabras de Domingo Badía o, si se prefiere, Alí Bey, que expresan el rechazo de la sociedad mercantilista o industrial - moderna-, contraponiéndola a unas formas de vida más libres y auténticas, que en su tiempo podían hallarse todavía en los países que visitó en su recorrido africano y asiático:

Lo confesaré, ya que lo he experimentado: al entrar en estos países [europeos] circunscritos por la propiedad individual el corazón del hombre se encoge y comprime. No vuelvo los ojos, no puedo dar un paso sin tropezar con un seto que parece me diga: "Alto ahí, no traspases este límite". Mi corazón se desanima, mis fibras se relajan, me abandono muellemente al movimiento de mi caballo y me parece no ser ya el mismo Alí Bey, aquel árabe que, lleno de energía y fuego, se lanzó en medio de los desiertos de

22. No he tomado en consideración algunos romances moriscos, hechos a imitación de un tipo de poesía cultivado en el Siglo de Oro; tal vez el ejemplo más conocido sea el de Los bereberes de V. García de la Huerta. 
África y Arabia, como el atrevido navegante que se abandona a las olas de un mar tempestuoso con la fibra siempre en tensión y el espíritu preparado a todo evento. No hay duda que es un grande bien la sociedad; que la mayor dicha del hombre consiste en vivir bajo un gobierno bien organizado que, con el sabio empleo de la fuerza pública, asegura a cada individuo la posesión pacífica de su propiedad; mas también me parece que cuanto se gana en seguridad y tranquilidad se pierde en energía (Véase Badía 1986, II, pág. 397).

Poco comentario necesitan tales consideraciones. En cualquier caso, el espíritu que las sustenta es muy distinto del puramente curioso, basado en el ansia de conocimiento y en la difusión del mismo, que animaba a los viajeros del XVIII. Precisamente la inflexión que puede apreciarse en este texto es la señal de un cambio de mentalidad y de gusto que caracteriza el paso del XVIII al XIX.

\section{REFERENCIAS BIBLIOGRÁFICAS}

AA.VV. 1952. Poetas líricos del siglo XVIII, ed. L.A. CUETO Madrid, Atlas, vol. II (BAE LXIII).

- 1989. España y el mar en el siglo de Carlos III, Madrid, Marinvest.

AGUILAR PIÑAL, Francisco. 1981 y ss. Bibliografía de autores españoles del siglo XVIII, Madrid, CSIC.

- 1987. Un escritor ilustrado: Cándido María Trigueros, Madrid, CSIC.

- 1988. Bibliografía de estudios sobre Carlos III y su época, Madrid, CSIC.

ÁLVAREZ BARRIENTOS, Joaquín. 1991. La novela del siglo XVIII, Madrid, Júcar (dentro de la Historia de la literatura española de R. de la Fuente).

BADÍA, Domingo (Alí Bey). 1986. Viajes por Marruecos, Trípoli, Grecia y Egipto, prólogo de Juan GOYTISOLO, Barcelona, José Olañeta, 2 vols.

BRAVO MORATA, Federico. 1972. Carlos III y su tiempo, Madrid, Fenicia.

BREMER, Klaus-Jürgen. 1971. Montesquieus "Lettres persanes" und Cadalsos "Cartas marruecas", Heidelberg, Carl Winter.

CADALSO, José. 1966. Cartas marruecas, ed. Lucien DUPUIS y Nigel GLENDINNING, Londres Tamesis Books.

CARNERO, Guillermo. 1988. "Sensibilidad y exotismo en un novelista entre dos siglos: Gaspar Zavala y Zamora" en Romanticismo 3-4. Atti del IV Congreso sul Romanticismo spagnolo, Bordighera, 1987, Génova, Universidad, pp. 23-29.

- (ed.). 1992. Gaspar ZAVALA y ZAMORA. Obra narrativa: La EumeniaOderay, Barcelona, Sirmio \& Universidad de Alicante. 
COTARELO Y MORI, Emilio. 1897. Iriarte y su época, Madrid, Sucesores de Rivadeneyra.

COTTON, Emily. 1931. "Cadalso and his Foreign Sources", Bulletin of Spanish Studies VIII, pp. 5-18.

CRUZ, Ramón de la. 1915. Sainetes, ed. Emilio COTARELO, Madrid, Bailly-Baillere, vol. II (NBAE, 23).

DEACON, Philip. 1981. "Las perdidas Cartas turcas de Meléndez Valés", Bulletin Hispanique LXXXIII, pp. 447-462.

DEFOURNEAUX, Marcelin. 1973. Inquisición y censura de libros en la España del siglo XVIII, Madrid, Taurus.

ESCOBAR, José y Anthony PERCIVAL. 1984. "Viaje imaginario y sátira de costumbres en la España del siglo XVIII: los Viajes de E. Wanton al país de las monas" en Aufstieg und Krise der Vernunft, Viena, Hermann Böhlaus Nachf, pp. 79-94.

FERNÁNDEZ CARDO, José M"a . 1989. "La otra cultura en esta literatura: funciones exóticas de la escritura" en F. LAFARGA (ed.), Imágenes de Francia en las letras hispánicas, Barcelona, PPU, pp. 371-378.

FERNÁNDEZ MONTESINOS, José. 1966. Introducción a una historia de la novela en España en el siglo XIX, Madrid, Castalia.

FITZMAURICE-KELLY, James. 1908. "Noroña's Poesía asiáticas", Revue Hispanique 18, pp. 439-467.

GUINARD, Paul J. 1958. "Une adaptation espagnole de Zadig au XVIIIe siècle" Revue de littérature comparée 32, pp. 481-495.

HUGUES, John B. 1969. José Cadalso y las "Cartas marruecas", Madrid, Tecnos.

IGLESIAS, Nieves y Ana M MAÑÁ. 1968. Correo de Madrid o de los Ciegos, Madrid, Hemoroteca Municipal.

JOURDA, Pierre. 1938. L'exotisme dans la littérature française depuis Chateaubriand, reimpr. Ginebra, Slatkine, 1970.

LABORDE, Paul. 1952. "Cadalso et Montesquieu" Revue des langues romanes LXXI, pp. 171-180.

LAFARGA, Francisco. 1977. "Sobre la fuente desconocida de Zara, sainete de R. de la Cruz" Anuario de Filología 3, pp. 361-371.

- 1982. Voltaire en España, 1734-1835, Barcelona, Universidad.

- 1989. Voltaire en Espagne (1734-1835), Oxford, The Voltaire Foundation (Studies on Voltaire, 261).

MENDOZA FILLOLA, Antonio. 1979. La tragedia neoclásica española, 17101819, Universidad de Barcelona (tesis doctoral inédita). 
- 1981. "Aspectos de la tragedia neoclásica española" Anuario de Filología 7, pp. 369-389.

- 1988. "El compromiso colonial y el despotismo en la tragedia neoclásica" en Coloquio internacional sobre el teatro español del siglo XVIII. Bolonia, octubre de 1985, Abano Terme, Piovan, pp. 267-287.

SAMANIEGO, Félix. 1976. El jardín de Venus, ed. Emilio PALACIOS, Madrid, Siro.

SANTORO, Paola. 1988. "II Gran Visir otomano ritrova il suo autore" Nuovi Annali della Facoltà di Magistero dell' Università di Messina 6, pp. 723-734.

VARELA, Eulogio. 1966. El Espíritu de los mejores diarios, Madrid, Hemeroteca Municipal. 


\title{
VARIANTES Y MODULACIONES DE LAS SOLEDADES DE ANTONIO MACHADO
}

\author{
Dolores ROMERO LÓPEZ DE LAS HAZAS \\ Universidad de Salamanca
}

Como es bien sabido, la primera edición de las Soledades, realizada por la Imprenta de A. Álvarez en 1903, volvió a ser emitida con distintas solapas por la Imprenta Valero Díaz en 1904. Esta vez el ejemplar se vendía a una peseta, es decir , a mitad de precio que el original (Valle 1949, pág. 81); se trataba, pues, como apunta G. Ribbans, de una reventa del material en stock (Ribbans 1962, pág. 195). Desde su publicación, la crítica ha sentido gran interés por esta primicia literaria ${ }^{1}$. A pesar de ello, todavía no se ha hecho un estudio sistemático de las variaciones y modulaciones que presentan los poemas de 1903 que fueron seleccionados y publicados en la edición de 1907. No hay ningún poema original de la edición de 1903 que no haya cambiado, aunque sea mínimamente, en la edición de Pueyo. Por lo tanto, no se puede concluir, como en su día lo hizo Luis Cernuda, que "Machado nace formado enteramente y el paso del tiempo nada le añadirá, antes le quitará" (1957, pág. 111). Aunque es verdad que los mejores poemas de Antonio Machado fueron muy tempranos y en sus Soledades encontramos la mejor poesía del poeta, lo cierto es que, como apunta D. Dámaso Alonso, "en los primeros tiempos la releyó, corrigió y seleccionó con gran cuidado y muchas veces" (1975, pág. 607). En 1903-4? dice Antonio Machado en carta a Juan Ramón: "No estoy muy satisfecho de las cosas que hago últimamente. Estoy en un período de evolución y todavía no he

1. Juan Ramón Jiménez publica en El País de 1903 un artículo donde alaba la poesía del sevillano. Posteriormente se realizaron otros estudios entre los que hay que destacar el artículo de Lauxar (1929, pp. 225-42) y el que Dámaso Alonso publicó por pirmera vez en 1949, recopilado posteriormente en sus Obras completas de donde se cita en la presente investigación. En 1959 fue publicada la obra del Prof. Oreste Macrí Poesie di Antonio Machado; un año más tarde aparecía en Insula el estudio del Prof. Ricardo Gullón sobre "Las Soledades de Antonio Machado"; Geoffrey Ribbans publica “Antonio Machado's Soledades (1903); A critical Study" (1962) y en 1968, Rafael Ferreres publica la edición crítica de las Soledades. Hoy, gracias a la edición de Oreste Macrí podemos disponer de todas las variantes textuales de este primer libro de A. Machado. 
encontrado la forma de expresión de mi nueva poesía. Lo último que se domina es la forma" (Cit. por Gullón 1964, pág. 41).

Queda clara, pues, la intención del poeta por superarse formalmente durante la época de recomposición de su libro Soledades. Sin embargo, en la introducción a las Páginas escogidas decía Antonio Machado que era su costumbre "no volver nunca sobre lo hecho y no leer nada de cuanto escribo" (1940, pág. 29). Esta afirmación no puede aplicarse a su primer libro de poesías dado que en él realizó un gran número de correcciones.

En mi estudio parto de las variantes textuales que aparecen al contrastar las concordancias de las dos primeras ediciones de las Soledades. Teniendo en cuenta que "el estudio de las variantes de la obra de un autor puede arrojar luz sobre los procedimientos de la crítica textual" (Segre 1990, pp. 55-56), la intención básica de esta investigación es ver cómo a través de dos versiones distintas de una obra se puede demostrar la evolución sufrida por el autor y por ende del período literario al que este se empezó adscribiendo. La comparación de estas dos ediciones constata científicamene la depuración del Modernismo hacia una estética más personalizada y objetiva y además demuestra un mayor grado de conciencia crítica en el poeta de 1907 frente al joven escritor de 1903.

Por supuesto que soy de la opinión de Cesare Segre al afirmar que "no tiene sentido buscar en la confrontación entre dos variantes correspondientes los motivos del cambio, si no se tiene en cuenta el texto en conjunto, las atracciones a distancia entre fragmentos en algún modo conectados, y finalmente las demás eventuales correcciones intervenidas en estos fragmentos" (Segre 1990, pp. 55-56), pues desde el momento en que los poemas se unen en cadena se ilustran recíprocamente ${ }^{2}$. Por este principio relacionante hay que tener en cuenta que aquellos significados implícitos en un libro de poemas pueden considerarse explícitos para el resto de artes o líricas afines.

Parece conveniente tener unos esquemas aclaratorios de cuáles son los poemas que fueron olvidados ${ }^{3}$, de aquellos otros que fueron cambiados $^{4} y$ de los que incorpora en la edición de 1907 (véase Apéndice I).

2. Como afirmaba Carlos Bousoño (1952, pág. 107), "el concepto de modificante puede tener aún mayor alcance quizá, si pensamos que, dentro de un mismo libro, unos poemas se apoyan en otros y a su lado cobran relieve".

3. Ésta es la serie de poesías olvidadas: 1. Desolaciones y monotonías: La Fuente "Desde la boca de un dragón", Invierno "Hoy la carne aterida", Cenit "Me dijo el agua clara", El Mar Triste "Palpita un mar de acero de olas", Crespúsculo "Caminé hacia la tarde de verano", Otoño "El cárdeno otoño". 2. Del camino: IV "Dime, ilusión alegre", XIV "Siempre que sale el alma de la obscura galería". 3. Salmodias de Abril: Preludio "El pífano de Abril sonó en mi oído", La tarde en el jardín "Era una tarde de un jardín", Nocturno "Sobre el campo de abril", Nevermore "¡Amarga primavera!". 4. Humorismos: La muerte "Aquel juglar burlesco".

4. 1. Desolaciones y monotonías-Soledades: Tarde "Fue clara tarde", Los cantos de los niños "Yo escucho", La noche "Siempre fugitiva y siempre", Horizonte "En una tarde clara". 2. Del camino: 
En la edición de 1907 se observan varios tipos de cambios que modulan nuevamente el texto.

\section{Modificaciones que afectan exclusivamente a la separación estrófica}

La mitad de las correcciones llevada a cabo por Antonio Machado en la edición de Pueyo son correcciones de separación estrófica o paraestrófica ${ }^{5}$ encaminadas a dar una mayor claridad física al poema. Los nuevos versos en blanco que separan una paraestrofa de otra son como las vidrieras por donde entra la claridad al verso haciéndolo más transparente a los sentidos. Ello se debe a que cuando Antonio Machado vuelve a esta poesía de nuevo lo hace desde una óptica más racional, con un espíritu más crítico y estético.

Hay dos criterios básicos de separación estrófica: separación en núcleos semánticos cerrados o separación en núcleos semánticos incompletos. Otros criterios de separación estrófica son los diálogos entre el yo lírico y un interlocutor natural, o incluso las terminaciones tajantes de poemas para los que selecciona dos versos simbólicamente antitéticos que en definitiva resumen el contenido del mismo. En general, el poeta tiende a separar grupos de cuatro versos, quizá porque sean las formas más cercanas al sentir popular, aunque no sea necesariamente pertinente ni por cambio de rima ni por cambio de ritmo estrófico.

Preludio "Mientras la sombra pasa de un santo amor", I "Daba el reloj las doce... y eran doce", II "Sobre la tierra amarga", III "En la miseria lenta del camino", V "Crear fiestas de amores", VI "Arde en tus ojos un misterio", VII "TTenue rumor de túnicas que pasan", VIII "¡Oh, figuras dẹl átrio, más humildes”, IX "Quizás la tarde lenta todavía”, X “Algunos lienzos del recuerdo tienen”, XI "Crece en la plaza en sombra", XII "Las ascuas de un crepúsculo morado", XIII "¿Mi amor?... ¿Recuerdas, dime", XV "Me dijo un alba de la primavera", XVI " ${ }_{\mathrm{O}} \mathrm{Oh}$, dime, noche amiga, amada vieja".3. Salmodias de Abril-Canciones y Coplas: Canción "Abril florecía", Ocaso "Me dijo una tarde", Campo "La vida hoy tiene ritmo", Mai Piu "Era un mañana y Abril", Fantasía de una noche de Abril "Sevilla?", Tierra Baja "El sueño bajo el sol que aturde", La Mar alegre "El caso roído y verdoso". 4. Humorismos-Humorismos, Fantasías, Apuntes: La noria "La tarde caía", El cadalso "La aurora asomaba", Glosa "Nuestras vidas son los ríos".

5. Entiendo por paraestrofas "grupos irregulares de versos cada uno de los cuales no guarda relación formal con los demás - a diferencia de la «estrofa»-, y está motivado en su extensión sólo por el contenido" (Paraíso 1971, pp. 253-54). He aquí la lista de poemas que se ven afectado por cualquiera de las antedichas separaciones: 1. Desolaciones y monotonías: Los cantos de los niños "Yo escucho", Noche "Siempre fugitiva y siempre", Horizonte "En una tarde clara y amplia". 2. Del camino: Preludio "Mientras la sombra pasa", I "Daba el reloj las doce... y eran doce", II "Sobre la tierra amarga", III "En la miseria lenta del camino", V "Crear fiestas de amores", VI "Arde en tus ojos un misterio", VII “iTenue rumor de túnicas que pasan”, VIII “¡Oh, figuras del átrio, más humildes", IX "Quizá la tarde lenta todavía", X "Algunos lienzos del recuerdo tienen", XI "Crece en la plaza en sombra", XIII "¿Mi amor?... ¿Recuerdas, dime", XV "Me dijo un alba de la primavera".3. Salmodias de Abril: Campo "La vida hoy tiene ritmo", Tierra Baja "El sueño bajo el sol que aturde". 4. Humorismos: La noria "La tarde caía", Cadalso "La aurora asomaba", Glosa "Nuestras vidas son los ríos". 
El caso de la silva es particularmente atractivo porque ventisiete de las cuarenta y dos composiciones de las primeras Soledades son silvas, seis de ellas mantienen una rima consonante, diecinueve una rima asonante y dos tienen un tipo de rima libre-alterna. A pesar de ser la silva un poema no estrófico, los poetas suelen dividirlo en formas paraestróficas desiguales (Quilis 1985, pág. 161). No ha de extrañar, por tanto, el distinto número de versos que contengan las estrofas de los poemas compuestos en silvas, pero es anormal tratar de separar un poema compuesto en silvas en estrofas de cuatro versos, máxime cuando, en algunos de los casos, no hay un contenido semántico completo.

En las Soledades de 1903 aparece la "silva arromanzada de endecasílabos y heptasílabos libremente combinados y sin otro enlace que la asonancia uniforme en los versos pares, serie menos corriente en el Modernismo que la de metros fluctuantes de diversas medidas, la cual Machado ensayó una sola vez en la poesía amétrica Oh, tarde luminosa (Navarro Tomás, 1964, pp. 425-443). En las Soledades de 1907 no sólo tiene el verso como unidad rítmica básica, sino también la estrofa que proporciona una alternancia rítmica visual a base de pareados, tercetos, cuartetos, etc.

\section{Modificaciones que afectan al orden de los poemas}

En cuanto al orden de los poemas que aparecen en la edición de 1903, por lo general se mantiene en la edición de 1907. El proceso de configuración ordinal de este último poemario se basó en una inserción de poemas sobre la edición de 1903. La edición de 1907 se presenta como una edición más abultada respecto a la anterior (Véase Apéndice II).

Los cambios que el autor ha hecho se pueden resumir así: 1. Poemas que aparecen endosados en el nuevo poemario con un nuevo funcionamiento textual ${ }^{6}$. 2. Poemas que no han variado su orden funcional en el poemario 7 .3. Poemas que han sido claramente sustituidos por otros poemas ${ }^{8}$. 4. Poemas que han sido

6. Son los poemas de la sección de Soledades: Tarde, Los cantos de los niños, Noche, Horizonte.

7. Son los siguientes poemas de la sección Del camino: Preludio "Mientras la sombra pasa", I "Daba el reloj las doce", II "Sobre la tierra amarga", III "En la miseria lenta del camino", V "Crear fiestas de amores", VI "Arde en tus ojos un misterio, virgen”, VII "¡Tenue rumor de túnicas que pasan", VIII " $\mathrm{O}$ Oh, figuras del atrio", IX "Quizás la tarde lenta todavía", X "Algunos lienzos del recuerdo tienen", XI "Crece en la plaza en sombra", XII "Las ascuas de un crepúsculo morado", XIII "¿Mi amor?... ¿Recuerdas, dime" y los siguientes de la sección Humorismos: Fantasías, Apuntes, La noria, El Cadalso.

8. En las Soledades están XVIII El poeta "Maldiciendo su destino", XIX “¡Verdes jardincillos!" que sustituyen a Crepúsculo y Otoño. En la sección Del camino el poema IV "El sol es un globo de fuego" sustituye al IV "Dime, ilusión alegre". 
eliminados sin dejar rastro ${ }^{9} .5$. Poemas que han sido levemente cambiados de orden dentro de la misma sección ${ }^{10}$. 6. Poema que ha sido cambiado de sección ${ }^{11}$.

Es difícil precisar con acierto el porqué de los cambios, tampoco hay que esforzar la actitud crítica para tratar de justificar una serie de modificaciones. Lo más importante es que la base de creación de la edición de Pueyo sigue la línea estructural creada en 1903. El Antonio Machado de 1907 es el que se transparenta en la sección Galerías o Varia y aún ahí el poeta sigue los pasos de su primer poemario.

\section{Transfiguración de la tópica}

Desde 1898, año en el que Antonio Machado empezó a componer poemas, hasta 1907, año de publicación de su segundo libro, han pasado casi 10 años. En los últimos años del siglo XIX y los primeros años del siglo XX se está gestando en España el Modernismo.

La tópica del Modernismo, fuentes, jardines, ocasos, caminos, pueblos abandonados, ríos soñolientos, viejas leyendas, mujeres angelicales, sentimientos de melancolía inundan los primeros poemas de los hermanos Machado, de Villaespesa, Antonio de Zayas, Juan Ramón Jiménez, Rubén Darío. No es el objeto de esta investigación analizar la gestación de esta tópica. Gracias a la precisión semántica y léxica que me han proporcionado distintos grupos de concordancias realizadas sobre las principales obras del Modernismo desde 1900 a 1907, he podido acotar aquella parte de la configuración tópica que cambia desde las Soledades de 1903 a las de 1907. Es decir, son básicos dentro del Modernismo conceptos como lentitud, lejanía, risa, alegría, que Antonio Machado modifica o quita en la edición de 1907. Un análisis pormenorizado de estos conceptos sería interesante porque se podría comprobar la mejora técnica que suponen para la poesía machadiana, pero rebasaría los límites de esta publicación. Lo que propongo aquí es una abstracción sucinta y básica de las principales conclusiones a las que he llegado después del análisis de los cambios de las dos ediciones.

9. En la sección Soledades han sido eliminados: La fuente, Invierno, Cenit, El Mar triste. De la sección Del camino han sido eliminados XVI "Siempre que sale el alma de su oscura galería". De Canciones y Coplas fueron eliminados, Preludio "El Pífano de Abril sonó en mi oído". La tarde en el jardín, Nocturno, Nevermore, y de la sección Humorismos, Fantasías fue eliminada La muerte.

10. El poema que en Ia sección Del camino de 1903 tenía el número XIV ha desaparecido y este orden lo ocupa en 1907 el poema "Me dijo un alba de la primavera" que en 1903 tenía el número XV. El que en 1903 tenía el número XVI "¡Oh, dime, noche amiga, amada”, pasa en la versión de 1907 a figurar con el número XV. En la sección Coplas y canciones se han cruzado ordinalmente otros dos poemas los que en 1903 llevaban el título Ocaso y Campo y lo mismo ocurre con la pareja de poemas que en 1903 se titulaban La Mar alegre y Tierra baja.

11. Se trata del poema Fantasia de una Noche de Abril "Sevilla?..." que en 1903 estaba Salmodias de Abril mientras que en 1907 aparece en la sección Humorismos, Fantasías, Apuntes. 
Los conceptos que han sido eliminados, sustituidos, o reducido en número en la edición de 1907 y que modulan la tópica del Modernismo machadiano desde su gestación son, como he dicho antes lentitud, lejanía, risa y alegría. Estos cambios manifiestan una evolución de la lírica modernista hacia una búsqueda de una mayor objetividad expresiva y una depuración del simbolismo. Mientras que en 1903 el sentimiento simbolista de lentitud vital del yo lírico impregna desde la analogía conceptos como camino, corazón, rueca, campana y sus equivalentes matices simbólicos, la vida, la intimidad, el tiempo, o la muerte, en los poemas que se mantienen en el edición de 1907, la lentitud es un concepto más objetivo: lento es el viejo mendigo, la hiedra que trepa por la pared y la noria movida por una mula vieja. El Modernismo está dando sus primeros y lentos pasos hacia otra forma de sentir la vida.

La lejanía, el segundo de los conceptos cambiados, ha dado lugar a que se diga que uno de los tópicos del Modernismo es la huida en el tiempo o en el espacio. Huir a países lejanos es un tópico que el Modernismo hereda del Romanticismo: España, Oriente Medio, China, Japón, incluso el África, son extensiones por las que vuelan la fantasía de Víctor Hugo, Byron, los hermanos Schlegel y que después heredaran los modernistas (Foster 1969, pp. 1-22).

\section{Cambios léxicos}

La edición de 1907 incorpora una serie de cambios que afectan al léxico. Cada uno de ellos aporta una mayor precisión al significado poético. Voy a analizar sólo algunos de estos cambios.

En el poema Tarde "Fue una clara tarde, triste y soñolienta", se sustituye "sonó" por "golpeó"; así se acentúa más el sonido producido por el golpe de la puerta de hierro al cerrarse. Unos versos más adelante se sustituye "clara harmonía" por "monotonía" pues es el monótono sonido del agua de la fuente la característica innata de esta fuente machadiana. No se puede decir que el agua de la fuente vierta "clara harmonía", cuando es la propia fuente la que no deja entrever por sus espejos el misterio del pasado. Igualmente es muy acertado el tercer cambio léxico que sufre este poema cuando en los últimos versos se sustituye "triste" por "amarga" pues la monotonía de esta fuente capaz de revivir en la sensibilidad del poeta un estado que pertenece a un recuerdo frustrado lo que le produce más que tristeza es amargura, acritud.

En el poema Los cantos de los niños, el primer cambio es la sustitución de "coplas" por "cantos" y ello creo que fue debido a que en el título figura la palabra cantos y no coplas. En la III parte de este poema se sustituye "A la paz en sombra" por "Jugando, a la sombra", de esta forma el simbolismo interno del poema - la inocencia con la que se nos presenta el misterio de la vida- se agarra más a la analogía que lo genera: unos niños que simplemente juegan cantando en corro viejas canciones. 
Ya dentro de la sección Del camino, en el Preludio hay de nuevo otra sustitución verbal: "leer" reemplaza a "poner". Si tenemos en cuenta que el poema es un ofertorio de sensaciones a la mágica palabra poética, el verbo "poner" se acerca más a "ofrecer" y es por tanto más acertado que la simple lectura de un salmo que se deriva de la edición de 1903.

En el poema III de esta misma sección se sustituye la palabra "borrasca" por "tormenta", términos aparentemente sinónimos. En principio este cambio se nos presenta como el fruto de un mero gusto individual del poeta, pero no es así. "Borrasca" es, al igual que "tormenta", un temporal en el mar con lluvia, viento y relámpagos; en cambio el término "tormenta" tiene una acepción que al simbolismo de esta poesía le viene como anillo al dedo y es que por "tormenta" también entendemos la alteración violenta del estado de ánimo de alguien; además "tormenta" tiene la misma raíz etimológica que "tormento", lo cual acrecienta en mayor medida su valor simbólico etimológico.

En el poema Campo de esta misma sección ha sido sustituida "blanca" por "rápida". Evidentemente en el contexto no importa el color de la corza sino su rapidez, por hacerse inalcanzable para los deseos del yo lírico.

Otro cambio, que a simple vista se nos antoja caprichoso, es el realizado sobre el poema Mai Piu, pero en el fondo demuestra la sutil lectura crítica que realizó Antonio Machado sobre su obra. En este poema se sustituye "alcoba triste" por "triste alcoba". El Oriente en la simbología machadiana y en todo el Modernismo conlleva sentimientos de alegría y dulzura. En la edición de 1903 el adjetivo triste puede ser entendido como un predicativo subjetivo que atribuye al Oriente la cualidad de estar triste. Pero esto no es aceptable desde el punto de vista tópico y por ello en la edición de 1907 antepone "triste" a "alcoba" convirtiéndolo en un adjetivo que no interesa tanto por su función de epíteto sino porque tan sólo puede calificar a "alcoba", dejando el concepto Oriente libre de anfibologías. Otro de los múltiples cambios sufridos por este poema es la sustitución de "plañir" por la palabra "doblar", en dos ocasiones. La expresión "plañir de campanas" es más simbólica en tanto en cuanto se entiende que las campanas tocan a muerto y alguien llora/plañe de dolor. Pero es mucho más acertada la expresión "doblar de campanas" pues se dice que las campanas cuando tocan a muerto doblan.

\section{Cambios Gráficos}

Esta primera edición aparecía al final con una Fe de erratas en la que la mayoría de ellas son faltas de ortografía que aparecen corregidas, en el caso de que se recoja el poema, en la edición de 1907. Esta edición incorpora también otros cambios gráficos: 1. "Zenit" cambia a "cenit" en el poema IX de Del camino. En el poema Fantasías de una noche de Abril en la sección Salmodias de Abril 
se cambia "dezires", con registro idiomático antiguo por "decires" con grafía modernizada. 2. "áscua" en 1907 pasa a estar correctamente escrito como "ascua" en el poema XII de Del camino" ${ }^{12}$. 2. Frente a las normas que aceptamos actualmente, los monosílabos fué, á, y ó aparecen acentuados en ambas ediciones de principios de siglo. 4. Otra rareza gráfica que aparece en ambas ediciones es la letra mayúscula con la que se escriben tres palabras, Oriente, Primavera y Abril debido a su importancia semántica. 5. Otras dos palabras que deberían haber entrado en la "Fe de erratas" de 1903 son, "canjilón" donde debería leerse "cangilón"13 y donde dice "trajedia" debería poner "tragedia"14. Son faltas de ortografía que podrían haber sido cometidas por el propio Antonio Machado. De cualquier forma ningún testimonio nos queda de la época sobre la corrección de pruebas de este libro y es aventurado dar una respuesta sobre quién cometería estos flagrantes errores.

\section{Sustitución de títulos en los poemas y en las secciones}

Si parte de la tópica modernista se difumina tras la sustitución de unos conceptos por otros, otra parte de esa tópica, quizá la más emblemática, se esfuma a través de la supresión de la mayoría de los títulos de los poemas ${ }^{15}$ y de la dedicatoria que algunos de los poemas de 1903 tenían $^{16}$. Debido a que la mayor parte de los poemas que han perdido su título aparecen ahora bajo números romanos $^{17}$, las subdivisiones dentro de los poemas que aparecían en 1903

12. Este es el único cambio sufrido por este poema, con lo que se convierte en el poema menos cambiado de todos. Por otro lado hay bastantes palabras que en la edición de 1903 aparecen o sin acentuar o mal acentuadas. Dichas palabras, en el caso de ser mantenidas en la segunda edición, aparecen corregidas.

13. Esta palabra se encuentra en el verso 5 del poema La Noria.

14. Este error se encuentra en el verso cuatro del poema El Cadalso.

15. Los poemas a los que se les ha mantenido el título son dos, Horizonte y Fantasía de una noche de abril. Sin embargo, nueve poemas han perdido el título, Tarde, Los cantos de los niños, Noche, Canción, Ocaso, Campo, Mai Piu, Tierra Baja, La Mar Alegre y además otros once títulos que no aparecen en la edición de 1907 porque han sido eliminados completamente: La Fuente, Invierno, Cenit, El Mar Triste, Crepúsculo, Otoño, Preludio, Tarde en la Jardín, Nocturno, Nevermore, Muerte.

16. Todas las dedicatorias a sus compañeros en la lucha modernista han desaparecido. Los poetas a los que se les había dedicado algún poema en la edición de 1903 son: A Rubén Darío Los cantos de los niños, la sección Salmodias de Abril a D. Ramón del Valle-Inclán, el Nocturno a Juan Ramón Jiménez, Mai Piu a Francisco Villaespesa y Fantasía de una noche de Abril que está dedicado "Al venerable maestro D. Eduardo Benot". Con la supresión de estas dedicatorias se pierde parte del ambiente modernista en estos poemas. En la edición de 1907 no aparece ningún verso dedicado aunque en el último poema Elogio lleva un recordatorio de Flor de la santidad de Valle-Inclán.

17. Los poemas que tras haber perdido el título aparecen con números romanos son: Soledades: VI «Fue una tarde...», VIII "Yo escucho los cantos...", XVI «Siempre fugitiva y siempre...", XVII "Horizonte, En una tarde clara...". Canciones y coplas: I "Abril florecía...", IV "Me dijo una tarde de la primavera...", V "La vida hoy tiene ritmo..." VI "Era una mañana y Abril sonreía..." VII "E1 caso roido y verdoso", VIII "El sueño bajo el sol...". 
presentadas con esos mismos números, en la edición de 1907 aparecen separadas simplemente por asteriscos ${ }^{18}$. En cambio, hay un poema, el titulado en ambas ediciones La Noria, que mantiene sus números romanos para separar las dos partes de las que consta, porque la sección a la que pertenece, Humorismo, Fantasías, Apuntes, utiliza un título para cada poema y no la habitual numeración romana.

En cuanto al cambio de nombre de las distintas secciones hay que decir que este cambio se hacer por dos motivos: para justificar el título del poemario completo o para suprimir connotaciones tópicas modernistas. En 1903 el libro Soledades se dividía así: Desolaciones y monotonías, Del camino ${ }^{19}$, Salmodias de Abril, Humorismos ("Los grandes inventos"); en cambio en 1907 aparece la siguiente división: Soledades (Del camino, Canciones y coplas, Humorismos, Fantasías, Apuntes), Galerías, Varia. Es decir, se ha sustituido Desolaciones y monotonías por el título genérico del libro que está semánticamente muy cercano al título de esta parte y que por lo tanto, ahora sí, justifica que el libro se llame Soledades. En la edición de 1907 las Soledades contienen las cuatro subsecciones que en 1903 aparecían exentas porque Antonio Machado es consciente de que todo ese material pertenece a su primer libro, a pesar de que aparezca ahora ampliado, y que lo que trae de nuevo la edición de 1907 son las Galerías y Varia, por ello el libro de 1907 se titula Soledades, Galerías. Otros poemas.

La sustitución de la sección Salmodias de Abril por Canciones y Coplas se debe a que se han suprimido el Preludio y el Nocturno, que eran los poemas que junto con Canción y Fantasía de una noche de Abril justificaban el título de esta sección. Pero es que además el poema Fantasía ahora aparece en la siguiente sección y por lo tanto es lógico que el título que le sugiera esta sección sea el de Canciones, pues el poema Canción aparece en primer lugar sin título. La sección Humorismos pasa a denominarse Humorismos, Fantasías, Apuntes. Evidentemente, al haber trasladado el poema de Fantasías de una noche de Abril a esta sección el poeta es consciente de que tiene que variar el título y lo hace dejándose llevar de nuevo por el cambio realizado, de ahí que aparezca Fantasías en este título. Tampoco la sección Galerías es enteramente original dado que en 1903 el poema XIV de la sección Del camino, suprimido en la edición de 1907 , recoge la idea de que el alma tiene galerías de ensueño, matiz simbólico que permanece a lo largo de toda la nueva sección de este poemario ${ }^{20}$.

18. Me refiero a los poemas que en 1903 se titulaban Tarde, Los cantos de los niños, Canción, Mai Piu, Ocaso.

19. Esta sección está compuesta por un Preludio más dieciséis poema numerados con números romanos. Los poemas de todas Ias demás secciones llevan título.

20. En la edición de 1903 la palabra "galería" aparece una sola vez en un poema que en la edición de 1907 es suprimido. En cambio, en esta misma edición aparece una sección entera titulada Galerías, donde se repite este concepto seis veces en seis poemas distintos pero siempre se refiere a las galerías del alma o del recuerdo, como en la edición de 1903. 
Podemos concluir, pues, diendo que, a pesar de que críticos de reconocido prestigio se han negado a admitir una evolución en el autor de las Soledades, a través de este trabajo de investigación se ha intentado demostrar que el primer Antonio Machado fue un lector atento de su obra y el primer crítico de su poesía. Cada cambio realizado sobre la edición de 1903, la separación estrófica, modificaciones léxicas y gráficas, es un paso adelante en el camino hacia la perfección poética, pero es además una transformación consciente de la mentalidad de su autor y por ende de la época en la que empezó a escribir. La depuración del Modernismo se hace a través de la estilización de la tópica, de la supresión de títulos, poemas, y dedicatorias. Por otro lado, se ve claramente que la edición de 1907 fue realizada bajo la pauta estructural y estética de la edición princeps que es, sin duda, uno de los pocos grandes primeros libros.

\section{BIBLIOGRAFÍA}

ALONSO, Dámaso. 1975. "Poesías de las Soledades de 1903, olvidadas por Machado" en Obras completas IV, Madrid, Gredos, pp. 607-628.

BOUSOÑO, Carlos. 1985. Teoría de la expresión poética, Madrid, Gredos, 2 vols.

CERNUDA, Luis. 1957. Estudios sobre poesía española contemporánea, Madrid, Guadarrama.

CRISPO ACOSTA, O. 1929. "Antonio Machado y sus Soledades", Hispania, XII, pp. 225-42.

FOSTER, David William. 1969. "Un índice introductorio de los «tópicos» de la poesía romántica española: Lugares comunes en la lírica de Rivas, Espronceda, Bécquer y Zorrilla", Hispanófila, no 37, pp. 1-22.

GULLÓN, Ricardo. 1960. "Las Soledades de Antonio Machado", Insula, ํำ 158, pp. 1 y 16.

- 1964. Relaciones entre Antonio Machado y Juan Ramón Jiménez, Pisa, Universidad.

MACHADO, Antonio. 1940. Obras (Poesías completas, Juan de Mairena, Sigue hablando Mairena a sus discípulos, Otros sueltos), México, Séneca.

- 1968. Soledades, ed. Rafael FERRERES, Madrid, Taurus.

- 1989. Poesía y prosa, ed. Oreste MACRÍ, Madrid, Espasa-Calpe.

NAVARRO TOMÁS, Tomás. 1964. "La versificación de Antonio Machado", La Torre, XII, nos. 45-46, pp. 425-443.

PARAISO, Isabel. 1971. "El verso libre de Juan Ramón Jiménez en Dios deseado y deseante", Revista de Filología Española, LIV, pp. 252-269.

QUILIS, Antonio. 1985. Métrica española, Barcelona, Ariel. 
RIBBANS, Geoffrey. 1962. “Antonio Machado's Soledades (1903); A critical Study”, Hispanic Review, XXX, pp. 194-215.

ROMERO LÓPEZ, Dolores. 1993. Concordancia y variantes de las Soledades de Antonio Machado, Salamanca, Universidad.

SEGRE, Cesare. 1990. Semiótica filológica (Textos y modelos culturales), Murcia, Universidad.

\section{APÉNDICE I}

Ésta es la lista de los nuevos que se incorporan en la edición de 1907. El asterisco $(*)$ significa que en ese lugar aparece un poema tomado de la edición de 1903. 1. Soledades: I El viajero "Está en la sala familiar", II "He andado muchos caminos", III "La plaza y los naranjos encendidos", IV En el entierro de un amigo "Tierra le dieron una tarde horrible", V Recuerdo Infantil "Una tarde parda y fría", *, VII "El limonero lánguido suspende", *, IX Orillas del Duero "Se ha asomado una cigueña", X "A la desierta plaza", XI "Yo voy soñando caminos", XII "Amada, el aura dice", XIII "Hacia un ocaso radiante", XIV Cante Hondo "Yo meditaba absorto, devanando", XV "La calle en sombra", *, *, XVHI El poeta "Maldiciendo su destino", XIX "¡Verdes jardincillos!". 1.2. Del camino: *,*, *, IV "El sol es un globo de fuego", *, *, *, *, *, *, * *, *, *, XVI "Al borde de un sendero nos sentamos", XVII "Es una forma juvenil que un día". 1.3. Canciones y coplas: *, II De la vida, Coplas, Elegiacas, " „Ay del que llega", III Inventario galante "Tus ojos me recuerdan", *, *, *, *, * 1.4. Humorismos, fantasías, apuntes: *, *, Las moscas "Vosotras, las familiares", Elegia de un madrigal "Recuerdo que una tarde", Acaso "Como atento no más a mi quimera", Jardín "Lejos de tu jardín quiera la tarde, " *, A un naranjo y un limonero visto en una tienda de plantas y flores, Los sueños malos, Hastío "Pasan las horas de hastío", Consejos "Este amor que quiere ser", *. 2. Galerías: Introducción "Leyendo, un claro día", I "Desgarrada la nube, el arco iris", II "Y era el demonio de mi sueño el ángel", III "Desde el umbral de un sueño me llamaron", VI Sueño Infantil: "Una clara noche", V "Si yo fuera un poeta", VI "Llamó a mi corazón", VII "Hoy buscarás en vano", VIII "Y nada importa ya que el vino de oro", IX "Tocados de otros días", X "La casa tan querida", XI "Ante el pálido lienzo", XII "Tarde tranquila", XIII "Yo, como Anacreonte", XVI "Y no es verdad, dolor, yo te conozco", XVII "Y ha de morir contigo el mundo mago", XVIII "Desnuda está la tierra", XIC Campo "La tarde está muriendo", XX A un viejo distinguido señor "Te he visto, parque", XXI Los sueños "El hada más hermosa ha sonreído", XXII "Guitarra del mesón que hoy sueñas jota", XXIII "El rojo sol de un seuño en el Oriente asoma", XXIV "La primavera besaba", XXV Renacimiento "Galerías del alma...", XXVI "En nuestras almas, todo", XXVII "Tal vez la mano, en sueños", XXVIII "Y podrás conocerte recordando", XXIX "Los árboles conservan", XXX "Húmedo está, bajo el laurel, el bando", 3. Varia: Caballitos "Pegasos, lindos pegasos", Ruidos "Deletreos de armonía", Pesadilla "En medio de la plaza", De la vida: "Poeta ayer, hoy triste y pobre", Sol de invierno "Es medio día. Un parque", Elogios "Esta leyenda en sabio romance campesino". 


\section{APÉNDICE II}

Veamos primero un esquema básico para comprobar como se organiza el nuevo texto: (*** significa poema de 1903 insertado en la edición de Pueyo)

\section{Desolaciones y monotonías-Soledades}

$\begin{array}{ll} & \text { I El viajero: "Está en la sala familiar" } \\ \text { II "He andado muchos caminos" } & \\ \text { III "La plaza y los naranjos encendidos" } & \text { IV En el entierro de un amigo "Tierra" } \\ & \text { V Recuerdo Infantil "Una tarde parda y fría" } \\ & * * * \text { Tarde "Fue una tarde triste" } \\ & \text { VII "El limonero lánguido suspende" } \\ & \text { *** "Yo escucho los cantos" } \\ \text { La Fuente } & \text { IX Orillas del Duero "Se ha asomado" } \\ \text { Invierno } & \text { X "A la desierta plaza" } \\ \text { Cenit } & \text { XI "Yo voy sonando caminos" } \\ \text { Mar Triste } & \text { XII "Amada, el aura dice" } \\ & \text { XIII "Hacia un ocaso radiante" } \\ & \text { XIV Cante Hondo "Yo meditaba absorto," } \\ & \text { XV "La calle en sombra" } \\ & \text { *** Noche "Siempre fugitiva y siempre" } \\ & \text { ***Horizonte "En una tarde clara" } \\ \text { Crepúsculo } & \text { XVIII El poeta "Maldiciendo su destino" } \\ \text { Otoño } & \text { XIX "iVerdes jardincillos" }\end{array}$

\section{Del camino}

*** Preludio: "Mientras la sombra pasa"

*** I "Daba el reloj las doce"

*** II "Sobre la tierra amarga"

*** III "En la miseria lenta del camino"

IV. "Dime..."IV "El sol es un globo de fuego"

*** V "Crear fiestas de amores"

*** VI "Arde en tus ojos un misterio, virgen"

*** VII " "Tenue rumor de túnicas que pasan"

*** VIII " $\mathrm{O}$, figuras del atrio,"

*** IX "Quizás la tarde lenta todavía"

*** X "Algunos lienzos del recuerdo tienen"

$* * * \mathrm{XI}$ "Crece en la plaza en sombra"

*** XII "Las ascuas de un crepúsculo morado"

*** XIII "¿Mi amor?.. Recuerdas, dime," 
XVI "Al borde de un sendero"

XVII "Es una forma juvenil que un día"

3. Salmodias de Abril. Canciones y coplas

Preludio

*** Canción "Abril florecía"

La tarde II De la vida, coplas elegiacas

III Inventario galante "Tus ojos"

Ocaso *** IV "Me dijo una tarde"

Campo *** V "La vida hoy tiene ritmo"

Nocturno *** VI "Era una mañana y Abril sonreía"

Fantasía *** VII "El casco roído y verdoso"

Nevermore *** VIII "El sueño bajo el sol que aturde"

\section{Humorismos. Humorismos, Fantasías, Apuntes}

*** La Noria "La tarde caía"

*** El Cadalso "La aurora asomaba"

La Muerte . Las moscas: "Vosotras, las familiares"

Elegia de un madrigal "Recuerdo..."

Acaso... "Como atento no más"

Jardín: "Lejos de tu jardín quiera la tarde"

Fantasía de una noche de Abril "Sevilla?... Granada?..."

A un naranjo y un limonero...

Los sueños malos

Hastio: "Pasan las horas de hastío"

Consejos "Este amor que quiere ser"

*** Glosa "Nuestras vidas son los ríos" 



\title{
EL CONCEPTO DE FANTASÍA, DESDE LA ESTÉTICA CLÁSICA A LA DIECIOCHESCA ${ }^{1}$
}

\author{
Guillermo SERÉS \\ Universidad Autónoma de Barcelona
}

El concepto de fantasía, o imaginación, como pintor interior del alma figura ya en el Filebo (39 b), de donde arranca una larga tradición:

Sócrates. - Acepta, entonces, la presencia en nuestra alma de otro artífice [además del escribiente] al mismo tiempo. Protarco. -¿Quién? Sóc.Un pintor que, después del escribiente, pinte en el alma las imágenes de lo dicho. Pro. -Pero ¿cómo y cuándo? Soc. -Cuando un hombre, tras haber recibido de la visión o de cualquier otro sentido los objetos de la opinión y de los discursos, mira, de alguna manera, dentro de sí las imágenes de estos objetos.

De las palabras de Platón se desprende que la fantasía es meramente una opinión proveniente de una sensación, o a ella vinculada. En concreto, que la phantasia "pinta en el alma las imágenes [...] de la visión o de otra sensación", o sea, "el hombre mira en sí mismo las imágenes de los objetos " (ibíd.). La fantasía, por lo mismo, es el artista que pinta en el alma las imágenes (eikonas) de las cosas; imágenes que un poco más abajo (40 a) son definidas como "fantasmas" (phantasmata). El tema central del Filebo, sin embargo, no es el conocimiento, sino el placer; y si Platón se refiere al problema de la fantasía (y de la memoria) es porque necesita demostrar que deseo y placer no son posibles sin esta pintura del alma. El fantasma, puesto aquí bajo el signo del deseo y del placer, es un extremo que no hay que olvidar. Las metáforas del pintor interior

1 La amplitud del tema me ha forzado a elegir sólo algunas etapas clave de este recorrido histórico, aunque me he detenido más en la primera y en la última. Asismismo, he de confesar en seguida que he seguido principalmente la tradición naturalista o, digamos, fisio-psicológica, o sea, apenas me he adentrado en el terreno de las chimerae y otras derivaciones en mayor o menor medida fantásticas (neoplatonismo, filosofía oculta, magia y cábala, misterios órficos, hermetismo, teología poética...), salvo algún caso concreto (Llull, Ficino, Pico...). También quiero indicar que he procurado reducir las notas y demás aportaciones documentales y eruditas a la mínima expresión, ya que la mayor parte de conceptos y ejemplos expuestos son harto conocidos. 
y la de la tablilla de cera del Teeteto (191 d-e) fundamentan la historia de la psicología clásica a este respecto. Naturalmente, la fantasía, la imaginación, bosqueja una imagen, digamos, estilizada, irreal, reelaborada a partir de las improntas depositadas en le memoria; es decir, no copia directamente, sino que reconstruye, por evocación, las speciei que entran por los sentidos y se imprimen en el almacén de la memoria. Cosa bien distinta es la opinión que le merece a Platón dicho proceso psíquico (o sea, su vertiente ética), pues, precisamente porque depende de una sensación, sujeta a la opinión individual y vinculada con las pasiones del alma, no es fiable, hay que relativizarla ${ }^{2}$.

Abunda en ello en el Sofista, cuando dice que el pensamiento, la opinión, la imaginación, "son géneros a los que les puede afectar, en nuestras almas, tanto la falsedad como la verdad" ( 263 d). La opinión, continúa, "cuando no se presenta espontáneamente, sino por la mediación de la sensación, tal afecto ¿puede recibir otro nombre que no sea imaginación [phantasia]?" (264 a); así, "esta pasión que designamos con la palabra phainetai [= yo imagino] es una combinación de sensación y de opinión que puede ser verdadera o falsa" (264 b). De forma que, si puede haber opiniones falsas, también las imágenes de éstas provenientes pueden serlo. Ello es así porque la imaginación, facultad intermedia entre el sentir y el pensar, momentánea y transitoria, no posee ni la evidencia de la sensación directa, ni la coherencia lógica del razonamiento abstracto; su dominio es el parecer, no el ser.

Un poco antes (República, X, 602), había diferenciado entre mimesis eikastiqué y mímesis fantastiqué. El artista, opina, puede crear copias exactas (icásticas), que reproduzcan el contenido de la realidad sensible $\mathrm{y}$, por tanto, limitarse a una inútil duplicación del mundo fenoménico, que sólo imita las ideas; o bien puede crear simulacros inexactos y engañosos que, en el sentido de la mímesis fantástica, empequeñecen lo grande y agradan lo pequeño, para engañar a nuestra vista imperfecta: entonces su obra aumenta la confusión en nuestra alma, y está en un nivel inferior al del mundo sensible. Por tanto, nunca un phantasma o un eidos, formado por la mímesis fantástica, que depende de una apreciación subjetiva u opinión, podrá reflejar una idea (innata y eterna); sí podrá la mímesis icástica, aunque tenuemente, duplicándola.

En el Timeo (52 b) insiste diciendo que, a diferencia del acto de intelección, que precisa una demostración verdadera, no así la opinión. Ésta, en tanto que fruto de la sensación y canalizada por la imaginación, sólo es capaz de crear una "segunda realidad: parecida a la primera, pero dependiente de los sentidos", de la que no podemos afirmar que sea testigo fiable de la verdad, "pues la

2 De hecho, en el Filebo (38b-39c) pone en entredicho el proceso entero de aprehensión y representación imaginaria mediante una descripción vivísima: alguien ve de lejos una estatua grosera (sensación), se interroga sobre ella (opinión) y se imagina ver a un hombre (Véanse, simplemente, Starobinski 1974, pp. 137-140 y Ross 1986, pp. 145-165). 
imagen [eidos] no le pertenece, ni siquiera lo que representa, sino que es como un fantasma de otra realidad" (52 c), por lo que es contingente y relativa. En $L a$ República reafirma (VI, 508 d) dicha contingencia de la fantasía (cf. Ross 1986, pág. 56).

Así, las imágenes, según Platón, son la primera sección del mundo visible: "Llamo imágenes en primer lugar a las sombras, luego a los fantasmas (phantasmata) reflejados en el agua o en alguna superfice lisa y brillante, y al resto de representaciones del mismo género [...] por lo que la imagen es al modelo lo que el objeto de la opinión es al objeto del conocimiento" (República, 510 a). Los fantasmas, por tanto, no son más que el segundo acercamiento (de los cuatro posibles) al conocimiento del ser, al principio absoluto; no son más que "el intermediario entre la opinión y la inteligencia" (511 d); no participan de la idea.

Por todo ello, cuando, más abajo, quiere echar a los poetas de la república lo que en realidad pretende es expulsar a los representantes de la poesía imitativa (de la "mímesis fantástica"), pues la imitación es el tercer grado de alejamiento de la idea: el poeta, como el pintor, se limita a trazar la simple imagen refleja de las cosas y de su aparente realidad (República, $596 \mathrm{~d}$ ), crea un mundo de mera apariencia (597 d-e). Según él, los poetas desde Homero no han hecho más que representar, fantásticamente, las imágenes reflejas (eidola) de la areté humana, pero sin tocar la verdad, por lo que no podían ser sinceros educadores de hombres (600 e 5; cf. Jaeger 1974, pp. 767-772). Y si el arte es imitación de una apariencia (mimesis phantasmatos), también es, por tanto, productor de una segunda apariencia, de una imagen de la imagen (homoioma). Las nociones de phantasia, phantasma y homoioma subyacen, pues, al concepto de mimesis, ya que no la hay sino por y para la imaginación (véase el detallado estudio de Bundy 1927, complétese con Ruth Harvey 1976 y Agamben 1977). La debilidad ontológica de lo imaginario compromete al arte y lo apresa en la región del no-ser y de la mentira. Por lo mismo, la objeción fundamental contra la poesía (y, claro, contra la fantasía a aquella vinculada) es que no habla a la parte mejor del alma, la razón, sino a los instintos y a las pasiones, a los que espolea $(603 \mathrm{c})$; la poesía, al imitarlo, acentúa todavía más el sentimiento de dolor (o tristeza, etc.), la pasión o la emoción que representa y que embarga al poeta. Con ello empuja al hombre (poeta o lector) a entregarse con toda intensidad a este afecto, en vez de acostumbrar al alma a dedicarse a la cura de sus partes afectadas por el mal, por el sufrimiento o por la tristeza $(604 \mathrm{c}-\mathrm{d})$. Platón explica la tendencia de la poesía a gustar en toda su plenitud los sentimientos del dolor por su interés natural en la parte pasional de la vida del alma humana. De este modo, el poeta incapacita al alma para distinguir lo importante de lo que no lo es, pues unas veces, en tanto que cultivador de la mímesis fantástica, como arriba recordaba, magnífica algunos objetos o pasiones, otras los minimiza. Y este relativismo e imprecisión son, en consecuencia, los que demuestran que el poeta crea ídolos y no reconoce la verdad. 
Otro grave reproche, asociado al anterior, es el de que la poesía corrompe nuestros juicios estimativos. Al escuchar el comportamiento pasional o las quejas de un héroe trágico, o al recrear en nuestra fantasía las imágenes que nos presta el poeta, sentimos goce y nos dejamos caer por entero en sus manos. Lo seguimos arrastrados por el movimiento de simpatía de nuestros sentimientos y fantasía; e incluso ensalzamos como buen poeta a quien mejor sabe producirnos estas emociones, pues la simpatía es la esencia de todo efecto poético (605 c 10 d). Dicho en otros términos: el ideal moral del hombre según Platón se halla en abierta oposición con los sentimientos poéticos. De este modo, su concepción no sólo reprueba la fantasía (mera opinión relativizante), sino también la emoción que pueda comportar, por simpatía, el efecto en el público. Rechaza, por lo tanto, los phantasmata y las emociones derivados de la poesía, porque ambos, al fin y al cabo (ora por la mímesis, ora por la simpatía), dependen de la misma facultad: la phantasia.

Aristóteles, por su parte (De anima, III, 3; De memoria et reminiscencia, 449 b ss; Retórica, 1370 b), le sigue y le contradice. Le sigue al afirmar que "el sentido es la facultad capaz de recibir las formas sensibles sin la materia, al modo en que la cera recibe la marca del anillo sin el hierro o el oro" (De anima, 424 a); en el De memoria (450 a), a esta marca o impronta en la cera la llama "dibujo" (xographema). Le contradice cuando declara que la fantasía no puede ser reducida a una opinión, sino que es un "movimiento" procedente de la sensación, que es conducido después a la fantasía, que puede producir el fantasma incluso en ausencia del objeto percibido (428 a).

La fantasía es, por tanto, la facultad intermedia entre el sentido común (o percepción) y el intelecto o (o pensamiento), en tanto que participa de los dos. Todo conocimiento, viene a decir, deriva de las impresiones sensoriales; el pensamiento actúa sobre ellas, ya cualificadas o sublimadas, tras haber sido tratadas y absorbidas por la fantasía. Ésta es la parte hacedora de imágenes, figurae, del alma, la que realiza el trabajo de los procesos más elevados del pensamiento; de ahí que el alma nunca piensa sin una imagen (sin un phantasma; De anima, 432 a 17); es decir: "todo pensamiento se acompaña de fantasmas". Antes ha dicho que "la facultad cognoscitiva piensa sus formas en imágenes" (431 b 2); o bien: "No se puede aprender o entender nada si no se tiene la facultad de la percepción; incluso cuando se piensa especulativamente se ha de tener alguna imagen con la que pensar" (432 a 9). "La imagen es, en suma, el cuerpo sutil del pensamiento, así como la imaginación es el del alma" (Klein 1980, pág. 76). Por lo mismo, es medio sensación y medio idea. Lo fantástico,

3 Ibíd., 402 b- 403 a. "Las percepciones que aportan los cinco sentidos son, en primer lugar, tratadas y elaboradas por la facultad de la imaginación, y son las imágenes así formadas las que constituyen el material de la facultad intelectual" (Yates 1974, pág. 48). 
por tanto, no hay que entenderlo como lo irreal, sino como lo intermediario entre lo anímico y lo sensible. Se diferencia de la sensación precisamente en esto, en que es capaz de recrear el fantasma sin su intervención: "La fantasía será un movimiento producido por la sensación en acto. Y como la vista es el sentido por excelencia, la palabra fantasía deriva de la palabra luz [phaos], puesto que no es posible ver sin luz. (De anima, 429 a). La imaginación, por tanto, alumbra el interior de la mente con su luz, pues esta facultad está también henchida de la luz que ilumina los objetos exteriores, "y puesto que, a lo que parece, no existe cosa alguna separada y fuera de las magnitudes sensibles, los objetos inteligibles [...] se encuentran en las formas sensibles [...]. De ahí también que, cuando se contempla intelectualmente, se contempla a la vez y necesariamente alguna imagen, puesto que las imágenes son como sensaciones, sólo que sin materia" (ibíd., 429a, 432a).

"Sin materia" y sin tiempo, puesto que el hombre tiene necesidad de las imágenes "para pensar en el tiempo lo que está fuera del tiempo" (ibíd.). La función del fantasma en el proceso cognoscitivo es tan importante, que se puede afirmar que es, en un cierto sentido, la condición necesaria de la inteligencia; incluso llega a decir que el intelecto es una especie de fantasía (phantasia tis) y repite el axioma omnipresente en la epistemología medieval que la Escolástica fijará en la fórmula "Nihil potest homo intelligere sine phantasmata" (432 a 17). Pero no acaba aquí la función del fantasma: también interviene decisivamente en el sueño y en las técnicas advinatorias, pues en estos y otros casos, la imagen se nos impone con una especie de espontaneidad, de autonomía, como alumbrada por una luz que le es propia. Valga este ilustrativo esquema ${ }^{4}$.

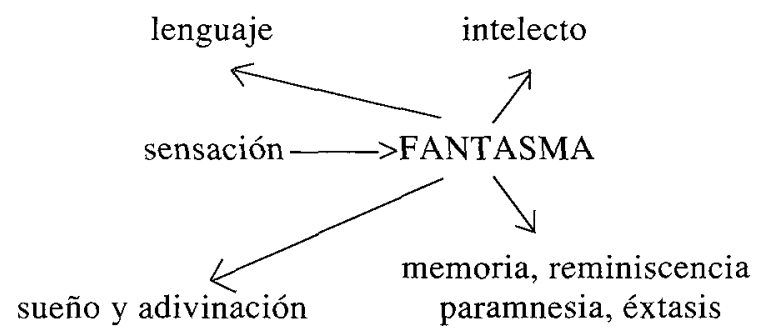

En colaboración con la fantasía, la memoria, que, situada en la misma parte del alma que aquélla, funciona a modo de almacén de imágenes. Sería muy larga de explicar la diferencia entre phantasia e imaginatio: algunos autores

4 Agamben 1977, pág. 89; puede completarse, entre otros, con las definiciones de los estoicos que poco menos que exhaustivamente ofrece Pigeaud 1983, en especial, la diferenciación entre phantasia, phantaston y phantasticon (pág. 25.) Como he dicho arriba (nota 1), me centraré especialmente en la concepción naturalista, o sea, en su mediación cognoscitiva entre la sensación $y$ el intelecto. 
las distinguen, indicando que a la imaginación le correspondería retener lo percibido y a la fantasía unirlo o separarlo; otros no (por ejemplo Tomás de Aquino); otros, por fin, desestiman la imaginatio (o la vinculan al sensus communis), concibiendo la phantasia como una réplica de la razón, puesto que es su fundamento (abajo lo amplío). En fin, quedémonos, de momento, con la sinonimia, pues este proceso y asignación funcional de las potencias del alma (sentido común, fantasía, memoria, entendimiento) estarán presentes, tácita o explícitamente, con o sin matices, en la mayoría de formulaciones filosóficas o fisio-psicológicas hasta el siglo XVII y, por supuesto, se tendrá en cuenta a la hora de explicar estéticamente los mecanismos de la imaginación, invención o, en definitiva, creación artísticas ${ }^{5}$.

Las artes, en efecto, transfieren la realidad objetiva a formas irreales de la construcción imaginaria. De este modo, el modelo artístico, verosímil, como hipótesis fantástica de la realidad, se consiente holguras y libertades muy especiales, que no se puede permitir el modelo cognoscitivo realista. Esas licencias se orientan, sobre todo, a dos fines distintos: proveer, primero, un tipo de conciencia sobre la realidad, en sectores de la experiencia que son inasequibles para el conocimiento mediante sensaciones y percepciones orientadas al conocimiento racional; y segundo producir, un tipo de reacciones bajo forma de emociones y de sentimientos, en las esferas ética y estética, que no podría activar nunca el conocimiento. Para ello, y a diferencia de Platón, Aristóteles parte del presupuesto de que la poesía es útil, es natural en el hombre, pues éste se deleita por naturaleza y aprende imitando, fantaseando; o sea, conoce por la mímesis, que es el origen, el fundamento y el fin último de su Poética: "Siéndonos, pues, natural el imitar, así como la armonía y el ritmo [...] desde el principio los mejor dotados para estas cosas, avanzando poco a poco, engendraron la poesía partiendo de las improvisaciones" (1448 b). En esta última afirmación no sólo se ve un ataque a la concepción platónica de la poesía como furor divino, además se defiende la necesaria mediación de la fantasía, pues la literatura es imitación, creación de una realidad fantástica no necesariamente realista. Se trata, pues, de una definición de poesía en relación con la realidad y con el grado de fidelidad de la imitación, no tanto de un modelo real como de un tipo y, sobre todo, de unas acciones ideales.

5 Baste ver los trabajos de Avicena, Averroes y toda la tradición consiguiente que explican el proceso de denudatio, o sea, la progresiva liberación de los accidentes materiales de la imagen hasta sublimarla conceptualmente o utilizarla artística, poéticamente. Sin estas premisas teóricas no se puede explicar la mayor parte de la gran poesía medieval (la trovadoresca, el dolce stil nouvo...) y sus derivaciones hasta el XVII. Véase, por ejemplo, el Canon (I, fen. i, doc. vi, cap. 5) de Avicena, donde se explica el preceso de purificación o despojamiento del fantasma, de la imagen, desde el sensus communis hasta la facultad humana rationalis, pasanto por la virtus imaginativa, virtus cogitativa, virtus aestimativa y la conservativa et memorialis; de estas cinco facultades, los médicos y fílósofos posteriores (en tanto que unifican el sensus con phantasia y omiten la aestimativa) sólo reconocen tres, pero confirman el proceso, que se ha cumplido entero cuando el alma racional puede ser informada por el fantasma completamente puro: en el acto de intelección o contemplación la forma ya está desnuda. En general, puede consultarse Ruth Harvey 1976, págs. 21-30 y passim. 
Ahora bien, como la imagen, cauce de la imitación, es mitad sensación, mitad idea, necesita una base o fundamento mitad cuerpo y mitad alma: ese sustrato se hallaba ya en el neuma de los estoicos y en los espíritus animales de las escuelas médicas antiguas. Se consideraba que la imagen o fantasma, una vez reflejada en el espejo del ojo, era transportada por el neuma o spiritus, que es una suerte de intermediario entre el alma y el cuerpo que circula por la sangre; o lo que es lo mismo: el espíritu era el instrumento del alma para todas las operaciones de ésta que conciernen al cuerpo (cf., por ejemplo, Klein 1980 , pp. 29-59 y Nardi 1984, pp. 135-172), el vehiculum animae que dirá después Alberto Magno (De somno et vigilia, I, 1, 7).

Por todo ello, no será extraño encontrar entre los filósofos naturales afirmaciones del tipo: el espíritu animal engendra los cinco sentidos y emite, a través de los ojos, el neuma visual que reflejará las imágenes de los objetos o de los fantasmas; se trata del spiritus lucidus, transportado por los nervios, que a este fin están perforados. Se solía ilustrar la descripción de su funcionamiento con la conocida imagen platónica de la transmisión de la luz solar (República, VI, xix, 508 b-509 d): el alma poseedora de la verdad esencial alumbra los objetos contemplados intelectualmente de la misma forma que la luz del Sol ilumina los objetos reales.

Con la bien hallada imagen del Sol, se resuelve la dificultad de tener que explicar un concepto espiritual (el funcionamiento de las facultades) con elementos materiales (espíritus); además, como los espíritus "animales" son los que encauzan y transmiten la percepción sensible (son lucidi), la imagen de la luz solar deja de ser una imagen, pues según la descripción que después ofrecerán Aristóteles y los filósofos naturales es estrictamente literal, siendo la cavidad cerebral correspondiente el Sol de las cavidades interiores del hombre. Con lo que, además se consigue dotar de realidad tangible a la phantasia, que, como hemos visto, el Estagirita hacía derivar de phaos (luz), en tanto que era la encargada de encauzar las percepciones visuales, las imágenes, al intelecto; o sea, la encargada de "alumbrar" la parte estrictamente racional, para que puedan ser "contemplados" los phantasmata. En otras palabras: la encargada de sacar a la luz las imágenes previamente depositadas en la memoria. Vale decir: de la misma forma que los ojos han menester luz y claridad para ver las imágenes y colores, así la fantasía tiene necesidad de luz allá dentro en el cerebro, para ver los fantasmas que están en la memoria. Esta claridad, como dice Aristóteles, "no la da el sol ni el candil ni la vela, sino los espíritus vitales que nacen del corazón y se distribuyen por todo el cuerpo" (De anima, 432 a).

De esta forma, también logra relacionar directamente (mejor dicho, "fisiológicamente") la luz física, la del sentido de la vista, con la de la fantasía, pues ambas, en tanto que ligadas al sensus communis, son espirituales, es decir, se sirven de los mismos medios o conductos: los espíritus y los nervios. Los fantasmas, las imágenes, así, no son más que una suerte de espíritus sutiles. Por 
lo tanto, del mismo modo que la imagen es "el cuerpo sutil" del pensamiento, la imaginación lo es del alma; incluso se llegó a utilizar la denominación phantastikón neuma (Nemesio de Emesa, De natura himinis, I) o spiritus phantasticus. No pudo ser de otro modo, pues si la imagen es medio sensación y medio idea, necesitaba una base o fundamento mitad cuerpo mitad alma; la phantasia será, así, indumentum animae (al decir, por ejemplo, de Hugo de San Víctor, De unione corporis et spiritus, en PL, vol 177, cols, 285 ss.).

El espíritu, pues, sería la frontera entre el alma y el cuerpo, mediaría (según Alberto Magno, De somno et vigilia, III, i, 9) entre la percepción animal y la razón angélica, de forma análoga a como el hombre es el puente entre el ángel y la bestia. De ambas premisas se deduce que el espíritu, fa fantasía, es lo propio del hombre, en tanto que participa de la sensación y de la idea: el hombre, así es el animalis phantasticus por excelencia (corrobórese también, v.g., con Santo Tomás, Summa, I, 76, 7, 2), porque los phantasmata que cogita son instrumentos imprescindibles para la posterior contemplación intelectual y elaboración de universales, ya que subliman las sensaciones (y percepciones) intelectualmente. El hombre, por lo mismo, utiliza las imágenes, transportadas por los espíritus, para formar ideas y conceptos; alumbra con la fantasía, en suma, su parte racional, su entendimiento (cf. Pigeaud 1983). La fantasía (o sea, la meditación del espíritu lucidus, o luminoso), por ello y hasta el XVII, es considerada esencialmente como intermediaria del conocimiento, esto es, como vínculo entre el objeto y el concepto, y, forzosamente, entre lo particular y lo universal, entre el cielo (alma racional) y la tierra (el cuerpo) ${ }^{6}$.

Tal como ocurría en la Antiguiedad, en la Edad Media será definida desde los puntos de vista gnoseológico y moral (véase, por ejemplo, Du Cange 1886 s. v. phantasia). Desde el primero, valga la definición de Tomás de Aquino: Phantasia est thesaurus formarum per sensum acceptarum (Summa, I, q. 78, a. 4); desde el segundo (a través de Orígenes, el primero en definir los sentidos interiores), sirva la de Ramón Llull, quien, sin negar a Sto. Tomás ni la necesidad de los fantasmas para el conocimiento, afirma que, a diferencia de la sensación, la imaginativa sí puede miltiplicare chimaeras. Por ejemplo, con su libro Phantasticus, Llull ilustra la acepción ética, normal en la Edad Media, de la fantasía como phantasma, spectrum, vana visio, imago, e incluso vanitas; el verbo phantasiari valdrá, pues, por hacer funcionar la imaginación en el terreno de las chimaerae ${ }^{7}$. Noción que no es nueva, pues, como hemos visto en el

6 La noción de vinculus la desarrolla, más tarde Pico della Mirandola, a partir de Aristóteles, De Coelo, 289; del Ps. Aristóletes, De spiritu, 1, 481, y de Plotino, Ennéadas, IV, iv, 45: "Verum inter terrenum corpus es caelestem animi substantiam opus fuit medio vinculo, quod tan distantes naturas invicem copularet; huic muneri delegatum illud tenue et spiritale corpusculum, quod et medici et philosophi spiritum vocant" (Pico 1942, pág. 270).

7 Además de en el Phantasticus, Llull también habla de ello en otros libros, v.g., en el Liber de Lamentatione Philosophiae (en $R$. Lulli Opera Latina, VII, 113), donde dice que la sensitiva "non potest multiplicare chimaeras"; sí, en cambio, la imaginativa (apud Badia 1991, pág. 46). 
esquema aristotélico, hay que tener en cuenta otra acepción de phantasia relacionada con las visiones, apariciones, sueños premonitorios, etc. Pero no voy a entrar en ello; sólo indicar que un precedente muy importante es el comentario de Macrobio al Sueño de Escipción, incluido en De re publica de Cicerón, compilador, sabido es, de tantas tradiciones ${ }^{8}$.

No obstante, la mayoría de escritores se acoge a la descripción psíquica (o sea: fisio-psicológica). Así, la noción del phantasma, asociada, por ejemplo, a la imagen de la dama grabada o pintada en el corazón (cf. Mancini 1988), se encuentra en el amor cortes, el dolce stil novo, el petrarquismo, el neoplatonismo del Renacimiento y del Barroco. Reconvertida, o sea aligerada del neoplatonismo y de la carga fisio-psicológica, también figura en el ocultismo del XVIII, el Romanticismo y la época moderna.

Dicha concepción, siguiendo el orden cronológico, permite explicar la mayor parte de poemas del dolce stil nouvo y sus derivados posteriores hasta Petrarca; v.g., el poema XCIV (vv. 1-4) del Canzoniere del aretino:
Quando giugne per gli occhi al cor profondo
l'imagin donna, ogni altra indi si parte, et le vertù che l'anima comparte
lascian le membra, quasi immobil pondo.

O sea, la imagen, el fantasma, dominante ("donna") desaloja a las demás, y los espíritus que la transportan a la fantasía ("le vertù") acaparan toda la atención del sujeto, quedando el resto de miembros inertes (o inermes= "quasi immobil pondo"). El proceso psíquico de recreación en la fantasía de la imagen vista o recordada, es, pues, central, axiológico, puesto que el ejercicio poético consiste en la descripción de su origen, sus patógenas manifestaciones y su transcripción figurada. Se trata, casi (o sin el casi), de un cuadro clínico y de una recreación filosófica. Ello es así porque la imagen es, en última instancia, material, sanguínea, espiritual; también es emocionalmente indisoluble de la sensación o aprehensión originaria (véanse los trabajos de Klein 1980, pp. 3059, Nardi 1984, pp. 9-124 y Bruni 1988). Se establece, por tanto, una continuidad real entre fantasía e invención (o recreación) literaria: ambas son etapas de un proceso iniciado en la sensación o emoción; los límites de la fantasía coinciden con los de la poesía. Por lo que al final de su Commedia (Paraíso, XXXIII, 142) afirmaba Dante: "All'alta fantasia qui mancò [=le faltaron las fuerzas] possa". Y más si tenemos en cuenta que, según los parámetros averroístas, el amor (u otra pasión) se asienta en la parte del alma donde, según la doctrina aristotélica,

8 Esta teoría del sueño será posteriormente retomada por los neoplátonicos y conceptualizada en el spiritus phantasticus, especialmente, por Ficino, Pico o Bruno. En general, véase el clásico trabajo de Patch 1956, con la adición de Lida de Malkiel, La visión del trasmundo en las literaturas hispánicas, esp. pág. 419. 
están la memoria y la imaginación, es decir, en el alma sensitiva, o sea en la comunicación entre el corazón y el cerebro.

He citado a Dante y Petrarca porque nos permitirán entender mejor a Garcilaso, máximo representante de nuestro clasicismo (soneto VIII):
De aquella vista pura y excelente salen espirtus vivos y encendidos, y siendo por mis ojos recebidos, me pasan hasta donde el mal se siente: éntranse en el camino fácilmente por do los míos, de tal calor movidos, salen fuera de mí como perdidos llamados d'aquel bien que'stá presente. Ausente, en la memoria la imagino; mis espirtus, pensando que la vían, se mueven y se encienden sin medida; mas no hallando fácil el camino, que los suyos entrando derretían, revientan por salir do no hay salida.

Está estableciendo, como Cavalcanti, como Petrarca, una continuidad entre visio (los cuartetos), cogitatio o recreación fantástica en ausencia (los tercetos) y creación literaria. Obsérvese que en los tercetos, el fantasma de la amada, conducido por los espíritus sanguíneos, quiere servir de cuerpo sutil de la imaginación, mediante el calor que los "enciende" (v. 11) y sublima, con lo que se consigue la recreación espiritual (o sea, "neumática") de la imagen. No obstante, si leemos atentamente comprobaremos cómo el poeta intenta imaginársela impulsando los espíritus para que transporten la imagen a la memoria y a la fantasía, que, según seguían creyendo en su época, ocupaban ventrículos contiguos, (v. 10); pero no lo logra (v. 14). La descripción de todo el proceso imaginativo-espiritual es, precisamente, el poema (su inventio); o sea, se sigue dando la continuidad fantasía-creación que arriba veíamos en Petrarca.

No obstante, como apunta en sus Anotaciones Fernando de Herrera, la imaginación o fantasía está vinculada al alma sensitiva, por lo que no sirve para la contemplación de universales ni para representar las ideas (por ejemplo, la de belleza, o la de amor); o mejor dicho: ha de ponerse al servicio de la contemplación intelectual'.

9 "Es la fantasía potencia natural del ánima sensitiva, y es aquel movimiento o acción de las imágenes aparentes y de las especies impresas. Tomó nombre griego de la lumbre, como dice Aristóteles, porque el viso, que es el más aventajado y nobilísimo sentido, no se puede ejercer sin lumbre; y porque así como la lumbre y claridad [...] muestra las cosas que rodea e ilustra, así se muestra la fantasía mesma. Tulio lo interpretó viso, Quintiliano visión y los modernos imaginación [...]. Esta se engaña muchas veces y se confunde en error más que los sentidos inferiores. $Y$ por ésta se representan de tal suerte en el ánimo las imágenes de las cosas ausentes, que nos parece que las vemos con los ojos y las tenemos presentes. $Y$ podemos fingir y formar en el ánimo verdaderas $y$ falsas imágenes a nuestra voluntad y arbitrio, y estas imágenes vienen a la fantasía de los sentidos exteriores" (Gallego Morell 1973, pág. 88-89). 
$\mathrm{Al}$ decir de Platón, por tanto, este tipo de goce fantástico del amor (y su recreación poética) es, meramente, una opinión, no es esencial o ideal. A la fantasía, como mucho, le compete una función ancilar: proporcionar imágenes para la posterior formación de conceptos o universales que reflejen, bien que parcialmente, nociones ideales ${ }^{10}$. No así para los representantes del Neoplatonismo, que acortaron la distancia entre la fantasía y el entendimiento con la noción de ratio. En efecto, para Ficino o Bruno, el pincel de la fantasía está hecho de luz interior (recuérdese la phaos aristotélica) que ilumina las visiones de nuestros sueños o las imágenes depositadas en la memoria. Esta luz invisible e incorpórea, inmaterial y emanada de nuestra alma, es la sustancia espiritual arriba mencionada. Ficino (a través de Proclo, Porfirio y otros) enumera distintos tipos de luz interior o fantástica: la de Dios, la de los ángeles, la racional, etc., hasta la luz solar de todos los días; y establece una trabada y gradual relación entre ellas, pues, al fin ya al cabo, todas participan de la luz del espíritu universal, del alma del mundo. La diferencia con Platón radica en que la luz con que la fantasía pinta las figuras mentales es la misma que la del alma racional, con lo que hermana así fantasía y razón.

Dicha concepción tendrá plena vigencia, como decía, hasta el siglo XVII. Empezará a derrumbarse a partir de Descartes, quien publica, además del Discurso del método, el Tratado de las pasiones (Les passions de l'âme, 1646) y, un poco más tarde, J. Locke su Ensayo sobre el entendimiento humano (1690), que van a suponer no tanto un giro copernicano de la cuestión cuanto una aproximación filosófica y estética distintas. Aunque diferentes, ambas obras arrancan de presupuesto muy parecidos. En ambas se rechaza la esencia platónica y se sustituye por la fuerza constitutiva del pensamiento: el sujeto se concebirá como creador de la realidad, en tanto que la aprehenderá a partir de los contenidos de conciencia; ya sea mediante el cogito cartesiano, ya mediante el sensismo lockiano. En ambos se elimina el carácter participado (platónico) del conocimiento humano y se subraya el papel originante del acto de sentir y de percibir, que sustituyen progresivamente al acto de ser, a la esencia, pues la unidad e identidad del sujeto cartesiano radican en el acto, lockiano, de percibir las propias sensaciones. Sujeto y acto de conciencia reemplazan, pues, a la esencia y a la idea innata. En palabras de Paul Hazard (1963, pág. 225), la revolución intelectual y estética consistiría en "ver elaborarse el pensamiento humano y ver edificarse, al mismo tiempo, las creencias que permiten al hombre tener una vida feliz, con la conciencia de que no hay nada, ciencia moralidad, arte, que no venga de sus propias operaciones".

10 Léanse, si no y por ejemplo, las palabras del preceptista López Pinciano: "No atiende la imaginación a las especies verdaderas, mas finge otras nuevas, y acerca dellas obra de mil maneras: unas veces, las finge simples; otras, las compone; ya finge especies de montes que nunca fueron; ya de las especies del monte y de las del oro hace un monte de oro; ya del oro hace un coloso, y ya un animal que tenga cabeza de hombre, cuello de caballo, cuerpo de ave y cola de pece porque abraza las especies pasadas, presentes y futuras" (I, pp. 48-49) 
En las obras citadas, Descartes considera que el hombre está compuesto de dos esferas: la superior, que alberga a la razón, y la inferior, dominio de las pasiones, provocadas por lo que captan los sentidos. El arte, la estética ("razón inconsciente" la llama el francés), se situaría en la intersección formada por la esfera superior (idea o inspiración artística) y la inferior (estímulo y materialización de esa idea en objeto artístico). Obsérvese que, al igual que Aristóteles, ambas secciones no son compartimentos estancos, sino que hay una continuidad psíquica: el artista asume plenamente la sensación, la pasión, y la canaliza estéticamente (véase Garin 1989, pp. 148-157).

Locke, por su parte, divide las ideas en simples y complejas; las primeras son aquellas que "no producen en el espíritu más que una sola imagen" (II, ii, 2); representan todo el material de que dispone nuestra mente; a partir de ellas, componiéndolas a voluntad, el espíritu forma ese universo maravilloso que cada uno lleva dentro de sí (descarta las que él llama "ideas fantásticas", II, $\mathrm{xxx}, 1$ ). Las ideas complejas son "combinaciones de ideas simples reunidas y unidas en un nombre general" (II, xxx, 3), por lo que parece que "la mente humana goza de alguna suerte de libertad para formar esas ideas complejas [...] la cuestión entonces estriba en saber cuáles de esas combinaciones son reales y cuáles son únicamente imaginarias. En saber qué colecciones de esa ideas están de acuerdo con la realidad de las cosas y cuáles no lo están" (ibid.). La solución, claro, es evidente: las "ideas [complejas] no son reales sino en la medida en que son combinaciones de ideas simples realmente unidas y que coexisten en las cosas que están fuera de nosotros. Por el contrario, son fantásticas aquellas que están formadas de tales colecciones de ideas simples que realmente nunca han estado unidas, nunca se han encontrado juntas en ninguna sustancia [...] debemos tenerlas únicamente como ideas imaginarias" (II, xxx, 5).

Sean o no reales, lo que nos importa, de momento, es que considere al hombre capaz de combinar a su voluntad las ideas simples; en tal sentido, sigue de cerca el Tratado de las pasiones de Descartes, quien afirma (arts. XX y XXVI):

Cuando nuestra alma se aplica a imaginar alguna cosa que no existe, como en representarse un palacio encantado [...] las percepciones que ella tiene de estas cosas dependen principalmente de la voluntad que hace que ella las perciba $[\ldots]$ Así, a menudo cuando se duerme, y también a veces estando despierto, se imagina tan fuertemente ciertas cosas, que cree verlas ante sí o sentirlas en su cuerpo, aunque no estén allí.

Lo explica Descartes por la acción de los espíritus animales en el cerebro y por el funcionamiento de una glándula, también cerebral, que permite fantasear: "Cuando se quiere imaginar alguna cosa que nunca se ha visto, esta voluntad tiene la fuerza de hacer que la glándula se mueva de la manera que se requiere para impulsar los espíritus hacia los poros del cerebro por cuya abertura esta cosa puede ser representada" (art. XLIII). 
Ni que decirse tiene que Descartes no habla de la voluntad en el sentido escolástico, pues "nuestras pasiones no pueden ser directamente excitadas ni anuladas por la acción de nuestra voluntad" (XLV), sino que casi todas van "acompañadas de alguna emoción que se produce en el corazón, y, por consiguiente, también en toda la sangre y los espíritus, de suerte que, hasta que esta emoción haya cesado, permanecen presentes en nuestro pensamiento de la misma manera que los objetos sensibles están en él presentes mientras obran sobre los órganos de nuestros sentidos" (XLVI). Como se puede ver, y arriba indicamos al hablar de las dos secciones humanas, la explicación funcional de lo fantástico y lo emotivo no está demasiado alejada de la circulación espiritual (neumática) de la fisiología clásica; sí difieren en la conciencia individual añadida: la voluntad de representar el objeto en la fantasía (parte superior del hombre), o la de asociarlo emocionalmente con alguna pasión (porción inferior).

Retomemos a Locke, pues igualmente encontramos en él esta defensa de la capacidad de fantasear del alma humana: "Es misión de la memoria proporcionar a la mente aquellas dormidas ideas de que tiene necesidad; tenerlas dispuestas para todas las ocasiones consiste lo que llamamos invención y fantasía" (II, ix, 8). Cosa bien distinta es la realidad o irrealidad del conocimiento, pues " ¿existe algo más extravagante que la imaginación del cerebro humano? ¿Dónde existe una cabeza que no tenga una quimera?" (IV, iv, 1). Pero, habida cuenta de que somos dueños de las voluntarias combinaciones de las ideas simples, "las visiones de un entusiasta y los razonamientos de un hombre sobrio serán igualmente ciertas. Nada importa cómo sean las cosas: será suficiente con que un hombre observe el acuerdo de sus propias imaginaciones, y con que hable de manera convincente, para que todo sea verdad, para que todo sea cierto" (ibíd.) Cosa bien distinta es "¿para qué le sirve todo este bonito conocimiento de la imaginación $[\ldots]$ al hombre que pregunte por la realidad de las cosas?" (ibid.) Pero, al menos, reconoce la capacidad individual de crearlas mediante la combinación de recuerdos, emociones, $\mathrm{o}$ ambos ${ }^{11}$.

Y, claro, por aquí plasma su desacuerdo tanto con los conceptos platónicos de entusiasmo y participación en la divinidad (IV, xix, 6 ss.) cuanto con el aristotélico de fantasía: "¿Qué mejor camino puede existir para conducirnos a los errores y desvaríos más extravagantes que el tomar la fantasía como la guía suprema y única $[\ldots]$ ? La fuerza de nuestras persuasiones no constituye ninguna

11 De hecho, una vez desacreditada la platónica participación del alma en la divinidad, esta capacidad es la principal función del alma, "porque la psique humana es, según Locke, cognoscible a través de los patrones asociacionistas de acuerdo con los cuales convertimos nuestras percepciones sensoriales en ideas... tanto más cuanto que para los asociacionistas el alma no es más que el agregado de las percepciones de los sentidos materiales transmitidas a la conciencia [...]. He aquí anticipada [...] la idea romántica de que la naturaleza es alma visible, y el alma es naturaleza invisible" (Sebold 1989, págs. 14-15). 
prueba de su propia rectitud (IV, xix, 11), pues "la $l u z$, la verdadera luz en la mente es [...] la evidencia de la verdad de una proposición [...]. Hablar de cualquier otra luz [clara referencia a la phaos aristotélica] en el entendimiento significaría sumirnos en las tinieblas o situarnos bajo el poder del Príncipe de las Tinieblas" (IV, xix, 13). Vale decir: hemos pasado de la fantasía o iluminación como participación en la luz cósmica, de Ficino o Bruno, a la iluminación individual: la conciencia del sujeto tiene su propia luz (sensación-percepción) y, por tanto, juzga por sí misma. En dos palabras: el individualismo sensista, unido al cogito cartesiano.

Locke, al menos, dejó bien claras la capacidad y la libertad combinatorias de la imaginación humana para formar ideas reales o irreales (fantásticas); para crear una realidad propia, que ya no está, como anteriormente, al servicio del concepto o del arquetipo. La Fantasía ya no es ancilla intelecti, sino un instrumento con que la parte racional (angélica) pueda contemplar o pueda formar universales; o sea, el phantasma ya no es un intermedio entre lo particular y lo universal. Como consecuencia, a partir del siglo XVIII parece que esa necesidad imperiosa de formar universales no sea tan perentoria, sino que se tiende a individualizar las imágenes; o, al decir del profesor Sebold, a "dinamizarlas": "en la anacreóntica de Meléndez se nombran el oído y la vista, y estos sentidos, junto con el tacto y el gusto, contribuyen a la representación de una naturaleza dinámica y viva, todo ello debido a la observación sensualista lockiana" (1977, pág. 44). Sentir, por tanto, significa que el sujeto tiene conciencia de la sensación, es decir, sentir vale por sentirse. El sujeto no se concibe únicamente como inteligencia, sino que se descubre como un complejo de sentimientos y de imágenes, solas o asociadas con aquéllos; sentimientos e imágenes que, en muchos casos (apuntará Locke), son contradictorios y falto de lógica. Lo ilógico de algunas combinaciones de la fantasía, sin embargo, no la descartan como facultad creativa.

Sin embargo, en seguida hay que decir que en la primera parte del siglo XVIII muchos autores redujeron la fantasía (¿por ese mismo peligro de falta de lógica?) a labores subsidiarias: embellecer, deleitar, adornar; otros la dotaron, precisamente por su vinculación con la emoción y su capacidad de recrear mentalmente las imágenes, de un papel protagónico; con todo, la diferencia de planteamientos entre unos y otros es gradual. Entre los segundos, destaca Joseph Addison y sus Placeres de la imaginación (1712). A diferencia de Descartes, Addison establece tres porciones en el ser humano: la razón, la parte sensual y pasional (a excepción de la vista) y la imaginación, intermedia entre las dos (nótese que ya la conceptuaban así a partir de Aristóteles). Dada su situación intermedia, explorar los placeres de la imaginación valdrá por hallar las causas por las que ciertos objetos mueven "fuertemente nuestras pasiones": lo bello, lo grande y lo singular. Procediendo de tal modo, estaba poniendo los fundamentos de tres claves estéticas que desarrollará el Romanticismo, a saber: lo bello, lo sublime y lo pintoresco, respectivamente. 
Según Addison, uno de los mecanismos básicos (en realidad, su máximo logro) por el que la imaginación nos da tales placeres es el de la evocación, asociación de ideas o conceptos en la fantasía:

Podemos observar que una sola circunstancia de lo que ya hemos visto recuerda a veces una escena entera de imágenes, y despierta innumerables ideas que antes dormían en la imaginación [...]. Enciéndese nuestra imaginación, y sin pensarlo nos lleva a ciudades o teatros, llanuras o prados [...] y la memoria de esto da nuevo realce al deleyte que le causó el original [...]. En vano será investigar si el poder de imaginar cosas extrañas procede de mayor perfección en el alma [...]. Lo cierto es que un grande escritor debe haber nacido con este poder en toda su fuerza o vigor; de suerte que sea capaz de recibir ideas vivas de los objetos exteriores, de retenerlas por mucho tiempo, y de combinarlas cuando se ofrezca en aquellas figuras y representaciones más a propósito para herir la imaginación del lector ${ }^{12}$.

El otro fundamento de la fantasía es su capacidad para reordenar o recomponer la realidad o su recuerdo, pues "podemos retener, alterar y componer las imágenes recibidas, y formar de ellas cuantas pinturas y visiones agraden más a la fantasía ${ }^{13}$. El poeta está especialmente dotado para ello, siempre, claro que no intente "aventajar" a la naturaleza (pp. 191-193):

Como la imaginación se puede siempre figurar cosas más grandes, nuevas o bellas que las ya vistas, y hallar algún defecto en lo ya visto, los poetas tienen el arte de lisonjearla en sus ideas enmendando y perfeccionando la naturaleza cuando describe una cosa real, y aumentado nuevas bellezas que las que hallan en la naturaleza cuando describe una cosa fingida [...]. El poeta $[. .$.$] elige los vientos y tuerce el curso de los ríos, encaminándolos con$ toda la varia tortuosidad que contemple más deliciosa a la imaginación del lector. En una palabra, tiene en su mano el modelo de la naturaleza, y puede darle los encantos que guste; con tal de que no la reforme demasiado y caiga en absurdos por querer aventajarse a ella.

12 Pág. 179-182; nótese que lo que plantea no es más que el desarrollo y nueva concepción de la reminiscencia de Aristóteles (v.g., De memoria et reminiscencia, 452a) reelaborada por Descartes en su concepción mecanicista de la memoria; véase cómo el francés explica la función de los espíritus animales que recorren el cerebro en busca de los surcos que dejó el objeto que queremos recordar en su Tratado de las pasiones, art. X ("Cómo se producen los espíritus animales en el cerebro")-XVI, XX-XXVI, etc.; especialmente el art. XXI, donde se refiere a las "imaginaciones", "que no pueden ser puestas en el número de las acciones del alma, y no proceden sino de que los espíritus, siendo diversamente agitados y encontrando las huellas de diversas impresiones en el cerebro, toman en él su curso fortuitamente por ciertos poros antes que por otros. Tales son las ilusiones de nuestros sueños" (pág. 17); y las evocaciones fortuitas, reminiscencias o asociaciones de ideas.

13 "En otras palabras, una vez tengamos registrados en la memoria los objetos, la imaginación tiene una doble función: o bien se encarga de representarlos cuando están ausentes, actuando como memoria; o bien los combina y dispone formando así composiciones que le plazcan. Addison afirma que la imaginación no sólo está limitada a recomponer imágenes recordadas de la naturaleza, sino que es capaz de crear mundos nuevos al mostrarnos personas que no se hallan en ella. Distingue, así, el mundo de la poesía del mundo de la experiencia y, por tanto, establece implícitamente una diferencia entre la verdad poética y la filosófica" (Raquejo, en Addison 1991, págs. 68-69). 
A esta capacidad se refiere Jovellanos (y valga la intromisión), a quien tanto influyó Addison, en su Tratado teórico-práctico de la enseñanza (1801), en ocasión de criticar poemas cuyos autores "no han conocido que en el lenguaje de la poesía la imaginación ocupa el lugar y ejerce los oficios de la razón, y aunque recibe de ésta el fondo de sus ideas, se encarga de colorirlas y de engalanarlas; no han conocido que esta facultad sabe tomar de la naturaleza las bellezas de unos objetos para transportarlas a otros, y adornarlas, inventar formas e imágenes para representar las ideas más abstractas“"(1987, pp. 20-21).

Vuelvo a Addison para confirmar que, según él, ambos presupuestos estéticos (evocación y reordenación de lo evocado) se combinan perfectamente y pueden (tal como ya vimos también en Aristóteles) ser encauzados por la palabra; siendo ellos, además, los que fundamentan la libertad, originalidad y subjetivismo del poeta y del lector: "en la descripción nos lo pinta [el objeto] el poeta libremente, y como más le agrada; y nos hace ver diversas partes, a las cuales no atendimos, o no estaban al alcance de nuestra vista al mirarlo [...] el poeta nos puede dar de él una idea más compleja o excitar solamente las más aptas para herir la imaginación" (pág. 176).

Tales facultades deberían tender, según sus propias palabras, a hacer que la fantasía lograse complementar las obras de la naturaleza y las del arte, aunque siempre aquélla superará a éste, pues las obras de arte "podrán parecer algunas veces tan bellas o singulares [lo larvadamente pintoresco] como las de la naturaleza; pero nunca tendrán aquella desmedida grandeza e inmensidad que transporta el alma al contemplar las de la naturaleza" (Ibid.). O sea, las naturales son grandes (sublimes) y singulares (pintorescas). Pese a ello, a renglón seguido afirma que "hallamos, sin embargo, más agradables las obras de la naturaleza cuanto más se parecen a las artes, porque en este caso el placer nace de un principio doble: del agrado que los objetos causan a la vista, y de la semejanza a otros objetos" (compárese con la mímesis de Aristóteles, Poética, IV; y, abajo, con Burke).

Aún se puede citar un texto de Jovellanos en que parece seguir los planteamientos últimos de Addison. Me refiero a las célebres Reflexiones (1789) sobre Las Meninas de Velázquez, donde subraya aquella subjetividad del artista, su capacidad para ver, mediante la luz de su fantasía, lo que el hombre normal no ve. Aquí parece defender Jovellanos, a la vez, el aspecto icástico (o sea, la mímesis, como Luzán) y el fantástico, pues, viene a afirmar que si lo icástico causa más admiración, lo fantástico, más deleite; por lo que, deducimos, el arte perfecto debería albergar ambos aspectos. A renglón seguido parece desmentir esta solución de compromiso para decir que la naturaleza vence al arte; sin embargo, un poco más abajo toma partido por lo fantástico: "No por esto [o sea, por su mímesis icástica] diremos que Velázquez no alcanzó aquel don de expresión que pertenece a la parte sublime y filosófica del arte. ¿Cómo sin él hubiera dado a sus cuadros tanto movimiento y tanta 
viveza?". Con el "don de expresión" se refiere a la capacidad de emocionar (o sea, de "herir la imaginación" como diría Addison), que prevalece sobre la belleza ideal. En última instancia, predica que el arte, de algún modo, transforma la naturaleza a través de la imaginación. Se corrobora cuando más abajo habla de que Velázquez está haciendo una "imitación de lo invisible", que es lo que más admira del boceto: "De él [de Velázquez] se dice que llegó a pintar hasta lo que no se ve, esto es, hasta lo que se ve más bien con el espíritu que con los ojos $[\ldots]$ y si hay magia en la pintura, sin duda que ningún pincel fue más mágico que el de Velázquez".

Obviamente, esta magia es la misma que Addison confiere al poeta en el tercer párrafo, al afirmar que "pinta" lo que no hay en la naturaleza, o sea, lo que sólo encuentra en su imaginación; fruto, eso sí, de sensaciones anteriores, evocaciones o asociaciones, o sea, de combinaciones de fantasmas. Compárese con lo que M.H. Abrams (1974, pág. 285) denomina "teoría mecánica de la invención poética", o sea, la herencia psicológica y estética cartesiano-lockiana recogida por Hume, Gerard y otros: "Las imágenes se mueven siguiéndose unas a otras cruzando por el ojo de la mente. Si ellas vuelven en el mismo orden espacial y temporal [...] tenemos la memoria. Pero si las imágenes íntegras [...] vuelven en un orden diferente, o también si partes segmentadas de dichas imágenes son combinadas en un todo nuevo que nunca estuvo presente a los sentidos, tenemos la fantasía o imaginación".

Como ilustración de estas palabras, y para cotejarlo con Addison, oigamos a Condillac, que concibe la fantasía como un complemento de la verdad, pues le asigna una función, de nuevo, subsidiaria, aunque de signo distinto a la que tenía hasta el siglo XVII:

L'imagination a sur-tout les agrémens en vue, mais elle n'est pas opposée à la vérité. Toutes ses fictions sont bonnes lorsqu'elles sont dans l'analogie de la nature, de nos connoissances ou de nos préjugés; mais dès qu'elle s'en écarte, elle n'enfante plus que des idées monstrueuses et extravagantes. C'est là, je crois, ce qui rend cette pensée de Despréaux si juste: "Rien n'est beau que le vrai; le vrai seul est aimable. II doit régner partout, et même dans la fable", (Boileau, Epitre IX, 43-44). En effet, le vrai appartient à la Fable: non que les choses soient absolument telles qu'elle nous les représente, mais parce qu'elles les montre sous des images claires, familières, et que, par conséquent, mous plaisent, sans nous engager dans l'erreur (1973, pág. 149).

Poniendo por testigo a Boileau, la fantasía se limita, o debiera limitarse, a alumbrar (recuérdese, de nuevo, la etimológica definición de Aristóteles) y a complementar la verdad. Consciente, eso sí, de su poder "embellecedor", de su capacidad para ordenar de nuevo las sensaciones recordadas, las imágenes evocadas (pág. 148). En los pasajes siguientes, y a partir de la máxima de Boileau, insiste en que el cometido, subsidiario, de la fantasía es, básicamente, embellecer la verdad. 
En otra obra suya, el Tratado de las sensaciones también lo apunta: "la imaginación aproxima las más distintas [ideas], cambia el orden que tenían en la memoria y forma con ellas una cadena totalmente nueva [...]. En virtud de la imaginación, las ideas se enlazan de mil maneras diferentes, y con frecuencia se recuerda menos el orden en el cual experimentó sus sensaciones que aquel en que las imaginó" (1963, pág. 83). Nótese que de nuevo la prerrogativa que le reserva a nuestra facultad es la de reordenar, recomponer y enlazar diversamente las sensaciones, las emociones y las imágenes, aunque siempre partiendo (aristotélicamente, diríamos, aunque también es una de las claves de Addison) de las imágenes referidas a la realidad.

Así, la realidad, lejos de ser descartada, es el referente, mediato o inmediato, para aquilatar el mayor o menor deleite conseguido mediante su complementaria: la fantasía. Por ello, más abajo establece una correlación gradual, sin solución de continuidad, entre sensaciones, fantasía, reflexión, etc. La capacidad de fantasear, como vemos, está entre la memoria y la reflexión; no está claramente diferenciada, ni funcional ni estéticamente. No en balde, en el Essai la diferencia se limita a que la fantasía "conserve la perception même", mientras que la memoria, "n'en conserve que le nom ou les circonstances" (pág. 121). O sea: fantasear supone, meramente, recordar más vivamente.

También esperábamos encontrar en el Muratori de la Fuerza de la humana fantasía (1743) una defensa a ultranza de la facultad, pero sus planteamientos estéticos se quedan más acá que los citados. La definición y características se corresponden, básicamente, con las citadas, aunque más bien nos recuerda el Thesaurus de Sto. Tomás: Fantasía "es aquel arsenal en que se recogen y aprehenden las especies de una infinidad de cosas, que sirven después de materia para los pensamientos. [...], en ella especialmente consiste el comercio del alma con el cuerpo". Ello se debe a que la fantasía (habida cuenta de que es el comercio entre alma y cuerpo) "es poderosa motriz de nuestro cuerpo, a causa de la comunicación que con el corazón y con todos los nervios tiene nuestro celebro" (Ibíd.).

Lo más interesante es la derivación hacia el ut pictura poesis horaciano de la capacidad expresiva del poeta mediante la mímesis fantástica (págs. 270275):

La pintura es una poesía hecha con colores $[\ldots]$. El saber un poeta imaginar y pintar bien algún objeto o alguna acción proviene de su vivaz fantasía, [pintará] con ideas sensibles lo abstracto y sutil de las doctrinas [...] con gracioso estilo poético, hijo también de la fantasía, teniendo en tal asunto atento y divertido al lector con lo admirable y nuevo [...]. Es de maravillar del mismo modo el poeta que sabe imaginar vivazmente los sucesos, ya verdaderos o ya fingidos, y como si los viese con sus propios ojos, los describe circunstanciadamente, de modo que experimentáis aquel mismo placer o movimiento interior que si los vierais pintados en un cuadro de Tiziano. 
También se adhiere a la prerrogativa fantástica de combinar o reordenar los recuerdos; pero cuando se trata de hallar conceptos (en el sentido barroco), la fantasía vuelve a su condición de ancilla intellect $i^{14}$. De semejantes atribuciones (la variación y nueva disposición de los aprehendido por los sentidos) parece dotarla Burke ([1757] 1987, págs. 11-12):

La mente del hombre posee una especie de poder creativo de por sí, representando a su antojo imágenes de cosas en el orden y según la manera en que fueron recibidas por los sentidos, o combinando aquellas imágenes de una nueva manera y según un orden diferente. Este poder se llama imaginación; y a ella pertenece todo lo que llamamos ingenio, fantasía, invención, y lo que se le parece. Pero hay que tener en cuenta que tal poder de la imaginación es incapaz de producir nada absolutamente nuevo; sólo puede variar la disposición de aquellas ideas que ha recibido de los sentidos. Ahora bien, la imaginación es la provincia más extensa del placer y del dolor [...] de nuestros miedos y esperanzas, y de todas las pasiones que están en conexión.

Hasta ahora, todo parece acorde con lo dicho y, claro, con la remota mímesis icástica. No obstante, hacia el final del libro asume con vigor inusual de defensa de la mímesis fantástica, que hace coincidir con la "simpatía" poética que condena Platón. O sea, se basa en la emoción, que no comporta semejanza, para definir los efectos de la poesía, con lo que desmiente la mala interpretación del horaciano Ut pictura poesis (compárese con Lessing 1985, pp. 151-157 y passim). Parte para ello de la descripción homérica de Elena; descripción que, precisamente porque no es mimética, "nos afecta mucho más", pues, "a diferencia de la pintura, la misión de la poesía y de la retórica consiste en afectarnos más bien mediante la simpatía que mediante la imitación; mostrar, especialmente, el efecto de las cosas en la mente del que habla, o de los otros, que dar una idea clara de estas mismas cosas" (pág. 129). En tal sentido, Burke se alejaría de la visualización de Addison y, en general, de la tendencia de asociar imaginación con intensidad visual; defendería, en cambio, la progresiva tendencia a subrayar el poder de evocar sensaciones, especialmente emotivas, de penetrar por simpatía en los sentimientos ajenos.

Como se puede apreciar, con el discurrir de los años se va tendiendo hacia la concepción sentimental del arte, esto es, se va a ir reduciendo al mínimo su función mimética y subrayando su capacidad de suscitar evocaciones y afectos en la mente del lector: simpatía, terror, emoción... (compárese con De lo bello y lo sublime, 1764 , de Kant). No muy alejado (aunque en pro de representar la

14 Así lo declara en Della perfetta poesia (1821., II, pág. 21): "Indizio di grande ingegno è iI trovar bellissime e nuove similitudini [...]. E queste somiglianze poi dall'intelletto ritrovate [...] da noi si vogliono chiamare immagini intellettuali o ingegnose, a differenza delle immagini della fantasia: non già perchè la fantasia nulla serva all 'intelletto nel ritrovamento e nell'unione delle simiglianze, ma perch'e più propia dell'intelletto ci par questa operazione [...]. La fantasia a lui reppresenta gli oggetti fra loro diversissimi lontani; egli [...] ne reccoglie quanto veramente v'ha di somigliante fra loro [...] e solamente corre per gli oggetti compresi nella fantasia" (cf. Manero 1989 , pág. 306 y passim). 
belleza ideal) se muestran Sir Joshua Reynolds en sus Discourses (1769-70) y otros tantos críticos ingleses (no puedo pormenorizar; la explicación de la teoría de los críticos ingleses puede verse en Wellek 1969, I, pp. 117-139 y en Carnero 1983).

También se podría convocar aquí a Diderot, que lleva al extremo dicha concepción de la poesía, del poeta. Así, en Le Rêve de D'Alambert (1769) la imaginación se presenta como capaz de percibir analogías superiores a las de la pura asociación. La función de la fantasía no es únicamente la de reordenar, reelaborar o embellecer las imágenes depositadas en la memoria, sino que afirma que al poeta las imágenes le sobrevienen de modo impredictible e inexplicable, como resultado de la emoción que en aquel momento le asalte. Defiende, por ello, las asociaciones originales del creador y afirma que dichas asociaciones, si no verdaderas, sí son reales, proque se originan en el interior del poeta, que puede sentirlas y asumirlas con una emoción mayor que la que le pudieran producir las impresiones directas de los sentidos. De hecho, el criterio de grandeza poética viene aquilatado por la intensa emoción que experimenta el individuo. En poesía y en cualquier arte, una idea, lejos de ser mero dato sensorial, ha de transformarse en emoción, no en concepto. Es la otra cara de la fantasía, la que vimos que rechazaba Platón: la emoción, la simpatía (a las que hay que asociar toda la estética de los sublime y demás categorías), ya las sienta el poeta, ya intente conseguir ese efecto en el lector.

Ello también lo posibilita, retomo a Burke, el hecho mismo de que la poesía se haga con palabras, (o sea, que no sea una arte plástica) pues (y aquí el inglés vuelve al principio clave), "mediante las palabras, podemos hacer combinaciones que posiblemente no podemos hacer de otros modos". Merced a ellas, la fantasía (y emoción) del autor, y del lector, puede evocar, connotar conceptos o ideas (lo ejemplifica con Milton). En el fondo, late el subjetivismo que hemos visto en Diderot y que tan bien supo expresar David Hume en su $O f$ the Standard of Taste (1757): "La belleza no es ninguna cualidad de las cosas mismas. No existe más que en la mente del que las contempla". O las premisas de Edward Young en sus Conjectures on Original Composition (1759), donde subraya la necesidad del individualismo y originalidad del poeta; de sus palabras se deduce que lleva más allá una de las ideas clave que hasta ahora hemos manejado: la imaginación del poeta deja de ser facultad combinatoria y constructiva para hacerse creadora de otro mundo (bien es cierto que pocos defienden en la Inglaterra de su tiempo tal concepto).

La otra idea, la progresiva defensa de la emoción respecto de la visualización, también tiene sus geniales continuadores; valga citar a Lessing, que, como hará luego Blanco, retoma el ejemplo homérico de Burke: "Lo que Homero no podía describir en sus partes constitutivas nos lo da a conocer por medio de sus efectos. Oh poetas, pintadnos el deleite, la emoción, el amor, el éxtasis que la belleza causa y habréis pintado con ello la belleza misma" (pág. 152). 
Herder (y en general el Sturm und Drang) a ese poder de la poesía lo denomina energía, con lo que quiere indicar que aquélla permite expresar no sólo acciones sucesivas, sino también cuerpos, imágenes, pinturas: "Sé por Homero que el efecto de la poesía es [...] sobre la imaginación [...]. Por eso la opongo a la pintura". Repárese - habría que subrayarlo- en que es la primera vez que se desliga de la fantasía una de sus componentes: la imagen, la "pintura" (o sea, la mímesis icástica), reduciéndola a la otra: la emoción. Poesía es "efecto sobre nuestra alma o energía". De aquí a decir que la poesía no es imitación de la naturaleza, sino, como harán los románticos, "imitación de la divinidad creadora, denominadora", no hay más que un paso. Así, para Herder, el poeta es "segundo creador, poietes, hacedor".

Antes de seguir adelante, quizá valdría la pena ver plasmada, muy sucintamente, porque no es el tema del trabajo, la evolución de algunas de estas cuestiones en algunas poéticas españolas. Pero antes volveré a citar el influyente Dalla Perfetta Poesia Italiana (1703) de Muratori, muy anterior a la Fuerza de la humana fantasía (escrita en 1743) y que tanto influyó en Luzán y en los posteriores. Aunque el italiano desde un principio establece una clara diferencia, como hemos visto, entre imágenes intelectuales e imágenes de fantasía (en la línea de Vico), al final acepta la existencia de un tipo mixto que encaja muy bien con los presupuesto románticos. Por pasos: el primer tipo de imagen corresponde más o menos al concepto moderado barroco, en el que el nexo entre lo real y lo figurado mantiene una relación lógica; el segundo, las fantásticas, carecen de relación lógica entre sus términos reales e imaginarios, suscitada tal carencia por la construcción metafórica y por lo inusitado de la relación entre los términos. Con todo, la operación importante es la intelectual: "appartien prima all'intelletto, o vogliam dire all'ingegno, il ritrovar simiglianza fra gli oggetti; e su questo fondamento poscia può la fantasia appoggiare le immagine sue" (Muratori, 1821 II, pág. 24). Sin embargo, las imágenes que encuadra en el tercer tipo, las "verisimili alla fantasia" (por ejemplo, decir que un "arroyo se enamora del florido terreno por el que discurre"), "riconoscono più evidentemente essere dalla fantasia, la quale insieme unisce due o più immagini vere o naturali, per formare una nuova che mai naturalmente non è stata, ne può essere o apparire all'intelletto" (ibíd., pág. 207).

Repárese en que este tercer tipo es el reflejo poético de la función estética atribuida por otros teóricos (Addison, Condillac, Burke...) a la fantasía. Además, Muratori también asigna a la fantasía como facultad otra característica ya vista: la emoción, pues el italiano parte del análisis del sentido, del sentimiento, de la pasión y del afecto como origen de la fantasía, derivando, de este modo, hacia planteamientos románticos, también anunciados con el concepto seudoplatónico de "simpatía" por Burke. Apunta que el afecto o la pasión dan la suficiente verosimilitud a las imágenes fantásticas: "Si formano queste dalla fantasia allorche esse commosa de qualche affetto unisce due diverse immagini semplici e naturali, 
e da loro una figura o un essere differente da quanto la reppresenta il senso" (II, pág. 255). Imágenes que, claro, siguiendo a Muratori, no aprueba Luzán:

La tercera manera [de imágenes] es cuando la fantasía se usurpa las riendas del gobierno y manda despóticamente el alma, sin oír los consejos del entendimiento. Pero, semejantes imágenes, hijas de una loca y desenfrenada fantasía, en las cuales todo es falsedad, desorden y confusión, no caben en la poesía, ni aun en los discursos de hombres de sano juicio, dejándose sólo para los que, o dormidos sueñan, o calenturientos desvarían, o enloquecidos desatinan. (1977, pág. 246)

Por lo que decide hablar sólo "de las dos primeras especies de imágenes, esto es, de las que forma el entendimiento solo o la fantasía guiada por el entendimiento" (a reglón seguido). Lo que no es óbice para que a continuación el aragonés, siguiendo a Addison, haga corresponder cada tipo de imagen con las tres claves estéticas de éste: lo sublime corresponderá al primer tipo, la belleza al segundo y lo singular o extraordinario al tercero, o sea, a las imágenes quiméricas o fantásticas. Pero no olvidemos que Addison no exhortaba al poeta a copiar, sino a perfeccionar la naturaleza a través de la imaginación, eligiendo de aquélla lo más grande, bello y extraño, y combinándolo, emotivamente, mediante la asociación y la evocación de su fantasía. Como se ve, no deja de apostar por la mímesis, pues "imitación de la naturaleza no quiere decir reproducción realista de cualquier cosa que exista en el mundo natural o humano" (Carnero 1983, pp. 19-20). Pero, claro, Addison, al aceptar el pleno protagonismo de la fantasía (es decir, al no asignarle una función meramente ancilar), va más allá de concepto de mímesis de Muratori o Luzán, que subrayaban la preeminencia del entendimiento.

A partir de esta polaridad entendimiento/fantasía se puede medir el progresivo alejamiento de la norma neoclásica en los posteriores preceptistas, poniendo como raseros el mayor o menor grado de imitación de la naturaleza por la intervención de la fantasía, siendo sus límites la imitación particular y la universal (o icástica y fantástica). Desde Luzán, podríamos citar a Burriel (1757), Esteban de Arteaga (1789), Santos Díez González (1793), Francisco Sánchez Barbero (1805) y Juan Francisco Masdeu (1826). Quizá el más firme defensor de la imitación fantástica sea Arteaga, el más cercano a Luzán, Burriel; Masdeu y Sánchez Barbero son más eclécticos. Pero, como digo, es gradual; desde, digamos, el naturalismo (icástico) hasta la modificación o perfeccionamiento de la naturaleza, o sea, hasta — valga de momento el concepto - la idealización por la fantasía. El más osado a este respecto es Arteaga, que establece cuatro escalones miméticos; el último consiste en dotar al original de "atributos ficticios sacados de fábulas recibidas o de la propia imaginación"15.

15 Pág. 54; Rudat (1971, pág. 106) da en el clavo al afïrmar que Arteaga "coincide con Harris, Diderot y Lessing en su oposición a la fórmula horaciana ut pictura poesis sostenida por la estética neoclásica, especialmente Batteux, quien identificaba poesía y pintura". Vale decir: no quiere hacer equiparable la mímesis con la reproducción (cf. Checa 1991, pp. $42-43$ y passim) 
Paralelo al avance de la mímesis icástica, el del reflejo de la impresión (o impacto) que en la sensibilidad del escritor tiene la naturaleza; o sea, la consideración de la emoción como elemento estético fundamental. Se tiende cada vez más a valorar el proceso fantaseador del artífice en el proceso de creación artística, claro reflejo del empuje del sensualismo y relacionado con el paso de una poética preceptiva a otra "estética". Vale decir fantástica en el doble sentido: imaginación y emoción.

Arteaga, citando a Locke y Condillac, apunta que hay que suplir las carencias de la naturaleza con la reordenación de sensaciones y evocaciones que permite la fantasía: "Yo no soy esclavo de la imitación [...], poseo una imaginación con la cual dispongo en un cierto modo de todo el universo [...], perfecciono a la naturaleza, me levanto sobre ella" (pág. 136). Díez González también apunta que "todo poeta tiene libertad de usar de la ficción también en el sentido vulgar de fingimiento o cosa puramente ideal, que sólo existe en su mente" (pág. 7).

Todos ellos, a lo que se ve, aplican, o desarrollan, los principios arriba citados de selección, reordenación, o perfeccionamiento de lo aprehendido, recordado, asociado, evocado o sentido. Para ello es central la facultad de la fantasía. Bien está que a todo ello lo llamen imitación universal, siguiendo la división tradicional, pero en germen está la progresiva sustitución de la realidad y su visualización en el sentido aristotélico por el proceso imaginativo-creativo del poeta. Tales ideas, obviamente, se pueden encontrar en la mayor parte de autores del primer tercio del XIX, en quienes también planea la contradicción surgida de haber penetrado simultáneamente en España varias de las corrientes citadas: desde el racionalismo ilustrado hasta el irracionalismo romántico, pasando por el sensualismo.

Así, Blanco White, recogiendo muchas de las tradiciones citadas, apunta que la poesía es el lenguaje de las pasiones; el poeta ha de experimentar el mundo pero a través de su propia conciencia, "se siente vivir y todo vive a sus ojos". Por lo mismo, la reflexión sobre el sentido de las cosas, filtrada por la fantasía del poeta, es parte integrante de la poesía; la introspección llega a ser un imperativo estético, sin dejar de ser "natural". Tal es el fundamento estético de uno de sus discursos: Sobre el placer de las imaginaciones inverosímiles (1971, pp. 214-216):

El placer de las ficciones que nos transportan a un mundo imaginario [...] es tan natural y tan inherente en nuestra constitución, que no puede arrancarse del alma sino con violencia [...]. En vano se cansan los que [...] quieren extirpar de la mente humana la facultad que nos lleva a pintar mundos invisibles de que la misma mente como que percibe ser parte. En estas creaciones de la imaginación consiste la parte más sublime y peculiar de la poesía. 
Para ello, "el artista [...] puede exigir ciertas concesiones mentales de parte de los que han de gozar sus obras" (pág. 216); pero siempre que tales invenciones guarden cierta verosimilitud: "el verdadero ingenio poético puede excitar interés hasta en favor de objetos inanimados, con tal que les dé expresiones correspondientes a las que verdaderamente usarían si tuviesen vida y sentimiento" (pág. 217). Semejantes asertos se podrán ver en el conspicuo crítico Alberto Lista (1836), pues, pese a sus reticencias frente a lo inverosímil, permanece fiel a la teoría del genio que ya desarrollaran otros: el poeta tiene, en última instancia, que crear a partir de sus sensaciones íntimas. La realidad, la naturaleza, se subjetiviza a través de la fantasía individual.

$\mathrm{Ni}$ que decirse tiene que la mayor parte de poetas posteriores describen sus vivencias íntimas, $o$, al menos, las simultanean con las del mundo exterior. Los precedentes son muchos; valga como ilustración este texto de Coleridge (Biographia literaria, apud Ambrams 1975, pág. 297):

La Fantasía, en verdad, no es otra cosa que un modo de Memoria emancipada del orden en el tiempo y el espacio; a la vez combinada y modificada por esa facultad empírica de la voluntad que expresamos con la palabra elección. Pero al igual que la memoria ordinaria, la Fantasía debe recibir todos sus materiales ya hechos por la ley de asociación.

En el siguiente, en cambio, el autor da preeminencia a la elaboración individual de la emoción, de la pasión; la poesía ya no es meramente un espejo que refleja miméticamente, sino una lámpara con luz propia, la luz de la fantasía individual, que proyecta los fantasmas íntima y pasionalmente elaborados: "Las imágenes [...] llegan a ser pruebas de genio original sólo en la medida en que son modificadas por una pasión predominante o por pensamientos o imágenes asociados despertados por aquella pasión" (ibíd., pág. 101).

Fácil resulta comprobar que la pasión, emoción o simpatía (provenientes de la fantasía individual) que rechazaba Platón acaban usurpando su papel central a la idea y a la representación. La fantasía del poeta romántico ya no es, usando la imagen de Abrams, un "espejo" que recibe luz ajena, por mucha grandeza y capacidad idealizadora que tenga, como nos indica Quintana (1969, pág. 206):

Mira el espejo rutilante y puro

de tu imaginación, que en su grandeza

el mundo todo, el universo entero,

sin contenerse en límites, abarca,

sino que acaba por asumir la función de "lámpara" que irradia luz propia (o apropiada; cf. Sebold 1989, pág. 296). El mundo interior del poeta romántico constituye la única guía, la única luz, para la comprensión del mundo exterior, puesto que es él mismo quien lo alumbra. Al decir de Blanco, "el poeta se siente vivir y todo vive a sus ojos" (pág. 173); esto es: desde sus ojos irradia una luz que proyecta sobre los objetos exteriores, una visión nueva de la realidad. Si en la 
Antigüedad, como vimos, la luz (phaos) de la fantasía servía para iluminar la memoria y el entendimiento, para reconocer las imágenes (speciei) impresas en el corazón o en el cerebro, ahora se invierte el proceso: el poeta rehace la naturaleza "a la imagen de su propia psique" (Sebold 1983, pág. 19) y la proyecta al exterior: la realidad se subjetiviza, es un producto de la fantasía individual.

Si no se tienen en cuenta estas premisas, no se entenderá una gran parte de la poesía romántica, no se apreciará el imperativo estético de la introspección, el análisis y testimonio de las vivencias del creador romántico, fundamento de su poética. Aunque escape un poco al período que nos interesa, valga como ilustración el testimonio de El diablo mundo (1840) de Espronceda, cuya reflexión ya no consiste en la recreación (cogitatio) en la fantasía de las imágenes previamente aprehendidas, sino en (vv. 1084-1087):
cuanto fingió e imaginó la mente, cuanto del hombre la ilusión alcanza, cuanto creara la ansiedad demente, cuanto acaricia en sueño la esperanza.

La representación mimética, en mayor o menor medida idealizada por la fantasía, deja paso a la emoción, a la vivencia individual, sea ésta un sueño, una quimera o una premonición. La luz interior de la fantasía (phaos) ya no ilumina, para evocarlas o recrearlas, las imágenes exteriores, sino que éstas (el mundo, la realidad...) acaban adquiriendo los contornos de los fantasmas individuales y se dejan ver a la luz que éstos proyectan.

Para resumir, podría decirse que hemos visto cómo las representaciones de la fantasía interior individual acaban reemplazando a las speciei, figurae, imagines o phantasmata exteriores. Se puede, por tanto, establecer una evolución desde la Antigüedad en este sentido:

La imago (eidolon) pintada en el alma (o sea, visual), indefectiblemente unida al phantasma y vehiculada por la sensación (y los indefectibles espiritus), conectada con la phantasia (Platón-Aristóteles), perdurará (ética y estéticamente) hasta el XVII, ya sea por la participación en la idea, ya como remedo suyo (icástica o fantásticamente). Esta imagen, casi siempre estereotipada o ancilar respecto del concepto o de la idea hasta el siglo XVII, va adquiriendo vida propia conforme avanza el sensismo y la autoconciencia; avance que es paralelo a la progresiva pérdida de su referente mimético (icástico, visualizado) y a la reivindicación de sus componentes afectivo, emotivo y simpático; paralelo asimismo a la privacidad (individualismo, subjetivismo) y a la menor capacidad referencial o representativa. Diríase que del estereotipo se pasa a la imagen vivida individualmente, sentida, recordada, evocada y combinada; de ahí a la consecuente ausencia de imagen referencial que ello comporta.

En cierto modo, se pasa progresivamente de la primacía estética de la representación mimética (icástica o fantástica) a la de la experiencia individual 
del autor, vinculada a la fantasía en su vertiente emotiva o sentimental. En palabras del profesor Sebold (1983, pág. 88) referidas a la poesía naturalista: "el realismo de ésta depende menos de la capacidad del poeta para describir la naturaleza que de su talento para captar las sensaciones que él ha experimentado cuando está en contacto con los diferentes objetos naturales que se ha propuesto representar". O sea, "la naturaleza viene a ser espíritu dinámico, visible, mientras que el espíritu es naturaleza invisible" (ibíd., págs. 76-77). El poeta proyecta su fantasía (vale decir: su emoción) sobre los objetos exteriores, que, por tanto, acaban siendo un reflejo de su experiencia individual, se subjetivizan. Cabe preguntarse si tal proceso también comporta una menor participación del lector, del receptar. Seguramente, a no ser que comparta la sensibilidad o la cultura del autor.

A tenor de lo dicho, el esquema aristotélico arriba presentado tendría que modificarse: se mantiene la relación sensación-fantasma, pero éste ya no está directamente relacionado con el lenguaje, digamos, convencional (aunque sí con el del poeta); ni sirve ancilarmente al intelecto o a la representación mimética; además, se refuerza (por Blake y otros visionarios) su vinculación con el sueño y con la premonición individuales. También mantiene su vínculo con la memoria, la reminiscencia y la paramnesia, y especialmente con las evocaciones, asociaciones y connotaciones individuales.

Acorde con esta concepción estética de la fantasía, la creación artística ya no será un reflejo o representación del mundo, sino su emotiva o fantástica iluminación (valga el pleonasmo) a partir de una vivencia interior.

\section{OBRAS CITADAS}

ABRAMS, M. H. (1953) 1975. El espejo y la lámpara, Barcelona, Barral.

ADDISON, Joseph. (1712) 1991. Los placeres de la imaginación y otros ensayos de "The Spectator", ed. Tonia RAQUEJO, Madrid, Visor.

AGAMBEN, Giorgio. 1977. Stanze. La parola e il fantasma nella cultura occidentale, Turín, Einaudi.

ARISTÓLELES. 1974. Poética de Aristóteles, ed. Valentín GARCÍA YEBRA, Madrid, Gredos.

- 1983. Acerca de alma, ed. Tomás CALVO MARTÍNEZ, Madrid, Gredos.

ARTEAGA, Esteban de. (1789) 1955. Investigaciones filosóficas sobre la belleza ideal, ed. Miguel BATLLORI, Madrid, Espasa-Calpe.

ASSUNTO, Rosario. 1989. Naturaleza y Razón en la estética del Setecientos, Madrid, Visor. 
A VICENA. 1508. Canon, en Opera, Venecia.

BADÍA, Lola. 1992. Teoria i pràctica de la literatura en Ramón Llull, Barcelona Quaderns Crema.

BINNI, Francesco. 1970. Gusto e invenzione nel Settecento inglese, Urbino, Argalia.

BLANCO WHITE, José María. 1971. Antología, Ed. Vicente LLORENS, Barcelona, Labor.

BRUNI, Francesco. 1988. "Le costellazioni del cuore nell antica lirica italiana", en Francesco BRUNI (ed.), Capitoli per una storia del cuore, Palermo, Sellerio, pp. 79-118.

BUNDY, M. W. 1927. The Theory of Imagination in Classical and Medieval Thought, Urbana, Universidad de Illinois.

BURKE, Edmund. [1757] 1987. Indagación filosófica sobre el origen de nuestras ideas acerca de lo sublime y de lo bello, ed. M. GRAS BALAGUER, Madrid, Tecnos.

BURRIEL, Antonio. 1757. Compendio del Arte Poética, Madrid, s.i.

CARNERO, Guillermo. 1983. La cara oscura del Siglo de las Luces, Madrid, Fundación March-Cátedra.

- 1984. "Ignacio de Luzán ante el prerromanticismo francés de mediados del siglo XVIII", Romanticismo, II, pp. 107-112.

CASSIRER, Ernest. 1943. Filosofía de la Ilustración, México-Buenos Aires, Fondo de Cultura Económica.

CICERÓN. 1915. De re publica, Leipzig, Teubner.

CONDILLAC, Étienne Bonot de. 1963. Tratado de las sensaciones, ed. Rodolfo MONDOLFO, Buenos Aires, Universitaria.

- 1973. Essai sur l'origine des connaissances humaines, París, Galilée.

CHECA BELTRÁN, José. 1991. "El concepto de imitación de la Naturaleza en las poéticas españolas del siglo XVIII", Anales de Literatura Española. Universidad de Alicante, VII, págs. 27-48.

DANTE ALIGHIERI. 1965. Divina commedia, ed. Giuseppe VANDELLI, Milán, Hoepli.

DESCARTES, René. [1646] 1985. Tratado de las pasiones. Discurso del método, ed. J. NUÑEZ DE PRADO, Barcelona, Iberia.

DÍEZ GONZÁLEZ, Santos. 1793. Instituciones poéticas, Madrid, s.i.

ESPRONCEDA, José de. 1982. El estudiante de Salamanca. El diablo mundo, ed. Robert MARRAST, Madrid, Castalia.

FICINO, Marsilio. [1469] 1986. De Amore. Comentario al "Banquete" de Platón, ed. Rocío DE LA VILLA ARDURA, Madrid, Tecnos. 
GALLEGO MORELL, Antonio. (ed.) 1973. Obras de Garcilaso de la Vega con anotaciones de Fernando de Herrera (ed. Facsímil), Madrid, CSIC.

GARIN, Eugenio. 1989. Descartes, Barcelona, Crítica.

HAZARD, Paul. 1963. La Pensée européenne au XVIII' siècle. De Montesquieu à Lessing, París, Fayard.

HILL, J.S. (ed.) 1977. The Romantic Imagination, a selection of critical essays, Londres, The Macmillan Press.

JAEGER, Werner. (1933) 1955. Paideia, México, FCE.

JOVELLANOS, Gaspar Melchor de. 1969. Memoria del castillo de Bellver. Discursos. Cartas, ed. Angel DEL RIO, Madrid, Espasa-Calpe.

- 1970. Obras, I: Epistolario, ed. José CASO, Barcelona, Labor.

- 1987. Escritos literarios, ed. José CASO, Madrid, Espasa-Calpe.

KLEIN, Robert [1970] 1980. La forma y lo inteligible, Madrid, Taurus.

LESSING, Gotthold E. 1985. Laooconte o sobre los limites en la pintura y la poesía, Barcelona. Orbis.

LISTA, Alberto. [1836] 1951. Lecciones de Literatura Española, en Hans JURETSCHKE. Vida, obra y pensamiento de Alberto Lista, Madrid, CSIC.

LOCKE, John. [1690] 1980. Ensayo sobre el entendimiento humano, ed. s. RABADE y M. Esmeralda GARCÍA, Madrid, Editora Nacional, 2 vols.

LÓPEZ PINCIANO, Alonso. [1596] 1953. Philosophía Antigua Poética, ed. A. CARBALLO PICAZO, Madrid, CSIC, 3 vols.

LUZÁN, Ignacio de [1737] 1977. La poética, ed. Russell P. SEBOLD, Barcelona, Labor.

LLULL, Ramon. 1985. Phantasticus, ed. Lola BADIA, Bellaterra (Barcelona), Stelle dell'Orsa.

McCLELLAND, Ivy. 1975. The origins of the Romantic movement in Spain, Liverpool, Universidad.

MANCINI, Franco. 1988. La figura nel cuore fra cortesia e mistica, Nápoles, Edizioni Scientifiche Italiane.

MANERO, M. Pilar. 1989. "Preceptiva neoclásica e imaginismo en Italia y España. Las poéticas de Muratori y Luzán", en Homenaje al prof. A. Gallego Morell, Granada, Universidad, II, pp. 301-313.

MASDEU, Juan Francisco de. 1826. Arte Poética fácil, Gerona, Antonio Oliva.

MELÉNDEZ VALDÉS, José. 1990. Poesía y prosa, ed. Joaquín MARCO, Barcelona, Planeta.

MONK, Samuel H. 1960. The Sublime. A Study of Critical Theories in XVIIICentury England, Ann Arbor, Universidad de Michigan. 
MURATORI, Luis Antonio. [1703] 1821. Della perfetta poesia italiana, ed. A. Maria SALVINI, Milán, Società Tipografica dei Classici Italiani, 2 vols.

- [1745] 1777. La Fuerza de la humana fantasía, trad. Vicente María DE TERCILLA, Madrid, Manuel Martín.

NARDI, Bruno. 1985. Dante e la cultura medievale, Roma-Bari, Laterza.

PATCH, Howard R. [1950] 1983. El otro mundo en la literatura medieval, México, FCE.

PETRARCA, Francesco. 19724. Canzoniere, Ed. Gianfranco CONTINI y Daniele PONCHIROLI, Turín, Einaudi.

PICO DELLA MIRANDOLA, Giovanni. 1942. Heptapuls, en Tutte le opere, ed. Eugenio GARIN, Florencia, Vallecchi, I.

PIGEAUD, Jackie. 1983. "Voir, imaginer, être fou. Quelques remarques sur I'hallucination et l'illusion dans la philosophie stoïcienne, épicurienne, sceptique, et la médecine antique", Littérature, Médecine, Société, V, pp. 23-53.

PLATÓN. 1986. Diálogos, ed. Carlos GARCÍA GUAL et al., Madrid, Gredos, 5 vols.

PUPPO, Mario. 1975. Crítica e linguistica del Settecento, Verona, Fiorini.

QUINTANA, Manuel José. 1969. Poesías completas, ed. Albert DEROZIER, Madrid, Castalia.

ROSS, David. 1986. Teoría de las ideas de Platón, Madrid, Cátedra.

RUDAT, Eva M. K. 1971. Las ideas estéticas de Esteban de Arteaga, Madrid, Gredos.

RUTH HAVEY, E. 1975. The Inward Wits, Londres, The Warburg Institute.

SÁNCHEZ BARBERO, Francisco. 1805. Principios de Retórica y Poética, Madrid, s.i.

SARRAILH, Jean. 1957. La España ilustrada de la segunda mitad del siglo XVIII, México, FCE.

SCHURLKNIGHT, Donald E. 1982. "En busca de los orígenes del Romanticismo en España: Cadalso, Young y las conjeturas: Hipótesis y analogía", Boletín de la Biblioteca Menéndez Pelayo, LVIII, págs. 237-261.

SEBOLD, Russell P. 1983. Trayectoria del Romanticismo español, Barcelona, Crítica.

- 1985. Descubrimiento y fronteras del Neoclasicismo español, Madrid, Fundación Juan March-Cátedra.

- $1989^{2}$. El rapto de la mente, Barcelona, Anthropos. 1ª ed. 1970

STAROBINSKI, Jean. [1970] 1974. La relación crítica, Madrid, Taurus-Cuadernos para el Diálogo. 
VICO, G. Battista. [1725] 1911. La Scienza Nuova, ed. Fausto NICOLINI, Bari, Laterza.

WADE, Ira O. 1971. The Intellectual Origins of the French Enlighenment, Princeton, Universidad.

WELLEK, René. 1969. Historia de la crítica moderna (1750-1950). Madrid, Gredos, 4 vols.

YATES, Frances A. [1966] 1974. El arte de la memoria, Madrid, Taurus. 


\section{IRRACIONALIDAD POPULAR EN EL ARTE FIGURATIVO ESPAÑOL DEL SIGLO XVIII}

Jesusa VEGA

La ignorancia $[\ldots]$ no se debe por ningún motivo defender, sino darle muchas gracias al que nos la descubre, para que huyamos de tan horrendo monstruo (Ponz [1772] 1947, vol. I, pág. 2).

La irracionalidad, entendida como expresión de la ignorancia y la superstición, fue tenaz y continuamente criticada por los ilustrados españoles que veían, en la mayoría de sus compatriotas, una clara tendencia al fanatismo como consecuencia de unas carencias seculares de educación y cultura'. Las expresiones plásticas de estos comportamientos irracionales en términos ilustrados eran, por ejemplo, los que habían adornado los templos de disparatados altares llenos de hojarascas, en palabras de Ponz ${ }^{2}$, las imágenes sagradas que movían a la piedad sin apenas atender al buen gusto, los amuletos y dijes que alejaban al demonio, etc. A pesar de una decidida voluntad de los ilustrados por desterrar de los comportamientos sociales manifestaciones ajenas a la razón, se da una perpetuación de costumbres e imágenes irracionales de las que conservamos

1 Por supuesto no fue sólo patrimonio de los ilustrados la crítica a expresiones de ignorancia y superstición. Una prueba evidente de la lucha de los sectores más cultos de la sociedad frente a la credulidad de las gentes es el sistemático ataque a la falsa existencia de las brujas, y de ello da testimonio el estudio de Lisón Tolosana, 1992. No obstante, aunque tanto la crítica cómo la sátira hacia comportamientos irracionales no eran novedosas en la España del XVIII, sin duda se agudizaron en este siglo entre los ilustrados. Hubiera sido imposible redactar este texto sin la ayuda y colaboración de Antonio Correa, José Manuel Matilla y Javier Portús. A ellos, amigos y aficionados, según expresión ilustrada, de la estampa, les agradezco su colaboración. También agradezco a Nigel Glendinning y a Guillermo Carnero su ambilidad por haberme invitado a participar en el Curso Superior de Filología de la UIMP de 1992.

2 Ponz, 1947. La primera edición se publicó en 18 volúmenes entre 1772 y 1794. De los 13 primeros volúmenes hubo una segunda edición entre 1776 y 1788 , y se hizo la tercera edición de los 6 primeros entre 1787 y 1793 . 
testimonios gráficos coetáneos a través de las estampas ${ }^{3}$ y escritos contemporáneos. En esta ocasión vamos a contrastar las opiniones de aquellos que reflejan o respetan los gustos y creencias populares y autores que tratan de enjuiciar desde la razón aunque, en muchas ocasiones acaben adoptando un tono burlón como lo demuestran algunos textos de Leandro Fernández de Moratín o de Blanco White, incluso del mismo Antonio Ponz.

Valenciano de origen, amante de las bellas artes y educado con los jesuitas, Ponz abandonó los estudios de Teología sin llegar a ordenarse sacerdote para dedicarse, casi exclusivamente, al estudio de las distintas manifestaciones artísticas que, en España, habían tenido su principal medio en el ámbito de las creencias religiosas. Ilustrado y relacionado con los círculos jansenistas debía ser habitual en él emplear "la tarde en ver iglesias, que es donde suele estar lo que hay de bueno". En otra parte de su Viaje por España escribe:

Repetidas veces he dicho y no es menester decirlo, porque todos Io saben, que las iglesias es lo primero que se va a ver en las ciudades y pueblos, porque dan por supuesto que en ellas es donde se halla lo más precioso, lo más digno y bien ejecutado de cada país (Ponz, 1947, pág. 964).

Pero si allí era donde arquitectura, pintura y escultura encontraban su mayor desarrollo, también allí era donde se reunían los frutos de la impericia e irracionalidad de artistas y mecenas que habían educado durante décadas el gusto del vulgo, un vulgo o muchedumbre ignorante a la que Ponz, como buen ilustrado, creía que había que reeducar: "Cuán lejos debe estar del que tiene amor a los suyos el dejarlos recrear en sus delirios, por más gusto y placer que en ellos encuentren, y de no poner cuantos medios sean posibles para volverlos en sí, aunque mucho lo repugnen", porque "si el vulgo gusta de estas figuras [...] es porque no le ponen otra cosa a la vista, ni se le instruye", ya que "estas cosas", continua Ponz, "no nacen de la impiedad, sino de la ignorancia; y siendo así, no hay razón para que pudiendo desterrarse, no se destierre (Ibíd, pp. 302-303).

De ninguna mano mejor podríamos acercarnos a las manifestaciones artísticas que para los ilustrados eran fruto de la irracionalidad y del mal gusto. Para Ponz, como para muchos otros ilustrados, la piedad popular y la religiosidad tenían una expresión plástica y un ceremonial que había que modificar y renovar profundamente. Ponz se sirve de su Viaje de España para opinar, criticar, censurar y dar nuevos modelos de actuación.

3 Las estampas que sirven de ilustración al texto pertenecen a la colección madrileña de Antonio Correa. El conjunto es un repertorio representativo del tipo de grabado que estaba vigente en España durante el siglo XVIII (la talla dulce académica, el grabado en madera popular) y se completa con las estampas al aguafuerte y aguatinta de Francisco de Goya, que por ser las más conocidas hemos obviado reproducir. Por otro lado, es importante recordar que entre los artífices españoles se dio una especialización local en la producción de estampas religiosas, por lo que todas las que se reproducen, incluidas las anónimas, son españolas. 
El primer arte que se va a tratar es el de la arquitectura referida al adorno interior de los templos. Al tratar de Guadalajara Ponz comenta:

Ya sabe V. cuan rematada cosa son, por falta de artificio, tantos altares como en nuestros días se han ido ejecutando, sin valerse para ello de los que hubieran sabido hacerlos con toda propiedad [...] entre los cuales deben tener el ínfimo lugar los que se han ejecutado en el siglo presente. Yo bastantes especies procuro sembrar, para que, supuesto que en esa Corte hay en el día sujetos capaces y que han estudiado Arquitectura como se debe estudiar, se valgan de ellos; y también cito las obras que han hecho con acierto, inteligencia, y aplauso (Ibíd, pág. 122).

De esta manera se resume la labor llevada a cabo desde las instituciones oficiales por desterrar el Barroco e introducir entre el vulgo el buen gusto, es decir, la conocida como arquitectura neoclásica.

Entre las mejores estampas que conservamos en la que se aprecia el retablo barroco en todo su esplendor y riqueza están las que muestran a la Virgen de la Soledad de Madrid (fig. 1) "como se venera en su capilla y retablo", o a la Virgen de la Novena (Arte y devoción, 1990, núm. 41). Su aspecto se ajusta a las fórmulas que espantaban a Ponz:

Cornisamentos rotos, frontispicios dentro de frontispicios, cuerpos multiplicados sobre un mismo plano, nichos que no vienen al caso, pilastras y columnas agrupadas para no sostener cosa alguna, líneas tortuosas por rectas, adornos fuera de propósito, y últimamente miembros que no se puede atinar lo que significan, se descartarán ciertamente (Ibíd, pág. 318$)^{4}$.

Otro de los elementos irracionales que horrorizaban a don Antonio eran las columnas salomónicas:

Puestas por fin en tantos altares monstruosos, que con el arte nada tienen que ver, no hemos de hacer alto en ellas. Estas columnas retorcidas, no se con qué fundamento llamadas salomónicas, sólo las pudo sostener la novedad y el capricho: escollo en que se precipita la razón de casi todos los hombres, cuando se trata de las bellas artes. Si las columnas deben ser la imitación de un tronco de árbol, ¿en dónde se hallan árboles de semejante figura? Y si se hallasen en una parte, o en muchas ¿quién sino un loco los hubiera escogido para adornar y sostener aquellos primeros edificios que han sido la norma de lo que adelantaron después los buenos arquitectos? Dirá alguno que el célebre altar mayor del Vaticano tiene columnas

4 Opinión compartida por Jovellanos en su Elogio de don Ventura Rodríguez (Jovellanos, 1956, pág. 372): "Cornisamentos curvos, oblicuos, interrumpidos y ondulantes; columnas ventruadas, tabidas, opiladas y raquíticas; obeliscos inversos, sustituidos a pilastras; arcos sin cimiento, sin base, sin imposta, metidos por los arquitrabes, y levantados hasta los segundos cuerpos; metopas injertas en los dinteles, y triglifos echados en las jambas de las puertas; pedestales enormes, sin proporción, sin división ni miembros, o bien salvajes, sátiros y aun ángeles, condenados a hacer su oficio; por todas partes parras y frutales, y pájaros que se comen las uvas, culebras que se emboscan en la maleza; por todas partes conchas y corales, cascadas y fuentecillas, lazos y moños, rizos y copetes, bulla y zambra y despropósitos insufribles; he aquí el ornato, no sólo de los retablos y hornacinas, sino también de las puertas, pórticos y frontispicios, y de los puentes y fuentes de la nueva arquitectura". 


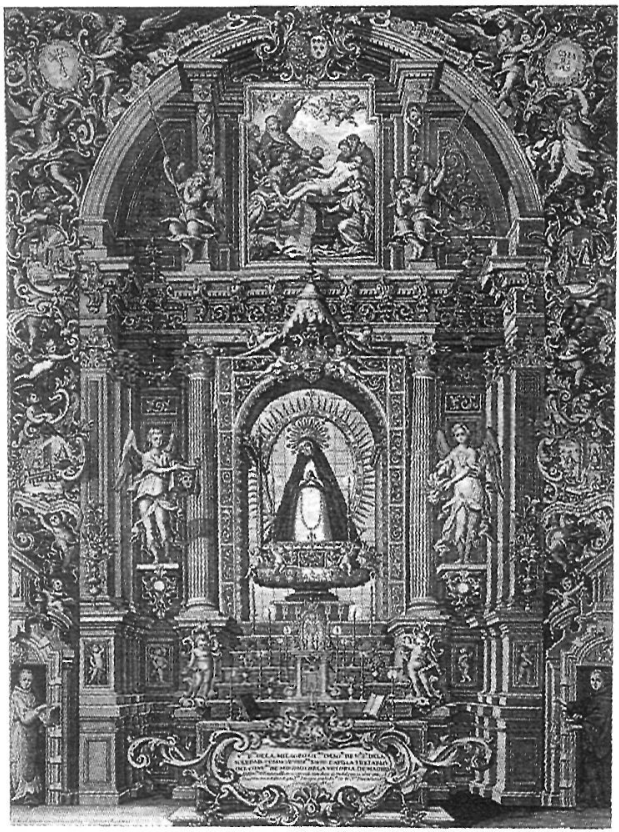

Fig. 1. Virgen de la Soledad. Dibujada y grabada en cobre por Matías Irala en 1726.

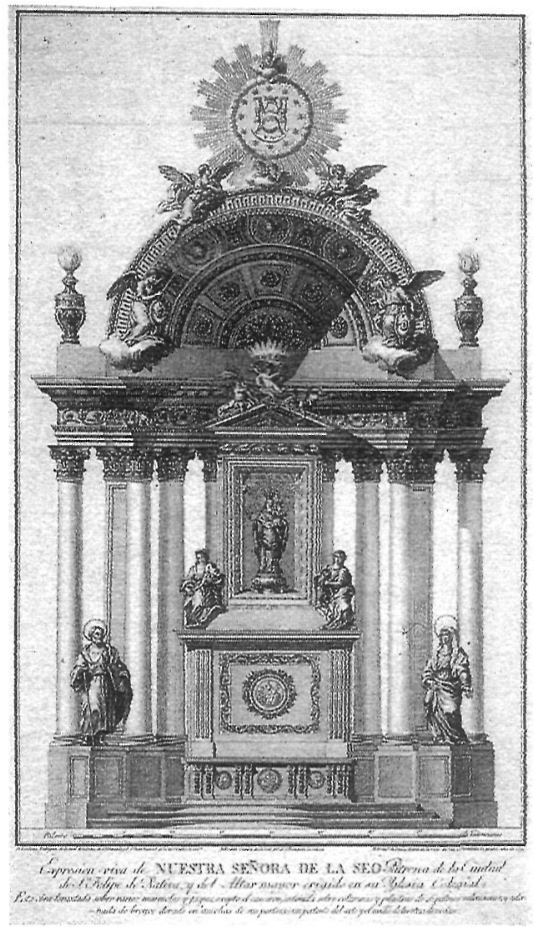


salomónicas, y que las hay en otras obras de gran reputación. En cualquier parte que estén las criticará, háyalas hecho quien quiera, el hombre que busca la razón y origen de las cosas (Ibíd, pág. 368).

La riqueza sinuosa de las columnas del retablo de la Virgen de la Novena (Arte y devoción, 1990, núm. 41) contrasta con la desnudez y escaso volumen de las que parecían adornar el retablo de la Virgen Mayor de la catedral de Sigüenza y que se aprecian en la estampa de Lorenzo Sánchez Mansilla, grabado hecho a devoción de Francisco Gutiérrez Urraca (Páez, 1981, núm. 1983-2), quizá por un deseo intencionado de simplificar los excesos barrocos del retablo. Ésta es otra de las circunstancias dignas de comentario. Las denuncias de Ponz no cayeron en saco roto, y además de establecerse una nueva legislación que impedía continuar con esas costumbres de época barroca, se mandó que las obras de arquitectura fueran vistas y aprobadas por la Academia. Pero no todos los retablos o adornos de buen gusto que conocemos a través de las estampas existieron en realidad. Con sus críticas Ponz no pretendía, como él mismo declara, censurar el adorno de las iglesias sino quitar "ciertos adornos impropios de las casas de Dios, que sirven de hacer reír a los que conocen las Artes", es decir limpiar y hermosear las iglesias desembarazándolas de objetos extravagantes y ridículos retablos de madera, pero esto en ocasiones sólo se llevó a cabo de forma imaginaria, a través del grabado, en las estampas.

Entre los altares antiguos Ponz pone por modelo el gran altar de la Iglesia del Oratorio del Salvador:

De varios mármoles y bronces en el mismo crucero al lado del Evangelio, se trabajó en Roma, y fue éste de los primeros que en este siglo sirvieron de ejemplo para ejecutar cosas verdaderamente grandes y nobles. Consiste principalmente en cuatro columnas de mármol verde sobre el basamento, con sus capiteles de orden compuesto. En el medio hay un relieve cuyas figuras son del tamaño natural [...] Sobre la cornisa hay puestos otros dos ángeles mancebos, y toda la obra es de lo mejor que hay en los templos de Madrid (Ibíd, pág. 464).

A lo largo de su texto Ponz pone por modelo a Ventura Rodríguez y a Juan de Villanueva. Un buen ejemplo del tipo de adorno que se consideraba ajustado a la razón en la mente de nuestros ilustrados es el altar de Nuestra Señora de la Seo, Patrona de la Ciudad de San Felipe de Játiva, cuya estampa (fig. 2) muestra el altar mayor erigido por invención de Ventura Rodríguez y Juan Guixart, ambos académicos de Nobles Artes, el primero de la de San Fernando de Madrid, y el último de la de San Carlos de Valencia.

5 A pesar de la riqueza de nuestro patrimonio en estampas religiosas, aún en la actualidad no hay abundantes repertorios gráficos sobre este tema. Desde esta perspectiva resulta sin duda fundamental el catálogo de la exposición Arte y devoción, 1990. 
De esta manera podemos comentar la doble función que tenía este tipo de estampas: con la excusa de una estampa de devoción se introducían los modelos arquitectónicos que Ponz y los profesores de las Nobles Artes querían hacer familiares al vulgo. Esa clara finalidad de educar visualmente al pueblo se pone de manifiesto en el comentario que encontramos en la estampa de la Virgen de la Seo, obra de Francisco de Paula Martí, también de la Real Academia de San Fernando: "Esta obra levantada sobre varios mármoles y jaspes, excepto el cascarón, sostenida sobre columnas y pilastras de 26 palmos valencianos, y adornada de bronce dorado en muchas de sus partes, es un portento del arte y el exidio de las otras de su clase". Y lo mismo ocurre con la enorme estampa de la Virgen del Pilar (fig. 3) "según se venera en su magnífico tabernáculo, manifestándose parte de los cuatro machones, sus arcos, pechinas, con su respectiva media naranja de la iglesia, en cuyo espacio esta dicha fábrica", dibujada y grabada por Mariano Latasa en 1805; los 9.020 días de indulgencia que se podrían ganar ante ella más parecen una excusa para dar a conocer la arquitectura ideada por Ventura Rodríguez para la venerada imagen de la Virgen, que apenas si se ve en la parte derecha de la estampa ${ }^{6}$. Era ésta una de esas estampas que consideraría convenientes Ponz, pues también su interés y preocupación por el arte del grabado como firme aliado para difundir el buen gusto le llevaba a lamentarse cuando era empleado de manera inadecuada:

Se ha gastado el tiempo, el dinero y el cobre en representar ridículos altares de talla, imágenes que por su fealdad debían apartarse de la vista de los fieles y otras tales cosas muy conducentes para radicar el mal gusto; y de tantos objetos peregrinos, de tantos prodigios del arte, no se ha hecho caso para este efecto (Ibíd, pág. 555).

El adorno y la iluminación eran fundamentales en los diferentes actos religiosos. Según fuera la iluminación se podía conseguir de la audiencia recogimiento, miedo o admiración. Cuando Blanco White comenta el entorno en el que se desarrollaban los ejercicios espirituales, explica cómo la primera reunión en la capilla se hacía con la estancia casi a oscuras, tan sólo una "lamparilla, cegada por todos los lados excepto uno, iluminaba tenuemente la estatua de un Cristo agonizante en la cruz. Como el artista se había propuesto impresionar los sentidos, sin ninguna consideración por el gusto, la estatua era

6 Cinco años antes el mismo grabador había publicado una Vista exterior e interior del magnífico tabernáculo de Nuestra Señora del Pilar. Se encuentra reproducción de la estampa en el catálogo de la exposición Ventura Rodríguez, 1983, núm. 18. Conviene recordar que la estampa que siempre tuvo una demanda constante en España fue la de carácter religioso. El ejemplo más elocuente de esta realidad lo encontramos en la actividad desarrollada por el mejor grabador español en talla dulce y maestro de grabadores, Manuel Salvador Carmona; un 30\% de su producción está formada por estampas de devoción. 
Fig. 3. Virgen del Pilar. Dibujada y grabada en cobre por Mariano Latasa en 1805.

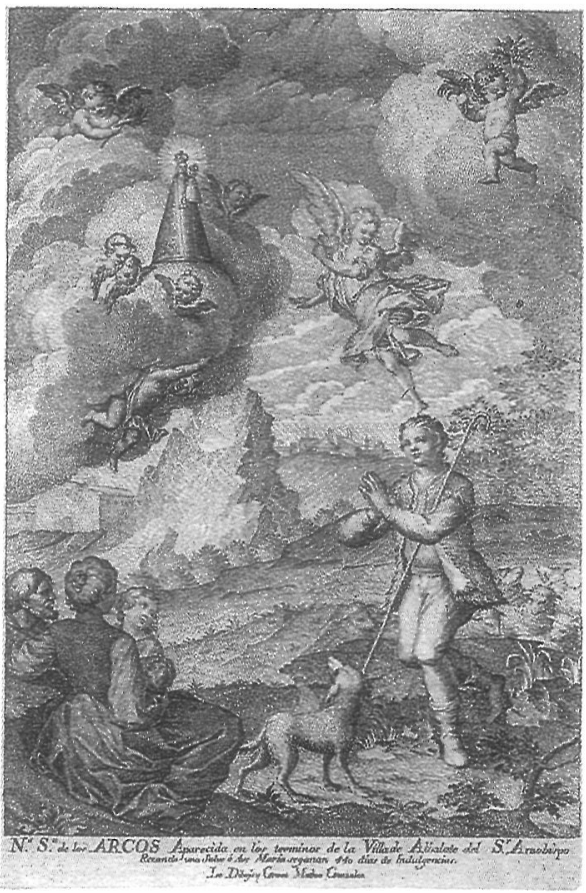

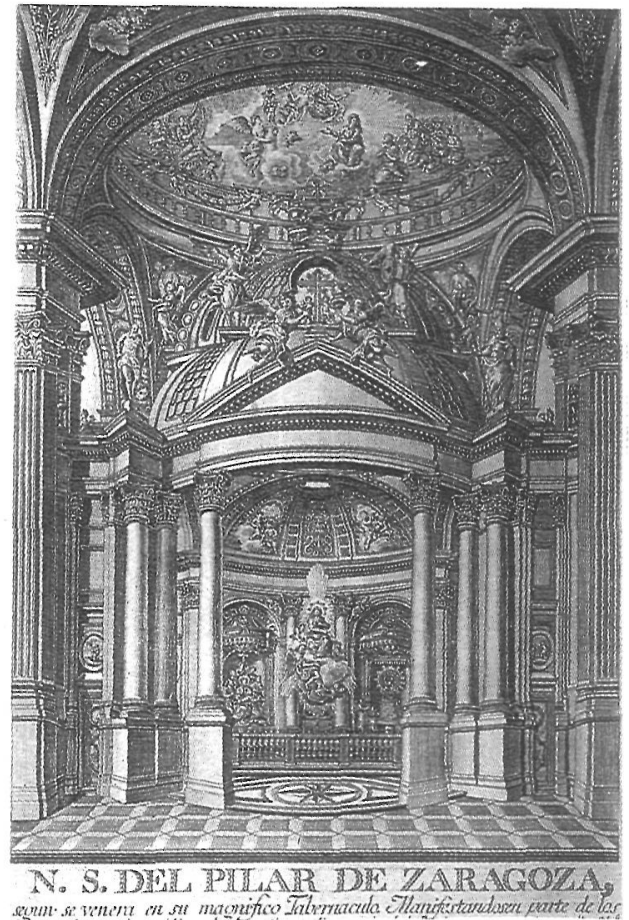

Fig. 4. Virgen de los Arcos. Dibujada y grabada en cobre por Mateo González. 
de tamaño natural, con ojos de vidrio y el cuerpo coloreado de tal modo que reproducía los cuajarones de sangre que salpicaban la carne". Avanzados los ejercicios, y después de haber consagrado un día al tema de los castigos eternos, venía la tarde de la meditación en la que se hablaba de gracia y esperanza. El aspecto de la capilla contribuía al cambio de sentimientos: "Entonces no era una tumba sombría como antes; en el altar había velas de cera en medio de las cuales una imagen sonriente de la Virgen María parecía saludar a los acongojados penitentes que entraban" (Blanco White, 1972, pp. 122-124).

Lámparas, luminarias y velas eran fundamentales en el entorno sagrado de iglesias, capillas, etc. En muchas fábricas se amontonaban las lámparas de plata para disgusto de Ponz. En la iglesia de Illescas el erudito comenta:

Lo que más ha desfigurado esta iglesia es un especie de balcón con balaustres, que corre desde la capilla mayor hacia el crucero, rompiendo las pilastras de orden corintio que allí hay, y sólo parece haberse hecho el tal balcón para amontonar en él cerca de cincuenta lámparas de plata, como si consistiera en esto la magnificencia y la verdadera devoción (Ponz, 1947, pág. 26).

Pero eran muchos los altares que habían sido transformados a lo largo de los tiempos con el fin de facilitar la iluminación. Para ello se añadían al altar graderías de madera - ejemplo de esas graderías se aprecian en las estampas comentadas anteriormente- lo que había provocado la existencia de "infinitos rimeros de madera dorada", según Ponz, quien apostilla "en tal grado, que para ponerlos se han quitado muchos, que si bien eran de la misma materia, se veía en ellos alguna razón de arquitectura. ¡Qué gastos! ¡Qué diligencias! ¡Qué aturdimiento para llenar los templos de los objetos más quiméricos, que a entendimiento humano podían ocurrir!” (Ibíd, pág. 407).

Entre los ejemplos que más indignaban a Ponz se encontraba el altar mayor del convento de monjas de Santo Domingo de Loeches, sobre cuya mesa de altar había un tabernáculo de orden corintio de ébano, lapislázuli y varios metales, todo ello de buen gusto:

Mas para que en tan peregrino altar no faltase una chafarrinada comenta el ilustrado-, sepa V. que han colocado sobre la mesa una gradería en que puedan poner muchas luces, y algunos santos de madera mal hechos, sirviendo esto para ocultar las imágenes dignas de los cuadros, los escalones para cubrir los bellísimos cuadritos del basamento y la multitud de luces cuando las pongan para ennegrecer todo lo pintado, y acaso para quemarlo algún día (Ibíd, pág. 106).

En la iluminación de los templos el valenciano consideraba que debía seguirse el modelos de las "iglesias más serias, esto es, las Catedrales, [que] regularmente se sirven de seis velas, o pocas más, sobre la mesa del altar, aun en las mayores solemnidades. Cuando el mismo Papa celebra, y los obispos, 
sólo se añade una a las seis que se han dicho: con que lo demás ya es en cierto modo desviarse de los ejemplos que se deben seguir. Ha de añadirse que con cuatrocientas o quinientas velas, como frecuentemente se amontonan en nuestros retablos [...] es una distracción para los que se hallan en el templo el ver cruzar todo el altar desde arriba abajo los que andan ocupados en encender tantas luces: un continuo cuidado en observar, como en las decoraciones teatrales, si se tuerce una vela, o si cae un pábilo que pegue fuego en un instante a toda la máquina" (Ibíd, pág. 432).

A esto se añadía el riesgo a perder la vida por parte de estos empleados:

¿Cuántas veces - se pregunta Ponz- ha causado a muchos la muerte la ridícula operación de ir cruzando por los retablos para encender tantas velas, cayendo desde lo alto, como en el mes de Enero de 1776 sucedió en la Iglesia de los Premonstratenses [de Madrid] a José García, que aunque no murió, estuvo a los últimos de su vida? (Ibíd, pág. 407).

Pero, por si no fuera suficiente con estas críticas a la iluminación, Ponz expone también su severa opinión sobre los adornos de estos espacios sagrados:

Si adornan las iglesias con motivo de festividades, ¿en dónde se hace con gusto e inteligencia? Con amontonar muchos platos, bandejas, jarrones, soperas y cosas semejantes, poniendo en el santuario todo el aparato profano de un convite, ya piensan haber hecho cosa grande. Cualquier ornato extraño debería desterrarse de los templos; pero éste con más razón, por ser indecente y ridículo (Ibíd, pág. 407).

Y en otra parte de su texto se pregunta:

¿No sería cosa muy propia el que los prelados cuidasen en despojar los altares de ciertas puerilidades contrarias a la majestad que les corresponde, ejecutadas sin ningún arte, y que los trasforman en unos espectáculos teatrales impropios de los templos, y tan contrarios al buen gusto y seriedad que debe reinar en la casa del Señor? Esto no podría lograrse sin que la celasen sujetos de inteligencia, y sin rehusar lo que para este fin ofrecen ciertas personas buenas, que creyendo hacer una gran cosa no lo logran; antes bien todo lo contrario, poniendo en el santuario lo que no debía estar sino muy lejos de él. Es mucha lástima que estos tales no se informen antes de los que entienden, y así emplearían sus ofertas mucho mejor de lo que comúnmente vemos. ¿Y qué diremos del uso disparatado mediante el cual en las festividades transforman los altares en un aparador de todo género de vajilla de plata, como si en aquella iglesia se hubiese de servir una gran comilona? Otra usanza me han asegurado que se ha introducido, aún mas ridícula, por los altareros; y es que esta vajilla se hace ya en muchas partes de cartón plateado, porque solían robar la verdadera plata entre la bulla de las funciones; y así siendo este ornato una extravagancia, como cualquiera conoce, aun cuando concurría la preciosidad del metal, se deja ver cuánto más despreciable es en materia tan vil como el cartón (Ibíd, pág. 107).

Todas estas actuaciones eran motivo para que se riesen las gentes de juicio y de buen gusto. Pero, además, entre las consecuencias que tenía la iluminación de los templos se encuentra el continuo ennegrecimiento de retablos e imágenes, 
amén del riesgo permanente de incendio, tema de interés pero del que no vamos a ocuparnos en esta ocasión. Hoy en día estamos acostumbrados a contemplar muchas de las vírgenes con tez oscura, pero es evidente que en su día no eran imágenes morenas, sino que el paso del tiempo ha ido ennegreciéndolas. Ponz lo explica así al tratar de la patrona de Madrid, la Virgen de la Almudena, que se veneraba en una capilla oscura, junto a la sacristía, de la parroquia de Santa María:

Aunque el altar mayor es rico de plata, en cuanto al arte no lo es. La imagen de nuestra Señora que se venera en él, llamada de la Almudena, es patrona de Madrid, y uno de los objetos más principales de su devoción [...] Visten la imagen con ricas telas y la adornan de pedrería como a la de Atocha. Ambas tienen el color muy obscuro, porque con la antigüedad el albayalde de que se hizo la encarnación, que no es otra cosa que plomo, se ha convertido en su natural color, a que habrá ayudado no poco el humo continuo de las luces. Por la misma causa, y no por otra, tienen el mismo color todas las imágenes antiguas hechas de madera (Ibíd, pág. 453).

El centro de los retablos y de las devociones lo ocupaban lógicamente las imágenes. Muchas de estas imágenes eran, en opinión de Ponz, verdaderos errores que se proponían al entendimiento o se presentaban a la vista:

¿Y qué mayor [error] para ésta — se refiere a la vista—como representar a Jesucristo y a sus santos en figuras feas, dislocadas, sin proporción ni parte ninguna en su lugar? ¿Destínanlas después a que el devoto pueblo las venere en aquellos informes retablos cuyos ornatos suelen consistir en colgajos de berzas, en bichos y otras sabandijas? (Ibíd, pág. 964).

Nos vamos a ocupar seguidamente de las esculturas, más concretamente de las imágenes de la Virgen, sirviéndonos, para introducirnos en el tema, de la ingenua estampa de la Virgen de los Arcos (fig. 4) donde el grabador muestra la aparición de la Virgen a un pastor. Las pautas de cómo se generaba la historia y la leyenda de la mayoría de estas imágenes marianas veneradas en el siglo XVIII sería la siguiente: hallazgo de una imagen por un joven, frecuentemente pastor, y que estaba en ese lugar de modo ocasional; a partir de este momento comienza el proceso de extensión de la creencia, que suele ser rápida entre las capas populares pero encuentra reticencias entre las clases altas y las instituciones religiosas (Velasco, 1989, pp. 401-410). El esquema o pauta que hemos descrito llegó a ser tan habitual que incluso los falsos santeros habían asimilado la manera de narrar estas actuaciones sobrenaturales. Puede ser un ejemplo la historia de Francisco Martínez? Primero se inventó que tenía un Santo Cristo que llevaba en el pecho y que sudaba sangre —el impostor admitió que mojaba el crucifijo y después él se hacía sangre y se la pegaba-, pero como se lo quitaron, después ideó la siguiente historia: "Se le apareció una imagen de nuestra Señora pequeñita, muy morena y con vestidos al parecer naturales,

7 Christian, 1989. En las obras de este mismo autor (1981 a, y b) se basó Velasco, 1989, para hacer su estudio. 
acercándose a él al modo como anda una paloma y que le dijo «Devoto mío del rosario, baja al pueblo y di que vengan por mí», y allí la encontraron a "la Divina Señora en una peña que llamaban Barrancos". La realidad es que Martínez había robado la imagen en Priego, su pueblo natal, de un nicho al lado de una de las puertas de la ciudad, para engañar a sus convecinos de Taravilla, aldea a $40 \mathrm{~km}$. de Priego. Muchas de estas imágenes tenían además la singularidad de que el artífice había sido a su vez un santo, o habían sido labradas por algún ser divino, o gracias a algún tipo de intervención sobrenatural. En este último caso estaría la Virgen de la Soledad de Madrid (fig. 1) ${ }^{8}$ y en el primero la Virgen de Valvanera (fig. 5).

Hay que poner de relieve que, tanto en la narración de Martínez como en la estampa de la Virgen de los Arcos, la imagen aparece vestida. La riqueza del guardarropa de la imagen era consecuencia casi directa de la mayor o menor devoción que existía hacia ella. Antes de introducirnos en el tema de las imágenes vestidas, conviene tener presente que la devoción a determinadas imágenes no era algo exclusivo del vulgo, sino que la misma familia real tenía sus predilecciones en estas cuestiones. A modo de ejemplo, podemos citar que en su testamento la reina Bárbara de Braganza hizo mandas a diversos conventos: "un ramo de diamantes a la Virgen del convento lisboeta de la Madre de Dios, otro de brillantes y rubíes y uno de sus vestidos más costosos a la imagen de la Virgen del Patrocinio que se venera en El Escorial, otros vestidos a las Vírgenes de Atocha y Guadalupe, seis candeleros de plata al Cristo de El Pardo" (Rodríguez G. de Ceballos, 1987, pág. 199). Estas predilecciones entre una u otra imagen eran comunes entre la población y fueron puestas en solfa de esta manera en El Censor:

El [culto] que se rinde vulgarmente a las imágenes, jcuán ajeno es del espíritu con que la Iglesia las venera! ¡Cuánto se mezcla de idolatría en esta mayor devoción a la Divina Pastora que a la Peregrina, o a la Peregrina que a la de la Leche! ¡Al San Antonio de Piedra que al de San Francisco el Grande, o a éste que al de los Portugueses! [...] Hay muchos que imaginan en las imágenes un no se qué de divino que, independientemente del original que representan y sin relación a él ninguna, atrae su atención (Censor, 1972, pp. 83-84).

La costumbre de vestir imágenes era otra de las expresiones más irracionales en opinión de los ilustrados. Esta costumbre tenía su origen en los oratorios y capillas privadas que los nobles poseían en sus palacios, en los cuales las imágenes de bulto recibían vestiduras a modo de aderezo. Pronto surgieron las críticas; por ejemplo San Juan de la Cruz en La subida al Monte Carmelo (cap. XXXV) escribe:

8 En la estampa se hace una breve relación de las circunstancias en las que Gaspar Becerra hizo la imagen. La historia completa con toda suerte de detalles se puede consultar en Ares, 1640. 


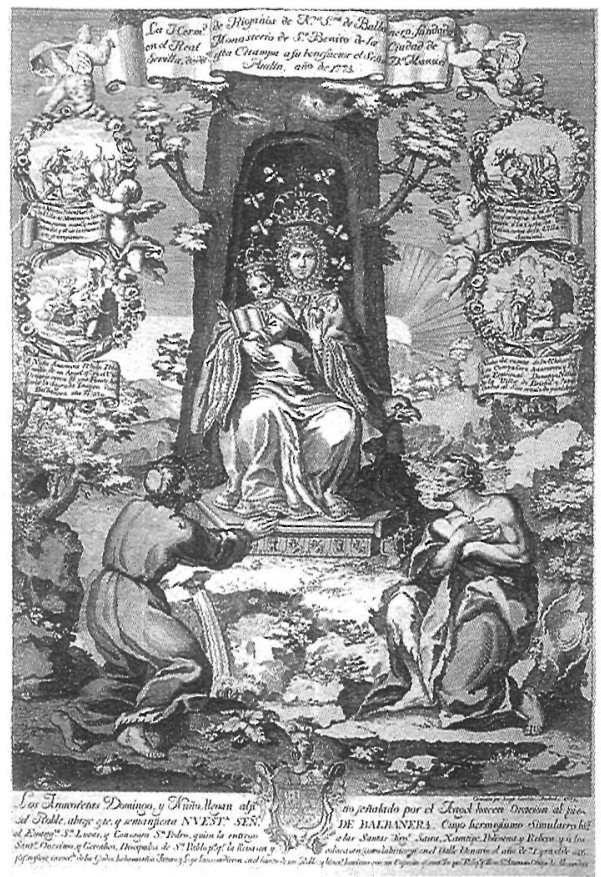

Fig. 5. Virgen de la Valvanera. Grabada en cobre por José Giraldo en 1775.

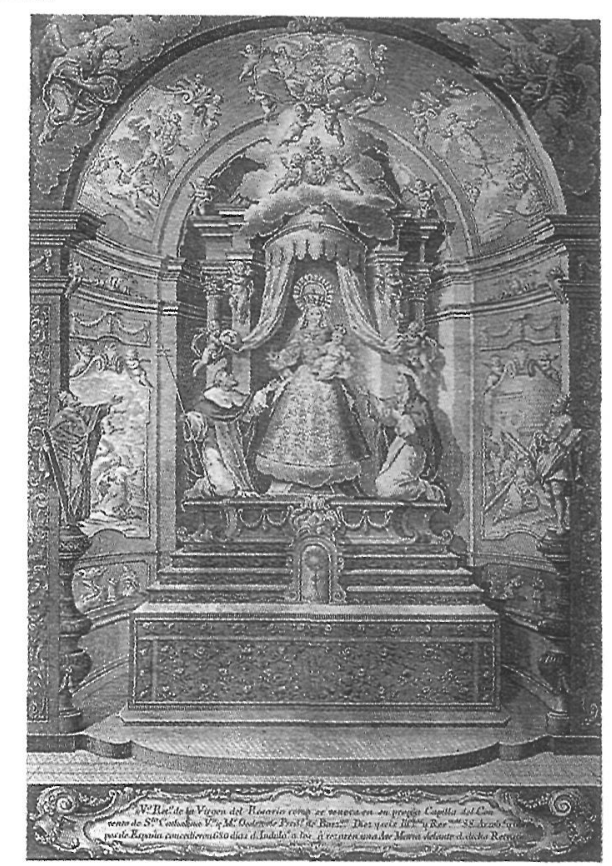

Fig. 6. Virgen del Rosario. Grabada en cobre por Mateo González. 
Esto se verá bien por el uso abominable que en estos tiempos usan algunas personas, que no teniendo ellas aborrecido el traje que la gente vana por tiempo va inventando para el cumplimiento de sus pasatiempos y vanidades, y del traje que en ellas es reprendido, viste las imágenes, cosa que a los santos que representan fue tan aborrecible [...] y de esta manera la honesta y grave devoción del alma [...] ya se les queda en poco más que en ornato de muñecas, no sirviéndose alguno de las imágenes en poco más que de unos ídolos en que traen puesto su gozo (cit. Martínez-Burgos García, 1990, pág. 151. Véase también Rodríguez G. Ceballos, 1989).

El carácter íntimo y particular del oratorio no era acorde con el afán de ostentación que en ellos había, por lo que progresivamente se produjo un cambio de mentalidad en la que el gusto por lo privado fue sustituido, poco a poco, por la exposición pública.

Bernardino de Villegas escribía en 1635:

De la afición a las galas, que dijimos arriba nace en algunas personas por un abuso digno de remedio, y es que, como por una parte tiene esta aficioncilla arraigada en el corazón, y por otra su estado no permite la superfluidad de las galas y dijes que apetecen para parecer bien, viene a ser que a las santas que tienen en sus oratorios las visten de damas muy bizarras y compuestas; y si bien suele ser este abuso más ordinario y común en el mundo, y truco muy usado, en que a las imágenes las visten ya de damas, y a las damas las visten de imágenes: pero también suele haber en esta materia algún abuso en personas virtuosas; de las cuales algunas, como traen el alma galana allá dentro, visten a los santos de sus oratorios con tantos dijes y galas, que es cosa indecentísima; y a veces le da a un hombre gana de reír viendo las brujerías que ponen a los santos; y otras de 1lorar, mirando la indecencia con que los santos y santas son tratados. ¿Qué cosa más indecente que una Imagen de nuestra Señora con saya entera, ropa, copete, valona, arandela, gargantilla y cosas semejantes? ¿Y unas santas vírgenes vestidas tan profanamente y con tantos dijes y galas que si las adorará por Santa Lucía o Santa Catalina, o si apartará los ojos por no ver la profanidad de sus trajes: porque sus vestidos y adorno no parecen santas del cielo, sino damas del mundo: y a no estar Santa Catalina con su espada en la mano, y Santa Lucía con sus ojos en el plato, por lo que toca al vestido y traje galán con que las visten nadie dijera que eran santas, ni vírgenes honestísimas como lo fueron (Villegas, 1635, pp. 430-31, cit. Caro Baroja, 1985, pág. 134).

A medida que las cofradías y hermandades sacramentales adquieren un status propio, generan un tipo de imagen que les es específico y que forma capítulo aparte dentro de la iconografía barroca. Bajo su impulso es cuando se van conformando las imágenes de vestir —conocidas también como imágenes de devanadera (fig. 1) - plenamente barrocas, es decir, esos armazones de madera a manera de maniquíes - a veces incluso articulados- en los que únicamente se tallaban las manos, pies y rostro, quedando el resto oculto bajo el despliegue de sedas, brocados y damascos. A la vez se procede a vestir imágenes anteriores. De esta manera la imagen habitual que tenemos de las vírgenes dieciochescas es la de una Virgen con el Niño a los que apenas se les ve el rostro y las manos. El resto subyace bajo enormes y ricos vestidos. 
Por ejemplo, Jovellanos al expresar en su Carta Décima a don Antonio Ponz (Jovellanos, 1952, pág. 310) su opinión contraria al valor estético de la imaginería religiosa de su tiempo, aduce como causas no sólo la exigua capacidad artística de la época, sino además otras extravagancias propias del mal gusto y la superstición reinante:

Tal es la de sobreponer valonas y vueltas de encaje a las vestidas de talla, la de engalanarlas con lazos y cintas clavados sobre ellas y la de afear la belleza de la escultura con adornos igualmente distantes de su sencillez que de la santidad de los objetos que representan.

\section{Al tratar Ponz sobre el templo barcelonés de Santa Catalina escribía:}

No hay paciencia para ver que a una imagen de Nuestra Señora del Rosario (fig. 6), de mármol y acabada de todo punto, que se venera en esta iglesia con particular devoción, le hayan puesto sobre los vestidos que ya tenía de dicha materia otros de tela, haciéndola comparecer ridícula como V. se puede figurar, cuando antes con sus vestidos, que trazó el escultor, no lo era, habiéndolos adaptado con la conveniente propiedad a la figura. Dicen que fue dádiva de S. Pío V: tal vez el Santo Padre no la hubiera hecho a saber la extravagante transformación que le esperaba a su precioso regalo. Considere V. qué gentileza resultará a las figuras de invenciones tan extrañas practicadas, no solamente en esta imagen, sino en otras muchas también de la Virgen que en diferentes partes he visto: ni se qué razón puede haber (vaya de sermón) para acostumbrar la vista de los fieles a semejantes puerilidades, y a veces indecencias. Quisiera que me dijere el devoto dotado de discreción y de prudencia cuánto tiempo se tardaría en condenar un escrito que descubriese a nuestra Señora conforme yo he visto repetidas veces sus imágenes, con cotillas, escotes, pendientes, aderezos, collares, mucho encaje, y en fin con todos los atavíos de que hace pompa la profanidad y el lujo. Semejantes dijes no pertenecen a la Madre de Dios, ni en ellos consiste la majestad y modestia con que se ha de exponer a la veneración de los fieles. La Virgen no está así en el Cielo, ni en la tierra anduvo de este modo (Ponz, 1947, pág. 1226).

Muchas de estas imágenes vestidas son sencillas esculturas sedentes de la época bajomedieval que han sufrido aditamentos y transformaciones para poder adecuarlas al gusto de la época. A algunas hubo que cortarles las manos por no ser adecuadas, y en su mayoría llevan un armazón a modo de miriñaque para que el manto y la túnica adquirieran esa forma piramidal que caracteriza estas vírgenes diechiochescas. En las iglesias ricas se les hacía un basamento de metal noble, y en las pobres un simple armazón de madera era suficiente para poder ajustar el traje?

9 Entre las más profundas transformaciones se cuenta la de la Virgen de los Desamparados de Valencia. La imagen de la Virgen era yacente, ya que se llevaba reposada sobre el féretro de los ajusticiados y de los cofrades muertos. Se transforma en una escultura erguida por medio de un añadido en la parte posterior y un armazón para vestirla. Las transformaciones sufridas por esta imagen han sido estudiadas por C. Alarcón, La religiosidad popular española en tiempos de Carlos III, manuscrito inédito. Agradezo la consulta de este estudio, que ha resultado de una ayuda inapreciable para redactar estas páginas. Las conclusiones y parte de la documentación han sido publicadas en Alarcón Román, 1990. 
Fig. 7. Virgen del Sagrario. Grabado anónimo en cobre (s. XVIII) a devoción de Manuel de Medina.

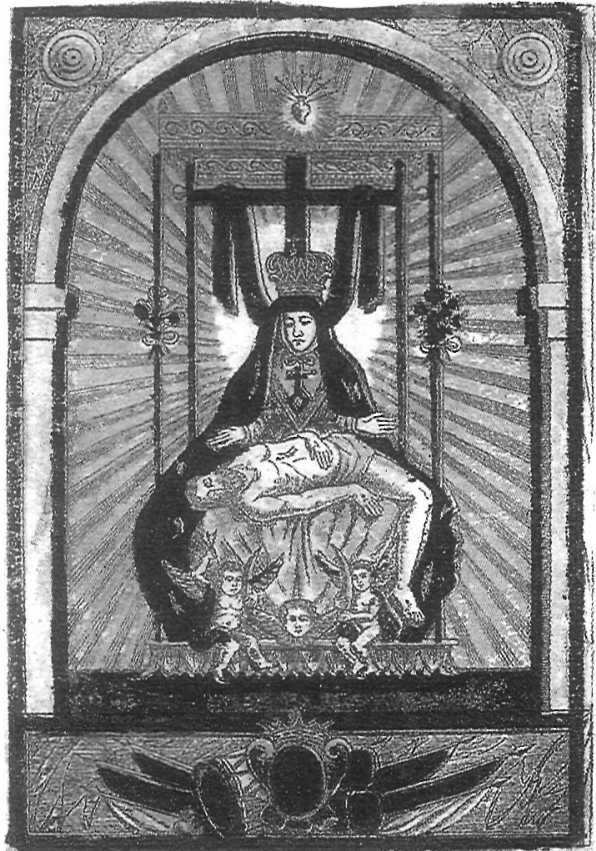

7 N NUESTRA SENOR F DE LAS AVGUSTIAS

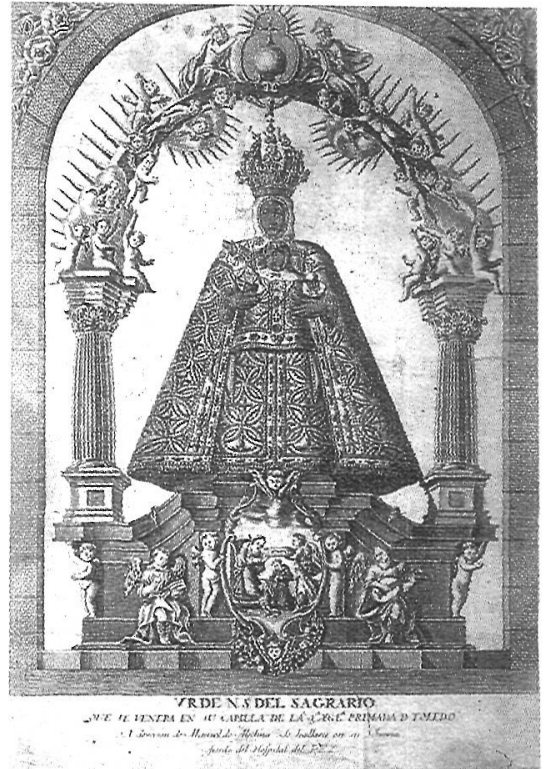

Fig. 8. Virgen de las Angustias. Grabado anónimo en madera (s. XVIII), iluminado. 
Sobre la riqueza del vestuario de algunas vírgenes se puede ver la variedad que presentan en el vestido las estampas de las diferentes imágenes. Entre ellas destacan, por ejemplo, la Virgen del Sagrario de Toledo que se venera en la catedral Primada (fig. 7) o la Virgen de Atocha de Madrid (Arte y devoción, 1990, núms. 4-8), una de las más ricas por la especial devoción que sentían los miembros de la famila Real ${ }^{10}$.

La riqueza del vestuario impresionaba. Por ejemplo, se sabe que la Virgen de Montserrat, que es una talla de la primera mitad del siglo XII, contaba con medio centenar de vestidos en la época de la invasión francesa. No obstante, es cierto que dependía de la actitud personal la valoración que se hacía de la belleza de la imagen y su riqueza de vestuario. Por ejemplo, la Virgen de Guadalupe, que es una talla del siglo XII, era descrita en el siglo XVIII de esta manera por Vilafañe:

Está la prodigiosa imagen en sitio elevado del retablo, para que más y mejor campee su hermosura. Tiene de alto poco más de una vara, sin peana, y corona, que la hace al parecer de mayor estatura. El color es moreno y el rostro es a maravilla grave y en todo perfecto, y causa tanta veneración a los que la miran que de puro respeto no se atreven a tener los ojos fijos en $\mathrm{Su}$ Divino semblante [...] Tiene la mano siniestra al Niño Dios, de extremada belleza y perfección, y en la derecha un cetro de oro, sembrado de piedras preciosas, como quien es Emperatriz de cielos y tierra: está vestida y tiene tanta diversidad de riquísimos vestidos, y tanta cantidad de preciosísimas joyas, que es cosa de admiración a quien la ve y registra despacio (Vilafañe, 1740, pág. 270).

De esta misma imagen Ponz hace este único y lacónico comentario:

Me aseguraron que los vestidos de la imagen pasaban de ochenta: vi entre ellos algunos cubiertos de pedrería, perlas, etc. y había uno que costó cuarenta mil ducados. Allí hay dones de reyes, reinas, príncipes y de otros grandes señores. En una alhacena, que llaman de la plata, se guarda (Ponz, 1947, pág. 1258).

Tan sólo una minoría accedía, por lo general, al conocimiento real de las sagradas imágenes, de ahí el interés de las descripciones, redactadas muchas de ellas en términos de admiración y adoración por haber llegado a participar de semejante intimidad. Por ejemplo, la imagen de la segoviana Virgen de Nieva fue descubierta según cuenta Vilafañe (Vilafañe, 1740, pág. 370) "11 "con mucha

10 Son muchas las imágenes de vírgenes vestidas: por ejemplo la Virgen de la Almudena de Madrid, la Virgen del Prado de Ciudad Real, la Virgen de la Natividad de Pinto, la Virgen de Piedraescrita en el retablo que existe en la iglesia parroquial del pueblo del mismo nombre en los montes de Talavera, la Virgen de los Nogales de la villa de Cameros, etc. De todas ellas se pueden ver estampas del siglo XVIII, tanto por mano de grabadores académicos como por artesanos. La diferente calidad de la técnica y el grabador es evidente en los ejemplos que reproducimos de las vírgenes del Sagrario y de Atocha. Sobre las imágenes vestideras véase Cea Gutiérrez, 1992.

11 En las descripciones se hace patente la diferencia existente entre las pequeñas dimensiones de la talla y la altura que suele alcanzar ésta cuando está vestida. 
reverencia y decencia por nuestro Reverendo Padre" para mudarla de vestido el 16 de Diciembre de 1624 , y con aquel motivo hubo algunos frailes que pudieron ver esta santa imagen:

Es de madera, y no se puede conocer qué madera sea, por el barniz que tiene; es de escultura, labrado todo el cuerpo con poca curiosidad; mas el rostro es hermoso, algo moreno, puede ser de la mucha antigüedad; la nariz aguileña bien sacada, derecha y muy proporcionada; las manecitas también, en buena proporción, ni muy llenas ni muy flacas; el rostro no es redondo; sino más largo que ancho; está sentada; los pies estriban como en un estradito, y representa el asiento más de escaño que de silla; las manos salían poco del cuerpo afuera, sin verse brazos, que los que ahora tiene son postizos; mas no lo eran las manos, que por haberse gastado mucho las tenía envueltas en un lienzo, guardadas y escondidas en el pecho. Desde la cabeza a los pies tiene media vara, y un dozavo; sale del lado izquierdo un Niño, no sentado ni torcido sino derecho, mas ladeado un poco, como que se inclina o reclina al brazo, con una tunicela desde el cuello abajo; tiene todo él una cuarta escasa; el color de la tunicela es colorado; parece también postizo, como el azul de la tunicela que de cuello a pies tiene la Madre, con un poco colorado a un lado.

Pero vestir y desvestir a las imágenes era un acto que requería un determinado respeto. Así en 1757 se observó en el vestir y desnudar la imagen de la Virgen de la Fuensanta en el presbiterio de la capilla mayor de la catedral; siendo forzoso "por su gran estatura" ponerla en un tapete en el suelo para poderle colocar los adornos correspondientes y desnudarla para vestirla de nuevo, "a vista de la mucha gente que suele concurrir por las verjas de dicha Capilla Mayor [...] lo que no es decente ni corresponde la veneración con que se debe tratar", acordará el Cabildo que siempre que se haya de vestir dicha imagen se hará en la sacristía, conduciéndola a ella con decencia, y estando allí con la misa "ínterin se le muda la ropa, cerrándose las puertas" (Peñafiel Ramón, 1988, pp. 89-90) $)^{12}$.

La Virgen de la Peña de Francia (Páez, 1981, núm. 1725-3) también era una imagen mariana medieval sedente:

En medio del retablo está el trono magnífico de plata en que se ostenta la gran Señora, la imagen sagrada de María rodeada de un arco de plata con lucidísimos rayos, corona imperial de oro filigranada en la cabeza, y en ella engastadas piedras muy preciosas. Vestidos según los tiempos, de mucho lustre y valor; y pendientes de ellos, joyas muy ricas. Sobresale a la parte exterior del arco una riquísima cama de plata con raso y primoroso arte labrada [...] Es la santísima imagen muy morena; y algunas veces se muestra tan agraciada y hermosa, que arrebata los corazones y se lleva los ojos hacia

12 Las hijas de la camarera, que llevaba 40 años en el cargo, se excusan de tener que hacerlo así "ante la estrechez de sacristía y falta de luz que hay en ella". El Cabildo exige a la camarera que se haga como se indica o renuncie al cargo, finalmente la camarera accede al deseo del Cabildo. 
sí misma. Pero en otras ocasiones (especialmente cuando hay tempestades) ostenta un rostro tan severo y airado que son pocos los que se atreven a mirarla de hito en hito [...] De los que hoy viven nadie la ha descubierto, porque hay tradición de que un prior quiso registrar la materia de que estaba fabricada (y es de madera sin duda) y la forma que tenía en lo interior; y quedó allí pasmado y sin poderse mover, persuadiéndose a que era castigo de su devoto atrevimiento (Caballero, 1728, pp. 79-80).

Caso distinto es el de la Virgen de las Angustias de Granada (fig. 8) que ha sufrido diversas transformaciones ya que en su origen era una Dolorosa a la que se añadió la imagen de Cristo muerto y la cruz en los siglos XVII y XVIII. Vestida de reina viuda como la Virgen de la Soledad de Madrid (fig. 1), los cambios sufridos por la imagen - debidos según parece a la necesidad de vestir a la Virgen- los describió en el siglo XVIII Sánchez Saravia ${ }^{13}$ de esta manera:

Dije ya el motivo de vestir a nuestra madre soberana con el traje que hoy se observa; en cuyos principios de él se significaban las manos de esta Señora unidas sobre el pecho, pero con la ofrenda que hizo el prelado del rico pectoral de corpulento tamaño pareció competente cerrar por el pecho la rizada túnica blanca, colocando en él esta preciosa alhaja, y separar manos y brazos, demostrándolos en acción más expresiva. Así se ejecutó, concurriendo a la disposición de este aderezo el eminente escultor [... Pedro Cornejo, que con la sabia pericia de su acierto proporcionó la acción con bello decoro, muy a satisfacción de los interesados, por los años de 1718. Dando comodidad para ello la situación de las manos ocultas, por estar comprimidas en el pecho, tendida una sobre otra; y como en la pintura y escultura sólo se atiende a la representación exterior del trasunto sensible, para componer el espíritu a la contemplación del objeto celestial, no se halla reparo en practicar lo expresado (Sánchez Saravia, 1777, pág. 29).

Las imágenes de los santos cambiaban normalmente poco en su aspecto. En ocasiones los artistas las vestían con los hábitos de alguna regla monástica porque, cómo anota Ponz en su obra, es "común entre nosotros el pintar a los Santos fundadores y aun a Nuestra Señora con los hábitos que presentemente se practican en ellas"14. No obstante había casos extremos que no se escaparon a los ojos críticos de los ilustrados. Fruto de una visita de Leandro Fernández de Moratín a la catedral de Córdoba es el siguiente comentario:

13 Parece que el Cristo muerto y la insignia de la cruz se pusieron a esta imagen dolorosa para que fuera igual a la pintura en tabla de la Virgen de las Angustias que regaló o trajo Isabel la Católica a Granada (citado por C. Alarcón, véase nota 19). La transformación de las imágenes religiosas ha sido una constante a lo largo de los siglos, incluso muchos de ellos se han llevado a cabo en época muy reciente como pone de manifiesto Villar Movellán, 1989.

14 Vestir con hábitos monásticos las imágenes también estaba prohibido por las autoridades de la Iglesia Católica ya que en 1642 el papa Urbano VIII (Bullarum, 1760, pp. 321-322) prohibió que "Jesucristo, la Virgen y los santos fueran pintados o esculpidos con el hábito de alguna orden religiosa particular, como las del Carmen o La Merced"; citado por Rodríguez G. de Ceballos, 1989, pág. 98. 
Siempre he oído citar a San Sebastián por ejemplo de desnudez; pero, ¿quién creerá que en esta iglesia, en la capilla que llaman de Villaviciosa, existe un San Sebastián muy jovencito, afeitadillo, con su peluca, su vestido de militar, su sombrero de tres picos debajo del brazo, sus flechas en la mano para denotar el martirio que padeció, su espadicico de plata, sus medias de seda, sus hebillas y sus zapaticos de castor? Yo pregunté por qué habían puesto de aquella manera al santo bendito, y me dijeron que era mayordomo de la Virgen, y estaba vestido de aquella manera para acompañarla con la decencia correspondiente en las festividades; a lo cual no hallé nada que responder (Fernandez de Moratín, 1867, t. II, pp. 17-18).

Pero dentro de esta temática de esculturas de bulto que podían ser vestidas ocupan un lugar privilegiado las pequeñas imágenes del Niño Jesús, por contarse entre los objetos más preciados de devoción, sobre todo entre las órdenes regulares femeninas. La presencia de imágenes del Niño en la calle debía ser bastante común. Blanco White hace el siguiente relato:

En los conventos de franciscanos están los donados que se dan al servicio del convento. Llevan el hábito de la Orden y son empleados en los oficios más bajos, a no ser que, si son capaces de representar o por lo menos de soportar la fama de una extraordinaria santidad, los manden a pedir limosnas para beneficio de sus señores. Todos los días se puede ver a estos santos idiotas caminar por las calles con pasos vacilantes y con el aspecto de la más profunda humildad ${ }^{15}$, paseando una imagen del Niño Jesús, a la que han adosado un cepillo para las limosnas, y ofreciendo no su mano, que es el privilegio de los sacerdotes, sino el extremo de su manga derecha para que 10 besen las personas pías (Blanco White, 1986, pâg. 180).

Por otro lado Ponz comenta que era habitual para el público la presencia del Niño en múltiples pinturas y la justifica incluso en aquellas composiciones en las que pudiera parecer un anacronismo, a pesar de que en opinión de este ilustrado era también censurable que los pintores los cometieran. Para Ponz se explica que en determinadas pinturas, como por ejemplo el Desposorio de Santa Catalina con el Niño Dios, San Antonio de Padua - a veces el Niño Jesús que lleva este santo recibe la atención por sí solo ${ }^{16}$ - San Ignacio de Loyola y otros muchos santos tengan al "mismo Niño en brazos" porque estas

15 Entre estos donados se encontraba el "hermanito Sebastián, penúltimo de los limosneros franciscanos en esta ciudad, del cual llevaba siempre una carta autógrafá manuscrita como amuleto el rey Carlos III, y como hubo que trasladarla a Roma para que fuera examinada en el proceso de beatificación, durante los días que no tuvo la carta el monarca no se atrevió a salir de palacio", según relato del mismo Jovellanos recogido por Blanco White, 1986, pág. 181. El retrato del venerable Fray Sebastián de Jesús Sillero, muerto en Sevilla en 1734, pintado por Gregorio Ferro "teniendo presente un retrato que se hizo en la vida del venerable, y un vaciado que se sacó después de muerto", fue grabado por Manuel Salvador Carmona en Madrid en 1782, y según la documentación conservada en el Archivo Histórico Nacional: "Esta obra se hizo a expensas del Rey Padre (que esté en gloria) por haber conocido y tratado en su infancia al dicho venerable cuando la Corte estaba en Sevilla" (citado por Carrete Parrondo, 1989, núm. 197).

16 Verdadero retrato del Niño de San Antonio que se venera en San Luis, y se lleva a los enfermos por los muchos milagros que hace $S_{u}$ Divina Majestad con ellos, grabada por Lorenzo Sánchez Mansilla (Arte y devoción, 1990, núm. 133). 


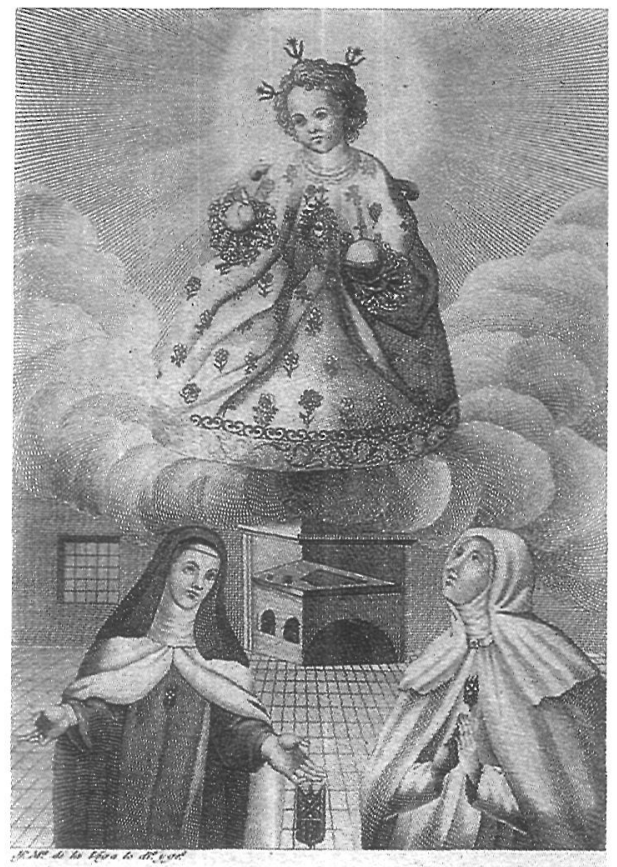

VA LMAGEN DE JESUS DEL DOLOR -

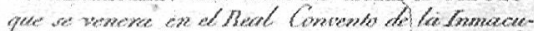

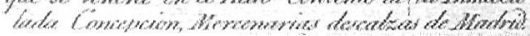

Fig. 10. Divino Emperador. Grabado en cobre por José Andrade, iluminado.
Fig. 9. Niño Jesús del Dolor. Dibujado y grabado en cobre por José María Ramos de la Vega.

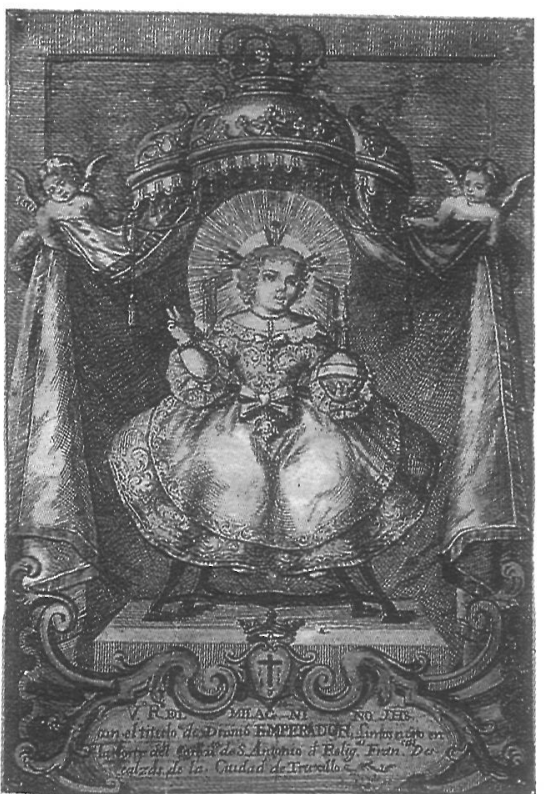


composiciones eran en realidad "piadosas representaciones de algunos favores que el Señor quiso hacer a aquellos siervos suyos; pues es cierto que su Majestad puede comunicarse a sus escogidos cuando y como quiere [...] Y el que pudo después de resucitado presentarse a la Magdalena en traje de hortelano, y en traje de peregrino a los discípulos de Emaús, puede también en forma de niño colocarse en los brazos de cualquiera de sus escogidos en esta vida mortal" (Ponz 1947, pág. 199).

En El pintor Cristiano y Erudito —obra a la que textualmente remite Ponz en este tema-Interián de Ayala comenta los errores que cometen habitualmente los artífices (Interián de Ayala, 1782 pág. 243), y le parece intolerable que pinten a "Cristo en su infancia enteramente desnudo" por considerarlo poco decente y decoroso, y añade: "No le representaron así los pintores y artífices antiguos, que atendían a la piedad y a la modestia, aunque en el arte de dibujar hayan sido muy inferiores a los modernos que ha habido en estos últimos tiempos: pero éstos, por persuadirse que el representar los cuerpos enteramente desnudos es cosa de más primor y artificio, han seguido este modo de pintar; olvidándose tal vez de que en todas las imágenes sagradas, principalmente en las de Cristo y de su Purísima Madre, se debe hacer mucho aprecio". Tampoco le gusta a Interián el ver pintado "con mucha frecuencia a Cristo como niño y aun como muchacho ya grandecillo, divirtiéndose en juegos pueriles: por ejemplo, cuando le pintan que está jugando con un pajarillo, teniéndole atado con un hilo y llevándole en sus manos o cuando le pintan montado a caballo sobre un cordero o de otros modos semejantes. Todo esto y otras cosas a este tenor son meras necedades y bagatelas [...] No se ocupaba en esto Cristo Señor nuestro, aun en la edad pueril: cosas mucho mayores y más graves revolvía en su mente santísima, con cuya memoria, a no haber sujetado sus pasiones con su soberano imperio, podía haberse contristado y entristecido. Tenía además perfectísimo uso de razón, no sólo desde que nació sino desde el primer instante en que fue animado y concebido [...] Por lo que no es razón que le imaginemos ocupándose en juegos pueriles y de niños, sino en pensamientos y meditaciones muy serias".

Es conocida la presencia de pequeñas imágenes del Niño Jesús en diferentes ámbitos — seglares y religiosos- y en diferentes clases sociales, ya fueran de bulto, ya en estampas. Pero donde más imágenes de bulto del Niño Jesús existían era en los conventos de monjas (fig. 9); según W. Coxe en su obra L'Espagne sous les rois de la maison de Bourbon también era común entre las monjas españolas llevar consigo un Jesús de cera al que se entretenían en vestir como a un muñeco (Fernández de Moratín, 1968, pág. 178) ${ }^{17}$. Parece mera variante

17 El mismo Moratín en el acto I (escena II) de esta obra pone en boca de doña Francisca la siguiente relación de objetos de devoción: "Pero mire usted, mire usted (Desata el pañuelo y manifiesta algunas cosas de las que indica el diálogo) cuántas cosillas traigo. Rosarios de nácar, cruces de ciprés, la regla de S. Benito, una pililla de cristal... Mire usted qué bonita. Y dos corazones de talco... ¡Qué sé yo cuánto viene aquí!... ¡Ay!, y una campanilla de barro bendito para los truenos... 
de la tradición de los Cristos vestidos y adornados por los feligreses. Llompart anota que en todos los conventos de clausura de Mallorca se conserva un elevado número de imágenes del Niño Jesús de los siglos XVII al XIX, en general de más devoción que valor artístico (Llompart, 1982). Un tipo corriente es la devoción del Nombre de Jesús: de pie, bendiciendo con la derecha y sujetando la esfera del mundo con la izquierda (fig. 10); los niños que aluden a la Pasión, de la manera que comentaba Interián de Ayala, durmiendo sobre la cruz o llevándola, o por ejemplo el tipo de Niño similar al que perteneció a la infanta Margarita durante su vida en el monasterio de las Descalzas Reales -donde en la actualidad se conservan unos 32 niños Jesús, ya que en casi todas las celdas de las monjas había un pequeño altar para ellos-: la infanta llevaba siempre en el cesto de labor o en el bolsillo del delantal un Niño dormido que estrechaba como preciados juguetes la cruz, la lanza, la corona de espinas y el sudario, símbolos de la Pasión ${ }^{18}$.

Como hemos visto hasta ahora, lo normal es que estas imágenes recibieran también un tratamiento especial en el vestido, como es el caso del Santo Niño del Remedio (Arte y devoción, 1990, núms. 130-132). Es muy interesante comprobar que algunos recibían una vestimenta un tanto extravagante, motivo de irónica crítica por parte de Blanco White:

Es muy corriente en España la representación de Dios en forma de niño. En muchos conventos el número de pequeñas imágenes del Niño Dios o el Niño Jesús, de un pie de altura, es casi igual al número de monjas, que lo visten con todas las formas del vestido nacional: de clérigo, de canónigo, en hábitos corales, de doctor en teología, de médico con su peluca y bastón de puño de oro, etcétera. También se ven muchas imágenes del Niño Jesús en las casas particulares; y en algunos lugares de España en que la principal ocupación es el contrabando, también se le puede ver vestido de contrabandista, con pistolas a la cintura y su trabuco en la mano (Blanco White, 1986, pp. 345-346).

Es posible que Blanco exagerara, pero el mismo Ponz, cuando visitó el monasterio de Guadalupe comenta:

El tabernáculo, que debía ser lo mejor por lo que en él se deposita, es de pésimo gusto ¿Y creerá V. que encima de él hay un Niño Dios vestido de militar? Cosa bien ridícula en una iglesia de esta seriedad (Ponz, 1947, pág. 606).

Aunque, es cierto, que en la posterior edición anota que "hay noticia de que se le ha mudado de traje".

¡Tantas cosas!". Entre estas cosas también se encontraba una figura de "Santa Gertrudis de alcorza"; la alcorza es una pasta muy blanca de azúcar y almidón con la que se cubren dulces y se hacen piezas o figurillas.

18 Esta iconografía es bastante común en las estampas dedicadas al Niño Jesús. Sobre estas imágenes en el convento de las Descalzas véase Ruiz Alcón, 1965; resulta también interesante el inventario de este tipo de figuras de bulto redondo realizado por Herrero Sanz, 1990, y Vega Jiménez, 1984. 
Fig. 11. Buen Pastor.

Grabado anónimo en cobre en 1820.

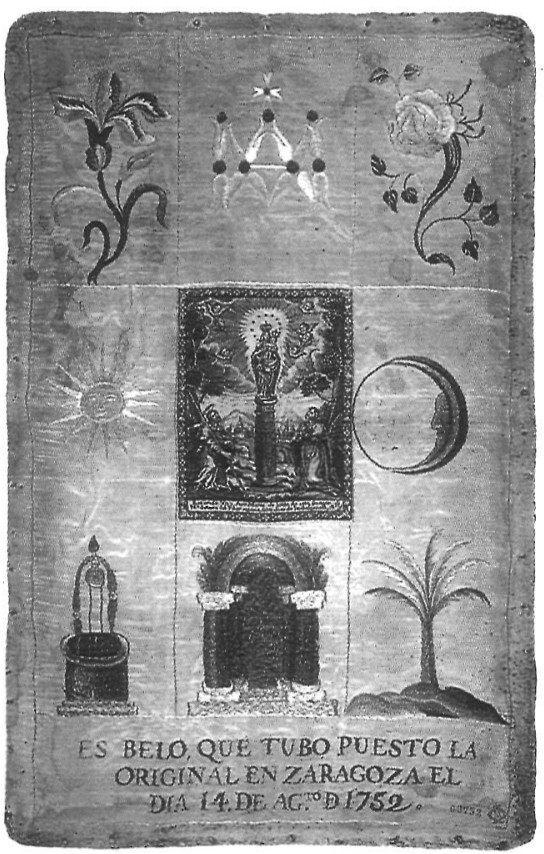

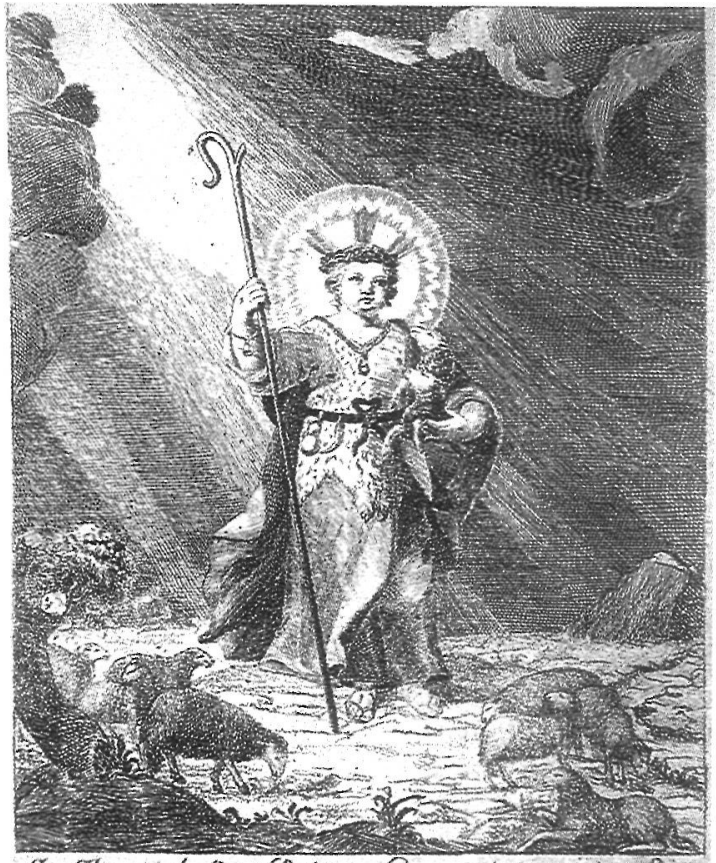

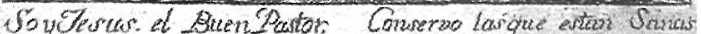

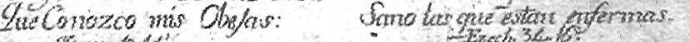

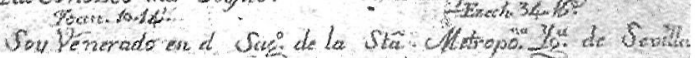

Fig. 12. Virgen del Pilar. Grabado en cobre y estampado sobre una parte del velo "que tuvo puesto la original en Zaragoza el día 14 de Agosto de $1752 "$. 
Pero quizá lo más interesante, pero ser sin duda lo más irracional, es que a las sagradas imágenes del Niño les añadían elementos propios de los niños de la época, educados en un ambiente supersticioso de protección a la infancia. La ignorancia seguía colocando a los niños amuletos para combatir el mal de ojo, incluso entre los vástagos de los grandes. En Feijoo encontramos una dura crítica a aquellos que creen "que los niños hermosos están más expuestos a este daño; porque la ternura de su edad es más capaz de recibir la maligna impresión, y la hermosura excita la envidia en los que la miran". Esos niños iban cargados de adminículos para ahuyentar todo tipo de efecto maligno sobre ellos:

Un chupador de cristal con cerco de plata; una uña de gran bestia (cuanto más peluda mejor) para ahuyentar las brujas, una esquila de plata, una higa de azabache y coral con la medalla de San Benito, un ochavo segoviano con un agujero y un cascabelero en forma de semicírculo ${ }^{19}$.

La representación más crítica de esas creencias la podemos ver en el Capricho 4 de Goya, El de la royona; del ceñidor que lleva el niño cuelgan dos higas para conjurar el mal de ojo, un escapulario o estampas de efectos milagrosos y una campanilla ${ }^{20}$. El empleo cotidiano de objetos religiosos como protectores de la infancia hizo que incluso aquellos que lo aprobaban reclamaran una cierta dignidad en su uso como, por ejemplo fray Jaime Barón y Arín, en Luz de la Fe (1717).

Pero también podemos apreciar elementos semejantes en figuras del Niño Jesús. El Buen Pastor (fig. 11) lleva en el cinto un colmillo y al cuello un tipo de medalla imposible de identificar; los conocidos como Niños de Pasión tienen, entre los símbolos que parecen bordados en el vestido, una higa, y la imagen responde a una forma tradicional de representación cuyos orígenes en estampas lo podemos rastrear hasta los comienzos del siglo XV y la pervivencia hasta finales del siglo $\mathrm{XIX}^{21}$; por último, el Santo Niño del Remedio (Arte y devoción, 1990, núm. 130) que lleva una campanilla, una higa y los Evangelios, destaca por su dieciochesca vestimenta y nos da una idea de cómo se podía llegar a vestir este tipo de imágenes.

Aunque en algunas de las estampas que hemos comentado se ve la transformación que sufren las imágenes dependiendo del gusto reinante o del

19 Félix Ponce de León, Vida, hechos y aventuras de Juan Mayorazgo, cap. citado por Mercader Riba y Domínguez Ortiz, 1972, pp. 119-120.

20 Este Capricho ha sido estudiado por Alcalá Flecha, 1987. Este autor ha hecho una exhaustiva búsqueda de textos coetáneos relacionados con la obra de Goya, Alcalá Flecha, 1988. Sobre las higas véase Hidburbh, 1955.

21 Por ejemplo, se puede mencionar la estampa del Evangelio según San Mateo, perteneciente al Rationarum Evangelistarum de 1510, reproducido por Westheim, 1981, pág. 78. Llompart, 1982, reproduce uno casi idéntico titulado Lo dulcissim nom de Jesus y publicado en la Imprenta de Pau Roca de Manresa, carrer de S. Miquel en 1865; el estudioso identifica el atuendo como de tiempos velazqueños. 
que se desea imponer, las innovaciones iconográficas son bastante limitadas. Para Bialostocky, "las transformaciones iconográficas significan vida, cambio, movimiento, renovación, en oposición a las fuerzas de la tradición, de la inercia o de la inmovilidad. El arte popular, ni el individual ni el tradicional, apenas presenta transformaciones iconográficas, o sólo en una medida muy escasa. Las imágenes de este arte son transmitidas con muy pocos o ningún cambio. Lo mismo ocurre en el arte religioso ortodoxo. En contraposición a esto, cuando más importante es la participación de la individualidad de un artista en una época histórica, tanto más variadas y numerosas son las transformaciones iconográficas que aparecen en dicha época" (Bialostocky, 1972, pp. 111-112). Se da una verdadera resistencia por parte del vulgo a sustituir una imagen de su devoción por otra, aunque sea más adecuada. Éste sería el caso comentado por Ponz en Cádiz:

En las iglesias de regulares nada hay de nuevo, excepto haberse renovado el culto público a un muy antiguo crucifijo que se veneraba en la de los reverendos Franciscanos de la Observancia. Según noticias [...] esta santa efigie, que es vaciada en pasta de papel, fue obra original de un indio en qué sé yo qué provincia de América [...] Hará poco más o menos cuarenta años que, sorprendida la procesión en que se conducía el crucifijo por una recia turbonada, no pudo evitarse que el agua hiciese un estrago tal en la pasta de papel, que por poco se hubiera disuelto [...] En este triste estado se emprendió la reparación; y si la efigie era disforme cuando salió de su primera mano, puede usted inferir qué tal quedaría después de restaurada con tales disposiciones.

Doce años hará que algunos caballeros cofrades trataron de colocar en su lugar un crucifijo de mejor forma; que en efecto lo hicieron venir de Nápoles; pero no bien apareció en el altar, cuando el pueblo que se dice piadoso comenzó (como los judíos contra el divino original) a gritos contra la imagen [...] Lo cierto es que al cabo de poco tiempo, ha sido depuesta la moderna y restituida la antigua a su lugar primero" (Ponz, 1947, pp. 15634).

Por cuestiones de espacio no vamos a tratar aquí por extenso el tema de las imágenes de Cristo. Éstos son igualmente vestidos, aunque no con tanto adorno como las imágenes de la Virgen. Por lo general se les colocan enaguas de lino y faldones de colores y adornos diversos, y les ponen pelucas de pelo natural largo encima de su cabellera original. Richard Twiss, en su Viaje por España y Portugal (1773), encontró en El Escorial el famoso crucifijo cincelado por Cellini, pero cuando lo vio su mitad inferior aparecía ridículamente cubierta por un terciopleo morado y un corpiño bordado en oro. Por último, podemos anotar algunos textos elocuentes sobre la imagen del Cristo de Burgos. Pedro de Loviano lo describía de esta manera en 1740:

Es tan admirable su arquitectura y su contextura tan rara, que toda es naturalmente tratable, y flexible de suerte que cede fácilmente en cualquiera parte que le apliquen el dedo, como si fuera de carne. La sagrada cabeza la tiene inclinada al lado derecho y se deja mover con facilidad al lado 
contrario y sobre el pecho [...] Su rostro es tan representativo del Divino original, de aspecto tan venerable, que [...] ha sucedido no poderle mirar de cerca con atención algunas personas de valor y esfuerzo, que se han empeñado en verle cara a cara [...] El cabello, barba y uñas exceden en propiedad las perfecciones del arte: porque imitan tanto lo natural, que parecen nacidos de la misma imagen. Tiene el brazo izquierdo algo más delgado que el derecho; lo que es o propiedad que imita la naturaleza, o lo que consideran algunas almas contemplativas en el original, que habiendo clavado al Redentor un brazo en la Santa Cruz porque el otro no llegaba al barreno correspondiente, se la tiraron y extendieron hasta que alcanzó la mano al lugar destinado para el otro clavo. Los nervios, arterias y huesos se perciben en número de un cuerpo perfectamente orgánico, siendo una extensión tan descubierta que en su modo se le adapta la frase, con que David explicó la extensión del Redentor en la Cruz, diciendo que se le podían contar todos sus huesos. Las llagas de los azotes [...] las heridas y la sangre pendiente de ellas tiene tales matices que parece se acaban de sellar en el original mismo [...] Finalmente, la estatura de la Santa Imagen es de hombre perfecto, y le hace hermosísima la misma fealdad de las llagas.

La realidad es que en el siglo XVII los escultores castellanos y andaluces, acaso más todavía que los pintores, dan a la imaginería religiosa un aspecto material terrible, reproduciendo las manifestaciones físicas del dolor en heridas, llagas, lágrimas, rostros abatidos, etc. Estas formas de representación que ya horrorizaban a los ilustrados eran, no obstante, del gusto de las gentes, ya que éstas se encontraban verdaderamente atraídas por las secuencias e historias cruentas: a través de la literatura de cordel, son las vidas de santos más melodramáticas y violentas las que tienen un público más popular.

\section{Para Ponz esta imagen sólo fue merecedora del siguiente comentario:}

Es ésta la iglesia que posee la comunidad de padres agustinos, donde se venera la milagrosa imagen que todos conocen por el nombre del Santo Cristo de Burgos, y ya sabe usted los prodigios que de ella se han escrito y la historia del mercader de Burgos que volviendo de Flandes la encontró, y cómo es tenida por obra de Nicodemus, que ciertamente hubiera sido este varón un escultor incansable si hubiera ejecutado todas las imágenes que se le atribuyen. La capilla donde está el Santo Cristo es muy rica de alhajas presentadas por soberanos y personas poderosas, con cuarenta y ocho lámparas de plata y de la misma materia son frontal, candeleros, gradas, rejas, etc. (Ponz, 1947, pág. 1048).

Resulta mucho más interesante la opinión de Jovellanos. En sus Diarios comentaba la visita realizada al convento en Abril de 1795 en estos términos:

Ayer tarde vimos también el Santo Cristo de Burgos en el convento de agustinos; su capilla, una gruta por la forma y la oscuridad; cincuenta lámparas, nueve de enorme tamaño, dos arañas, frontal, retablo y dosel de plata maciza; tres cortinas corridas, una en pos de otra, con mucho aparato, mucho encendimiento de luces, mucha devoción del vulgo; al fin, una efigie de malísima y hórrida forma; la mayor parte de las lámparas, dotadas; dentro y fuera de la capilla y por todo el claustro, carros de muletas, de piernas y brazos, y tetas de cera y aun de plata, votos, testimonios de estupidísima 
superstición. El fraile vende cruces de plata de varios tamaños y labores, estampas, medidas, todas tocadas a la efigie, en que ganará ciento por ciento (Jovellanos, 1992, pág. 219).

Otro tema de interés, por tanto, era la forma de presentación de las imágenes al público y el tipo de objetos que podían ser vistos en los santuarios. En el santuario de la Virgen de la Peña de Francia, según descripción de Domingo Caballero, se veía lo siguiente:

Las paredes de la iglesia están llenas de cuadros, lienzos y pinturas que expresan los innumerables milagros, pieles de lagarto o caimanes. Es tradición de los naturales que antes de aparecer la santa imagen salían de aquellos riscos aquellas serpientes, y hacían graves daños en hombres y animales: y que después, por intercesión de María Santísima, mediando súplicas y rogativas de los pueblos en esta su casa, los mataron milagrosamente y trajeron sus pieles por despojos de su iglesia (Caballero, 1728, pág. 78).

Además de estos monstruos sigue enumerando otros exvotos:

Hay también muchísimas cadenas de cautivos. Hay banderas, fusiles, mosquetes, bombas, muletas, velas y mortajas, todo prueba de los innumerables milagros de la imagen. Al lado derecho del coro, en lo bajo, está la sacristía vieja, y al siniestro lado la cerería, en donde se dan o escriben las limosnas de los votos; y se dan también medida y medallas de Nuestra Señora y hay efigies de cera, que según el voto de cada uno las paga y las pone tiempo determinado en el altar de Nuestra Señora.

La imagen más crítica de lo que podía ser uno de estos rincones la podemos apreciar en la estampa de Goya ;Qué locura! perteneciente a la colección de los Desastres de la guerra; en la parte derecha de la composición se puede ver un revuelto de estampas, exvotos, piernas e imágenes de cera, muleta, etc. Aunque sabemos que en estos santuarios vendían muchos de estos objetos devocionales - contar con una imagen milagrosa y sanadora reportaba pinguies beneficios económicos al centro-, hay que apuntar la existencia de un arte popular referente a los exvotos pintados o de cera, que eran fabricados por artífices especializados de vida itinerante. Por ejemplo, hasta época reciente ha existido la figura del cerero que iba por distintas localidades y según la necesidad de la gente y por medio de los distintos moldes de los que disponía, elaboraba el exvoto deseado: niños, piernas, brazos, cabezas..., que podían ser huecos o macizos, según la situación económica de la persona que los encargaba (García Román y Martín Soria, 1989, pág. 356). En este sentido conviene recordar que estos vendedores tenían otro tipo de cliente, aquellos individuos relacionados con el mundo de la brujería y los hechizos, ya que no es raro encontrar figuras de cera entre las pertenencias de las hechiceras. El mismo Goya en los Caprichos dejó algunas imágenes del uso de estas figurillas de cera que representaban a niños: 44 Hilan delgado, 45 Mucho hay que chupar, y 47 Obsequio al maestro 22 .

22 Goya cuando quiere expresar claramente que son niños lo hace incluso dentro de los mismos Caprichos. Nos referimos no sólo a los que aparecen en Que viene el coco o Si quebró el 
Curiosidades al margen, también conviene recordar, aunque no nos vayamos a ocupar de ello, que existían profesionales de pintar exvotos. Suelen ser pintados sobre tabla, de forma casi siempre rectangular, a menudo mal labrada y preparada, y se suele emplear el óleo. En ocasiones se utilizan las estampas de la propia imagen del santuario para hacer, a modo de collage, el exvoto.

La manipulación o embellecimiento de las estampas fue algo común en el siglo XVIII. Entre las estampas era habitual que las más lujosas fueran estampadas en tafetán o seda; había quien se ocupaba en adornarlas y embellecerlas a través de bordado o sirviéndose de papeles de colores como la de la Virgen del Rosario (fig. 13); también son muy frecuentes las que están iluminadas o estampadas en una tinta de color.

Por último, nos vamos a ocupar brevemente de algunos aspectos de la estampa como objeto de uso e, incluso, veneración. Cuando, por ejemplo, el maestro Juan de Ávila en la primera parte del Epistolario Espiritual ${ }^{23}$ escribía a cierto prelado de Granada acerca de lo que creía que se debía hacer en su diócesis para adoctrinar a la gente de los pueblos, indica que consideraba útil que los predicadores y misioneros llevaran no sólo rosarios, cartillas y libros devotos, como los de fray Luis de Granada, sino también "algunas imágenes del santo crucifijo y Nuestra Señora y San Juan, para que las diesen a los pobres", poniéndoles algunas imágenes en las casas y añade: "Y los pueblos han menester todas estas salsas para comer un manjar: rosarios, imágenes han de ser muchas, y los ricos cómprenlos de las ciudades" (Caro Baroja, 1985, pág. 126).

De cómo era la venta en las ciudades, al margen de aquellas estampas que se podían adquirir en las librerías, da testimonio al escrito de 1740 del Marqués de la Villa de San Andrés:

Andan por el día un enjambre de embusteros con estampitas de santos o con imágenes de bulto pidiendo limosna por las casas; suben como por la suya propia, y si los encuentran dan a besar el santito, besan si pueden a las criadas, gorran sus cuartejos a lo menos, pero si no los encuentras, con lo que encuentran ellos se vuelven a bajar las escaleras (Domínguez Ortiz, 1970).

cantaro, sino al que sirve de fuelle en la escena de brujería del Capricho 69, Sopla, o al que lleva en brazos la figura monstruosa que aparece detrás en esta misma estampa. Las figurillas que se ven en los tres caprichos que comentamos no parecen realmente humanas y no son tan horribles como deberían ser si en realidad se tratase de verdaderos fetos, según describen algunos estudiosos de esta colección, sino que se parecen bastante a la que se ve en el "santuario" de los Desastres. Por otro lado, como comenta Bozal, 1992, pág. 32, al tratar del Capricho 52, composición que podría ser una crítica a la devoción a las imágenes piadosas si no fuera por la presencia de brujos y brujas volando, "la devoción a las imágenes - simple madera revestida - es tan irracional como la brujería, pertenece al mismo orden de cosas".

23 La primera edición es de 1578. Hay edición de 1618. Se tradujo al italiano, francés e inglés. En el siglo XVIII se publicó formando parte de sus Obras, Madrid, Imprenta de Ortega, 1759-1760 en 9 vols. y nuevamente en 9 tomos en Madrid Imprenta Real, 1792-1806. 
Los grandes santuarios, al extender su culto y devociones y pedir ayuda económica a las gentes por los pueblos, daban a cambio medallas, estampas, crucifijos, etc. De ahí que se procurara evitar por todos los medios los fraudes. El convento de Santa María de Nieva, por privilegio dado por Felipe V en 1733, era el único que podía imprimir, fundir y vender estampas y medallas con el título de su Virgen, o dar licencia al platero o impresor que quisiera hacerlo. La razón es que tanto las estampas como las medallas debían estar tocadas a la mano derecha de la imagen de la Virgen, "donde el poder de su precioso Hijo tenía formada la figura o materia de un rayo" de manera que aquellas personas que las llevaban "iban seguras de cualquier peligro". De lo que se deduce que aquellas que no habían sido tocadas al original no tenían supuestamente el poder de librar de rayos y centellas, por lo que eran un engaño. Los puntos de venta y distribución de estampas y medallas de Nieva que se ajustaban a la legalidad estaban, además del convento donde se encontraba la imagen, en los conventos dominicos del Rosario de Madrid, San Pablo de Valladolid y Santa Cruz de Segovia. Debido a la producción fraudulenta llevada a cabo por muchos plateros e impresores, desde el convento segoviano se difundieron circulares de aviso entre grabadores y plateros, incluso entre buhoneros, de Segovia, San Sebastián, Alcalá de Henares, Granada, Córdoba, Ávila y Arévalo, para dar a conocer el carácter exclusivo que tenían sobre la producción. En 1768 se requisaron a estamperos, impresores y plateros de Córdoba estampas y medallas hechas sin licencia y sin tocar a la Virgen.

Existían además estampas especialísimas como la de la Virgen del Pilar, estampada sobre un trozo del manto que tuvo puesto la misma imagen (fig. 12), pero, por lo común, las estampas eran de papel y su presencia en un ambiente era casi sinónimo de humildad y austeridad. Por ejemplo la mayoría de los conventos veían adornadas las celdas de los religiosos o religiosas con estampas, en los hospitales sobre las cabeceras de las camas suelen verse estampas, etc.; quizá un ejemplo elocuente de devoción y austeridad sea el mismo Goya. En carta a su amigo Zapater le dice:

Para mi casa no necesito de muchos muebles, pues me parece que con

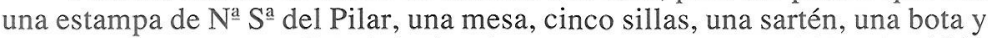
un tiple y asador y candil todo lo demás es superfluo (Goya, 1982, pág. 56) ${ }^{24}$.

La proliferación de las imágenes de papel en los distintos escenarios de la vida cotidiana fue exageradamente descrita por León de Arroyal:

La ciudad metrópoli tiene más templos que casas, más sacerdotes que seglares, y más aras que cocinas: hasta en los sucios portales, hasta en las infames tabernas se ven retablitos de papel, pepitorias de cera, pilitas de agua bendita y lámparas religiosas [...] Hasta los más recónditos y venerables

24 La estampa como objeto modesto y humilde, así como la figura del estampero y la función de las estampas en la sociedad barroca, han sido estudiadas por Portús, 1990. 


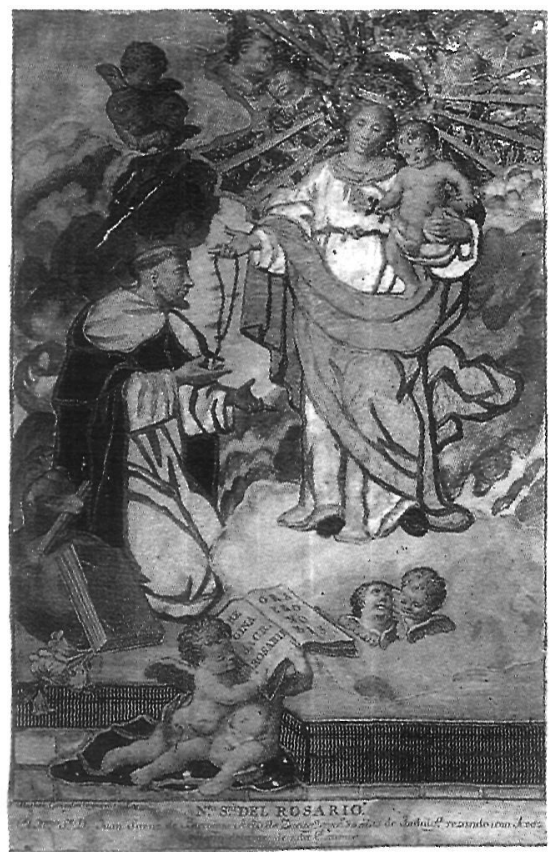

Fig. 13. Virgen del Rosario. Grabada en cobre por Mateo González, recortada con adiciones de bordados y pan de oro.

Fig. 14. Santa Macrina. Grabado

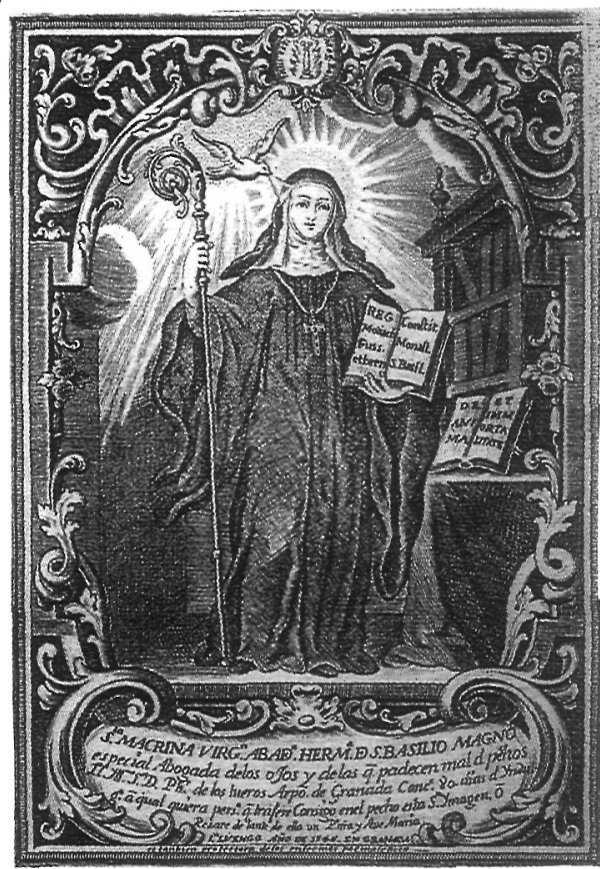
anónimo en cobre (s. XVIII). 
misterios de la religión se cantan por ciegos a las puertas de los bodegones al agradable y majestuoso compás de la guitarra (Arroyal, 1971, pág. 19).

Pero es que una sociedad desprotegida ante las enfermedades y las catástrofes naturales tenía lógicamente que buscar medios para prevenirse de estos males que la acosaban. En muchas ocasiones eran las estampas las que servían de talismán frente a los peligros, y su presencia era habitual en las casas según podemos ver en una pintura de Luis Paret (1991, $\left.\mathrm{n}^{\mathrm{o}} 28\right)$. Blanco White hace una elocuente referencia a esa intervención de los santos en la vida cotidiana de las gentes:

Las fiebres recurrentes, especialmente las tercianas y cuartanas, son muy generales en Andalucía, y es el verano la estación que más atacan [...] Está tan de acuerdo con las ideas católicas que haya un santo encargado del departamento médico de curación de fiebres, que ciertamente me sorprendería más encontrar una falta aquí que un dedo del pie no puesto bajo la influencia de algunas disposición de los cielos en la Vox Stellarum, libro que fue una de mis mayores sorpresas en Inglaterra. De hecho, esta parcela le ha tocado a San Bartolomé [...] Cada santo tiene su particular fantasía, desde San Antonio de Padua, que muchas veces retrasará hạcer un milagro hasta que no lo metan en un pozo o claven en la pared una estampa suya con la cabeza para abajo, hasta San Pascual Bailón, que atiende con preferencia a todo aquel que acompañe su petición con saltos y cabriolas. Con respecto a San Bartolomé, nada le inducirá a curar unas tercianas a no ser el voto de abstenerse el día de su fiesta de toda comida que no sea pan y fruta, precisamente lo mismo que, si no fuera por su milagrosa interferencia, causaría, según la opinión común, la recaída o agravamiento de la enfermedad (Blanco White, 1986, pág. 236).

En ocasiones se hacía un uso un tanto extravagante de este tipo de impresos para recuperar la salud. De nuevo White nos sirve de cronista:

En una de las principales parroquias de Sevilla hay una imagen venerada con el título de Virgen de la Salud. Esta denominación atrae a muchos a su santuario, que por estar enclavado en la parte más rica de la ciudad obtiene muchas y valiosas ofrendas. A cambio de ellas los fieles reciben una estampita o tira de papel impreso que contiene a intervalos regulares las palabras salus infirmorum en caracteres muy pequeños. En caso de enfermedad se recorta una de las líneas y se hace con el trocito una minúscula bolita que el paciente ingiere ayudado por un vaso de agua.

Y seguidamente comenta:

En la habitación de un enfermo grave suele haber más reliquias y amuletos que frascos de todas clases y hechuras en la alcoba de un inválido al cuidado de un boticario londinense. También cuando una señora está próxima a dar a luz sus amigas rivalizan entre sí para procurarle toda suerte de ayudas sobrenaturales [...] Hay dos cuya asistencia nunca deja de implorarse por medio de reliquias, cuadros o imágenes: los nombres de estos invisibles comadrones son San Ramón Nonato y San Vicente Ferrer.

En resumen, se ponían estampas de los santos protectores en el revellín de la chimenea contra las enfermedades en general, contra las más temidas o 
contra aquellas a las cuales la familia tenía más propensión. Frente a las epidemias, la gente tenía estampas de San Sebastián, San Roque o San Cristóbal, a fin de que les guardase de la peste; en las casas de campo cerca de la chimenea era común la estampa de Santa Bárbara, y era normal que la llevaran los caminantes para guardarse de los relámpagos y las tempestades. En ellas se puede apreciar la pervivencia de $\operatorname{los} \operatorname{modelos}^{25}$, o la mala factura de algunas estampas ${ }^{26}$ como la que llevaba al cuello Justo Martín, soltero natural de Castro de Fuentidueña de Segovia, que estando ebrio se coló en el cuarto de la reina en 1817; e incluso el uso indistinto que se hacía a veces de las oraciones para diferentes santos. Pero entre las estampas protectoras, sanadoras o defensoras las había con imágenes obviamente supersticiosas, y son aquellas que libran del maleficio como la de santa Macrina (fig. 15), que además de ser abogada de los ojos y de las que padecen mal de pechos, "es también protectora de los enfermos de maleficio", como abajo en letra muy diminuta se lee ${ }^{27}$.

Como es sabido, a principios del siglo XIX la sociedad española fue víctima de la sangrienta guerra contra los ejércitos napoleónicos, y son bastante numerosas las estampas que se conservan relacionadas con aquellos años fatales y sus consecuencias, para parafrasear el título que dio Goya a la colección que en la actualidad conocemos como los Desastres de la guerra. Es cierto que existían estampas con imágenes de abogados que libraban de la guerra, pero en esta guerra concreta sabemos que las estampas tuvieron una presencia activa. Por ejemplo, Lord Blayney, oficial inglés hecho prisionero por los franceses, por lo que atravesó la Península en su marcha hacia Francia, escribía en 1810 :

25 En la colección de A. Correa se conserva una estampa de santa Bárbara del siglo XIX en la que se ha empleado un taco grabado por Juan de Vingles, artífice de origen galo, activo durante el segundo tercio del siglo XVI en España.

26 El Santo Oficio prohibió algunas estampas por su tosca ejecución y las autoridades académicas tomaron medidas ante la mala factura de las imágenes religiosas, por ejemplo en los Estatutos, 1768 , cap. XXXI, núm. 4 se dice: "Deseando que las imágenes sagradas se hagan con la perfección posible, y que la impericia de los que las forman no prosiga haciendo irrisibles los objetos de nuestra veneración. Prohíbo bajo la misma multa de cincuenta ducados, a todo profesor de pintura, escultura y grabadura, que no tenga licencia para ello de la Academia, pintar, esculpir, y grabar para el público Imágenes sagradas". El 12 de Febrero de 1817 se dictaba una real resolución para tomar nuevas medidas contra las imágenes religiosas deformes y mal ejecutadas, véase Vega, 1987, pág. 29. Agradezo a Teresa Fernández su amabilidad al haberme dado a conocer la existencia de la documentación sobre Justo Martín en el Archivo de Palacio.

27 Hay que tener en cuenta que las estampas se empleaban también por curanderas, hechiceras y brujas. La Inquisición prohibió algunas de estas estampas; por ejemplo en 1739 se prohíbe una estampa de San Antonio que decía: "quien tuviese su casa adornada con estas armas, será libre de incendio, de peste y de encantamiento". Y en 1733 se prohíben las de la Virgen de la Fuensanta y la de la Virgen del Pilar por llevar escrito: "Palabras santísimas contra hechizos, tempestades de rayos, brujerías, etc. por ser palabras de Dios mismo". Era habitual emplear contra el mal de ojo medallas de san Benito, estampas y bolsitas con los Evangelios; sobre este tema véase Carrete Parrondo, 1981, pp. 36-43. 
Sin duda es asombroso que de la encarnizada lucha que sostiene España no haya brotado un hombre de talento superior, mientras que la Revolución Francesa ha producido tantos, y en todos los géneros. Pero se debe atribuir a Ia influencia del clero, siempre demasiado severo con cualquier sistema de educación más liberal. ¿Qué energía se puede esperar de un pueblo que tiene más confianza en la protección de un santo que adopta como patrón que en su propio valor? El soldado que se creerá invencible porque lleva sobre su pecho una reliquia de un santo podra mostrar algún valor al marchar al combate, pero huirá en cuanto crea que su santo le abandona (Savine, pág. 99).

Sobre la valerosa actuación de las mujeres en el sitio de Zaragoza podemos añadir otro singular testimonio de la época referido a la circulación de estampas religiosas:

Las mismas mujeres se presentaron junto a los cañones que cebaron, dando sin cesar agua y vino a los artilleros, que no podían resistir más, animándolos con las expresiones más tiernas y diciéndoles: "Hijos, refrescaos que la Virgen nos asiste y favorece", y como había quien se dedicaba en distribuir estampas de Nuestra Señora del Pilar, todos las colocaron sobre sus sombreros (Memoria, 1808, pág. 38).

Y en la descripción de cómo era el ejército español que entró en Madrid el 14 de Agosto de 1808 Alcalá Galiano cuenta:

Pero la mayor parte de los nuevos huéspedes vestían los holgados zaragüelles y traían la manta al hombro; y en la cabeza, cuyo pelo caía por los lados y espaldas en largas mal peinadas y sucias melenas, sombrero redondo con escarapela patriótica, cintas con lemas y muchas estampitas con imágenes de la Virgen y de los Santos [...] Se iban a los conventos de monjas a pedir oraciones y algunas estampas para sus sombreros y pechos (Alcalá Galiano, 1955, pág. 353).

Pero introducidos en la guerra y en la crítica a la irracionalidad popular, nada hay mejor que la visión del propio Goya de estas devociones. Pertenecen las imágenes a la serie de los Desastres. Goya toma un tema del dominio público, y mezclado con hechos reales, configura una realidad irónica y amarga. En el desatre 66, Extraña devoción, el pintor ha tomado el tema del asno cargado de reliquias en clara referencia visual al asno portando el ídolo. Parece seguro que hasta el pueblo llano conocía esta fábula que Covarrubias ya recogió en su Diccionario y el mismo Lope de Vega empleó en una de sus comedias. Mas el asno de Goya porta unas reliquias concretas, las de la beata Mariana de Jesús, por la que sentía una gran devoción el pueblo llano de Madrid. Por el contrario, en el siguiente desastre, Esta no lo es menos, son dos imágenes de la Virgen las que aparecen: la Virgen de la Soledad (fig. 1) - a la cual se la tenía especial devoción para que conservara la salud del monarca-, y la Virgen de Atocha (Arte y devoción, 1990, núms. 4 y 5), en cuyas manos dejó el reino Fernando VII cuando lo abandonó en 1808 (Carrete Parrondo, 1981, núm. 308). La audacia de ambas composiciones sólo es comparable a la del comentario que lleva cada una de ellas. Los esfuerzos ilustrados cayeron en saco roto, y frente 
a la firme voluntad educadora de éstos, se estableció el régimen oscurantista del Deseado, que el mismo Goya reflejó en la parte final de su colección de estampas (Véase Vega, 1992). No cabe duda de que uno de los pilares en los que se asentó el regreso a la corona de Fernando VII fue la irracional devoción, la ignorancia y la ingenuidad popular.

\section{BIBLIOGRAFÍA}

ALARCÓN ROMAN, C. 1988. Catálogo de Amuletos del Museo del Pueblo Español, Madrid, Ministerio de Cultura.

- 1990. "La iconografía religiosa en el siglo XVIII", Revista de Dialectología y Tradiciones Populares, núm. 45, pp. 247-277.

ALCALÁ FLECHA, R. 1987. "El tema del niño mal criado en el capricho 4, El de la rollona, de Goya", Goya, núm. 198, pp. 340-42.

- 1988. Literatura e ideología en el arte de Goya, Zaragoza, Diputación General de Aragón.

ALCALÁ GALIANO, A. 1955. Obras escogidas, Madrid, Biblioteca de Autores Españoles, 2 vols.

ARES, A. 1640. Discurso del ilustre origen y grandes excelencias de la misteriosa imagen de nuestra Señora de la Soledad del convento de la Victoria de Madrid de la Sagrada Orden de los Mínimos de S. Francisco de Padua, Madrid, Pedro Taço.

ARROYAL, L. de 1971. Pan y Toros y otros papeles sediciosos de fines del siglo $X V I I I$, edición de A. ELORZA, Madrid Ayuso.

ARTE Y DEVOCIÓN. 1990. Arte y devoción. Estampas de imágenes y retablos de los siglos XVII y XVIIl en iglesias madrileñas, Madrid, Calcografía Nacional.

BIALOSTOCKY, I. 1972. Estilo e iconografía: contribución a una ciencia de las artes, Barcelona, Barral Editores.

BLANCO WHITE, J.M. 1972 Obra inglesa, prólogo de J. GOYTISOLO, Buenos Aires, Ediciones Formentor.

- 1986. Cartas de España, introducción V. LLORENS, Madrid, Alianza.

BOZAL, V. 1992. Instantáneas. Caprichos, Madrid, Turner.

BULLARUM. 1760. Bullarum, Privilegiorum et Diplomatum Romanorum Pontificum amplissima Collectio..., vol. VI, Roma, s.i.

CABALLERO, D. 1728. Historia de la admirable invención y milagros de la taumaturga imagen de Nuestra Señora de la Peña de Francia, patrona tutelar y defensora de Orán, Salamanca, Imprenta de la Viuda de Gregorio Ortiz. 
CARO BAROJA, J. 1985. Las formas complejas de la vida religiosa (Religión, sociedad y carácter en la España de los siglos XVI y XVII), Barcelona, Sarpe.

CARRETE PARRONDO, J. 1981. Estampas. Cinco siglos de imagen impresa, Madrid, Ministerio de Cultura.

- 1989. El grabado a buril en la España Ilustrada: Manuel Salvador Carmona, Madrid, Fundación Casa de la Moneda.

CEA GUTIÉRREZ, A. 1992. Religiosidad popular. Imágenes vestideras, Zamora, Caja España.

CENSOR. 1972. El Censor. Antología, edición de E. GARCÍA PANDAVENES, Barcelona, Labor.

CHRISTIAN, W.A. 1989. "Francisco Martínez quiere ser santero. Nuevas imágenes milagrosas y su control en la España del siglo XVIII", El Folk-lore Andaluz, núm. 4, pp. 103-114.

- 1990. Apariciones en Castilla y Cataluña. Siglos XIV a XVI, Madrid, Nerea.

- 1991. Religiosidad local en La España de Felipe II, Madrid, Nerea.

DOMÍNGUEZ ORTIZ, A. 1970. "Una visión crítica del Madrid del siglo XVIII. Hechos y figuras del siglo XVIII español", Anales del Instituto de Estudios Madrileños, vol. VI, pp. 313-316.

ESTATUTOS. 1768. Estatutos de la Real Academia de San Carlos, Valencia, s.i.

FERNÁNDEZ DE MORATÍN, L. 1867. Obras póstumas, Madrid, Rivadeneyra.

- 1968. El si de las niñas, edición de R. ANDIOC, Madrid, Castalia.

GARCíA ROMÁN, C. y M.T. MARTÍN SORIA. 1989. Religiosidad popular: exvotos, donaciones y subastas, en C. ÁLVAREZ SANTALÓ, J. J. BUXÓ Y S. RODRÍGUEZ BECERRA (coords.), La religiosidad popular. III. Hermandades, Romerias y Santuarios, Barcelona, Anthropos, pp. 353-368.

GOYA, F. 1982. Cartas a Martín Zapater, edición de M. AGUEDA y X. SALAS, Madrid, Turner.

HERRERO SANZ, M.J. 1990. La escultura en el Convento de Agustinas Recoletas de Santa Isabel de Madrid, en Catálogo IV Centenario de la Real Fundación del Convento de Santa Isabel de Madrid, Madrid, Patrimonio Nacional, pp. 111-142.

HIDBURGH, W.L. 1955. "Images of the Human Hand as Amulets in Spain", Journal of the Warburg and Courtauld Institutes, núm. 18, pp. 67-89.

INTERIÁN DE AYALA, J. 1782. El pintor Cristiano y Erudito o tratado de los errores que suelen cometerse frecuentemente en pintar y esculpir la imágenes sagradas, Madrid, Joaquín Ibarra.

JOVELLANOS, M.G. de 1952. Obras, Madrid, Biblioteca de Autores Españoles, t. II. 
- 1956. Obras, Madrid, Biblioteca de Autores Españoles, t. III.

- 1992. Diario (Antología), edición de J.M. Caso González, Barcelona, Planeta.

LISÓN TOLOSANA, C. 1992. La bruja en España, Madrid, Ediciones Temas de Hoy.

LLOMPART, G. 1982. Imágenes mallorquinas exentas del Niño Jesús, en Religiosidad popular. Folklore de Mallorca, folklore de Europa, vol. I, Palma de Mallorca, J.J. de Olañeta Editor, pp. 73-84.

LOVIANO, P. 1740. Historia y milagros del Santísimo Cristo de Burgos con su novena, Madrid, Alonso Orozco.

LUIS PARET. 1991. Luis Paret y Alcázar 1746-1799, Vitoria-Gasteiz, Gobierno Vasco.

MARTÍNEZ-BURGOS GARCÍA, P. 1990. La imagen de vestir: el origen de una devoción barroca, en Pedro Mena y su época. Simposio Nacional, Málaga, Junta de Andalucía.

MEMORIA. 1808. Memoria de lo más interesante que ha ocurrido en la ciudad de Zaragoza con motivo de haberla atacado el Ejército francés, Madrid, Imprenta de la calle de la Greda.

MERCADER RIBA, J. y A. DOMÍNGUEZ ORTIZ, 1972. La época del Despotismo Ilustrado, Barcelona, Vicens Vives.

PAEZ, E. 1981-1983. Repertorio de grabados españoles, 3 vols., Madrid, Ministerio de Cultura.

PEÑAFIEL RAMÓN, A. 1988. Mentalidad y religiosidad popular murciana en la primera mitad del siglo XVIII, Murcia, Universidad de Murcia.

PONZ, A. 1947. Viaje de España, o Cartas en que se da noticia de las cosas más apreciables, y dignas de saberse que hay en ella, Madrid, M. Aguilar.

PORTÚS, J. 1990. "Uso y función de la estampa suelta en los Siglos de Oro (testimonio literario)", Revista de Dialectología y Tradiciones Populares, núm. 45 , pp. 227-246.

PUENTE, J. de la. 1968. La visión de la realidad española en los viajes de Don Antonio Ponz, Madrid, Moneda y Crédito.

RODRÍGUEZ G. DE CEBALLOS, A. 1987. Piedad y vida religiosa en la Corte durante el siglo XVIII, en El Real Sitio de Aranjuez y el arte cortesano del siglo XVIII, Madrid, Comunidad de Madrid.

- 1989. "Iconografía y Contrarreforma: a propósito de algunas pinturas de Zurbarán", Cuadernos de Arte e Iconografia, núm. 4, pp. 97-105.

RUIZ ALCÓN, M.T. 1965. "Imágenes del Niño Jesús del Monasterio-Convento de Las Descalzas Reales", Reales Sitios, núm. 4, pp. 28-36.

SÁNCHEZ LORA, J.L. 1989. Claves mágicas de la religiosidad barroca, en C. 
ÁLVAREZ SANTALÓ, J.J. BUXÓ y S. RODRÍGUEZ BECERRA (coords.), La religiosidad popular. II. Vida y muerte: La imaginación religiosa, Barcelona, Anthropos, pp. 125-145.

SÁNCHEZ SARAVIA, D. 1777. Compendio histórico del origen y culto en Granada de Nuestra Señora de las Angustias, Granada, s.i.

SAVINE, A. 1910. España en 1810, París, c. 1910, s.i.

VEGA, J. 1987. "Estampas del Trienio Liberal", Villa de Madrid, núm. 94, pp. 2852.

- 1992. Instantáneas. Desastres, Madrid, Turner.

VEGA JIMÉNEZ, M.T. 1984. Imágenes exentas del Niño Jesús. Historia, iconografía y evolución, Valladolid, Caja de Ahorros Provincial.

VELASCO, H.M. 1989. Las leyendas de hallazgos y de apariciones de imágenes. Un replànteamiento de la religiosidad popular como religiosidad local, en C. ÁLVAREZ SANTALÓ, J.J. BUXO Y S. RODRÍGUEZ BECERRA (coords.), La religiosidad popular. II. Vida y muerte: La imaginación religiosa, Barcelona, Anthropos, pp. 401-410.

VENTURA RODRÍGUEZ, 1983. El arquitecto D. Ventura Rodríguez (1717-1785), Madrid, Museo Municipal de Madrid.

VILAFAÑE, J. de 1740. Compendio histórico en que se da noticia de las milagrosas y devotas imágenes de la reina de los cielos y tierra, María Santísima, Madrid, Imprenta de Manuel Fernández.

VILAR MOVELLÁN, A. 1989. "Santos travestidos: imágenes condenadas", Cuadernos de Arte e Iconografía, núm. 4, pp. 183-191.

VILLEGAS, B. de. 1635. La esposa de Christo, instruida con la vida de Santa Lutgarda, Murcia, Juan Fernández Fuentes.

WESTHEIM, P. 1981. El grabado en madera, México DF, Fondo de Cultura Económica. 



\title{
DE INMINENTE APARICIÓN
}

\author{
IGNACIO GARCÍA MALO \\ (1760-1812)
}

\section{VOZ DE LA NATURALEZA}

Edición, estudio preliminar

y notas de Guillermo Carnero

Londres, Támesis Books

en coedición con la Fundación Juan March y la Universidad de Alicante 


\title{
ANTOLOGIA DE LA NOVELA CORTA ERÓTICA ESPAÑOLADE ENTREGUERRAS (1918-1936)
}

\author{
Edición de Lily Litvak \\ Catedrática de la Universidad de Texas
}

Una obra de enorme novedad, que pone en manos del lector novelas de difícil localización, perseguidas por la censura y habitualmente omitidas en la Historia de la novela española del siglo XX. El volumen incluye 18 novelas, de autores como Ramón Gómez de la Serna, Rafacl Cansinos Asssens, Juan José Domenchina, Antonio de Hoyos y Vinent, Eugenio Nocl, Emilio Carrere, Joaquín Belda, Artemio Precioso, René Renolt y otros.

El estudio preliminar de Lily Litvak pone de manificsto su detallado conocimiento de las fronteras y territorios marginales $\mathrm{k}$ la literatura española de este siglo. Lleva la obra 31 láminas on blanco y negro, y 17 en color.

\section{Colección “Clásicos Taurus” n” 20 Madrid, Taurus, 1993 \\ Segunda Edición, 1994 627 páginas}




\title{
Mª de los Ángeles Ayala
}

\section{LAS COLECCIONES COSTUMBRISTAS (1870-1885)}

\author{
Alicante, Universidad, 1993, 194 págs.
}

Las colecciones costumbristas (1870-1885) es un detenido estudio de la producción costumbrista aparecida en estos años. La influencia de Larra y Mesonero Romanos se deja sentir en toda esta ingente relación de escritores que desde su peculiar visión de la historia de España ofrecen un fiel mosaico de comportamientos humanos. Colecciones que si bien siguen el camino inaugurado por Los Españoles pintados por sí mismos se enriquecen tanto desde el aspecto puramente literario, al desarrollar los recursos y procedimientos utilizados por los costumbristas románticos, como al ampliar su campo de observación hacia tierras y tipos oriundos de otras zonas geográficas y recoger las principales cuestiones que inquietaban a los hombres a finales de siglo. El estudio de estas coleccioneses un eslabón de gran importancia para el entendimiento y comprensión de la realidad social, política y literaria de esta época.

Pedidos a su librero habitual o al Secretariado de Publicaciones,

Universidad de Alicante - Apdo. de Correos 99

03080 ALICANTE 


\section{JUAN GIL-ALBERT}

\section{RACIM0 DE LOS DIOSES}

\section{Antología Poética}

Selección, estudio preliminar, notas y variantes de Guillermo Carnero

\section{Valencia \\ Consell Valencià de Cultura 1993}

355 páginas 


\section{Gregorio Mayans y Siscar OBRAS COMPLETAS}

Dada la dificultad de encontrar en librerías o bibliotecas las obras de Mayans y Siscar (1699-1781), una de las máximas figuras de la Ilustración española, el intento del Ayuntamiento de Oliva, con la ayuda de la Diputación de Valencia y la Consejería de Cultura de la Generalidad Valenciana, de publicar las Obras Completas de Mayans, debe ser celebrado con el máximo elogio. Cuida de la edición Antonio Mestre, que ha centrado su interés en ofrecer un texto depurado, señalando las variantes entre las diferentes ediciones y respecto a los manuscritos autógrafos que se conservan en los fondos mayansianos. Un prólogo global de cada volumen y una breve introducción a cada una de las publicaciones mayansianas, que exponen las circunstancias concretas en que aparecieron, contribuyen a clarificar el contexto y sentido de la obra. En un principio, aparecen las obras escritas en castellano, que constan de 5 volúmenes:

Vol. I. Historia, 621 págs., Valencia, 1983.

Vol. II. Literatura, 564 págs., Valencia. 1984.

Vol. III. Retórica, 653 págs., Valencia 1984.

Vol. IV. Jurisprudencia y regalismo, 585 págs., Valencia, 1985.

Vol. V. Ensayo y varia, 489 págs., Valencia, 1986.

\section{EPISTOLARIO}

Continuando laedición del Epistolario mayansiano, Mayans y los médicos (I), Mayans y Burriel (II), Mayans y Martí (III), Mayans. Escritos económicos (IV), Mayans y Nebot (V), Mayans y Pérez Bayer (VI), Mayans y Martínez Pingarrón (VII, VIII, IX), Mayans, Manuel Roda y el conde de Aranda (X), Mayans y Blas Jover (XI), ha aparecido últimamente:

- G. MAYANS Y SISCAR, Epistolario XII, Mayans y los libreros; transcripción, estudio preliminar y notas de Antonio Mestre, Valencia 1993.

\section{Pedidos:}

Albatros, La Olivereta, 28 - 46018 VALENCIA 


\section{Gaspar Melchor de Jovellanos}

\section{POESÍA • TEATR0 • PROSA LITERARIA}

\section{Edición de John H.R. Polt \\ Catedrático de la Universidad de Berkeley}

Una cuidada selección de la obra literaria de Jovellanos, a cargo de uno de los mejores especialistas actuales en el ámbito del siglo XVIII español. El volumen incluye una antología de la obra poética de Jovellanos, la tragedia Pelayo, la comedia sentimental El Delincuente honrado, y textos en prosa como el Elogio de Carlos III, la Memoria sobre espectáculos y diversiones públicas y muestras del Diario y epistolario del autor, con el habitual aparato crítico y estudio preliminar.

\section{Colección "Clásicos Taurus" nº 10 Madrid, Taurus, 1993 518 páginas}




\section{ÁNGEL L. PRIETO DE PAULA}

\section{ANTOLOGÍA DE POESÍA ESPAÑOLA}

\section{(1939-1975)}

Alicante, Aguaclara, 1993 389 paginas

Presenta esta antología una muestra de los principales cursos creativos - por su cantidad, por su calidad intrínseca, por su repercusión en el entorno cultural- de la poesía escrita en castellano desde 1939 hasta 1975. Los poetas seleccionados, pertenecientes a las tres generaciones sucesivas que atravesaron la época franquista, desarrollaron su tarea en contacto con la cultura del interior. En la abarcadora Introducción se efectúa un recorrido por la poesía española durante el período acotado, se señalan los momentos constitutivos de ese período y se aborda la caracterización de las escuelas, tendencias o núcleos estéticos más importantes. Contiene este libro una nota bibliográfica de cada uno de los poetas seleccionados, así como una orientadora bibliografía general.

PEDIDOS A SU LIBRERO HABITUAL. 


\title{
Ramón de Mesonero Romanos
}

\section{ESCENASYTIPOS MATRITENSES}

\author{
Edición, estudio preliminar y notas de \\ ENRIQUE RUBIO CREMADES
}

Cátedra, Madrid, 1993, 511 páginas.

La primera mitad del siglo XIX ofrece al lector un panorama literario poco común. El cauce vertiginoso de tendencias, escuelas y nuevos credos políticos e ideológicos se entrecruza y amalgama con singular personalidad. Algunos escritores escrudiñan la realidad española sirviéndose de un género —el cuadro de costumbres-y de un medio - el periódico- para reflejar los cambios de la sociedad española. Entre ellos destaca por sus especiales dotes de observación Ramón de Mesonero Romanos. La anécdota personal o las vivencias del propio autor, las amistades, tertulias, impresiones de viajes o de las nuevas configuraciones urbanas aparecen como un documento imprescindible para quien quiera adentrarse en esta primera mitad del siglo XIX.

Pedidos a su librero habitual. 


\section{José de Cadalso}

\section{Noches lúgubres}

\section{Edición de Russell P. Sebold}

Clásicos Taurus, núm. 23, Madrid, Taurus Ediciones, 1993, 215 paginas, 650 pesetas.

Modelo de poetas y prosistas neoclásicos y románticos, Cadalso nos ha dado en esta obra, compuesta en 1771, el primer poema en prosa de la literatura española y la primera obra plenamente romántica del continente europeo. Sebold ofrece un texto fidedigno y una anotación rigurosamente científica. En la Introducción estudia la azarosa vida de Cadalso, así como las fuentes, cosmovisión romántica, genero, mímesis y el tema del suicidio en las Noches lúgubres. Sebold es un denodado estudioso de la literatura española clásica, neoclásica, ilustrada y romántica; es un colaborador asiduo del diario $\mathrm{ABC}$ con artículos literarios, es doctor honoris causa por la Universidad de Alicante, y es académico correspondiente de la Real Academia Española. 


\title{
MIGUEL HERNÁNDEZ, CINCUENTA AÑOS DESPUÉS
}

\author{
(Actas del I Congreso Internacional)
}

Coordinación: José Carlos Rovira

Alicante, Comisión del Homenaje a Miguel Hernández, 1993

Dos volúmenes con un total de 1029 paginas conteniendo las ponencias, comunicaciones y mesas redondas del Congreso dedicado a Miguel Hernández en Marzo de 1992, coincidiendo con el cincuentenario de su muerte. Entre los 105 ponentes, hay textos de José Carlos Mainer, Andrew P. Debicki, Eutimio Martín, Marie Chevallier, Miguel Ángel Lozano, Guillermo Carnero, Gabriele Morelli, Agustín Sánchez Vidal, Serge Salaün, Dario Puccini, Juan Cano Ballesta, Joaquín Marco, Iris M. Zavala, Jorge Urrutia, Francisco Javier Díez de Revenga, Mariano de Paco, Jesucristo Riquelme, Enrique Rubio, José Carlos Rovira, Carmen Alemany, Joan Oleza, Claude Couffon, Leopoldo de Luis, Pedro Aullón de Haro, Concha Zardoya, Geraldine Nichols, Ángel Luis Prieto de Paula, etc.

Pedidos a Instituto de Cultura Juan Gil-Albert. Avda. de la Estación, 6. Alicante (España) 


\title{
GASPAR ZAVALA Y ZAMORA
}

\author{
0 B R A S \\ VOLUMEN I. \\ OBRAS NARRATIVAS \\ LA EUMENIA - ODERAY
}

Edición de Guillermo Carnero

Colección "El Bosque de Aristarco", dirigida por Alberto Blecua, $n^{0} 1$

\section{Barcelona Sirmio 1992}

En coedición con la Universidad de Alicante 265 páginas 


\title{
DAVID T. GIES y RUSSELL P. SEBOLD, eds. \\ HISTORIA Y CRITITICA \\ DE LA LITERATURA ESPANOLA
}

Vol. 4: El siglo XVIII

\author{
Suplemento \\ Barcelona, Editorial Crítica, 1992
}

\section{ÍNDICE:}

Prólogo. Bibliografía monográfica. Teoría novelística en la primera Ilustración (Pérez Magallón). El sentido del término 'neoclásico' (Sebold). En la Academia del Buen Gusto (Tortosa Linde). Melancolía y tumbas en la poesía dieciochesca (Carnero). La polémica teatral de 1788 (Aguilar Piñal). Traducción y teatro en el siglo XVIII español (Lafarga). María Rosa Gálvez de Cabrera y la defensa del teatro neoclásico (Rudat). El estilo humano de Feijoo (McClelland). Feijoo, fisonomista (Fabbri). Torres Villarroel, costumbrista moderno (Sebold). Utopía en los Pronósticos de Torres (Zavala). La Giganteida de Luzán (Egido). Moratín en El arte de las putas (Gies). Ilustración y toros (Sebold). Características y estructura del sainete (Dowling). Los sainetes de Ramón de la Cruz (Vilches de Frutos). El verso lírico de Huerta (Lama Hernández). La otra tragedia original de Huerta (Sebold). Lectura y escritura en Fray Gerundio (Briesemeister). Las Cartas marruecas y la novela (Baquero Goyanes). Cadalso, buen amigo (Gies). Sentimentalismo y pasión en Jovellanos y Cadalso (Dowling). Jovellanos, dramaturgo romántico (Sebold). Josefa Amar y Borbón y la educación femenina (McClendon) Batillo, poeta (Polt). Cienfuegos: Ilustración y revolución (Gies). Quintana y el romancero (Dérozier). Samaniego en El jardín de Venus (Palacios Fernández). Samaniego, fabulista: De la deuda a la originalidad (Palacios Fernández). Autobiografía y romanticismo en El viejo y la niña (Dowling). El sí de las niñas: Realidad y ficción realista (Sebold). Trigueros: traductor, refundidor, poeta, dramaturgo, novelista (Aguilar Piñal). Las novelas de Zavala y Zamora (Carnero). Guía Bibliográfica. 


\title{
TOMÁS DE IRIARTE
}

\section{Fábulas Literarias}

\section{Edición, introducción y notas de Ángel L. Prieto de Paula}

\author{
Madrid, Cátedra, 1992
}

La estampa ilustrada y neoclásica de Iriarte ha de considerarse con un rasgo de filiación rigurosamente moderno: el desasosiego (tedio, sensación de vacío) que marca la diferencia entre valores establecidos y valores asumidos. Iriarte, en cuanto ilustrado, es un escritor del XVIII que anda a vueltas y revueltas con su siglo. Las Fábulas concilian sátira y didactismo en su crítica de vicios literarios. El contumaz polemista que fue Iriarte encontró en ellas cauce idóneo para sus ataques a pecados y pecadores. Este fabulario es además uno de los más variados muestrarios métricos de la literatura española anterior al Modernismo, alguno de cuyos hallazgos anticipó Iriarte.

Pedidos a su librero habitual 


\title{
MIGUEL HERNÁNDEZ
}

\section{OBRA COMPLETA}

Edición de Agustín Sánchez Vidal y José Carlos Rovira, con la colaboración de Carmen Alemany Bay

\author{
Madrid, Espasa Calpe, 2 vols.Colección "Clásicos \\ Castellanos", 1992
}

Se publican más de un centenar de poemas inéditos. La estructura de la edición responde a: 1) Poesía; 2) Obra teatral; 3) Prosas; 4) Correspondencia, convirtiéndose en la única edición completa existente.

Dos volúmenes con más de 2.700 páginas, en las que un amplísimo aparato textual da cuenta del conjunto de materiales previos que van creando la escritura, con una anotación centrada en estos materiales y en la determinación de las variantes, correciones y supresiones de los poemas, lo que convierte esta obra en una rigurosa edición crítica. 


\section{JOSÉ MARÍA ARGUEDAS}

\section{UNA RECUPERACIÓN INDIGENISTA DEL MUNDO PERUANO. UNA PERSPECTIVA DE LA CREACIÓN LATINOAMERICANA}

Selección e introducción de José Carlos Rovira. Barcelona, Anthropos (Suplemento $\mathrm{n}^{\mathrm{0}} 31$. Antología temática), 1992.

Esta antología temática de José María Arguedas, estructurada en los siguientes apartados: "Fragmentos autobiográficos", "De la autobiografía a la reflexión cultural", "Reflexiones teóricas", "El mundo de la infancia recuperado: canciones quechuas", "El educador y el antropólogo", "Fragmentos narrativos", "Poesía", "Bibliografía de y sobre José María Arguedas", "Mariátegui y Luis Alberto Sánchez: en los inicios de la polémica sobre el indigenismo", se complementa con el número 128 de la Revista Anthropos (Enero de 1992): José María Arguedas. Indigenismo y mestizaje cultural como crisis contemporánea hispanoamericana, coordinado por José Carlos Rovira, en el que intervienen los más destacados especialista en la obra arguediana. 


\title{
MIGUEL HERNÁNDEZ
}

\section{VIENTO DEL PUEBLO} (edición facsímil)

\section{Edición de José Carlos Rovira y Carmen Alemany Bay}

\author{
Madrid, Ediciones La Torre / Instituto \\ de Cultura Juan Gil-Albert, 1992
}

Junto al facsímil de la primera edición de 1937 de Ediciones Socorro Rojo de Valencia, libro en el que cada poema va acompañado de fotografías de la época, se acompaña un volumen de edición en el que se transcriben los procesos de escritura de cada poema y se estudian las circunstancias de creación de los mismos. 


\title{
JOSÉ CARLOS ROVIRA (ED)
}

\section{LITERATURA E}

\section{IDENTIDAD CULTURAL}

\author{
Alicante, Instituto Juan Gil-Albert-Comisión \\ Valenciana del V Centenario, 1992
}

Colección Pensamiento crítico hispanoamericano, vol. VII

Una amplia introducción presenta una antología de textos del Siglo XX concernientes al problema de la Identidad Cultural y la creación literaria hispanoamericana. Los textos, en algunos casos de difícil acceso, recogen elementos del pensamiento de Borges, Pedro Henríquez Ureña, Manuel González Prada, Luis Alberto Sánchez, JoséCarlos Mariátegui, Francisco García Calderón, Manuel Gálvez, José Vasconcelos, Manuel Ugarte, Raúl Scalabrini, Alfonso Reyes, Leopoldo Zea, etc. La lengua, la expresión, la polémica del indigenismo, o la reflexión de creadores sobre las identidades nacionales son el objeto de la antología. 


\section{RUSSELL P. SEBOLD}

\section{DE ILUSTRADOS Y ROMÁNTICOS}

Madrid, Ediciones «El Museo Universal», 1992, xiii + 228 páginas, numerosos grabados, encuadernado en cartoné.

Con $3 \%$ IVA: 2.880 pesetas

PEDIDOS A:

Francisco Serrano, La Productora de Servicios Avanzados

Costanilla de los Ángeles, 2-28013 Madrid

En este libro se recogen treinta y cinco ensayos de crítica literaria que el autor publicó en la sección «Tribuna Abierta» del madrileño diario $\mathrm{ABC}$ entre los años 1985 y 1992. La temática se concentra en los siglos XVIII y XIX, pero abarca desde el Siglo de Oro hasta el nuestro. El volumen se divide en cuatro partes correspondientes a los géneros de la poesía, la narración, el teatro, y el ensayo y temas generales. Algunos de los autores estudiados son Sor Gregoria Francisca de Santa Teresa, Francisco Gregorio de Salas, el conde de Torrepalma, Cadalso, Jovellanos, Lista, el duque de Rivas, Escosura, Espronceda, Zorrilla, Bécquer, José Gautier Benítez, las poetisas de la época romántica, Pedro Montengón, Mesonero Romanos, Galdós, García Márquez, Ramón de la Cruz, García de la Huerta, García Gutiérrez, la Avellaneda, el conde de Fernán Núñez, Feijoo, Larra, Ramiro de Maeztu, etc..., a los que se añaden trabajos generales sobre la novela, el teatro y la poesía. 


\section{Etudes Hispaniques 19}

Actes du IVe Colloque International

d'Aix-en-Provence (6-7-8 Décembre 1990)

\section{L'Autoportrait en}

\section{Espagne}

Littérature \& Peinture

\section{2}

Publications de l'Université de Provence 29, avenue Robert Schuman - 1361 Aix-enProvence Cedex 1 


\section{GABRIEL MIRó}

\section{NUESTRO PADRE SAN DANIEL EL OBISPO LEPROSO}

Edición de Miguel Ángel Lozano Marco

Se publican en un solo volumen las dos partes de una única novela en la que se nos muestra la vida y la muerte de una ciudad levítica, Oleza, a finales del siglo XIX, y las pasiones, las crueldades, los amores, los odios, los sacrificios y los heroísmos de sus habitantes. La magistral prosa de Miró intensifica esta honda meditación, realizada con lucidez y amor, sobre la condición humana, el poder transformador del tiempo y la búsqueda de la felicidad, dando cuerpo a un mundo complejo y denso, percibido y gozado con demorada sensualidad mediante los cinco sentidos. El propósito mironiano de "decir las cosas por insinuación" afecta a todos los estratos de la novela, y sitúa al escritor alicantino entre los más radicales renovadores de un género que, en aquellos años, estaba sufriendo profundos cambios.

ESPASA-CALPE. Colección AUSTRAL 1991 


\title{
GABRIEL MIRÓ
}

\section{NOVELAS CORTAS}

Nómada - La Palma rota - El hijo santo Los pies y los zapatos de Enriqueta

\author{
Edición, introducción y notas de \\ MIGUEL ÁNGEL LOZANO MARCO \\ Segunda Edición, 1991
}

Publicación del Instituto de Estudios «Juan Gil-Albert» de la Excma. Diputación Provincial, y de la Caja de Ahorros de Alicante y Murcia

Las novelas cortas de Gabriel Miró vienen a ser la contribución del escritor alicantino a ese fenómeno literario y editorial, tan característico del primer tercio de nuestro siglo, que es la aparición y proliferación de colecciones de relatos a partir del éxito de El Cuento Semanal (1907). En las páginas de esta publicación —en la que Miró consiguió una notoria fama gracias a Nómada - y en las de Los Contemporáneos aparecieron los relatos que aquí se recogen, muestras de una época todavía juvenil, de formación, en la que el escritor va afirmando su personal arte. Contiene este libro El hijo santo, interesante novela que no ha vuelto a imprimirse desde su primera edición en Los Contemporáneos (1909).

Pedidos a su librero habitual o al Instituto «Juan Gil-Albert» de la Diputación de Alicante Avda. de la Estación, 6 - ALICANTE (España) 


\title{
ÁNGEL L. PRIETO DE PAULA
}

\section{La Lira de Arión}

\section{De poesía y poetas españoles del siglo $\mathrm{XX}$}

\author{
Alicante, Universidad /C.A.P.A., 1991 \\ 288 páginas
}

La lira de Arión es una indagación sobre diversos hitos que vertebran la poesía española del siglo XX. Se aclaran aquí episodios de un vastísimo panorama, y se reflexiona sobre algunos de los aspectos que, ensamblados con otros, constituyen todos juntos la verdadera riqueza de un siglo eminentemente lírico. Contiene el libro los capítulos titulados «La poesía prometeica de Miguel de Unamuno», «Panenteísmo y mística activa en Antonio Machado (Sobre “A don Francisco Giner de los Ríos")», «La poesía de la prosa azoriniana: circularidad y fluencia», «La diáspora de los hijos de la ira (Lírica española de 1944 a 1952)», «La noche solar de Claudio Rodriguez», «Carlos Sahagún: un poeta en la frontera», «La tradición literaria de las ruinas en los poetas del 70», «Elegía y transparencia en Eloy Sánchez Rosillo».

Pedidos a su librero habitual o al

Secretariado de Publicaciones de la Universidad de Alicante

Apartado 99

03080 ALICANTE 


\section{FERNÁN CABALLERO}

\section{LA GAVIOTA}

Edición de Enrique Rubio Cremades Espasa-Calpe, Colección Austral, 1991

Hija de un insigne folclorista, Fernán Caballero abre el camino a la gran novela española del siglo XIX. "La novela no se inventa, se observa. Escribo en lisa prosa castellana lo que realmente sucede en nuestros pueblos; lo que piensan y hacen nuestros paisanos en las diferentes clases de nuestra sociedad". Tal era su propósito teórico, que en la práctica se reviste de idealizaciones y se supedita a un objetivo moralizador de claro signo tradicional. Aunque la técnica es realista, estamos aún lejos de los grandes logros narrativos del final de la centuria. Pero nadie negará a Fernán Caballero su riqueza de observación, la plasticidad de sus cuadros y, en definitiva, la fuerza de creación que convierte La Gaviota en una obra clásica de nuestro costumbrismo. 


\section{IGNACIO DE LUZÁN}

\section{OBRAS RARAS Y DESCONOCIDAS}

\section{VOLUMEN I}

Traducción de los Epigramas latinos de Ch. Weigel

Carta Latina de Ignacio Philalethes

Plan de una Academia de Ciencias y Artes

Informe sobre las Casas de Moneda

Informe sobre las Cartas de Van Hoey

Edición de Guillermo Carnero

Zaragoza

Institución Fernando el Católico

Excma. Diputación

1990 


\title{
PEDRO MONTENGÓN
}

\section{EL R0DRIG0}

\section{EUDOXIA, HIJA DE BELISARI0}

\section{Selección de ODAS}

\section{Edición de Guillermo Carnero}

Estudio Preliminar: 213 páginas

\author{
Alicante \\ Instituto Juan Gil-Albert \\ Excma. Diputación \\ 1990 \\ 2 volúmenes \\ 838 páginas
}




\section{RAMÓN PÉREZ DE AYALA}

\section{TIGRE JUAN \\ EL CURANDERO DE SU HONRA}

Edición de Miguel Ángel Lozano Marco

Con esta novela dividida en dos partes culmina el ciclo narrativo y se consuma el arte de Ramón Pérez de Ayala. Una poética historia de amor y muerte renueva en ella el viejo tema del amor como educador. La sabia organización de la estructura del relato y una espléndida prosa contribuyen a convertir esta obra en una de las más representativas de la novelística española del siglo $\mathrm{XX}$.

ESPASA-CALPE. Colección AUSTRAL 1990 


\section{JOSE CARLOS ROVIRA}

\section{HUMANISTAS Y POETAS \\ EN LA CORTE NAPOLITANA DE \\ ALFONSO EL MAGNÁNIMO}

Alicante, 1990, $256 \mathrm{pp}$.

Publicado por el Instituto de Cultura Juan Gil-Albert de la Diputación de Alicante.

El autor realiza una reflexión, en el terreno global de la cultura, sobre la corte de Nápoles durante el reinado de Alfonso el Magnánimo y su sucesor Ferrante, es decir, sobre una historia de 1442 a finales del siglo XV. La política mediterránea de la Corona de Aragón crea en el Reino de Nápoles un enclave cultural en el que se entrecruzan producciones que anuncian el final de la Edad Media con otras que significan el comienzo del mundo renacentista. Las dos producciones alumbran una historia en la que se entremezclan temas amorosos, reflejos sociales, polémicas culturales, pasado, presente y futuro en un momento crucial de la historia europea.

Pedidos a su librero habitual 


\title{
MIGUEL HERNÁNDEZ
}

\section{CANCIONERO Y ROMANCERO DE AUSENCIAS}

\author{
Ed. de José Carlos Rovira. \\ Espasa-Calpe, col. Austral, 1990.
}

Miguel Hernández escribió el Cancionero y romancero de ausencias - conjunto de manuscritos que definen el período final del poeta- desde 1938, en plena guerra civil, hasta unos meses antes de su muerte en la cárcel de Alicante. La peripecia biográfica del excepcional poeta oriolano se cierra entonces con estos materiales que no tuvieron conclusión, ni orden definitivo. En ellos, la ausencia, las contraseñas de lo vivido, la muerte del primer hijo y las esperanzas que genera el segundo en la perspectiva de un futuro imposible, la meditación interior, constituyen un estremecedor testimonio del final de una poética y de un hombre. El autor de esta edición se enfrenta en la introducción y las notas con un autor que ha recorrido frecuentemente en estudios y ediciones anteriores. En la actual, una nueva propuesta de ordenación, la separación de los poemas que el poeta tachó en sus originales, la corrección de algunas lecturas, o la incorporación de varios inéditos, intentan completar la visión final de un poeta que escribe amenazado por la historia y hace de su escritura un mecanismo esencial de supervivencia.

Pedidos a su librero habitual 


\section{Juan Valera}

\section{Edición de Enrique Rubio Cremades Editorial Taurus,}

\section{Colección "El escritor y la crítica", 1990.}

Volumen monográfico que ofrece un completo panorama de los estudios más importantes dedicados a don Juan Valera. Dicha Antología crítica, producto de una difícil selección de materiales, ha querido ofrecer trabajos de calidad y, lógicamente, de muy diversa metodología. El índice se estructura teniendo en cuenta la peculiar semblanza biográfica de Valera y sus incursiones en los distintos géneros literarios de la época. La obra narrativa de Valera - novela y cuento- ocupa un lugar privilegiado en esta monografía, analizándose todo este ingente material a través de sugerentes enfoques. Antología que incluye, finalmente, una actualizada bibliografía sobre la vida y la obra de Valera. 


\section{JUAN VALERA DONA LUZ}

Edición, estudio preliminar y notas de Enrique Rubio Cremades

Espasa Calpe, Colección Austral, 1990.

Don Juan Valera, uno de los escritores más cultos y, tal vez, el mejor prosista del siglo XIX, decía a propósito de la presente novela, lo siguiente: "Acabo de leerla de nuevo como si fuea de otro. Es mi vigésima lectura, por lo menos, y lo hallo todo $\tan$ bien, y tan elegantemente dicho, y tan hondamente pensado, que leo sin poder dejar el libro, hasta que termino". La crítica ha visto generalmente en Doña Luz una obra complementaria de Pepita Jiménez, señalando que el conflicto entre el amor espiritual y el humano se plantea en ella en términos más dramáticos y complejos. El talento de Valera brilla aquí en los finos análisis psicológicos y en la gradación del relato, al tiempo que su arte nos brinda cuadros de época, de plasticidad inigualable, que componen todo un retablo de la vida española del último tercio del siglo XIX. 


\title{
GUILLERMO CARNERO
}

\section{LAS ARMAS ABISINIAS}

Ensayos sobre Literatura y Arte del siglo $X X$

\author{
Barcelona, Anthropos, 1989 \\ 400 páginas - 34 ilustraciones en color
}

\section{Í N D I C E :}

El concepto de responsabilidad social del escritor en Miguel de Unamuno. Salvador Rueda: teoría y práctica del Modernismo. El tránsito del Modernismo a la Vanguardia en José Juan Tablada: del Japón exótico al haikú. Primitivismo, sensacionismo y abstracción como actitudes de ruptura cultural en la literatura y el arte de Vanguardia. La gastronomía del Futurismo italiano. La prehistoria del Superrealismo. El juego lúgubre: la aportación de Salvador Dali al pensamiento superrealista. La chuleta asada como metáfora epistemológica en el pensamiento de Salvador Dalí. José Moreno Villa y las orientaciones de la Vanguardia española. Luis Cernuda y el purismo poético: Perfil del Aire. El problema del conocimiento en la trayectoria poética de Vicente Aleixandre. "Conocer» y «saber" en Poemas de la Consumación y Diálogos del Conocimiento de Vicente Aleixandre. La generación poética de 1936... hasta 1939. Miguel Hernández y el cambio estético en la España de los años treinta. Precedentes de la poesia social de la postguerra española en la anteguerra y guerra civil. La poética de la poesía social en la postguerra española. Apuntes para la historia del Superrealismo en la poesia en español de la alta postguerra. Juan García Hortelano: del realismo a la experimentación. La novela faraónica de Luis Goytisolo. 


\title{
DAVID T. GIES
}

\section{EL ROMANTICISMO}

\author{
(El escritor y la crítica) \\ Madrid, Taurus, 1989 \\ 381 páginas
}

\section{ÍNDICE:}

Nota preliminar (Gies). El Romanticismo (Borao). El Romanticismo en España (Tubino). Sobre el nombre español del dolor romántico (Sebold). ¿Literatura prerromántica o literatura ilustrada? (Froldi). Nota histórica sobre el origen de la palabra romántico (Becher). La palabra Romanticismo en España (Peers). El lenguaje romántico de los periódicos madrileños publicados durante la monarquía constitucional (1820-1823) (Cullen). Imágenes y la imaginación románticas (Gies). El Romanticismo en la historia (Vicens Vives). Los costumbristas españoles del siglo XIX (Correa Calderón). El naranjo romántico: Esencia del costumbrismo (Herrero). Tendencias actuales en el entendimiento y estudios del Romanticismo español (Río). La reacción anti-romántica en España (Shaw). La autointerpretación del Romanticismo español (Varela). ¿Existe el Romanticismo español? (Picoche). La presencia del ideario romántico alemán en la estructura y evolución teórica del Romanticismo español (Juretschke). Romanticismo y revolución (Escobar). Romanticismo de acción y romanticismo de evasión (Poullain). El Romanticismo en España (Tarr). 


\title{
ÁNGEL L. PRIETO DE PAULA
}

\section{LA LLAMA Y LA CENIZA}

INTRODUCCIÓN A LA POESÍA DE CLAUDIO RODRÍGUEZ

\author{
Salamanca, Universidad, 1989
}

224 páginas

$2^{\underline{a}}$ edición, 1993

Claudio Rodríguez, poeta perteneciente al grupo poético de los años cincuenta, es uno de los escritores españoles de mayor originalidad de todo el siglo XX. El presente estudio analiza detalladamente la inserción del autor en un panorama en el que parece un extraño. Sin apenas vínculos con la tradición española (salvo que nos remontemos al siglo XVI), y con no demasiadas concomitancias con la lírica coetánea extranjera, Claudio Rodríguez aparece en estas páginas como el dueño de un universo cuyo contorno aparente se identifica con una realidad trascendida. Para el desciframiento de su mundo poético se han examinado su particular sistema simbólico, los nudos temáticos, las connivencias expresivas con la mística y, en fin, su lenguaje tropológico. Se cierra el libro con un recorrido por los poemarios de Claudio Rodríguez hasta 1989, desbrozándose las dificultades interpretativas y ofreciéndose soluciones de lectura.

Pedidos a su librero habitual o al

Servicio de Publicaciones de la Universidad de Salamanca

Apartado 325

37080 SALAMANCA 


\section{RUSSELL P. SEBOLD \\ El rapto de la mente POÉTICA Y POESÍA DIECIOCHESCA}

Segunda edición, corregida y aumentada con cinco nuevos capítulos y una Introducción, de un estudio clásico, no reeditado desde 1970 .

\section{CONTENIDO:}

Introducción: unidad y música. Prólogo: sobre la actualidad de las reglas. Contra los mitos antineoclásicos espan̄oles. Análisis estadístico de las ideas poéticas de Luzán: sus origenes y su naturaleza. Martin Sarmiento y la doctrina neoclásica. Menéndez Pelayo y el supuesto casticismo de la crítica de Forner en las Exequias. Sobre el nombre español del dolor romántico. Alcalá Galiano y la literatura dieciochesca: paradoja histórica y visión filosófica. Interián de Ayala en el neoclasicismo español. Un padrón inmortal de la grandeza romana: en torno a un soneto de Gabriel Alvarez de Toledo. Tomás de Iriarte, poeta de rapto racional. Dieciochismo, estilo místico y contemplación en La esposa aldeana de Iglesias de la Casa. Siempre formas en grandes modeladas: sobre la visión poética de Quintana. Neoclasicismo y creación en la Raquel de García de la Huerta. Autobiografia y realismo en $E l$ si de las niñas. El texto de una de las perdidas Cartas de Ibrahim de Meléndez Valdés.

Barcelona, Editorial Anthropos, 1989 


\title{
MIGUEL ÁNGEL LOZANO MARCO
}

\section{La literatura como \\ intensidad. Seis lecciones \\ (Clarín, Unamuno, \\ Azorín, Miró, Pérez de Ayala)}

\author{
Publicado por la \\ CAJA DE AHORROS PROVINCIAL \\ DE ALICANTE, 1988
}

En el presente libro se recoge media docena de estudios sobre esos cinco protagonistas del periodo literario de finales del XIX y comienzos de nuestro siglo. Contiene los ensayos «El relato Las dos cajas en la narrativa de Clarín", "Unamuno: Una historia de amor y Del sentimiento trágico de la vida", "Azorín. Una lectura de Un pueblecito: Riofrio de Avila», "El hijo santo, novela de Gabriel Miró. Consideraciones sobre un olvido", "En el umbral de las novelas poemáticas: Pilares, novela inconclusa de Pérez de Ayala" y "Azorín en la obra literaria de Ramón Pérez de Ayala».

Pedidos a su librero habitual 


\title{
RAMÓN LÓPEZ SOLER
}

\section{Jaime el Barbudo, 0 sea la sierra de Crevillente y Las señoritas de hogaño y las doncellas de antaño}

\author{
Edición crítica, estudio preliminar y notas de \\ ENRIQUE RUBIO CREMADES y MARIA DE LOS \\ ANGELES AYALA
}

Editorial Caballo-Dragón, Sabadell, 1988

Jaime el Barbudo y Las señoritas de hogaño y las doncellas de antaño se publicaron en Barcelona, por A. Bergnes, en el año 1832, no habiéndose editado ninguna de estas novelas en años posteriores. Los autores de la presente edición analizan el ideario estético de López Soler y sus artículos aparecidos en El Europeo y El Vapor, imprescindibles para el conocimiento de la introducción del Romanticismo en España. De igual forma se estudian en apartados distintos ambas novelas. En lo que respecta a Jaime el Barbudo destacan los capitulos que analizan el contexto histórico y las aventuras protagonizadas por este personaje, los recursos narrativos, disposición de la obra... En lo concerniente a Las señoritas de hogaño se hace especial hincapié en las fuentes literarias, en conexión con la obra del prolifico autor frances Scribe. La intencionalidad del autor, trama, enredo y otros aspectos significativos aparecen también detenidamente estudiados. Edición en la que se incluye una amplia bibliografia sobre la novela del siglo XIX, revisada y actualizada. 


\section{Clásicos Taurus}

\section{Directores: \\ Alberto Blecua, Guillermo Carnero y Pedro Cátedra}

Una cuidada colección de textos literarios, de atractiva presentación y precio muy asequible, en ediciones preparadas por especialistas de reconocido prestigio, a los que se ha encomendado el establecimiento de los textos y sus variantes, sintéticos estudios preliminares y un amplio repertorio de notas léxicas, historiográficas y críticas.

1. Juan Ruiz, Arcipreste de Hita, Libro de buen amor. Edición de Jacques Joset.

2. Fray Luis de León, Poesía completa. Edición de Guillermo Seres.

3. Miguei Hernández, Antología poética. El labrador de más aire. Edición de José Carlos Rovira.

4. Gustavo Adolfo Bécquer, Rimas. Leyendas escogidas. Edición de Rubén Benítez.

5. Luis de Góngora, Poesía selecta. Edición de Antonio Pérez Lasheras y José María Micó.

6. Juan García Hortelano, Nuevas amistades. Edición de Juan Cano Ballesta.

7. José de Espronceda, Antología poética. Edición de Rubén Benítez.

8. Juan Valera, Pepita Jiménez. Edición de Enrique Rubio Cremades.

9. Leopoldo Alas «Clarín», Su único hijo. Edición de José M Martínez Cachero.

10. Gaspar Melchor de Jovellanos, Poesía. Teatro, Prosa literaria. Edición de John H. R. Polt.

11. Poesía castellana de la Edad Media. Edición de Francisco López Estrada y $\mathrm{M}^{\mathrm{a}}$ Teresa López.

12. Gabriel Miró, Las cerezas del cementerio. Edición de Miguel Ángel Lozano.

13. Teatro castellano de la Edad Media. Edición de Ronald E. Surtz.

14. Gerardo Diego, Poesía española contemporánea. Edición de Andrés Soria Olmedo.

15. José Zorrilla. Don Juan Tenorio. El Capitán Montoya. Edición de Jean-Louis Picoche

16. Emilia Pardo Bazán. La madre Naturaleza. Edición de Ignacio Javier López.

17. Miguel de Cervantes. Los Baños de Argel. Pedro de Urdemalas. Edición de Jean Canavaggio.

18. San Juan de la Cruz, Poesía y prosa, edición de Cristóbal Cuevas.

19. Calderón de la Barca, La vida es sueño, edición de Enrique Rull.

20. Antología de la novela corta erótica española de entreguerras, edición Lily Litvack.

21 Romancero. Edición de Giuseppe di Stefano.

22. Federico García Lorca, Romancero gitano. Poeta en Nueva York. El Público. Edición de Derek Harris.

23. José Cadalso, Noches Lúgubres, edición de Russell P. Sebold.

24. Gregorio Mayans y Siscar, Escritos Literarios, edición de Jesús Pérez Magallón.

25. Gutierre Díaz de Games, El Victorial, edición de Rafael Beltrán Llavador.

26. Rubén Dario, Antología Poética, edición de Allen W. Phillips y José Carlos Rovira.

27. Miguel de Cervantes, Novelas ejemplares, edición de Julio Rodríguez Luis. 


\section{COLECCIÓN "EL ESCRITOR ALICANTIN0 Y LA CRÍTICA"}

Una iniciativa de la Caja de Ahorros Provincial de Alicante con el propósito de divulgar y poner al día la bibliografía dedicada a los más destacados escritores alicantinos.

\section{Cada volumen incluye lo siguiente:}

- Una monografía preliminar sobre el autor y sobre el estado actual de la historiografía y la crítica a él dedicadas.

- Un capítulo bibliográfico de y sobre el autor

- La recopilación de la más importante bibliografía que lo concierne, atendiendo tanto a la tradición crítica como a la relevancia e inaccesibilidad de los textos

- Una propuesta de líneas de investigación

Número 1: CARLOS ARNICHES

Edición de Juan A. Ríos Carratalá

225 páginas. Publicado en 1990

Número 2: PEDRO MONTENGÓN

Edición de Guillermo Carnero

237 páginas. Publicado en 1991

Número 3: JUAN GIL-ALBERT

Edición de José Carlos Rovira

247 páginas. Publicado en 1991

Número 4: MIGUEL HERNÁNDEZ

Edición de Carmen Alemany

Publicado en 1992

Números sucesivos serán dedicados a AZORÍN, GABRIEL MIRÓ y otros.

Pedidos a CAM. Biblioteca Gabriel Miró. C/Ramón y Cajal, 5 - ALICANTE. 


\section{PUBLICACIONES DEL INSTITUTO DE CULTURA "JUAN GIL-ALBERT"}

\section{Organismo Autónomo de la Excma. Diputación Provincial de Alicante}

\section{Algunos títulos}

\section{Colección "Ensayo e Investigación"}

VV.AA., La Ilustración Española, Actas del Coloquio Internacional celebrado en Alicante, Ed. de A. Alberola y E. La Parra, Pról. de A. Mestre, 1986.

Dario Puccini, Miguel Hernández: vida, poesía yotros estudios hernandianos, Pról. de J.C. Rovira, 1987.

Francisco Márquez Villanueva, La esfinge mironiana y otros estudios sobre Gabriel Miró, 1989.

C. Morange, Siete calas en la crisis del Antiguo Régimen español y un panfleto clandestino de 1800, 1990.

J. Pérez Magallón, En torno a las ideas literarias de Mayans, 1991.

Jean R. Aymes, La guerra de España contra la revolución francesa (17931795), 1992.

G. Cheyne, ed., El renacimiento ideal: epistolario de Joaquín Costa y Rafael Altamira (1888-1911), 1992.

F. Quilis, Revolución y guerra civil. Las colectividades en la provincia de Alicante, 1992.

P. Díaz Marín y J. A. Fernández Cabello, Los mártires de la Libertad (La revolución de 1844 en Alicante), 1992.

M". Carmen Romero Mateo, Entre el orden y la revolución, 1993.

F. Larrosa Martínez, La política educativa en Alicante en el siglo XVIII, 1993.

R. M. Cardá Ros, Psicología y educación en Domingo Barnés, 1993. 


\section{Colección "Espejo de Clío"}

R. Lea, Los moriscos españoles: su conversión y expulsión. Estudio preliminar y notas de R. Benítez, 1990.

Francisco Pérez Bayer, Por la libertad de la literatura española, Estudio preliminar y notas de Antonio Mestre Sanchis, 1991.

Sermones revolucionarios del trienio liberal (1820-1823). Estudio preliminar de Gérard Dufour, 1991.

A. Moliner Prada: Lesseps y los políticos españoles, 1993.

\section{Coediciones}

Mario Martínez Gomis, La Universidad de Orihuela (1610-1807). Uncentro de estudios superiores entre el Barroco y la Ilustración, 2 vols., Pról. de A. Mestre, 1987.

A. Alberola, ed., Estudios sobre Altamira. Actas del Coloquio celebrado en Alicante, 1987.

J. A. Ferrer Benimeli (Coordinador), Masonería, Revolución y reacción. IV Simposium Internacional de Historia de la Masonería Española (Alicante, 27-30 de Septiembre de 1989). 2 vols, 1990.

L. Quirante Santacruz, ed., Teatro y espectáculo en la Edad Media, 1992.

\section{Colección "Antología del pensamiento hispanoamericano"}

Vol. V.Pedro Enríquez Ureña: Del ensayo crítico a la historia literaria, ed. de Javier Lasarte Valcárcel, 1991.

Vol. VII. Identidad cultural y literaria, ed. de José Carlos Rovira, 1992.

\section{Colección "Literatura y Crítica"}

1. Vicente Martínez Colomer, El Valdemaro. Edición, introducción y notas de Guillermo Carnero, 1985.

2. Manuel Ciges Aparicio, El libro de la vida trágica. Del cautiverio. Edición, introducción y notas de Cecilio Alonso, 1985. 
3. Manuel Ciges Aparicio, El libro de la vida doliente. Del hospital. Edición, introducción y notas de Cecilio Alonso, 1985.

4. Manuel Ciges Aparicio, El libro de la crueldad. Del cuartel y de la guerra. Edición, introducción y notas de Cecilio Alonso, 1986.

5. Manuel Ciges Aparicio, El libro de la Decadencia. Del periódico y de la política. Edición, introducción y notas de Cecilio Alonso, 1986.

6. Gabriel Miró, Novelas cortas. Obras Completas, vol. V. Edición, introducción y notas de Miguel Ángel Lozano, 1986; segunda edición, 1991.

7. Cornelia Bororquia o la víctima de la Inquisición. Edición, introducción y notas de Gérar Dufour, 1987.

8. Gabriel Miró, El libro de Sigüenza, Obras Completas, vol. XI. Edición, introducción y notas de Ricardo Landeira, 1990.

9. Gabriel Miró, El humo dormido, Obras Completas, vol. XII. Edición, introducción y notas de Edmund L. King, 1991.

10. Pedro Montengón, Obras, vol. I, El Rodrigo; vol II, Eudoxia, hija de Belisario. Selección de odas. Edición, introducción y notas de Guillermo Carnero, 1991.

11. Manuel Molina, Versos escogidos, selección, edición, prólogo y notas de Cecilio Alonso, 1992.

12. Gabriel Miró, El abuelo del rey, Obras Completas, vol. VIII. Edición, introducción y notas de Gregorio Torres Nebrera, 1992.

13. Gabriel Miró, Dentro del cercado, Obras Completas, vol. IX. Edición, introducción y notas de Kevin S. Larsen, 1992.

14. Rafael Altamira. Reposo, edición, introducción y notas de Juan Antonio Ríos, 1992.

15. Azorín, Tomás Rueda, edición, introducción y notas de Miguel Ángel Lozano; en prensa.

16. Gabriel Miró, El obispo leproso, edición de Ian R. Macdonald, 1993. 


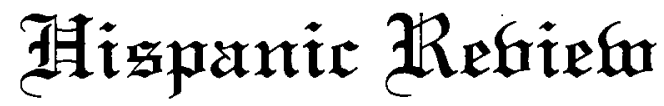

\section{DESDE 1933 LA MEJOR REVISTA HISPANÍSTICA DE ESTADOS UNIDOS}

Crítica, historia literaria, lingüistica Cuatro números anuales (más de 500 páginas)

Director: Russell P. Sebold. Subdirectores: Oreida Chú-Pund, Ignacio Javier López. Redactores: Marina S. Brownlee, Peter G. Earle, Anthony P. Espósito, Paul M. Lloyd, José Miguel Oviedo, José M. Regueiro, Jorge Salessi.

Suscripciones individuales: $\$ 28,00$ (dólares de EE. UU.) al año. Bibliotecas y otras instituciones: $\$ 38,00$ al año.

Dirigirse a: Hispanic Review, 512 Williams Hall, University of Pennsylvania, PA 19104-6305, U.S.A. 


\section{ANALES}

\section{GALDOSIANOS}

Publica anualmente artículos, reseñas y documentos sobre la obra de Benito Pérez Galdós y otros autores del siglo diecinueve, y textos para la historia intelectual de la España de Galdós y sobre los problemas teóricos de la novela realista.

Directores Honorarios: Rodolfo Cardona y John Kronik

Director: Peter A. Bly

Redactores: Alicia Andreu, Alfonso Armas Ayala, Carlos Blanco Aguinaga, Brian J. Dendle, Peter B. Goldman, Germán Gullón, Hans Hinterhäuser, Juan López-Morillas, Jennifer Lowe, Carmen Menéndez Onrubia, Agnes Moncy, Pedro Ortiz Armengol, Geoffrey Ribbans, Eamonn Rodgers, Harriet Turner, Diane F. Urey, J. E. Varey, James Whiston.

Asistenta: Paulette Bark

REDACCIÓN Y ADMINISTRACIÓN:

Department of Spanish \& Italian, Queen's University

Kingston, Ontario, Canada K7L 3N6

FAX NUMBER:(613) 545-6300 


\section{Boletín de la Fundación Federico García Lorca}

(Jorge Manrique, 27 - 28006 MADRID)

Revista fundada en 1987, aparece dos veces al año y en ella se publican trabajos de investigación sobre obras literarias del siglo XX y más especificamente relacionadas con Federico García Lorca, su generación y su entorno.

El Comité de Redacción está presidido por D ${ }^{\mathrm{a}}$ Isabel García Lorca, Presidente de la Fundación Federico García Lorca, y a él pertenecen: Margarita Ucelay, Prof ${ }^{\mathrm{a}}$ Emérita de Barnard College; Andrew A. Anderson, Univ. de Detroit; Christopher Maurer, Vanderbilt University; y Piero Menarini, Univ. de Parma. El Director Literario es el Prof. Mario Hernández, de la Universidad Autónoma de Madrid, y el Director Gerente, Manuel Fernández-Montesinos, Secretario de la Fundación Federico García Lorca.

La finalidad del Boletín de la Fundación es:

- Informar sobre la aparición de nuevos materiales de interés para el conocimiento y estudio de la vida y obra de Federico García Lorca: manuscritos, dibujos, cartas, etc.

- Poner en conocimiento de los lectores aspectos de la vida y obra de otros escritores y artistas valiosos, aunque menos conocidos.

- Estudiar la influencia de movimientos artísticos y literarios en la obra de Lorca, así como su influencia sobre el arte posterior.

- Estudiar nuevas manifestaciones artísticas, especialmente en países de habla castellana.

- Mantener al día a las personas interesadas en la obra de García Lorca sobre la ingente bibliografía lorquiana.

- Informar sobre las actividades de la Fundación Federico García Lorca. 


\section{IL CONFRONTO LETTERARIO}

QUADERNI DEL DIPARTIMENTO

DEI LINGUE E LETTERATURE STRANIERE MODERNE DELL'UNIVESITÀ DI PAVIA (ITALIA)

Consiglio Directivo:

GIOVANNI CARAVAGGI, GIORGIO CUSATELLI, GIORGETTO GIORGI, TOMASO KEMENY, LORENZA MARANINI, CESARE SEGRE, LEONARDO TERZO, GIORGIO VECCHI, SERENA VITALE

\section{Comitato Redazionale:}

ALBERTO CAPATTI, VICENZA GINI, LIA GUERRA, GUISEPPE MAZZOCCHI

Direzione, redaziones, amministrazione e stampa:

GRAFISCHENA, viale Stazione 177 - 72015 Fasano di Puglia (Italia)

Periodico semestrale. Autorizzazione del Tribunale di Brindisi n. 2/ 1985 del 26.2.1985

Directtore Responsabile: Carlo Schena

Abbonamento 1994: Italia lire 35.000; estero lire 40.000

Copia singola lire 20.000 ; estero lire 24.000

Per $\mathrm{i}$ versamenti in conto corrente postale servisi del n. 13147723, intestato a GRAFISCHENA, viale Stazione 177 - 72015 Fasano di Puglia (Italia) 


\title{
REVISTA ALICANTINA DE ESTUDIOS INGLESES
}

\section{ISSN 0214-4808 - CODEN RAEIEX}

\author{
Editor Emeritus \\ Pedro Jesús Marcos Pérez \\ Editors \\ Enrique Alcaraz Varó \\ José Antonio Álvarez Amorós
}

No. 6, November 1993

$* \quad * \quad *$

\section{Contributors}

María Antonia Álvarez Calleja • Agustín Coletes Blanco • Diane Ponterotto • Bill Phillips • Elena Martínez Caro • Pedro Domínguez Caballero de Rodas - Ana María Manzanas Calvo • Pilar Hidalgo • Fiona MacArthur • Luis Girón Echevarría • Lorelei Cederstrom • Lina Sierra

Ayala $•$ Susana Onega $•$ Manuel González de la Aleja Barberán

Francisco Javier García Rodríguez • Dieter Stein • Adriana Mattei Manuel Breva Claramont - José Ignacio García Alonso • Joaquín Pastor Pina • Ricardo Miguel Alfonso • Celia Rico Pérez • Yolanda Sánchez Mateo M. Carmen África Vidal • Javier Pérez Guerra

Manuscripts, books for review, and subscriptions

Revista Alicantina de Estudios Ingleses, Secretaría, Departamento de Filología Inglesa, Universidad de Alicante, P.O. Box 99, 03080 ALICANTE (Spain) 


\title{
REVISTA DE HISTORIA MODERNA. ANALES DE LA UNIVERSIDAD DE ALICANTE
}

\author{
№ 12 (1994)
}

\section{JURISDICCIÓN Y SEÑORÍO EN LA ESPAÑA MODERNA}

David BERNABÉ GIL: Una coexistencia conflictiva: municipios realengos y señoríos de su contribución general en la Valencia foral.

Primitivo PLA ALBEROLA: La jurisdicción alfonsina como aliciente para la recolonización del territorio.

Enrique GIMÉNEZ LÓPEZ: Fuero alfonsino y fuero de población de Sierra Morena en los proyectos de colonización de la Corona de Aragón en la segunda mitad del siglo XVIII.

Elia GOZÁLBEZ ESTEVE: Administración del marquesado de Llombai tras la "Nueva Planta".

Ana Rosa CANDELA: El proceso de desintegración de los patrimonios de origen señorial en el campo de Alicante.

Antonio GIL OLCINA y Gregorio CANALES MARTÍNEZ: La desintegración del patrimonio señorial en un gran estado valenciano.

\section{VARIA}

Paula y Jorge DEMERSON: La biblioteca de Estanislao de Lugo.

Alberto GIL NOVALES: Exaltación liberal y republicanismo en España.

P.V.P. 2.000 Ptas. 


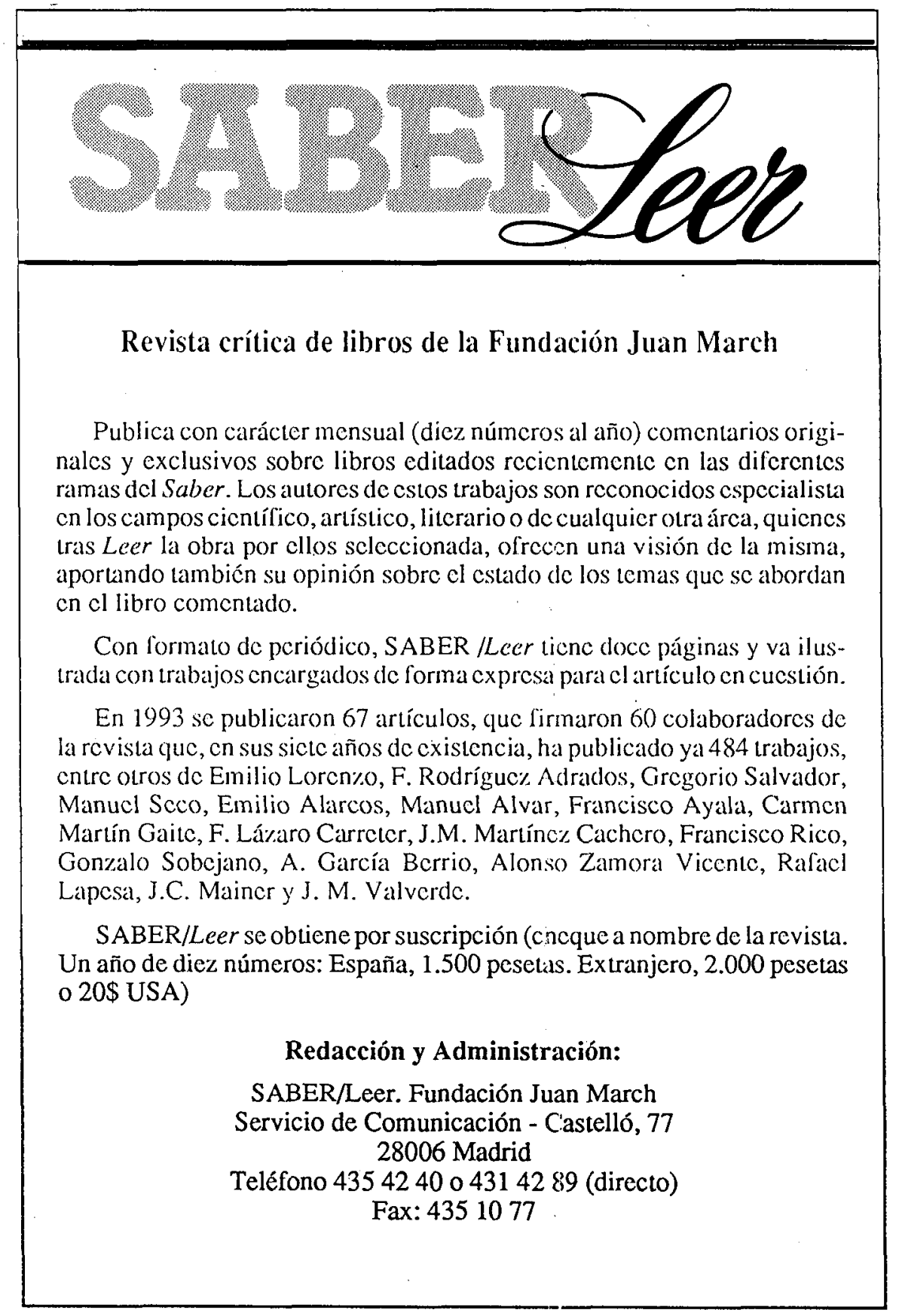




\title{
STUDIES IN TWENTIETH CENTURY LITERATURE
}

\author{
A SPECIAL ISSUE ON CONTEMPORARY SPANISH POETRY: 1939-1990
}

\author{
Guest Editor: Andrew Debicki \\ University of Kansas \\ Hall Center for the Humanities
}

Andrew Debicki: Introduction-Critical Perspectives on Contemporary Spanish Poetry

José Olivio Jiménez: Fifty Years of Contemporary Spanish Poetry (19391989)

Judith Nantell:The Quest(ioning) of Epistemological Ground:The Generation of 1956

John Wilcox: A Reconsideration of Two Spanish Women Poets: Angela Figuera and Francisca Aguirre

Guillermo Carnero: Culturalism and the "New" Poetry. A Poem by Pedro Gimferrer

Margaret Persin: Pere Gimferrer's "Los espejos"

Ignacio Javier López: Language and Consciousness in the Poetry of the "«Novísimos"

Biruté Ciplijauskaité: Recent Poetry and Essential Word

Sharon Keefe Ugalde: The Feminization of Female Figures in Spanish Women's Poetry of the 1980's

Studies in Twentieth Century Literature published semi-annually by Kansas State University and the University of Nebraska, is devoted to literary theory and practical criticism, with exclusive emphasis on twentieth-century literature written in French, German, Russian and Spanish. Manuscripts are welcome; they should be between 20 25 pages, and preparated in acordance with the MLA Style Manual (1985). Manuscripts must be English, but quotations may be given in the original. Subscriptions are $\$ 15$ for individuals, $\$ 20$ for institutions. The single issue price is $\$ 10$.

Manuscripts on German and Russian literatures, as well as subscription request should be sent to:

Editors, STCL

Department of Modern Languages 104 Eisenhower Hall Kansas State University Manhattan, KS 66506-1003
Manuscripts on French and Spanish literature and advertisements should be sent to:

Editors, STCL

Department of Modern Languages

Oldfather Hall

University of Nebraska, Lincoln

Lincoln, NE 68588-0318 



\section{COLABORADORES DE ESTE NÚMERO}

Joaquín Álvarez Barrientos. Doctor en Filología Hispánica por la Universidad Complutense de Madrid. Pertenece al Consejo Superior de Investigaciones Científicas. Es miembro del Consejo de Redacción de la Revista de Literatura. Ha publicado trabajos sobre los siglos XVIII y XIX en revistas como Anales Cervantinos, Anales de la Literatura Española, Bulletin Hispanique, Ínsula, Nueva Revista de Filología Hispánica, Revista de Literatura y otras. Ha editado diversas obras como El anillo de Giges de José de Cañizares (1983), Brancanelo el Herrero, anónima (1987); Fray Gerundio del Padre Isla (1991); en colaboración, las Memorias cronológicas sobre el teatro en España, de Armona (1987), su autobiografía (1989) y las Memorias de un. setentón de Mesonero Romanos (1994). Es también autor de La novela del siglo XVIII (1991) y de Madrid en la novela, II (1700-1850) (1993).

Ángeles Ezama Gil. Profesora titular de Literatura en el Departamento de Filología Española de la Universidad de Zaragoza. Ha publicado un libro, El cuento de la prensa y otros cuentos (Aproximación al estudio del relato breve entre 1890 y 1900), y diversos artículos en revistas como Boletín de la Real Academia Española, Revista contemporánea, Revista de Literatura, Boletín del Instituto de Estudios Asturianos, etc. Su área de investigación es la del cuento decimonónico, aunque ha realizado también algunos trabajos sobre la prensa y la ilustración y sobre la obra literaria de Clarín.

Luis Miguel Fernández. Profesor de las Facultad de Humanidades de Lugo (Universidad de Santiago). Su área de investigación es la Literatura Comparada, especialmente las relaciones de la literatura con el cine. Es autor de El neorrealismo en la narración española de los años cincuen$t a$, y ha publicado o tiene en prensa diversos trabajos en las revistas Anales de la Literatura Española Contemporánea, 1616, Lucanor, Ínsula, Revista Hispánica Moderna, España Contemporánea, Archivos de la Filmoteca, Signa y Boletin Galego de Literatura. Ha colaborado en los 
volúmenes colectivos Comentarios de textos contemporáneos y Actas del Congreso Internacional Sanjuanista.

Nigel Glendinning. Catedrático Emérito de la Universidad de Londres (Queen Mary and Westfield College), académico correspondiente en Inglaterra de la Real de Bellas Artes de San Fernando, y doctor honoris causa de la Universidad de Southampton. Ha publicado algunos ensayos y notas sobre temas de los siglos XVIII, XIX y XX (Quevedo, Góngora, Galdós, Darío, Antonio Machado, etc. ), pero es ante todo conocido por sus investigaciones sobre aspectos de la cultura española del siglo XVIII. Ha publicado un libro sobre José Cadalso (Gredos, 1962), dos ediciones de las Noches lúgubres (Clásicos castellanos, 1961; Clásicos Austral, 1992), ediciones de las Cartas marruecas (Támesis, 1966 y 1971) en colaboración con Lucien Dupuis, de los Escritos autobiográficos y epistolario (Támesis, 1979) en colaboración con Nicole Harrison, también de Los eruditos a la violeta (Anaya, 1967), y del Calendario Manual y Guía de forasteros en Chipre (CSIC, 1982). Es autor del tomo sobre el siglo XVIII en la Historia de la literatura española editada por Ernest Benn en Londres (1972) y en español por Ariel (1973, 1974, 1977, etc. ). Es asimismo historiador del arte, y en ese terreno destacan sus libros y artículos sobre Goya, entre ellos, Goya y sus críticos (en inglés, Yale, 1977, y en versión española, Taurus, 1983) y Goya. La década de los Caprichos. Retratos 1792-1804 (Real Academia de Bellas Artes de San Fernando, 1992).

Claudio Gullén. Catedrático Emérito de Literatura Comparada de la Universidad Pompeu Fabra de Barcelona. Sus libros últimos son El primer Siglo de Oro (1988), Teorías de la Historia literaria (1989) y The Challenge of Comparative Literature (1993). El librillo reciente La expresión total (Málaga, 1993) es el anticipo de un volumen de idéntico título, que reunirá ocho ensayos comparatistas aparecidos en revistas españolas y norteamericanas.

Solange Hibbs-Lissorgues. Profesora titular de Lengua y Literatura española en la Universidad de Toulouse-le-Mirail. Presentó su tesis doctoral (1987) sobre historia de la Iglesia española en el siglo XIX. Ha participado en las siguientes obras colectivas: Typologie de la presse hispanique (1984), Realismo y Naturalismo en España en la segunda mitad del siglo XIX (1988), Les révolutions Ibériques et Ibéroaméricaines à l'aube du XIX siècle (1991), Après 1789: la Révolution, modèle ou repoussoir? (1991), Hacia una literatura del pueblo. Del folletín a la novela (1993). Es autora del libro Iglesia, prensa y sociedad en España (1868-1900) (de próxima aparición).

Francisco Lafarga. Catedrático de Filología Francesa de la Universidad Pompeu Fabra. Se ha especializado en el estudio de las literaturas francesa y española del siglo XVIII, así como de las relaciones entre ambas, dentro del marco de la historia de las traducciones y de la literatura comparada. Es autor de Voltaire en España, 1734-1835 (Barcelona, Universidad, 1982; versión ampliada en francés, Oxford, The Voltaire Foundation, 1989); Las traducciones españolas del teatro francés, 1700-1835 (Bar- 
celona, Universidad, 1983 y 1988, 2 vols. ); Textos para el estudio de la literatura francesa (Barcelona, PPU, 1985, nueva ed. 1991); Repertorio de estudios franceses y provenzales en España (Barcelona, PPU, 1987). Ha editado los volúmenes Diderot (Barcelona, Universidad, 1987), Imágenes de Francia en las letras hispánicas (Barcelona, PPU, 1989), Sainetes de Ramón de la Cruz (Madrid, Cátedra, 1990), Traducción y adaptación cultural: España-Francia (Oviedo, Universidad, 1991). Ha realizado la traducción, con introducción, bibliografía y notas de Las bodas de Fígaro de Beaumarchais, Jacques el fatalista de Diderot y Zadig. Cándido de Voltaire (Barcelona, Bosch, 1977, 1978 y 1982, respectivamente); los prólogos a Manon Lescaut del abate Prévost (Barcelona, Planeta, 1983) y al Tractat sobre la tolerància de Voltaire (Barcelona, Edicions 62, 1988); así como la traducción de Bayaceto y Fedra de Racine (Barcelona, Bosch, 1984) y de Micromegas y otros cuentos de Voltaire (Madrid, Siruela, 1986). Ha publicado artículos en Anales de Literatura Española (Alicante), Annales de Littérature Comparée/Ikaku Bungaku Nenshi (Tokyo), Annali dell'Istituto Universitario Orientale (Nápoles), Anuario de Filología (Barcelona), Boletín de la Biblioteca Menéndez Pelayo (Santander), Cuadernos de Traducción e Interpretación (Barcelona), Études de langue e littérature française de l'Université de Hiroshima, ILT News (Tokyo), Insula (Madrid), Intercambio (Oporto), 1916. Anuario de la Sociedad Española de Literatura General y Comparada (Madrid), Récifs (París), Revue de Littéràture comparée (París), Studies on Voltaire and the Eighteenth Century (Oxford).

Dolores Romero López. Doctora en Filología Hispánica por la Universidad de Salamanca. El Servicio de Publicaciones de la Universidad de Salamanca publicará próximamente su Tesis doctoral, La tópica de la poesía modernista española (1900-1907): concordancias y teoría.

Guillermo Serés. Profesor Titular de Literatura Española de la Universidad Autónoma de Barcelona. Autor de La transformación de los amantes. Para una historia del amor desde Platón al siglo XVII, Barcelona, Crítica, en prensa; La traducción en el siglo XV: la «Iliada» en romance y textos afines, Salamanca, Universidad («Textos recuperados»), en prensa. Editor de Juan Huarte de San Juan, Examen de ingenios, Madrid, Cátedra, 1989; Fray Luis de León, Poesía completa, Madrid, Taurus, 1990 , Pedro Calderón de la Barca, La vida es sueño, Barcelona, Circulo de Lectores, 1990; Don Juan Manuel, El conde Lucanor, Crítica, Barcelona (de inminente aparición); Bernal Díaz del Castillo, Historia verdadera de la conquista de la Nueva España, Barcelona, Crítica, en preparación. Artículos aparecidos o de inminente aparición en el Boletín de la Biblioteca Menéndez Pelayo, Nueva Revista de Filología Hispánica, Lucanor, Huarte de San Juan, Criticón, Bulletin Hispanique, Scriptura, Boletín de la Real Academia Española, Anuari de Filologia, Voz y Letra, Hispanic Review, Revista de Literatura Medieval, etc.

Jesusa Vega. Doctora en Historia del Arte por la Universidad Complutense de Madrid. Sus investigaciones están orientadas hacia el estudio de la estampa desde los orígenes (siglo XV) hasta la actualidad. Además de diversas colaboraciones en revistas especializadas, ha participado en 
los catálogos de las exposiciones Estampas, Cinco siglos de imagen impresa (1981), Los Madrazo: una familia de artistas (1985), Goya y el espíritu de la Ilustración (1988), La formación del artista. De Leonardo a Picasso (1989), Reyes y Mecenas. Los Reyes Católicos, Maximiliano I y los inicios de la Casa de Austria en España (1992); y es autora de los libros La imprenta en Toledo. Estampas del Renacimiento (1983) El aguafuerte en el siglo XIX. Técnica, carácter y tendencia de un nuevo arte (1985), Origenes de la Litografía en España. El Real Establecimiento Litográfico (1990), Goya. Los desastres de la guerra, Instantáneas (1992), Museo del Prado. Catálogo de estampas (1992). 


\section{NORMAS PARA LA PRESENTACIÓN DE ORIGINALES DESTINADOS A ANALES DE LITERATURA ESPAÑOLA (UNIVERSIDAD DE ALICANTE)}

Estas normas resultan de la necesidad de unificar la presentación de los originales para facilitar el trabajo de la imprenta. Rogamos a nuestros colaboradores que las lean atentamente antes de redactar sus trabajos. No disponemos de personal dedicado a la corrección o adaptación de originales, y lamentaremos tener que devolver aquellos que no se adapten a estas normas, para que sean nuevamente mecanografiados.

1. Cada artículo deberá ir encabezado por su título en mayúsculas, y por el nombre de su autor (apellidos en mayúscula) seguido del de la Universidad o institución a que pertenezca, en el lado derecho del folio. Título y autor no deberán ir en hoja aparte sino en la primera del texto.

2. Todo el texto, incluidas las notas y bibliografía, deberá escribirse a doble espacio, sin cortar palabras al final de línea. No deberán existir adiciones o correcciones manuscritas. Revise la legibilidad de su original antes de enviarlo.

3. Las citas extensas y que deban aparecer exentas se mecanografiarán con márgenes mayores que el texto, dejando antes y después doble espacio interlineal, a dos espacios y sin comillas. No las transcriba nunca a un espacio. Las citas englobadas en el texto irán entre comillas.

4. Aunque las notas aparecerán impresas a pie de página, en el original deberán mecanografiarse en folios aparte y a dos espacios. Las llamadas, en números volados y sin paréntesis.

5. Las notas al pie se reservan para comentario o excursos. No se usarán para indicaciones de referencia a páginas de fuentes o elementos bibliográficos. Esas referencias se harán en el cuerpo del texto y entre paréntesis, sea cual sea su extensión, y en ellas se mencionará, por este orden: apellido del autor, obra por su año tal como venga en la bibliografía (nunca por su título completo o abreviado), y páginas cuando se quieran citar. Ejemplo: (Pérez López 1937b, págs. 19-21). Este mismo sistema se usará cuando las citadas referencias aparezcan en las notas a pie de página. 
6. La bibliografía deberá figurar al final en hojas aparte, y tendrá que incluir todos los elementos bibliográficos citados en el texto y notas, sin excepción. Se ordenará del siguiente modo:

- por orden alfabético de apellidos de autores, que se escribirán en mayúsculas, seguidos del nombre de pila en minúsculas (no use mayúsculas en las referencias de las que trata el punto cinco de estas normas).

- cuando se citen varias obras de un mismo autor, éstas aparecerán por orden cronológico de primera publicación, pudiéndose indicar después publicaciones posteriores. Si ha de mencionar el nombre del editor de un texto ajeno, ponga nombre y apellidos en orden natural, y estos últimos en mayúsculas.

- si hubiera más de una publicación del mismo año, distíngalas desde la primera con letras minúsculas en orden alfabético.

En la bibliografía las entradas deberán figurar con los datos bibliográficos completos. Si se trata de libros: apellidos, nombre, año, título, editor en su caso, ciudad, editorial o imprenta. Si de artículos: apellidos, nombre, año, título, nombre de la revista (no abreviado), tomo y número, páginas. Si de capítulos de libro: apellidos, nombre, año, título, título del libro precedido de en, datos bibliográficos del libro, páginas que ocupa el capítulo. Si el primer dato bibliográfico de ese libro es su título, estará Vd. indicando que todo él es obra del autor citado por el capítulo. Cuando se esté refiriendo a obras colectivas, indique antes del título el nombre del recopilador si lo hay, o AA.VV. (autores varios). Recuerde que los títulos de libro y nombres de revista deben ir subrayados, y los de artículo o capítulo entre comillas.

\section{Ejemplo:}

PÉREZ LÓPEZ, Antonio. 1937 a. "El teatro lírico", Revista de Filipinas VII, 2 , págs. 123-141; en Estudios literarios, Madrid, Halcón, 1948, págs. 80-96; y en Antonio GÓMEZ GÓMEZ (ed.), Puntos de vista, Barcelona, Lux, 1973, págs. 95-119.

-. 1937 b. "Ópera y zarzuela", Revista de España XXX, 1, págs. 3-29.

Si maneja una obra en una edición que no es la primera, pero desea hacer constar la fecha de ésta, indique entre corchetes la fecha de la primera edición del siguiente modo:

VELÁZQUEZ, Luis José. [1754] 1989. Orígenes de la poesía castellana, ed. Antonio PÉREZ LÓPEZ, Salamanca, Universidad.

Observe que en la enumeración de datos bibliográficos se usa punto tras nombre y año, usándose comas en los demás casos.

7. Si su texto va dividido en apartados, titúlelos en minúscula y con doble subrayado, para que se impriman en negrita. 
8. Cuando quiera resaltar una palabra o frase en el texto use subrayado, que indica cursiva. Use comillas sólo para la cita literal de otro texto. No use nunca comillas simples. Tampoco comillas, sino subrayado, dentro de comillas. La omisión de parte de un texto citado se indicará mediante tres puntos suspensivos entre corchetes; no use otro sistema. Si cita poemas, no inicie todos los versos con mayúscula (aunque así lo haga el original del que copia); use mayúscula sólo cuando lo exija la puntuación.

9. No ponga punto antes de comillas o de llamada de nota, sino después, usando la siguiente secuencia: ... moaxajas" ${ }^{20}$. y no éstas: ... moaxajas." $0 .{ }^{20}$. Tanto en el texto de su artículo como en las notas, no transcriba nunca un texto a dos columnas, aunque conste de versos cortos; use dos columnas sólo cuando quiera enfrentar dos textos diferentes.

10. Si cita textos o títulos que en su original usan ortografía arcaica, queda en libertad de mantenerla o modernizarla; pero adopte un criterio único a lo largo de todo su artículo, bibliografía y notas incluidas.

11. Para la reproducción de material gráfico es imprescindible que nos envíe fotografía brillo de tamaño no menor que $18 \times 24 \mathrm{cms}$., o negativo. 


- 


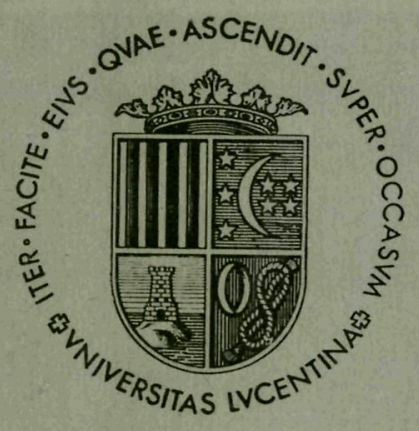

